SYLVIA RAMOS LEITÃO

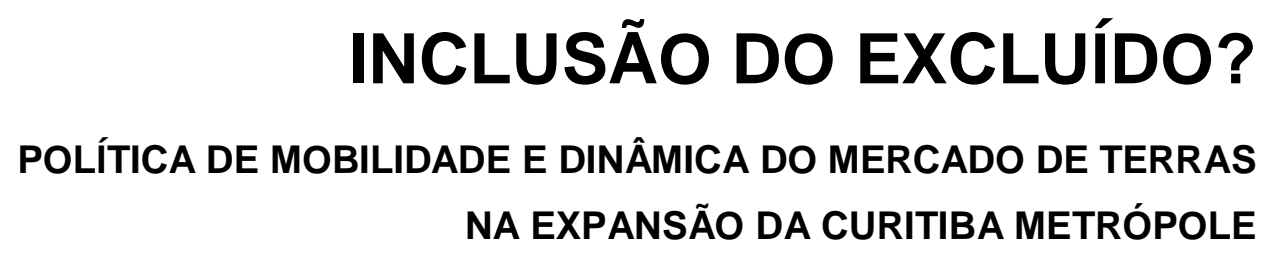

SÃO PAULO

ABRIL . 2010 


\section{INCLUSÃO DO EXCLUÍDO? \\ POLÍTICA DE MOBILIDADE E DINÂMICA DO MERCADO DE TERRAS NA EXPANSÃO DA CURITIBA METRÓPOLE}

Tese apresentada à Faculdade de Arquitetura e Urbanismo da Universidade de São Paulo para obtenção do título de Doutor em Estruturas Ambientais Urbanas

Orientador: Prof. Dr. Wilson Edson Jorge SÃO PAULO ABRIL . 2010 
AUTORIZO A REPRODUÇÃO E DIVULGAÇÃO TOTAL OU PARCIAL DESTE TRABALHO, POR QUALQUER MEIO CONVENCIONAL OU ELETRÔNICO, PARA FINS DE ESTUDO E PESQUISA, DESDE QUE CITADA A FONTE.

E-MAIL: sylvia.leitao@pucpr.br

\section{Leitão, Sylvia Ramos}

L533i Inclusão do Excluído? Política de mobilidade e dinâmica do mercado de terras na expansão da Curitiba Metrópole / Sylvia Ramos Leitão - São Paulo, 2010.

282 p. : il.

Tese (Doutorado - Área de Concentração: Planejamento Urbano Regional) - FAUUSP.

Orientador: Wilson Edson Jorge

1.Planejamento territorial urbano - Curitiba (PR)

2.Áreas Metropolitanas 3.Expansão urbana I.Título

CDU $711.4(816.21)$ 
PARA SOFIA 


\section{AGRADECIMENTOS}

Ao Prof. Dr. Wilson Edson Jorge pela orientação, pelo incentivo e pela amizade Aos professores e colegas da FAUUSP

pela troca de idéias

Aos meus colegas professores da PUCPR pelo companheirismo A COMEC, URBS, IBGE e INPESPAR pela disponibilização de dados À Manoela Fajgenbaum Feiges e Erika Naomi Fukunishi pela produção do material gráfico

Aos meus amigos pelo estímulo À minha família pelo afeto

A meus pais pelo apoio incondicional À Sofia pela sabedoria, ainda que em tenra idade 


\section{RESUMO}

Em Curitiba, a metrópole segmentada formou-se à sombra das sucessivas ideologias de planejamento urbano - a Curitiba planejada do transporte coletivo e a Curitiba reificada pela qualidade de vida, sob o valor maior do pertencimento à Capital Ecológica do país. As alterações recentes na estrutura intra-urbana da Curitiba Metrópole oriundas da expansão do capital e da extensão dos meios de consumo coletivo à periferia conurbada, lá impactaram profundamente os valores de uso da terra urbana, produzindo assim novas tipologias de localizações no território. A tese a ser aqui demonstrada é a de que a lógica da expansão urbana na Curitiba metrópole transformou-se ao longo das duas últimas décadas. O primeiro movimento de expansão veio atrelado à valorização imobiliária do centro em direção à periferia, expulsando a população de mais baixa renda para cada vez mais longe, um processo de periferização imposto pela lógica classista centro-periferia, responsável pela segmentação da metrópole. O segundo movimento advém da política de mobilidade de caráter inclusivo, com a extensão da rede integrada de transporte à periferia segmentada - a RIT metropolitana. O maior impacto daí decorrente foi o da mobilidade social das classes de mais baixa renda, dado o incremento da renda propiciado pelos movimentos pendulares do cidadão metropolitano ao emprego no centro da metrópole. O terceiro movimento de expansão se deu por uma lógica de inclusão do excluído, lógica essa peculiar à Curitiba Metrópole, da qual resulta o acesso à metrópole pelo cidadão metropolitano anteriormente excluído. Da acessibilidade urbana vem a possibilidade de permanência do cidadão metropolitano na nova localização produzida, que nada mais é, do que o bairro popular agora conectado a todos os pontos da Curitiba Metrópole. Por meio da pesquisa empírica, constatou-se que o maior número de localizações produzidas nos últimos quinze anos no cone leste da Curitiba Metrópole, referia-se à lógica de inclusão do excluído, o que veio a revelar um fenômeno - o da tendência de homogeneização dos preços da terra pela homogeneização da acessibilidade urbana. Em última instância, a lógica da inclusão do excluído vem legitimar, portanto, as ideologias da qualidade de vida e do pertencimento à Curitiba planejada.

Palavras-chave: áreas metropolitanas, expansão urbana, periferização, mercado de terras, mobilidade urbana, planejamento urbano em Curitiba. 


\section{ABSTRACT}

In Curitiba, the segmented metropolis was formed by the shade of successive ideologies of urban planning - the Planned Curitiba of the collective transport and the Re-stayed Curitiba by the quality of life, under the bigger value of the belonging to the Ecological Capital of the country. The recent alterations in the Curitiba Metropolis's intra-urban structure derived from the expansion of the capital and the extension of the ways of collective consumption to the conurbationed periphery, deeply impacted the values of the use of its urban land, thus producing new localization's typologies in the territory. The thesis here demonstrated is that the logic of the urban expansion in Curitiba metropolis was changed along the two last decades. The first movement of expansion came hitched up to the real state valuation from the downtown in direction to the periphery, banishing the population of lower income more and more far away, a periphery process imposed by the downtown-peripheral classist logical, responsible for the segmentation of the metropolis. The second movement comes from the mobility politics of inclusive character, with the extension of the integrated net of transport to the segmented periphery - the RIT metropolitan. The biggest impact resulting from this was the social mobility of lower income classes by the income increment proposed by the pendulum movements of the metropolitan citizen to the employment in the downtown of the metropolis. The third movement of expansion happened by a inclusion of the excluded one logical, logical peculiar to the Curitiba Metropolis from which results the access to the metropolis by the previously excluded metropolitan citizen. From the urban accessibility comes the possibility of permanence of the metropolitan citizen in the new produced localization, that is nothing more than the popular quarter now connected to all the points of the Curitiba Metropolis. By the empirical research was evidenced that the biggest number of localizations produced in the last fifteen years in the east cone of the Curitiba Metropolis, mentioned to the inclusion of the excluded one logical which came to reveal a phenomenon - the homogenization trend of the land prices by the urban accessibility homogenization. Lastly, the inclusion of the excluded one logical comes to legitimize, therefore, the ideologies of the quality of life and the belonging to Planned Curitiba.

Word-key: Metropolitan Areas, Urban Expansion, Peripheryment, Land Market, Urban Mobility, Urban Planning in Curitiba. 


\section{SUMÁRIO}

INTRODUÇÃO

CAPÍTULO 1

A FORMAÇÃO DA METRÓPOLE NA TRANSIÇÃO DAS IDEOLOGIAS:

DA CURITIBA PLANEJADA À CURITIBA REIFICADA

O binômio industrialização e urbanização na formação da metrópole

A CURITIBA PLANEJADA e a grande intervenção urbana: os corredores estruturais e a RIT - Rede Integrada de Transporte

19

À CURITIBA REIFICADA sob a Capital Ecológica: qualidade de vida e pertencimento para alguns

26

CAPÍTULO 2

DA METRÓPOLE SEGMENTADA À CURITIBA METRÓPOLE:

ENTRE A EXPANSÃO DO CAPITAL E A EXPANSÃO DA REDE INTEGRADA DE TRANSPORTE

49

Empresariamento Urbano e a segunda fase da industrialização

49

Novos ícones urbanos e a expansão do terciário

54

Novas localizações intra-urbanas e o mercado imobiliário

65

RIT Metropolitana: acessibilidade e consolidação da Curitiba Metrópole

91 
CAPÍTULO 3

AS NOVAS LOCALIZAÇÕES NA CURITIBA METRÓPOLE: ENTRE A POLÍTICA DE MOBILIDADE E A DINÂMICA DO MERCADO DE TERRAS

101

EXPANSÃO URBANA DA CURITIBA METRÓPOLE

E A LÓGICA EXCLUDENTE DO MERCADO DE TERRAS

113

A evolução do preço da terra na Curitiba Metrópole

113

O preço da terra e a movimentação das classes sociais na apropriação do território da Curitiba

Metrópole

131

EXPANSÃO URBANA DA CURITIBA METRÓPOLE E A LÓGICA INCLUDENTE DA POLÍTICA DE MOBILIDADE

148

Política de mobilidade na Curitiba Metrópole: a evolução da rede integrada de transporte - RIT

150

Impactos da RIT metropolitana sobre a relação entre a acessibilidade e renda

163

A RIT e o movimento das classes sociais na Curitiba Metrópole: as direções da expansão e a emergência dos corredores intra-urbanos

166

A evolução da mancha urbana na Curitiba Metrópole (1996-2009)

171

INCLUSÃO DO EXCLUÍDO NA CURITIBA METRÓPOLE: EXPANSÃO URBANA E TIPOLOGIAS DAS NOVAS LOCALIZAÇÕES

178

A dinâmica do mercado de terras e a inclusão do excluído: bairros populares e corredores de transporte intra-urbanos

180

As novas localizações na Curitiba Metrópole: valores de uso e preço da terra urbana 
ANEXO 1

Entrevista com a arquiteta Zulma das Graças Lucena Schussel

ANEXO 2

Levantamento da oferta de terrenos à venda em Curitiba, Colombo, Pinhais e São José dos Pinhais em 1996, 2000, 2004 e 2009

ANEXO 3

Quadro Operacional da RIT Metropolitana relativo a Colombo, Pinhais e São José dos Pinhais 


\section{LISTA DE MAPAS}

MAPA 1

AS NOVAS LOCALIZAÇÕES INTRA-URBANAS NA CURITIBA METRÓPOLE: ENTRE A EXPANSÃO DO CAPITAL E A EXPANSÃO DA REDE INTEGRADA DE TRANSPORTE (DÉCADAS 1990 e 2000)

68

MAPA 2

SETORES DO SECOVI-PR, PARA MONITORAMENTO DA OFERTA DE IMÓVEIS EM CURITIBA (DESDE 1996) E EM SÃO JOSÉ DOS PINHAIS (DESDE 2004)

89

MAPA 3 POTENCIAL CONSTRUTIVO, ÁREAS DE MANANCIAIS PROTEGIDAS E OCUPACÔES IRREGULARES NA CURITIBA METRÓPOLE

90

MAPA 4

A RIT METROPOLITANA (2008)

94

MAPA 5

O CONE LESTE DA CURITIBA METRÓPOLE

102

MAPA 6

PREÇO MÉDIO DE TERRENOS OFERTADOS PARA VENDA NO CONE LESTE DA CURITIBA METRÓPOLE, EM R $\$ / \mathrm{m}^{2}$, POR BAIRRO (1996)

115

MAPA 7

PREÇO MÉDIO DE TERRENOS OFERTADOS PARA VENDA NO CONE LESTE DA CURITIBA METRÓPOLE, EM R $\$ / \mathrm{m}^{2}$, POR BAIRRO (2000)

117

MAPA 8

PREÇO MÉDIO DE TERRENOS OFERTADOS PARA VENDA NO CONE LESTE DA CURITIBA METRÓPOLE, EM R $\$ / \mathrm{m}^{2}$, POR BAIRRO (2004)

120

MAPA 9

PREÇO MÉDIO DE TERRENOS OFERTADOS PARA VENDA NO CONE LESTE DA CURITIBA METRÓPOLE, EM R $\$ / \mathrm{m}^{2}$, POR BAIRRO (2009)

123

MAPA 10

RENDA DO CHEFE DO DOMICÍLIO POR SETORES CENSITÁRIOS DO IBGE EM 1991, NO CONE 
MAPA 11

RENDA DO CHEFE DO DOMICÍLIO POR SETORES CENSITÁRIOS DO IBGE EM 2000, NO CONE LESTE DA CURITIBA METRÓPOLE

137

MAPA 12

ABRANGÊNCIA DA RIT METROPOLITANA NO CONE LESTE DA CURITIBA METRÓPOLE (1996)

151

MAPA 13

ABRANGÊNCIA DA RIT METROPOLITANA NO CONE LESTE DA CURITIBA METRÓPOLE (2001)

152

MAPA 14

ABRANGÊNCIA DA RIT METROPOLITANA NO CONE LESTE DA CURITIBA METRÓPOLE (2004)

153

MAPA 15

ABRANGÊNCIA DA RIT METROPOLITANA NO CONE LESTE DA CURITIBA METRÓPOLE (2008)

154

MAPA 16

RIT METROPOLITANA EM 2008, NO CONE LESTE DA CURITIBA METRÓPOLE, POR NÍVEIS DE

INTEGRAÇÃO

161

MAPA 17

RIT METROPOLITANA EM 2008, NO CONE LESTE DA CURITIBA METRÓPOLE, POR TEMPO DE DESLOCAMENTO E DISTÂNCIA AO CENTRO DE CURITIBA

162

MAPA 18

RENDA 1991 E RIT METROPOLITANA EM 1996, NO CONE LESTE DA CURITIBA METRÓPOLE

167

MAPA 19

RENDA 2000 E RIT METROPOLITANA EM 2004, NO CONE LESTE DA CURITIBA METRÓPOLE

168

MAPA 20

RIT METROPOLITANA EM 2008, NO CONE LESTE DA CURITIBA METRÓPOLE, POR CARREGAMENTO DE LINHAS, POR RENDA

169

MAPA 21

EVOLUÇÃO DA MANCHA URBANA NO CONE LESTE DA CURITIBA METRÓPOLE EM 1996, 2000 E 2004

176

MAPA 22

RIT METROPOLITANA E PREÇO DA TERRA NO CONE LESTE DA CURITIBA METRÓPOLE EM 1996

181 
MAPA 23

RIT METROPOLITANA E PREÇO DA TERRA NO CONE LESTE DA CURITIBA METRÓPOLE EM 2000-2001

182

MAPA 24

RIT METROPOLITANA E PREÇO DA TERRA NO CONE LESTE DA CURITIBA METRÓPOLE EM 2004

183

MAPA 25

RIT METROPOLITANA E PREÇO DA TERRA NO CONE LESTE DA CURITIBA METRÓPOLE EM 2008-2009

184

MAPA 26

INCLUSÃO DO EXCLUÍDO: AS NOVAS TIPOLOGIAS DE LOCALIZAÇÕES PRODUZIDAS NO CONE

LESTE DA CURITIBA METRÓPOLE, ENTRE 1996-2009

207

\section{LISTA DE TABELAS}

TABELA 1.1

POPULAÇÃO URBANA E ÍNDICE DE URBANIZAÇÃO EM CURITIBA, NA RMC, NO PARANÁ E NO BRASIL, NO PERÍODO 1950-2000

TABELA 1.2

TAXAS DE CRESCIMENTO POPULACIONAL DAS REGIÕES METROPOLITANAS NO PERÍODO 1970-1996

TABELA 1.3 TAXAS GEOMÉTRICAS DE CRESCIMENTO ANUAL DO NÚCLEO E DA PERIFERIA EM REGIÕES METROPOLITANAS DO BRASIL - 1970/200

TABELA 1.4 INDICADORES SOCIAIS DE REGIÕES METROPOLITANAS DO BRASIL - 1991/2000

TABELA 1.5 NÚMERO DE LOTES APROVADOS NO NUC/RMC SEM CURITIBA** POR DÉCADA

TABELA 1.6 NÚMERO DE LOTES APROVADOS NO NUC/RMC SEM CURITIBA** POR DÉCADA 
TABELA 2.1

EVOLUÇÃO DOS 10 BAIRROS MAIS DENSOS DE CURITIBA - 1970 A 2000

TABELA 2.2

TRANSFERÊNCIA DE POTENCIAL CONSTRUTIVO DAS UNIDADES DE CONSERVAÇÃO - ÁREAS VERDES - EM CURITIBA

79

TABELA 2.3

COMPARATIVO DO PATAMAR DE URBANIZAÇÃO ENTRE ALPHAVILLE GRACIOSA E ZUMBI DOS PALMARES, EM PINHAIS, RMC

TABELA 2.4

POPULAÇÃO E DEMANDA DOS MUNICÍPIOS DO NUC QUE DEMANDAM À CURITIBA

97

TABELA 3.1

- COMPLEMENTAÇÃO DO UNIVERSO DE PESQUISA: LOTES OFERTADOS PARA A VENDA, POR MUNICÍPIO, POR DATA DE ANÚNCIO

105

TABELA 3.2 - CURITIBA - SETOR LESTE: PREÇO MÉDIO (R\$/m²) DE TERRENOS OFERTADOS PARA VENDA, POR BAIRRO, EM 1996, 2000, 2004 E 2009; ÍNDICE DE VALORIZAÇÃO DO PREÇO DA TERRA NO PERIODO $1996-2009$

125

TABELA 3.3

COLOMBO: PREÇO MÉDIO (R\$/m²) DE TERRENOS OFERTADOS PARA VENDA, POR BAIRRO, EM 1996, 2000, 2004 E 2009; ÍNDICE DE VALORIZAÇÃO DO PREÇO DA TERRA NO PERÍODO 1996 - 2009

TABELA 3.4

PINHAIS: PREÇO MÉDIO (R\$/m²) DE TERRENOS OFERTADOS PARA VENDA, POR BAIRRO, EM 1996, 2000, 2004 E 2009; ÍNDICE DE VALORIZAÇÃO DO PREÇO DA TERRA NO PERÍODO 1996 - 2009

127

TABELA 3.5

SÃO JOSÉ DOS PINHAIS: PREÇO MÉDIO (R\$/m²) DE TERRENOS OFERTADOS PARA VENDA, POR BAIRRO, EM 1996, 2000, 2004 E 2009; ÍNDICE DE VALORIZAÇÃO DO PREÇO DA TERRA NO PERÍODO 1996 - 2009

128

TABELA 3.6

CURITIBA - SETOR LESTE: PREÇO MÉDIO $\left(R \$ / \mathrm{m}^{2}\right)$ DE TERRENOS OFERTADOS PARA VENDA, POR BAIRRO, EM 1996, 2000, 2004 E 2009; ÍNDICE DE VALORIZAÇÃO DO PREÇO DA TERRA NO PERÍODO 1996 - 2009; EVOLUÇÃO DA RENDA ENTRE 1991-2000, EM SALÁRIOS MÍNIMOS

140

TABELA 3.7

COLOMBO: PREÇO MÉDIO (R\$/m²) DE TERRENOS OFERTADOS PARA VENDA, POR BAIRRO, EM 1996, 2000, 2004 E 2009; VALORIZAÇÃO IMOBILIÁRIA NO PERÍODO 1996 - 2009; EVOLUÇÃO DA

RENDA ENTRE 1991-2000, EM SALÁRIOS MÍNIMOS 
TABELA 3.8

PINHAIS: PREÇO MÉDIO (R\$/m²) DE TERRENOS OFERTADOS PARA VENDA, POR BAIRRO, EM 1996, 2000, 2004 E 2009; ÍNDICE DE VALORIZAÇÃO DO PREÇO DA TERRA NO PERÍODO 1996 2009; EVOLUÇÃO DA RENDA ENTRE 1991-2000, EM SALÁRIOS MÍNIMOS

TABELA 3.9

SÃO JOSÉ DOS PINHAIS: PREÇO MÉDIO (R\$/m²) DE TERRENOS OFERTADOS PARA VENDA, POR BAIRRO, EM 1996, 2000, 2004 E 2009; ÍNDICE DE VALORIZAÇÃO DO PREÇO DA TERRA NO PERÍODO 1996 - 2009; EVOLUÇÃO DA RENDA ENTRE 1991-2000, EM SALÁRIOS MÍNIMOS

TABELA 3.10

EVOLUÇÃO DAS OCUPAÇÕES IRREGULARES NO CONE LESTE DA CURITIBA METRÓPOLE (1992-1998)

TABELA 3.11

PASSAGEIROS TRANSPORTADOS POR DIA ÚTIL NAS CIDADES METROPOLITANAS

(1996, 2000, 2004 E 2008)

155

TABELA 3.12

TEMPO DE DESLOCAMENTO MÉDIO AO CENTRO DE CURITIBA, POR NÍVEL DE INTEGRAÇÃO, POR MUNICÍPIO, EM 2010

159

TABELA 3.13

POPULAÇÃO RESIDENTE DE 15 ANOS E MAIS DE IDADE QUE TRABALHA OU ESTUDA E PESSOAS QUE REALIZARAM MOVIMENTO PENDULAR - RMC - 2000

163

TABELA 3.14

EVOLUÇÃO DA RENDA DO CHEFE DO DOMICÍLIO POR FAIXA, POR MUNICÍPIO E RMC (1991-2000)

165

TABELA 3.15

COLOMBO - EVOLUÇÃO DO PREÇO MÉDIO $\left(\mathrm{R} \$ \mathrm{~m}^{2}\right)$ DE TERRENOS OFERTADOS PARA VENDA, POR BAIRRO, COM A EVOLUÇÃO DE ABRANGÊNCIA DA RIT METROPOLITANA

189

TABELA 3.16

PINHAIS - EVOLUÇÃO DO PREÇO MÉDIO $\left(\mathrm{R} \$ / \mathrm{m}^{2}\right)$ DE TERRENOS OFERTADOS PARA VENDA, POR BAIRRO, COM A EVOLUÇÃO DE ABRANGÊNCIA DA RIT METROPOLITANA

190

TABELA 3.17

SÃO JOSÉ DOS PINHAIS - EVOLUÇÃO DO PREÇO MÉDIO $\left(\mathrm{R} \$ \mathrm{~m}^{2}\right)$ DE TERRENOS OFERTADOS PARA VENDA, POR BAIRRO, COM A EVOLUÇÃO DE ABRANGÊNCIA DA RIT METROPOLITANA

TABELA 3.18

CORREDORES METROPOLITANOS DA RIT - CURITIBA / COLOMBO AVENIDA PARANÁ/ ESTRADA DA RIBEIRA 
TABELA 3.19

CORREDORES METROPOLITANOS DA RIT - CURITIBA / COLOMBO AVENIDA PARANÁ/ RODOVIA DA UVA

194

TABELA 3.20

CORREDORES METROPOLITANOS DA RIT - CURITIBA / PINHAIS - AV. PRES. AFFONSO CAMARGO

/ AV. IRAI E AV. VICTOR FERREIRA DO AMARAL / RODOVIA JOÃO LEOPOLDO JACOMEL

195

TABELA 3.21

CORREDORES METROPOLITANOS DA RIT - CURITIBA / SÃO JOSÉ DOS PINHAIS - AV. MAL.

FLORIANO PEIXOTO/ AV. DAS AMÉRICAS/ RUA XV DE NOVEMBRO/ AV. RUI BARBOSA

196

TABELA 3.22

CORREDORES METROPOLITANOS DA RIT - CURITIBA / SÃO JOSÉ DOS PINHAIS - BR-277 /

AVENIDA RUI BARBOSA e AVENIDA DAS TORRES / BR-376

197

TABELA 3.23

OCORRÊNCIA DE MAIOR PREÇO, MENOR PREÇO E RELAÇÃO ENTRE MAIOR E MENOR PREÇO, POR MUNICÍPIO (1996, 2000, 2004, 2009)

199

TABELA 3.24

OFERTA DE TERRENOS À VENDA POR FAIXA DE TAMANHO E MÉDIA DE PREÇO NO CONE LESTE DA CURITIBA METRÓPOLE (2007)

202

TABELA 3.25

RELAÇÃO ENTRE VALORIZAÇÃO MAIS EXPRESSIVAS DO PREÇO DA TERRA E O MOVIMENTO DAS CLASSES SOCIAIS, EM BAIRROS DE CURITIBA (1996-2009)

203

TABELA 3.26

RELAÇÃO ENTRE VALORIZAÇÃO MAIS EXPRESSIVAS DO PREÇO DA TERRA E O MOVIMENTO DAS CLASSES SOCIAIS, EM BAIRROS DE COLOMBO (1996-2009)

204

TABELA 3.27

RELAÇÃO ENTRE VALORIZAÇÃO MAIS EXPRESSIVAS DO PREÇO DA TERRA E O MOVIMENTO DAS CLASSES SOCIAIS, EM BAIRROS DE PINHAIS (1996-2009)

205

TABELA 3.28

RELAÇÃO ENTRE VALORIZAÇÃO MAIS EXPRESSIVAS DO PREÇO DA TERRA E O MOVIMENTO DAS CLASSES SOCIAIS, EM BAIRROS DE SÃO JOSÉ DOS PINHAIS (1996-2009) 


\section{LISTA DE FIGURAS}

REGIÃO METROPOLITANA DE CURITIBA - CONFORMAÇÃO ATUAL 1

FIG. 2 EVOLUÇÃO DA COMPOSIÇÃO DA REGIÃO METROPOLITANA DE CURITIBA

FIG. 3

EVOLUÇÃO DA OCUPAÇÃO URBANA NA RMC - 1955 a 1999

18

FIG. 4 LINEARIZAÇÃO E SETORES ESTRUTURAIS OESTE E SUL

FIG. 5 DETALHES DO SISTEMA TRINÁRIO EM CURITIBA

22

FIG. 6

NÚCLEO URBANO CENTRAL - 2002 RELAÇÃO ENTRE A MANCHA CONURBADA E A ESTRUTURA VIÁRIA BÁSICA DA RMC

FIG. 7

EVOLUÇÃO DO PARCELAMENTO DO SOLO NO NÚCLEO URBANO CENTRAL DA RMC ATÉ 2004

FIG. 8 NÚCLEO URBANO CENTRAL E ÁREAS DE RESTRIÇÃO AMBIENTAL - RMC 2000

36

FIG. 9

OCUPAÇÕES IRREGULARES NA AGLOMERAÇÃO METROPOLITANA DE CURITIBA - 2000

FIG. 10 MIGRAÇÃO INTRA-METROPOLITANA NA RMC EM 1991

FIG. 11

TRANSPORTE COLETIVO E PAISAGEM URBANA

48

FIG. 12 NOVOS MARCOS REFERENCIAIS URBANOS - ANOS 90 
FIG. 13

PARQUES URBANOS EM CURITIBA

57

FIG. 14 TRANSFERENCIA DE POTENCIAL E ÁREAS VERDES URBANAS EM CURITIBA

58

FIG. 15

RENOVAÇÕES URBANAS - ANOS 2000

61

FIG. 16 LINHÃO DO TURISMO, LINHA VERDE E LINHÃO DO EMPREGO EM CURITIBA

62

FIG. 17

CONURBAÇÃO NA CURITIBA METRÓPOLE - 2000

66

FIG. 18

CONTORNO LESTE E ACESSIBILIDADE LOGÍSTICA NA RMC - 2005

69

FIG. 19

ESQUEMA DE VERTICALIZAÇÃO DETALHADO NA LEI DE ZONEAMENTO DE 1975

PARA OS CORREDORES ESTRUTURAIS EM CURITIBA

71

FIG. 20 - VERTICALIZAÇÃO EM CURITIBA: VISTA DO CORREDOR ESTRUTURAL OESTE, A PARTIR DO PARQUE BARIGÜI

FIG. 21

DENSIDADE DEMOGRÁFICA EM CURITIBA - 2000

75

FIG. 22 ESQUEMA DAS UNIDADES TERRITORIAIS DE PLANEJAMENTO UTP'S PREVISTAS NA LEI 12.248/98

81 


\section{LISTA DE GRÁFICOS}

GRÁFICO 3.1

NÚMERO DE PASSAGEIROS EM MOVIMENTO PENDULAR NO CONE LESTE (1996)

GRÁFICO 3.2

NÚMERO DE PASSAGEIROS EM MOVIMENTO PENDULAR NO CONE LESTE (2008)

GRÁFICO 3.3

EVOLUÇÃO DO MOVIMENTO PENDULAR A PARTIR DE COLOMBO (1996, 2000, 2004 E 2008)

GRÁFICO 3.4

EVOLUÇÃO DO MOVIMENTO PENDULAR A PARTIR DE PINHAIS (1996, 2000, 2004 E 2008)

GRÁFICO 3.5

EVOLUÇÃO DO MOVIMENTO PENDULAR A PARTIR DE SÃO JOSÉ DOS PINHAIS 1996, 2000, 2004 E 2008)

GRÁFICO 3.6 EVOLUÇÃO DO PREÇO DA TERRA NOS BAIRROS QUE MAIS VALORIZARAM NO CONE LESTE

$(1996-2009)$

GRÁFICO 3.7

VALORIZAÇÃO DAS LOCALIZAÇÕES POR TIPOLOGIAS E APROPRIAÇÃO PELAS CLASSES SOCIAIS NO CONE LESTE (1996 - 2009) 


\section{INTRODUÇÃO}

No processo da urbanização brasileira, constata-se que a metamorfose das grandes cidades ocorreu num período muito curto: nos últimos quarenta anos, vimos emergir a metrópole, a sua formação e a sua segmentação, o que vem revelando as reais facetas de um desenvolvimento periférico. A metropolização contém e é contida por vários outros processos de distintas naturezas, porém relacionados entre si político, econômico, social.

Em Curitiba, a metrópole segmentada formou-se à sombra das sucessivas ideologias de planejamento urbano - a Curitiba planejada do transporte coletivo e a Curitiba reificada pela qualidade de vida, sob o valor maior do pertencimento à Capital Ecológica do país. As alterações recentes na estrutura intra-urbana da Curitiba Metrópole oriundas da expansão do capital - relativamente ao secundário e ao terciário - bem como da extensão dos meios de consumo coletivo à periferia conurbada - o transporte metropolitano integrado - causaram impactos significativos nos valores de uso da terra urbana, visivelmente percebidos na dinâmica dos seus preços. Como resultado, novas tipologias de localizações foram produzidas no território, em detrimento de antigas localizações mais privilegiadas.

Diante disso, a tese a ser aqui demonstrada é a de que:

A lógica da expansão urbana na Curitiba metrópole transformou-se ao longo das duas últimas décadas, por meio de três processos inter-relacionados e interdependentes:

(i) um processo de periferização imposto pela lógica classista centroperiferia, responsável pela segmentação da metrópole, em que o movimento de expansão vem atrelado à valorização fundiária do centro em direção à periferia, expulsando a população de mais baixa renda para cada vez mais longe, dificultando ainda mais o acesso à metrópole;

(ii) um segundo processo que advém da política de mobilidade de caráter inclusivo, no qual a expansão urbana se dá a partir da extensão da rede integrada de transporte - a RIT metropolitana: a integração entre a 
periferia segmentada e a cidade central ocorre por meio dos movimentos pendulares, que ampliam a possibilidade do trabalhador aos empregos de maiores salários, do que decorre o incremento da sua renda;

(iii) O terceiro movimento de expansão se deu por uma lógica de inclusão do excluído, peculiar à Curitiba Metrópole, da qual resulta o acesso à metrópole pelo cidadão metropolitano anteriormente excluído: da acessibilidade e mobilidade urbanas vem a possibilidade de consumo da localização produzida, ou seja, o acesso à terra urbana.

As hipóteses que darão sustentação a tese lançada também são três:

(i) A integração física da metrópole via rede integrada de transporte constitui-se como a base de sustentação da Curitiba Metrópole, pois ao satisfazer a relação clássica entre habitação e trabalho mediante o movimento pendular, favorece a diminuição do custo da reprodução da força de trabalho e da reprodução do capital;

(ii) Contraditoriamente, os constantes investimentos em transporte coletivo na cidade central da metrópole, de um lado, conduziram à segmentação do território e à exclusão decorrente do movimento de valorização da terra, e de outro, propiciaram a sustentação das sucessivas ideologias de planejamento - a Curitiba Planejada e a Capital Ecológica - promovendo assim a manutenção do poder do Estado e dos interesses da sociedade de elite;

(iii) A integração metropolitana alcançada com a RIT - rede integrada de transporte - ao conferir o acesso à terra ao cidadão excluído, dele obteve a legitimação da nova ideologia atrelada à qualidade de vida e a disseminação do discurso de pertencimento à Capital Ecológica, apesar da visibilidade do conjunto de demandas ainda reprimidas.

A tese desenvolvida estrutura-se a partir de quatro capítulos. No primeiro deles, pretende-se retratar a formação da metrópole e os seus movimentos de expansão, tendo por fio condutor a sucessão de ideologias criadas pelo planejamento urbano - a Curitiba Planejada dos anos 70 e 80 e a da Curitiba Reificada sob a Capital Ecológica 
nos 90 - em contraposição à metrópole: uma metrópole dinâmica, atraente para investimentos; uma metrópole em crescimento, segmentada pela expansão e integrada pela mobilidade urbana.

O segundo capítulo tem por objetivo maior evidenciar as relações entre 0 Estado e o mercado, bem como os seus impactos sobre a estrutura intra-urbana, principalmente no tocante à produção das novas localizações e à dinâmica da sua apropriação pelas classes sociais na Curitiba Metrópole. Serão destacados os novos distritos industriais, os deslocamentos das camadas de alta renda da área central de Curitiba para a periferia e por último, a metropolização da RIT e sua expansão ao longo dos últimos quinze anos. Almeja-se portanto desmistificar a ideologia da qualidade de vida a partir da Curitiba Metrópole, que nas duas últimas décadas vem se consolidando "efetivamente como uma metrópole".

O terceiro capítulo remete-se à pesquisa empírica propriamente dita, onde se interpretará o processo de produção das novas localizações na Curitiba Metrópole, relativas à expansão urbana e, portanto, à reestruturação da sua periferia. Para tanto, serão demonstradas as diferentes lógicas que configuraram a Curitiba Metrópole - a da exclusão pelo mercado de terras; a da inclusão pela mobilidade urbana, por meio da relação moradia-pendularidade-trabalho; e a da inclusão do excluído, voltada à reprodução da força de trabalho, no contexto da dinâmica do mercado de terras e da política de mobilidade. Buscar-se-á o entendimento das contradições, sob a produção social do espaço intra-urbano, e sob a apropriação das localizações produzidas pelas classes sociais.

Por fim, no quarto e último capítulo - sob o título a inclusão do excluído: uma nova leitura da expansão urbana na Curitiba Metrópole - serão apresentadas as conclusões desta tese. Aqui é onde se pretende demonstrar a originalidade deste estudo, quando por meio da integração das abordagens sociológica, econômica e espacial, tornou-se possível constatar a especificidade do fenômeno da homogeneização de preços na Curitiba Metrópole, dada pela homogeneização da acessibilidade. 


\section{CAPÍTULO 1}

\section{A FORMAÇÃO DA METRÓPOLE NA TRANSIÇÃO DAS IDEOLOGIAS: DA CURITIBA PLANEJADA À CURITIBA REIFICADA}

A Curitiba Metrópole - objeto dessa pesquisa - é na verdade o que VILLAÇA chama de espaço intra-urbano, aquele em que a estruturação é "dominada pelo deslocamento do ser humano, enquanto portador da mercadoria força de trabalho ou enquanto consumidor." Tal objeto, em constante transição, sofreu desde a sua formação profundas alterações originadas pelas mudanças que se operaram nos processos produtivos. Assim, neste primeiro capítulo, pretende-se explicitar a formação da Curitiba Metrópole, tendo como recorte o período relativo às duas fases de industrialização - nos anos setenta e nos anos 90. Desse modo, o processo de urbanização será vislumbrado a partir de duas óticas: a primeira corresponde aos impactos da industrialização na dinâmica sócio-espacial do território; e a segunda, a das ideologias que foram produzidas pelo planejamento urbano - a Curitiba planejada e a Curitiba reificada - a fim de se apreender sob essa dialética as especificidades do processo de produção social do espaço intra-urbano.

A Curitiba planejada emerge da implementação do Plano Diretor de Curitiba (datado de 1966) no início dos anos setenta - época em que se operaram transformações de grande porte na morfologia urbana, guiadas pelos eixos estruturantes de transporte coletivo, símbolo maior do planejamento - período que também corresponde à primeira fase da industrialização já em meados da década de 70, quando da instalação da Cidade Industrial de Curitiba (CIC) e da REPAR, a Refinaria de Petróleo da PETROBRÁS, contígua à CIC, porém no município de Araucária. Já a Curitiba reificada refere-se ao período inicial da década de 90 , quando em função da reformulação das estratégias de desenvolvimento, Curitiba é lançada ao país como a Capital Ecológica, sustentada pelo marketing urbano sobre valores de qualidade de vida e do sentimento de pertencimento ao lugar. Desta estratégia resulta uma nova fase de industrialização, marcada pela disputa acirrada de atração de investimentos do setor automotivo entre as metrópoles brasileiras, concretizada com a vinda de indústrias montadoras e fornecedoras para os municípios contíguos à Curitiba, na área metropolitana. 


\section{O binômio industrialização e urbanização na formação da metrópole}

Sendo assim, cabe iniciar a contextualização da formação da Curitiba Metrópole pelo resgate do processo de industrialização e de metropolização no cenário nacional. No período da política desenvolvimentista de Juscelino Kubitschek, a substituição das importações pela implantação da indústria de bens de consumo durável contribuiu sobremaneira para alavancar o processo da metropolização brasileira. ${ }^{1} \mathrm{O}$ crescimento populacional caracterizou-se pela concentração nas capitais, principalmente em São Paulo e Rio de Janeiro, locais de maior investimento e de excedente de capital. Se em 1960, o índice de urbanização no Brasil alcançou a marca de 45,42\%, em 1950 representava apenas 36,13\%. Considerando que os efeitos da industrialização se fizeram sentir da década de 60 para 70, pode-se atribuir a ela a inversão campo-cidade, ao se atingir em 1970 o índice de 56,80\% de urbanização. Esse período compreendido entre o final dos anos sessenta e o início dos anos setenta é tido como a época do milagre econômico, quando a classe média experimentou uma elevação significativa do seu poder de consumo. Porém, esse superávit advindo da produtividade agrícola nada mais era do que a consolidação da expansão capitalista a partir das bases econômicas e políticas anteriormente implantadas. Segundo AGLIETTA (1989), "a condição econômica fundamental para que o capitalismo industrial se desenvolva é a formação de um excedente agrícola crescente e a sua realização sob a forma de bens". ${ }^{2}$

Essa fase de acumulação extensiva do capitalismo não conseguiu anular 0 efeito negativo decorrente da rápida industrialização baseada em pólos de crescimento: a concentração de renda nas mãos de uma pequena classe dominante. ${ }^{3}$ Conforme HABERT, "o arrocho salarial e a intensificação da exploração do trabalho foram os elementos básicos para a grande acumulação de capitais." ${ }^{4}$ Para MAUTNER "A predominância de um estágio extensivo de acumulação requer e se reflete claramente em baixos níveis de reprodução - tanto no que se refere à moradia, educação, como também a própria nutrição. A distribuição de renda no Brasil e seus níveis de concentração são uma ilustração eloqüente disso". ${ }^{5}$ Assim, o modelo de

\footnotetext{
${ }^{1}$ REIS (1996), p. 11-16.

2 AGLIETTA (1989), p. 10.

${ }^{3}$ NAMUR (1992), p. 9: autores como Bresser Pereira, Octavio Ianni, Geraldo Serra.

${ }^{4}$ HABERT (1996), p. 14.

${ }^{5}$ MAUTNER (1999), p. 254.
} 
desenvolvimento brasileiro teve um rebatimento espacial de caráter excludente, principalmente em decorrência da migração de massas populacionais para as cidades, da incapacidade dos novos mercados de trabalho no atendimento às demandas, das disparidades crescentes de renda pessoal e de déficits de infra-estrutura urbana. Nesse sentido, recorre-se ao conceito de espoliação urbana em KOWARICK:

"A noção de espoliação urbana é a somatória de extorsões que se opera através da inexistência ou precariedade de serviços de consumo coletivo que (conjuntamente com o acesso à terra e à habitação) se apresentam como socialmente necessários em relação aos níveis de subsistência e que agudizam ainda mais a dilapidação que se realiza no âmbito das relações de trabalho.

[...] O conflito social (de classes) espelha-se no tecido urbano gestando contínuos e variados processos de produção e apropriação dos assim chamados espaços construídos. Sua expressão mais visível reside na segregação sócio-econômica e espacial imperante nas áreas desigualmente providas de bens e serviços: constatava-se que, ao valorizar certas áreas, as populações pobres que não podem pagar o assim chamado preço do progresso, são delas expulsas, e desta forma, novas zonas periféricas destituídas de benfeitorias básicas são constantemente produzidas, aumentando o caos urbano e os custos de urbanização." 6

Sob o projeto de desenvolvimento da ditadura militar, a industrialização e a infra-estruturação em escala nacional em curso foram acompanhadas pela discussão da institucionalização das metrópoles. Tal discussão foi iniciada já na Constituição de 1967, quando se propôs a criação de regiões metropolitanas, e embasou a realização de estudos desenvolvidos pela SERFHAU em 1968, para uma política diferenciada para as maiores aglomerações urbanas do país, em reconhecimento de pólos metropolitanos. ${ }^{7}$ A figura da região metropolitana foi então oficialmente instituída ${ }^{8}$ pela legislação federal em 1973, a fim de se planejar a alocação de investimentos em infraestrutura e equipamentos de maior envergadura, além de controlar o crescimento e a expansão urbana. A COMEC - Coordenação da Região Metropolitana de Curitiba criada em 1974, tinha como competências mestras dentro da formulação e execução das políticas públicas metropolitanas, o planejamento integrado da metrópole, bem

\footnotetext{
${ }^{6}$ KOWARICK (1997), p. 105 e 106.

${ }^{7}$ MOURA et al (2003), p 33-56.: "Embora definidas mediante critérios técnicos, foram verificados sinais de fragilidade na seleção das áreas, como se evidenciou no caso das RMs de Belém e Curitiba, cuja dinâmica metropolitana na época podia ser considerada menos intensa que a de outros centros, como Brasília, preterido do processo federal de institucionalizações."

${ }^{8}$ Lei Federal n. ${ }^{\circ}$ 14/73.
} 
como direcionar os planos municipais de desenvolvimento. ${ }^{9}$ Das diretrizes nacionais posteriormente discutidas no primeiro Plano de Desenvolvimento Integrado, vale ressaltar como forças agentes e mecanismos de metropolização: (i) a imensidão continental do espaço disponível posto à disposição do habitante, (ii) a fortíssima e constante imigração do campo e das cidades menores, responsável por $60 \%$ do incremento populacional na época, (iii) o uso do solo como bem intensamente comerciável, força essa agindo com maior eficácia precisamente onde a imigração e o crescimento se acentuam, e (iv) a força indutora de qualquer equipamento urbano quando inserido no contexto de cidades desprovidas de melhorias. ${ }^{10}$ Cabe inserir que em 1978, é formulado o primeiro Plano de Desenvolvimento Integrado da Região Metropolitana de Curitiba, a partir das diretrizes da Política Nacional de Desenvolvimento Urbano. ${ }^{11} \mathrm{Na}$ época, tanto Curitiba como as áreas mais periféricas absorveram significativos contingentes populacionais de baixa renda, face a acentuação da crise econômica nacional. Assim, um dos principais pilares do plano regional era a contenção da expansão à leste, em função da concentração de mananciais da Serra do Mar.

A composição inicial da Região Metropolitana de Curitiba - a RMC - contava com quatorze municípios, sendo sete deles contíguos à Curitiba - Almirante Tamandaré, Colombo, Piraquara, São José dos Pinhais, Mandirituba, Araucária e Campo Largo.

\footnotetext{
${ }^{9}$ Lei Estadual n. ${ }^{\circ} 6517 / 74$.

${ }^{10}$ COMEC (2006), p. 32, em PDI-RMC.

${ }^{11}$ COMEC (1999), p. 21, em Metrópolis em Revista, $\mathrm{n}^{\circ} 1$.
} 


\section{FIG. 1 - REGIÃO METROPOLITANA DE CURITIBA - CONFORMAÇÃO ATUAL}

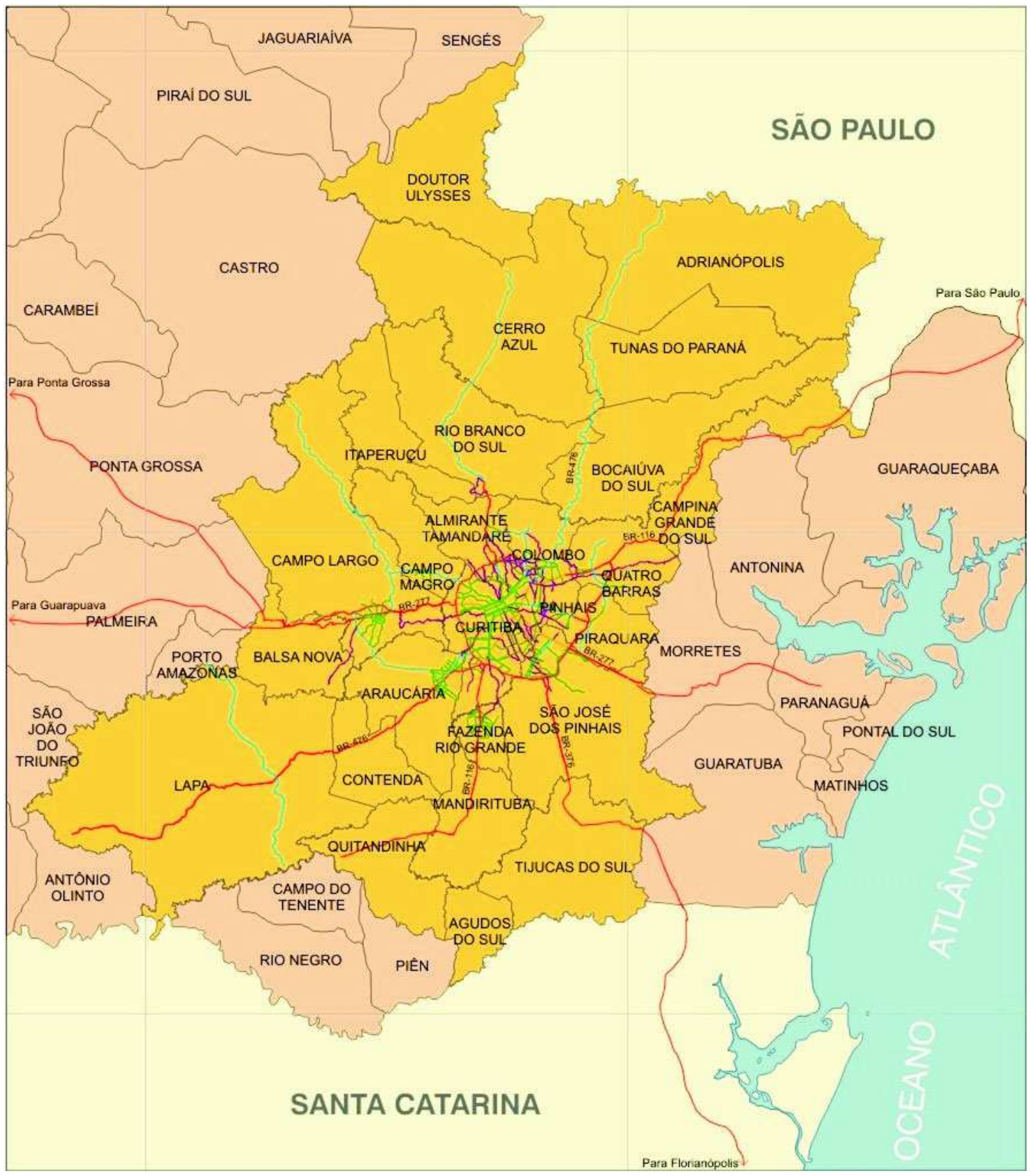

\section{FONTE: COMEC, PDI-RMC (2006)}




\section{FIG. 2 - EVOLUÇÃO DA COMPOSIÇÃO DA REGIÃO METROPOLITANA DE CURITIBA}

\section{A 2002}
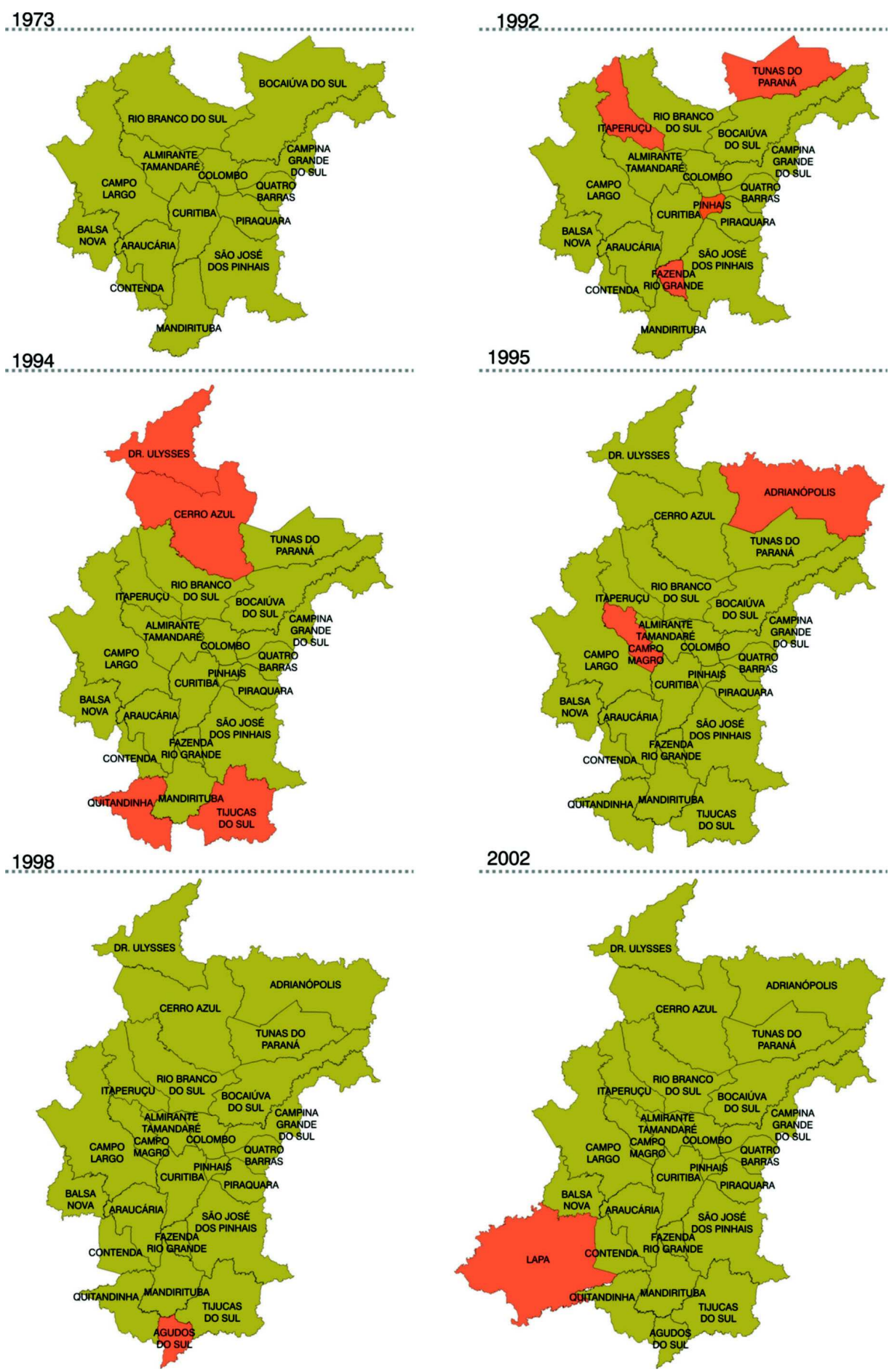

\section{FONTE: COMEC, PDI-RMC (2006)}


De acordo com SCHUSSEL, as mudanças na configuração espacial da RMC se deram em função de que na constituição de $1988,{ }^{12}$ a competência de legislar sobre a criação das regiões metropolitanas no país passava da União para os Estados:

“(...) a partir disso, a Assembléia Legislativa do Estado do Paraná incluiu doze novos municípios na região entre 1988 e 2005, sendo alguns desmembrados ${ }^{13}$ de municípios já pertencentes à região metropolitana, fazendo com que a área da região, que inicialmente era de $8.000,00 \mathrm{~km}^{2}$, passasse para $13.306,00 \mathrm{~km}^{2} \mathrm{em}$ 2000, o que corresponde praticamente ao dobro da área da região metropolitana de São Paulo. A incorporação de novos municípios, baseada em critérios exclusivamente políticos fez com que a região absorvesse problemas de ordem social e econômica, cuja origem era muito mais rural do que urbana." ${ }^{14}$

Sobre as fases de desenvolvimento da economia paranaense, tem-se apoio em MACEDO et al, quando discutem as transformações que ocorreram na dinâmica espacial da economia brasileira. Os autores destacam uma tentativa do Paraná, na década de 60, em montar um projeto de industrialização autônoma, com base na concepção de um modelo paranista de desenvolvimento, agenciado pela CODEPAR Companhia de Desenvolvimento do Estado do Paraná. O modelo centrava-se em três objetivos "potencialmente sinérgicos: (i) integração do Estado, então fracionado no Paraná cafeeiro-paulista e nas fronteiras de ocupação do oeste; (ii) a integração vertical plena da economia paranaense, via um processo radical de substituição das importações, principalmente de bens intermediários e de capital, e (iii) o fortalecimento e a expansão dos pequenos e médios capitais locais." ${ }^{15}$ Porém, na prática, nos anos 70 e 80 , alguns fatores contribuíram para definir os limites de um desenvolvimento "autônomo" das economias regionais, refletidos principalmente nos I e II PND's, e que induziram a um processo de desconcentração da atividade econômica a partir do centro dinâmico paulista-paulistano. Foram eles: a modernização da agricultura, os

\footnotetext{
12 "Findava, assim, um modelo considerado autoritário e centralista - que criou regiões sobre as quais os estados federados não tinham autonomia para intervenção -, e se abriam possibilidades de inserção das regiões metropolitanas em processos estaduais de planejamento regional. Além de regiões metropolitanas, admitiu outras categorias de organização regional, como as aglomerações urbanas e as microrregiões.” Em MOURA et al (2003), p 33-56.

${ }^{13}$ Os municípios desmembrados foram cinco: Campo Magro (de Almirante Tamandaré), Pinhais (de Piraquara), Fazenda Rio Grande (de Mandirituba), Tunas do Paraná (de Bocaiúva do Sul) e Itaperuçu (de Rio Branco do Sul).

${ }^{14}$ SCHUSSEL (2006), p. 122-124.

${ }^{15}$ MACEDO et al (2002), p. 11.
} 
novos rumos da industrialização e as diferentes articulações do tripé capital estatal / capital estrangeiro / capital nacional. Assim, o desenvolvimento paranaense neste período caracterizou-se como complementar ao núcleo dinâmico de São Paulo.

Observa NAMUR que o projeto mais audacioso implantado na primeira gestão de Lerner (1971-1974) foi a CIC - Cidade industrial de Curitiba. Sua concepção ia ao encontro às diretrizes do plano diretor quanto à descentralização das atividades urbanas. ${ }^{16}$ De acordo com Cássio Taniguchi, em função da abertura da economia brasileira ao capital estrangeiro, a idéia era atrair investidores por meio de alternativas locacionais vantajosas em âmbito nacional. Disto resultaram as estratégias de incentivos fiscais e também o enfoque conceitual do projeto: "[...] Com a clarividência de marketing do Jaime Lerner o empreendimento passou a chamar-se Cidade Industrial de Curitiba, pois não era um distrito, uma área segregada. Não deveria ser um núcleo industrial marginalizado, mas interligado à cidade". ${ }^{17}$

Dessa forma para o projeto da CIC foi contratado o arquiteto Jorge Wilheim, que em 1966 havia concebido o Plano Preliminar de Urbanismo de Curitiba. A área disponível, localizada na bacia do Rio Barigüi, contava com aproximadamente quatro mil hectares. Em função da sua escala, deveria congregar outras funções além do uso industrial - serviços de apoio às indústrias, um terminal de cargas e habitação. ${ }^{18}$ As soluções adotadas no projeto propiciaram a criação de uma paisagem típica. Para promover a integração da CIC com o sistema de vias estruturais previsto no Plano Diretor, foram propostas cinco vias de ligação, chamadas de eixos conectores. A fim de possibilitar uma solução mais econômica, conseguiu-se junto ao governo federal que o traçado do Contorno Sul fosse alterado e passasse dentro da Cidade Industrial, fazendo o papel do seu eixo estruturante. A implantação da CIC ficou a cargo da URBS, que na época tinha atribuição para implantar o sistema viário: foram executados ao longo da gestão cerca de $400 \mathrm{~km}$ de vias através de planos comunitários, viabilizados mediante contribuição de melhoria. Na presidência do órgão estava o engenheiro Cássio Taniguchi (1972-75). ${ }^{19}$ A partir de 1972, coube à URBS a implantação da infra-estrutura na área sul da CIC - em uma primeira etapa - que teve uma duração aproximada de dois anos. Várias empresas lá se implantaram até o final da gestão de Lerner. Objetivava-se atrair indústrias que utilizassem tecnologias de ponta, não poluentes, agregadoras de mão-de-obra. Como o processo de implantação

\footnotetext{
${ }^{16}$ NAMUR (1992), p. 83.

17 Conforme Taniguchi, em entrevista à NAMUR (1992), p. 81.

18 Segundo Taniguchi, em NAMUR (1992), p. 81.
} 
das indústrias foi gradativo, foi criada na seqüência a CIC S.A., empresa desdobrada da URBS para assumir a implantação. ${ }^{20}$ A segunda fase de implantação da CIC foi marcada pela instalação da VOLVO no Brasil, em 1977. Segundo LOURENÇO, “[..] $A$ definição dos projetos da refinaria de petróleo de Araucária e da montadora sueca VOLVO constitui um exemplo acabado de influência das gestões de natureza política na garimpagem de empreendimentos-âncora pelos estados de industrialização retardatária”. ${ }^{21}$

NAMUR, ao referenciar-se aos períodos da economia adotados por SERRA (1981), ${ }^{22}$ a CIC teria sido concebida no período ascendente - milagre econômico - e implantada no período descendente do desenvolvimento brasileiro, ou seja, o caso de Curitiba teria se dado de forma anti-cíclica. Cabe ainda ressaltar algumas especificidades da dinâmica da economia estadual paranaense desse período: de um lado, a concentração industrial na RMC, principalmente ligada ao setor metalmecânico, e de outro, o processo de industrialização da agricultura que desencadeou fortes impulsos dinâmicos no Paraná como um todo. As transformações nas relações de produção no campo, aliadas às mudanças na estrutura de emprego, conduziram a intensas migrações rural-urbanas, responsáveis por intensificar os processos de urbanização e de metropolização no Estado, além da expulsão de expressivo contingente populacional para outras regiões do país.

A implantação da CIC alterou o perfil industrial paranaense, promovendo mudanças de ordem qualitativa em sua esfera econômica. Em contraposição a este fato inicia-se em Curitiba nos idos de 1973-74, um processo de favelização associado à sua implantação, por meio do fluxo migratório impulsionado pela oferta de empregos. ${ }^{23}$ Conforme observa MOURA,

"A dinâmica de urbanização no Paraná se deu num ritmo intenso e num curto espaço de tempo, com o êxodo rural desenvolvendo um vetor convergente à Curitiba e adjacências. [...] Essa velocidade e intensidade do crescimento urbano geraram impactos perversos na estrutura das cidades. [...] Durante a década de 70, o crescimento do pólo metropolitano foi expressivo, resultando na densificação das áreas centrais e na horizontalização da ocupação em direção ao setor sul da cidade, área até então carente de infra-estrutura e serviços. No mesmo período,

\footnotetext{
${ }^{20}$ OLIVEIRA (2000), p. 104.

${ }^{21}$ LOURENÇO (2000), p. 3-4.

22 NAMUR (1992), p. 9: 1947-1967 - as bases da industrialização no Brasil; 1967-1973 - o milagre econômico; 1973-1980 - a inflexão do crescimento e a desaceleração. Tais períodos seriam também adotados por Bresser Pereira e Otavio Ianni.
}

${ }^{23}$ IPPUC (1991), Depoimentos 6, p. 21-32. 
intervenções urbanísticas e modernização de estruturas urbanas fizeram de Curitiba um espaço singular, mais valorizado, capacitado ao desempenho de complexas relações econômicas e sociais e à localização de plantas das mais diversas atividades. Conseqüentemente, o preço da moradia tornou-se excludente a uma parcela significativa da população originada do processo migratório e do próprio empobrecimento da população local, o que resultou na incompatibilidade criada entre o valor da moradia ofertada e o padrão aquisitivo da demanda. Um processo seletivo se constata na apropriação do solo urbano." ${ }^{24}$

Faz-se necessário citar que, em 1978, foi elaborado pela COMEC o primeiro Plano de Desenvolvimento Integrado para a RMC, embasado nas diretrizes da Política Nacional de Desenvolvimento Urbano e nos princípios teóricos dos lugares centrais e na teoria dos sistemas. Apresentava três premissas básicas: (i) preservação dos recursos naturais com ênfase nos recursos hídricos, (ii) geração de riqueza, mediante a otimização da exploração mineral e agropecuária, bem como do desenvolvimento industrial, e (iii) melhoria das condições de vida da população metropolitana pela orientação do crescimento urbano e pela criação de subcentros regionais de forma a estruturar uma rede urbana hierarquizada de serviços e funções urbanas. Em SCHUSSEL, tem-se que:

"A elaboração do Plano ocorreu na fase áurea do planejamento no Brasil, em que se acreditava na viabilidade dos planos de desenvolvimento integrado e na possibilidade de sua implantação por meio de grandes inversões de recursos na infra-estrutura regional. Tratava do macrozoneamento regional, que não contemplava as questões intra-urbanas de Curitiba." 25

O desenvolvimento urbano foi orientado para oeste, pois na Serra do Mar à leste, estão as cabeceiras do Rio Iguaçu, área então reservada aos mananciais de abastecimento. Os impeditivos ao norte referiam-se ao relevo acidentado, impróprio para a urbanização e, ao sul, a grande calha do Rio Iguaçu, que limitava a expansão da malha urbana.

Entre 1950 e 1980, a população da Região Metropolitana de Curitiba passou de 317.442 para 1.440.626. A distribuição da população caracterizava-se pela concentração em Curitiba e seu entorno imediato. A participação de Curitiba no total da população regional passa de 68,87\% em 1960 para 74,15\% em 1970; em 1980, Curitiba sozinha supera a faixa de um milhão de habitantes, representando $71,14 \%$ da

\footnotetext{
${ }^{24}$ MOURA (1998a), p. 57-61.

${ }^{25}$ SCHUSSEL (2006), p. 97.
} 
região. Este declínio, segundo ULTRAMARI e MOURA, demonstra que começa a ocorrer uma busca maior pela ocupação nos demais municípios em detrimento da cidade central. Segundo os autores, "os municípios que mais cresceram foram também os que mais se urbanizaram", ${ }^{26}$ tendo sido Colombo o que teve o maior crescimento da população urbana registrado na região entre 1950-1980.

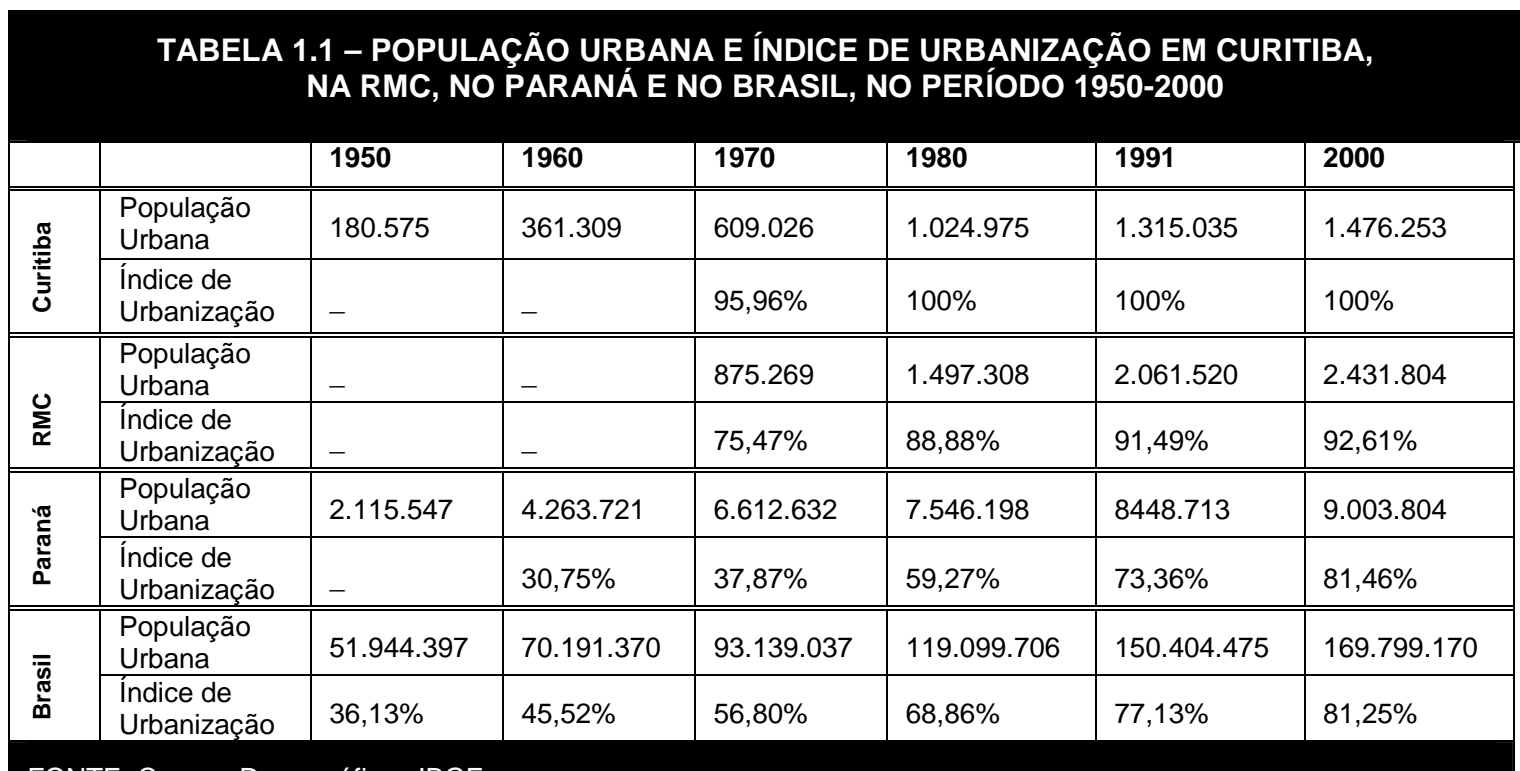

FONTE: Censos Demográficos IBGE

ULTRAMARI e MOURA apontam que a intensidade do processo de ocupação do espaço metropolitano deveu-se a dois fatores:

"O primeiro ligado à presença de atividades produtivas e geradoras de emprego, como ocorre em Araucária - segundo distrito industrial ${ }^{27}$ em importância na região, superado apenas pela Cidade Industrial de Curitiba; São José dos Pinhais, que conjuga atividades produtivas do setor secundário e a maior acessibilidade ao pólo, acumulando assim a função "dormitório"; e Rio Branco do sul - pólo de atividades da indústria de transformação de minerais não metálicos. O segundo fator, e nesse caso o mais forte, está ligado ao custo da terra e às restrições impostas pelo planejamento urbano de Curitiba que direcionaram a ocupação para áreas contíguas ao pólo, em territórios de outros municípios. Estes ofereciam disponibilidade de terra parcelada e de menor valor, aliada à acessibilidade ao pólo, garantindo a moradia a uma faixa de população economicamente ligada às atividades do secundário e terciário concentradas em Curitiba". ${ }^{28}$

\footnotetext{
${ }^{26}$ ULTRAMARI e MOURA (1994), p. 9.

${ }^{27}$ Somente até meados da década de 1990, quando a indústria automotiva passa a São José dos Pinhais o segundo lugar, ficando Araucária em terceiro lugar.

${ }^{28}$ ULTRAMARI e MOURA (1994), p. 9.
} 
Os municípios que se enquadram neste segundo fator são os que mais cresceram entre 1970 e 1980 - Almirante Tamandaré, Colombo e Piraquara, à norte, nordeste e leste de Curitiba - podendo ser caracterizados como municípios dormitórios. Nesses três municípios, a maioria da população urbana reside nas áreas contíguas à Curitiba, distantes das sedes, fenômeno que também se verifica em menor escala nos demais municípios da região, "o que ressalta o extravasamento da metrópole e a criação de periferias em uma faixa extensa e contígua ao pólo, abrangendo áreas dos municípios limítrofes". ${ }^{29}$ Os autores ainda ressaltam que:

"[...] o fenômeno da periferização, principal traço da metropolização de Curitiba, vêse acarretar agravos ao setor público no que tange à oferta de serviços e infraestrutura, impondo uma qualidade de vida de baixo padrão a uma população crescente. [...] Por conseguinte, as feições das cidades sofrem abruptas transformações. [...] A descaracterização original das cidades vem acompanhada por uma mudança na estrutura produtiva regional. A participação percentual dos setores de atividade na renda interna bruta da Região demonstra que a indústria assume grande importância, passando de 24,65 para 43,8\% da renda, na última década [1970-1980], enquanto os serviços e a agricultura perdem em termos relativos".30

Segundo MAUTNER, deve-se evitar uma aproximação fragmentada antes de definir o conceito de periferia:

"O conceito mais óbvio para definir periferia é sem dúvida o geográfico, dada sua posição em relação às áreas centrais; na sociologia a tendência dominante foi seguir o viés "marginalista", via "urbanização sem industrialização" (inchamento do terciário). A contribuição da economia sendo a indicação da periferia como o locus de menor renda diferencial urbana." 31

"[...] consideramos a periferia como base de um processo de produção de espaço urbano. A periferia é de fato um local onde vivem os pobres, é socialmente segregada, e o preço da terra é baixo, porém, ao mesmo tempo, é um local mutante, sempre reproduzido em novas extensões de terra, enquanto velhas periferias são gradualmente incorporadas à cidade, ocupadas por novos moradores e reorganizadas pelo capital'. ${ }^{32}$

\footnotetext{
${ }^{29}$ ULTRAMARI e MOURA (1994), p. 10.

${ }^{30}$ Idem.

${ }^{31}$ MAUTNER (1999), p. 253, nota 16.

${ }^{32}$ Idem, p. 253-254.
} 
Em BONDUKI e SANTORO, tem-se que "muitas vezes a criação de novas áreas urbanas atendem mais aos interesses imobiliários, do que a necessidade de espaço para comportar o crescimento populacional [...]. Na década de 70, houve uma significativa produção de literatura sobre o crescimento periférico. [...] Nessas pesquisas o ator principal era o Estado, sua ausência, e suas políticas." Mesmo a Lei Federal 6.766/79 tendo transferido a responsabilidade de infra-estruturação dos loteamentos para o empreendedor, "ainda é freqüente a existência de loteamentos privados à espera do poder público completar a infra-estrutura". ${ }^{33}$

Com relação às características do processo de parcelamento do solo nos municípios lindeiros à Curitiba - especialmente à leste - durante o período que antecede a criação da COMEC, explica SCHUSSEL que:

"Até a década de 1980, o processo de parcelamento do solo nos municípios lindeiros à Curitiba ocorreu sem controle, gerando vazios urbanos entre os loteamentos aprovados, falta de continuidade no sistema viário e um excesso de lotes que eram vendidos com infra-estrutura mínima. Esses lotes eram vendidos nos terminais de ônibus de Curitiba, com facilidades de pagamento e parcelados a longo prazo, e eram adquiridos pela população de baixa renda, que em muitos casos não conseguia a documentação do imóvel. Com a instituição da Lei Lehman em 1979, e a exigência da anuência prévia pela COMEC, esse cenário se alterou e houve uma diminuição no número de lotes aprovados nesses municípios.

Nos municípios à leste, principalmente em Piraquara, o processo de parcelamento intensivo ocorreu na década de 1950, com a aprovação de loteamentos em áreas frágeis do ponto de vista ambiental e que posteriormente se transformaram em áreas de proteção dos mananciais de abastecimento de Curitiba, com a execução das represas do rio Piraquara e do rio Iraí. Esses loteamentos não foram implantados e suas áreas se tornaram focos de invasões na década de 1990, surgindo a maior ocupação da RMC, o Guarituba, onde atualmente residem em torno de 40.000 pessoas. No município de São José dos Pinhais foram implantados muitos loteamentos ao longo da BR 277, criando um grande conflito entre o tráfego rodoviário e as áreas residenciais, com um número expressivo de atropelamentos na região" ${ }^{34}$

Importante se faz caracterizar os agentes desse processo de parcelamento até o final dos anos setenta: "os loteadores eram empresas imobiliárias que implantavam

\footnotetext{
${ }^{33}$ BONDUKI e SANTORO (2009), p. 4-6.

${ }^{34}$ SCHUSSEL, em entrevista à autora, no Anexo 1 .
} 
os loteamentos com uma infra-estrutura mínima e vendiam em prestações de 10 a 15 anos. Os compradores por sua vez, eram de baixa renda e muitas vezes se tornavam inadimplentes, possibilitando que os loteadores retomassem os lotes e os vendessem novamente" ${ }^{35}$ A produção de lotes populares nas décadas de 60 e 70 foi maior que a demanda na região metropolitana de Curitiba. Em vista disso, a ocupação ocorreu de maneira muito dispersa. Como resultado, formaram-se significativos vazios urbanos que se somaram aos vazios intersticiais existentes entre os loteamentos. "Em 1985, foi feito um levantamento pela COMEC do número de lotes aprovados nesses municípios e do número de lotes vagos, e o resultado mostrou essa situação: Mandirituba $87,14 \%$ dos lotes existentes no município se encontravam vagos (Fazenda Rio Grande nessa época ainda era distrito de Mandirituba); Quatro Barras - 82,64\%; Campina Grande do Sul - 78,58\%; São José dos Pinhais - 70,34\%; Piraquara - 62,29\%". 36

\footnotetext{
${ }^{35}$ SCHUSSEL, em entrevista à autora, no Anexo 1.

${ }^{36}$ Idem.
} 


\section{FIG. 3 - EVOLUÇÃO DA OCUPAÇÃO URBANA NA RMC - 1955 a 1999}

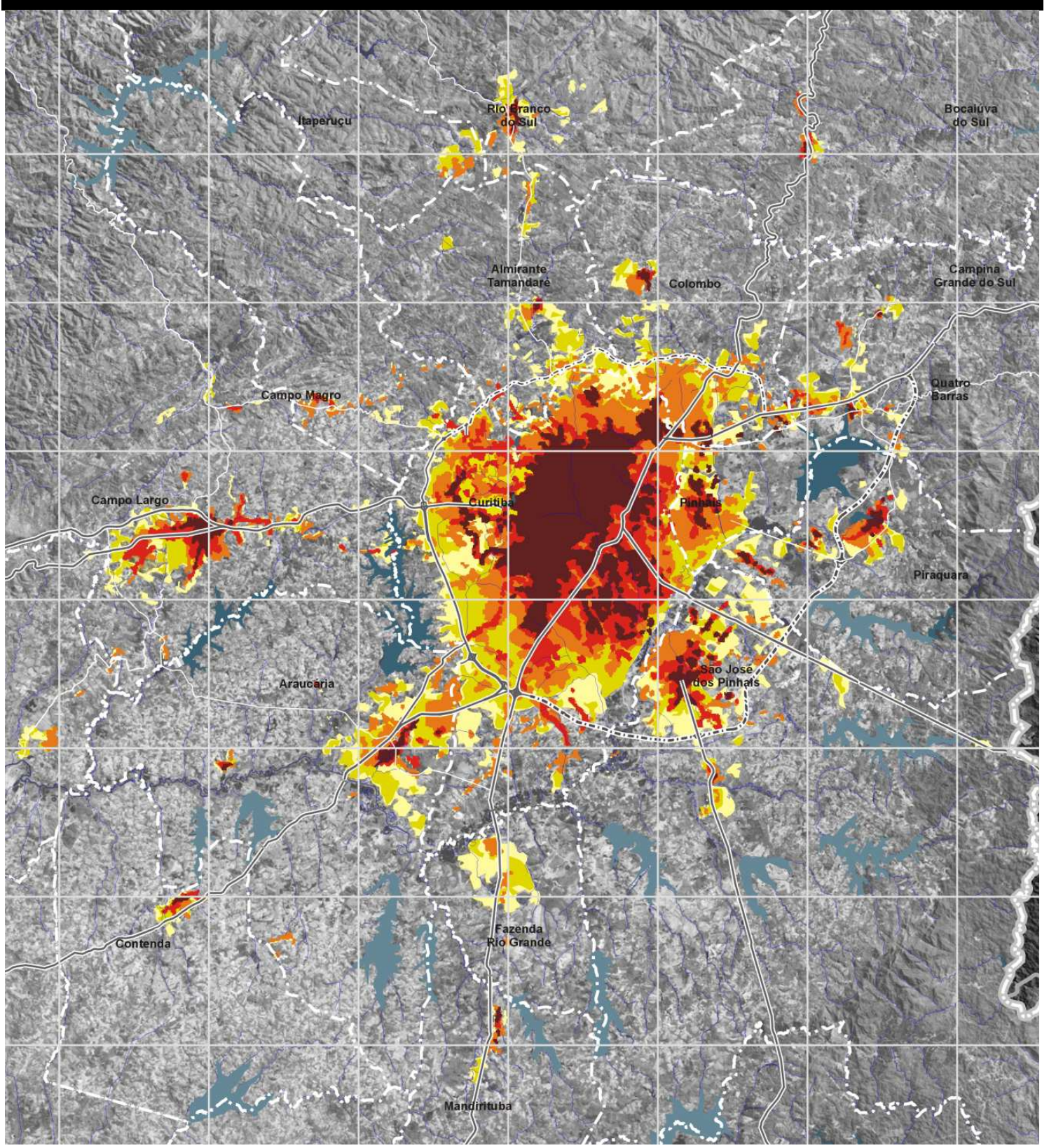

FONTE: COMEC - MANCHAS 1955, 1965, 1975, 1985 E 1999

Em termos de dinâmica de ocupação do território, é importante ressaltar que na década de 70, a malha urbana de Curitiba, até então compacta, ultrapassara a BR 116 que até então a limitava. Os municípios de São José dos Pinhais e o distrito de Pinhais, ainda pertencente à Piraquara, já apresentavam áreas conurbadas a leste 
com Curitiba. Também a oeste, a implantação das áreas industriais em Curitiba e Araucária induziram novas ocupações. ${ }^{37}$ Nota-se pela evolução da ocupação que os vazios gerados nas décadas de 60 e 70 foram sendo preenchidos no período mais recente.

\section{A CURITIBA PLANEJADA e a grande intervenção urbana: os corredores estruturais e a RIT - Rede Integrada de Transporte}

“[...] na virada da década de 70, São Paulo passava de uma grande cidade a uma aglomeração urbana de primeira grandeza, cuja população de 7 milhões já ultrapassava aquelas de Paris e logo de Londres, e que continuava crescendo a taxas acima de 5\% ao ano. Passava também por uma "crise de crescimento": suas estruturas físicas tinham sua capacidade esgotada e estavam à beira do colapso. O sistema de vias e de transportes em particular, instalado na década anterior e baseado no bonde, no ônibus, e uma incipiente, mas rapidamente crescente motorização individual sobre as "avenidas" do Plano de Prestes Maia - era a época da desova das primeiras levas de produção da indústria automobilística recéminstalada - havia se tornado inteiramente obsoleto. Não se tratava da necessidade de mera melhoria do sistema existente, senão da criação de estruturas de características, e principalmente, de escala inteiramente novas." 38

Em Curitiba, a história do transporte é na verdade, a história do planejamento urbano. Para se falar da RIT - Rede Integrada de Transporte - faz-se necessário contextualizar historicamente, sua concepção e implantação. O plano diretor de 1966 tinha como premissa básica a linearização da cidade, no sentido de desafogar a área central e ao mesmo tempo expandir as funções centrais ao longo de eixos estruturais, eixos esses concebidos a partir da integração entre uso do solo, transporte e sistema viário - segundo o IPPUC, o "tripé" conceitual do planejamento em Curitiba. Tendo como idéia central a priorização do transporte coletivo sobre o individual, os eixos estruturais - numa extensão de $20 \mathrm{~km}$ - foram desenhados para serem grandes corredores de transporte coletivo, e para tanto com uma proposta de sistema viário

\footnotetext{
${ }^{37}$ COMEC (1999), p. 18, Metrópolis em Revista, $\mathrm{n}^{\circ} 1$.

${ }^{38}$ DÉAK (1990), p. 42.
} 
diferenciada, e ao mesmo tempo, áreas de alta densidade atingidas via verticalização. Sobre a configuração diferenciada para as vias estruturais, cabe ressaltar que são compostas a fim de estabelecer um sistema trinário. As vias externas do trinário deveriam ter o papel de expressas, no sentido de ligar os bairros à área central da cidade - uma no sentido centro-bairro e outra no bairro-centro. A via central deveria comportar duas funções: propiciar acesso ao comércio ao longo do eixo - e para tanto, abrigando estacionamento - e abrigar as linhas troncais de transporte coletivo. Sendo assim, foi dividida em três pistas - duas de tráfego lento (sentidos centro-bairro e bairro-centro) separadas por uma canaleta exclusiva para o transporte.

Do detalhamento do Plano Preliminar de Urbanismo pelo IPPUC, resulta o Plano Diretor de Curitiba, aprovado pela Câmara de Vereadores em 1966, pela Lei 2828. Desse detalhamento surgiram os Corredores Estruturais de Curitiba, que alteraram sensivelmente a morfologia urbana de Curitiba - sua paisagem, agora associada à verticalização e ao adensamento - juntamente com a priorização do sistema de transporte coletivo sobre o individual - circulando em canaletas de uso exclusivo - passa a ter uma identidade não somente do desenho, mas a almejada visibilidade da modernidade. ${ }^{39}$ Esses corredores estruturais resultam da adaptação das vias estruturantes propostas por Wilheim no Plano Preliminar, com largura aproximada de 60 metros, agora adaptadas em um sistema trinário: uma via especial central entre duas vias rápidas - sentido centro-bairro e bairro centro. A via central também é dividida em três partes: uma canaleta exclusiva para transporte coletivo ao centro e duas vias de tráfego lento, contendo estacionamentos, também nos sentidos centro-bairro e bairro centro, a fim de atender ao princípio de linearização das funções do centro da cidade ao longo dos corredores.

Para as duas quadras localizadas entre as vias do sistema trinário, foi proposto um plano de ocupação denominado Plano Massa, que associava a verticalização e o adensamento ao partido da linearização. Nos pavimentos térreos e nas sobrelojas, abrigaria uma sucessão de galerias de comércio e serviços, para que as funções centrais fossem estendidas para os bairros e, sobre essas galerias, torres residenciais para promover o adensamento populacional ao longo dos corredores de transporte coletivo.

${ }^{39}$ SALLEM (2006). p. 88. 


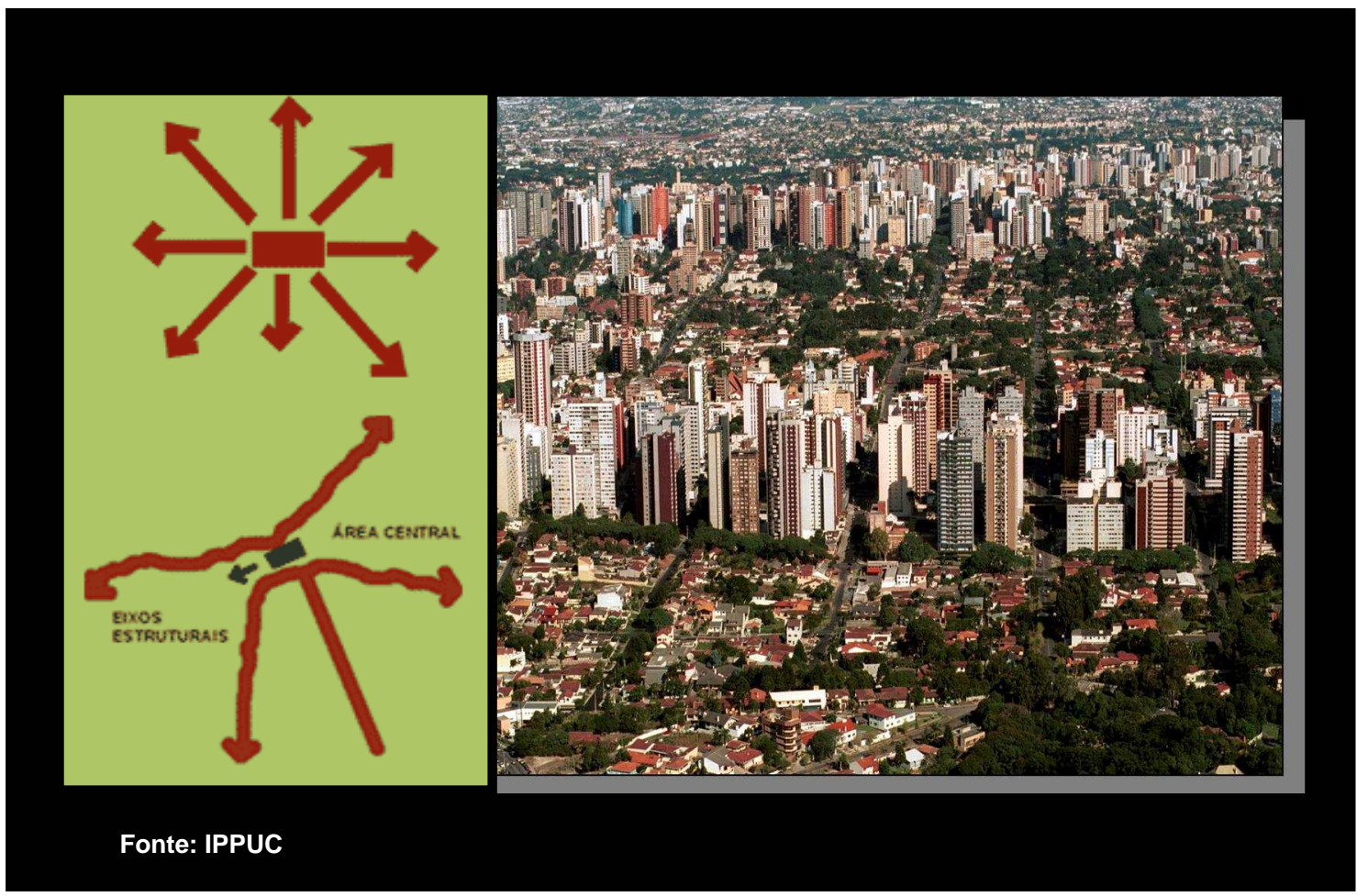

A implantação do sistema de transporte em Curitiba teve início ao final da primeira gestão municipal de Lerner (1971-1974). A primeira etapa do sistema de transporte coletivo, que circularia nas pistas exclusivas - as canaletas - teriam paradas a cada 400 metros. Ao mesmo tempo, foram abertas as vias rápidas nos setores norte e sul. As estações de embarque e desembarque, localizadas ao longo das vias estruturais, foram objeto de um projeto específico, a fim de que se criasse uma linguagem própria e comunicante na paisagem da cidade. Assim, em setembro de 1974, 20 ônibus expressos entraram em funcionamento em caráter experimental. 


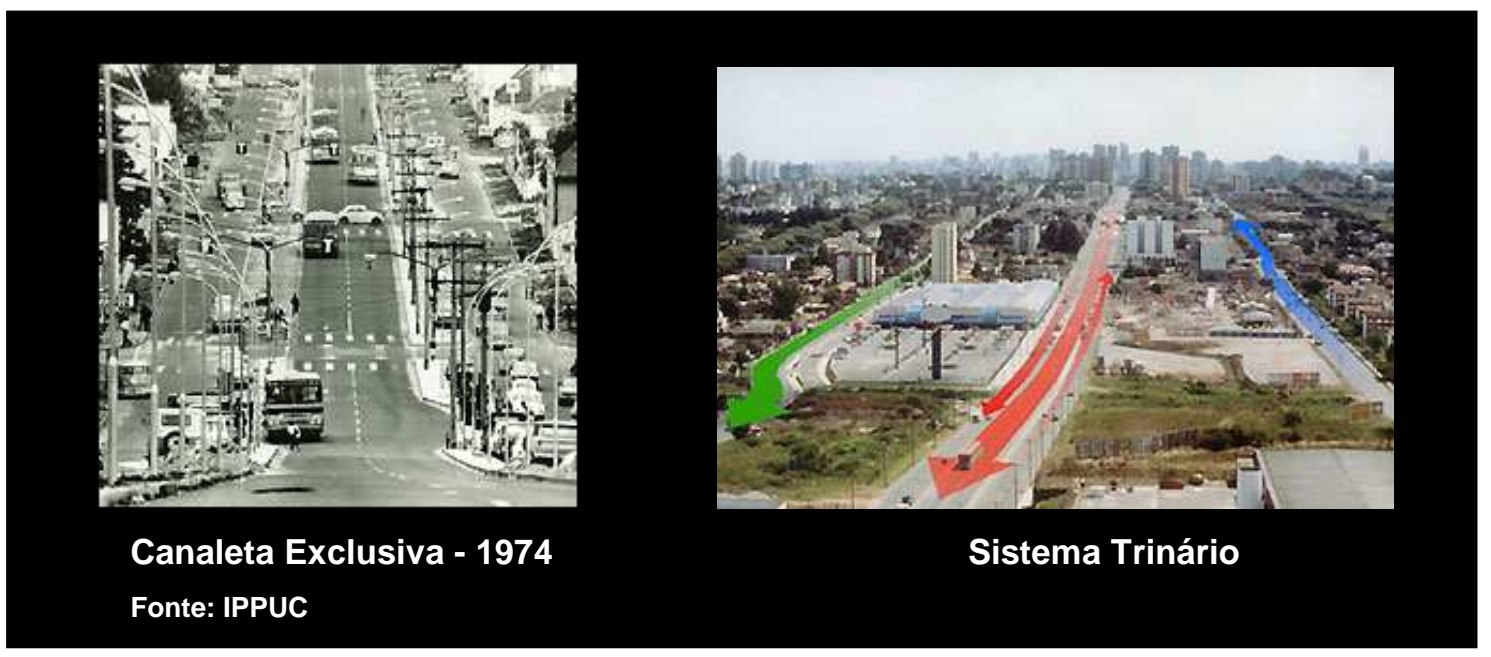

O fato de Lerner retornar como prefeito em 1979, uma nova imagem da cidade é produzida então por um discurso legitimado a priori, a cidade-modelo em planejamento no país. Tal imagem, amplamente divulgada, disseminou-se em função da credibilidade advinda da experiência anterior - a primeira fase de implantação do Plano Diretor - e, principalmente, do respaldo político federal e estadual que the garantiu a sustentação. LEITÃO revela que a sustentação do discurso da cidade modelo diante da crise econômica que assolava o país é agora a RIT, que se constituiu em um sistema de transporte de massa que passou a englobar linhas dos ônibus expressos, interbairros e alimentadores, articuladas nos terminais de integração. Em uma segunda etapa, foram inseridas as linhas interbairros, que formavam círculos sucessivos e de diâmetros crescentes, abrangendo assim, toda a cidade. Pelo fato da integração físico-tarifária, a acessibilidade ao sistema foi ampliada, bem como os níveis de mobilidade urbana; a rede propiciava portanto, eficiência e tarifas acessíveis. ${ }^{40}$

Anteriormente à RIT, o transporte coletivo em Curitiba era caracterizado por linhas que ligavam os bairros com o centro e também linhas diametrais. A operação da RIT, iniciada em 1974, se deu a partir das linhas expressas nos corredores estruturais norte e sul. Os ônibus, projetados para uma capacidade de 100 passageiros - em parceria com a VOLVO - tinham cores diferenciadas para as tipologias de linhas. De

\footnotetext{
${ }^{40}$ LEITÃO (2002), p. 92.
} 
acordo com Euclides Rovani, os alimentadores teriam a função de levar o passageiro aos terminais de integração - locais fechados que permitiam a integração tarifária implantados ao longo dos eixos estruturais. Essa concepção da RIT possibilitou que a tarifa do transporte coletivo em Curitiba até hoje se mantivesse entre as mais baixas do país. ${ }^{41}$ Entre os princípios que orientaram a sua implantação estavam a identificação do sistema de transporte com a cidade e sua participação enquanto elemento da paisagem urbana. O sistema transportava inicialmente 54 mil passageiros/dia, o que correspondia a 8\% da demanda, já em 1977, ao incorporar o eixo Boqueirão - em direção a São José dos Pinhais - o atendimento foi ampliado para $32 \%$, e em 1979, com a inserção de linhas interbairros, para 34\%. Findada a implantação dos eixos leste e oeste, a partir de 1980 a rede estava completa e a sua gestão passa a ser feita pela URBS:

"A RIT foi consolidada pela adoção da tarifa única, com os percursos mais curtos subsidiando os mais longos. A tarifa única possibilitou aos usuários efetuarem diversos trajetos com o pagamento de uma única tarifa, através da utilização dos terminais de integração ou, mais tarde, das estações tubo. Nesta época a URBS assume a gerencia do sistema como concessionária das linhas e empresas privadas operam como permissionárias. A remuneração dos serviços passa a ser feita por quilômetro rodado e não mais por passageiro". ${ }^{42}$

Em LEITÃO, tem-se que houve forte reação contrária à implantação da rede por parte dos empresários do setor de transporte. ${ }^{43}$ Desde a década de 50 , as empresas operavam por áreas seletivas, que agora seriam rompidas pela nova lógica de estruturação do sistema. Já naquela época, quando houve a concorrência para operação das áreas seletivas, os donos de lotação tiveram que se reunir em cooperativas - que por sua vez deram origem às atuais empresas - pois tais áreas eram definidas a partir de pares de linhas - uma de bom rendimento e outra de baixo

\footnotetext{
${ }^{41}$ IPPUC (1990), p. 69-82, Depoimentos 2: Conforme Euclides Rovani, responsável pela operacionalização da RIT quando da sua implantação.

${ }^{42}$ IPPUC - website acessado em dezembro de 2009.

${ }^{43}$ LEITÃO (2002), p. 16-17 e 92-93.
} 
rendimento. ${ }^{44}$ Segundo OLIVEIRA, o outro resultado importante da política dos anos 50 foi:

"[...] a criação de um sistema de transporte coletivo que, se dava algum controle do poder público sobre os serviços prestados, aumentava desproporcionalmente $o$ poder dos próprios empresários de ônibus. Para reforçar essa tendência, justamente nesta época foi fundado o Sindicato Estadual de Transportadores de Passageiros do Paraná, com sede em Curitiba, que congregava os novos empresários do ramo dos ônibus urbanos". ${ }^{45}$

OLIVEIRA ${ }^{46}$ conta que quando os ônibus expressos entraram em operação, a questão mais polêmica junto ao empresariado era a de se romper com as áreas seletivas fixadas vinte anos antes, seguida da postura contrária à adoção de um veículo "tão original e tão mais caro". Quanto ao veículo, prevaleceu o interesse da prefeitura; quanto à lógica de divisão das linhas, permaneceu a das áreas seletivas. Derivou disso que, para o passageiro percorrer a linha expressa norte-sul no início da operação - 1974 - era obrigatório descer do ônibus no centro e pegar o ônibus de outra empresa para seguir. "Concluindo, a tremenda revolução operada pela reforma urbana de Curitiba no ramo dos transportes coletivos em nada atingiu os interesses fundamentais dos empresários do setor, tendo contribuído, a médio prazo, para o reforço do seu poder político e econômico". Esse cenário começou a mudar no início dos anos 80 , quando da ascensão dos movimentos sociais urbanos. O reduzido número de empresários de ônibus em Curitiba - variou de 8 a 10 grupos entre 1975 e 2009 - apresentavam acirrada rivalidade até o final dos anos oitenta. De lá para cá, alteraram a sua prática política via fortalecimento do sindicato. Diz OLIVEIRA:

"Claro que entre os políticos sempre existiram empresários de ônibus. Os dois maiores deles, aliás, foram vereadores e, mais tarde, deputados estaduais (Donato Gulim e Erondy Silvério). Mas o que se viu surgir a partir de 1988 foi uma coisa totalmente diferente. Nesse novo padrão, o sindicato deixou sua postura meramente reativa face às iniciativas do poder público. Ele próprio passou a atuar junto à Câmara, deslanchando uma postura agressiva de eleição e cooptação de

\footnotetext{
${ }^{44}$ Conforme citado em "Documento Roteiro da Cidade: do bonde de mula ao ônibus expresso", editado pela Assessoria de Imprensa da Prefeitura Municipal de Curitiba (1975), p.20.

${ }^{45}$ OLIVEIRA (2000), p. 137-138.

${ }^{46}$ Idem, p. 139-150.
} 
vereadores, bem como criando um bloco parlamentar hegemônico, capaz não só de salvaguardar o setor contra quaisquer ameaças estatizantes, como também impor os seus pontos de vista sobre a gerência do transporte coletivo e, no limite, até mesmo se transformar em porta-voz de demandas de outros setores empresariais." 47

A implantação da rede impactou sensivelmente também os hábitos da população, que inicialmente resistia à idéia de trocar de veículo durante o percurso. Porém, a regularidade das viagens e a rigidez dos horários facilitaram posteriormente sua aceitação. ${ }^{48}$ Sobre esses impactos, comenta ROVANI:

“[...] fugindo ao padrão tradicional dos ônibus usados em todas as capitais brasileiras na época, Curitiba partiu para o veículo com uma porta no meio e depois, mais uma porta traseira. [...] Depois, junto à EBTU (Empresa Brasileira de Transportes Urbanos, vinculada ao Ministério dos Transportes) forçamos uma legislação na área de veículos. [...] conseguimos com o governo federal montar um projeto de ônibus urbano padrão". 49

O primeiro Plano de Desenvolvimento Integrado para a RMC, elaborado pela COMEC em 1978, embasado nas diretrizes da Política Nacional de Desenvolvimento Urbano e nos princípios teóricos dos lugares centrais e na teoria dos sistemas. Apresentava três premissas básicas: (i) preservação dos recursos naturais com ênfase nos recursos hídricos, (ii) geração de riqueza, mediante a otimização da exploração mineral e agropecuária, bem como do desenvolvimento industrial, e (iii) melhoria das condições de vida da população metropolitana pela orientação do crescimento urbano e pela criação de subcentros regionais de forma a estruturar uma rede urbana hierarquizada de serviços e funções urbanas. Em SCHUSSEL, tem-se que:

"A elaboração do Plano ocorreu na fase áurea do planejamento no Brasil, em que se acreditava na viabilidade dos planos de desenvolvimento integrado e na possibilidade de sua implantação por meio de grandes inversões de recursos na

\footnotetext{
${ }^{47}$ OLIVEIRA (2000), p. 151-152.

${ }^{48}$ IPPUC (1990), p. 76, Depoimentos 2.

${ }^{49}$ Idem, p. 77, Depoimentos 2.
} 
infra-estrutura regional. Tratava do macrozoneamento regional, que não contemplava as questões intra-urbanas de Curitiba." 50

O desenvolvimento urbano foi orientado para oeste, pois na Serra do Mar a leste, estão as cabeceiras do Rio Iguaçu, área então reservada aos mananciais de abastecimento. Os impeditivos ao norte referiam-se ao relevo acidentado, impróprio para a urbanização e, ao sul, a grande calha do Rio Iguaçu, que limitava a expansão da malha urbana.

\section{À CURITIBA REIFICADA sob a Capital Ecológica: qualidade de vida e pertencimento para alguns}

Conforme observam RIBEIRO e CARDOSO, ao final da década de 70, a ideologia do nacional-desenvolvimentismo entra em decadência, decorrente da falência da modernização conservadora empreendida a partir de do golpe militar. Sob um quadro de fortes tensões sociais, tanto no campo da organização sindical como da mobilização em torno das condições de vida, a crescente pressão dos movimentos sociais urbanos provocou a uma nova tematização da cidade: a dimensão social da questão urbana. ${ }^{51}$

Na década de 80, Curitiba passa da faixa de um milhão de habitantes para 1,3 milhão, a uma taxa de crescimento de $2.34 \%$ aa. No mesmo período, a RMC cresceu a uma taxa de 3,36\%, fazendo emergir os municípios periféricos à Curitiba, consolidando assim a sua área metropolitana. Entre os fatores que condicionaram esse processo de periferização figuraram o elevado preço da terra em Curitiba e as restrições impostas pelas legislações de uso e ocupação. Os municípios que mais cresceram no período foram: Colombo, Piraquara e São José dos Pinhais, seguidos por Almirante Tamandaré, Araucária e Campo Largo.

"Dessa forma, a periferização de Curitiba é acelerada rumo aos seus municípios vizinhos, que passam a receber a pressão de uma demanda crescente $e$ desestruturadora. [...] $O$ agravante desse processo é que o início da periferização

\footnotetext{
${ }^{50}$ SCHUSSEL (2006), p. 97.

${ }^{51}$ RIBEIRO e CARDOSO (1994), p. 85-87.
} 
deu-se, fundamentalmente, em áreas que mais tarde conviveriam com o dilema entre vetores de crescimento e a preservação de mananciais [...]" 52

Traçar um quadro da evolução da população e das características do crescimento populacional é de fundamental importância para a compreensão da metropolização recente em Curitiba. É, portanto, o que se passará a fazer, com apoio em SCHUSSEL. ${ }^{53}$ De 1970 a 2000, a população da RMC passou de 870 mil habitantes para o patamar de 2.770 mil habitantes. Nesse ponto é que a região alcançou efetivamente a escala metropolitana. Sua participação no total da população do Paraná saltou de 12,5\% em 1970, para 24,9\% em 1991 e 28,9 \% em 2000. Isso vem revelar que a tendência de crescimento populacional se mantém relativamente elevada, mas com uma estimativa de curva negativa para os próximos 20 anos, quando as taxas de crescimento permanecerão superiores a 2,0\% a.a. em 2010, tendo por referência que, atualmente, a taxa de crescimento brasileira é de 1,64\% a.a. Os números indicam, portanto, a continuidade das correntes migratórias externos para a região, embora em menor número dos que os verificados na década de 90 . Em um comparativo entre as regiões metropolitanas do sudeste e do sul do país neste período, a de Curitiba foi a única a apresentar taxas de crescimento demográfico do núcleo (Curitiba) e da periferia (demais municípios) superiores à taxa brasileira, que pode ser considerada como a de seu crescimento vegetativo, pois a imigração para o Brasil é inexpressiva.

\begin{tabular}{|c|c|c|c|}
\hline RM's & $1970 / 80$ & 1980 / 91 & $1991 / 96$ \\
\hline Belém & 4,15 & 2,65 & 2,23 \\
\hline Fortaleza & 4,15 & 3,50 & 2,33 \\
\hline Recife & 2,55 & 1,86 & 1,47 \\
\hline Salvador & 4,21 & 3,19 & 1,68 \\
\hline Belo Horizonte & 4,49 & 2,53 & 2,25 \\
\hline Rio de Janeiro & 2,31 & 1,03 & 0,77 \\
\hline São Paulo & 4,36 & 1,88 & 1,46 \\
\hline Curitiba & 5,56 & 3,03 & 3,99 \\
\hline Porto Alegre & 3,62 & 2,61 & 1,44 \\
\hline Total das RM's & 3,65 & 2,00 & 1,57 \\
\hline Brasil & 2,34 & 1,93 & 1,38 \\
\hline
\end{tabular}

\footnotetext{
${ }^{52}$ COMEC (1999), p.21, Metrópolis em Revista, $\mathrm{n}^{\circ} 1$.

${ }^{53}$ SCHUSSEL (2006), p. 124-125.
} 
Ainda em SCHUSSEL, são apresentadas projeções de crescimento populacional para as próximas décadas:

“(...) Mantidas essas taxas de crescimento, a população chegará a 3,5 e 4,2 milhões respectivamente em 2010 e 2020 e o crescimento mais intenso continuará a ocorrer no aglomerado metropolitano. Enquanto em Curitiba, o acréscimo de população em 2020 será de cerca de 400 mil habitantes (25\% do total existente atualmente), no aglomerado metropolitano (sem Curitiba) esse acréscimo deverá alcançar cerca de um milhão de pessoas (100\% a mais do contingente atual). Por outro lado, o município de Curitiba vem reduzindo sua participação no total da região e as projeções populacionais indicam que, em 2010, sua população será igual à soma da população dos demais municípios." 54

Importante se faz também ilustrar, nesta caracterização preliminar da metropolização em Curitiba, o rebatimento espacial do crescimento demográfico, pois este é entendido como integrante do processo social. Assim, quanto à evolução urbana, percebe-se que o processo de periferização alterou a morfologia do aglomerado urbano, verificado principalmente nos municípios contíguos à Curitiba. Se na década e 60 o crescimento se deu no sentido nordeste-sudoeste, tendo a BR-116 como barreira a leste, nas décadas seguintes, além da transposição da citada rodovia, o crescimento transpôs inclusive a várzea do rio Iguaçu. Esse vetor de ocupação a leste foi caracterizado neste período pela ocupação por assentamentos informais, apoiada fortemente sobre a estrutura viária e de transportes. No estudo da expansão urbana é fundamental interpretar a relação entre as vias regionais de transporte e o crescimento da área urbanizada, pois o transporte atua fortemente sobre o arranjo territorial desse crescimento, ou melhor, "induz a ocupação".

Diz VILLAÇA:

"As ferrovias provocam crescimento descontínuo e fortemente nucleado, em que 0 núcleo ou pólo se desenvolve junto às estações. As rodovias, especialmente as expressas, provocam um crescimento mais rarefeito e descontínuo, menos nucleado que as ferrovias. Isso se deve às diferenças de acessibilidade oferecidas pelos dois tipos de via. Na ferrovia, a acessibilidade só se concretiza nas estações; na rodovia, pode se concretizar em qualquer ponto." 55

\footnotetext{
${ }^{54}$ SCHUSSEL (2006), p. 124-125. As projeções elaboradas a partir das informações censitárias para o PDI-RMC/2002.

${ }^{55}$ VILLAÇA (1998), p. 70.
} 
FIG. 6 - NÚCLEO URBANO CENTRAL - 2002

RELAÇÃO ENTRE A MANCHA CONURBADA E A ESTRUTURA VIÁRIA BÁSICA DA RMC

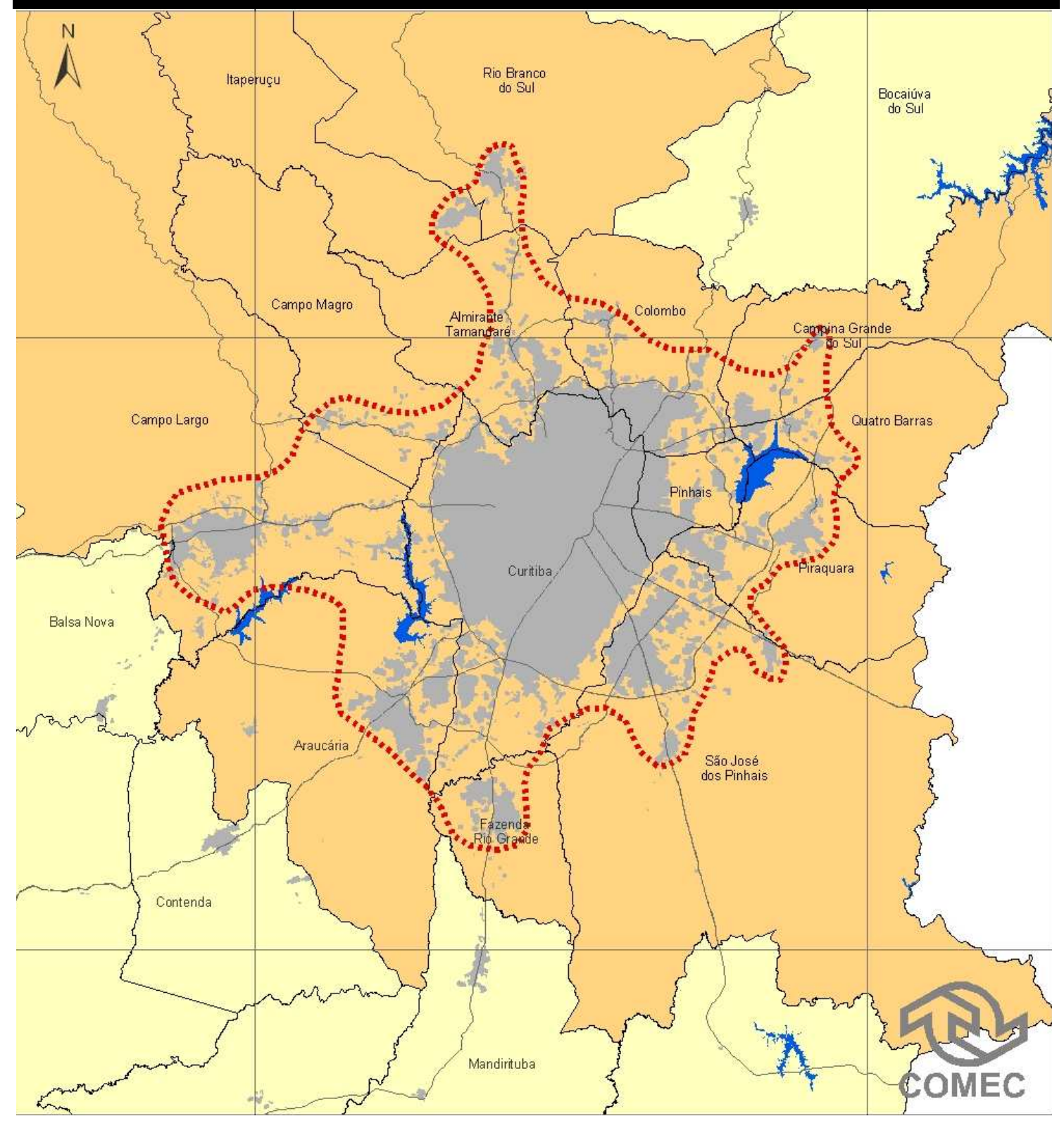

\section{FONTE: COMEC, 2002}

Ainda de acordo com SCHUSSEL, ao final da década de 70, a área do aglomerado correspondia a $10,8 \%$ da área total da região, e perfazia uma densidade média urbana de 41,78 hab/ha. Em 2000, a densidade reduziu para a marca de 23,69 hab/ha, em 20,92\% do território. A diminuição da densidade nesse período decorreu 
da duplicação das áreas dos perímetros urbanos nestes 20 anos: apesar do grande crescimento populacional e da redução da densidade média verificados no período 70/00, foram incorporados ao mercado imobiliário urbano aproximadamente $510 \mathrm{~km}^{2}$, área correspondente ao incremento da mancha de aglomeração.

A partir da década de 80, a nova legislação urbanística e ambiental associada à crise econômica impactou sobremaneira o espaço regional. Ao mesmo tempo em que foi restringido o parcelamento legal, intensificaram-se os movimentos sociais urbanos de ocupação da terra, que propiciaram a invasão de áreas impróprias à urbanização, seja por insalubridade do próprio sítio ou por se localizarem em bacias hidrográficas de mananciais de abastecimento.

A periferização em Curitiba, assim como no Brasil, é um processo decorrente da disputa entre as classes pela terra e pelo trabalho, o que MEDEIROS denomina de "a urbanização da industrialização de baixos salários". ${ }^{56}$ MARICATO atesta que "ao lado de intenso crescimento econômico, o processo de urbanização com crescimento da desigualdade resultou numa inédita e gigantesca concentração espacial da pobreza." 57 A década de oitenta assiste ao fim do projeto desenvolvimentista do Estado: a população urbana cresceu - passou a representar $76,3 \%$ do total - e houve a intensificação da periferização nas grandes metrópoles, confirmada no Censo de 1991. O maior aumento populacional foi verificado nas franjas das metrópoles, onde ocorreu a expansão e a reprodução das favelas.

\footnotetext{
${ }^{56}$ MEDEIROS apud MARICATO (1996), p. 39.

${ }^{57}$ MARICATO (1996), p. 55.
} 


\begin{tabular}{|c|c|c|c|c|c|}
\hline \multicolumn{2}{|c|}{$\begin{array}{c}\text { TAXAS CRESCIMENTO } \\
\text { POR PERÍODOS }(\% \text { A.A.) }\end{array}$} & \multirow{2}{*}{$\begin{array}{l}\text { CURITIBA } \\
5,34\end{array}$} & \multirow{2}{*}{$\begin{array}{l}\text { PORTO } \\
\text { ALEGRE } \\
2,43\end{array}$} & \multirow{2}{*}{$\begin{array}{l}\text { BELO } \\
\text { HORIZONTE } \\
3,73\end{array}$} & \multirow{2}{*}{$\begin{array}{l}\text { SÃO PAULO } \\
3,67 \\
6,34\end{array}$} \\
\hline $1970-1980$ & $\begin{array}{l}\text { NÚCLEO } \\
\text { PERIFERIA }\end{array}$ & & & & \\
\hline \multirow[t]{2}{*}{$1980-1991$} & NÚCLEO & 2,28 & 1,06 & 1,14 & 1,15 \\
\hline & PERIFERIA & 6,40 & 3,12 & 4,98 & 3,20 \\
\hline \multirow[t]{2}{*}{$1991-2000$} & NÚCLEO & 2,11 & 0,83 & 1,12 & 0,84 \\
\hline & PERIFERIA & 5,74 & 3,51 & 6,92 & 2,86 \\
\hline
\end{tabular}

Para caracterizar o fenômeno na RMC, cabe demonstrar alguns indicadores sócio-econômicos. A título de contextualizar a periferização no Brasil, serão apresentados também indicadores para Porto Alegre, Belo Horizonte e São Paulo.

TABELA 1.4 - INDICADORES SOCIAIS DE REGIÕES METROPOLITANAS DO BRASIL - 1991/2000

\begin{tabular}{|c|c|c|c|c|c|c|}
\hline \multicolumn{3}{|l|}{ INDICADOR } & CURITIBA & PORTO ALEGRE & BELO HORIZONTE & SÃO PAULO \\
\hline \multirow{3}{*}{\multicolumn{2}{|c|}{ IDH-M 2000}} & RM & 0,824 & 0,833 & 0,811 & 0,828 \\
\hline & & Pólo & 0,856 & 0,865 & 0,839 & 0,841 \\
\hline & & Pólo/RM & 3,9 & 3,8 & 3,5 & 1,6 \\
\hline \multicolumn{3}{|l|}{ ICH 2000 (1) } & 0,673 & 0,865 & 0,720 & 0,864 \\
\hline \multirow{5}{*}{$\begin{array}{l}\text { PESSOAS COM } \\
\text { RENDA } \\
\text { PER CAPITA } \\
\text { ABAIXO DE } \\
1 \frac{1}{2} \text { SM }\end{array}$} & \multirow[t]{2}{*}{1991} & Número & 353.049 & 517.323 & 921.831 & 1.456 .283 \\
\hline & & $\%$ & 16,80 & 16,18 & 26,17 & 9,43 \\
\hline & \multirow[t]{2}{*}{2000} & Número & 413.595 & 525.364 & 873.641 & 2.519 .436 \\
\hline & & $\%$ & 14,94 & 14,13 & 20,05 & 14,09 \\
\hline & \multicolumn{2}{|c|}{ Variação 1991/2000 } & 60.545 & 8.042 & $(48.190)$ & 1.063 .154 \\
\hline \multirow{3}{*}{\multicolumn{2}{|c|}{$\begin{array}{lrr}\text { RENDIMENTO } & \text { MÉDIO } \\
\text { DE TODOS } & \text { OS } \\
\text { TRABALHOS } & -2000 \text { (R\$) }\end{array}$}} & RM & 881,24 & 820,72 & 747,76 & $1.049,30$ \\
\hline & & Pólo & 1102,99 & 1170,81 & 968,37 & $1.200,35$ \\
\hline & & Pólo/RM & 25,2 & 42,7 & 29,5 & 14,4 \\
\hline
\end{tabular}

Com base nos estudos apresentados no PDI-RMC (2006) é importante ressaltar que a renda média per capita das famílias pertencentes aos grupos das 
famílias 10\% mais ricas era, em 1992, cerca de 39,66 e 18,30 vezes maior do que a renda per capita das famílias dos grupos 10\% e 40\% mais pobres. Em 1999, essa relação aumentou para 41,20 e 19,65 vezes, respectivamente.

As diferenças de remuneração média são bastante expressivas entre os municípios da RMC, principalmente se comparadas com o município pólo. Um trabalhador formalmente empregado em Curitiba ganha cerca de 5,63 salários mínimos por mês, enquanto essa remuneração em Cerro Azul - município pertencente ao segundo anel metropolitano - é de 1,77 salários mínimos. Cerca de 111.000 trabalhadores de todos os municípios da RMC (exceto Balsa Nova, São José dos Pinhais, Araucária e Curitiba), mesmo quando inseridos em relações formais de trabalho, ganham menos de 4 salários mínimos de remuneração média anual por mês.

O padrão de desigualdade se assemelha ao do quadro nacional. Segundo o Censo de 2000, se o valor do rendimento médio mensal do município de Curitiba for considerado como 100, o valor correspondente a Doutor Ulysses será 16,15 e o da Administração Geral do Bairro Novo, no próprio município de Curitiba, alcançará somente 42,05. Já o valor da Administração Regional da Matriz (que inclui o Centro e o bairro do Batel), em Curitiba, representará cerca de 202,99. Nos municípios mais populosos da RMC (Colombo, Almirante Tamandaré, Pinhais e São José dos Pinhais), esse índice varia entre 36,2 (Almirante Tamandaré) e 52,9 (São José dos Pinhais). ${ }^{58}$

GROSTEIN comenta sobre o padrão de urbanização nas metrópoles brasileiras:

"O avanço da urbanização, sua escala e velocidade não constituem problema em si, não fosse o modo como ocorreu. Deve-se estar atento para esse processo, pois a sustentabilidade do aglomerado urbano/metropolitano, em sua componente físico-urbanística, relaciona-se com as seguintes variáveis: a forma de ocupar o território; a disponibilidade de insumos para seu funcionamento (disponibilidade de água); a descarga de resíduos (destino e tratamento de esgoto e lixo); o grau de mobilidade da população no espaço urbano (qualidade do transporte público de massa); a oferta e o atendimento às necessidades da população por moradia, equipamentos sociais e serviços; e a qualidade dos espaços públicos." 59

\footnotetext{
${ }^{58}$ COMEC (2006), p. 32, em PDI-RMC.

${ }^{59}$ GROSTEIN (2001), p.2.
} 
Por meio da evolução do parcelamento do solo na região, mais especificamente na mancha conurbada - denominada pela COMEC como "núcleo urbano central - NUC" - pode-se apreender a temporalidade e a extensão do fenômeno no espaço, segundo a atuação do mercado na produção de lotes. (19402004).
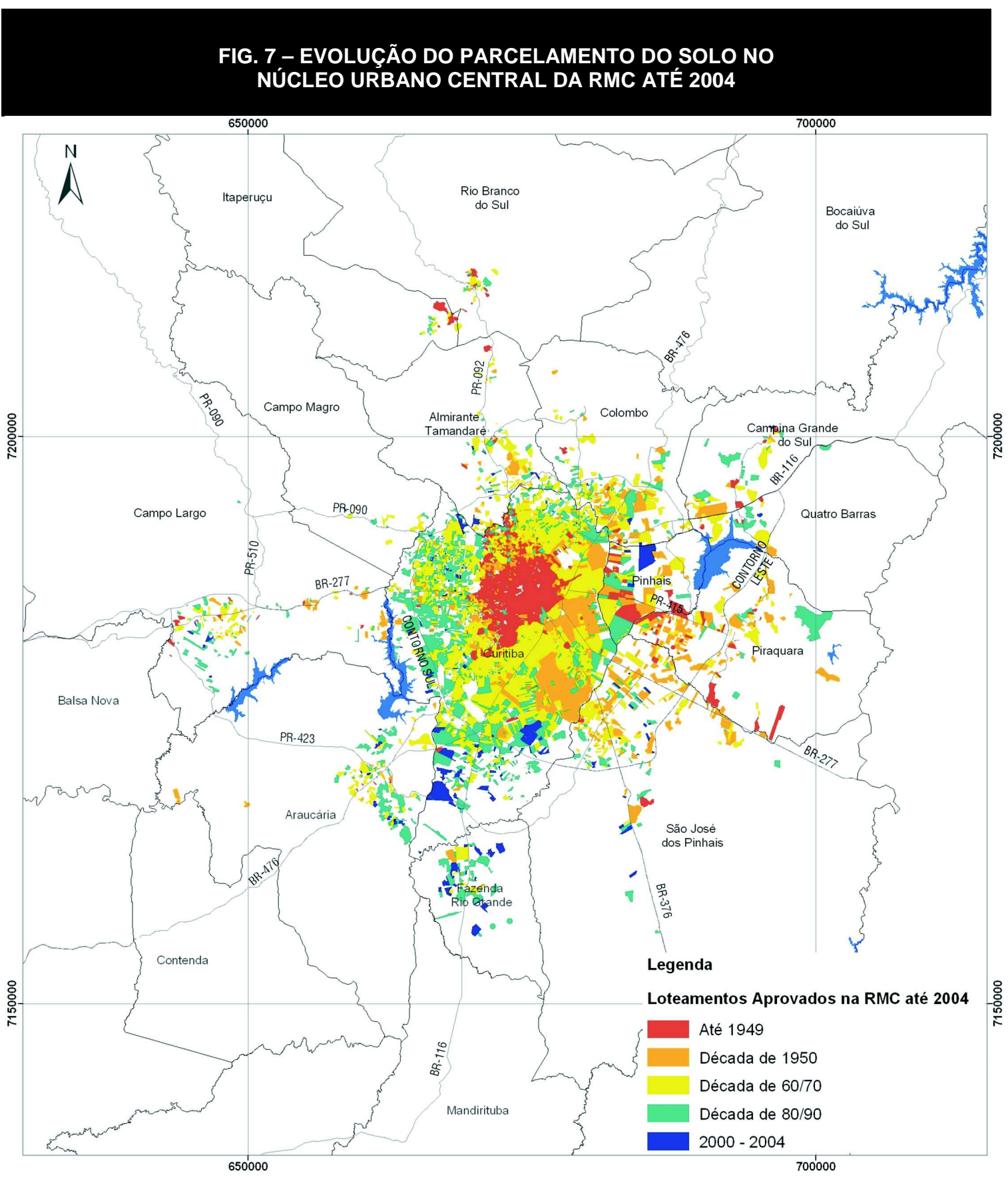

Fonte: PDI-RMC, COMEC (2006) 
Em relação à dinâmica do parcelamento legal na região até a década de setenta, deve-se salientar que $30,23 \%$ dos lotes existentes tiveram origem até os anos 50, sendo 67,87\% destes nos municípios de São José dos Pinhais, Pinhais e Piraquara. No período que compreende as décadas de 60 e 70, os municípios de São José, Colombo e Almirante Tamandaré foram responsáveis por $56 \%$ da produção de lotes no NUC. Na década de 80, o parcelamento mais intenso ocorreu nos municípios de Araucária, seguido por Colombo e São José dos Pinhais. Na década de 90, houve uma sensível redução na produção de lotes formais em praticamente todos os municípios da região; apenas Fazenda Rio Grande e Itaperuçu apresentaram aumento na produção em relação aos períodos anteriores. Em compensação, de 2000 a 2004, verifica-se um vetor de expansão ao sul, caracterizado por uma produção de lotes da ordem de $6 \%$ do total já produzido no NUC, sendo $42 \%$ destes na Fazenda Rio Grande.

Segundo a COMEC, a produção de lotes em relação ao crescimento populacional nos municípios integrantes do NUC, evoluiu de 2,2 habitantes por lote em 1980, para 2,9 em 1991 e 4,11 em 2000. Isto indica que até 1980, a produção foi maior que a demanda gerada pelo crescimento populacional. ${ }^{60}$

TABELA 1.5 - NÚMERO DE LOTES APROVADOS NO NUC/RMC SEM CURITIBA** POR DÉCADA

\begin{tabular}{|c|c|c|c|c|c|c|c|c|c|c|}
\hline MUNICÍPIO & $\begin{array}{l}\text { Sem Data } \\
\text { Aprovação }\end{array}$ & $\begin{array}{l}\text { Déc. } \\
40\end{array}$ & $\begin{array}{l}\text { Déc. } \\
50\end{array}$ & $\begin{array}{l}\text { Déc. } \\
60\end{array}$ & $\begin{array}{l}\text { Déc. } \\
70\end{array}$ & $\begin{array}{l}\text { Déc. } \\
80\end{array}$ & $\begin{array}{l}\text { Déc. } \\
90\end{array}$ & $\begin{array}{l}2000 \\
2004\end{array}$ & TOTAL & $\begin{array}{l}\% \text { total } \\
\text { do } \\
\text { NUC }\end{array}$ \\
\hline $\begin{array}{l}\text { Almirante } \\
\text { Tamandaré }\end{array}$ & 777 & 0 & 2.991 & 1.916 & 9.821 & 2.688 & 708 & 1.512 & 20.413 & 8,21 \\
\hline Campo Magro & 0 & 0 & 78 & 0 & 1.903 & 688 & 36 & 63 & 2.768 & 1,11 \\
\hline Araucária & 80 & 123 & 1.526 & 948 & 4.769 & 10.333 & 2.975 & 918 & 21.671 & 8,72 \\
\hline $\begin{array}{l}\text { Campina } \\
\text { Grande do Sul }\end{array}$ & 92 & 0 & 3.080 & 790 & 1.289 & 2.020 & 542 & 40 & 7.853 & 3,16 \\
\hline $\begin{array}{l}\text { Campo } \\
\text { Largo** }^{*}\end{array}$ & 1.597 & 0 & 4.417 & 1.745 & 1.589 & 3.604 & 2.635 & 629 & 16.216 & 6,52 \\
\hline Colombo & 580 & 311 & 9.591 & 6.751 & 10.566 & 6.114 & 3.255 & 494 & 37.662 & 15,15 \\
\hline $\begin{array}{ll}\text { Fazenda } & \text { Rio } \\
\text { Grande } & \end{array}$ & 198 & 0 & 1.111 & 1.528 & 901 & 3.219 & 3.914 & 5.877 & 16.748 & 6,74 \\
\hline Pinhais & 4.596 & 0 & 8.736 & 5.468 & 1.631 & 5.632 & 2.207 & 1.711 & 29.981 & 12,06 \\
\hline Piraquara & 4.555 & 0 & 17.522 & 4.285 & 1.055 & 1.898 & 390 & 0 & 29.705 & 11,95 \\
\hline Quatro Barras & 463 & 0 & 1.298 & 1.838 & 310 & 890 & 371 & 179 & 5.349 & 2,15 \\
\hline $\begin{array}{l}\text { Rio Branco do } \\
\text { Sul }\end{array}$ & 1.318 & 0 & 44 & 20 & 1.527 & 458 & 383 & 0 & 3.750 & 1,51 \\
\hline Itaperuçu & 2.321 & 0 & 0 & 334 & 886 & 164 & 489 & 21 & 4.215 & 1,70 \\
\hline $\begin{array}{l}\text { São José dos } \\
\text { Pinhais }\end{array}$ & 1.687 & 242 & 24.732 & 8.432 & 4.772 & 5.965 & 3.820 & 2.542 & 52.192 & 21,00 \\
\hline TOTAL NUC & 18.264 & 676 & 75.125 & 34.055 & 41.019 & 43.673 & 21.725 & 13.986 & 248.523 & 100,00 \\
\hline \% por Década & 7,35 & 0,27 & 30,23 & 13,70 & 16,51 & 17,57 & 8,74 & 5,63 & 100,00 & \\
\hline
\end{tabular}

${ }^{60}$ COMEC (2006), p. 60-61, em PDI-RMC. 
Atualmente, observa-se que o parcelamento formal do solo tem como principal vetor de crescimento o sul da Região Metropolitana de Curitiba. Na porção sul de Curitiba, na Fazenda Rio Grande e em Araucária foram produzidos 22.043 lotes nessa última década - ao passo que as áreas informais ocuparam grandes áreas a leste, em sítios considerados ambientalmente frágeis (13.286 unidades), o que veio a resultar em altas taxas de crescimento demográfico nesse compartimento regional.

Depois disso, fica claro que a defasagem na relação produção e demanda foi suprida por assentamentos irregulares. No NUC, não considerando o pólo, entre 1992 e 1997 foram produzidos 5.019 lotes populares e acrescidas 19.603 unidades em assentamentos irregulares; em Curitiba, entre 1998 e 2000, 6.595 lotes populares produzidos ao passo que foram acrescidas 19.603 unidades habitacionais irregulares. ${ }^{61}$

Já é sabido que o vetor de expansão a leste foi o mais expressivo em termos de conurbação na Curitiba Metrópole, e também o mais combatido por pressionar as áreas de mananciais. Representa, em termos de transporte, o setor de maior carregamento, ao considerarmos o conjunto de municípios de Colombo, Pinhais, Piraquara e São José dos Pinhais. Porém, apesar das restrições do planejamento ao longo dos últimos trinta anos, o que se percebe, em termos de localização das classes sociais, é a produção do espaço a partir de bairros populares desde a década de 70 . As vantagens locacionais que estas áreas apresentavam - e apresentam até hoje - se devem à proximidade com a área central da metrópole, baixo preço da terra e à condição de mobilidade propiciada posteriormente pelo sistema de transporte integrado. Não foi por acaso que a localização tornou-se atraente à implantação, nos anos 80 , de atividades ligadas ao setor de logística e indústrias de pequeno e médio portes, fato esse que possibilitou o desmembramento de Pinhais em 1992, (anteriormente distrito de Piraquara); e nos últimos anos, aos condomínios de alta renda, a exemplo do Alphaville Graciosa, como possibilidade de uma localização nobre.

De acordo com SCHUSSEL, a atual configuração espacial da aglomeração metropolitana de Curitiba é resultante do padrão de urbanização periférica comum às cidades brasileiras. Como está localizada próxima a uma região de nascentes - do Rio Iguaçu - a disponibilidade hídrica fica comprometida em relação à crescente demanda da terra. Isto acirra o conflito entre urbanização e proteção de mananciais de abastecimento.

\footnotetext{
${ }^{61}$ COMEC (2002), Documento para discussão PDI-RMC, p. 121.
} 


\section{FIG. 8 - NÚCLEO URBANO CENTRAL E ÁREAS DE RESTRIÇÃO AMBIENTAL - RMC 2000}

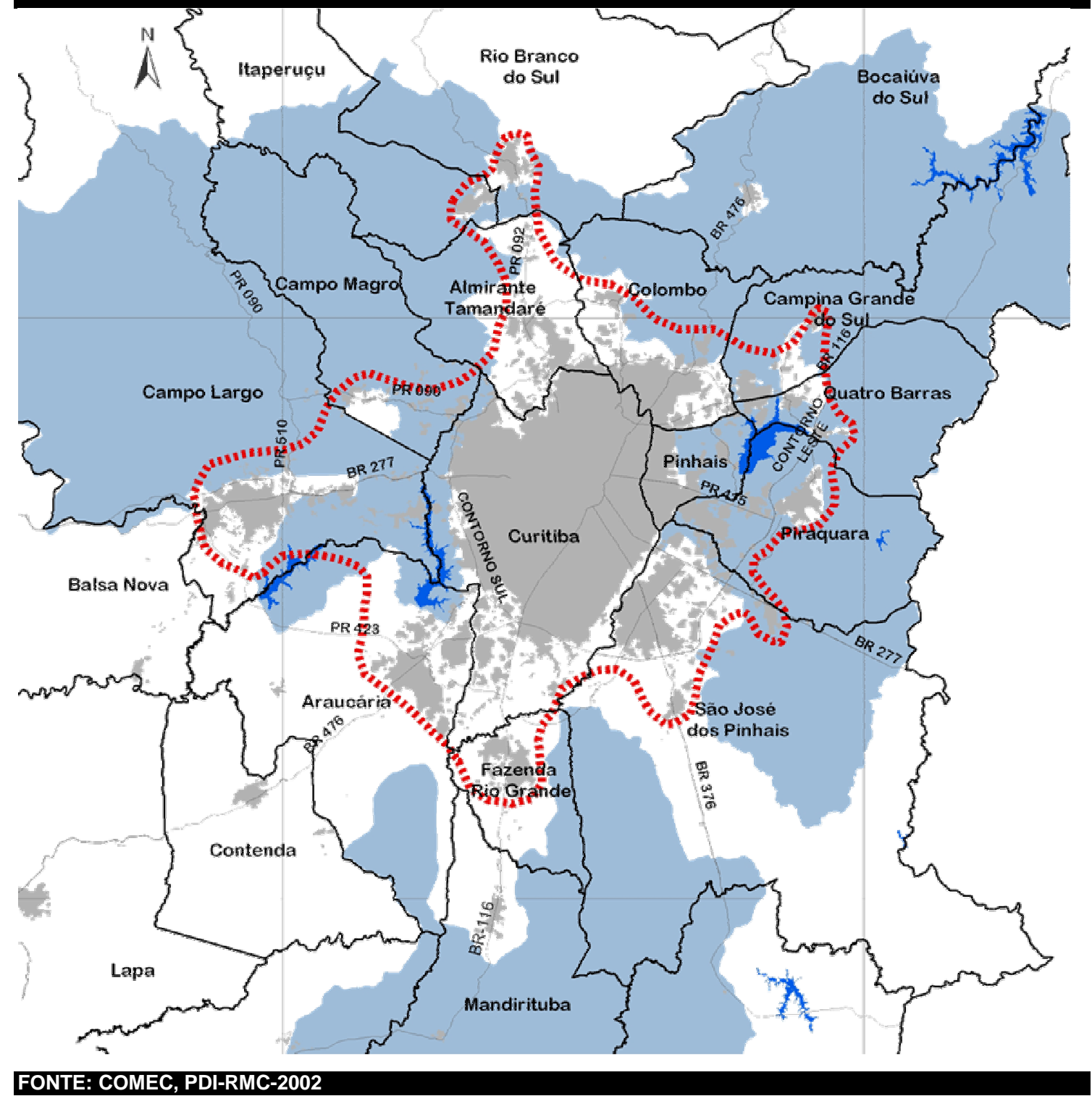

Comenta a autora:

"Com a área urbanizada confinada entre as áreas de proteção ambiental, os vetores de crescimento não respeitaram a legislação de uso do solo, atrelados às regras do mercado, acessibilidade e proximidade das áreas centrais. $O$ entroncamento dos corredores viários que passam pela região: (São Paulo/ Rio Grande do Sul/ Buenos Aires/ Montevidéu) e (Paranaguál Foz do Iguaçu/ Argentina), situado no leste da aglomeração, juntamente com o aeroporto internacional Afonso Pena e a ferrovia que liga Curitiba a Paranaguá, caracterizase como um forte potencial logístico para a implantação industrial, apesar do impedimento de ordem ambiental. Da mesma forma, as altas declividades ao norte e a represa do rio Passaúna são fortes barreiras ambientais para a expansão urbana da aglomeração metropolitana; (...) enquanto os assentamentos informais 
de população de baixa renda situam-se nas franjas da metrópole, com uma concentração expressiva junto às várzeas do Iguaçu." 62

O agravamento das condições de moradia dos pobres nas metrópoles é verificado pela intensidade de crescimento de suas periferias e de suas favelas. Sobre o posicionamento do Estado frente a esses assentamentos informais, observa MARICATO:

"É notável a tolerância que o Estado brasileiro, especialmente o Judiciário, tem manifestado em relação às ocupações ilegais de terra urbana. Esse processo é significativo em suas dimensões, se levarmos em conta, sobretudo, a grande massa de migrantes que rumou para as cidades neste século e que se instalou ilegalmente já que não teve acesso ao mercado imobiliário privado e nem foram atendidos pelas políticas públicas de habitação." 63

Para GROSTEIN, a "cidade informal" faz parte de um padrão de urbanização acelerada associada ao processo de industrialização no Brasil. Ela critica o modelo de gestão baseado no conceito de zoneamento urbano enquanto instrumento que contribui para o agravamento da ilegalidade:

"a reprodução e a permanência desse padrão de urbanização apontam para a incapacidade recorrente do Estado em controlar e fiscalizar o uso e a ocupação do solo e atuar como controlador, financiador ou provedor de moradia para as populações com menos recursos.

(...) esse processo também é a expressão da crise do modelo de instrumentos formulado na década de 70, dominado pelo conceito de zoneamento urbano, que, ao invés de ampliarem benefícios para o conjunto da população, funcionaram como limitadores da oferta de moradias ou loteamentos no mercado regular. Mais do que difusores de padrões de qualidade urbana e ambiental, como pretendia 0 legislador, estes instrumentos contribuíram decisivamente para a escalada da ilegalidade urbana." 64

$\mathrm{Na}$ RMC, as condições e a amplitude da informalidade dos assentamentos confirmam a desigualdade social presente no processo de metropolização e reflete uma concentração espacial da carência. Em 2000, havia 43.127 domicílios em aglomerados subnormais, nos quais viviam cerca de 170 mil pessoas, e sua maior

\footnotetext{
${ }^{62}$ SCHUSSEL (2006), p. 130.

${ }^{63}$ MARICATO (1996), p. 62.

${ }^{64}$ GROSTEIN (2001), p. 2.
} 
concentração era verificada no pólo e no seu entorno. De fato, em Curitiba tinha-se que $8 \%$ do total de domicílios do município, correspondendo a 37.716 moradias e aproximadamente 148 mil pessoas estavam em aglomerados subnormais - cerca de $87 \%$ do total da RMC, seguida de Colombo com 1.675 domicílios, Araucária com 1.291, e Almirante Tamandaré com 1.117, representando respectivamente, 3,4\%, $5,2 \%$ e $4,8 \%$ do total de seus domicílios.

TABELA 1.6 - RMC: OCUPAÇÕES IRREGULARES E UNIDADES HABITACIONAIS - 1997

\begin{tabular}{|c|c|c|c|}
\hline MUNICÍPIO & $\begin{array}{l}\text { № DE } \\
\text { OCUPAÇÕES } \\
\text { IRREGULARES }\end{array}$ & $\begin{array}{l}\text { № DE } \\
\text { UNIDADES } \\
\text { HABITACIONAIS }\end{array}$ & $\begin{array}{l}\% \text { № UNIDADES } \\
\text { HABITACIONAIS } \\
\text { NA RMC }\end{array}$ \\
\hline Adrianópolis & 2 & 93 & 0,15 \\
\hline Almirante Tamandaré & 88 & 4.785 & 7,75 \\
\hline Araucária & 64 & 1.621 & 2,63 \\
\hline Bocaiúva do Sul & 7 & 127 & 0,21 \\
\hline Campina Grande do Sul & 13 & 586 & 0,95 \\
\hline Campo Largo & 53 & 1.719 & 2,79 \\
\hline Campo Magro & 9 & 730 & 1,18 \\
\hline Cerro Azul & 3 & 42 & 0,07 \\
\hline Colombo & 92 & 6.274 & 10,17 \\
\hline Contenda & 3 & 66 & 0,11 \\
\hline Curitiba & 279 & 32.346 & 52,41 \\
\hline Fazenda Rio Grande & 23 & 1.567 & 2,54 \\
\hline Itaperuçu & 17 & 566 & 0,92 \\
\hline Mandirituba & 3 & 31 & 0,05 \\
\hline Pinhais & 24 & 2.241 & 3,63 \\
\hline Piraquara & 47 & 4.259 & 6,90 \\
\hline Rio Branco do Sul & 13 & 817 & 1,32 \\
\hline São José dos Pinhais & 69 & 3.820 & 6,19 \\
\hline Tunas do Paraná & 2 & 22 & 0,04 \\
\hline Total & 811 & 61.712 & 100,00 \\
\hline
\end{tabular}

Além dos dados do IBGE e IPARDES, uma outra fonte de informação, disponível para o território que compreende a Região Metropolitana de Curitiba legalmente instituída, permite dimensionar as disfunções associadas à ocupação irregular do solo urbano e à concentração da pobreza. Trata-se dos levantamentos feitos em campo pela COMEC em 1997. Esse levantamento abrange toda a RMC e, de acordo com essa informação, havia na região um total de 811 áreas ocupadas irregularmente, reunindo 61.712 unidades habitacionais, concentradas em sua maioria (52\%) em Curitiba, seguidas por Colombo, Almirante Tamandaré e Piraquara. A tabela que segue revela a dimensão da irregularidade na RMC, segundo o levantamento de campo de 1997.

"A dinâmica habitacional da RMC encontra no mercado fundiário um dos principais fatores para a sua caracterização e estruturação. O funcionamento do mercado fundiário e os preços da terra na RMC são uma fonte importante para a análise da 
organização funcional da metrópole e, também, para explicar o comportamento da segmentação da população por classe de renda no espaço metropolitano. $O$ mercado fundiário na RMC, na década de 1990, também se afirmou como um mercado de escala metropolitana, não só no que se refere ao volume de seus negócios, mas principalmente pelo seu poder de subordinar a uma lógica comum à oferta e à procura por imóveis na totalidade do espaço efetivamente metropolitano. ${ }^{65}$

FIG. 9 - OCUPAÇÕES IRREGULARES NA AGLOMERAÇÃO METROPOLITANA DE CURITIBA - 2000

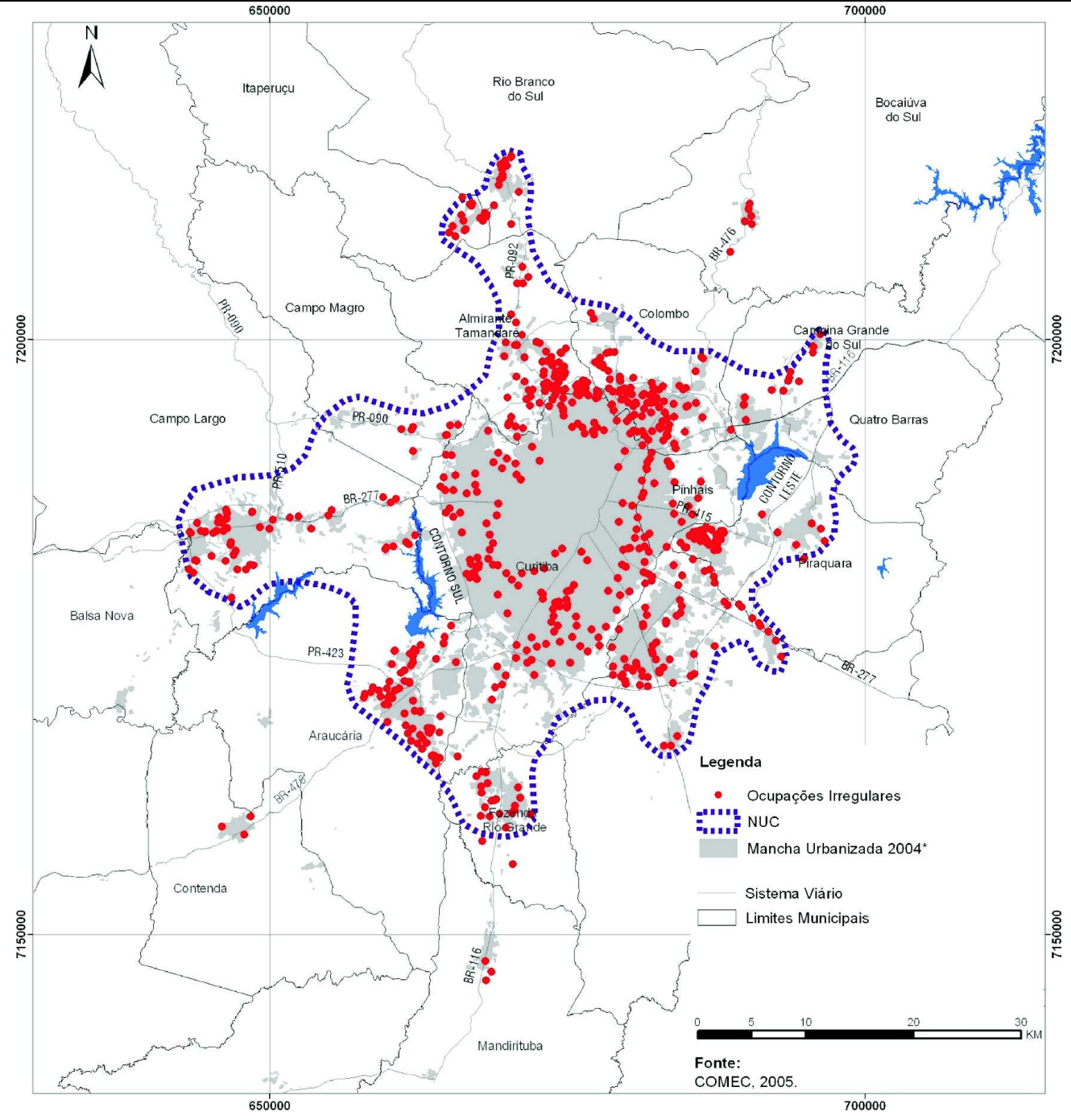

Fonte: ADAPTAÇAO COM BASE EM PDI-RMC 2002. Apud SCHUSSEL (2006).

De acordo com PEREIRA, "a ausência de controle quanto ao uso da propriedade urbana para benefício individual torna o mercado imobiliário o grande

\footnotetext{
${ }^{65}$ COMEC (2006), p. 138, em PDI-RMC.
} 
agente estruturador da cidade e, nesse contexto, a população com menores recursos é excluída dos benefícios da urbanização, passando a ocupar de forma irregular o território da cidade." 66

ABRAMO reflete sobre o esgotamento das possibilidades de expansão das áreas ocupadas irregularmente como uma nova dinâmica. Dessa forma, o acesso à moradia passa a se dar via mercado imobiliário informal: "a favela passa a incorporar uma demanda habitacional que não consegue entrar no mercado imobiliário formal" e o acesso às moradias se faz "pela via do mecanismo de mercado". É importante reconhecer, como coloca o autor, que o funcionamento do mercado imobiliário informal nas favelas terá como conseqüência os mesmos efeitos de hierarquização sócioespacial produzidos pelo mercado imobiliário formal nas áreas legalizadas da cidade. Por meio de pesquisa realizada confirma-se que o resultado dessa lógica de mercado na produção da moradia nas ocupações irregulares no Rio de Janeiro, "que os preços imobiliários na favela são excessivamente elevados quando comparados com as qualificações do imóvel em si mesmo elou quando comparados com os preços dos imóveis dos bairros do seu entorno." 67

ABRAMO aponta ainda que a comercialização de imóveis nas áreas ocupadas irregularmente tende a se consolidar como prática corrente, seguindo as mesmas regras de diferenciação de preços do mercado formal. Essa comercialização irá expulsar a população mais pobre desses lugares, em geral também ocupados por população de baixa renda. Como conseqüência, tem-se a expansão espacial da localização da pobreza, caracterizada pelo processo seqüencial ocupação/comercialização/expulsão, que reafirma e reproduz o padrão de segregação sócio-espacial da cidade brasileira, manifestada claramente em Curitiba.

Em relação ao mercado imobiliário informal no município de Curitiba, PEREIRA revela que a expansão da cidade, com predomínio ao sul/sudoeste, além de ocorrer nas terras de menor valor e ser comandada pela população de baixa renda, ocorre de forma irregular, ou ilegal. Segundo ela, os dados demonstram que há uma polarização em relação aos padrões de ocupação do solo: na parte norte/nordeste a concentração de população de maior renda, melhores condições sociais e maiores valores imobiliários; na sul/sudoeste, a menor renda, a pior condição social, os menores valores imobiliários e, significativamente, maiores taxas de crescimento populacional e maior número de ocupações irregulares. PEREIRA conclui, portanto, que a produção de moradias mediante ocupações irregulares vem exercendo papel fundamental na

\footnotetext{
${ }^{66}$ PEREIRA (2002).p. 71-72.

${ }^{67}$ ABRAMO, apud PEREIRA (2002). p. 71.
} 
estruturação da cidade de Curitiba, confirmando o processo de associação entre pobreza e segregação sócio-espacial.

Quanto ao Estado frente à irregularidade da ocupação, temos apoio em MARICATO (1996) quando diz "Direito à ocupação, sim. Direito à cidade, não."

"A maior tolerância e condescendência para com a produção ilegal do espaço urbano vem dos governos municipais aos quais cabe a maior parte da competência constitucional de controlar a ocupação do solo. A lógica concentradora da gestão pública urbana não admite a incorporação ao orçamento público da imensa massa, moradora da cidade ilegal, demandatária de serviços públicos. Seu desconhecimento se impõe, com exceção de ações pontuais definidas em barganhas políticas ou períodos pré-eleitorais. Essa situação constitui, portanto, inesgotável fonte para o clientelismo político." 68

Segundo DESCHAMPS, o maior incremento populacional, seja reprodutivo ou migratório, na Região Metropolitana de Curitiba se deu em municípios limítrofes a Curitiba, formando uma mancha contínua de ocupação:

“Essa periferização da população começa a ser mais bem delimitada a partir dos anos 80. Entre 1970 e 1980, Curitiba absorveu 66,8\% do acréscimo populacional da Região Metropolitana, enquanto o conjunto de municípios adjacentes absorveu 30,3\%, ao passo que entre 1980 e 1991, este mesmo conjunto absorve 48,2\% e Curitiba, 51,8\% deste aumento. Na última década a situação se inverte, com Curitiba absorvendo $45,5 \%$, enquanto aquele conjunto passa a absorver $54,5 \%$ de todo o acréscimo populacional da RMC." 69

Deschamps comenta que essa atratividade populacional estaria relacionada à concentração de atividades produtivas, gerando oportunidades, diretas e indiretas de trabalho, bem como a redução de oportunidades de inserção produtiva no interior do Paraná e em outros estados. Sendo assim, configura-se uma tipologia metropolitana: pela existência de um pólo, pela emergência de centralidades surgidas de municípios anteriormente com características de cidades-dormitórios, aqueles que permanecem cidades-dormitório, evidenciando o padrão marcante de periferias pobres e, por fim, municípios ainda rurais. ${ }^{70}$ Estes últimos, incorporados recentemente à RMC.

\footnotetext{
${ }^{68}$ MARICATO (1996), p. 63.

${ }^{69}$ DESCHAMPS (2002), p.8.

${ }^{70}$ Idem.
} 
Quanto à migração para a RMC, Curitiba é o destino preferencial: $77 \%$ na década de 70 e $70 \%$ na década de 80 . Outros quatro municípios juntos receberam $17 \%$ dos migrantes nos anos 70 e $21 \%$ nos anos 80 . São eles: São José dos Pinhais, Colombo, Piraquara e Araucária, todos limítrofes à Curitiba. Comenta Deschamps, com apoio em MOURA (2001), que essa dinâmica demonstra certa seletividade na ocupação do espaço metropolitano uma vez que, "[...] o valor da terra e da moradia e o custo das melhorias urbanas reservam para Curitiba um morador com melhores níveis de renda, direcionando os grupos empobrecidos e os migrantes de menor poder aquisitivo para as áreas periféricas internas e de outros municípios." Curitiba recebe segmentos de maior escolaridade; entre os municípios contíguos que recebem contingentes metropolitanos mais numerosos destacam-se, mas em patamar pouco inferior a Curitiba, somente Araucária e São José dos Pinhais por serem municípios industriais; os demais municípios - Almirante Tamandaré, Colombo, Piraquara e Mandirituba - recebem populações menos escolarizadas.

Já ao se analisar a migração intra-metropolitana, Deschamps indica que do total de emigrantes na década de 70 , Curitiba enviou para os demais municípios metropolitanos $72 \%$, aumentando para $75 \%$ na década seguinte. Os municípios limítrofes ao pólo, em especial os de Almirante Tamandaré, Araucária, Colombo, Mandirituba, Piraquara e São José dos Pinhais, foram os que receberam os maiores volumes da migração intra-metropolitana, mais de $75 \%$ do total. ${ }^{71} \mathrm{~A}$ espacialização dessa dinâmica está representada na figura que segue.

\footnotetext{
${ }^{71}$ DECHAMPS (2002), p. 7.
} 


\section{FIG. 10 - MIGRAÇÃO INTRA-METROPOLITANA NA RMC EM 1991}

\section{MAPA 1 - TROCAS LIQUIDAS MIGRATÓRIAS INTRAMETROPOLITANAS -}

RMC, $1981 / 1991$

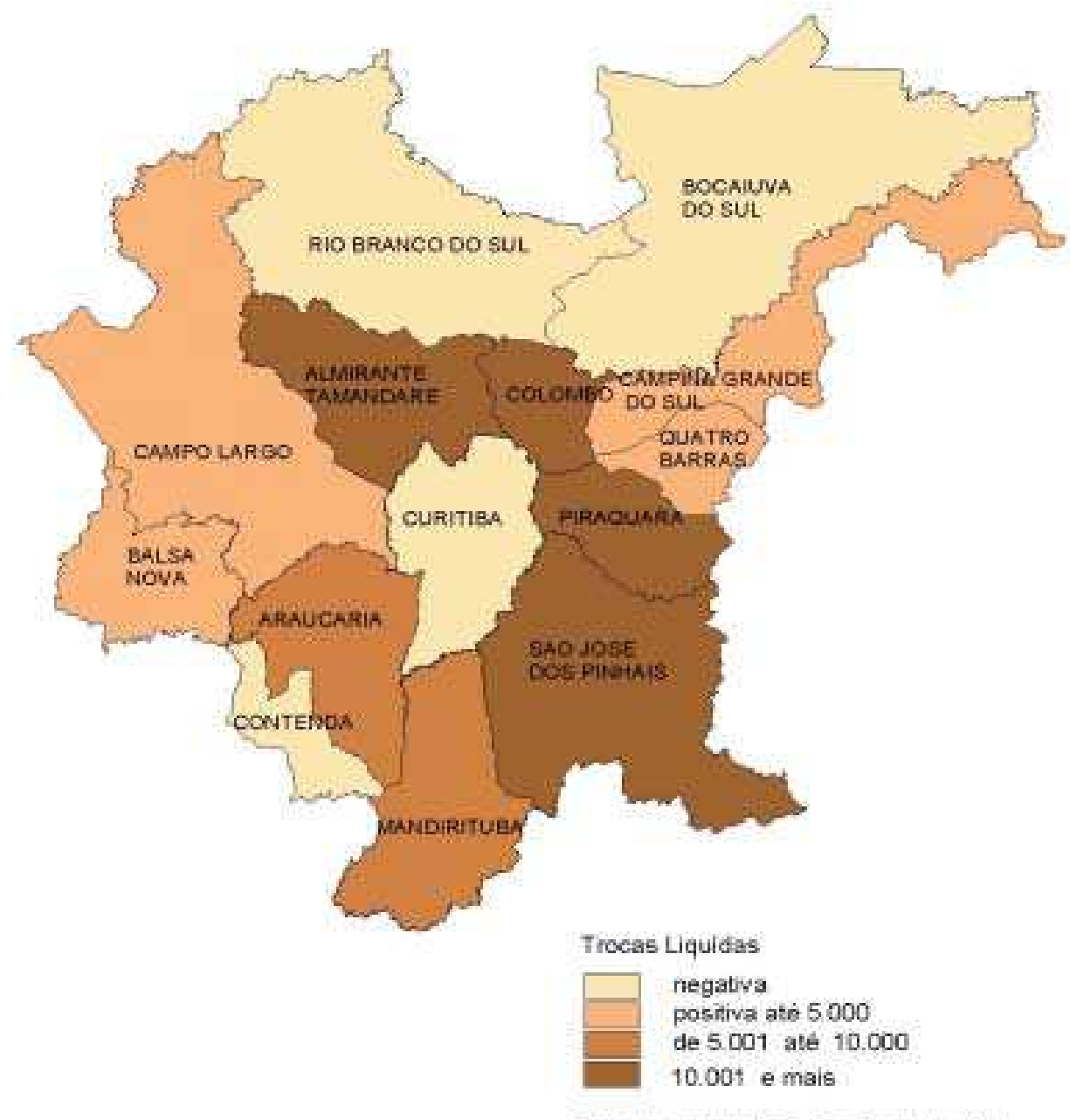

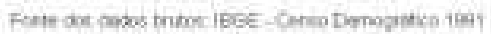

\section{FONTE: Censo Demográfico 1991, em DECHAMPS (2002), p. 14}

No mapa acima se percebe com clareza que os municípios do entorno de Curitiba são os grandes receptores de crescente contingente populacional, muito provavelmente em busca de trabalho no município pólo. Nesse sentido, segundo DESCHAMPS, "dois aspectos merecem ser mencionados: o primeiro se refere à existência de uma rede de transporte bem estruturada, integrando esses municípios 
entre si e à capital; o segundo se refere à maior facilidade de acesso à terra, seja ela de modo formal ou informal. Levando em consideração esses dois aspetos, pode-se sugerir que esse espraiamento da malha urbana a partir do pólo se dá de forma seletiva." Ainda conforme a autora, com apoio em MOURA (2001), concorreram sobremaneira para essa segregação sócio-espacial:

"As intervenções urbanísticas e os mecanismos de controle associados ao planejamento - que serviram tanto para valorizar o solo quanto para conter os efeitos da ocupação no interior do município - assim como a lógica do mercado prevalecente na aquisição da moradia. Ao mesmo tempo, a legislação flexível dos municípios vizinhos, a oferta de terras pela iniciativa privada - muitas vezes em áreas de mananciais parceladas antes da Lei federal 6.766 - e o sistema de transporte coletivo, que sustenta a ligação ao pólo industrial, viabilizaram a ocupação de suas áreas fronteiriças." 152

Diante desse contexto é que a nova Constituição Federal de 1988 incluiu na agenda de reforma social a política urbana; e é justamente nesse momento político de redemocratização do país que emergiu o discurso da Capital Ecológica. LAMPARELLI observa que:

De maneira geral, não se fala mais na década de 80, em Planos Diretores. [...] Muda o discurso e ele se desloca para o social. Importante é ressaltar a participação nos movimentos sociais, as capacidades da iniciativa privada e da sociedade civil e a redução da interferência do Estado na vida da economia. Esses argumentos entram em contradição com as pressões para que o Estado forneça condições de melhoria de vida à população, como nas áreas de transporte e habitação. Surge então a Constituição, que retoma um velho discurso do Plano Diretor. ${ }^{153}$

Em SCHUSSEL, tem-se que:

"Curitiba na década de 70, alterou sua imagem física com a implantação de projetos urbanos e de um sistema de transportes públicos que tiveram um impacto sobre sua configuração espacial e auxiliaram na implementação do plano normativo e regulatório de uso e ocupação do solo. A experiência curitibana ficou conhecida internacionalmente muito mais pelas ações pontuais desenvolvidas em

\footnotetext{
${ }^{152}$ DESCHAMPS (2002), p.7.

${ }^{153}$ LAMPARELLI (1989), p. 113.
} 
curto prazo e em parceria com a iniciativa privada do que propriamente pelo plano diretor urbano no sentido tradicional que tem sido conhecido no Brasil." 154

Ao assumir seu terceiro mandato como prefeito de Curitiba (1989-1992), Jaime Lerner apresenta a Capital Ecológica, já em seu discurso de posse:

"[...] Se, no início da década de 80, a preocupação do poder público era tornar os equipamentos e os serviços urbanos acessíveis à maioria da população, o compromisso para os noventa é e será com a qualidade desses equipamentos e serviços colocados à sua disposição. O povo de Curitiba merece o melhor: 0 melhor ensino, a melhor creche, o melhor transporte de massa, o melhor posto de saúde, os melhores parques e áreas de lazer, moradias bem construídas, enfim, a melhor qualidade de vida.

[...] Curitiba será a cidade de uma só gente através da solidariedade e das parcerias [...] Terá que provar que é possível reduzir a distância entre ricos e pobres. Terá que resgatar a credibilidade da população nos administradores públicos. Terá que assegurar a melhor qualidade de vida a toda a população. Terá que novamente, inovar e ousar nas soluções urbanas. [...] O compromisso com o futuro: Curitiba, Capital Ecológica do país". ${ }^{155}$

O novo projeto político da cidade de Curitiba tem como variável protagonista do discurso a relação entre a qualidade de vida e o processo permanente de planejamento urbano:

"O meio ambiente primário de cada um é a casa, a rua, a cidade onde mora. E é neste "universo", em primeiro lugar, onde temos que construir as condições ecológicas de vida.

Quer dizer, é no ambiente imediato do homem que se necessita buscar o equilíbrio entre ele e a natureza, uma integração perfeita entre todos os fatores ambientais, como forma de assegurar uma existência digna e saudável.

Curitiba entendeu essa verdade e começou a implementá-la há 20 anos. Pode ser que tenha sido a primeira cidade a desenvolver o que apropriadamente poderíamos chamar de uma escola de urbanismo - o urbanismo ecológico - e principalmente dar-Ihe lógica e seqüência.

Curitiba entendeu por exemplo, que a qualidade de vida de seus habitantes estava relacionada com a quantidade de verde na cidade - e aumentou do insignificante

\footnotetext{
${ }^{154}$ SCHUSSEL (2006), p. 141-142.

155 IPPUC (1989), Depoimentos 1, p. 37: trecho do discurso de posse de Jaime Lerner à prefeitura de Curitiba, em 01/01/1989.
} 
meio metro quadrado de então para nada menos que 50 metros quadrados de cobertura vegetal por habitante, o que representa a taxa mais alta do país.

Se esta foi uma decisão claramente vinculada ao projeto ecológico que se queria implantar, outras decisões não eram igualmente tão claras. Por exemplo: $O$ que tem a ver com ecologia a implantação dos "ônibus expressos"? o Calçadão da Rua $X V$ é somente ecológico por causa de suas floreiras? Até que ponto a Cidade Industrial é também uma obra ecológica?

Esta integração entre política de desenvolvimento urbano e projeto ecológico é o que distingue Curitiba da grande maioria das cidades brasileiras. E faz da capital do Paraná um ponto de referência de teses que se revelaram absurdas, como a que considerava impossível compatibilizar crescimento com preservação ambiental, assegurando a melhor qualidade de vida para todos". 156

Em 1990, a cidade de Curitiba recebeu dois prêmios internacionais, que "contribuíram para mostrar ao mundo que os centros urbanos podem unir progresso e desenvolvimento com melhor qualidade de vida para seus habitantes". O primeiro deles foi concedido pelo International Institute for Energy Conservation, pela promoção da melhoria da eficiência energética global, em função do modelo concebido para o sistema integrado de transporte, que prioriza o transporte coletivo sobre o individual, possibilitando assim a economia do consumo de combustível e diminuindo a emissão de gases tóxicos na atmosfera. A segunda premiação, considerada o Oscar do meio ambiente, foi outorgado pela ONU durante o Congresso Mundial de Autoridades Locais para um Futuro Sustentável. O programa premiado foi o Lixo que não é lixo, ${ }^{157}$ um programa alternativo que buscava solução para a questão da coleta e destinação do lixo, que tratava da separação prévia dos resíduos domiciliares recicláveis nas próprias residências.

Estas práticas - desenvolvidas pela SMMA a partir da terceira gestão de Lerner - respaldadas pelo conceito de desenvolvimento sustentado, além de conferirem visibilidade à cidade e propiciarem o reconhecimento internacional, promoveram as condições de legitimação do discurso da capital ecológica junto à população em geral, que se sentia participante de um projeto comum de cidade.

156 IPPUC (1992), vol.8, p. 3-4. Em Memória da Curitiba Urbana, edición especial: Escuela de Urbanismo Ecológico.

${ }^{157}$ TRINDADE (1997), p. 105-109. 
LERNER explica que "a cidade é o cenário de um encontro. Mas o encontro tem de ser feliz, um encontro de pessoas de sensibilidade, que pertencem à cidade. $O$ sentimento de pertencer é fundamental. É o maior componente da qualidade de vida. [...]". ${ }^{158}$ Ao se referir à questão das identidades territoriais, CASTELLS observa que as pessoas resistem ao processo de individualização e atomização, tendendo assim a agrupar-se em organizações comunitárias. Tais organizações comunitárias geram, ao longo do tempo, um sentimento de pertencimento e, em última análise, de uma identidade cultural, comunal. Assim, Castells apresenta a hipótese de que para que isso ocorra, faz-se necessário um processo de mobilização social pelo qual são revelados e definidos interesses em comum: a vida é de algum modo compartilhada e um novo significado pode ser produzido. ${ }^{159}$

Ainda em 1990, foi criado o Fundo Municipal de Habitação, para dar suporte financeiro aos programas de habitação social. Os recursos seriam advindos do instrumento da transferência de potencial construtivo para implantação de programas de interesse social. No ano seguinte, com o propósito de divulgar amplamente as concepções urbanísticas e ambientais da cidade, foi criada a Universidade Livre do Meio Ambiente - a UNILIVRE. Ao lado de ações que visavam a formação de uma consciência ecológica junto à população, a instituição teria como atribuição desenvolver um trabalho voltado à sistematização das referências teóricas das ações ambientais de Curitiba. Ainda em 1991, a UNILIVRE tornou-se uma entidade nãogovernamental, sem fins lucrativos, e passou a atuar como parceira da prefeitura pelo intermédio de convênios de cooperação. Enquanto isso, coube ao IPPUC desenvolver os projetos dos novos marcos referenciais urbanos da capital ecológica, ${ }^{160}$ complementares à filosofia ambiental - piás ambientais, parques, entre outros.

Com relação ao transporte coletivo, houve no período a ampliação da capacidade de atendimento da RIT, tanto em função da criação de mais uma linha - a linha direta ou a dos ônibus ligeirinhos, assim denominada por ter seus pontos de parada mais espaçados - como pelo aumento da capacidade dos ônibus expressos, que agora passariam a ser biarticulados. Os pontos de parada da linha direta e da linha expressa foram redesenhados sob a forma de estações-tubo. Nestas estações, concebidas para embarque e desembarque em nível, o pagamento da tarifa é feito

\footnotetext{
${ }^{158}$ IPPUC (1992), vol.8, p. 3. Em Memória da Curitiba Urbana, edición especial: Escuela de Urbanismo Ecológico.

${ }^{159}$ CASTELLS (1999), p. 79.

${ }^{160}$ OBA (1998), p. 278-290.
} 
quando do acesso ao seu interior. Este conjunto de medidas buscava otimizar o tempo dos deslocamentos.

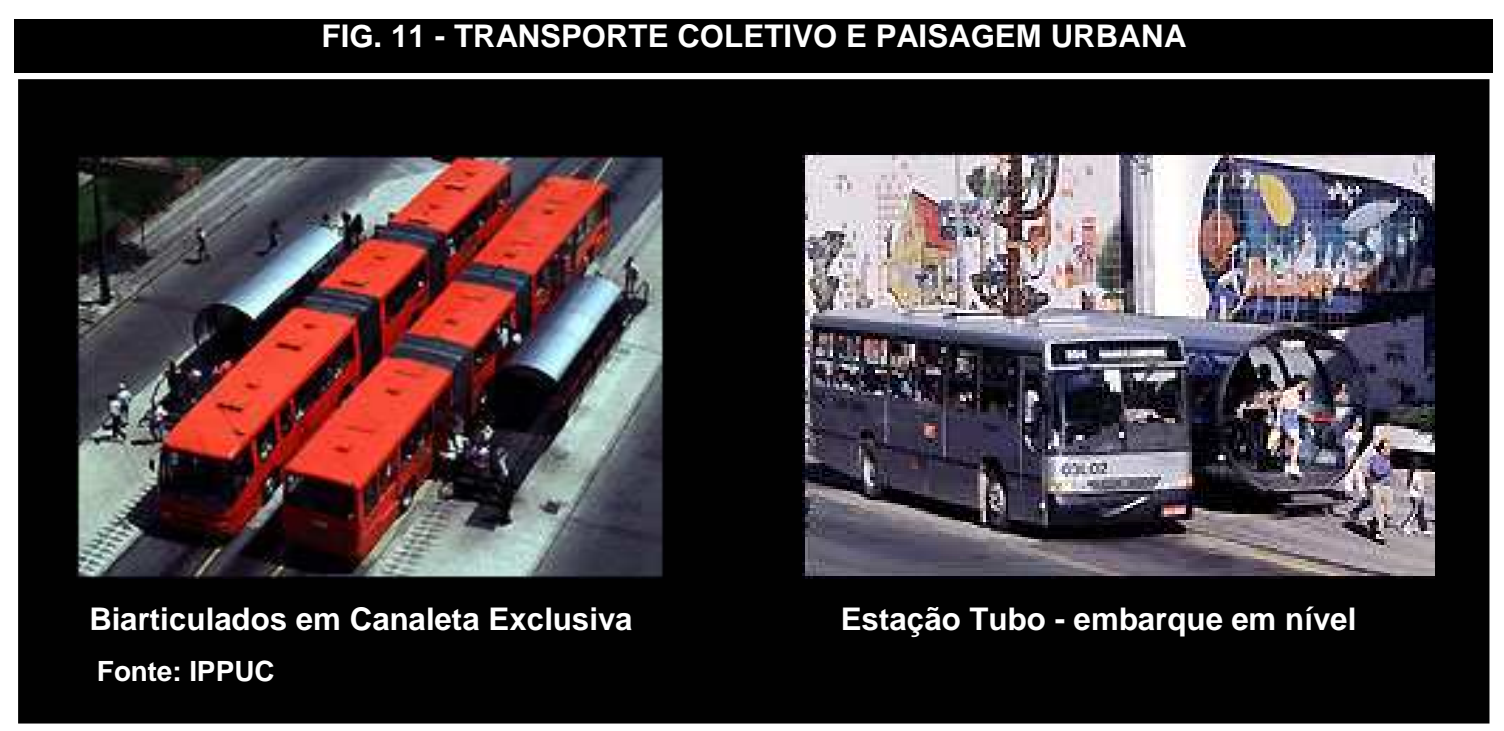

A Capital Ecológica - a reificação da Curitiba Planejada - firma-se então como a nova ideologia do planejamento: pela política de mobilidade alicerçada nos contínuos investimentos em transporte. E é assim que se dá a passagem da Curitiba Planejada para a Curitiba Reificada, na qual a história do planejamento é recontada a partir dos "novos valores de uso" atribuídos à cidade central de uma metrópole segmentada, ou seja, a da qualidade de vida enquanto base para a nova estratégia de desenvolvimento. Portanto, na Curitiba Reificada sob a Capital Ecológica instaura-se "o clima do bom negócio". A pauta nacional referente à gestão participativa e à gestão metropolitana ainda deveria aguardar. 


\section{CAPÍTULO 2}

\section{DA METRÓPOLE SEGMENTADA À CURITIBA METRÓPOLE: ENTRE A EXPANSÃO DO CAPITAL E A EXPANSÃO DA REDE INTEGRADA DE TRANSPORTE}

Neste segundo capítulo, pretende-se evidenciar as relações entre o Estado e o mercado, bem como os seus impactos sobre a estrutura intra-urbana, principalmente no tocante à produção das novas localizações e à dinâmica da sua apropriação pelas classes sociais na Curitiba Metrópole.

\section{Empresariamento Urbano e a segunda fase da industrialização}

Segundo HARVEY, deve-se investigar o papel que o processo urbano vem desempenhando na profunda reestruturação em curso, quanto à distribuição geográfica das atividades humanas e à dinâmica político-econômica do desenvolvimento geográfico desigual: "o novo empreendedorismo assumiu o centro do palco na reformulação da política urbana e nas estratégias de desenvolvimento urbano., ${ }^{161} \mathrm{O}$ autor explica assim o novo papel do urbano enquanto atratividade de capital:

“(...) a reificação das cidades em combinação com a linguagem que considera o processo urbano aspecto ativo em vez de passivo do desenvolvimento políticoeconômico impõe grandes riscos. Faz parecer como se as cidades pudessem ser agentes ativos quando são simples coisas. De modo mais apropriado, dever-se-ia considerar a urbanização um processo social espacialmente fundamentado, no qual um amplo leque de atores, com objetivos e compromissos diversos, interagem por meio de uma configuração específica de práticas espaciais entrelaçadas. Em uma sociedade vinculada por classes, como a sociedade capitalista, essas práticas espaciais adquirem um conteúdo de classe definido, o que não quer dizer que todas as práticas possam ser assim interpretadas. De fato, como muitos estudiosos demonstraram, as práticas espaciais podem adquirir conteúdos burocráticoadministrativos, raciais e de gênero (para relacionar apenas um subconjunto de possibilidades importantes.) Mas, sob o capitalismo, o amplo leque das práticas de classe, em associação com a circulação do capital, a reprodução da força de

${ }^{161}$ HARVEY (2005), p. 166-168. 
trabalho e das relações de classe, e a necessidade de controlar a força de trabalho permanecem hegemônicos." 162

Harvey aponta que o dinamismo do capitalismo hoje torna as concepções de urbano e de cidade instáveis, não por insuficiência conceitual, mas pelo próprio conceito ter que refletir as relações mutantes entre forma e processo: "assim, quando falamos da transição do administrativismo urbano para o empreendedorismo urbano nessas duas últimas décadas, temos de reconhecer os efeitos reflexivos de tal mudança através dos impactos sobre as instituições urbanas, assim como sobre os ambientes urbanos construídos." 163

Para definir o novo empreendedorismo - em contraposição ao administrativismo - Harvey estabelece três pontos-chave. O primeiro deles é que 0 novo empreendedorismo tem como elemento principal a noção de parceria públicoprivada, na qual a iniciativa privada local se integra com o uso dos poderes governamentais locais, em busca de atrair fontes externas de financiamento, novos investimentos diretos ou novas fontes de emprego. O segundo ponto é que a atividade da parceria público-privada é empreendedora, e, portanto, especulativa. Por isso, está sujeita a todos os riscos associados ao desenvolvimento especulativo, ao contrário do desenvolvimento racionalmente planejado e coordenado. $\mathrm{O}$ último ponto refere-se ao fato do empreendedorismo enfatizar muito mais a economia política do lugar do que a do território. A construção do lugar ou a melhoria das suas condições pode ter um impacto maior ou menor do que o território específico em que os projetos se localizam. ${ }^{164}$

Busca-se apoio também em GUNN, quando apresenta sua reflexão sobre "a mídia na guerra dos lugares". Ele ressalta o conceito de boosterismo, concebido em termos da promoção e marketing de lugares, e aponta para tanto, a visão de Mike Davis, para quem o boosterismo adquire seu potencial de instrumentação econômica somente por conta de seu poder cultural e ideológico de criar imagens e promover mitos, como em Los Angeles. Explica GUNN:

"Um valor imagético de cidades, antigamente mais restrito ao ramo da cultura, emerge como um valor em si, com conseqüências tangíveis em dólares, no novo cenário de globalização e da produção flexível. (...) Outras cidades, atingidas por problemas de imagem, também desenham suas estratégias empresariais e

\footnotetext{
${ }^{162}$ HARVEY (2005), p. 169.

${ }^{163}$ Idem, p. 169.

${ }^{164}$ Ibidem, p. 172-174.
} 
programas oficiais de reconstrução. (...) como Belfast e Detroit). (...) Na GrãBretanha, a questão de reestruturação econômica e a imagem das cidades como parte de uma política urbana vem sendo divulgada com exposições sobre casos como Manchester, Edimburgo, Milton Keynes. Mas, no caso de Los Angeles, é interessante observar que o apoio do governo federal para a reconstituição da imagem da cidade foi coordenado, em nível federal, por um ex-presidente de uma fábrica de máquinas de reprodução gráfica, indicado pelo presidente Bush." 165

As alterações no modo de produção alavancadas com a globalização tiveram rebatimentos tanto na configuração das redes de cidades, como no processo de estruturação interna das metrópoles também no Brasil. Ao fazer seu sucessor à frente da prefeitura de Curitiba - gestão Greca (1993-1996) - Lerner assume sua primeira gestão no governo do Estado. Dá-se então início a um novo projeto de desenvolvimento industrial, alicerçado na atração de investimentos do setor automobilístico para o Paraná.

GARCÍA observa que o city marketing conferiu à Curitiba a visibilidade necessária à venda da sua imagem: a capital ecológica é a cidade-espetáculo ${ }^{166}$, e portanto, a cidade-mercadoria. Sua apropriação se deu em duas escalas: a do cidadão - que é seduzido pelo novo discurso que reforça a sua identidade coletiva - e a do capital - revelada por meio dos investimentos externos que transformaram o perfil produtivo da região metropolitana. Ao tratar da cidade à venda, WILDERODE remetese à experiência de planejamento estratégico de Curitiba. Na publicação de 03/05/00, a revista Exame publicou em reportagem de capa "as melhores cidades para fazer negócios":

"Além de computar os dados que tradicionalmente figuram em trabalhos dessa natureza, como o tamanho da população e o seu potencial de consumo, considerou-se também itens como a qualidade de vida no município, o grau de escolaridade de sua força de trabalho, a localização geográfica em relação aos maiores centros consumidores e a segurança pública. A cidade campeã em qualidade de vida, potencial de consumo e bom nível de escolaridade no Brasil é Curitiba. Até o Banco Mundial identificou-a como a capital que oferece a seus moradores a melhor qualidade de vida no país. [...] Outros quesitos que colocaram Curitiba em primeiro lugar entre as melhores cidades para negócios no Brasil são os seguintes: a distância de $408 \mathrm{~km}$ até São Paulo (o maior mercado

\footnotetext{
${ }^{165}$ GUNN (1999), p. 150-151.

${ }^{166}$ GARCIA (1997), p 53-56.
} 
consumidor do país), o maior consumo per capita (4.768 dólares contra 4.293 dólares em São Paulo) de uma população que mais cresceu nos anos 90 (como Brasília) e uma maior proporção de domicílios concentrada nas classes A e B (42\%, igual a de Porto Alegre e Florianópolis)." 167

Faz-se necessário neste momento, apresentar os impactos da reificação da cidade pelo discurso da capital ecológica, bem como das estratégias de visibilidade da cidade. O resultado desses esforços políticos foi a implantação das montadoras Renault, Audi e Chrysler na Região Metropolitana de Curitiba - mais especificamente nos municípios de São José dos Pinhais as duas primeiras, e em Campo Largo a última. ${ }^{168}$ Ao vencer disputas pela implantação de montadoras estrangeiras, Curitiba alcançou um novo patamar no cenário do desenvolvimento econômico nacional.

Com apoio em MACEDO et al e no diagnóstico econômico contido no PDIRMC (2006), pode-se dizer que a intensidade e a natureza do fluxo de novos investimentos vêm redefinindo a forma de inserção da economia paranaense - em particular, da RMC - na dinâmica espacial da economia brasileira. As decisões locacionais para os investimentos industriais foram influenciadas pela disponibilidade de economias de aglomeração, de aprendizado e de eficiência coletiva e pela existência de trabalhadores tecnicamente qualificados. O atendimento a esses requisitos locacionais para a implantação da indústria automobilística abriu para a RMC novas possibilidades de negócios derivados das vantagens regionais criadas como qualidade da infra-estrutura logística, serviços urbanos em geral, serviços urbanos especializados, instituições de apoio na área de ciência-tecnologia-indústria (CT\&I), dimensão do mercado local, rede de empresas fornecedoras, melhoria e modernização nos padrões industriais da região, maior qualificação e profissionalização, em diferentes níveis, da força de trabalho etc. Assim, no período 1996-2000, a participação do valor da transformação industrial na RM de Curitiba em relação ao total da indústria brasileira aumentou de 2,90\% para 3,30\%, o que equivale a uma taxa de crescimento de 13,80\%. A participação da RM de São Paulo sofreu uma forte queda, de 22,50\% para 17,40\%. Em 1996, a indústria da RM de São Paulo era 7,8 vezes maior do que a existente em Curitiba; em 2000, essa proporção caiu para 5,3 vezes. Curitiba já se destaca então como o segundo maior pólo automobilístico do Brasil, atrás do ABC paulista. Segundo os autores, o intenso fluxo de investimentos verificado no Brasil, principalmente a partir de meados da década de

\footnotetext{
${ }^{167}$ WILDERODE (2000), p. 265-257.

${ }^{168}$ LOURENÇO (2000), p. 2-20.
} 
1990, indica a emergência de significativas transformações no padrão de localização regional das atividades econômicas, caracterizado a partir da tese das "ilhas de produtividade". Um indicativo dessas "ilhas" é dado pelo mapa da distribuição de empregos da indústria segundo as microrregiões brasileiras e pela participação relativa de suas principais aglomerações industriais no total da indústria brasileira, conforme informações da Pesquisa Industrial Anual de 2000, realizada pelo IBGE.

Nos anos 90, a configuração da Região Metropolitana de Curitiba sofreu uma transformação por conta do desdobramento de alguns municípios. Foram assim emancipados os municípios de Fazenda Rio Grande, Tunas do Paraná, Doutor Ulisses e Itaperuçu, seguidos logo depois por Pinhais e Campo Magro. Em função da ocupação desordenada, a RMC estaria caracterizada por extensas áreas periféricas, onde o custo da urbanização apresentava-se incompatível com o nível de renda da população. ${ }^{169}$ Um estudo sobre as configurações das espacialidades no Paraná entre 1986-91 e 1991-96, realizado por KLEINKE, DESCHAMPS e MOURA ${ }^{170}$ identificou a "confirmação da atratividade metropolitana e secundariamente das principais aglomerações urbanas interioranas" e também a ocorrência de "movimentos de partida da metrópole e dos principais pólos, majoritariamente na direção de suas periferias imediatas". Também o IPARDES - Instituto Paranaense de Desenvolvimento Econômico e Social - realizou em 1997, estudos sobre as condições de pobreza no Paraná e em Curitiba. MOURA comenta que tais estudos revelaram que as condições sociais da RMC assemelhavam-se às das demais regiões metropolitanas brasileiras:

"Como resultado da urbanização concentrada e desprovida de investimentos em infra-estrutura e serviços urbanos compatíveis ao volume e à complexidade das demandas, concomitantemente com um empobrecimento generalizado da população, essas áreas passam a viver uma deterioração crescente da qualidade de vida. O espaço que prometia acesso a facilidades, oportunidades e à diversidade transforma-se num espaço de privação e de exclusão, palco de tensões sociais e de violência. Essa constatação torna evidente que as características que ainda permitem a imagem de "cidade-modelo" ou "cidade de primeiro mundo" atribuída à Curitiba são sustentadas pela pobreza de seus municípios periféricos e de sua própria periferia interna". ${ }^{171}$

\section{Novos ícones urbanos e a expansão do terciário}

\footnotetext{
${ }^{169}$ COMEC (1999), p. 20. Metrópolis em Revista $n^{\circ} 1$

${ }^{170}$ KLEINKE, DESCHAMPS e MOURA (1999), p. 48.

${ }^{171}$ MOURA (1998a), p. 65-66.
} 
HARVEY, em Condição pós-moderna, propõe analisar as mudanças nas práticas culturais e político-econômicas que coincidiram com a primeira grande crise de caráter estrutural ocorrida após a longa prosperidade capitalista do pós-II Guerra. Para Harvey, essas mudanças têm vínculo com a maneira com que o tempo e o espaço são experienciados e relaciona-as com a emergência de uma nova forma do regime de acumulação capitalista operar - forma essa que denomina de acumulação flexível ou pós-fordismo. Durante a década de 70 afloram as idéias neoliberais. 0 neoliberalismo vem para justificar a gigantesca especulação do capital financeiro. Para o neoliberalismo, o capitalismo de massa passa a não fazer mais sentido, pois o mercado - inclusive o imobiliário, encontra-se amplamente diversificado. É o pósmodernismo, onde há a mistura de todos os símbolos. De acordo com Harvey, é a multiplicidade de linguagens, um novo ecletismo: a possibilidade de enriquecimento cultural vende uma imagem social, como um "espelho deformado do passado". O incorporador apropria-se deste argumento para realizar as suas vendas. A especulação convive então com imagens, a partir da ideologia da burguesia "querendo ser aristocracia".

Uma vez que as relações que definem e estruturam o urbano transformam-se ao longo do tempo e alcançam escalas diferenciadas, vai-se tentar avaliar em que medida as rupturas e as permanências ainda respondem aos fundamentos teóricos da metrópole industrial - fundamentos esses apontados por MEYER como não mais suficientes para explicar a totalidade da "nova metrópole". 172

WILDERODE apóia-se em ASCHER $(1993,173)$ para demonstrar a convergência dos teóricos do planejamento estratégico sobre a venda da cidade:

"Consideramos, geralmente, que o processo de internacionalização - de globalização - vai continuar, ampliando de maneira cada vez mais clara, as economias nacionais e relativizando as potencialidades de crescer. $O$ "marketing urbano" se converte em um elemento chave na definição das políticas locais. As autoridades buscam, através de todo tipo de meios, atrair os investidores; isto supõe especialmente, acessos rápidos e cômodos a todas as redes de transporte e de comunicação (auto-estradas, TGV, aeroportos, portos)" 173

Ressalta também que ASCHER (ibidem) reconhece que "a nova tendência de metropolização" acentua os fenômenos de "fragmentação social e territorial",

\footnotetext{
${ }^{172}$ MEYER (2004), p. 18-19.

${ }^{173}$ ASCHER (1993) p. 173, apud WILDERODE (2000), p. 260.
} 
condenando as cidades médias e pequenas, assim como as cidades periféricas e mono-industriais, à maior marginalização. Assim, ao desenvolvimento rápido de um setor internacional de alta tecnologia contrapõe-se o "desenvolvimento de um setor relegado, isto é, excluído, marginalizado, de populações dificilmente integráveis no "novo ciclo"." 174

WILDERODE destaca ainda que também para BORJA e FORN $(1996,41)$ : "há uma dialética entre a centralidade das cidades (atração internacional, terciário superior, dinamismo sócio-cultural e turístico, etc.) e as tendências à dualidade, que não é a divisão da cidade em dois blocos, mas a importância que adquirem dois grupos extremos, um alto, privilegiado, que atribui "marca" à cidade, ainda que se mova por cima dela, e outro baixo, marginal, que exerce as funções menos valorizadas ou vive das sobras da cidade". ${ }^{175}$

Vê-se portanto aí, que a Capital Ecológica é a "marca" da cidade central da metrópole, da visibilidade; metrópole essa mais uma vez segmentada, pois a sua periferia além de excluída, deve ser tornada invisível. A "marca" Capital Ecológica advém da qualidade de vida resultante da experiência de planejamento urbano, pelas ações desenvolvidas ao longo de vinte anos, retratadas sob a forma de postulados da "escola de urbanismo ecológico" em publicação específica do IPPUC. Tais postulados revelam que a estrutura do discurso é sustentada pela noção de ecologia vista de forma restrita, referindo-se apenas à questão das áreas verdes urbanas. Esta redução tem um forte rebatimento sobre a ação do Estado no período, que tem por expressão maior a implantação projetos estratégicos - uma série de novos parques e bosques urbanos - "um diferencial em relação a outras metrópoles brasileiras" ${ }^{176}$ - que vem constituir a base do marketing da Capital Ecológica. Frente a este contexto, cabe analisar a atuação também reduzida do órgão de planejamento nesta fase relativa ao "discurso sedutor": o IPPUC restringiu as suas atribuições à produção de projetos inovadores, nos quais têm origem os novos marcos referenciais urbanos da capital ecológica - Piá Ambiental, Farol do Saber, Rua da Cidadania, memoriais étnicos, sendo os mais importantes, sem dúvida, os parques e bosques. As Ruas da Cidadania constituem-se por "ruas cobertas" - implantadas junto aos terminais de transporte -

\footnotetext{
${ }^{174}$ WILDERODE (2000), p. 261.

${ }^{175}$ BORJA e FORN (1996), p. 41 apud WILDERODE (2000), p. 261.

${ }^{176}$ Entre as várias publicações a esse respeito, ressalta-se a titulo de ilustração: CURITIBA: a cidade modelo de um país viável. Revista Veja, ed. 1281, ano 26, n. 13, 31 mar. 1993.
} 
que objetivam oferecer ao cidadão os serviços municipais mais próximos de sua casa, evitando o seu deslocamento até a região central da cidade. Quanto ao Farol do Saber, trata-se de uma pequena biblioteca comunitária do bairro, que pode se integrar a uma escola municipal existente. Suas torres - os faróis - funcionariam como postos da Guarda Municipal. ${ }^{177}$

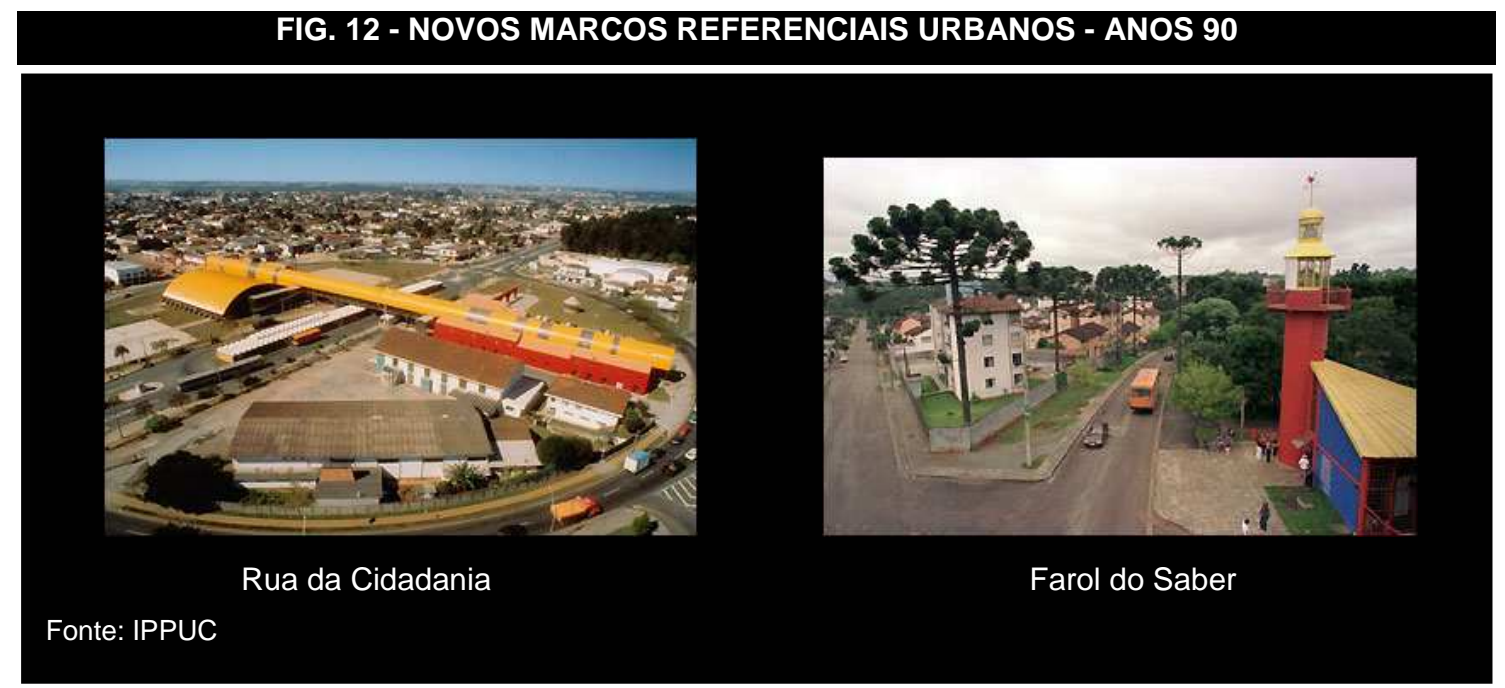

Entre as renovações urbanas dos anos 90 e 2000, interessa aqui pontuar aquelas que visibilizaram a construção da imagem da Capital Ecológica, promovidas pelo Estado por meio do empresariamento urbano e os seus respectivos impactos, revelados pelas novas formas de atuação do mercado imobiliário, quando da apropriação da nova imagem e portanto, da produção das novas localizações em Curitiba.

O novo quadro de alinhamento político em meados dos anos noventa - na Prefeitura de Curitiba o engenheiro Rafael Greca de Macedo (1993-96), enquanto Jaime Lerner assume agora o governo do Paraná - vem resgatar a condição de consonância política entre as esferas de governo municipal e estadual, que desde a institucionalização do planejamento urbano em Curitiba havia sido interrompida apenas durante a terceira gestão municipal de Lerner. Por esta situação, o discurso da Capital Ecológica teve amplas condições além de continuidade em nível municipal, de ecoar em nível estadual. Houve o fortalecimento da SMMA - tanto com relação à sua estrutura como também às competências, à medida que foram implantados mais oito parques e cinco bosques municipais, que somados a praças e pequenos jardins públicos, incorporaram quase três milhões de metros quadrados de áreas verdes à cidade, perfazendo um total de 19.127.371 metros quadrados de áreas públicas

${ }^{177}$ OBA (1998), p. 289. 
preservadas. ${ }^{178}$ Este número não contempla as áreas verdes em poder de particulares, que se encontram protegidas especialmente pela Lei Municipal $n$ ․ 8.353 de 22 de dezembro de 1993, que "dispõe sobre o monitoramento da vegetação arbórea e estímulos à preservação das áreas verdes do Município de Curitiba".

\section{FIG. 13 - PARQUES URBANOS EM CURITIBA}

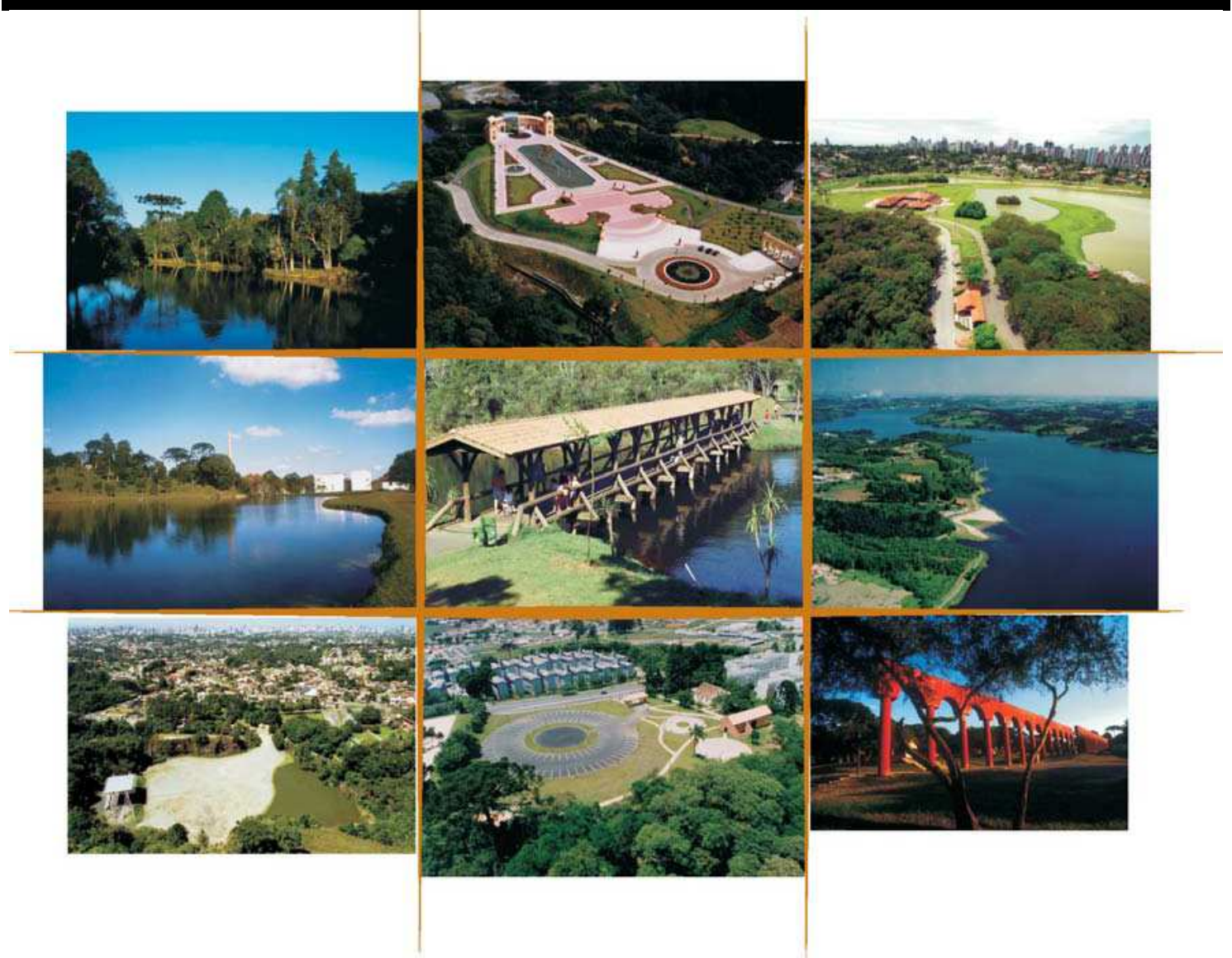

Fonte: ESPAÇO URBANO N. 3, IPPUC, JAN. 2003

Nos anos 70, Curitiba havia iniciado a implantação de seus primeiros parques urbanos, dentro do conceito de parques lineares que visavam a proteção do sistema de drenagem natural. Nos anos 80 , uma segunda geração de parques foi implantada e se caracterizava pela recuperação ambiental de áreas com problemas de drenagem ou ocorrência de ocupações irregulares. Já aqui chamada "segunda geração" de parques urbanos foi viabilizada pela parceria entre Estado e mercado imobiliário, com base na transferência de potencial construtivo dos lotes com significativa presença de áreas verdes. $O$ instrumento foi bastante eficaz, na parceria entre o Estado e o mercado imobiliário em Curitiba. Essa parceria viabilizou de um lado a criação da e de

178 TRINDADE (1997), p. 122. 
outro, além da possibilidade de verticalização nas zonas de média densidade - as ZR 4 - a transformação da ocupação das áreas contíguas às áreas preservadas com a presença de condomínios horizontais fechados.

FIG. 14 - TRANSFERENCIA DE POTENCIAL E ÁREAS VERDES URBANAS EM CURITIBA

\section{FONTE: IPPUC}

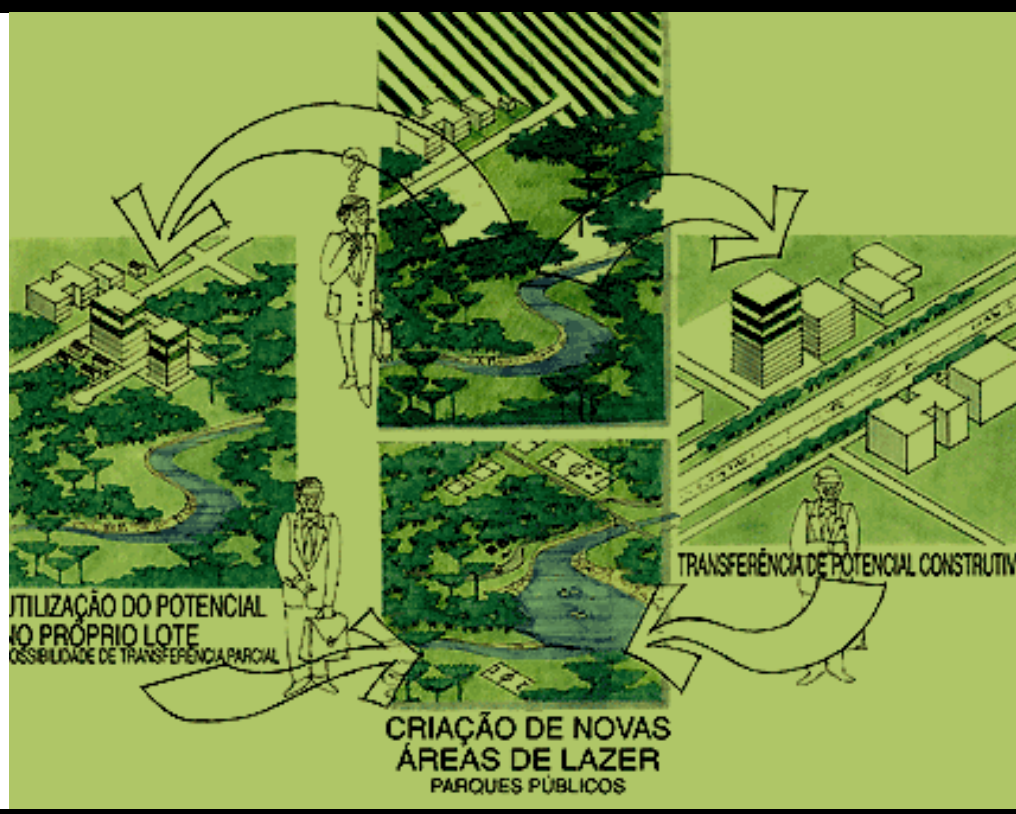

Em pesquisa realizada anteriormente ${ }^{179}$ para avaliar a valorização imobiliária advinda da implantação dos parques urbanos em Curitiba, optou-se por comparar o cenário anterior ao projeto - área degradada - com o cenário pós-implantação - área recuperada - e calcular o incremento dos preços de propriedade. Para este estudo, foram selecionados os parques Barigüi e São Lourenço (anos 70) e Bacacheri, Tapajós e Ribeirão dos Padilhas (anos 80 ) e constatou-se que a valorização mínima das propriedades foi da ordem de $400 \%$ e ocorreu em um curtíssimo prazo pósimplantação. A valorização máxima correspondeu a 715\% para o entorno imediato do Parque Barigüi e 860\% para o Parque São Lourenço. Daí concluiu-se que, apesar do parque urbano se apresentar como projeto extremamente viável em avaliações prévias do tipo custo-benefício, sua avaliação pós-implantação demonstra que o rápido e também alto incremento de valor imobiliário desencadeia o surgimento do que poderíamos chamar de externalidades - alguns processos ocorridos e não considerados - como a gentrificação. A especulação imobiliária ocorrida em função da renovação urbana acarreta uma "nova localização" e induz à elitização desses

\footnotetext{
${ }^{179}$ Pesquisa anterior realizada pela autora em consultoria realizada em 1991 para a fase de elaboração do Programa de Saneamento Ambiental, para a Região Metropolitana de Curitiba - o PROSAM-RMC, financiado pelo BIRD.
} 
espaços a partir de um gradativo processo de substituição da população original da área, que deixa assim de ser beneficiada pela requalificação. Isto, por sua vez, altera o padrão de apropriação por classes de renda superiores, capazes de consumir o espaço requalificado.

Em SMITH, encontra-se apoio para reflexão a respeito do conceito de gentrificação. Ele coloca que hoje as experiências de gentrificação são bastante diferentes e desiguais em relação aos primeiros casos europeus e norte-americanos, pois fazem parte de contextos culturais e econômicos de nível muito local e se conectam de maneira muito complexa com as economias nacionais e globais. Deve-se registrar a rapidez da evolução de um processo urbano particular e ainda tão marginal para uma dimensão marcante no urbanismo contemporâneo. Seja qual for a sua forma, a gentrificação caracterizou-se inicialmente pelo deslocamento dos moradores de classes populares dos centros, em cidades como Londres e Nova York, quando "famílias de classe média tinham transformado os bairros operários". Segundo o autor, a generalização da gentrificação apresenta diversas dimensões, e isso pode ser compreendido em termos de cinco características interligadas: o novo papel do Estado, a penetração do capital financeiro, as mudanças nos níveis de oposição política, a dispersão geográfica, e a generalização da gentrificação setorial.

"Neste fim do século $X X$, a gentrificação - considerada como uma aliança concertada e sistemática entre o urbanismo público e do capital, privado e público preencheu $o$ vazio deixado pelo retraimento das políticas urbanas progressistas.(...)" 180

Quanto ao papel do Estado, SMITH ressalta a intensificação da parceria entre o capital privado e os governos locais, constituíndo-se a parceria enquanto norma. Quanto ao capital financeiro, o novo papel representado pela globalização do capital, que foi investido em grandes projetos para áreas centrais (Canary Wharf, Battery Park City, entre outros), e também em projetos residenciais de caráter exclusivo, uma marca da última fase da gentrificação. Como um terceiro ponto, estão as lutas contra a gentrificação, como manifestações dos sem-teto e outros grupos ligados a temas afins. Em quarto lugar, SMITH coloca a difusão da gentrificação para além do perímetro central. Diz ele:

"Estamos longe de um processo ligeiro e banal e do mesmo modo que a gentrificação do centro se estendeu a espaços e dinâmicas imobiliárias mais amplas incluindo ainda as construções antigas e ainda intactas, distritos mais

${ }^{180}$ SMITH (2006), p. 75. 
afastados foram atingidos. O modelo de difusão varia bastante e é influenciado por elementos relacionados com a arquitetura, com a presença de parques ou da água, mas acima de tudo ele é adaptado aos modelos históricos de investimentos e desinvestimentos na urbanização." 181

Durante a gestão de Rafael Greca, o discurso da Capital Ecológica assumiu grande ênfase em relação à construção de uma "identidade social". Diversos espaços públicos receberam a implantação de memoriais para celebrar a influência das diferentes etnias que formaram a população curitibana. Fazem parte desta política, os bosques de Portugal, o Alemão e o Italiano, o Memorial da Imigração Ucraniana instalado no Parque Tingüi, o Memorial Árabe e outras construções em praças da cidade, além do repertório de projetos inovadores já mencionados.

É nesse contexto que o engenheiro Cássio Taniguchi elege-se o sucessor de Rafael Greca, para governar Curitiba no período 1997-2000. Taniguchi integrava a equipe de Lerner - desde a sua primeira gestão municipal (1971-74) - como diretorpresidente da URBS, quando da implantação da CIC, e presidente do IPPUC, de 1989 a 1992. Totalmente identificado com o processo de planejamento urbano de Curitiba, Taniguchi daria prosseguimento ao discurso da capital ecológica em sua gestão. $\mathrm{O}$ IPPUC recupera parte de seu prestígio dentro da estrutura administrativa municipal: da condição de "escritório de projetos inovadores", retoma a discussão das questões de estruturação urbana. Por esse motivo, o discurso ambiental passa por um processo de rearticulação interna em relação às duas gestões precedentes: novas variáveis emergem para sustentar a imagem da capital ecológica. Inicia-se, portanto, o que LEITÃO denominou de a segunda fase da capital ecológica. ${ }^{182}$ Logo no início do mandato de Taniguchi, o seminário Plano Diretor: uma abordagem metropolitana é promovido pela Câmara Municipal de Curitiba. ${ }^{183} \mathrm{~A}$ idéia era que a discussão subsidiasse um processo de revisão do Plano Diretor de Curitiba, que seria aprovado em 2000. Uma das grandes questões consideradas no processo de revisão do plano foi o projeto "BR-CIDADE", que previa a transformação do trecho urbano da BR-116 em avenida, possibilitada a partir do desvio do tráfego rodoviário com a conclusão do Contorno Leste. Para se ter uma noção da magnitude dos conflitos gerados pela condição da rodovia atravessar a malha urbana da cidade, cabe comentar que os bairros localizados além da BR-116 concentravam já neste período, cerca de um terço

\footnotetext{
${ }^{181}$ SMITH (2006), p. 78.

${ }^{182}$ LEITÃO (2002), p. 129.

${ }^{183}$ O seminário ocorreu em meados de maio de 1997.
} 
da população de Curitiba. A concepção foi alterada, passou a ser chamada de "Linha Verde", mas permanece a sua essência.

FIG. 15 - RENOVAÇOES URBANAS - ANOS 2000

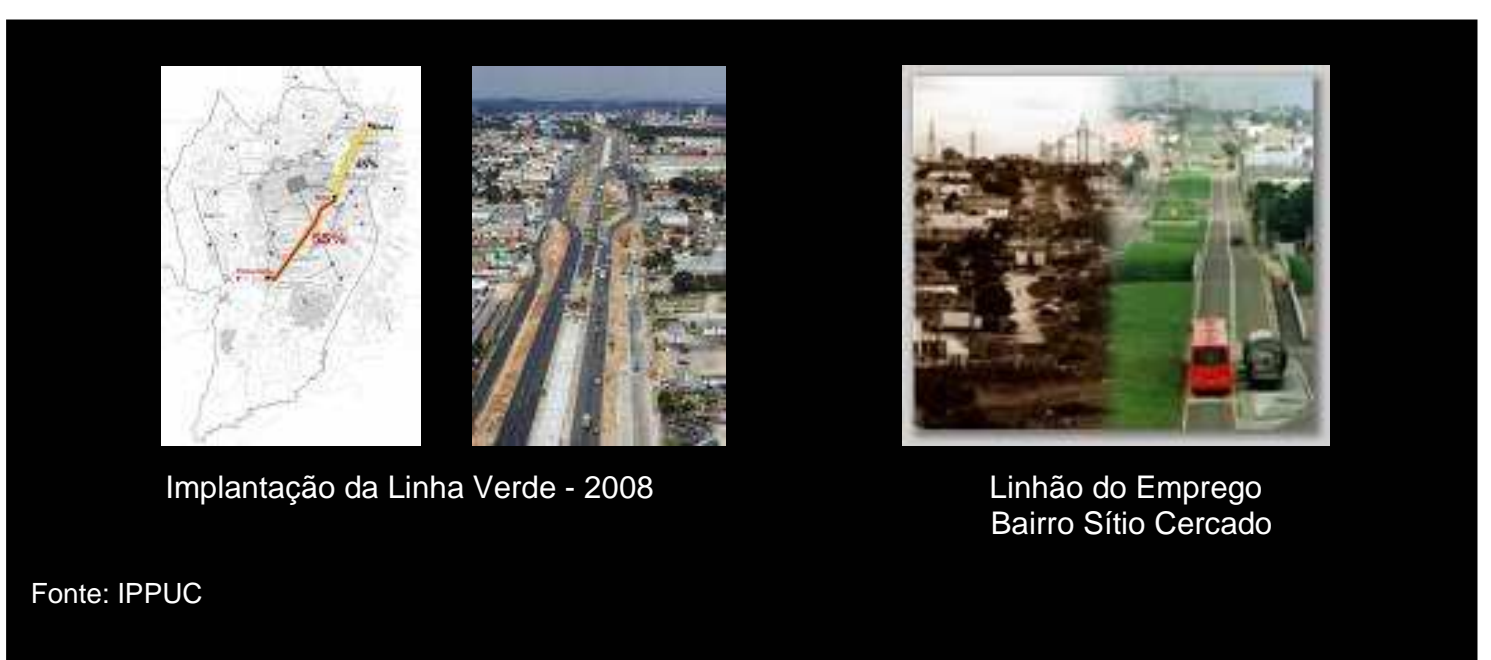

Ao final da primeira gestão de Taniguchi, após uma longa sucessão de apresentações públicas, é aprovada pela Câmara Municipal a nova legislação urbana de uso e ocupação do solo de Curitiba, em janeiro de 2000. O zoneamento contemplava o trecho urbano da BR-116 como um novo eixo estruturador da cidade, novamente sob o conceito de corredor de transporte e de adensamento - via solo criado - trecho onde seria posteriormente implantada a Linha Verde. Hoje o trecho sul encontra-se implantado e as obras prosseguem no trecho norte.

Em MOURA (2001), fazendo uma avaliação do zoneamento proposto em 2000, diz que a lei que trata da política urbana enfatiza dois instrumentos - o solo criado e a transferência de potencial construtivo - "relegando mecanismos verdadeiramente capazes de promover melhorias sociais":

"Fueran privilegiados los instrumentos que permiten la creación de parques públicos o la preservación del patrimonio histórico, por el cambio del potencial constructivo, más, según el Sindicato de la Industria de la Construcción Civil (SINDUSCON), el alto costo del suelo creado - lo correspondiente a $75 \%$ del valor del m2 adicionado - "estaría perjudicando la eficiencia de la medida, pues no incentiva propietarios de inmuebles a su uso" (MARTINS, 1999a). Además, los cambios de potencial inducen a una significativa especulación en el valor del suelo, lo que transforma la tierra en Curitiba en algo todavía más selectivo." 184

${ }^{184}$ MOURA (2001), p. 119 


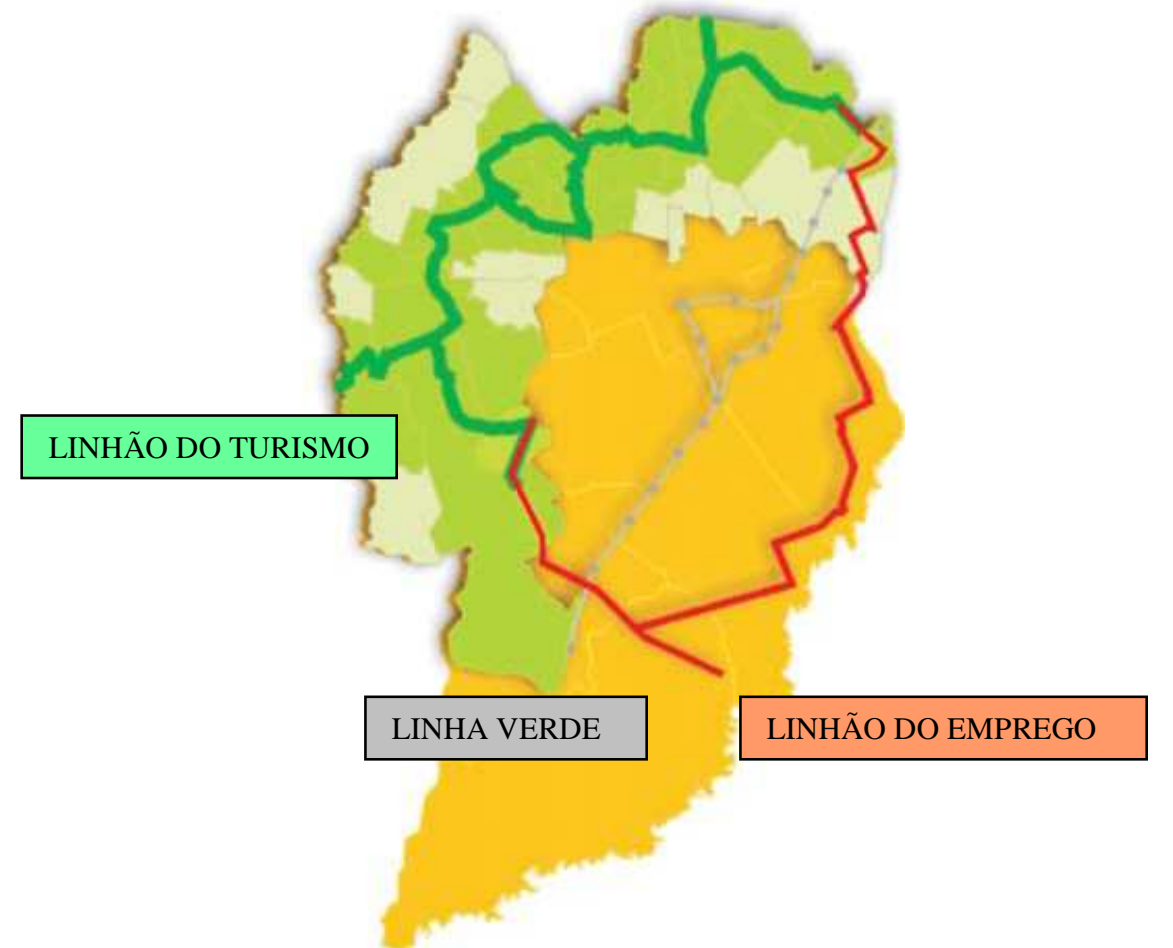

FONTË ESPAÇO URBANO N. 3, IPPUC (2002)

O anel de conservação sanitário-ambiental formado pelos novos parques - na porção norte e noroeste de cidade - foi ao mesmo tempo objeto de uma estratégia de visibilidade, ao se constituir no Linhão do Turismo. Segundo dados do IPPUC em 2003, os 20 bairros cortados pelo Linhão do Turismo concentram nove dos quinze grandes parques urbanos da cidade, perfazendo uma área verde total - particular e pública - de 23.009.283,29m2.

A questão do emprego, presente na agenda nacional é agora incorporada na pauta municipal, com o projeto Linhão do Emprego. Sua concepção baseou-se na implantação de uma nova avenida que segue a linha de alta tensão da COPEL - em uma extensão de $34 \mathrm{~km}$ - do bairro do Atuba até a CIC. Sua área de abrangência atravessa 15 bairros periféricos, conectados pela avenida, onde seriam implantados pólos de emprego. A solução adotada foi a da instalação de barracões empresariais para a incubação de pequenas empresas, apoiadas por centros de comercialização. Como política social integrada, o programa prevê a infra-estruturação de áreas de ocupação recente, reurbanização de áreas de ocupação irregular e acesso a linhas de crédito para fomento à produção. ${ }^{185}$

${ }^{185}$ IPPUC (2002), p. 33. Curitiba, na Prática. 
Sobre a natureza do planejamento de Curitiba nos anos 90, SCHUSSEL reconhece que se aproxima bastante das metodologias de planejamento estratégico que vêm sendo utilizadas, no sentido de identificar alguns pontos-chave na cidade e a partir deles desenvolver projetos específicos que sejam rapidamente absorvidos pela população, passando a compor o imaginário da cidade: "a sua diferença com a metodologia de planejamento estratégico atual é que na época as decisões eram tomadas pelos planejadores do IPPUC, sem consultar a população como apregoa a metodologia." Com relação ao marketing urbano e a visibilidade alcançada nos anos 90, diz a autora:

"Cabe a ressalva de que a transferência de modelos centralizadores para a realidade latino-americana inclui problemas adicionais, que vão desde as articulações sociais possíveis, até as dificuldades de transpor o abismo social e de integração e qualidade de vida nas cidades". ${ }^{186}$

Segundo SCHUSSEL, no período de 2000 a 2002, a COMEC tentou elaborar um plano de desenvolvimento integrado a partir da metodologia estratégica, "mas foi atropelada pela ausência de apoio institucional e político, acabando por abortar a experiência." O processo inicial de discussão do plano durou em torno de aproximadamente um ano e após isso, foi interrompido na alternância de gestão estadual; posteriormente prosseguiu adotando outras metodologias de trabalho, sendo concluído em 2006. ${ }^{187}$

Em MACEDO et al tem-se que a atual fase da economia brasileira é tida como de desenvolvimento difuso - "nem concentração, nem desconcentração". Um novo modelo começa a se definir na economia paranaense a partir da década de 90 , em função da intensidade e da natureza do fluxo de novos investimentos: “(...) grande parte desses investimentos vem sendo realizada no setor automotivo - montadoras e fornecedores - com elevado potencial de geração de efeitos endógenos diretos e indiretos, em particular no setor de serviços." ${ }^{188}$ Desse modo, a RMC está se firmando como um dos pólos automotivos de maior importância no país e no Mercosul. Ao mesmo tempo, como decorrência, no município de Curitiba o setor de serviços vem se expandindo em grande medida. Sendo assim, a idéia de complementaridade em relação à economia paulista vem dando espaço para a afirmação de uma economia paranaense enquanto um dos núcleos dinâmicos na rede nacional, cada vez mais articulada e integrada com o exterior. Os autores caracterizam assim o cenário econômico emergente:

\footnotetext{
${ }^{186}$ SCHUSSEL (2006), p. 142.

${ }^{187}$ Idem.

${ }^{188}$ MACEDO et al (2002), p. 13.
} 
"A constatação mais relevante quanto à inserção da RMC no cenário econômico do Paraná refere-se à persistência de tendências de forte concentração das atividades econômicas, dos postos de trabalho e da população estadual nessa região, já verificadas a partir dos anos 70. São três os principais eixos das transformações estruturais em curso no cenário econômico da RMC que evidenciam esse fato: 0 de crescimento e transformações na estrutura da indústria; o de expansão do setor de serviços; e o de desenvolvimento da área de Ciência, Tecnologia e Inovação."189

FIRKOWSKI, ao tratar da expansão do setor de serviços e, portanto, do dinamismo do setor terciário nesta fase, descreve o novo cenário a partir das seguintes constatações:

(i) até 1995, com base nas informações da APRAS - Associação Paranaense de Supermercados existiam três hipermercados na região; entre 1995 e outubro de 2002, foram inaugurados 13;

(ii) na década de noventa, a expansão de shoppings tornou-se mais intensa a partir de 1995; até 1990 existiam 7 shoppings, ao passo que em 2001 eram 19 ;

(iii) a rede hoteleira e de flats na RMC apresentou alta taxa de crescimento após 1995, com a participação crescente das grandes redes mundiais; de 65 estabelecimentos em 1990, passaram para 129 até julho de 2002.

Especialmente os shoppings centers provocaram rearranjos no espaço onde foram inseridos, levando a formação de novos fluxos de deslocamento, provocando a redução do dinamismo comercial nas áreas centrais, estimulando a localização de outros pontos comerciais e de serviços no seu entorno, criando portanto, novas centralidades urbanas. ${ }^{190}$ Quanto aos impactos dessas alterações sobre o redesenho das localizações na Curitiba Metrópole, tem-se apoio em VILLAÇA, para explicar a deterioração do centro da cidade. Com a migração das camadas de alta renda para as novas centralidades, as localizações ou os pontos comerciais se desvalorizaram, e a partir disso, começaram a se deteriorar por falta de manutenção e investimentos. 0 comercio e serviços centrais passaram a atender então às demandas das camadas populares. Diz VILLAÇA:

\footnotetext{
${ }^{189}$ MACEDO et al (2002), p. 13-18.

${ }^{190}$ FIRKOWSKI (2001), p. 211-216.
} 
"aquilo que se chama ideologicamente de "decadência" do centro é tão somente sua tomada pelas camadas populares, justamente sua tomada pela maioria da população. Nessas condições, sendo o centro realmente da maioria, ele é o centro da cidade". 191

Diante do exposto, cabe analisar as tendências econômicas na RMC e seus impactos. Entre eles, o alto crescimento populacional ainda em curso, e o fortalecimento da periferização de caráter cada vez mais excludente. As preocupações aumentam em relação à questão "emprego, informalidade e desemprego" e vem se intensificando em termos de dinâmica demográfica o envelhecimento da população, forte condicionante das políticas públicas. Por fim, é mais do que necessário apreender a relação Estado e sociedade, que está passando por sensíveis transformações: a emergência de um padrão descentralizado, caracterizado pela horizontalidade nas relações entre os agentes produtores do espaço e entre os novos formatos de gestão desse mesmo processo. ${ }^{192}$

\section{Novas localizações intra-urbanas e o mercado imobiliário}

VILLAÇA, em sua pesquisa sobre o espaço intra-urbano, objetiva "entender as localizações intra-urbanas, a constituição e os movimentos do espaço intra-urbano das metrópoles brasileiras - entendido como uma estrutura territorial." 193 Como metodologia de investigação, o autor propõe a análise do processo histórico da constituição da estrutura territorial metropolitana, inicialmente pelo estudo da forma, apreendendo o fenômeno da conurbação e do crescimento da urbanização, no qual "as condições de transporte aparecem como fator decisivo na estruturação do espaço urbano". ${ }^{194} \mathrm{Na}$ seqüência, devem ser analisados "os processos de constituição das grandes áreas onde se segregam as nossas burguesias urbanas. Esses processos se destacam como os mais distintivos de nossas estruturas territoriais metropolitanas."

\footnotetext{
${ }^{191}$ VILLAÇA (1998), p. 283.

${ }^{192}$ MACEDO et al (2002), p. 18.

${ }^{193}$ VILLAÇA (1998), p. 11, com base nos seguintes estudos de caso: áreas metropolitanas de São Paulo, Rio de Janeiro, Belo Horizonte, Porto Alegre, Salvador e Recife. Segundo o autor, a estrutura urbana já foi estudada por alguns teóricos por meio de "modelos espaciais", dos quais destaca o modelo de BURGESS, da década de 20, que pretendia explicar os movimentos da estrutura urbana.
}

${ }^{194}$ Idem, p. 13. 
Para se entender o processo de expansão urbana, deve-se compreender segundo o autor "as formas e as direções de expansão territorial das metrópoles, ou melhor, da área edificada mais ou menos, continuamente as nossas áreas metropolitanas." 195

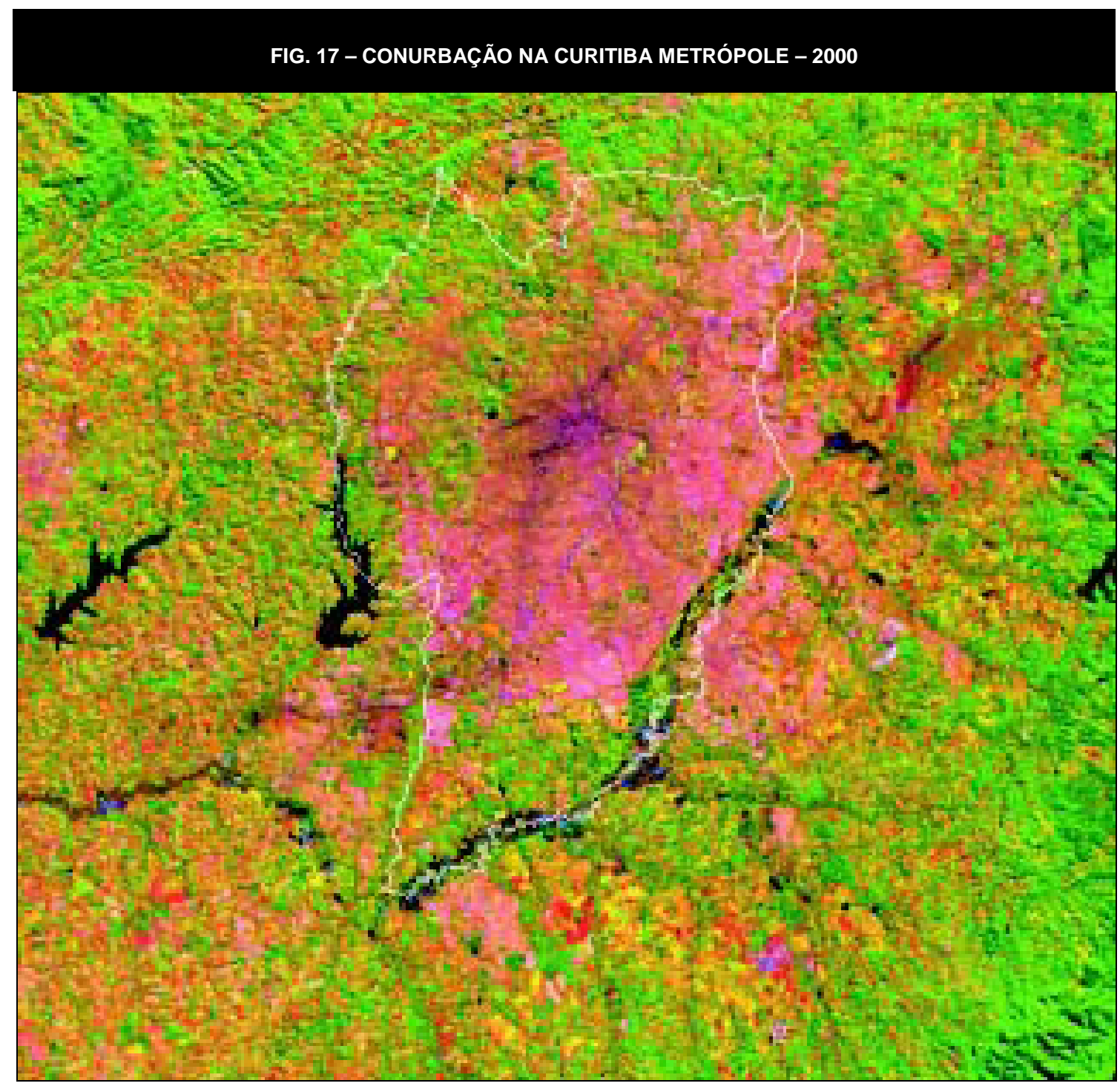

FONTE: Revista Espaço Urbano, no3 - janeiro 2003 - IPPUC

A imagem anterior corresponde ao aglomerado metropolitano de Curitiba, percebido pela mancha em rosa, em roxo os setores estruturais em evidência, e a conurbação explicitada pelo extravasamento da mancha rosa além do limite municipal à leste - calha do Rio Iguaçu - com os municípios de Colombo, Pinhais e São José dos Pinhais, respectivamente à nordeste, à leste e à sudeste.

195 VILLAÇA (1998), p. 69. 
Na rearticulação recente da estrutura intra-urbana, três foram os movimentos que a caracterizaram: o primeiro deles, refere-se à implantação do Contorno Leste e à criação dos novos distritos industriais automotivos; o segundo movimento diz respeito ao deslocamento de parte das camadas de mais alta renda para a periferia da metrópole; e o terceiro deles é impulsionado pela expansão da RIT à escala da metrópole. Dos três movimentos decorreram as novas localizações intra-urbanas, espacializadas no mapa 1, e detalhadas a seguir. 


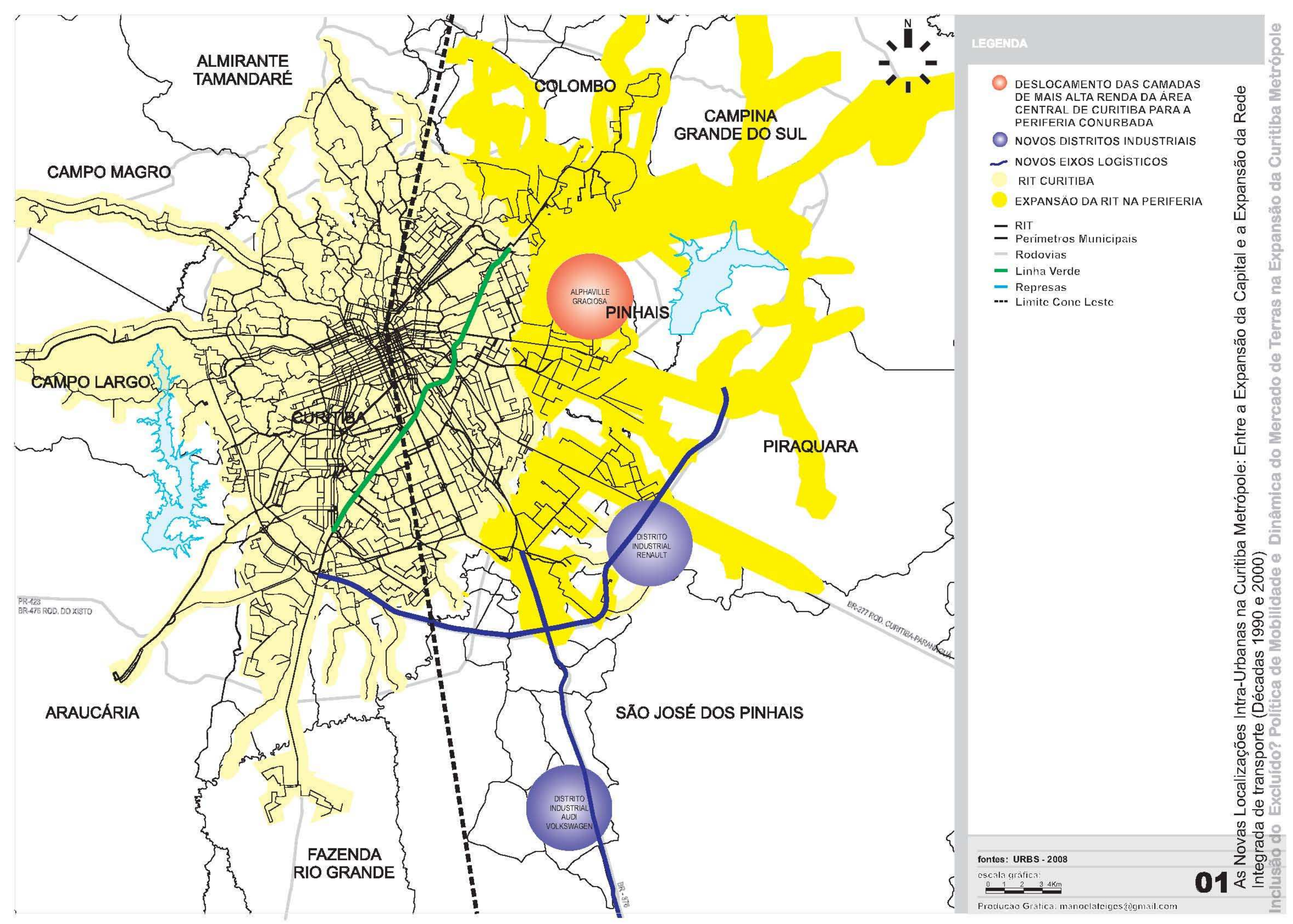


FIRKOWSKI aponta para o decisivo papel do Contorno Leste enquanto estruturador da localização industrial após 1990. Se anteriormente se preconizava a inibição das atividades industriais à leste - em função dos mananciais - agora a atratividade logística propiciada pelo contorno altera o padrão de localização industrial, confirmada pela implantação dos novos distritos industriais automotivos.

\section{FIG. 18 - CONTORNO LESTE E ACESSIBILIDADE LOGÍSTICA NA RMC - 2005}

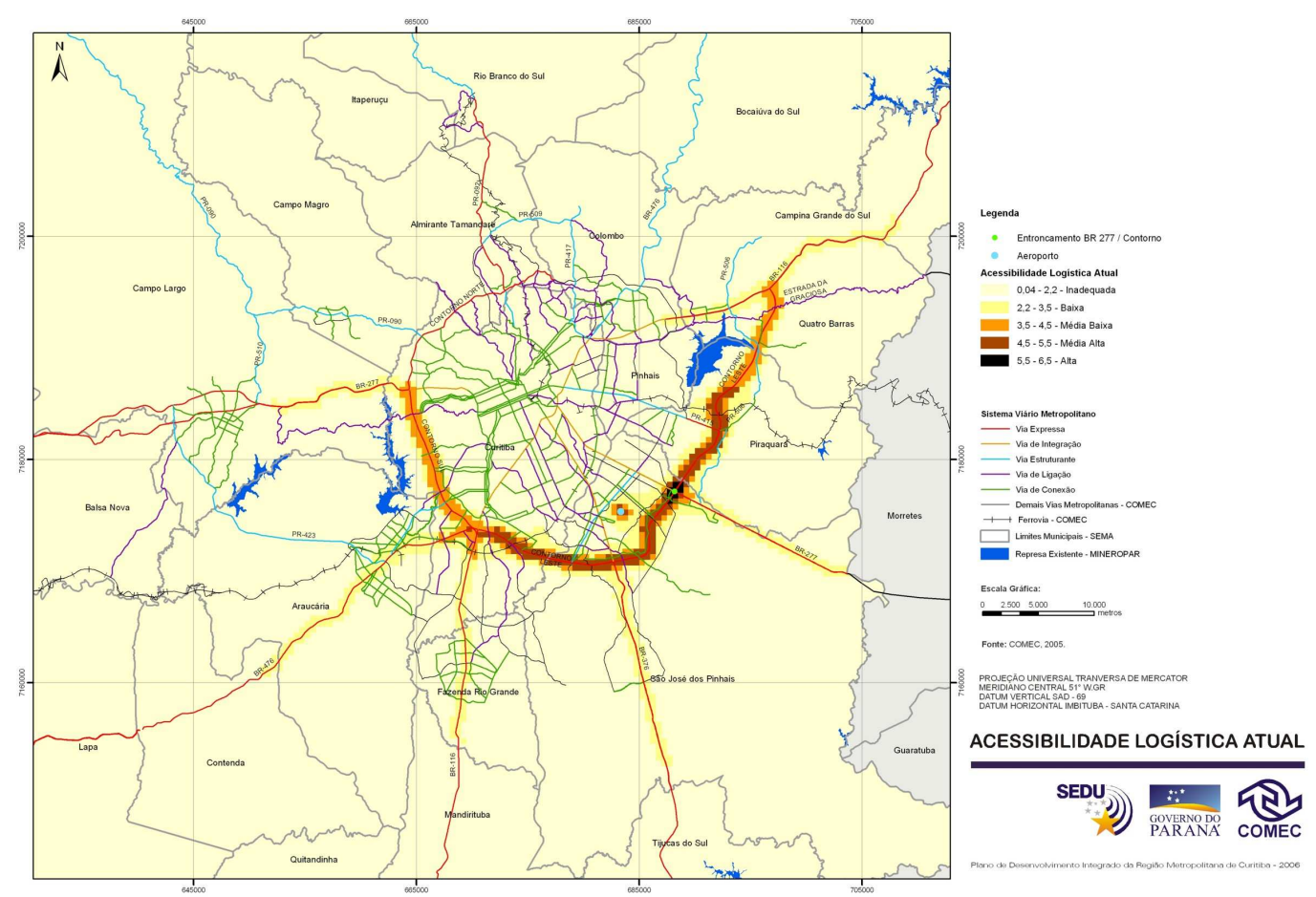

\section{Fonte: Em PDI-RMC, COMEC (2006)}

A autora prossegue com a crítica da subserviência do Estado ao capital transnacional:

"O que se temia com a implantação da Renault de fato já vem acontecendo, ou seja, a sua presença desencadeou a instalação não só de novas indústrias, como também de outras atividades econômicas e da população [...] Tal é o caso dos fornecedores localizados em Piraquara e Quatro Barras, aliás, locais destinados no passado à preservação ambiental e à produção leiteira.

O interesse do governo estadual em atrair empresas transnacionais para o Paraná e sua subserviência ao grande capital, revelaram uma faceta importante e contraditória não só em relação ao Paraná como também às grandes empresas, qual seja, aquela que pode ser considerada uma falsa preocupação ambiental. No 
caso das grandes empresas, porque grande parte delas teve seus interesses de localização materializados sobre áreas de proteção ambiental, e no caso do governo, por ter permitido a implantação nesses locais, salvaguardados por legislação". ${ }^{196}$

Ainda segundo FIRKOWSKI, o caso mais notório teria sido o da Renault, cujo interesse na localização teria motivado a alteração da Área de Proteção Ambiental do Rio Pequeno: a área original foi fragmentada em três áreas menores, "ficando de fora exatamente os locais onde hoje está implantada a maioria das novas fábricas". Ao atentar para a possibilidade de implantação de certas atividades em áreas onde antes as restrições eram mais amplas, comenta:

"A incorporação dessas áreas ao processo de valorização do solo se dá a partir de dois movimentos aparentemente opostos, quais sejam, o primeiro que é a qualidade de área preservada, representando uma importante reserva de área verde, produto raro e caro nas cidades brasileiras e que representa alta lucratividade para os proprietários ou incorporadores dos diversos segmentos do mercado imobiliário; o segundo é a tese de que se não houver uma política de ocupação dirigida e formal essas áreas tornam-se passíveis de ocupação clandestina e irregular, portanto, a indústria tecnologicamente avançada e as populações de alta renda representam as formas de ocupação menos danosas ao ambiente, pelo fato de poderem pagar o preço da preservação".

"[...] As modificações no uso e na ocupação do solo e na legislação efetuadas em função da grade indústria também foram benéficas a outros setores, particularmente o imobiliário, demonstrando mais uma vez a parceria que se estabelece entre o público e o privado, enquanto agentes fundamentais para a produção do espaço e a definição da nova lógica de localização das atividades e pessoas em Curitiba." 197

O segundo movimento que aqui se pretende demonstrar é o referente aos recentes deslocamentos das camadas de alta renda das áreas centrais de Curitiba para a periferia conurbada. Para tanto, faz-se necessário retornar à década de 70 - a fase da Curitiba Planejada - para se explicitar os citados deslocamentos na transição para a ideologia da Capital Ecológica.

\footnotetext{
${ }^{196}$ FIRKOWSKI (2001), p. 196-198.

${ }^{197}$ Idem, p. 200 e 201.
} 
Diz VILLAÇA:

“(...) nossas metrópoles - com exceção de São Paulo e do Rio de Janeiro só nas últimas décadas começaram a desenvolver áreas industriais significativas. Suas estruturações têm sido dominadas, então, pelos centros principais, seus subcentros e por suas áreas residenciais das camadas de alta renda. São, por isso, os elementos das estruturas metropolitanas aqui privilegiados. Como as áreas industriais são elementos cujas localizações são determinadas por forças externas aos espaços metropolitanos, a segregação espacial das camadas de alta renda surge como elemento interno mais poderoso no jogo de forças que determina a estruturação do espaço intra-urbano de nossas metrópoles." 198

É a partir das diretrizes do Plano Preliminar de Urbanismo (1965) que a verticalização passa a compor a paisagem da metrópole em formação nos idos de setenta. O partido do zoneamento proposto baseava-se na verticalização como instrumento de adensamento ao longo de corredores estruturais, para conciliar habitação e transporte, traduzindo assim a idéia de um urbanismo eficiente, e por outro lado, em concordância com os princípios da cidade modernista: abrigar a classe trabalhadora por meio de um plano de ocupação em massa a ser alcançado com edifícios de apartamentos ao longo dos novos eixos. A proposta de verticalização a partir dos corredores estruturais consistia, portanto, em um decréscimo do número de pavimentos à medida que houvesse o afastamento do eixo estrutural, tanto para dar referência em termos de circulação como para criar um desenho característico para a cidade. Dessa forma, o zoneamento também ia se modificando: do Setor Especial Estrutural no sistema trinário, para a ZR-4, seguida da ZR-3, ZR-2, até chegar a ZR-1, como explicita o esquema que segue.

FIG. 19 - ESQUEMA DE VERTICALIZAÇÃO DETALHADO NA LEI DE ZONEAMENTO DE 1975 PARA OS CORREDORES ESTRUTURAIS EM CURITIBA

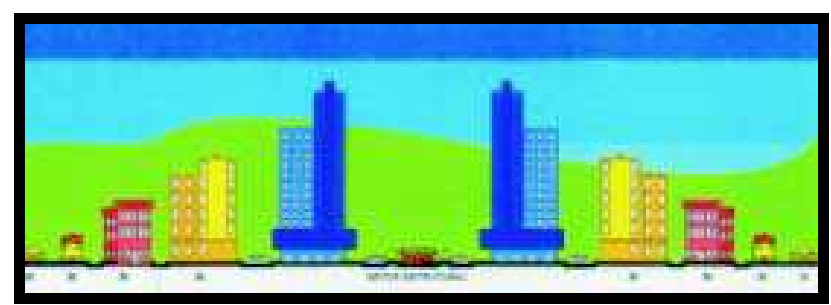

Fonte: Revista Espaço Urbano, no3 - janeiro 2003 - IPPUC

${ }^{198}$ Em VILLAÇA (1998), p. 13. 
Em função dos usos permitidos, as torres ao longo desses eixos estruturantes poderiam ser destinadas tanto à habitação coletiva como a edifícios comerciais, em função da idéia da expansão linear da área central. As áreas contíguas aos corredores estruturais atingiriam dessa forma uma média densidade, o que viabilizaria a implantação do sistema de transporte de massa. De acordo com a Lei 5.234/75, os parâmetros de uso e de ocupação estabelecidos no zoneamento ${ }^{199}$ para estes corredores visavam ao mesmo tempo liberar o número de pavimentos e controlar a ocupação por meio de um coeficiente de aproveitamento máximo. Entre 1975 a 1980, por pressões do empresariado do setor imobiliário, o coeficiente de aproveitamento foi praticamente triplicado, fixado em 6 vezes a área do terreno pelo Decreto 399/80, que dispunha sobre os setores especiais e o plano massa. Segundo SOMEHK, "a legislação que interfere efetivamente na verticalização é aquela que limita a potencialidade construtiva do terreno". ${ }^{200}$

É importantíssimo ressaltar que no ano seguinte à aprovação do plano diretor, em 1967, o Banco Nacional da Habitação (BNH) e o Sistema Financeiro da Habitação (SFH) ${ }^{201}$ passaram a promover a aquisição da casa própria junto à população de baixa renda, com recursos advindos de um novo fundo - o FGTS - Fundo de Garantia por Tempo de Serviço. Em ZAMBERLAN (2006), consta que a apropriação da verticalização se inicia na ZR-4, e não nos Setores Especiais Estruturais: "em entrevista com o Engenheiro Civil Luiz Cláudio Mehl, ele relata que os curitibanos preferiam morar em casas, e o sucesso da verticalização e do conseqüente adensamento acontece mais tarde, e só foi possível através dos financiamentos obtidos com o Sistema Financeiro da Habitação, que nos anos 70 teve grande desenvolvimento e favoreceu o setor imobiliário". 202

SOUZA afirma sobre a verticalização que

“(...) em nenhum lugar do mundo o fenômeno se apresenta como no Brasil, com o mesmo ritmo e com a destinação prioritária para a habitação. Essa última tendência vai ficar muito mais evidente após 1964, com a criação do

\footnotetext{
${ }^{199}$ SOMEHK (1997), p. 116, conta que no caso de São Paulo, o zoneamento foi uma "fórmula importada dos Estados Unidos para fazer crer à opinião pública que algum controle era exercido. Mas as primeiras normativas de zoneamento estimulavam a verticalização ao invés de controlá-la."

${ }^{200}$ Idem, p. 22.

${ }^{201}$ O BNH e o SFH foram criados pela Lei Federal 4.380/64.

${ }^{202}$ ZAMBERLAN (2006), p. 70.
} 
$B N H$, aliás o mais importante instrumento (agente financeiro) do processo de verticalização no Brasil. Essa função habitacional, ligada à verticalização, por si só dá uma identidade e, repetimos, uma especificidade ao processo de urbanização brasileiro." 203

\section{MARICATO aponta que}

"Criados pelo regime militar, em 1964, o SFH e o BNH foram estratégicos para a estruturação e consolidação do mercado imobiliário urbano capitalista. O investimento de vultosa poupança (...) no financiamento à habitação, saneamento básico e infra-estrutura urbana, mudou a face das cidades brasileiras, financiando a verticalização das áreas residenciais mais centrais, contribuindo para o aumento especulativo do solo, dinamizando a promoção e construção de imóveis." 204

A implantação do sistema de transporte teve início em 1971, com o eixo NorteSul, o que impactou sensivelmente a valorização da terra nessas áreas. SOMEHK diz que "a infra-estrutura urbana influi decisivamente no preço da terra e certamente também na estrutura e na forma urbanas. É importante explicar a evolução das redes de infra-estrutura e de transporte para entender a própria evolução das cidades. (...) Existe extrema coincidência entre extensão da rede de transportes e crescimento da cidade, mas a crítica mais recorrente a essa assertiva é que o crescimento precede a implantação do transporte". 205

Outro fato a comentar é que esses corredores estruturais, por representarem o símbolo da modernidade - da Curitiba Planejada - passaram a se constituir como "novas localizações", rapidamente apropriadas pelo mercado como possibilidade de reprodução de capital pela oferta de novos produtos imobiliários voltados às classes altas e médias. Nesse sentido, houve um boom imobiliário em Curitiba nessa fase, amparado tanto pelo BNH como pelo "milagre econômico", que propiciou o aumento dos rendimentos das classes médias.

OLIVEIRA, ao apresentar sua crítica à Curitiba planejada - "a cidade modelo" aponta a relação entre os interesses do capital imobiliário no zoneamento, mais especificamente nos setores especiais estruturais. Comenta Oliveira que na segunda

\footnotetext{
${ }^{203}$ SOUZA (1994), p. 129.

${ }^{204}$ MARICATO (1996), p. 44.

${ }^{205}$ SOMEHK (1997), p. 115.
} 
gestão Lerner - 1979-82 - os padrões de ocupação que constavam na lei aprovada em 1975 foram sensivelmente alterados, do que resultou forte especulação imobiliária, associada à verticalização de alta densidade. Ao liberar o número de torres por quadra, anteriormente fixado em três, houve um super-adensamento, impactando a posteriori, a circulação e a insolação e ventilação. Quanto ao preço da terra, cabe dizer que a valorização foi imediata, pois afinal se tratavam de áreas onde o poder público municipal já havia investido pesadamente. ${ }^{206}$

FIG. 20 - VERTICALIZAÇÃO EM CURITIBA:

VISTA DO CORREDOR ESTRUTURAL OESTE, A PARTIR DO PARQUE BARIGÜI

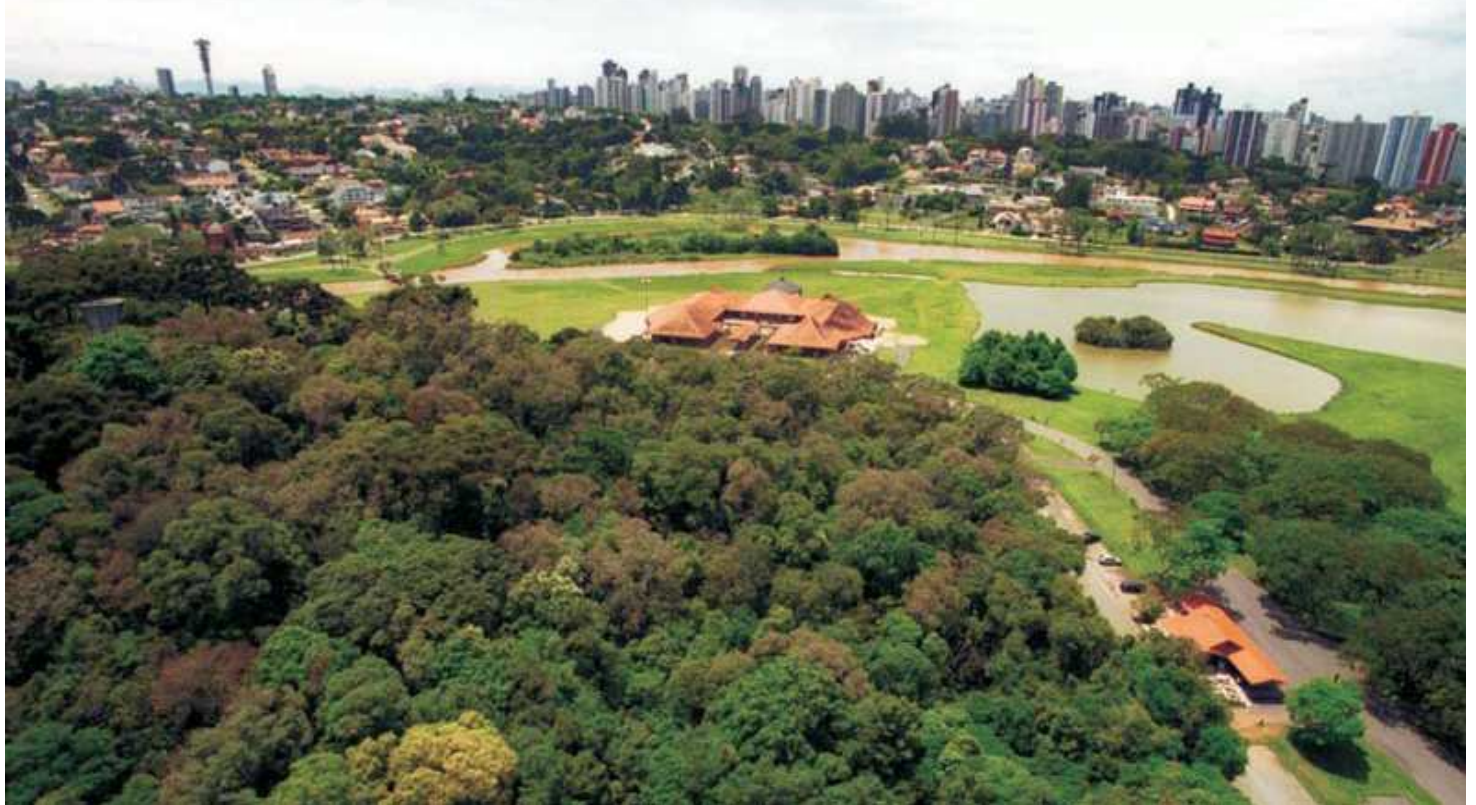

Fonte: Revista Espaço Urbano, nº3 - janeiro 2003 - IPPUC.

Em relação à expansão preconizada pelo planejamento em Curitiba - a de que o sistema viário é indutor de ocupação - verifica-se a relação entre a expansão vertical a partir do eixo estrutural norte e a consolidação de áreas conurbadas - nas décadas de 70 e 80 - ao norte com Almirante Tamandaré e a nordeste com Colombo, confirmando assim a dialética entre a verticalização e a periferização em Curitiba, pela lógica excludente do mercado de terras.

Quanto à geografia da verticalização em Curitiba, o processo se deu ao longo dos corredores estruturais a partir do centro tradicional, alterando o padrão de

\footnotetext{
${ }^{206}$ OLIVEIRA (2000), p.153-155.
} 
desenho urbano nas décadas de 70 e 80. SOUZA destaca que "a pequena burguesia não pode residir em edifícios muito distantes do centro". Ela verifica a ocorrência deste fato tanto em São Paulo - na Vila Mariana, Perdizes e Pompéia - como em Paris, no $13^{\text {éme }}$, um bairro operário que foi arrasado e reconstruído para abrigar as classes médias. Quanto ao processo de adensamento em Curitiba, na mesma área onde vivia um milhão de pessoas em 1980, em 2000, morava 1,5 milhão: houve, portanto, um acréscimo de população da ordem de 50\% nesse período de 20 anos. ${ }^{207} \mathrm{Na}$ figura abaixo, a densidade populacional medida através dos setores censitários do IBGE em Curitiba no ano 2000, demonstram que as maiores densidades foram atingidas via verticalização, ao longo dos eixos de desenvolvimento da cidade - setores estruturais assinalados em azul claro - e via padrão de parcelamento periférico - nos bairros CIC, Sítio Cercado e Cajuru, assinalados em azul escuro.

FIG. 21 - DENSIDADE DEMOGRÁFICA EM CURITIBA - 2000

Fonte: Revista Espaço Urbano, nº3 - janeiro 2003 - IPPUC

${ }^{207}$ COMEC (2006), p. 56, em PDI-RMC. 
A tabela que segue foi elaborada no sentido de demonstrar a evolução do processo de adensamento enquanto um indicador da apropriação da verticalização. Pode-se constatar claramente a assertiva feita anteriormente, sobre o crescente adensamento do centro em direção aos corredores estruturais, verificados já no período 1970 a 1980 - no eixo sul - e no período 1991 a 2000, nos demais eixos. Os bairros constantes na tabela - bem como suas respectivas densidades - ressaltados em amarelo claro, referem-se aos fenômenos da expansão do centro e da verticalização; já os destacados em branco, denotam um outro fenômeno - o da periferização. 
TABELA 2.1 - EVOLUÇÃO DOS 10 BAIRROS MAIS DENSOS DE CURITIBA - 1970 A 2000

\begin{tabular}{|c|c|c|c|c|}
\hline 1970 & 1980 & 1991 & 1996 & 2000 \\
\hline & & & & \\
\hline $\begin{array}{l}\text { CENTRO } \\
112,48 \\
\text { habitantes/ha }\end{array}$ & $\begin{array}{l}\text { CENTRO } \\
128,51 \\
\text { habitantes/ha }\end{array}$ & $\begin{array}{l}\text { CENTRO } \\
112,23 \\
\text { habitantes/ha }\end{array}$ & $\begin{array}{l}\text { CENTRO } \\
108,72 \\
\text { habitantes/ha }\end{array}$ & $\begin{array}{l}\text { ÁGUA VERDE } \\
104,67 \text { habitantes/ha }\end{array}$ \\
\hline $\begin{array}{l}\text { SÁO FRANCISCO } \\
78,42 \text { habitantes/ha }\end{array}$ & $\begin{array}{l}\text { SÄO FRANCISCO } \\
83,44 \text { habitantes/ha }\end{array}$ & $\begin{array}{l}\text { ÁGUA VERDE } \\
95,38 \text { habitantes/ha }\end{array}$ & $\begin{array}{l}\text { ÁGUA VERDE } \\
104,67 \\
\text { habitantes/ha }\end{array}$ & $\begin{array}{l}\text { CENTRO } \\
98,65 \text { habitantes/ha }\end{array}$ \\
\hline $\begin{array}{l}\text { REBOUÇAS } \\
67,26 \text { habitantes/ha }\end{array}$ & $\begin{array}{l}\text { LINDÓIA } \\
81,17 \text { habitantes/ha }\end{array}$ & $\begin{array}{l}\text { JUVEVÊ } \\
87,29 \text { habitantes/ha }\end{array}$ & $\begin{array}{l}\text { JUVEVÊ } \\
91,47 \text { habitantes/ha }\end{array}$ & $\begin{array}{l}\text { SÍTIO CERCADO } \\
92,07 \text { habitantes/ha }\end{array}$ \\
\hline $\begin{array}{l}\text { ALTO DA XV } \\
63,46 \text { habitantes/ha }\end{array}$ & $\begin{array}{l}\text { ALTO DA XV } \\
76,38 \text { habitantes/ha }\end{array}$ & $\begin{array}{l}\text { VILA IZABEL } \\
76,95 \text { habitantes/ha }\end{array}$ & $\begin{array}{l}\text { VILA IZABEL } \\
85,95 \text { habitantes/ha }\end{array}$ & $\begin{array}{l}\text { JUVEVÊ } \\
91,94 \text { habitantes/ha }\end{array}$ \\
\hline $\begin{array}{l}\text { JUVEVÊ } \\
56,73 \text { habitantes/ha }\end{array}$ & $\begin{array}{l}\text { JUVEVÊ } \\
75,82 \text { habitantes/ha }\end{array}$ & $\begin{array}{l}\text { LINDÓIA } \\
72,10 \text { habitantes/ha }\end{array}$ & $\begin{array}{l}\text { CRISTO REI } \\
83,95 \text { habitantes/ha }\end{array}$ & $\begin{array}{l}\text { CRISTO REI } \\
91,02 \text { habitantes/ha }\end{array}$ \\
\hline $\begin{array}{l}\text { BATEL } \\
54,01 \text { habitantes/ha }\end{array}$ & $\begin{array}{l}\text { ÁGUA VERDE } \\
67,13 \text { habitantes/ha }\end{array}$ & $\begin{array}{l}\text { CRISTO REI } \\
71,76 \text { habitantes/ha }\end{array}$ & $\begin{array}{l}\text { SÍTIO CERCADO } \\
80,04 \text { habitantes/ha }\end{array}$ & $\begin{array}{l}\text { VILA IZABEL } \\
90,41 \text { habitantes/ha }\end{array}$ \\
\hline $\begin{array}{l}\text { MERCÉS } \\
53,15 \text { habitantes/ha }\end{array}$ & $\begin{array}{l}\text { VILA IZABEL } \\
64,95 \text { habitantes/ha }\end{array}$ & $\begin{array}{l}\text { BATEL } \\
68,86 \text { habitantes/ha }\end{array}$ & $\begin{array}{l}\text { CAJURU } \\
72,96 \text { habitantes/ha }\end{array}$ & $\begin{array}{l}\text { CAJURU } \\
77,72 \text { habitantes/ha }\end{array}$ \\
\hline $\begin{array}{l}\text { ÁGUA VERDE } \\
52,72 \text { habitantes/ha }\end{array}$ & $\begin{array}{l}\text { CAPÃO RASO } \\
64,70 \text { habitantes/ha }\end{array}$ & $\begin{array}{l}\text { CAJURU } \\
66,12 \text { habitantes/ha }\end{array}$ & $\begin{array}{l}\text { BIGORRILHO } \\
72,31 \text { habitantes/ha }\end{array}$ & $\begin{array}{l}\text { BIGORRILHO } \\
77,44 \text { habitantes/ha }\end{array}$ \\
\hline $\begin{array}{l}\text { LINDÓIA } \\
\text { 50,81 habitantes/ha }\end{array}$ & $\begin{array}{l}\text { REBOUÇAS } \\
62,30 \text { habitantes/ha }\end{array}$ & $\begin{array}{l}\text { CAPÁO RASO } \\
65,95 \text { habitantes/ha }\end{array}$ & $\begin{array}{l}\text { PORTÁO } \\
71,26 \text { habitantes/ha }\end{array}$ & $\begin{array}{l}\text { NOVO MUNDO } \\
71,76 \text { habitantes/ha }\end{array}$ \\
\hline $\begin{array}{l}\text { ALTO DA GLÓRIA } \\
47,10 \text { habitantes/há }\end{array}$ & $\begin{array}{l}\text { ALTO DA GLÓRIA } \\
60,16 \text { habitantes/ha }\end{array}$ & $\begin{array}{l}\text { ALTO DA XV } \\
64,96 \text { habitantes/ha }\end{array}$ & $\begin{array}{l}\text { LINDÓIA } \\
69,60 \text { habitantes/ha }\end{array}$ & $\begin{array}{l}\text { PORTÃO } \\
71,53 \text { habitantes/ha }\end{array}$ \\
\hline
\end{tabular}

Fonte: Revista Espaço Urbano, n³ - janeiro 2003 - IPPUC. Elaboração: IPPUC - Banco de Dados; adaptado pela autora.

Em meados dos anos oitenta, o instrumento da transferência de potencial construtivo viabilizou o fenômeno da verticalização em grande parte das ZR-4 relativas às médias densidades. A transferência de potencial surgiu com o intuito de permitir que os proprietários de imóveis a serem preservados - por interesse histórico, 
paisagístico ou ambiental - fossem compensados pelo fato de não conseguirem atingir o potencial construtivo estabelecido na legislação ${ }^{208}$ em função da preservação.

Mais recentemente, a partir do novo zoneamento em 2000, abre-se um novo eixo de verticalização, com a transformação do trecho da rodovia BR-116 que atravessa a cidade no sentido nordeste-sul em via urbana, entre os bairros Atuba e Pinheirinho. Desde 2008, está sendo implantado um novo corredor estruturante de transporte coletivo, dotado de terminais, mais conhecido como Linha Verde, com extensão de 20 km de extensão. Dentro de um conceito de integração metropolitana, no sentido de atender as crescentes demandas de deslocamentos pendulares, a ocupação prevê um uso misto - habitação, trabalho e lazer - porém o grande incentivo é para que se consolide um eixo voltado ao setor terciário, para abrigar sedes de grandes empresas. Dessa forma, prevê-se a possibilidade da transferência de potencial construtivo dos municípios vizinhos para o novo eixo, com o objetivo de proteger áreas de nascentes e fundos de vales, por meio de convênios ou consórcios. 209 Desde 2000, este novo eixo de verticalização da Curitiba Metrópole pouco se transformou em termos de uso do solo; com apenas a primeira etapa das obras viárias concluídas - setor sul - teve início apenas em 2009 a operação do transporte coletivo, conforme já dito anteriormente.

Depois de caracterizado o processo de verticalização ao longo dos corredores estruturais da Curitiba Planejada, passa-se agora para a fase mais recente, a que corresponde à Capital Ecológica, período em que, da relação entre Estado e setor imobiliário, resultou a produção de novas tipologias de localizações. Tais localizações, por serem fortemente associadas ao verde e à qualidade de vida - valores de uso impostos pela nova ideologia - logo foram apropriadas pelas camadas de mais alta renda. Isto veio a caracterizar o seu deslocamento das áreas centrais em duas direções: uma corresponde aos bairros de Curitiba à noroeste, deslocamento esse induzido pelo Anel de Conservação Sanitário-Ambiental formado pelo cinturão de parques da segunda geração; e a outra, à periferia da metrópole, mais especificamente às bordas urbanas do município de Pinhais. Para o mercado

\footnotetext{
${ }^{208}$ Lei $6.337 / 82$ e Lei $9.803 / 2000$.

209 MOURA (2001), p. 118: “(...) en la ley de transferencia de potencial constructivo, cuyo Artículo 3. dispone que será admitida la transferencia de potencial constructivo mediante convenios o consorcios entre Curitiba y los demás municipios que componen la RMC, de forma a asegurar las condiciones ambientales adecuadas a la protección y preservación de las nacientes.”
} 
imobiliário, uma oportunidade de lançar um novo produto: o condomínio horizontal voltado à alta renda. SCHUSSEL comenta sobre os condomínios em Curitiba:

"Os condomínios fechados que surgiram ao longo dos últimos 10 a 15 anos caracterizam-se por substituir as funções urbanas das ZR-1 (nomenclatura tradicionalmente usada para as zonas residenciais de uso exclusivamente residencial unifamiliar de baixa densidade) e pela privatização de espaços públicos, oferecendo equipamentos coletivos de lazer, serviços de apoio, diminuindo o dispêndio do tempo com as atividades domésticas." ${ }^{210}$

Em CALDEIRA, sobre o condomínio como um novo conceito de moradia:

“(...) os anúncios de venda dos condomínios propõem: um novo conceito de moradia (...) que articula cinco elementos básicos: segurança, isolamento, homogeneidade social, equipamentos e serviços. A imagem que confere o maior status (e é mais sedutora) é a da residência enclausurada, fortificada e isolada, um ambiente seguro no qual alguém pode usar vários equipamentos e serviços e viver só com pessoas percebidas como iguais. ${ }^{211}$

TABELA 2.2 - TRANSFERÊNCIA DE POTENCIAL CONSTRUTIVO DAS UNIDADES DE CONSERVAÇÃO - ÁREAS VERDES - EM CURITIBA

\begin{tabular}{|c|c|c|}
\hline ÁREA VERDE & POTENCIAL CONCEDIDO & POTENCIAL TRANSFERIDO \\
\hline Parque Tanguá & $13.633,00 \mathrm{~m} 2$ & $9.947,31 \mathrm{~m} 2$ \\
\hline Bosque Uberaba & $31.560 .00 \mathrm{~m} 2$ & $657,54 \mathrm{~m} 2$ \\
\hline Bosque Solitude & $49.272,55 \mathrm{~m} 2$ & $18.908,13 \mathrm{~m} 2$ \\
\hline Bosque Portugal & $894,60 \mathrm{~m} 2$ & --- \\
\hline Parque Barigüi Sul & $16.522,11 \mathrm{~m} 2$ & --- \\
\hline Bosque Fazendinha & $35.291,26 \mathrm{~m} 2$ & $7.216,65 \mathrm{~m} 2$ \\
\hline Parque das Nascentes do Iguaçu & $104.196,56 \mathrm{~m} 2$ & $104.196,56 \mathrm{~m} 2$ \\
\hline Vila Olímpica & $28.821,00 \mathrm{~m} 2$ & $28.821,00$ \\
\hline TOTAL & $280.191,08 \mathrm{~m} 2$ & $169.747,19 \mathrm{~m} 2$ \\
\hline
\end{tabular}

Nos anos noventa, oito áreas verdes foram transformadas em parques por meio do instrumento de transferência de potencial construtivo - como os Parques Tanguá, o Tingüi e Bosques Portugal, Fazendinha e Solitude. A área do Parque Tingüi que estava destinada a ser um depósito de lixo industrial foi objeto de transferência, e pela doação do fundo de vale, os empresários receberam, por lei, o direito de construir condomínios privados no restante da área, com restrições de fracionamento da área. Porém em termos de preferência para receber o potencial transferido, figurou a região

\footnotetext{
${ }^{210}$ SCHUSSEL (2006), p. 246.

${ }^{211}$ CALDEIRA (2000), p. 264.
} 
central de Curitiba. ${ }^{212}$ Mais uma vez, portanto, o Estado provê condições de manutenção dos interesses do setor imobiliário, agora tendo como alicerce as políticas ambientais de proteção às áreas verdes: ao mesmo tempo em que promove a manutenção das ideologias, promove também a manutenção das relações de poder. ${ }^{213}$

Com relação à segunda direção de deslocamento das classes de mais alta renda das áreas centrais de Curitiba, impulsionada pelas políticas ambientais de proteção aos mananciais. Cabe enfatizar que a motivação desse deslocamento novamente provém da articulação entre Estado e Mercado em atender aos interesses da elite.

Ao final dos anos 90, um conjunto de leis estaduais foi aprovado, com o propósito de proteger as bacias hidrográficas de manancial de abastecimento da RMC, face às predatórias tendências de ocupação em seu território. Com a finalidade de criar um sistema integrado de gestão e proteção dos mananciais da RMC SIGPROM, a lei estadual no 12.248/98, tem por princípios norteadores: (i) busca densidades populacionais compatíveis com a capacidade de esgotamento sanitário e de drenagem de áreas; (ii) estabelece novos conceitos de ocupação do solo; (iii) promove o envolvimento de atores públicos e privados no processo de decisão e (iv) propõe tratamento diferenciado para cada uma das bacias hidrográficas. Nesse contexto, além de regulamentar a delimitação das áreas de mananciais, cria a figura

\footnotetext{
${ }^{212}$ Em 1990, os recursos provenientes da transferência de potencial e do solo criado propiciaram a criação do Fundo Municipal de Habitação, de onde adveio o suporte financeiro aos programas habitacionais de baixa renda no início dos anos 2000 - Operação Bairro Novo e Operação Cajuru respectivamente nos bairros periféricos da porção sul de Curitiba - Sítio Cercado - da porção leste Cajuru.

213 OLIVEIRA (2000), p. 153-163: As relações entre o empresariado e o solo urbano constituem-se a partir do capital imobiliário, e compreende os setores de incorporação, de construção e as imobiliárias. Em Curitiba, "o setor tem conseguido defender suas demandas no interior do sistema político local, influenciando consistentemente o padrão vigente de urbanismo." Tais relações tiveram início quando da aprovação da Lei 5.234/75, referente ao zoneamento de uso e ocupação do solo, inicialmente com a participação da Associação Comercial do Paraná - ACP e do SINDUSCON. Quanto à ACP, a reivindicação era no sentido de se eliminar a proibição de "comércio de qualquer tipo" nos setores de ligação prioritária; em relação ao SINDUSCON, a pressão que se exercia era quanto à alteração do padrão de ocupação estabelecido para os setores estruturais, de três torres de no máximo 15 andares por quadra e a supressão da obrigatoriedade de participação na infra-estruturação das vias estruturais. As reivindicações do SINDUSCON foram sendo atendidas paulatinamente, por meio de decretos especiais sobre a ocupação do solo no setor especial estrutural, ao longo da década de oitenta. Do decreto 247/80 ao 579/90, os coeficientes de aproveitamento triplicaram, gerando assim um adensamento excessivo, comprometendo em parte a qualidade urbana quanto à aeração e ventilação. Com relação à tentativa de combate aos vazios urbanos em 1985, na gestão FRUET - fase do recorte oposicionista desde 1971 - com a mobilização para o veto da tributação progressiva no anteprojeto de lei encaminhado à Câmara Municipal, quando novamente a ACP e o SINDUSCON elaboraram um trabalho de cunho jurídico para comprovação do cerceamento do direito de propriedade.
} 
das UTP's - Unidades Territoriais de Planejamento, que objetiva controlar a pressão da ocupação nas sub-bacias contribuintes, a fim de garantir a efetividade das APA's. Para as UTP's, foram estabelecidos zoneamentos específicos, que prevêem além das zonas de restrição, zonas de ocupação orientadas. Nestas áreas, prevê-se a troca de potencial construtivo por áreas de interesse público de preservação, ao mesmo tempo em que contemplam áreas para atendimento de assentamentos ilegais - as AISO, áreas de interesse social de ocupação. Assim, além das APA's do Irai, Passaúna, Piraquara, Verde e Pequeno já existentes, são instituídas as UTP's de Pinhais, Guarituba, Itaqui, Quatro Barras e Campo Magro. ${ }^{214}$

FIG. 22 - ESQUEMA DAS UNIDADES TERRITORIAIS DE PLANEJAMENTO UTP'S PREVISTAS NA LEI 12.248/98

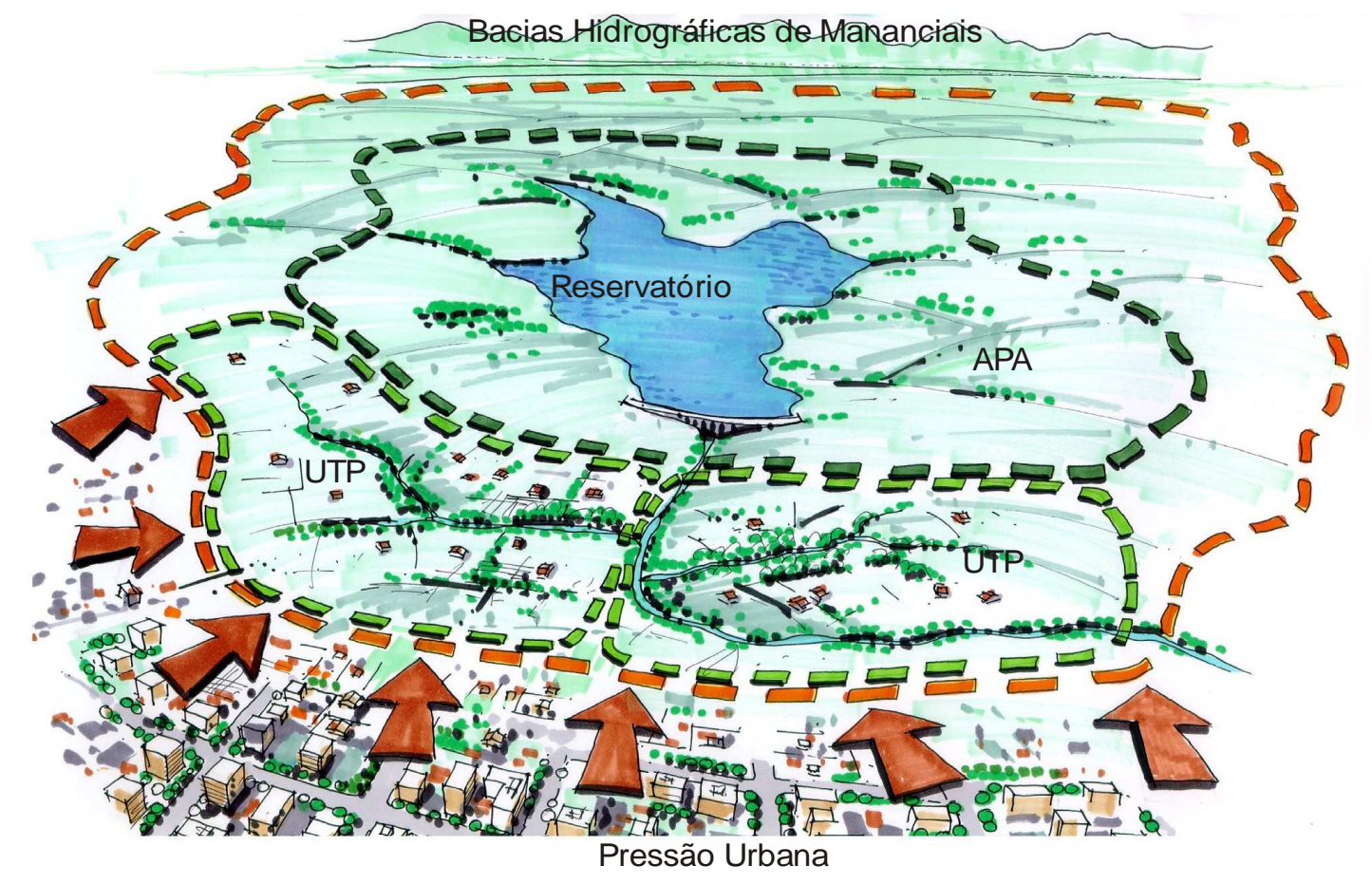

Fonte: COMEC, 2002

MENDONÇA et al, ao avaliarem a UTP de Pinhais enquanto instrumento de proteção ambiental, concluíram que, desde a sua implantação, "a área ocupada por loteamentos aumentou em 2,32 $\mathrm{km}^{2}$, ou seja, praticamente dobrou, fato explicado pela implantação da nova legislação que intensificou o parcelamento do solo. Observou-se também que a transformação da APA em UTP viabilizou a implantação de projetos

${ }^{214}$ COMEC (2006), p. 162-171, em PDI-RMC. 
imobiliários como conjuntos residenciais de alto padrão - Alphaville Graciosa e Alphaville Pinheiros - concretizados por promotores imobiliários e proprietários fundiários para atender a população de alta renda." 215

Nas áreas de fragilidade ambiental, vários diplomas legais sobrepõem-se no sentido de restringir o uso e a ocupação do solo com fins de proteção ambiental, sejam eles leis e decretos federais, estaduais ou municipais. Essas restrições são incorporadas nos zoneamentos de uso e ocupação do solo urbano pelos municípios atingidos.

MARICATO mais uma vez critica o Estado, com muita propriedade:

"A ação prática do Estado, no Brasil, fornece exemplos freqüentes nos quais o patrimônio fundiário privado merece mais cuidados que $o$ patrimônio público, incluindo aí as áreas legalmente submetidas à preservação ambiental. A ocupação ilegal como as favelas são largamente toleradas quando não interferem nos circuitos centrais da realização do lucro imobiliário privado. Qualquer análise superficial das cidades brasileiras revela relação direta entre moradia pobre e degradação ambiental. Isso não quer dizer que a produção imobiliária privada ou que o Estado, pela produção do ambiente construído, não causem danos ao meio ambiente." 216

Em contraponto à crise do Estado, está a crise do mercado imobiliário. Segundo LAGO, com a extinção do BNH houve, desde o final dos anos oitenta, de um lado a estagnação da produção empresarial da habitação, e de outro, a sua elitização, o que afetou sobremaneira a oferta para os segmentos médios. Por sua vez, o preço da terra nas áreas de restrição se mostrou uma alternativa viável ao mercado em busca da acumulação de capital: em atendimento às demandas da classe média e da insegurança generalizada, lançou um novo conceito de moradia por meio de condomínios fechados horizontais. Em relação a essa dinâmica na metrópole do Rio de Janeiro, diz LAGO:

"O loteador descapitalizado, predominante na região nos anos 50, 60 e 70, cede lugar à empresa imobiliária, que passa a realizar, além da

\footnotetext{
${ }^{215}$ MENDONÇA et al (2000), p.7.

${ }^{216}$ MARICATO (1996), p. 65.
} 
compra e do retalhamento da terra, a construção e a comercialização da moradia. Mudam a racionalidade da operação e as condições de acesso à terra. O resultado são loteamentos produzidos para os setores médios da população com algum acúmulo de capital e capacidade de endividamento". ${ }^{217}$

$\mathrm{Na}$ Curitiba Metrópole, é importante salientar que a implantação do Alphaville Graciosa em Pinhais, município conurbado com Curitiba à leste, seu deu ao lado de uma das maiores invasões da RMC - a Vila Zumbi dos Palmares, onde o preço da terra era muito baixo. O porte da intervenção atraiu famílias de renda mais alta para a compra dos lotes, mudando assim o perfil do mercado imobiliário da região e atraindo outros condomínios para o local.

Conforme descrito em POLLI, entre os impactos do empreendimento Alphaville Graciosa, ressalta-se a transformação espacial e a dinâmica imobiliária instalada no entorno imediato, "bem como a mais-valia incorporada pela compra da gleba a preços baixos $\left(R \$ 3,00 / \mathrm{m}^{2}\right)$ e sua transformação posterior em empreendimento que alcança alto preço de venda $\left(R \$ 130,00 / \mathrm{m}^{2}\right)$. Segundo dados da Gazeta do Povo, "O grupo Alphaville e Urbanismo S/A investiu no Paraná cerca de 170 milhões". O valor corresponde aos empreendimentos Condomínio Alphaville Graciosa, Alphaville Graciosa Il e outros dois empreendimentos em Londrina e Maringá." "218

No montante de investimentos está a recuperação ${ }^{219}$ e duplicação da Estrada Histórica da Graciosa, numa extensão de 3,7 km a partir de Curitiba, no trecho da Cruz do Atuba até a entrada do condomínio a fim de facilitar o acesso ao empreendimento cerca de $R \$ 5,2$ milhões.

\footnotetext{
${ }^{217}$ LAGO (2000), p. 212.

${ }^{218}$ POLLI (2000), p. 98-100.

${ }^{219}$ A empresa Alphaville Urbanismo S. A. investiu na duplicação da estrada, além de ter investido em pavimentação, sinalização, iluminação, construção de galeria de águas pluviais e recuperação de ponte sobre o Rio Palmital.
} 


\begin{tabular}{|c|c|c|}
\hline \multicolumn{3}{|c|}{$\begin{array}{c}\text { TABELA } 2.3 \text { - Comparativo do patamar de urbanização entre } \\
\text { ALPHAVILLE GRACIOSA e ZUMBI DOS PALMARES, em Pinhais, RMC }\end{array}$} \\
\hline & ALPHAVILLE GRACIOSA & ZUMBI DOS PALMARES \\
\hline tipologia de ocupação & $\begin{array}{l}\text { condomínio fechado, } \\
\text { aprovado como loteamento }\end{array}$ & $\begin{array}{l}\text { ocupação irregular, } \\
\text { existente há } 14 \text { anos }\end{array}$ \\
\hline estágio atual & $\begin{array}{l}\text { em processo de consolidação, com } \\
\text { aproximadamente } 600 \text { moradores }\end{array}$ & $\begin{array}{l}\text { em processo de regularização fundiária } \\
\text { financiada pelo governo do estado }\end{array}$ \\
\hline imagens associadas & $\begin{array}{l}\text { proximidade com o centro urbano; } \\
\text { o novo estilo de vida; melhor estilo de } \\
\text { vida; viva em alpha; conceito único de } \\
\text { empreendimento qualidade de vida. }\end{array}$ & $\begin{array}{l}\text { roubo, desmanche de carros, marginalidade, } \\
\text { violência, tráfico de drogas, precárias } \\
\text { condições de vida }\end{array}$ \\
\hline área ocupada & 2,5 milhões de $\mathrm{m}^{2}$ & $500 \mathrm{mil} \mathrm{m}^{2}$ \\
\hline população total & 6.500 habitantes & 6.649 habitantes \\
\hline $\begin{array}{l}\text { número de lotes e } \\
\text { habitações }\end{array}$ & 1.218 lotes & 1.797 habitações existentes \\
\hline densidade & $2.400 \mathrm{hab} / \mathrm{km}^{2}$ & $\begin{array}{l}13.298 \mathrm{hab} / \mathrm{km}^{2} \\
\text { (5,5 vezes mais que em alphaville) }\end{array}$ \\
\hline área do lote & $\begin{array}{l}\text { área mínima de } 550 \mathrm{~m}^{2} \text {, (maioria } \\
700 \mathrm{~m}^{2} ; \text { ultrapassando } 1.000 \mathrm{~m}^{2} \text { ) }\end{array}$ & $\begin{array}{l}\text { no máximo até } 200 \mathrm{~m}^{2} \\
\text { (4 a } 8 \text { vezes menor que em alphaville) }\end{array}$ \\
\hline $\begin{array}{l}\text { área mínima da } \\
\text { residência }\end{array}$ & $200 \mathrm{~m}^{2}$ & $\begin{array}{l}\text { variável: } 52 \% \text { das famílias com casas } \\
\text { de } 30 \text { a } 60 \mathrm{~m}^{2} ; \text { pela pesquisa, a área mínima } \\
\text { encontrada: } 15 \mathrm{~m}^{2} \text {; sobrados propostos no } \\
\text { projeto de regularização: } 40 \mathrm{~m}^{2} \text { (4,4 vezes a } \\
\text { mais) }\end{array}$ \\
\hline taxa de ocupação & $40 \%$ & $60 \%$ a $100 \%$ (ocupação total) \\
\hline infra-estrutura & completamente instalada & luz e água \\
\hline vias asfaltadas & $100 \%$ & $0 \%$ \\
\hline área verde & $\begin{array}{l}\text { 1,0 milhão de } \mathrm{m}^{2} \text {, sendo } 165 \\
\mathrm{~m}^{2} / \text { morador }\end{array}$ & $\begin{array}{l}35 \text { mil } \mathrm{m}^{2} \text { de faixa de preservação do } \\
\text { "parque linear do palmital a recuperar" }\end{array}$ \\
\hline áreas de uso comum & $630.000 \mathrm{~m}^{2}$ (área de lazer) & $3.800 \mathrm{~m}^{2}$ (campo de futebol) \\
\hline período analisado & $\begin{array}{l}\text { a partir de 1990, novas formas urbanas } \\
\text { alteram o então conteúdo da periferia }\end{array}$ & $\begin{array}{l}\text { a partir de } 1970 \text {, inicia-se o processo } \\
\text { de periferização em curitiba }\end{array}$ \\
\hline feições espaciais & centro e periferia se fragmentam & centro-periferia \\
\hline configuração espacial & $\begin{array}{l}\text { negação da cidade, espaço privatizado, } \\
\text { espetáculo, cidade toda enquanto } \\
\text { mercadoria, cidade fragmentada, } \\
\text { enclausurada }\end{array}$ & cidade dispersa, periferização \\
\hline $\begin{array}{l}\text { valores imobiliários } \\
\text { do terreno }\end{array}$ & $\begin{array}{l}\text { antes: } \mathrm{R} \$ 3,00 / \mathrm{m}^{2} \\
\text { pós-empreendimento: } \mathrm{R} \$ 180,00 / \mathrm{m}^{2}\end{array}$ & $\begin{array}{l}\text { mercado informal: } R \$ 8,00 / \mathrm{m}^{2} \\
\text { pós-início da regularização: } \mathrm{R} \$ 20,00 / \mathrm{m}^{2} \text {, } \\
\text { valor da desapropriação: } \mathrm{R} \$ 7,00 \mathrm{~m}^{2}\end{array}$ \\
\hline
\end{tabular}

Segundo POLLI, em relação ao discurso do grupo Alphaville, é a promessa de uma "nova fase do mercado imobiliário", que implica em uma aposta especulativa, num modelo de "fazer cidade" cujo carro chefe é a empresa privada incorporadora de terra e promotora de condomínios fechados. Diz ainda POLLI:

"O número de condomínios desse tipo (grande porte e luxo) existentes em todo o Brasil fortalece a certeza de que esses empreendimentos correspondem a uma tipologia já padronizada/codificada, multiplicando imagens emblemáticas, que 
visam à adesão a um novo modo de vida para as classes altas, que transforma as relações historicamente mantidas com o outro, a cidade e o Estado. ${ }^{220}$

Em nível de governo do Estado, em função do novo projeto de desenvolvimento calcado na desconcentração das atividades industriais no território da metrópole, a expansão urbana passa a demandar a gestão dos impactos da rearticulação da estrutura intra-urbana, destacando-se a orientação de que os vetores de crescimento não comprometessem as questões ambientais. ${ }^{221}$ Segundo MOURA, ${ }^{222}$ "[...] reforça-se a política do marketing urbano - agora não restrita à Curitiba, mas incorporando a "região" no discurso - como apoio à efetivação das estratégias de reestruturação econômica." Este fato demandou o fortalecimento do órgão de planejamento metropolitano - COMEC - para a qual foram deslocados muitos dos técnicos que compunham o IPPUC e também outras secretarias municipais. Ao mesmo tempo, foi criada junto à municipalidade em 1994, a Secretaria Extraordinária de Assuntos Metropolitanos, responsável por fazer a interlocução entre - IPPUC e a COMEC nas questões de planejamento referentes à escala metropolitana.

As UTP's, com o intuito de "controlar a ocupação e o adensamento" nas áreas referentes às sub-bacias de manancial como o freamento da urbanização em direção às APA's existentes, acabaram por promover novas frentes de mercado imobiliário. Por sua vez, coube ao mercado a estratégia de estender o "verde" e a qualidade de vida a ele associada, para além do pólo, por meio de um novo produto - o condomínio fechado de alto luxo - onde a qualidade de vida se encerra entre muros. Esta foi uma forma de criar novas localizações a partir da extrapolação do discurso da qualidade de vida para a "grande Curitiba Ecológica" - em sua periferia conurbada.

ROLNIK, ao construir sua critica em relação à legislação urbana e à valorização imobiliária, afirma que:

"Além de estabelecer fronteiras, demarcando e dissolvendo territórios, as normas que regulam a construção e o loteamento intervêm diferentemente na estruturação dos mercados imobiliários. Juntamente com os investimentos em infra-estrutura, a legislação configurou eixos de valorização

\footnotetext{
${ }^{220}$ POLLI (2006), p. 100.

${ }^{221}$ COMEC (1999), p. 26. Metrópolis em Revista $\mathrm{n}{ }^{\circ} 1$.

${ }^{222}$ MOURA (1998b), p. 49.
} 
do solo, hierarquizando e indexando mercados. Repetido infinitas vezes ao longo da história da cidade de São Paulo, esse processo sintetiza o movimento de um mercado cuja rentabilidade e ritmo de valorização são definidos por uma dupla lógica. Por um lado, são mais valorizadas as localizações capazes de gerar as maiores densidades e intensidades de ocupação; por outro, valorizam-se os espaços altamente diferenciados ou exclusivos." 223

A título de ilustrar os impactos na valorização da terra no entorno do Alphaville Graciosa em Pinhais, implantado em 2000, ao lado da invasão Zumbi dos Palmares, uma das maiores da RMC, comenta POLLI (2006):

"A implantação de Alphaville, as melhorias viárias, a mudança da legislação da área da UTP e o progressivo investimento público impulsionaram a produção imobiliária na região. Novos condomínios residenciais estão sendo implantados, dinamizando o comércio e os serviços. Segundo C. L.117, incorporador imobiliário da região, houve valorização de aproximadamente 30\% nos imóveis pósimplantação do Alphaville Graciosa, em 2000. Essa valorização deu-se num raio de aproximadamente $3 \mathrm{~km}$ do local do empreendimento. No entanto, em algumas áreas, a valorização atingiu o patamar excepcional de $300 \%$.

(...) Um imóvel no empreendimento Alphaville Graciosa custava, em planta no ano de $2000, R \$ 100,00 / m^{2}$ e, atualmente, encontra-se na faixa de $R \$ 180,00 / \mathrm{m}^{2}$. A valorização deve-se aos ganhos imobiliários apenas pela consolidação $e$ progressiva ocupação do empreendimento.

(...) Já no mercado informal, os lotes residenciais (área de $200 \mathrm{~m}^{2}$ ) em Zumbi dos Palmares que eram comercializados por $R \$ 3.000$ antes de Alphaville, passaram atualmente a valer $R \$ 10.000$ mesmo sem a conclusão da regularização $e$ urbanização da Vila. A tendência "é que subam ainda mais." 224

Quanto às restrições de caráter ambiental deve-se dizer que, por desvalorizarem as terras nas áreas de expansão periférica, passaram a representar uma alternativa ao mercado no sentido de garantir a alta lucratividade oferta de novo produto imobiliário às classes de maior renda, desde que resguardada as condições de acessibilidade e mobilidade urbanas. A Curitiba Metrópole redesenha a partir desse

\footnotetext{
${ }^{223}$ ROLNIK (1997), p-101

${ }^{224}$ POLLI (2006), p. 154.
} 
momento a clássica distribuição das classes sociais - estabelecida pela relação centro-periferia - constituindo assim uma "nova periferia" ou a "periferia intra-muros".

Para MARICATO (1996),

"A cidade do capitalismo periférico apresenta, como nos países centrais, a clássica luta de moradores de bairros tradicionais, contra a remoção motivada pela construção de megaprojetos, que invariavelmente estão associados à renda imobiliária. Ela apresenta também o fenômeno da gentrification - expulsão da população pobre dos bairros reciclados. Mas apesar de ambígua, arbitrária e repressora, a presença do Estado tem sido desejada nas áreas em que predominam relações que lembram o far west sem lei." 225

Em entrevista recente ao Le Monde Diplomatique, HARVEY comenta a relação da crise global atual e o mercado imobiliário americano, ressaltando que essa é, na verdade, uma crise urbana:

“(...) ao longo da história, nos momentos de crise vemos surgir um novo capitalismo. Vivenciamos isso na crise dos anos setenta, um ponto de inflexão importante que fez nascer o neoliberalismo, a financeirização, bem como um notável aumento da desigualdade social. E hoje estamos novamente num desses momentos. (...) Vivemos de fato um programa de ajuste estrutural em escala global que vem sendo administrado não pelo Fundo Monetário Internacional, mas sim pelo mercado.

(...) o período neoliberal é marcado por muitas crises financeiras. E por crise eu entendo ajuste estrutural. Como suas origens se vinculam ao contexto urbano, a crise atual tem de ser encarada como uma crise urbana. Nos Estados Unidos, deveríamos parar sobre algo chamado crise hipotecária ou do subprime - as hipotecas de risco - para discutir a crise urbana, que tem como base um superaquecimento do mercado imobiliário americano e começou quando, em 2000, os ricos deixaram de investir em atividades produtivas para se dedicar à especulação, dilapidando ativos patrimoniais, particularmente ações e propriedades. ${ }^{226}$

Sobre o atual momento do mercado imobiliário na Curitiba Metrópole, deve-se dizer que nos últimos cinco anos, após um período de retração entre o final dos anos

\footnotetext{
${ }^{225}$ MARICATO (1996), p. 86.

${ }^{226}$ HARVEY, em entrevista ao Le Monde Diplomatique Brasil, março de 2009, p. 6-7.
} 
90 ao início dos 2000, passa por uma fase de crescente dinamização. Uma das principais causas da retração no período anterior deve-se à saída da montadora Chrysler do município de Campo Largo em 1998, em função da crise na matriz mundial, onde permaneceu por apenas três anos. ${ }^{227}$ Em matéria intitulada "Curitiba, da cautela ao crescimento: Empresas locais foram mais conservadoras no boom imobiliário e agora sentem pouco o desaquecimento", tem-se que:

"Entre os anos de 1996 e 1997, houve um grande investimento no setor. Porém, de 1998 a 2001, com a saída de grandes indústrias do Estado e uma retração do setor industrial, o mercado imobiliário paranaense ficou estagnado. A demanda desse período ficou reprimida e em 2002, com a retomada do setor, não houve como suprir a busca por imóveis na capital, cenário que se reflete até hoje. Ainda vivemos um momento de maior demanda do que oferta, que aliado às mudanças econômicas no país, como a queda dos juros nos financiamentos imobiliários, propiciou um incentivo ao mercado da construção civil, que é mais intenso em Curitiba e na Região Metropolitana. Esse cenário puxa os índices de maior desempenho do Estado no setor perante o Brasil. Há ainda um outro atrativo para o Estado, que é a percepção da importância do Paraná como elo entre o Brasil e o Mercosul."

De acordo com Gustavo Selig, presidente da Ademi-PR (Associação de Dirigentes de Empresas do Mercado Imobiliário do Paraná), "a profundidade da estagnação do mercado imobiliário paranaense entre 1999 a 2004 explica o fôlego de crescimento atual. Naqueles anos, a capital do Estado registrou o valor por metro quadrado mais baixo dentre as capitais brasileiras e índices de lançamentos muito inferiores às médias do País, forçando a falência de empresas locais tradicionais". ${ }^{228}$

A fase de dinamização atual pode ser constatada inclusive pela ampliação do monitoramento de setores de interesse do setor imobiliário. O SECOVI-PR, por meio das pesquisas mensais do INPESPAR - Instituto de Pesquisa e Desenvolvimento do Mercado Imobiliário e Condominial - monitora setores agrupados por bairros relativos aos movimentos de venda e de aluguel. A abrangência do território monitorado restringia-se apenas à Curitiba; desde 2005 passou a incorporar São José dos Pinhais, estando em projeto a inclusão de Pinhais e Colombo. ${ }^{229}$

\footnotetext{
${ }^{227}$ Em FIRKOWSKI (2000), p. 180, tem-se que a volatilidade dos capitais no presente provoca situações de retirada para outros locais, quando não se satisfaz com o retorno.

${ }^{228}$ PINI WEB, acessada em março de 2010.

${ }^{229}$ Conforme informações da coordenadora Sra. Bernadete Jede à autora.
} 


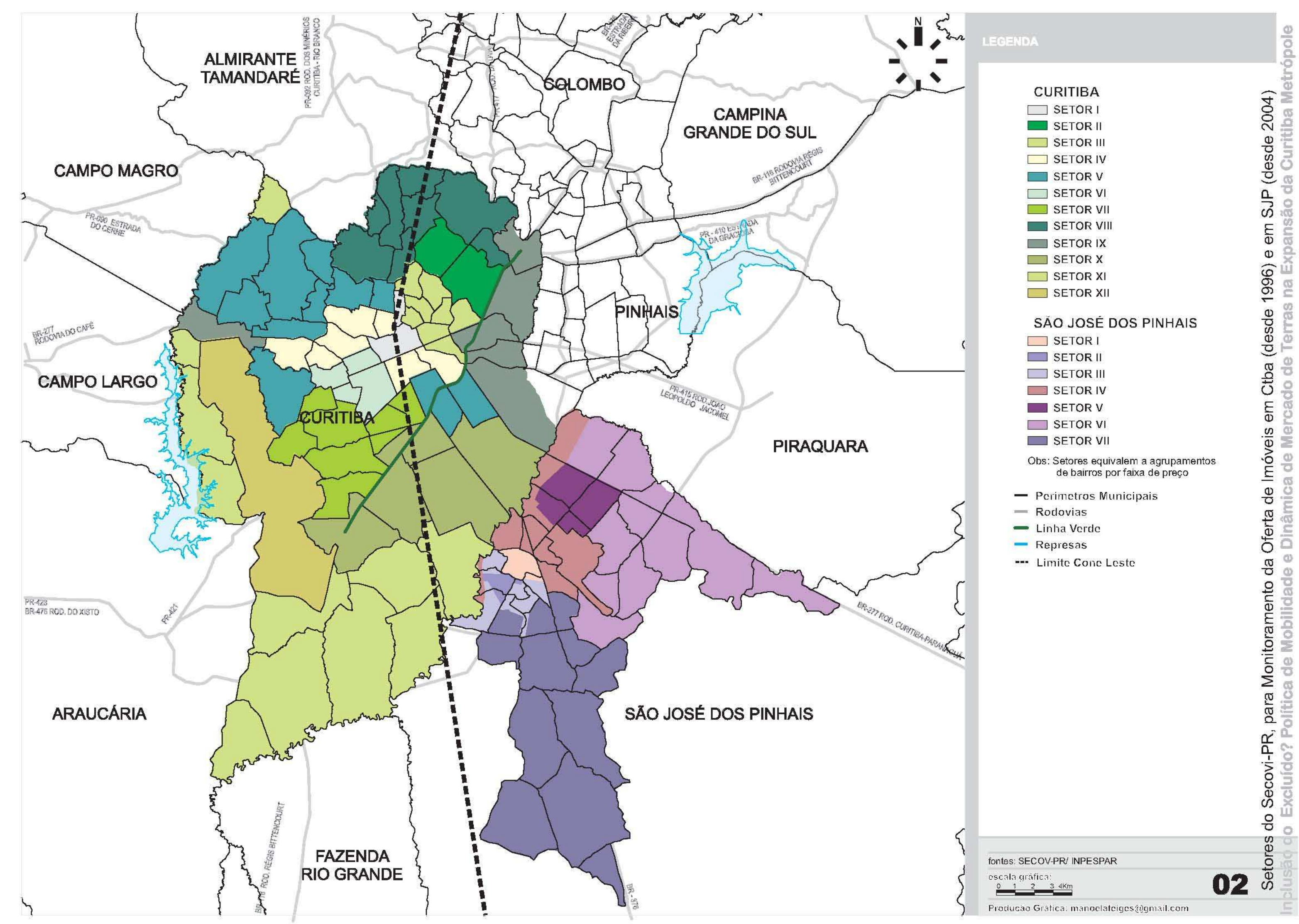




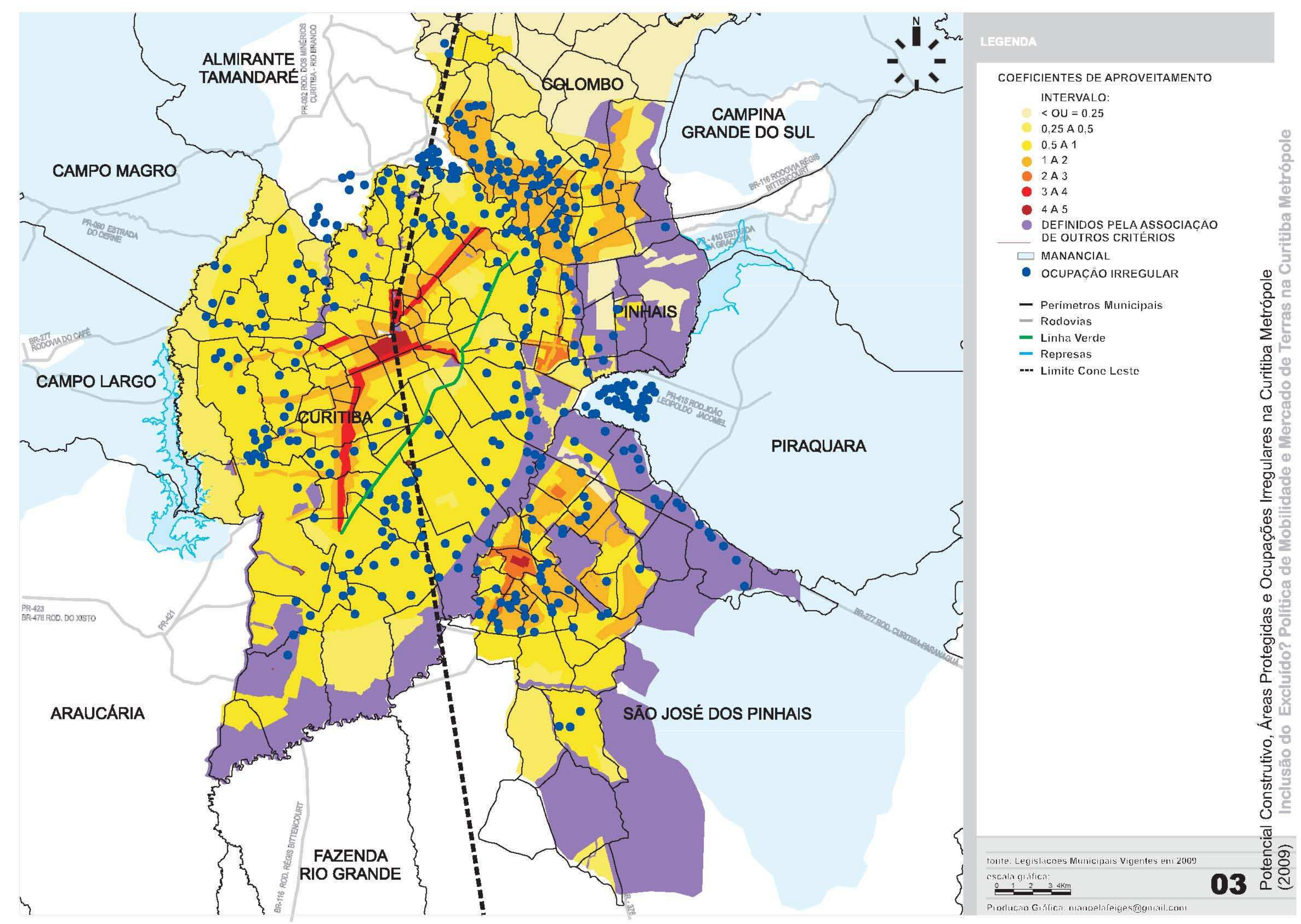


Vale ainda colocar que, esta fase de dinamização do mercado é caracterizada pela migração de capital imobiliário de outros circuitos - principalmente o de São Paulo - em função da demanda reprimida originada no período de estagnação, em associação com os preços de terrenos mais baixos em relação aos da matriz do capital.

Procurou-se sintetizar no mapa anterior algumas das ações ou ausências do Estado frente à Curitiba Metrópole em sua porção leste - aqui tratadas - para as quais se voltam os "olhares do mercado" em relação às possibilidades de investimentos. Diante da legislação urbanística e ambiental, destaca-se portanto dentre os critérios de valorização ou desvalorização das áreas, a relação entre os potenciais construtivos determinados pelos atuais zoneamentos municipais - bem como as áreas de restrição ambiental e as áreas de ocupações irregulares. (A relação com a acessibilidade será tratada com maiores detalhes no capítulo 3).

\section{RIT Metropolitana: acessibilidade e consolidação da Curitiba Metrópole}

O terceiro movimento de reestruturação intra-urbana que produziu novas localizações foi alavancado pela acessibilidade, a partir da expansão da rede integrada de transporte em direção à periferia.

Sobre o fenômeno da periferização na Curitiba Metrópole, cabe ressaltar que ela nasce enquanto o contraponto da verticalização da área central, expandindo-se ao longo dos corredores estruturais. Uma vez que agora se configurou a cidade planejada, a periferia passa a legitimá-la por se constituir no oposto à ordem racional. ${ }^{230}$ Construída com base no "não investimento", representa o esforço da população em criar os seus próprios meios de consumo coletivo em resposta à ausência do Estado e do mercado.

DÉAK aponta o papel da infra-estrutura urbana para assegurar a reprodução social:

"As aglomerações urbanas são o local precípuo de reprodução social. A elas cabe o papel de assegurar as condições de reprodução da força de trabalho, aos níveis requeridos pelo estágio de desenvolvimento da sociedade. No passado assistimos à miséria urbana que acompanha o estágio de acumulação extensiva, e não

\footnotetext{
${ }^{230}$ ROSÁRIO (2001), p.3-4.
} 
somente no Brasil, senão em todos os lugares históricos. [...] A transição ao estágio intensivo com a transformação da ordem elitista em ordem burguesa, deve impor sobre as aglomerações urbanas requisitos de performance, alguns a um patamar nitidamente superior aos atuais, e outros inteiramente novos. Tal performance deverá naturalmente ser assegurada por uma infra-estrutura urbana relativa a todos os aspectos da reprodução social, da produção de mercadorias à reprodução da força de trabalho." 231

Ao analisar a metrópole paulista, SANTOS refere-se à imobilidade relativa do morador da periferia e de seu isolamento em guetos em virtude das dificuldades com o transporte coletivo, que exige um longo tempo e um custo muito alto em seus percursos. Santos desenvolve o conceito de metrópole fragmentada a partir da constatação do isolamento dos pobres em seus bairros: "a imobilidade de tão grande número de pessoas leva a cidade a se tornar um conjunto de guetos e transforma a sua fragmentação em desintegração. (...) Quem mais ganha mais viaja. Quem ganha pouco, não se locomove". ${ }^{232}$

Em meados dos anos noventa, as demandas reprimidas da metrópole segmentada tornaram-se visíveis em função do contraponto da qualidade de vida na cidade central. Isto é claramente constatado quando da disputa das eleições municipais para a gestão 2000-2004, quando "inúmeras pesquisas de opinião realizadas apontavam que o então prefeito e candidato à reeleição Cássio Taniguchi sairia vencedor ainda em primeiro turno. Para surpresa geral, o processo eleitoral alongou-se para um segundo turno: de um lado estava Taniguchi, e de outro, Ângelo Vanhoni, representante do Partido dos Trabalhadores. Por uma margem de $3 \%$ no número de votos, margem esta considerada um empate técnico, Cássio Taniguchi é reeleito". ${ }^{233}$ O discurso da Capital Ecológica migra para o da Capital Social. Disso decorrem novos investimentos em transporte, porém dessa vez, na escala intraurbana. Em O Estado Capitalista e a Questão Urbana, LOJKINE analisa a cidade como um sistema produtivo - no qual produção e consumo são inseparáveis - e onde

\footnotetext{
${ }^{231}$ DÉAK (1999), p. 36-37.

${ }^{232}$ SANTOS (1990), apud MARICATO (1996), p. 91.

${ }^{233}$ LEITÃO (2002), p. 134.
} 
os conflitos de interesses de classe devem ser o tema central de análise. Baseia-se na sugestão de Marx, de que existem condições gerais de produção, improdutivas no sentido de gerar mais-valia, mas essenciais à operação do processo produtivo. Segundo a visão de Lojkine, o Estado é dominado pelos interesses do capital monopolista, que teriam o poder de determinar o resultado da sua ação. Assim a política urbana, em nome dos interesses do capital monopolista, faria então concessões marginais às classes dominadas. ${ }^{234}$

Até 1983, as linhas metropolitanas se davam por ligações entre a sede dos municípios e Curitiba; após 1983, as linhas foram reestruturadas a partir de terminais nas sedes dos municípios e vinham até o centro de Curitiba, com ponto final no Terminal Metropolitano do Guadalupe. Entre 1993 e 1994, foi implantada uma linha complementar que vinha direto para Curitiba - o "rápido metropolitano".

Em 1996, por delegação do Governo do Estado, a URBS passa a controlar 0 transporte de toda a região metropolitana, o que permitiu que a rede de transporte de Curitiba fosse integrada em escala intra-urbana. A operação do sistema é privada; dela participam 10 empresas urbanas e 18 metropolitanas. Cabe a URBS além da gerência técnica, também propor a tarifa, gerir a receita e remunerar as empresas por quilômetro rodado. Uma vez que a remuneração das empresas é realizada por quilômetro rodado, a questão maior que se apresenta é a de que, desde a integração intra-urbana, o governo municipal de Curitiba vem subsidiando a tarifa integrada, pois as linhas metropolitanas apresentam percursos bem mais longos.

\footnotetext{
${ }^{234}$ LOJKINE (1997), p. 126-141.
} 


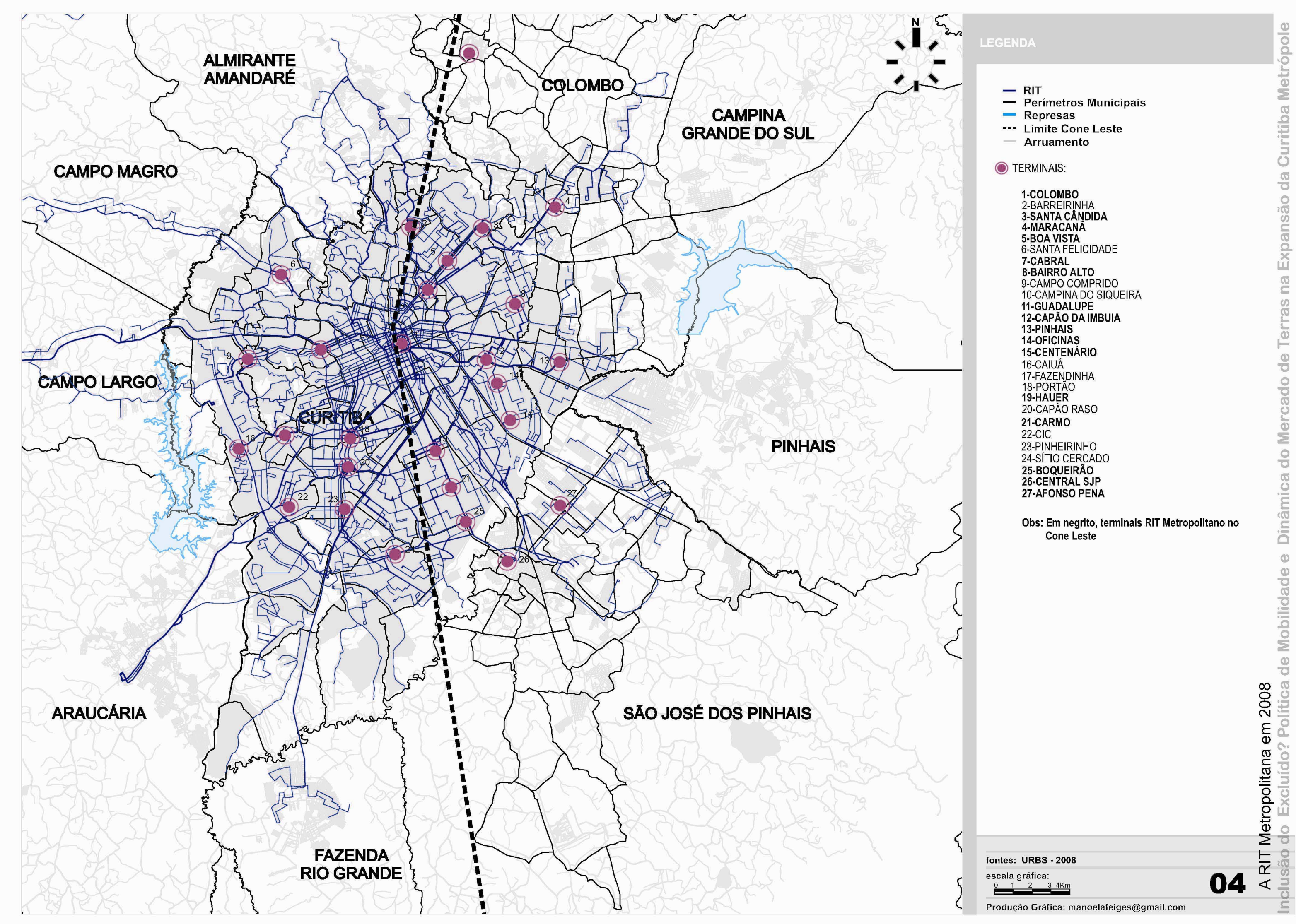


Para caracterizar a RIT, apresenta-se a tabela abaixo, referente ao resumo operacional de 2007, disponibilizado na página da URBS na internet: ${ }^{235}$

\begin{tabular}{|l|c|c|c|c|c|} 
& URBANO & $\begin{array}{c}\text { METROP. } \\
\text { INTEGRADO }\end{array}$ & SUB-TOTAL & $\begin{array}{c}\text { METROP } \\
\text { NAOINTEG. }\end{array}$ & TOTAL \\
\hline Frota Operante & 1.350 & 550 & 1.900 & 340 & 2.240 \\
\hline Frota Total & 1.570 & 630 & 2.200 & 400 & 2.600 \\
\hline Passag. Pagantes D.U. & 850.000 & 195.000 & 1.045 .000 & 130.000 & 1.175 .000 \\
\hline Passag. Transport. D.U. & 1.810 .000 & 450.000 & 2.260 .000 & 130.000 & 2.390 .000 \\
\hline Linhas & 285 & 105 & 390 & 75 & 465 \\
\hline Terminais & $21+1^{*}$ & 7 & 29 & 5 & 34 \\
\hline Estaçöes Tubo & 332 & 19 & 351 & - & 351 \\
\hline Km D.U. & 346.000 & 137.000 & 483.000 & 93.700 & 576.700 \\
\hline Viagens D.U. & 15.050 & 5.950 & 21.000 & 2.040 & 23.040 \\
\hline Vida Mèdia (anos) & 5,23 & 5,00 & 5,16 & 5,21 & 5,17 \\
\hline Empresas & 10 & $12(6+6)$ & 22 & $12(6+6)$ & 28 \\
\hline
\end{tabular}

A extensão da RIT para a área metropolitana em 1996 contemplou inicialmente a integração dos municípios de Almirante Tamandaré, Pinhais e São José dos Pinhais através da extensão de linhas diretas. Desde então, a integração entre a RIT e os sistemas urbanos do Núcleo Urbano Central intensificou-se, sendo que atualmente são 59 linhas $^{236}$ de 12 municípios: Almirante Tamandaré, Araucária, Campo Largo, Campo Magro, Colombo, Contenda (através de Campo Largo), Fazenda Rio Grande, Itaperuçu (através de Almirante Tamandaré), Pinhais, Piraquara (através de Pinhais), Rio Branco do Sul (através de Almirante Tamandaré) e São José dos Pinhais. A integração físico-tarifária se dá por diferentes tipologias - tanto totais como parciais dependendo da política adotada pelos municípios.

Desse modo é que se configurou a aqui denominada Curitiba Metrópole, definida pelos deslocamentos intra-urbanos a partir da integração via RIT. Disso deriva uma multiplicidade de novas localizações - os bairros populares anteriormente segregados pela falta de acessibilidade e mobilidade urbanas. Os fenômenos da polarização e da dependência constituem-se a partir das localizações das classes

\footnotetext{
${ }^{235}$ Acesso em dezembro de 2009.

${ }^{236}$ A rede integrada de transporte é formada hoje por linhas expressas, alimentadoras, interbairros, linhas diretas e convencionais, além de linhas complementares como a circular centro, a inter-hospitais, a linha turismo e a do ensino especial.
} 
sociais no espaço e da dinâmica de seus deslocamentos pendulares moradia-trabalho. Sendo Curitiba o principal pólo gerador de empregos e por isso o principal destino dos deslocamentos, destaca-se mais uma vez a importância da acessibilidade conferida pela integração da rede metropolitana de transporte. Nesse sentido, torna-se fundamental a leitura dos impactos advindos da acessibilidade à rede, da qual deriva a gama de possibilidades de deslocamentos, além da redução dos custos de transporte pela tarifa única. Quanto ao poder estruturador do transporte coletivo, decorre que à medida que a mancha urbana vai se compactando, "jardins" e "vilas" desconectados deixam de existir para ceder lugar a "bairros" estruturados e integrados pelo transporte. Deve-se pontuar nesse processo a emergência das novas centralidades urbanas nos municípios dormitórios - como em Colombo e em Pinhais - onde a extensão da RIT propiciou a entrada de capital via atividades do terciário, até então ausentes por ali. As centralidades conformam-se a partir dos bairros que, pela presença dos terminais metropolitanos - bairros Maracanã e Centro respectivamente passaram a apresentar alto grau de acessibilidade urbana, bem como a acessibilidade à própria metrópole.

As dimensões da integração metropolitana via RIT pode ser evidenciada pelos dados compilados na tabela que segue, onde se pode verificar o grau de polarização pela demanda e pelo seu atendimento em relação aos deslocamentos com destino Curitiba. Na Curitiba Metrópole, o município que apresenta maior grau de dependência do pólo é Pinhais, com uma proporção de $28,93 \%$ da população vindo para o pólo, e o menor é Quatro Barras, com 9,53\%, sendo que Almirante Tamandaré, com 27,51\%, Colombo, com 25,25\%, e Piraquara, com 22,37\%, podem ser considerados como muito dependentes de Curitiba. ${ }^{237}$

\footnotetext{
${ }^{237}$ COMEC (2001) p. 130, PDI-RMC - Documento para discussão.
} 


\begin{tabular}{|c|c|c|c|c|}
\hline \multicolumn{5}{|c|}{$\begin{array}{l}\text { TABELA } 2.4 \text { - POPULAÇÃO E DEMANDA DOS MUNICÍPIOS DO NUC } \\
\text { QUE DEMANDAM À CURITIBA }\end{array}$} \\
\hline MUNICÍPIO & POPULAÇÃO & $\begin{array}{c}\text { DEMANDA } \\
\text { PASS/DIA ÚTIL }\end{array}$ & $\begin{array}{c}\text { PESSOAS } \\
\text { TRANSPORTADAS }\end{array}$ & $\%$ DA POP \\
\hline Almirante Tamandaré & 92.051 & 50.651 & 25.325 & 27,51 \\
\hline Araucária & 91.087 & 23.957 & 11.978 & 13,15 \\
\hline Campina Grande do Sul & 39.439 & 13.311 & 6.655 & 16,88 \\
\hline Campo Largo & 92.030 & 22.136 & 11.068 & 12,02 \\
\hline Campo Magro & 21.218 & 6.944 & 3.322 & 16,36 \\
\hline Colombo & 202.977 & 102.509 & 51.2554 & 25,25 \\
\hline Fazenda Rio Grande & 65.944 & 22.865 & 11.858 & 17,98 \\
\hline Itaperuçu & 22.317 & 4.508 & 2.254 & 10,10 \\
\hline Pinhais & 101.445 & 58.689 & 29.344 & 28,93 \\
\hline Piraquara & 66.642 & 29.823 & 14.911 & 22,37 \\
\hline Quatro Barras & 19.933 & 3.799 & 1.899 & 9,53 \\
\hline Rio Branco do Sul & 22.281 & 7.443 & 3.721 & 16,70 \\
\hline São José dos Pinhais & 210.395 & 69.110 & 34.555 & 16,42 \\
\hline TOTAL RMC & 1.047 .759 & 415.745 & 207.872 & 19,83 \\
\hline Curitiba & 1.607 .793 & 1.870 .070 & 935.035 & 58,15 \\
\hline TOTAL GERAL & 2.655 .552 & 2.285 .815 & 1.142 .907 & 43,03 \\
\hline
\end{tabular}

Em se tratando da polarização, recorre-se a VILLAÇA quanto à noção de centralidade, que está atrelada à "possibilidade de minimizar o tempo gasto e os desgastes e custos associados aos deslocamentos espaciais dos seres humanos". Assim "o centro" e o "não centro" são dialeticamente produzidos pelo mesmo processo sob a égide dessas disputas, pelo controle das condições de deslocamento". Ainda em Villaça, "em uma sociedade de classes, famílias disputam as localizações e desenvolvem mecanismos sociais para regular essa disputa ao mesmo tempo que lutam pelo domínio dos meios e condições de transporte e procuram produzir espaços urbanos moldados por esses meios e condições. Acabam por produzir espaços urbanos diferenciados." 325

Já em SAMPAIO, pode-se entender além da relação de dependência histórica que a periferia tem do pólo, o impacto da sua estruturação desde a emergência do ônibus como modal de transporte. Ela conta que na expansão urbana paulistana, o ônibus se revela um elemento dinamizador a partir de 1924, "totalmente impulsionado pela iniciativa privada e que iria permitir uma maior mobilidade nos deslocamentos da população no espaço urbano, levando-a a se instalar além dos pontos finais das linhas de bondes e trens e nos espaços vazios entre as linhas. O ônibus permitiu que se

${ }^{325}$ VILLAÇA (1998), p. 242. 
estruturassem relações entre os subúrbios - estações e bairros que estavam fora do domínio ferroviário ou longe dos trilhos. " 326

É pela relação entre polarização e dependência que se confirma a importância do conceito dado por SOJA, com apoio em Lefèbvre, qual seja o da "dialética sócioespacial", uma vez que os processos sócio-econômicos da urbanização impactam os processos físicos da urbanização e vice-versa. A dialética sócio-espacial ${ }^{327}$ é definida pelas relações de produção, relações essas que são simultaneamente sociais e espaciais. Diz SOJA:

“(...) existe uma homologia espacial correspondente com as relações de classe tradicionalmente definidas e, por conseguinte, com as contingências do conflito de classes e da transformação estrutural. (...) essa homologia espaço-classe pode ser verificada na divisão regionalizada do espaço organizada em centros dominantes e periferias subordinadas, em relações sociais de produção socialmente criadas e polarizadas, captáveis com maior precisão no conceito de desenvolvimento geograficamente desigual. Essa conceituação dos vínculos entre a diferenciação social e espacial não implica que as relações espaciais de produção ou a estrutura centroperiferia sejam separadas e independentes das relações sociais de produção, das relações de classe. Ao contrário, os dois conjuntos de relações estruturadas (o social e o espacial) são não apenas homólogos, no sentido de provirem das mesmas origens no modo de produção, como também dialeticamente inseparáveis." ${ }^{328}$

Após a expansão da RIT à periferia, Cássio Taniguchi fala sobre deslocamentos e qualidade de vida em Curitiba, em sua primeira gestão (1997-2000):

"Em Curitiba, os deslocamentos são geralmente curtos. Há casos em que se gasta uma hora nos trajetos urbanos, mas com o benefício de poder pagar apenas uma tarifa. Em grandes cidades do Brasil, que não contam com transporte integrado, um trabalhador leva em média 4 horas no trajeto de ida e volta entre casa e trabalho. Para quem trabalha 8 horas por dia isso representa um desconforto desnecessário. Não há qualidade de vida em um processo como esse." 329

\footnotetext{
${ }^{326}$ SAMPAIO (1994), p. 23.

${ }^{327}$ SOJA (1993), p. 99.

${ }^{328}$ Idem.

${ }^{329}$ IPPUC (2003), p.3.
} 
Com relação ao caráter inclusivo presente na política de mobilidade na Curitiba Metrópole, cabe evidenciar a ampliação do subsídio por meio da "tarifa domingueira", implementada na atual gestão do prefeito Richa (2009-2012), ao custo de $R \$ 1,00$ (um real), fato que possibilitou o acesso do cidadão metropolitano à Curitiba também para o lazer, e daí ressalte-se a intensificação do uso dos parques urbanos, ícones Capital Ecológica, finalmente por ele acessados.

Em "Reinventar a democracia", diz SANTOS, B.:

"Assim, o capitalismo forja um sentido mutante do tempo e do espaço, levando a perpétuas reavaliações das representações do mundo que são resultantes da mudança do sentido do tempo (cada vez mais acelerado) e do espaço (cada vez mais fragmentado) na vida econômica, política e cultural. Desta forma, situando a pós-modernidade em um contexto histórico, percebe-se que na verdade ela faz parte de uma das sucessivas ondas de compressão do tempo-espaço gerada pela acumulação, que tenta aniquilar o espaço e acelerar o tempo de giro do capital, devendo portanto ser analisada na interpretação materialista da história". ${ }^{330}$

Considerando que o objeto desta pesquisa - a Curitiba Metrópole - encontra-se em estágio de transição, outra reflexão se dá com apoio em REIS, em suas críticas sobre a metropolização no Brasil. Ele alerta quanto à necessidade do Estado em interpretar a natureza e a dimensão dos "novos" problemas urbanos, e conseqüentemente, das "novas" dinâmicas metropolitanas. Mas, quanto a isso, pergunta-se: qual seria o efetivo papel que o Estado exerce sobre o urbano? Qual a sua essência, ou melhor, a sua natureza?

Em JORGE encontra-se uma reflexão sobre o conceito de Estado e de poder, nas teorias clássicas de Machiavel, Lênin, Gramsci e Weber. Para JORGE, "é impossível compreender o urbano, sem compreendê-lo como o produto de uma determinada sociedade". Para esta pesquisa, destaca-se aqui o conceito de Estado de Lênin, que retoma Marx e Engels. Sua definição de Estado abrange três pontos fundamentais: (i) o Estado surge historicamente; (ii) sua função é mediar o conflito das classes sociais existentes em determinada sociedade; e (iii) isso implica em uma opressão permanente à classe trabalhadora. Para Lênin, "o Estado é o produto e a manifestação do fato de que as contradições de classe são inconciliáveis. O Estado surge no momento e na medida em que, objetivamente, as contradições de classe não podem conciliar-se. ${ }^{1331}$ Ainda em JORGE, na teoria de Lênin, "a máquina burocrática

\footnotetext{
${ }^{330}$ SANTOS, B. (1998), sem página. em Reinventar a democracia.

${ }^{331}$ JORGE (1985), p.240.
} 
seria o outro elemento fundamental do Estado, através do qual é estabelecida a administração e o controle do poder junto à população". ${ }^{332}$

Outra questão que merece reflexão é a relação entre o Estado e o espaço, relação esta tão debatida entre os teóricos. Para os teóricos da corrente marxista, a ênfase é dada para o papel do aparelho estatal mais como um instrumento de política pública que administra a sociedade do que como um meio significativo de design espacial. Por isso, os economistas políticos transpõem a análise da relação entre o Estado e o espaço, para a das duas funções tradicionais do Estado na sociedade capitalista - a de acumulação e a de legitimação. Assim, Gottdiener ilustra tais funções como "a ação do governo em administrar o processo de acumulação de capital na forma como é desenvolvido no espaço, ou como ação de política pública em atenuar o conflito de classe." Segue quanto à legitimação, ao dizer que esta "envolve a natureza das relações ideológicas que controlam a consciência de classe pelo Estado, a qual pode ser tratada como se também interviesse no espaço." Ainda segundo Gottdiener, para a economia política marxista não se concebe que o Estado aja diretamente para produzir seu próprio espaço, mas ao contrário, apenas "atribui ao espaço o status de receptáculo, que é um produto indireto da administração, pelo Estado, da crise estrutural do capitalismo". ${ }^{333}$ Por fim, aponta-se uma reflexão: Gottdiener observa que tanto Lefebvre quanto Castells "optaram por não tratar do problema da determinação dos valores da terra urbana - e Lefebvre em particular, criou certas dificuldades, como veremos, devido à sua omissão estratégica. Em compensação, [...] a análise econômica do valor da terra é a pedra angular da economia política urbana do marxismo, especialmente na obra de Harvey e de Scott."

\footnotetext{
${ }^{332}$ Idem, p. 243.

${ }^{333}$ GOTTDIENER (1985), p.136.

${ }^{334}$ Idem, p. 177.
} 


\section{CAPÍTULO 3}

\section{AS NOVAS LOCALIZAÇÕES NA CURITIBA METRÓPOLE: ENTRE A POLÍTICA DE MOBILIDADE E A DINÂMICA DO MERCADO DE TERRAS}

Faz-se fundamental nesse momento colocar que foi em VILLAÇA que se encontrou a articulação teórica necessária à compreensão da questão maior dessa pesquisa empírica: a localização, como produto social, é um valor de uso da terra urbana; assim, o valor de uso de uma localização intra-urbana é o valor dessa localização enquanto parte de uma aglomeração social. Ao referenciar-se a autores como Marx, Lefèbvre, Lojkine, Milton Santos, Harvey, Gottdiener, entre outros, o autor constrói todo um arcabouço teórico-conceitual acerca da localização, do valor e do preço da terra urbana. O processo do conhecimento, tal qual o do espaço, também é socialmente construído. Em função disso, é a partir desse arcabouço teóricoconceitual construído por Villaça que se dará a interpretação da realidade observada a das novas localizações produzidas na Curitiba Metrópole. Essas e outras premissas teóricas mais serão apontadas e discutidas ao longo dessa pesquisa, que tem por idéia central demonstrar os movimentos da Curitiba Metrópole pós-1990, a partir das novas localizações resultantes da dialética entre a dinâmica do mercado de terras e a política de mobilidade, no contexto da produção social do espaço urbano.

Como fio condutor do processo histórico da produção das novas localizações tem-se a evolução da rede integrada de transporte (RIT), da sua metropolização ao cenário atual - 1996 a 2009. O compartimento definido para a pesquisa é o aqui denominado "cone leste" da Curitiba Metrópole composto pelos bairros localizados no setor leste de Curitiba e três dos seus municípios lindeiros - Colombo à nordeste, Pinhais à leste e São José dos Pinhais à sudeste - e portanto, é o aqui denominado "cone leste" da Curitiba Metrópole. 


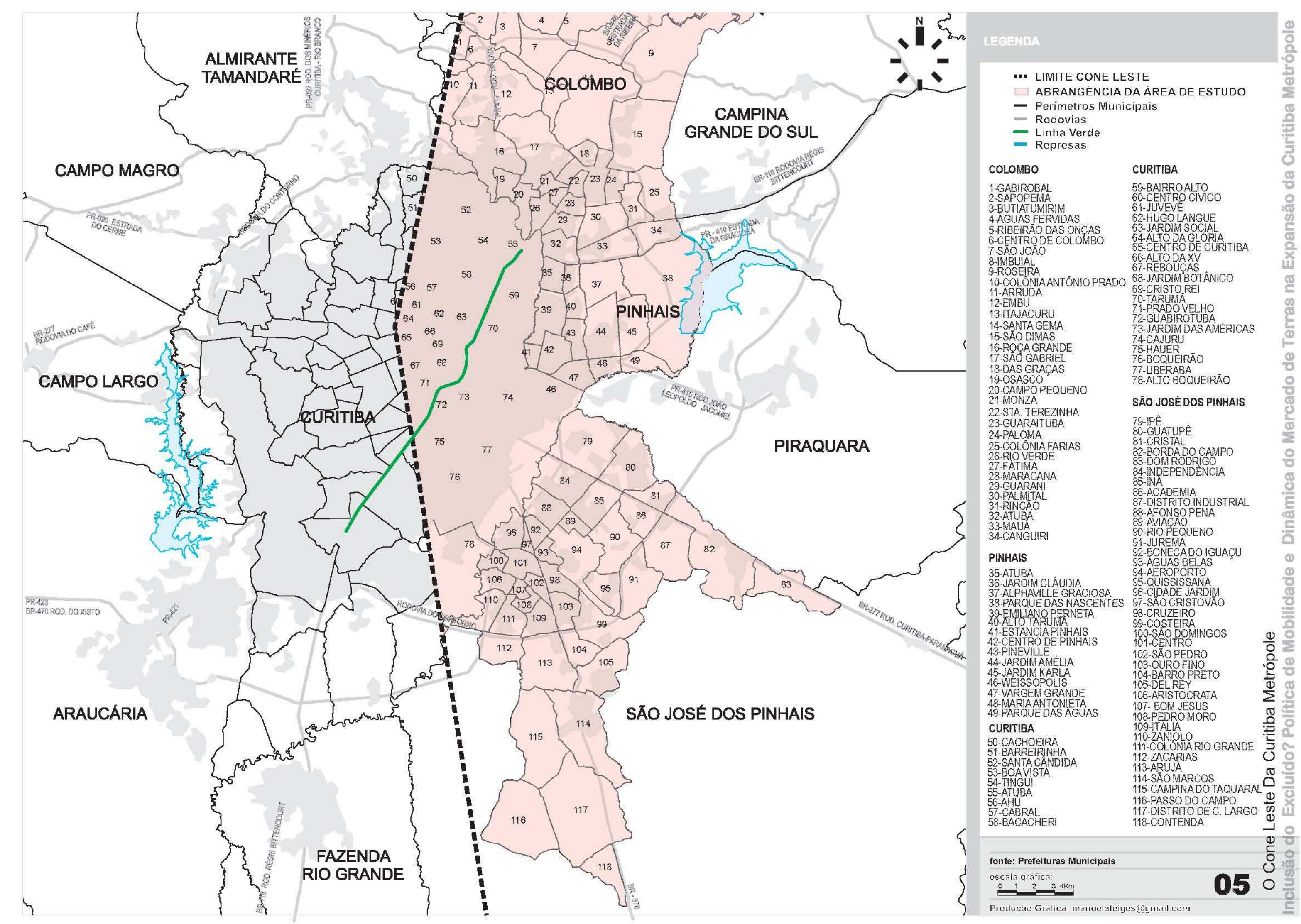


São apontadas como justificativas para a realização da pesquisa neste compartimento:

(i) os três municípios que o compõem, além de serem os mais populosos do colar metropolitano, juntos respondem hoje por praticamente um terço do total de deslocamentos na RIT, caracterizando assim o movimento pendular em direção ao pólo;

(ii) as relações entre estes municípios e o pólo se dão de maneira diversa; por isso, se observadas isoladamente, representam três das distintas tipologias de dinâmica metropolitana verificadas na Curitiba Metrópole: Colombo é um município dormitório; São José dos Pinhais e Pinhais configuram como novas centralidades na dinâmica recente do território - o primeiro pela expansão do capital industrial e de serviços; o segundo, pela inversão das características da expansão residencial na periferia da metrópole, a partir da fuga das elites do centro principal.

As correlações que se pretende aqui estabelecer dizem respeito ao fenômeno de expansão da Curitiba Metrópole, no qual a apropriação do território dada pelo consumo da terra urbana e, portanto, condicionada pela renda, será aqui revelada pela articulação de três processos: o da evolução do preço da terra, o da evolução da rede integrada de transporte e o da evolução da mancha urbana. Segue abaixo um esquema ilustrativo:

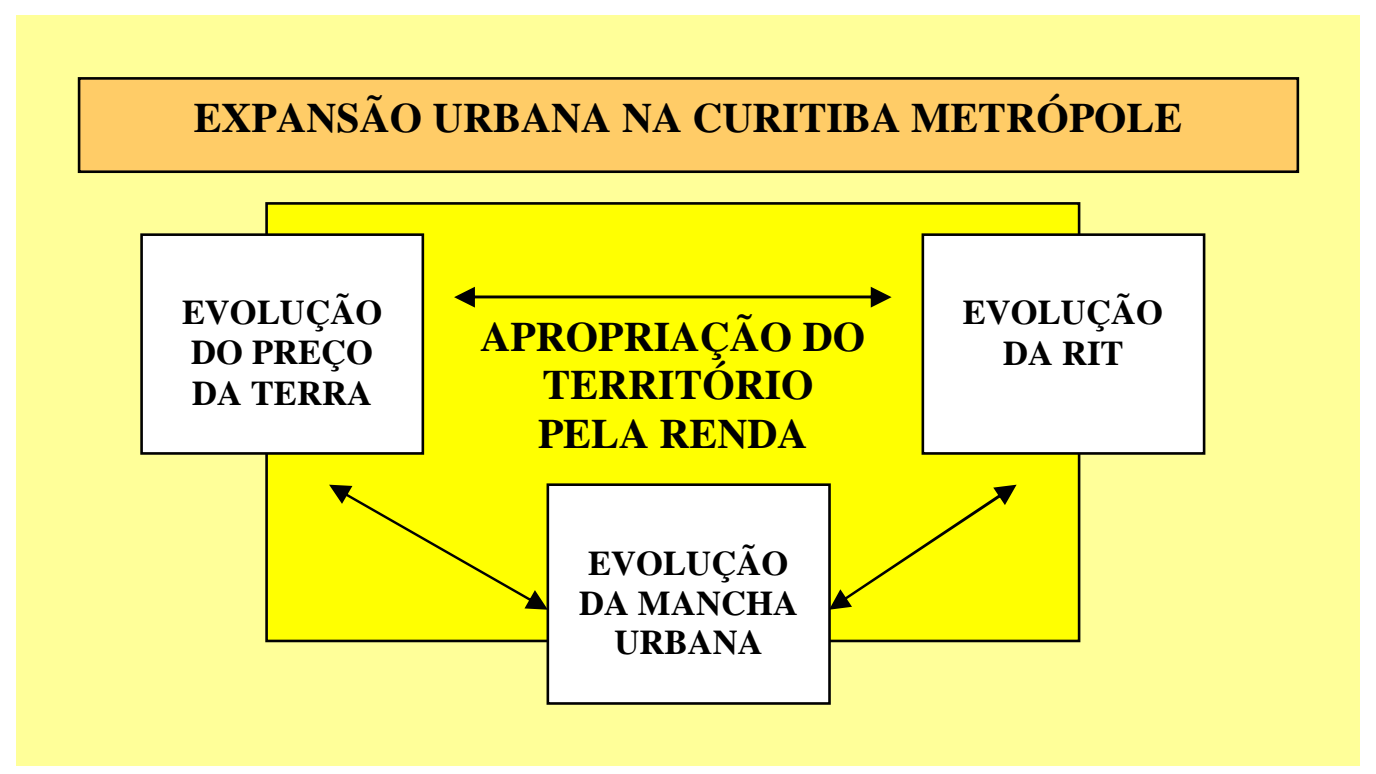

As hipóteses anteriormente levantadas serão verificadas, por meio da observação da realidade, com vistas a: 
(i) correlacionar as variáveis representativas dos temas centrais da pesquisa, quais sejam, a política de mobilidade - de natureza includente - e o mercado de terras - de natureza excludente, a fim de explicitar o movimento dialético entre a produção social do espaço da metrópole e a apropriação das novas localizações produzidas;

(ii) espacializar a evolução das variáveis - preço da terra partir da oferta de lotes, renda média do chefe da família, mancha de ocupação urbana e área de atendimento da RIT metropolitana - com vistas a facilitar a leitura das novas localizações produzidas;

(iii) interpretar a produção das novas localizações à luz dos fenômenos que caracterizaram o processo de expansão urbana - conurbação, centralidade, dependência, pendularidade - por meio da leitura de suas contradições; contradições estas inerentes à natureza do próprio objeto de estudo, o urbano.

Em HARVEY encontrou-se a fundamentação teórica necessária à interpretação da correlação entre a forma espacial e os processos sociais, que corresponde à abordagem adotada nesta pesquisa. Segundo o autor, "a única estrutura conceitual adequada para entender a cidade é a que inclui e se edifica ao mesmo tempo sobre as imaginações sociológica e geográfica". ${ }^{335} \mathrm{Em}$ função disso, na tentativa de reproduzir a dinâmica da metrópole no período estudado e ao mesmo tempo possibilitar a realização da análise das correlações propostas, as variáveis foram espacializadas em séries temáticas e em intervalos regulares, gerando assim mapas-base referentes aos anos de 1996, 2000, 2004 e 2009. Apenas para a renda média do chefe da família, os mapas correspondem aos anos de 1991 e 2000, respectivamente aos censos realizados pelo IBGE. Pelo método de sobreposição dos mapas-base foi possível apreender a produção e a apropriação das novas localizações na metrópole a partir da evolução da RIT, bem como interpretar as correlações entre as variáveis em diferentes escalas territoriais: (i) para a totalidade da região de estudo enquanto um compartimento da Curitiba Metrópole; (ii) por municípios e (iii) por bairros. Sendo assim, o processo de espacialização das correlações assumiu caráter imprescindível em termos metodológicos, uma vez que os mapas gerados constituíram-se ora em elementos de análise, ora em produtos da pesquisa.

Sobre as fontes de pesquisa e também em relação à coleta de dados e informações, tem-se a dizer que para retratar a evolução da RIT foram compilados dados relativos à área de abrangência da rede, ao detalhamento das linhas ofertadas -

\footnotetext{
${ }^{335}$ HARVEY (1980), p. 14.
} 
por tipo de integração e por demandas (1996-2009); já os dados relativos ao tempo de viagem foram disponibilizados apenas para 2009, pois órgão municipal que gerencia a RIT - a URBS - não monitora essa variável por série histórica.

Quanto à oferta de lotes e ao preço da terra, foram utilizados os dados do INPESPAR, ${ }^{336}$ que forneceu a série histórica de preço da terra por bairros em Curitiba (1996 a 2009) e o levantamento da oferta de lotes em Colombo, Pinhais e São José dos Pinhais referentes ao cenário atual (2009). Já a elaboração da série histórica para os três últimos municípios foi realizada pela autora, seguindo a metodologia de levantamento orientada pela coordenação da pesquisa mensal divulgada pelo instituto. ${ }^{337}$ Dessa forma, a complementação dos dados refere-se apenas aos lotes ofertados para venda no compartimento de pesquisa, anunciados nos classificados do caderno imobiliário da Gazeta do Povo, jornal local de grande circulação. O levantamento consistiu em resgatar as edições referentes ao primeiro domingo dos meses de junho e de dezembro, para os anos de 1996, 2000 e 2004, no acervo da Divisão Paranaense de Dados da Biblioteca Pública do Paraná. Sendo assim, da pesquisa para complementar as séries históricas disponibilizadas resultou uma amostra de 978 lotes anunciados para a venda na área de estudo.

Tabela - 3.1 - COMPLEMENTAÇÃO DO UNIVERSO DE PESQUISA: LOTES OFERTADOS PARA A VENDA, POR MUNICÍPIO, POR DATA DE ANÚNCIO

\begin{tabular}{|c|c|c|c|c|c|c|c|c|c|}
\hline \multirow[t]{2}{*}{ MUNICÍPIO } & \multirow[t]{2}{*}{ jun/96 } & \multirow[t]{2}{*}{$\operatorname{dez} / 96$} & \multirow[t]{2}{*}{ jun/00 } & \multirow[t]{2}{*}{$\operatorname{dez} / 00$} & \multirow[t]{2}{*}{ jun/04 } & \multirow[t]{2}{*}{$\operatorname{dez} / 04$} & \multirow[t]{2}{*}{ nov/09 } & \multicolumn{2}{|c|}{ TOTAIS } \\
\hline & & & & & & & & N. ${ }^{\circ}$ Abs. & Em \% \\
\hline Colombo & 21 & 6 & 14 & 26 & 1 & 11 & 97 & 176 & $18 \%$ \\
\hline Pinhais & 11 & 15 & 22 & 21 & 20 & 21 & 160 & 270 & $28 \%$ \\
\hline $\begin{array}{l}\text { São José dos } \\
\text { Pinhais }\end{array}$ & 32 & 63 & 61 & 88 & 15 & 7 & 266 & 446 & $46 \%$ \\
\hline TOTAL & 64 & 84 & 97 & 135 & 36 & 39 & 523 & 978 & $100 \%$ \\
\hline
\end{tabular}

Apesar da amostra pesquisada não corresponder à totalidade do universo da oferta no período 1996-2009, apresenta confiabilidade em termos de série histórica, o que satisfaz plenamente os objetivos dessa pesquisa. As tabelas que contêm os dados primários referentes aos anúncios classificados da Gazeta do Povo fazem parte

\footnotetext{
336 Instituto de Pesquisa e Desenvolvimento do Mercado Imobiliário e Condominial, vinculado ao Sistema SECOVI-PR - Sindicato da Habitação e Condomínios.

337 A coordenação geral da pesquisa mensal realizada pelo INPESPAR é realizada pela Sra. Bernadete Jede. Para Curitiba, essa pesquisa teve início em 1996; para São José dos Pinhais, em 2005. A pesquisa mensal tem sido utilizada para avaliações de pedidos de financiamentos imobiliários e perícia judicial.
} 
do anexo 01 deste documento. A tabulação dos dados coletados foi realizada a partir dos atributos dos lotes descritos nos anúncios, a fim de facilitar a leitura dos valores de uso e de troca a eles atribuídos. Foram descartados os lotes anunciados que não continham dados de localização - pela impossibilidade de geo-referência com os bairros - e também aqueles que não continham informações sobre o preço.

Com relação à evolução da mancha de ocupação - outra variável observada cabe dizer que foram utilizadas as manchas referentes aos anos de 1996, 2000 e 2004, praticamente mantendo os mesmos intervalos para análise processual no período.

Já a fim de comparar a situação da renda média do chefe da família, foi utilizado o mapeamento elaborado pelo IPPUC para os dados do censo de 2000, relativo ao aglomerado urbano da metrópole. Porém, como para o censo de 1991 a renda havia sido mapeada apenas para Curitiba, foi realizada pela autora a complementação necessária do mapa existente, por meio da inserção dos setores censitários urbanos de Colombo, Pinhais e São José dos Pinhais, para posterior lançamento dos valores correspondentes.

Antes de iniciar as leituras do fenômeno da expansão urbana na Curitiba Metrópole, cabe uma breve inserção de natureza teórica, a fim de elucidar um pouco mais as premissas que conduzirão à sua interpretação, relativas à produção social do espaço urbano, às localizações, ao valor e ao preço da terra urbana.

Parte-se do conceito de espaço enquanto força produtiva, e não como condição de produção. É LEFÈBVRE quem ressalta a importância e o papel do centro urbano na formação, na realização e na distribuição da mais-valia no capitalismo tardio. Ao referir-se ao urbano, indaga:

"Pode-se definir a realidade urbana como uma superestrutura econômica, capitalista ou socialista? Como um simples resultado do crescimento e das forças produtivas? Como uma modesta realidade, marginal em relação à produção? Não! A realidade urbana modifica as relações de produção, sem, aliás, ser suficiente para transformá-las. Ela torna-se força produtiva, como a ciência. O espaço e a política do espaço "exprimem" as relações sociais, mas reagem sobre elas." 338

Ao explorar o conceito de fenômeno urbano, diz LEFÈBVRE: "[...] esse espaço urbano é contradição concreta. O estudo de sua lógica e de suas propriedades formais conduz à análise dialética de suas contradições." ${ }^{339}$ Nessa mesma linha de

\footnotetext{
${ }^{338}$ LEFÈBVRE (1999), p.26 e 27.

${ }^{339}$ Idem, p.46.
} 
pensamento, SANTOS afirma ser o espaço um fator da evolução social e não apenas uma condição. Também para ele é por meio do movimento dialético que se deve interpretar as relações sócio-espaciais. O espaço é uma instância da sociedade, assim como a instância econômica, a cultural-ideológica ou a político-institucional: contém cada uma delas e é por elas contido. "A economia está no espaço, assim como o espaço está na economia. O mesmo se dá com o político-institucional e com o cultural-ideológico. Isso quer dizer que a essência do espaço é social." 340 Esse movimento dialético inerente ao fenômeno urbano - e, portanto, à sua lógica e às suas contradições - torna-se bastante claro a partir da diferenciação estabelecida por SANTOS entre lugar e localização:

"O movimento dialético entre forma e conteúdo, a que o espaço soma os dois, preside, é, igualmente, o movimento dialético do todo social, apreendido na e através da realidade geográfica. Cada localização é, pois, um momento do imenso movimento do mundo, apreendido em um ponto geográfico, um lugar. Por isso mesmo, cada lugar está sempre mudando de significação, graças ao movimento social: a cada instante as frações da sociedade que the cabem não são as mesmas. [...] O lugar pode ser o mesmo; as localizações mudam. E lugar é o objeto ou conjunto de objetos. A localização é um feixe de forças sociais se exercendo em um lugar." 341

Para GOTTDIENER, Lefèbvre e Castells seriam os grandes estudiosos do espaço. É a partir da elaboração da crítica às suas teorias que o seu conceito de produção social do espaço foi construído - fundamentado na abordagem dialética sócio-espacial de Lefebvre e tendo como contraponto a visão estruturalista de Castells, para quem "o urbano é uma unidade espacial de reprodução da força de trabalho". ${ }^{342}$ Gottdiener levanta a necessidade de um lado, de se romper com a visão dos analistas marxistas tradicionais - que estudam a determinação da renda urbana pela teoria do valor segundo o trabalho - e de outro, de se propor uma abordagem alternativa: "[...] evitarei o problema econômico da determinação do valor de troca da terra urbana sob as relações capitalistas de produção, a não ser estudando-a como se fosse produzida socialmente." 343 Se o espaço é produzido socialmente, é de fundamental importância apreender de que maneira as relações capitalistas atuam na

\footnotetext{
${ }^{340}$ SANTOS (1992), p.1.

${ }^{341}$ Idem, p.2.

${ }^{342}$ GOTTDIENER (1997), p. 33.

${ }^{343}$ Idem, p. 177.
} 
estruturação da organização sócio-espacial. Para Gottdiener, os padrões sócioespaciais seriam resultados contingentes das muitas relações contraditórias que interagem no modo de produção capitalista, e que "[...] a linha de frente dessas relações está incrustada, de forma inigualada, nas atividades do setor imobiliário. Assim, as relações espaciais e sociais estão relacionadas dialeticamente. Se as necessidades de capital se manifestam no espaço, as mudanças espaciais se manifestam nas necessidades de capital." 344 Daí a relevância ressaltada por Gottdiener do valor da terra e do papel do espaço no contexto da acumulação capitalista. Comenta o autor que para se tratar da questão dos valores da terra e das localizações, faz-se necessário o resgate da teoria de Lefebvre quando este propõe passar da análise da terra para a dos bens imóveis:

"[...] o valor da terra urbana é um produto social. [...] devo mudar da análise da terra como meio de produção para a análise do espaço como força de produção, e mudar da determinação do valor da terra e seu retorno - renda - para a determinação social do valor da localização no espaço e seu retorno - lucro." 345

Ainda conforme Gottdiener - ao considerar a análise lefebvriana - o valor do bem imóvel é resultante de uma matriz sócio-espacial de localizações e atividades associadas à produção de riqueza, que confere aos lugares valores de uso. Tais valores estariam associados a padrões espaciais socialmente determinados. Segundo o autor,

"[...] para os analistas convencionais esse processo se realiza como se não existisse um mercado imobiliário distinto a controlar esses valores. Dessa maneira, enfatizamos a natureza social do espaço, mais do que uma teoria de seu valor segundo o trabalho, quando focalizamos o mercado imobiliário como mecanismo mediador que traduz os valores de uso produzidos pela matriz espacial das atividades de acumulação de capital em valores de troca de mercadoria refletidos no preço do bem imóvel. [...] Em suma, a conexão entre o valor de uso da localização, que é um produto social, e o preço pelo uso do espaço, que é expropriado pelos particulares, é percebida quando entendemos o mercado imobiliário como um elo mediador no processo de acumulação do capital. "346

\footnotetext{
${ }^{344}$ GOTTDIENER (1997), p. 32.

${ }^{345}$ Idem, p. 179.

${ }^{346}$ Ibidem, p. 179 e 180.
} 
Diz VILLAÇA que hoje há o consenso de que o espaço urbano é produzido pelo trabalho social e que esse trabalho produz um valor. Porém, indaga:

"Uma pergunta fundamental que poucos se fazem: qual é o produto desse trabalho? Há aí dois valores a se considerar. O primeiro é o dos produtos em si os edifícios, as ruas, as praças, as infra-estruturas. O outro é o valor produzido pela aglomeração. Esse valor é dado pela localização dos edifícios, ruas e praças, pois é essa localização que os insere na aglomeração. A localização se apresenta assim como um valor de uso da terra - dos lotes, das ruas, das praças, das praias valor que no mercado, se traduz em preço da terra. Tal como qualquer valor, o da localização também é dado pelo tempo de trabalho socialmente necessário para produzi-la, ou seja, para produzir a cidade inteira da qual a localização é parte." 347

Assim, o espaço urbano produzido é constituído por localizações. O conjunto é a estrutura urbana, as partes, são as macro-localizações: áreas centrais, bairros nobres, bairros periféricos, áreas industriais. O que articula essas localizações é o deslocamento de pessoas. Diz ainda o autor: "a localização é, ela própria, também um produto do trabalho e é ela que especifica o espaço intra-urbano. Está associada ao espaço intra-urbano como um todo, pois se refere às relações entre um determinado ponto do território urbano e todos os demais." 348

Ainda sobre a contribuição de Henri Lefèbvre com relação à produção social do espaço urbano, cabe dizer que esta permitiu a apreensão do processo de produção do valor do espaço. Segundo Villaça, Lefèbvre expôs com muita clareza a distinção entre valor do espaço e o da sua matéria prima - o solo, no conceito fundiário antigo, vinculado à propriedade da terra agrícola, por transmissão patrimonial, da qual se extraia a renda fundiária. No caso da mobilização do espaço urbano voltada à produção industrial, LEFEBVRE ${ }^{349}$ coloca que:

"O espaço inteiro deve receber valor de troca [grifo no original]. Ora, a troca implica intercambialidade. A intercambialidade de um bem faz dele uma mercadoria, análoga a uma quantidade de açúcar ou de carvão; ela exige que o bem seja comparável a outros bens e mesmo a todos os bens do mesmo gênero. $O$ 'mundo da mercadoria' com seus traços se estende às coisas e bens produzidos no espaço e, de suas circulações e fluxos, ao espaço inteiro que torna assim a realidade autônoma (na aparência) da coisa, do dinheiro.

\footnotetext{
${ }^{347}$ VILLAÇA (1998), p. 72.

${ }^{348}$ Idem, p. 24.

${ }^{349}$ LEFEBVRE (1974, 388-389), apud VILLAÇA (1998), p. 71.
} 
O valor de troca - Marx, depois dos 'clássicos' mostrou-os para os produtos-coisa se exprime em dinheiro. Outrora, vendia-se, alugava-se a terra. Hoje, compra-se e vende-se (mais do que se aluga) um volume: apartamento, habitações, peças, andares, terraços, equipamentos diversos (piscinas, quadras de tênis, estacionamento). Cada lugar permutável figura assim no encadeamento das operações mercantis - oferta e demanda [grifo do Villaça], formação de um preço (os preços guardando, aliás, um vínculo elástico com os 'custos de produção', isto é, com o tempo de trabalho social médio necessário para a produção.) Neste caso, como em outros, diversas causas perturbam e complicam esta relação, notadamente a especulação... os preços se afastam dos valores e custos de produção [grifo do Villaça]...

Na referência de Villaça a Lojkine $(1981,164)$, quanto à critica aos preceitos teóricos de Marx sobre o valor de uso do solo, mais uma vez se evidencia o conceito da produção social do espaço urbano. Diz LOJKINE: ${ }^{350}$

"Marx reduz, em O Capital, o valor de uso do solo a duas funções: a de instrumento de produção (minas, quedas d'água, terreno agrícola) e de simples suporte passivo de meios de produção (usina), de circulação,(armazém, bancos) ou de consumo (moradias, etc.). [...] um terceiro valor de uso do solo assume, a nosso ver, crescente importância com a socialização das condições gerais de produção; o que chamamos de capacidade de aglomerar, logo de combinar socialmente, meios de produção e meios de reprodução de uma formação social".

Buscando agora apoio em HARVEY, ${ }^{351}$ vale dizer que na economia capitalista contemporânea, o solo e suas benfeitorias constituem-se em mercadorias; assim, um indivíduo tem duplo interesse na sua propriedade: como valor de uso - atual e futuro e como valor de troca potencial - hoje e também no futuro. Por terem a sua localização fixa, o solo (ou a terra) e as benfeitorias, quando institucionalizados como propriedade privada, assumem papel diferenciado em termos de uso do solo e, portanto, no significado de valor de uso e de troca. Nesse contexto, a interpenetração desses valores - de uso e de troca - estabelece a relação entre o sistema de sustentação da vida e o sistema do mercado de troca por meio da terra urbana, no processo de produção do espaço urbano. Daí advém a importância das localizações, tanto para a relação moradia-trabalho - ao entender a terra como mercadoria para consumo - como para a dinâmica do mercado - onde a propriedade da terra propicia uma oportunidade

\footnotetext{
${ }^{350}$ LOJKINE (1981, 163-164), apud VILLAÇA (1998), p. 73.

${ }^{351}$ HARVEY (1980), p. 135-137.
} 
de acumulação de riqueza. Ressalta Harvey que, na visão da teoria neoclássica, negociam-se no mercado da moradia segundo o conceito do valor de troca, a quantidade de moradia (usualmente concebida como espaço), a acessibilidade (usualmente, a do custo de transporte ao lugar do emprego) e a necessidade de todos os outros bens e serviços. Como contraponto, Harvey coloca que MARX acreditava ser a renda do solo urbano uma renda diferencial, assim como a fertilidade para a renda agrícola. A renda diferencial assumiria significado em um espaço relativo, estruturado por diferenciais em capacidade produtiva, em localizações diferentes e que é ainda, integrado espacialmente através das relações de custo de transporte. A renda diferencial não poderia ser conceituada sem a projeção em um espaço relativo. Mas na ótica de MARX, a renda diferencial é criada através da operação do modo capitalista de produção, no contexto da instituição da propriedade privada.

De outro lado, explica VILLAÇA ${ }^{352}$ que o conceito de renda diferencial que Marx desenvolveu para as terras agrícolas não se aplica ao urbano: comparar a fertilidade da terra - "um dom gratuito da natureza" - ao trabalho socialmente necessário para produzir uma localização se constitui em um equívoco. Quando trata das especificidades do espaço intra-urbano, Villaça afirma que a determinação de uma localização urbana é dada sempre por dois atributos - uma rede de infra-estrutura (vias, redes de água, esgotos, pavimentação) e as possibilidades de transporte (deslocamento de produtos, deslocamento de pessoas, de comunicação) - "tanto para o exercício imediato do trabalho, como para a reprodução da força de trabalho". Porém, ressalta ainda que "as condições de deslocamento do ser humano, associadas a um ponto do território urbano, predominarão sobre a disponibilidade de infraestruturas desse mesmo ponto. A acessibilidade é mais vital na produção das localizações do que a disponibilidade de infra-estrutura." Isto decorre em função de que a infra-estrutura é produzida pelo trabalho humano e pode ser por ele também reproduzida e estendida à toda a cidade; já a localização não: apesar de fruto do trabalho humano, não pode ser por ele reproduzida (assim como as obras de arte); somente a totalidade da cidade é que poderia reproduzi-la, e sendo assim, isto se torna impossível.

Por fim, para SANTOS, é através do estudo das interações entre os diversos elementos do espaço que se recupera a totalidade social - "o espaço como um todo e, igualmente, a sociedade como um todo." ${ }^{353}$

\footnotetext{
${ }^{352}$ VILLAÇA (1998), p. 78; p. 23; e p. 354.

${ }^{353}$ SANTOS (1992), p. 6.
} 
"[...] a cada momento histórico cada elemento ou variável muda seu papel e a sua posição no sistema temporal e no sistema espacial e, a cada momento, o valor de cada qual deve ser tomado da sua relação com os demais elementos e com o todo. [...] a verdade é que, seja qual for a forma de ação entre as variáveis ou dentro delas, não se pode perder de vista o conjunto, o contexto. As ações entre as diversas variáveis estão subordinadas ao todo e aos seus movimentos. [...] quando uma variável muda o seu movimento, isso remete imediatamente ao todo, modificando-o, fazendo-o outro, ainda que sempre e sempre, ele constitua uma totalidade." 354

Na seqüência, retratar-se-á o processo de produção das novas localizações, a ser interpretado à luz de três lógicas, consideradas essenciais para apreensão do fenômeno da expansão urbana recente na Curitiba Metrópole (1996 a 2009). São elas:

(i) a lógica da exclusão, a partir da correlação entre o mercado de terras e a apropriação do território pela renda;

(ii) a lógica da inclusão, a partir da correlação entre a expansão da mancha de ocupação urbana, o acesso à rede integrada de transporte - a RIT - e a apropriação do território pela renda;

(iii) a lógica da inclusão do excluído, que resulta da produção e apropriação das novas localizações intra-urbanas na periferia da Curitiba Metrópole, a partir da correlação entre o mercado de terras e a expansão da rede integrada de transporte.

${ }^{354}$ SANTOS (1992), p. 6 e p. 9. 


\section{EXPANSÃO URBANA DA CURITIBA METRÓPOLE E A LÓGICA EXCLUDENTE DO MERCADO DE TERRAS}

Pretende-se, com a leitura da expansão urbana na Curitiba Metrópole, demonstrar a dinâmica recente do mercado de terras, a fim de elucidar as dimensões da segregação e da segmentação sócio-espacial na produção e na apropriação do território - ou seja, explicar a expansão urbana a partir de uma lógica de exclusão. Para interpretar esse processo serão estabelecidas correlações entre a evolução do preço da terra (por m2 de lotes para venda ofertados por bairros), a evolução da renda (possibilidade de consumo da terra urbana) e a evolução da forma urbana (direções e modo de expansão).

\section{A evolução do preço da terra na Curitiba Metrópole}

Como um primeiro recorte temático para a análise da dinâmica do mercado de terras - bem como a dos seus impactos na produção das novas localizações intraurbanas - tem-se o preço da terra, a ser observado por meio da sua evolução, no já justificado período de 1996 a 2009. Os preços da terra coletados referem-se sempre aos preços médios de lotes ofertados por bairros, nos quatro municípios em questão. Isto passa a definir a partir de agora o modo de correlação espacial entre as variáveis propostas. Contudo, mais do que uma referência de método, a unidade do bairro enquanto uma referência espacial propicia a interpretação da apropriação do espaço pelo cidadão, por ser esta escala, de acordo com CAMPOS FILHO, a escala da vivência e, portanto, a da concretude dos processos socioespaciais. ${ }^{355} \mathrm{~A}$ introdução da unidade de bairro permite ainda entender, de forma mais clara, as possibilidades de consumo da terra dadas pela relação entre produção e apropriação das localizações quando da espacialização da renda, uma vez que os bairros estão estreitamente vinculados à espacialização das classes sociais no território. Com base em Castells (1978, 203 e 204), VILLAÇA ${ }^{356}$ explica que "a distribuição das residências no espaço produz a sua diferenciação social e há uma estratificação urbana correspondente a uma estratificação social." Castells, quando discorre sobre a organização do espaço,

\footnotetext{
$\overline{{ }^{355} \text { CAMPOS FILHO (1989), p. } 108 .}$

${ }^{356}$ VILLAÇA, (1998), p. 148 e 149.
} 
fala em "homogeneidade interna". Então, Villaça coloca o "conceito de bairro, que existe ainda em grande quantidade nas metrópoles brasileiras. Nossos bairros tendem a uma homogeneidade social muito grande."

A seguir, apresenta-se a pesquisa de evolução do preço da terra dos lotes ofertados para venda em Curitiba, Colombo, Pinhais e São José dos Pinhais, em reais por metro quadrado, por bairros, para os anos de 1996, 2000, 2004 e 2009. A evolução dos preços foi compilada em quatro tabelas básicas - por municípios e por bairros, a fim de captar especificidades locais - bem como espacializada em quatro mapas referentes ao conjunto do cone leste, por ano pesquisado, objetivando a leitura da totalidade da dinâmica no recorte pesquisado da Curitiba Metrópole. Em razão disso, serão apresentados primeiramente os mapas, precedidos logo após pelas tabelas. 


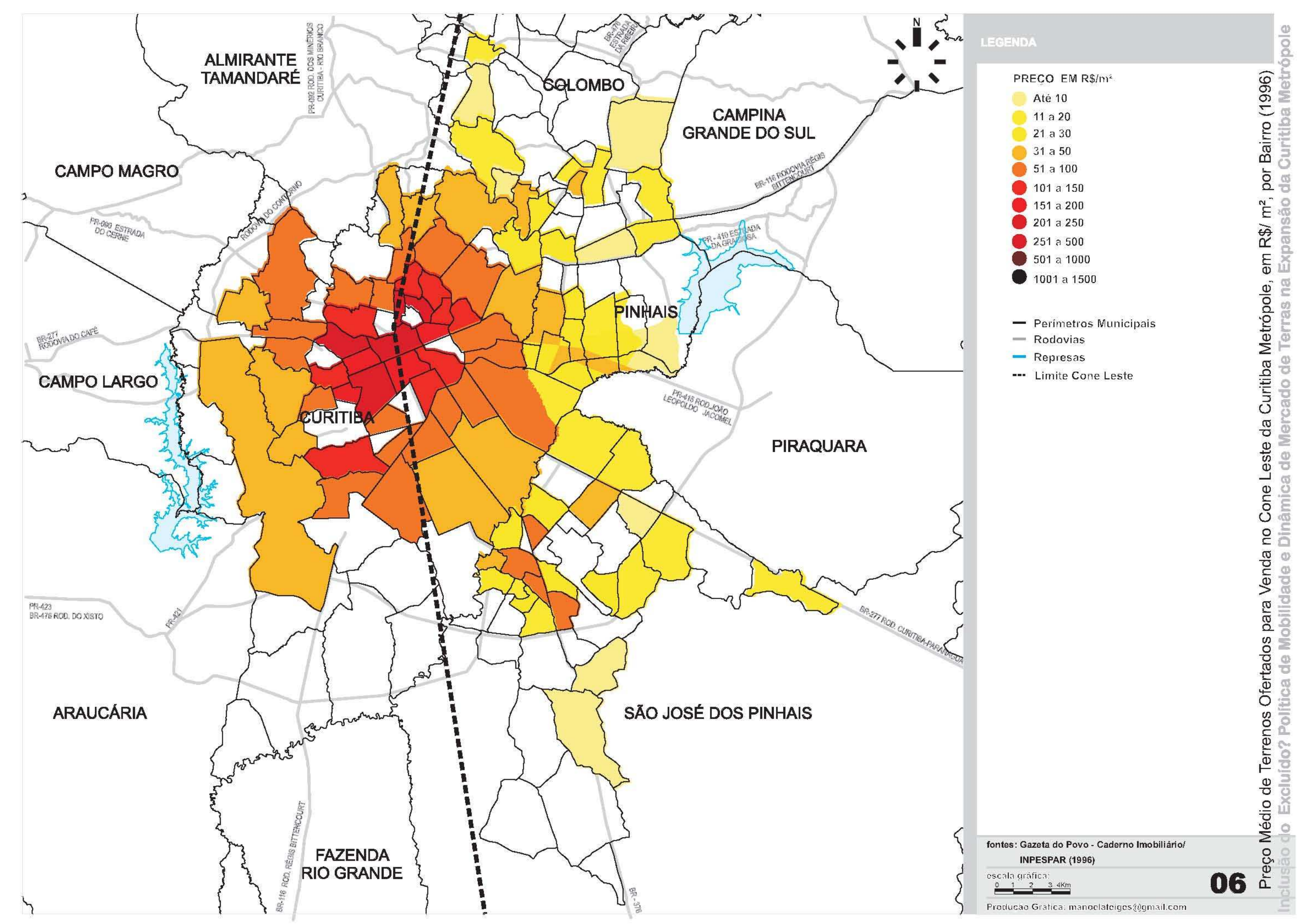


Em 1996, a situação do preço da terra no cone leste da Curitiba Metrópole era a seguinte: a área central de Curitiba apresentava os preços mais altos (de 501 a 1000), seguida por dois anéis concêntricos de bairros: o primeiro anel variando entre 101 a 500 reais e o segundo, entre 31 e 100 reais. Os bairros Centro e Centro Cívico em Curitiba, respondiam pelos preços mais altos - nas faixas de 501 a 1000 reais e 251 a 500 reais respectivamente. Os bairros de Curitiba limítrofes à área conurbada apresentavam-se, em média, na faixa de 31 a 50 reais. Os valores mais altos referiamse aos bairros Tarumã, Capão da Imbuia e Cajuru, na divisa com Pinhais, muito provavelmente por estarem mais próximos da área central de Curitiba - em torno de 7 $\mathrm{km}$ - e o preço mais baixo - entre 21 a 30 reais - foi verificado no extremo nordeste do de Curitiba, no bairro Atuba, já na divisa com Colombo.

Vale ressaltar que a lógica de comportamento dos preços por círculos concêntricos identificada em Curitiba altera-se, nas áreas conurbadas, para uma lógica de eixos viários, onde uma grande área mais homogênea de preços é rasgada por vias radiais a partir de Curitiba, onde se concentram os preços mais altos. Deve-se dar destaque, por hierarquia de valores, aos eixos viários correspondentes à Av. das Torres, em direção a São José dos Pinhais - principal acesso ao Aeroporto Afonso Pena (de 51 a 100 reais); à Av. João Leopoldo Jacomel em Pinhais - prolongamento da Av. Victor Ferreira do Amaral (de 21 a 50 reais); e em Colombo, à Estrada da Ribeira - a antiga estrada para São Paulo, também na faixa de 21 a 50 reais - seguido da rodovia BR-277 - em direção ao litoral e Porto de Paranaguá, entre menos de 10 a 50 reais. Segundo o PDI-2006, "os preços altos da terra coincidem com as áreas que apresentam maior mobilidade, garantida pela infra-estrutura viária e acessibilidade, ou seja, onde o sistema de transporte coletivo garante, ao longo dos principais eixos de comunicação, tempos menores de deslocamento até o centro".

Importante também frisar que a área central de São José dos Pinhais apresentou preços por bairros equivalentes ou superiores aos dos bairros do segundo anel de Curitiba (entre 51 a 100 reais), revelando, mesmo que incipiente, uma centralidade fora do pólo.

Importante ainda registrar que o preço da terra constatado nas áreas de transição entre urbano e rural, era da ordem de até 10 reais, fossem elas coincidentes ou não com as áreas protegidas ambientalmente por diplomas legais. 


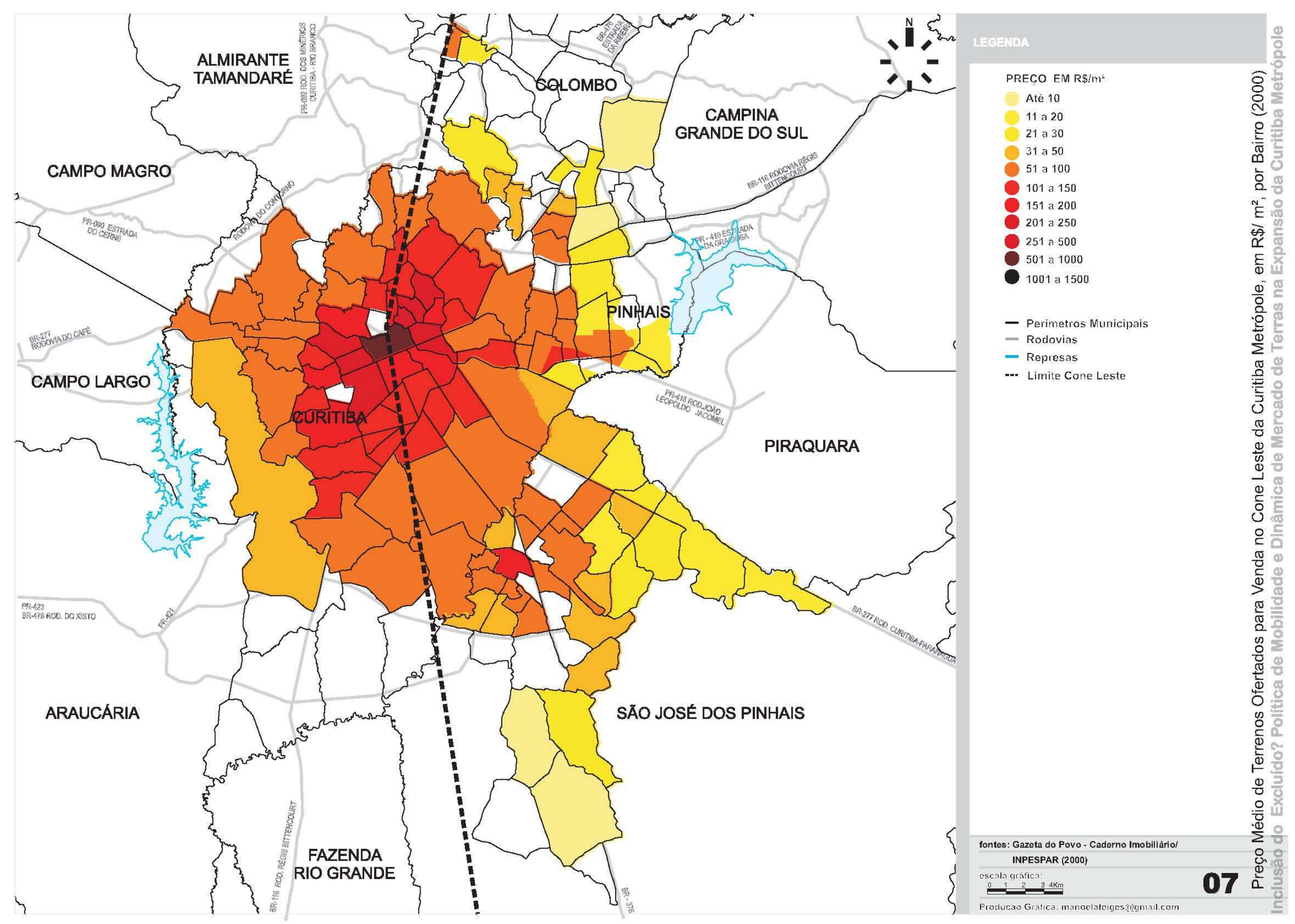


No ano de 2000, além do Centro de Curitiba, também os bairros a ele contíguos compõem a faixa de preço mais alta - de 500 a 1000 reais, sendo possível perceber a expansão de valorização da área central sobre o primeiro anel verificado em 1996. Nessa expansão, é visível a relação da faixa de preços mais alta - de 251 a 500 reais - com os bairros adjacentes a trechos dos eixos estruturais de Curitiba corredores de transporte associados ao maior potencial de verticalização - como nos casos do Centro ao Cabral no eixo norte e do Centro ao Alto da XV e ao Cristo Rei no eixo leste.

Interessante verificar que essa tendência de elevação de preços do eixo estrutural leste já se expande gradativamente em direção à área central de Pinhais (101 a 150 reais) onde foi implantado em 2000 o terminal metropolitano. Nota-se também um incremento nos preços relativos aos bairros lindeiros às principais vias regionais originadas a partir de Curitiba (51 a 100 reais) - a Av. João Leopoldo Jacomel e a Av. Irai, bem como aos eixos municipais no sentido norte-sul - como a Av. Maringá e a Av. Jacob Macanhan. Os preços dessas áreas equiparam-se aos dos bairros limítrofes de Curitiba, podendo ser explicados, mais adiante, por um processo de estruturação urbana interna de Pinhais, originado a partir da estruturação da RIT metropolitana.

Já em Colombo, constatou-se que, na mesma medida que se eleva o preço do solo nos bairros mais próximos à divisa com Curitiba - para 51 a 100 reais - vai-se consolidando uma área de maiores preços também ao longo da Estrada da Ribeira, até alcançar o bairro que abriga o terminal metropolitano, o Maracanã. Com relação às faixas de preço atingidas por estas áreas, vale contar que grande parte delas se assemelha ao padrão observado tanto em Pinhais como em São José dos Pinhais, um resultado inicialmente inesperado - por Colombo se tratar de um município dormitório mas condizente com a questão da relatividade do peso da infra-estrutura em relação às localizações propiciadas pela RIT metropolitana na formação do preço, conforme premissas encontradas em HARVEY e em VILLAÇA.

Quanto a São José dos Pinhais, lê-se claramente o surgimento de uma frente de valorização ao longo da BR-277 (entre 31 a 100 reais) - onde foi implantado o distrito industrial da montadora Renault, que passou a produzir a partir de 1999. Disso resultou que a área compreendida entre os dois eixos viários de importância regional as já citadas BR-277 e Avenida das Torres, mais a sudeste - ao rasgarem São José dos Pinhais, acabaram por delimitar um setor de círculo relativo a preços mais altos (51 a 100 reais), setor este delimitado perimetralmente pelo Contorno Leste. Deve-se destacar também neste setor de círculo o papel estruturante da Av. Rui Barbosa, que ao conectar esses dois eixos regionais, acabou por ligar o Aeroporto Afonso Pena ao 
bairro Centro em São José dos Pinhais. Quanto ao Centro, cabe dizer que o preço lá encontrado - de 151 a 200 reais - correspondeu à faixa mais alta verificada no município, equivalente ao mesmo patamar de preços dos bairros da área de expansão de valorização do Centro de Curitiba, há pouco observada. 


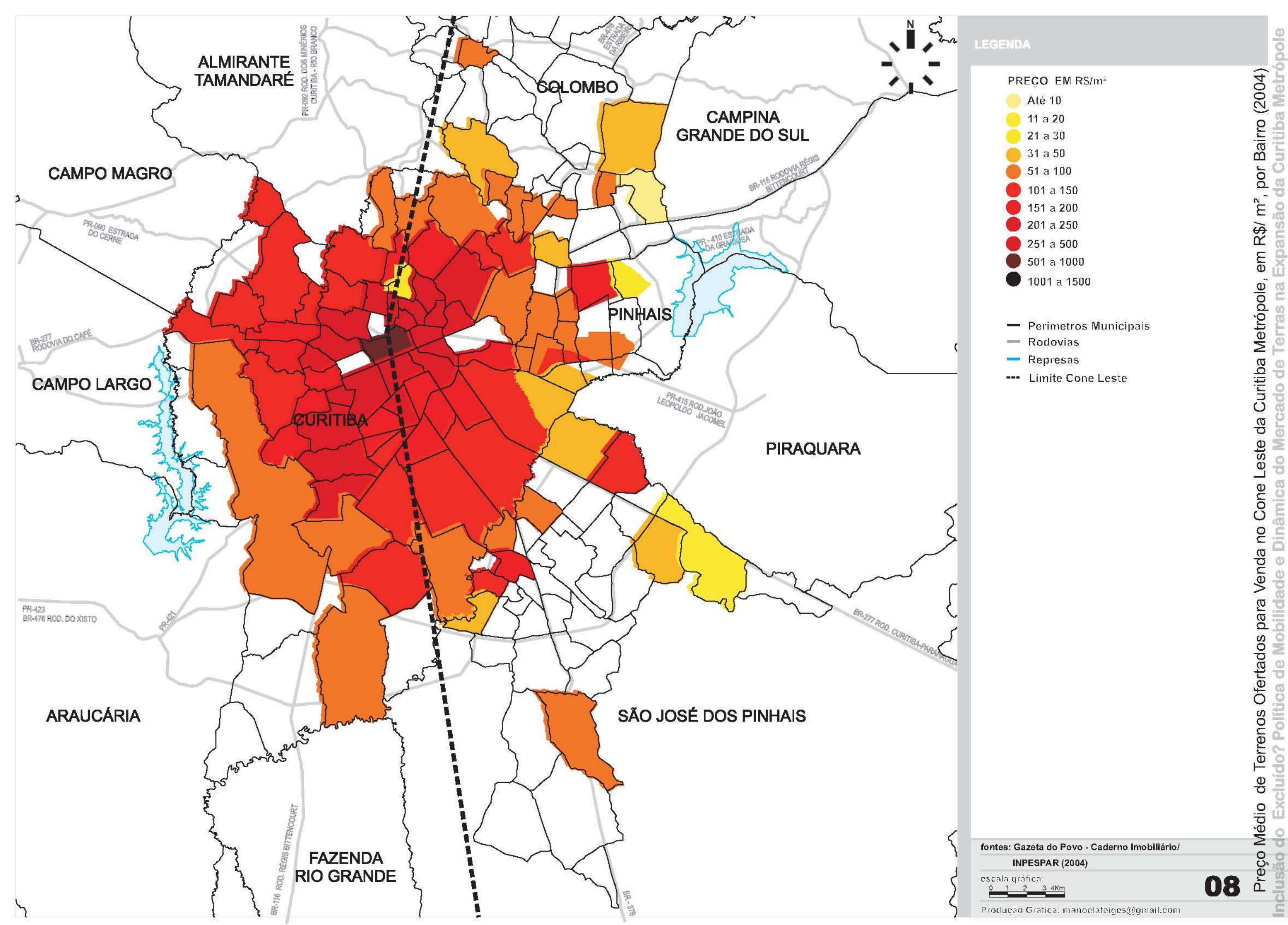


O panorama dos preços em 2004 para Curitiba denota, por meio da leitura espacial, que a lógica de comportamento dos preços revelada em 2000 - ainda a dos círculos concêntricos a partir da área central - altera-se agora para uma lógica ampliada á escala da Curitiba Metrópole. A nova lógica, caracterizada por preços mais altos nos bairros contíguos aos principais eixos viários - de interesse regional pelo deslocamento de cargas - BR-116 e BR-277 - e de interesse intra-urbano pelo fluxo de passageiros: Av. Paraná - Estrada da Ribeira; Av. Victor Ferreira do Amaral - Rodovia João Leopoldo Jacomel; Av. Presidente Affonso Camargo - Av. Irai; Av. das Torres Rua XV de Novembro; Av. Mal. Floriano Peixoto - Av. das Américas.). A faixa superior de preços anteriormente verificada na área central em expansão para os bairros contíguos aos corredores estruturais de transporte norte e leste, permanece (entre 251 a 500 reais) e agora se amplia, passando a englobar os bairros dos trechos mais centrais dos corredores leste e sul, respectivamente aos bairros Bigorrilho - Mercês, e bairros Água Verde - Vila Izabel.

Para os demais municípios do cone leste, a pesquisa empírica aqui realizada apresenta, neste momento, uma lacuna considerável pela falta de consistência de dados, tanto para a dinâmica de preços de São José dos Pinhais como de Colombo. Isto se deu em função do parco número de anúncios ofertados via jornal em 2004: de um lado pela alta no preço dos anúncios classificados e, de outro, em detrimento da crescente oferta de anúncios em portais de imóveis na internet. ${ }^{357}$ Porém, mesmo a partir de fragmentos de dados obtidos, arrisca-se dizer que em São José dos Pinhais, a tendência de valorização que vinha sendo observada ao longo da BR-277 se mantém e que os preços relativos ao bairro Centro (SJP, entre 151 a 200 reais) perde em valorização se comparado com os mesmos bairros de Curitiba aos quais se equiparava em 2000 , hoje na faixa de 201 a 250 reais.

Sobre Colombo, também se pode confirmar a manutenção da tendência dos preços mais altos (de 51 a 100 reais) corresponderem tanto aos bairros mais próximos à divisa com Curitiba como aos da Estrada da Ribeira, porém verifica-se que os tais preços se estendem além do bairro Maracanã, já citado pela presença do terminal metropolitano da RIT.

Para Pinhais, em relação à leitura anterior - a de 2000 - cabe dizer que, inusitadamente, a grande maioria dos bairros permaneceu na mesma faixa de preços; as exceções a esse fato são os bairros que apresentaram incrementos mais significativos de preço e, portanto, passaram para faixas superiores. Esses são os casos do bairro Vargem Grande - vizinho ao bairro Centro (Pinhais) e ao terminal

\footnotetext{
${ }^{357}$ Informação repassada pela coordenadora do INPESPAR, Sra. Bernadete Jede, em entrevista à autora.
} 
metropolitano da RIT (101 a 150 reais) - e do bairro Graciosa (151 a 200 reais), que corresponde em quase a sua totalidade ao Condomínio Alphaville Graciosa, lá implantado no ano 2000. 


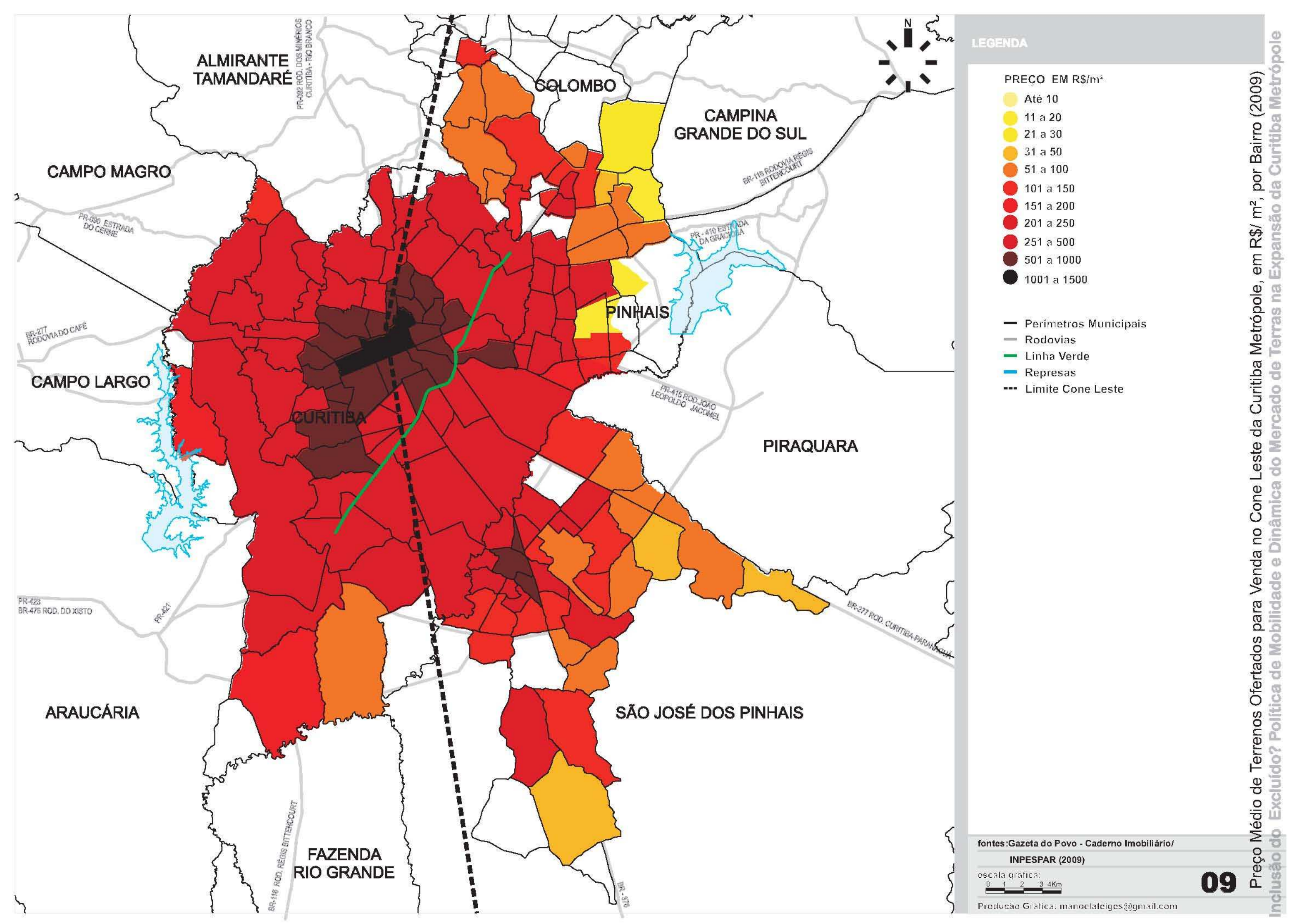


Em termos de leitura do preço da terra em 2009, para o conjunto do cone leste, faz-se necessário e importante registrar que mais uma vez a lógica de comportamento de preços se modifica em relação ao mapeamento de preços anterior, o de 2004. Da lógica de eixos viários - sejam eles regionais ou intra-metropolitanos - anteriormente observada, passa-se novamente à lógica dos círculos concêntricos com origem na região central de Curitiba, porém agora com um fato novo: o segundo círculo concêntrico de faixa de preço mais alta (251 a 500 reais) supera os limites municipais, englobando assim, as parcelas de maior preço de áreas conurbadas nos demais municípios. Isto abrange o eixo da Estrada da Ribeira em Colombo, a maioria dos bairros de Pinhais - incluindo o agora chamado "bairro Alphaville Graciosa" - e os bairros do entorno do Centro de São José dos Pinhais - com exceção do Centro em si, que recupera a equiparação verificada em 2000 com o primeiro anel de bairros concêntricos em Curitiba (de 501 a 1000 reais). Desta nova lógica, resultou uma grande área homogeneizada de preços da terra em 2009, fenômeno altamente legível a partir do mapeamento. Esse fenômeno pode ser atribuído tanto aos deslocamentos das camadas de alta renda para localizações fora da área central de Curitiba, como pela expansão da RIT Metropolitana, responsável diretamente pela produção de novas e múltiplas localizações nas áreas conurbadas, além da estruturação interna das áreas urbanas municipais em Colombo e Pinhais, o que será para frente melhor explorado na terceira leitura. Outra observação fundamental é a de que, para além do desse segundo anel mais valorizado, a lógica de comportamento de preços mais altos volta a ser a dos eixos viários, porém agora com ênfase naqueles de maior interesse regional, uma vez que os de interesse intra-urbano foram absorvidos no já citado segundo anel.

Seguem então as tabelas de preços e valorizações por bairros, para cada um dos municípios. Para facilitar a leitura dos preços, foram ressaltados em verde os preços mais altos encontrados para o conjunto dos bairros, por ano de pesquisa; em amarelo, os preços mais baixos. 
Tabela 3.2 - CURITIBA - SETOR LESTE

\begin{tabular}{|c|c|c|c|c|c|c|c|c|}
\hline \multicolumn{5}{|c|}{$\begin{array}{c}\text { PREÇO MÉDIO (R\$/m²) DE TERRENOS OFERTADOS PARA VENDA, POR } \\
\text { BAIRRO, EM 1996, 2000, } 2004 \text { E } 2009\end{array}$} & \multicolumn{4}{|c|}{$\begin{array}{l}\text { ÍNDICE DE VALORIZAÇÃO DO } \\
\text { PREÇO DA TERRA } \\
\text { NO PERIODO1996-2009 }\end{array}$} \\
\hline BAIRROS & 1996 & 2000 & 2004 & 2009* & $96-00$ & $00-04$ & $04-09$ & $96-09$ \\
\hline Ahú & 129,14 & 150,6 & 300,74 & 796,82 & 1,17 & 1,99 & 2,64 & 6,17 \\
\hline Alto Boqueirão & 41,67 & 62,37 & 90,81 & 279,15 & 1,50 & 1,45 & 3,07 & 6,69 \\
\hline Alto da Glória & 224,72 & 321,85 & 354,5 & $1.096,38$ & 1,43 & 1,10 & 3,09 & 4,87 \\
\hline Alto da XV & 163 & 284,11 & 322,05 & 834,59 & 1,74 & 1,13 & 2,59 & 5,12 \\
\hline Atuba & 26,58 & - & 103,78 & 259,58 & & 3,90 & 2,50 & 9,76 \\
\hline Bacacheri & 85,76 & 129,63 & 224,47 & 484,47 & 1,51 & 1,73 & 2,15 & 5,64 \\
\hline Bairro Alto & 40,16 & 67,88 & 97,84 & 288,42 & 1,69 & 1,44 & 2,94 & 7,18 \\
\hline Boa Vista & 72,05 & 106,7 & 173,5 & 454,33 & 1,48 & 1,62 & 2,61 & 6,30 \\
\hline Bom Retiro & 96,49 & 130,38 & 207,44 & 467,18 & 1,35 & 1,59 & 2,25 & 4,84 \\
\hline Boqueirão & 50,02 & 81,23 & 115,36 & 348,45 & 1,62 & 1,42 & 3,02 & 6,96 \\
\hline Cabral & 150,24 & 262,63 & 316 & 870,47 & 1,75 & 1,20 & 2,75 & 5,79 \\
\hline Cajuru & 64,84 & 81,97 & 106,14 & 371,83 & 1,26 & 1,29 & 3,50 & 5,73 \\
\hline Capão da Imbuia & 74,42 & 129,82 & 172,71 & 508,39 & 1,74 & 1,33 & 2,94 & 6,83 \\
\hline Centro Cívico & 258,38 & 199,76 & 379,79 & 875,52 & 0,77 & 1,90 & 2,30 & 3,38 \\
\hline Centro & 474,03 & 545,35 & 963,41 & $1.412,98$ & 1,15 & 1,76 & 1,46 & 2,98 \\
\hline Cristo Rei & 123,09 & 344,44 & 308,26 & 717,96 & 2,80 & 0,89 & 2,32 & 5,83 \\
\hline Fanny & 84,23 & 117,09 & 142,9 & 381,52 & 1,39 & 1,22 & 2,66 & 4,52 \\
\hline Guabirotuba & 69,63 & 115,43 & 186,31 & 477,67 & 1,66 & 1,61 & 2,56 & 6,86 \\
\hline Guaíra & 77,25 & 123,94 & 159,76 & 417,42 & 1,60 & 1,28 & 2,61 & 5,40 \\
\hline Hauer & 65,14 & 124,17 & 169,07 & 385,75 & 1,91 & 1,36 & 2,28 & 5,92 \\
\hline Hugo Lange & 117,27 & 184,25 & 308,79 & 641,33 & 1,57 & 1,67 & 2,07 & 5,46 \\
\hline Jardim Botânico & 134,89 & 152,95 & 248,45 & 679,61 & 1,13 & 1,62 & 2,73 & 5,03 \\
\hline Jardim Américas & 87,38 & 143,16 & 196 & 466,79 & 1,64 & 1,36 & 2,38 & 5,34 \\
\hline Jardim Social & 110,87 & 148,01 & 222,28 & 532,32 & 1,33 & 1,50 & 2,39 & 4,80 \\
\hline Juvevê & 217,3 & 286,13 & 309,76 & 851,1 & 1,32 & 1,08 & 2,74 & 3,91 \\
\hline Lindóia & 63,1 & 126,35 & 168,5 & 416,52 & 2,00 & 1,33 & 2,47 & 6,60 \\
\hline Mercês & 116,2 & 152,56 & 283,1 & 543,32 & 1,31 & 1,85 & 1,91 & 4,67 \\
\hline Parolin & 49,05 & 127,63 & 219,64 & 459,04 & 2,60 & 1,72 & 2,08 & 9,35 \\
\hline Pilarzinho & 50,66 & 74,58 & 111,36 & 299,62 & 1,47 & 1,49 & 2,69 & 5,91 \\
\hline Prado Velho & 105,75 & 128,54 & 169,11 & 643,34 & 1,22 & 1,31 & 3,80 & 6,08 \\
\hline Rebouças & 160,64 & 192,12 & 280,54 & 829,57 & 1,20 & 1,46 & 2,95 & 5,16 \\
\hline Santa Cândida & 34,18 & 56,51 & 88,42 & 260,91 & 1,65 & 1,56 & 2,95 & 7,63 \\
\hline São Francisco & 195,41 & 214,14 & $363-27$ & 907,32 & 1,10 & 1,69 & 2,49 & 4,64 \\
\hline São Lourenço & 75,8 & 104,65 & 174,98 & 481,3 & 1,38 & 1,67 & 2,75 & 6,34 \\
\hline Tarumã & 55,52 & 87,67 & 194,77 & 413,8 & 1,58 & 2,22 & 2,12 & 7,45 \\
\hline Tingüi & 93,62 & 81,22 & 126,24 & 331,66 & 0,87 & 1,55 & 2,62 & 3,54 \\
\hline Uberaba & 45,11 & 73,7 & 140,09 & 344,92 & 1,63 & 1,90 & 2,46 & 7,64 \\
\hline \multicolumn{5}{|c|}{ Valorização média por intervalo } & 1,36 & 1,46 & 2,4 & 5,41 \\
\hline
\end{tabular}




\section{Tabela 3.3 - COLOMBO}

\begin{tabular}{|c|c|c|c|c|c|c|c|c|}
\hline \multicolumn{5}{|c|}{$\begin{array}{c}\text { PREÇO MÉDIO (R\$/m²) DE TERRENOS OFERTADOS PARA VENDA, POR } \\
\text { BAIRRO, EM 1996, 2000, } 2004 \text { E } 2009\end{array}$} & \multicolumn{4}{|c|}{$\begin{array}{c}\text { ÍNDICE DE VALORIZAÇÃO DO } \\
\text { PREÇO DA TERRA } \\
\text { NO PERIODO1996-2009 }\end{array}$} \\
\hline BAIRROS & 1996 & 2000 & 2004 & $2009^{*}$ & $96-00$ & 00-04 & $04-09$ & 96-09 \\
\hline Centro & 13,44 & 26,44 & 71,32 & 108,40 & 1,97 & 2,70 & 1,52 & 8,07 \\
\hline Gabirobal & & 60,61 & & & & & & \\
\hline Arruda & 6,25 & & & 72,12 & & & & 11,54 \\
\hline Embu & & & & 55,59 & & & & \\
\hline Roça Grande & 14,77 & 32,40 & 37,76 & 83,97 & 2,19 & 1,17 & 2,22 & 5,69 \\
\hline São Gabriel & & & & 139,91 & & & & \\
\hline Osasco & 6,29 & 41,21 & 95,82 & 90,45 & 6,55 & 2,33 & 0,94 & 14,38 \\
\hline Campo Pequeno & 34,70 & 42,51 & 78,72 & 186,33 & 1,23 & 1,85 & 2,37 & 5,37 \\
\hline Rio Verde & 28,80 & & 74,07 & & & 2,57 & & \\
\hline Guarani & & 52,38 & & 105,60 & & & & 2,02 \\
\hline Atuba & 25,95 & 63,35 & 42,00 & 206.95 & 2,44 & 0,66 & 4,93 & 7,97 \\
\hline \multicolumn{9}{|l|}{ Monza } \\
\hline Fátima & & & & 120,41 & & & & \\
\hline Maracanã & & 43,61 & 62,50 & 479,95 & & 1,43 & 7,68 & 11,01 \\
\hline Santa Terezinha & 40,00 & & & 216,84 & & & & 5,42 \\
\hline Guaraituba & 16,49 & 23,43 & & 107,57 & 1,42 & & & 6,52 \\
\hline Das Graças & & & & 88,89 & & & & \\
\hline Paloma & & & 76,92 & 48,53 & & & 0,63 & \\
\hline Palmital & & 9,22 & & 83,85 & & & & 9,09 \\
\hline Mauá & 10,71 & 25,73 & & 64,29 & 2,40 & & 2,50 & 6,00 \\
\hline Canguiri & 20,33 & & & 90,46 & 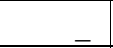 & & & 4,45 \\
\hline Rincão & & & & 53,91 & & & & \\
\hline Colônia Farias & 14,74 & & 9,50 & 18,50 & - & - & 1,95 & 1,26 \\
\hline São Dimas & 7,00 & 8,98 & 37,75 & 27,27 & 1,28 & 4,20 & 0,72 & 3,90 \\
\hline \multicolumn{5}{|c|}{ Valorização média por intervalo } & 2,44 & 1,88 & 2,55 & 6,85 \\
\hline
\end{tabular}




\section{Tabela 3.4 - PINHAIS}

\section{PREÇO MÉDIO (R\$ $\left./ \mathrm{m}^{2}\right)$ DE TERRENOS OFERTADOS PARA VENDA, POR BAIRRO, EM 1996, 2000, 2004 E 2009}

\begin{tabular}{|c|c|c|c|c|c|c|c|c|}
\hline BAIRROS & 1996 & 2000 & 2004 & 2009* & $96-00$ & 00-04 & $4 /$ set & $96-09$ \\
\hline Alto Atuba & & & & 406,68 & & & & \\
\hline Emiliano Perneta & 34,29 & 54,98 & 90,46 & 321,45 & 1,60 & 1,65 & 3,55 & 9,37 \\
\hline Estância Pinhais & 27,08 & 52,16 & 59,40 & 285,34 & 1,93 & 1,14 & 4,80 & 10,54 \\
\hline Weissópolis & 18,72 & 34,86 & 44,94 & 242,90 & 1,86 & 1,29 & 5,40 & 12,98 \\
\hline Vargem Grande & 26,74 & 28,10 & 48,17 & 181,96 & 1,05 & 1,71 & 3,78 & 6,80 \\
\hline Centro & 31,73 & 125,26 & 136,83 & 340,27 & 3,95 & 1,09 & 2,49 & 10,72 \\
\hline Palmital & 30,53 & 73,73 & 87,23 & 290,99 & 2,42 & 1,18 & 3,34 & 9,53 \\
\hline Sete Vilas & & & & 239,53 & & & & \\
\hline Vila Amélia & 22,46 & 47,90 & 86,68 & 147,26 & 2,13 & 1,81 & 1,70 & 6,56 \\
\hline Maria Antonieta & 34,97 & & & 160,78 & & & & 4,60 \\
\hline Vale das Águas & 2,61 & 16,99 & & & 6,51 & & & \\
\hline Graciosa & & 26,66 & 162,62 & 269,93 & & 6,10 & 1,66 & 10,12 \\
\hline Entre Rios & 15,00 & 11,68 & & 18,68 & 0,78 & & & 1,25 \\
\hline Vale das Nascentes & & & 24,54 & 11,62 & & & 0,47 & \\
\hline Esperança & & & & & & & & \\
\hline Vale do Capão & & & & & & & & \\
\hline \multicolumn{5}{|c|}{ Valorização média por intervalo } & 2,47 & 2,00 & 3,02 & 8,25 \\
\hline
\end{tabular}

FONTES: Gazeta do Povo - Caderno Imobiliário, para 1996, 2000, 2004, elaborado pela autora; $\left(^{*}\right)$ para 2009,

INPESPAR - Instituto Paranaense de Pesquisa e Desenvolvimento do Mercado Imobiliário e Condominial, elaborado

pela autora. 


\section{Tabela 3.5 - SÃO JOSÉ DOS PINHAIS}

\begin{tabular}{|c|c|c|c|c|c|c|c|c|}
\hline \multicolumn{5}{|c|}{$\begin{array}{c}\text { PREÇO MÉDIO (R\$/m²) DE TERRENOS OFERTADOS PARA VENDA, POR } \\
\text { BAIRRO, EM 1996, 2000, } 2004 \text { E } 2009\end{array}$} & \multicolumn{4}{|c|}{$\begin{array}{l}\text { ÍNDICE DE VALORIZAÇÃO DO } \\
\text { PREÇO DA TERRA } \\
\text { NO PERIODO1996-2009 }\end{array}$} \\
\hline BAIRROS & 1996 & 2000 & 2004 & $2009^{*}$ & $96-00$ & $00-04$ & $4 /$ set & $96-09$ \\
\hline Centro & 69,81 & 158,36 & 196,74 & 797,23 & 2,27 & 1,24 & 4,05 & 11,42 \\
\hline Aristocrata & 27,79 & 65,44 & 125,33 & 384,30 & 2,35 & 1,92 & 3,07 & 13,83 \\
\hline São Domingos & 35,03 & 93,41 & & 361,92 & 2,67 & & & 10,33 \\
\hline São Pedro & 67,05 & & & 539,12 & & & & 8,04 \\
\hline Pedro Moro & 22,26 & 67,13 & & 307,45 & 3,02 & & & 13,81 \\
\hline Bom Jesus & 17,87 & 85,65 & & 257,44 & 4,79 & & & 14,41 \\
\hline Colônia Rio Grande & 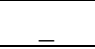 & 46,97 & 50,00 & 178,82 & & 1,06 & 3,58 & 3,81 \\
\hline Santo Antônio & & 45,70 & & 149,73 & & & & 3,28 \\
\hline Cidade Jardim & 26,85 & 49,70 & 78,13 & 344,10 & 1,85 & 1,57 & 4,40 & 12,82 \\
\hline São Cristóvão & & & & 504,85 & & & & \\
\hline Boneca do Iguaçu & 61,43 & 91,24 & & 244,15 & 1,49 & & & 3,97 \\
\hline Águas Belas & & & & 142,42 & & & & \\
\hline Cruzeiro & 27,96 & 56,73 & & 413,63 & 2,03 & & & 14,79 \\
\hline Aeroporto & & 66,93 & & 96,56 & & & & 1,44 \\
\hline Afonso Pena & 25,30 & 56,04 & 72,53 & 228,28 & 2,22 & 1,29 & 3,15 & 9,02 \\
\hline Aviação & & 78,67 & - & 286,23 & & & & 3,64 \\
\hline Independência & 21,48 & 37,24 & 36,11 & 185,54 & 1,73 & 0,97 & 5,14 & 8,64 \\
\hline Iná & 36,83 & 56,75 & & 201,87 & 1,54 & & & 5,48 \\
\hline Costeira & & 34,17 & & 213,40 & & & & 6,25 \\
\hline Quissisana & 27,46 & 42,65 & & 146,55 & 1,55 & & 3,44 & 5,34 \\
\hline Rio Pequeno & & 13,36 & & 115,75 & & & & 8,66 \\
\hline Academia & 10,68 & 30,69 & & 51,44 & 2,87 & & 1,68 & 4,82 \\
\hline Ipê & 20,45 & 45,02 & 50,00 & 127,31 & 2,20 & 1,11 & 2,55 & 6,23 \\
\hline Guatupê & 16,92 & 17,84 & 113,64 & 101,52 & 1,05 & 6,37 & 0,89 & 6,00 \\
\hline Cristal & 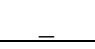 & 21,87 & & 67,88 & & & & 3,10 \\
\hline Borda do Campo & $=$ & 16,34 & 12,10 & 67,26 & & 0,74 & 5,56 & 4,12 \\
\hline Dom Rodrigo & 11,41 & 18,23 & & 39,35 & 1,60 & & & 3,45 \\
\hline Roseira de São Sebastião & 14,63 & 24,59 & 31,65 & 46,09 & 1,68 & 1,29 & 1,46 & 3,15 \\
\hline Jurema & 13,69 & 22,91 & & 90,53 & 1,67 & & & 6,61 \\
\hline Ouro Fino & 55,60 & & & 115,46 & & & & 2,08 \\
\hline Itália & 13,01 & 80,34 & & 113,89 & 6,18 & & 1,42 & 8,75 \\
\hline \multicolumn{9}{|l|}{ Arujá } \\
\hline Barro Preto & & & & 56,08 & & & & \\
\hline Del Rey & 5,00 & 37,24 & & 69,40 & 7,45 & & 1,86 & 13,88 \\
\hline São Marcos & 8,33 & 23,65 & 60,63 & 147,00 & 2,84 & 2,56 & 2,42 & 17,65 \\
\hline Campina do Taquaral & & 3,10 & & 227,43 & & & & 73,36 \\
\hline Campo Largo da Roseira & & 8,08 & & 41,56 & & & & 5,14 \\
\hline \multicolumn{5}{|c|}{ Valorização média por intervalo } & 2,62 & 1,83 & 2,98 & 9,62 \\
\hline
\end{tabular}


Em se tratando dos impactos diretos do novo ciclo produtivo instaurado na metrópole, cabe dizer que a dinâmica imobiliária metropolitana foi sensivelmente alterada. Mais precisamente, em relação à valorização do preço da terra no período de estudo, foi possível constatar na área estudada uma elevação significativa do preço da terra - entre 1996 e 2000 - tanto na área central (1,36\% em Curitiba) como na área periférica (2,44\% em Colombo, 2,47\% em Pinhais e 2,62\% em São José dos Pinhais).

Duas questões se apresentaram curiosas: a primeira, diferente do que se esperava encontrar até este ponto da pesquisa, a valorização das áreas conurbadas foi maior que a do pólo; e a segunda, que em Colombo - o município dormitório - a valorização advinda da estruturação urbana que se deu pelo transporte metropolitano integrado, atingiu os mesmos patamares de valorização que os demais municípios alcançaram - Pinhais e São José dos Pinhais - a partir da expansão de capital de naturezas industrial e imobiliária respectivamente.

Os patamares de valorização observados até então decaem, de forma geral, já no período de análise subseqüente - 2000 a 2004 - sendo 1,46\% em Curitiba, 1,88\% em Colombo, 2,00\% em Pinhais e 1,83\% em São José dos Pinhais. Nesta ocasião houve certa estagnação de produção imobiliária por parte da indústria da construção civil em Curitiba, indicada pela queda do número de lançamentos imobiliários. Tal fato certamente refletiu e ao mesmo tempo confirmou o caráter especulativo do mercado de terras observado entre 1996 e 2000.

Porém, a crescente oferta do mercado de condomínios residenciais de médio e grande porte, mais claramente percebida em Pinhais, denota o deslocamento das elites da área central para a periferia. Essa tendência evidencia em parte o redesenho da estrutura da metrópole pela criação de novas localizações intra-urbanas, comandada pelas camadas de mais alta renda, como afirmado por Villaça.

Interessante também ressaltar que, em Colombo, mesmo com a queda da valorização, o índice ainda assim se mantém superior ao de Curitiba e ao de São José dos Pinhais. Porém, a constatação mais inusitada com relação aos preços da terra, certamente foi a da valorização referente ao último período analisado (2004-2009), que superou àquela demonstrada no primeiro intervalo, de 2,40\% em Curitiba, 2,55\% em Colombo, 3,02\% em Pinhais e 2,98\% em São José dos Pinhais. Valores dessa envergadura comprovam a magnitude da especulação em torno do valor da terra urbana na Curitiba Metrópole. As causas desse fenômeno estão associadas inicialmente ao fato da migração de excedentes de capital imobiliário que foram alocados no mercado local, drenados de circuitos produtivos de outros estados - em sua maioria de São Paulo - migração essa ainda combinada com uma fase mais recente de expansão do crédito imobiliário no país. Em compensação, apesar disto, o 
incremento médio de valorização no cone leste neste período pode ser considerado relativamente homogêneo em função de uma pequena variação apresentada no intervalo - entre $61 \%$ e $73 \%$, vindo a confirmar um comportamento de valorização com tendência mais homogênea das macro-localizações, seguindo a já demonstrada tendência de homogeneização do preço da terra nas áreas periféricas em decorrência do surgimento de múltiplas localizações na periferia. Em relação a esse fato, cabe inserir o pensamento de Villaça, quando diz:

"A oferta de terrenos é altamente condicionada pelos transportes, que definem os espaços onde podem ocorrer terras "ofertáveis". Dessa disputa decorrem terras com preço mais alto, relativamente ao poder aquisitivo da demanda [...]". 358

Neste último período, além da alta generalizada dos preços no cone leste, vale esboçar o quadro de valorização por tipologia de municípios. Em Curitiba, a maior valorização constatada está fortemente associada à Linha Verde, já implantada no trecho sul - Prado Velho (3,80\%). A segunda valorização mais alta do período ocorreu no bairro Cajuru (3,50\%), na divisa com Pinhais a leste - um bairro que apresenta os indicadores menos favoráveis do setor leste. Em outros bairros também limítrofes a Pinhais, notou-se a elevada valorização no período - como no Bairro Alto (2,95\%) e no Capão da Imbuia (2,94\%). Em Pinhais, as valorizações mais expressivas deste período estão associadas aos bairros mais próximos à divisa com Curitiba, localizados ao longo dos corredores de transporte metropolitano da Av. Pres. Affonso Camargo Av. Irai (Weissópolis 5,40\% e Vargem Grande 3,78\%), e da Av. Victor Ferreira do Amaral - Rodovia João Leopoldo Jacomel (Estância Pinhais 4,80\%, e Emiliano Perneta 3,55\%), em detrimento das áreas relativas às ocupações mais recentes com os condomínios residenciais horizontais (Graciosa 1,66\%). Também se atribui a essas áreas valorizadas dos corredores de transporte o crescente interesse do terciário.

No limite Curitiba - Colombo, ao norte, o bairro Santa Cândida (2,95\%) ainda em Curitiba, seguiu o mesmo padrão de valorização dos da divisa com Pinhais ao leste. Já no bairro a ele contíguo em Colombo, o Atuba, a valorização foi de 4,93\%, Percebe-se assim facilmente que a valorização do corredor metropolitano de transporte da Estrada da Ribeira, nada mais é do que uma pressão exercida pela expectativa de continuidade da Linha Verde - o novo corredor metropolitano de transporte, ainda não implantado neste trecho norte.

${ }^{358}$ VILLAÇA (1998), p. 353. 
Em São José dos Pinhais, foram encontrados os maiores índices de valorização do cone leste neste último período de análise - em dois pontos ao longo da BR-277 (sentido Paranaguá) e na área central. No bairro Independência, limítrofe à Curitiba, e contíguo ao corredor metropolitano de transporte integrado da BR-277, a valorização chegou a atingir a marca de 5,14\%. Mais alta ainda foi a valorização no bairro Borda do Campo (5,56\%), uma área de expansão urbana distante da divisa, também localizada ao longo da BR-277, porém contígua à montadora Renault. A segunda área que apresentou expressiva valorização foi a área central - nos bairros Centro (4,05\%) e Cidade Jardim (4,40\%). Isto confirma a nova centralidade metropolitana atribuída a São José dos Pinhais, enquanto interesse imobiliário do mercado de terras e da recente expansão do terciário superior.

\section{O preço da terra e a movimentação das classes sociais na apropriação do território da Curitiba Metrópole}

De acordo com VILLAÇA 359 "o espaço urbano é produzido e consumido por um mesmo e único processo", e a sua estruturação interna se processa "sob o domínio de forças que representam os interesses de consumo (condições de vida) das camadas de mais alta renda". Com apoio em Castells, o autor explica que "tal estruturação se dá em torno da disputa pela apropriação diferenciada do espaço urbano enquanto produto do trabalho." Desse modo, deixa claro que a luta entre as classes sociais pela localização é na verdade uma luta em torno das condições de consumo, e não das condições da produção. Portanto, explica que uma das faces mais visíveis da metrópole brasileira é a da segregação espacial das classes sociais nos distintos bairros. O mais conhecido padrão de segregação da metrópole brasileira é o do centro-periferia. Por esse fato, a segregação dos bairros das camadas de mais alta renda - correspondente à média e à alta burguesias é facilmente identificável. $\mathrm{O}$ centro, "dotado da maioria dos serviços urbanos, públicos e privados, é ocupado pelas classes de mais alta renda"; a periferia, "subequipada e longínqua, é ocupada predominantemente pelos excluídos. O espaço atua como um mecanismo de exclusão." ${ }^{360}$ Villaça aponta que em Lojkine $(1981,166)$, tem-se que a segregação

\footnotetext{
${ }^{359}$ VILLAÇA (1998), p. 328 e 330.

${ }^{360}$ Idem, p. 141-143.
} 
seria "um fenômeno produzido pelos mecanismos de formação dos preços do solo, estes por sua vez, determinados (...) pela nova divisão social e espacial do trabalho". ${ }^{361}$ Como Lojkine não esclarece como a segregação é produzida, supõe-se que "as classes de mais alta renda fiquem com os terrenos mais caros e as de mais baixa renda, com os mais baratos".

Porém, diz ainda VILLAÇA:

"Esta tese já foi derrubada com vários casos empíricos. Ficaríamos um pouco mais próximos da verdade se afirmássemos que os terrenos mais caros são ocupados pelas camadas de alta renda, pois na periferia de metro quadrado barato a alta renda ocupa terrenos grandes ou, em se tratando de condomínios verticais, grandes quotas ideais de terrenos. Finalmente, deve-se considerar que a classe média também ocupa terra cara no que se refere ao preço do metro quadrado de terreno, consumindo pouca terra per capita ou por família, como em Copacabana, no Itaim ou Moema, ambos em São Paulo." ${ }^{362}$

Ainda para o autor, a segregação se revela como "um processo fundamental para a compreensão da estrutura espacial intra-urbana". [...] "Na verdade, não há dois tipos de segregação, mas um só. A segregação é um processo dialético, em que a segregação de uns provoca, ao mesmo tempo e pelo mesmo processo, a segregação de outros." 363

Sobre a estruturação básica da metrópole brasileira, Villaça constata que a organização espacial a partir de setores de círculo é preponderantemente sobre a dos círculos concêntricos. Isto se deve em razão de alguns fatores: a relação entre o sentido radial e a necessidade de se manter o acesso ao centro da metrópole; e à acentuada estratificação social, onde a classe burguesa representa pequena parcela de população, em relação à enorme dimensão das camadas populares. Afirma que nas metrópoles de primeiro mundo, ao contrário, a tendência é a organização espacial a partir de círculos concêntricos, em função do tamanho das classes médias, que acabam por desenvolver uma "forte simbiose com o centro, ambos se reforçando mutuamente e mantendo suas localizações." Assim, conclui Villaça: ${ }^{364}$

"Se nossa sociedade apresentasse uma estratificação social mais uniforme, mais semelhante a muitas metrópoles do Primeiro Mundo, nossas metrópoles apresentariam um espaço também mais homogêneo e mais próximo a círculos

\footnotetext{
${ }^{361}$ VILLAÇA (1998), p. 146.

${ }^{362}$ Idem, p. 147.

${ }^{363}$ Ibidem, p. 141 e 147-148.

${ }^{364}$ VILLAÇA (1998), p. 153-155.
} 
concêntricos. Mesmo a participação da classe média em nossa estrutura social é muito pequena. Assim sendo, a organização espacial das classes segundo setores de círculo permite [...] maior controle do espaço, através do controle do mercado imobiliário (deslocando o centro principal, por exemplo), do Estado e da Ideologia maior do que seria numa eventual segregação segundo círculos concêntricos."

Sob essa ótica é que se pretende aqui prosseguir com a análise da dinâmica do mercado de terras. Inferir-se-á agora a variável renda, objetivando correlacionar o preço da terra e a possibilidade de consumo da terra vinculada à capacidade de se pagar por ela, e explicitar a partir disso, a movimentação das classes sociais no território estudado. Assim, segue a leitura espacial da evolução da renda do chefe do domicílio, por setores censitários, no cone leste da Curitiba Metrópole, a partir dos censos 1991 e 2000. Para a interpretação da espacialização da renda - e, portanto, da espacialização das classes sociais - sobrepôs-se a divisão dos bairros utilizada como base para o preço da terra aos setores censitários do IBGE, a fim de verificar os intervalos de ocorrência da renda por bairros, por municípios e na totalidade do cone leste. Em função da presente pesquisa estar sendo desenvolvida na iminência da realização do censo 2010, deve-se ressaltar a existência de uma lacuna de análise que não pode ser, por hora, minorada. Segundo JORGE e SALGADO ${ }^{365}$ ao se referirem à Região Metropolitana de São Paulo, "no caso de estudos demográficos desagregados a níveis intra-urbanos, a dependência que se tem do Censo FIBGE é muito grande e os dados do censo são muito espaçados para uma realidade tão dinâmica como a estrutura urbana da RMSP."

Na seqüência, segue o mapeamento da evolução da renda e, posteriormente, as tabelas que correlacionam a evolução do preço da terra, a valorização imobiliária e a evolução da renda.

\footnotetext{
365 JORGE e SALGADO (1996), p. 156.
} 


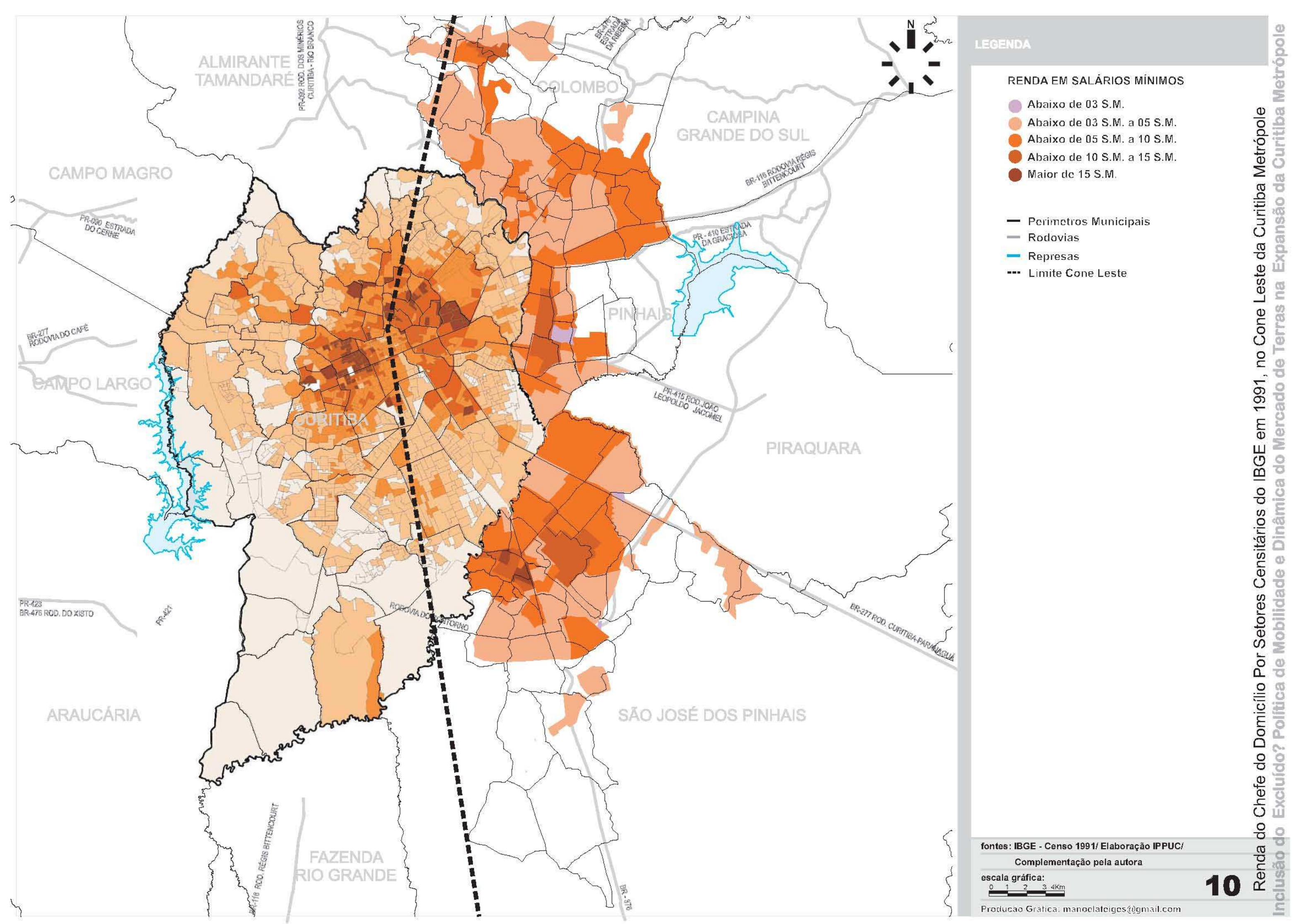


A distribuição da renda no território da Curitiba metrópole no início dos anos noventa foi tratada a partir de cinco intervalos de faixas de rendimento: menor que 3 SM, de 3 a 5 SM, de 5 a 10 SM, de 10 a 15 SM, e maior que 15 SM. Lê-se a partir do mapa da renda para 1991, que as classes mais altas - faixa correspondente à renda superior a 15 SM por chefe de domicílio - tinham sua distribuição no território da Curitiba Metrópole em duas localizações: no entorno do centro principal - o de Curitiba, e na área central de São José dos Pinhais - o subcentro metropolitano. Em Curitiba, concentravam-se em dois pontos: à oeste do centro - principalmente nos bairros Batel (centro expandido), Seminário e Bigorrilho (eixo estrutural oeste), região não pertencente à área da pesquisa; e à leste do centro, nos bairros Centro Cívico, Juvevê. Cabral e Jardim Social. Pode-se dizer que, de acordo com Villaça, conformavam dois setores de círculo a partir do centro, à oeste e à leste. Em São José dos Pinhais, as camadas de maior rendimento localizavam-se nos bairros Centro e São Pedro, contíguos à Av. das Torres.

Já a ocorrência da classe média-alta - entre 10 a 15 SM - foi verificada nos bairros do entorno das áreas centrais de Curitiba e em São José dos Pinhais, bem como no bairro Aeroporto e imediações. Em Colombo, localizava-se na sede administrativa (Centro), distante da área conurbada e, em Pinhais, na área central e no bairro Emiliano Perneta, prolongamento do Centro, entre as Avenidas Maringá e Jacob Macanhan.

Quanto às classes médias ( 5 a 10 SM) e às classes mais populares (3 a 5 SM e 0 a 3 SM), pode-se dizer que suas lógicas de localização apresentaram-se de maneiras distintas no conjunto dos municípios. Em Curitiba, as classes médias conformavam um circulo concêntrico no entorno do centro e dos setores de círculo correspondentes às camadas mais altas, seguido de outro circulo concêntrico de bairros periféricos onde se localizavam as classes mais baixas.

Em São José dos Pinhais, a classe média localizava-se entre o centro e a divisa com Curitiba, também no entorno do aeroporto e em mais dois pontos isolados o bairro Ipê, ao norte, contíguo à BR-277, e nos bairros Costeira e Barro Preto. Às classes mais populares restaram as áreas de expansão contidas pelo Contorno Leste e as localizadas ao longo do eixo da BR-277.

Em Pinhais, a lógica de distribuição da classe média era a de três áreas isoladas entre si, no entorno das camadas de mais alta renda, todas elas compostas por bairros vinculados aos eixos viários intra-metropolitanos (Av, Irai, Rodovia João Leopoldo Jacomel e Estrada da Graciosa). Às classes de menor renda localizaram-se então nos interstícios entre as áreas de classes médias, também no entorno das localizações das camadas de maior rendimento. 
A lógica mais singular foi a de Colombo, onde as classes médias estavam localizadas em bairros próximos às indústrias locais, muito provavelmente por proximidade ao emprego, ocupando assim, as bordas da mancha conurbada. Desse modo, as classes de menor rendimento formavam um continuum a partir de Curitiba, preenchendo as localizações mais centrais, delimitadas pelas referidas bordas de classe média. 


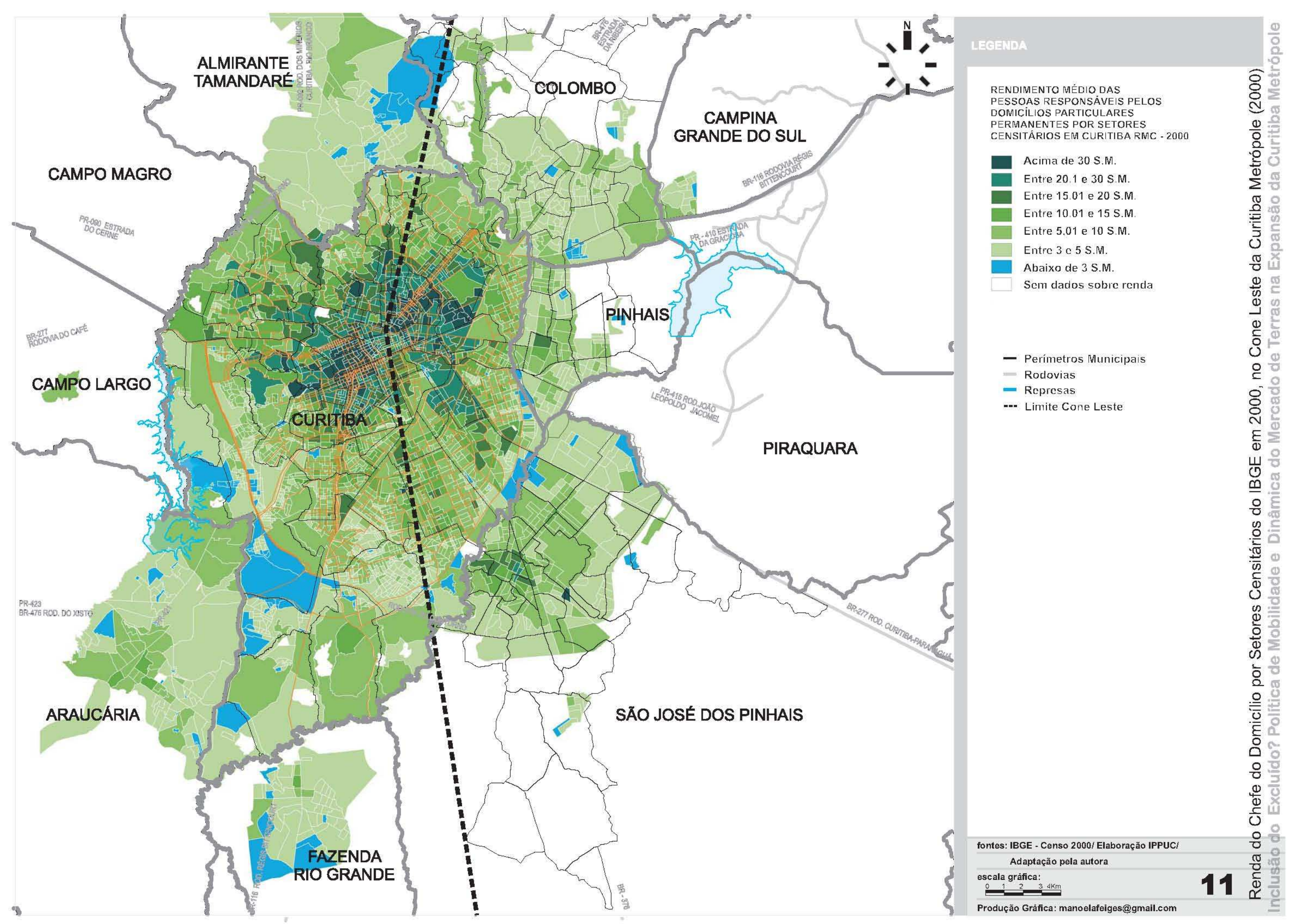


Quanto às características observadas em relação à localização das classes sociais no território em estudo em 1991, pode-se dizer que, em comparação ao mapeamento referente a 2000, a variação da renda analisada no período sugere novas interpretações das relações entre o centro e a periferia, por meio de uma nova lógica implícita no movimento das classes sociais no território da Curitiba Metrópole. Um primeiro movimento constatado - o das camadas de mais alta renda, caracterizado por seus deslocamentos do centro da metrópole para noroeste e para leste, na direção de Pinhais, ambos em razão da oferta de condomínios horizontais. O movimento à noroeste vem atrelado às áreas recuperadas ambientalmente com a implantação de alguns parques lineares em fundos de vale, ${ }^{366}$ porém ocorrem fora do recorte de pesquisa; quanto ao movimento à leste, cabe enfatizar que o mesmo não foi passível de espacialização, uma vez que ocorreu após o censo 2000, estando por hora comprometida pela lacuna gerada em relação ao aguardo do censo 2010. Em função disso, buscou-se um paralelo em JORGE e SALGADO, que ao se referirem à Região Metropolitana de São Paulo, também constataram a ocorrência de um movimento similar:

"[...] É interessante observar que nas faixas onde estão os bairros de Alphaville e da Granja Viana, seu peso em rendas mais altas não foram suficientes para elevar o nível médio de suas zonas. Isso ocorre porque o peso da variável nesses bairros está diluído, [...] pois abrangem grandes contingentes de população de baixa renda. Aqueles bairros representam a tendência mais recente de localização de classes alta e média, em condomínios fechados, em zonas periféricas, mas de fácil acesso às áreas de trabalho dessa população, isto é, o centro expandido da RMSP.” 367

Um segundo movimento, este sim observado a partir da espacialização da renda, demonstra como foi intensa a movimentação da classe de 5 a 10 SM - a que abrange a maior parcela de área do território do cone leste. Ao distanciar-se do centro, segue em direção aos bairros mais periféricos de Curitiba, e acaba por extravasar os seus limites administrativos, instalando-se nas franjas dos municípios conurbados. Essa tendência, comum a outras metrópoles brasileiras, também é apontada por JORGE e SALGADO em relação a São Paulo:

\footnotetext{
${ }^{366}$ Conforme já apontado no CAPÍTULO 2.

${ }^{367}$ JORGE e SALGADO (1996), p. 161.
} 
"A classe média, na medida em que vem perdendo renda, passa a emigrar para áreas mais periféricas. As populações iniciais de conjuntos habitacionais como os de Itaquera vêm sendo substituídas por populações de maior renda, na medida em que os conjuntos passam a ser melhor servidos por infra-estrutura, principalmente transporte. Da mesma maneira, as populações de renda mais baixa também apresentam movimentos migratórios internos à RMSP, dirigindo-se para áreas ainda mais periféricas ou engrossando a população encortiçada e favelada." 368

Eis que, paradoxalmente, um terceiro movimento, um tanto inesperado, foi verificado com relação à mesma classe (5 a 10 SM) nos demais municípios: em 1991 localizavam-se nos bairros mais periféricos e, portanto, os mais afastados do centro da metrópole; em 2000 vê-se esses mesmos bairros sendo apropriados por classes mais populares (3 a 5 SM). Esse movimento pode ser explicado por duas causas: a primeira, pela perda de rendimentos e conseqüente empobrecimento da população; e a segunda, pela possibilidade de migração para bairros mais próximos ao centro, em função da estruturação urbana atrelada ao transporte metropolitano integrado, a RIT, da qual se tratará com maiores detalhes logo adiante. Esse terceiro movimento, que praticamente se caracteriza por ser o inverso do segundo, ocorreu em áreas de expansão em Colombo - bairros mais à nordeste - e em São José dos Pinhais - bairros mais ao norte, ao longo da BR-277, já nas divisas com Pinhais e Piraquara. Se em 1991 lá ocorria a presença de faixas de renda entre 5 e 10 SM ou 5 e 15 SM, esses intervalos se modificam em 2000, para 3 a 5 SM e 3 a 10 SM. Este fato será também explorado no que tange à evolução da mancha urbana.

Apresentam-se agora as tabelas que darão suporte às correlações entre a evolução do preço da terra, a valorização imobiliária e a evolução da renda por ocorrência nos bairros. Da mesma forma como nas tabelas anteriores, em verde ressaltam-se valores mais altos e em amarelo, os mais baixos.

${ }^{368}$ JORGE e SALGADO (1996), p. 162. 


\section{Tabela 3.6 - CURITIBA - SETOR LESTE}

PREÇO MÉDIO (R\$/m²) DE TERRENOS OFERTADOS PARA VENDA, POR BAIRRO, EM 1996, 2000, 2004 E 2009

\begin{tabular}{|c|c|c|c|c|c|c|c|c|c|c|}
\hline \multicolumn{11}{|c|}{ Tabela 3.6 - CURITIBA - SETOR LESTE } \\
\hline \multicolumn{5}{|c|}{$\begin{array}{l}\text { PRECCO MÉDIO (R\$/m²) DE TERRENOS OFERTADOS } \\
\text { PARA VENDA, POR BAIRRO, EM 1996, 2000, } 2004 \text { E } 2009\end{array}$} & \multicolumn{4}{|c|}{$\begin{array}{c}\text { ÍNDICE DE VALORIZAÇÃO DO } \\
\text { PREÇO DA TERRA } \\
\text { NO PERÍODO1996-2009 }\end{array}$} & \multicolumn{2}{|c|}{$\begin{array}{l}\text { EVOLUÇÃO RENDA } \\
1991-2000 \\
\text { EM SALARIOS } \\
\text { MÍNIMOS }\end{array}$} \\
\hline BAIRROS & 1996 & 2000 & 2004 & $2009^{*}$ & $96-00$ & $00-04$ & $04-09$ & $96-09$ & 1991 & 2000 \\
\hline Ahú & 129,14 & 150,6 & 300,74 & 796,82 & 1,17 & 1,99 & 2,64 & 6,17 & $5 a>15$ & $20 a>30$ \\
\hline Alto Boqueirão & 41,67 & 62,37 & 90,81 & 279,15 & 1,50 & 1,45 & 3,07 & 6,69 & $<3$ a 5 & $<3$ a 10 \\
\hline Alto da Glória & 224,72 & 321,85 & 354,5 & $1.096,38$ & 1,43 & 1,10 & 3,09 & 4,87 & $10 a>15$ & $20 a>30$ \\
\hline Alto da XV & 163 & 284,11 & 322,05 & 834,59 & 1,74 & 1,13 & 2,59 & 5,12 & 5 a 15 & $20 a>30$ \\
\hline Atuba & 26,58 & - & 103,78 & 259,58 & & 3,90 & 2,50 & 9,76 & $<3$ a 5 & $<3$ a 20 \\
\hline Bacacheri & 85,76 & 129,63 & 224,47 & 484,47 & 1,51 & 1,73 & 2,15 & 5,64 & 5 a 15 & $5 a>30$ \\
\hline Bairro Alto & 40,16 & 67,88 & 97,84 & 288,42 & 1,69 & 1,44 & 2,94 & 7,18 & $<3$ a 10 & 5 a 15 \\
\hline Boa Vista & 72,05 & 106,7 & 173,5 & 454,33 & 1,48 & 1,62 & 2,61 & 6,30 & 3 a 10 & 5 a 30 \\
\hline Bom Retiro & 96,49 & 130,38 & 207,44 & 467,18 & 1,35 & 1,59 & 2,25 & 4,84 & 3 a 10 & 5 a 30 \\
\hline Boqueirão & 50,02 & 81,23 & 115,36 & 348,45 & 1,62 & 1,42 & 3,02 & 6,96 & 3 a 10 & 3 a 20 \\
\hline Cabral & 150,24 & 262,63 & 316 & 870,47 & 1,75 & 1,20 & 2,75 & 5,79 & $5 a>15$ & $20 a>30$ \\
\hline Cajuru & 64,84 & 81,97 & 106,14 & 371,83 & 1,26 & 1,29 & 3,50 & 5,73 & $<3$ a 10 & $<3$ a 20 \\
\hline Capão da Imbuia & 74,42 & 129,82 & 172,71 & 508,39 & 1,74 & 1,33 & 2,94 & 6,83 & 3 a 10 & 5 a 20 \\
\hline Centro Cívico & 258,38 & 199,76 & 379,79 & 875,52 & 0,77 & 1,90 & 2,30 & 3,38 & $5 a>15$ & $20 a>30$ \\
\hline Centro & 474,03 & 545,35 & 963,41 & $1.412,98$ & 1,15 & 1,76 & 1,46 & 2,98 & $5 a>15$ & $10 a>30$ \\
\hline Cristo Rei & 123,09 & 344,44 & 308,26 & 717,96 & 2,80 & 0,89 & 2,32 & 5,83 & 5 a 15 & $20 a>30$ \\
\hline Fanny & 84,23 & 117,09 & 142,9 & 381,52 & 1,39 & 1,22 & 2,66 & 4,52 & 3 a 5 & 3 a 10 \\
\hline Guabirotuba & 69,63 & 115,43 & 186,31 & 477,67 & 1,66 & 1,61 & 2,56 & 6,86 & 3 a 15 & 5 a 30 \\
\hline Guaíra & 77,25 & 123,94 & 159,76 & 417,42 & 1,60 & 1,28 & 2,61 & 5,40 & $<3$ a 10 & 3 a 20 \\
\hline Hauer & 65,14 & 124,17 & 169,07 & 385,75 & 1,91 & 1,36 & 2,28 & 5,92 & 3 a 10 & 5 a 20 \\
\hline Hugo Lange & 117,27 & 184,25 & 308,79 & 641,33 & 1,57 & 1,67 & 2,07 & 5,46 & $10 a>15$ & $20 a>30$ \\
\hline Jardim Botânico & 134,89 & 152,95 & 248,45 & 679,61 & 1,13 & 1,62 & 2,73 & 5,03 & 5 a 15 & 5 a 30 \\
\hline Jardim Américas & 87,38 & 143,16 & 196 & 466,79 & 1,64 & 1,36 & 2,38 & 5,34 & $3 a>15$ & 5 a 30 \\
\hline Jardim Social & 110,87 & 148,01 & 222,28 & 532,32 & 1,33 & 1,50 & 2,39 & 4,80 & $>15$ & $20 a>30$ \\
\hline Juvevê & 217,3 & 286,13 & 309,76 & 851,1 & 1,32 & 1,08 & 2,74 & 3,91 & $10 a>15$ & $20 a>30$ \\
\hline Lindóia & 63,1 & 126,35 & 168,5 & 416,52 & 2,00 & 1,33 & 2,47 & 6,60 & $<3$ a 5 & 3 a 10 \\
\hline Mercês & 116,2 & 152,56 & 283,1 & 543,32 & 1,31 & 1,85 & 1,91 & 4,67 & 3 a 15 & 15 a 30 \\
\hline Parolin & 49,05 & 127,63 & 219,64 & 459,04 & 2,60 & 1,72 & 2,08 & 9,35 & $<3 a>15$ & $<3$ a 30 \\
\hline Pilarzinho & 50,66 & 74,58 & 111,36 & 299,62 & 1,47 & 1,49 & 2,69 & 5,91 & $<3$ a 10 & 3 a 15 \\
\hline Prado Velho & 105,75 & 128,54 & 169,11 & 643,34 & 1,22 & 1,31 & 3,80 & 6,08 & $<3$ a 10 & $<3$ a 20 \\
\hline Rebouças & 160,64 & 192,12 & 280,54 & 829,57 & 1,20 & 1,46 & 2,95 & 5,16 & 3 a 15 & $5 a>30$ \\
\hline Santa Cândida & 34,18 & 56,51 & 88,42 & 260,91 & 1,65 & 1,56 & 2,95 & 7,63 & 3 a 5 & 3 a 15 \\
\hline São Francisco & 195,41 & 214,14 & $363-27$ & 907,32 & 1,10 & 1,69 & 2,49 & 4,64 & 3 a 10 & $10 a>30$ \\
\hline São Lourenço & 75,8 & 104,65 & 174,98 & 481,3 & 1,38 & 1,67 & 2,75 & 6,34 & $5 a>15$ & $5 a>30$ \\
\hline Tarumã & 55,52 & 87,67 & 194,77 & 413,8 & 1,58 & 2,22 & 2,12 & 7,45 & 5 a 15 & 5 a 30 \\
\hline Tingüi & 93,62 & 81,22 & 126,24 & 331,66 & 0,87 & 1,55 & 2,62 & 3,54 & 3 a 10 & 3 a 10 \\
\hline Uberaba & 45,11 & 73,7 & 140,09 & 344,92 & 1,63 & 1,90 & 2,46 & 7,64 & 3 a 10 & $<3$ a 30 \\
\hline VAL & $\overline{\mathrm{RIZAÇÁ}}$ & MÉDIf & OR IN & RVALO & 1,36 & 1,46 & 2,4 & 5,41 & & \\
\hline
\end{tabular}

FONTES: Preço da terra, INPESPAR; Renda do Chefe de Domicílio - Censos 1991 e 2000, IBGE. Elaboração da autora.

ÍNDICE DE VALORIZAÇÃO DO

PREÇO DA TERRA

Nota: ( ${ }^{*}$ média de janeiro a setembro de 2009; setembro/2009 corresponde à data da coleta dos dados para esta pesquisa) 


\section{Tabela 3.7 - COLOMBO}

PREÇO MÉDIO (R\$/m²) DE TERRENOS OFERTADOS PARA VENDA, POR BAIRRO, EM 1996, 2000, 2004 E 2009

\begin{tabular}{|c|c|c|c|c|c|c|c|c|c|c|}
\hline BAIRROS & 1996 & 2000 & 2004 & $2009^{\star}$ & $96-00$ & $00-04$ & $04-09$ & $96-09$ & 1991 & 2000 \\
\hline Centro & 13,44 & 26,44 & 71,32 & 108,40 & 1,97 & 2,70 & 1,52 & 8,07 & 5 a 15 & 3 a 10 \\
\hline Gabirobal & & 60,61 & & & & & & & 3 a 5 & 3 a 5 \\
\hline Arruda & 6,25 & & & 72,12 & & & & 11,54 & 3 a 5 & 5 a 10 \\
\hline Embu & & & & 55,59 & & & & & 5 a 10 & 5 a 10 \\
\hline Roça Grande & 14,77 & 32,40 & 37,76 & 83,97 & 2,19 & 1,17 & 2,22 & 5,69 & 3 a 10 & 3 a 10 \\
\hline São Gabriel & & & & 139,91 & & & & & 3 a 10 & 3 a 10 \\
\hline Osasco & 6,29 & 41,21 & 95,82 & 90,45 & 6,55 & 2,33 & 0,94 & 14,38 & 3 a 5 & 3 a 5 \\
\hline Campo Pequeno & 34,70 & 42,51 & 78,72 & 186,33 & 1,23 & 1,85 & 2,37 & 5,37 & 3 a 10 & 3 a 10 \\
\hline Rio Verde & 28,80 & & 74,07 & & & 2,57 & & & 3 a 10 & 3 a 10 \\
\hline Guarani & & 52,38 & & 105,60 & - & & & 2,02 & 3 a 5 & 3 a 5 \\
\hline Atuba & 25,95 & 63,35 & 42,00 & 206.95 & 2,44 & 0,66 & 4,93 & 7,97 & 3 a 10 & 3 a 10 \\
\hline Monza & & & & & & & & & 3 a 5 & 3 a 5 \\
\hline Fátima & & & & 120,41 & & & & & 3 a 5 & 3 a 5 \\
\hline Maracanã & & 43,61 & 62,50 & 479,95 & & 1,43 & 7,68 & 11,01 & 3 a 5 & 3 a 10 \\
\hline Santa Terezinha & 40,00 & & & 216,84 & & & & 5,42 & 5 a 10 & 3 a 5 \\
\hline Guaraituba & 16,49 & 23,43 & & 107,57 & 1,42 & & & 6,52 & 3 a 10 & 3 a 10 \\
\hline Das Graças & & & & 88,89 & & & & & 5 a 10 & 3 a 5 \\
\hline Paloma & & & 76,92 & 48,53 & & & 0,63 & & 3 a 10 & 3 a 10 \\
\hline Palmital & & 9,22 & & 83,85 & & & & 9,09 & 3 a 5 & $<3$ a 5 \\
\hline Mauá & 10,71 & 25,73 & & 64,29 & 2,40 & & 2,50 & 6,00 & 5 a 10 & $<3$ a 5 \\
\hline Canguiri & 20,33 & & & 90,46 & & & & 4,45 & 5 a 10 & 3 a 10 \\
\hline Rincão & & & & 53,91 & & & & - & 5 a 10 & 3 a 10 \\
\hline Colônia Farias & 14,74 & & 9,50 & 18,50 & & & 1,95 & 1,26 & 5 a 10 & 3 a 10 \\
\hline São Dimas & 7,00 & 8,98 & 37,75 & 27,27 & 1,28 & 4,20 & 0,72 & 3,90 & 3 a 10 & $<3$ a 10 \\
\hline VAL & RIZAÇÃ & MÉDIA & OR & VALO & 2,44 & 1,88 & 2,55 & 6,85 & & \\
\hline
\end{tabular}

FONTES: Preço da terra, INPESPAR; Renda do Chefe de Domicílio - Censos 1991 e 2000, IBGE. Elaborado pela autora.

Nota: ( ${ }^{*}$ média de janeiro a setembro de 2009 ; setembro/2009 corresponde à data da coleta dos dados para esta pesquisa) 


\section{Tabela 3.8 - PINHAIS}

PRECO MÉDIO (R\$/m²) DE TERRENOS OFERTADOS PARA VENDA, POR BAIRRO, EM 1996, 2000, 2004 E 2009

\begin{tabular}{|c|c|c|c|c|c|c|c|c|c|c|}
\hline & & & & & & & & & & \\
\hline BAIRROS & 1996 & 2000 & 2004 & $2009^{*}$ & $96-00$ & 00-04 & $04-09$ & $96-09$ & 1991 & 2000 \\
\hline Alto Atuba & & & & 406,68 & & & & & 5 a 10 & 3 a 10 \\
\hline Emiliano Perneta & 34,29 & 54,98 & 90,46 & 321,45 & 1,60 & 1,65 & 3,55 & 9,37 & 3 a 15 & 3 a 10 \\
\hline Estância Pinhais & 27,08 & 52,16 & 59,40 & 285,34 & 1,93 & 1,14 & 4,80 & 10,54 & 3 a 10 & 5 a 10 \\
\hline Weissópolis & 18,72 & 34,86 & 44,94 & 242,90 & 1,86 & 1,29 & 5,40 & 12,98 & 3 a 10 & 3 a 10 \\
\hline Vargem Grande & 26,74 & 28,10 & 48,17 & 181,96 & 1,05 & 1,71 & 3,78 & 6,80 & 3 a 5 & 3 a 10 \\
\hline Centro & 31,73 & 125,26 & 136,83 & 340,27 & 3,95 & 1,09 & 2,49 & 10,72 & 10 a 15 & 5 a 20 \\
\hline Palmital & 30,53 & 73,73 & 87,23 & 290,99 & 2,42 & 1,18 & 3,34 & 9,53 & 3 a 10 & 3 a 10 \\
\hline Sete Vilas & & & & 239,53 & & & & & 3 a 5 & 3 a 10 \\
\hline Vila Amélia & 22,46 & 47,90 & 86,68 & 147,26 & 2,13 & 1,81 & 1,70 & 6,56 & 5 a 10 & 3 a 10 \\
\hline Maria Antonieta & 34,97 & & & 160,78 & & & & 4,60 & 3 a 5 & 3 a 10 \\
\hline Vale das Águas & 2,61 & 16,99 & & & 6,51 & & & & 3 a 5 & 3 a 5 \\
\hline Graciosa & & 26,66 & 162,62 & 269,93 & & 6,10 & 1,66 & 10,12 & $-\left({ }^{* \star}\right)$ & $-(* *)$ \\
\hline Entre Rios & 15,00 & 11,68 & & 18,68 & 0,78 & & & 1,25 & & \\
\hline $\begin{array}{l}\text { Vale das } \\
\text { Nascentes }\end{array}$ & & & 24,54 & 11,62 & & & 0,47 & & & \\
\hline Esperança & & & & & & & & & & $<3$ a 5 \\
\hline Vale do Capão & & & & & & & & & & \\
\hline VAL & RIZAÇ & O MÉDIA & POR IN1 & RVALO & 2,47 & 2,00 & 3,02 & 8,25 & & \\
\hline
\end{tabular}

FONTES: Preço da terra, INPESPAR; Renda do Chefe de Domicílio - Censos 1991 e 2000, IBGE. Elaborado pela autora.

Nota: $\left(^{*}\right)$ média de janeiro a setembro de 2009. Setembro/2009 corresponde à data da coleta dos dados para esta pesquisa);

$\left({ }^{* *}\right)$ Bairro Alphaville Graciosa implantado somente em 2000. 
Tabela 3.9 - SÃO JOSÉ DOS PINHAIS

\begin{tabular}{|c|c|c|c|c|c|c|c|c|c|c|}
\hline \multicolumn{5}{|c|}{$\begin{array}{c}\text { PREÇO MÉDIO (R\$/m²) DE TERRENOS OFERTADOS PARA } \\
\text { VENDA, POR BAIRRO, EM 1996, 2000, } 2004 \text { E } 2009\end{array}$} & \multicolumn{4}{|c|}{$\begin{array}{c}\text { ÍNDICE DE VALORIZAÇÃO DO } \\
\text { PREÇO DA TERRA } \\
\text { NO PERIOODO1996-2009 }\end{array}$} & \multicolumn{2}{|c|}{$\begin{array}{l}\text { EVOLUÇÃO RENDA } \\
1991-2000 \\
\text { EM SALÁRIOS } \\
\text { MÍNIMOS }\end{array}$} \\
\hline BAIRROS & 1996 & 2000 & 2004 & $2009^{*}$ & $96-00$ & $00-04$ & $04-09$ & $96-09$ & 1991 & 2000 \\
\hline Centro & 69,81 & 158,36 & 196,74 & 797,23 & 2,27 & 1,24 & 4,05 & 11,42 & $10 a>15$ & 10 a 30 \\
\hline Aristocrata & 27,79 & 65,44 & 125,33 & 384,30 & 2,35 & 1,92 & 3,07 & 13,83 & 5 a 10 & 5 a 15 \\
\hline São Domingos & 35,03 & 93,41 & & 361,92 & 2,67 & & & 10,33 & 5 a 15 & 5 a 20 \\
\hline São Pedro & 67,05 & & & 539,12 & & & & 8,04 & $5 a>15$ & 5 a 20 \\
\hline Pedro Moro & 22,26 & 67,13 & & 307,45 & 3,02 & & & 13,81 & 3 a 10 & 5 a 15 \\
\hline Bom Jesus & 17,87 & 85,65 & & 257,44 & 4,79 & & & 14,41 & 5 a 10 & 5 a 10 \\
\hline $\begin{array}{l}\text { Colônia Rio } \\
\text { Grande }\end{array}$ & & 46,97 & 50,00 & 178,82 & & 1,06 & 3,58 & 3,81 & 3 a 5 & 3 a 5 \\
\hline Santo Antônio & & 45,70 & & 149,73 & & & & 3,28 & 3 a 5 & 3 a 10 \\
\hline Cidade Jardim & 26,85 & 49,70 & 78,13 & 344,10 & 1,85 & 1,57 & 4,40 & 12,82 & 3 a 10 & 3 a 10 \\
\hline São Cristóvão & & & & 504,85 & & & & & 5 a 10 & 5 a 10 \\
\hline $\begin{array}{l}\text { Boneca do } \\
\text { Iguaçu }\end{array}$ & 61,43 & 91,24 & & 244,15 & 1,49 & & & 3,97 & 5 a 10 & 5 a 10 \\
\hline Águas Belas & & & & 142,42 & & & & & 3 a 5 & 3 a 10 \\
\hline Cruzeiro & 27,96 & 56,73 & & 413,63 & 2,03 & & & 14,79 & 3 a 10 & 3 a 30 \\
\hline Aeroporto & & 66,93 & & 96,56 & & & & 1,44 & 10 a 15 & 3 a 10 \\
\hline Afonso Pena & 25,30 & 56,04 & 72,53 & 228,28 & 2,22 & 1,29 & 3,15 & 9,02 & 5 a 15 & 5 a 15 \\
\hline Aviação & & 78,67 & & 286,23 & & & & 3,64 & 5 a 10 & 5 a 10 \\
\hline Independência & 21,48 & 37,24 & 36,11 & 185,54 & 1,73 & 0,97 & 5,14 & 8,64 & 3 a 10 & $<3$ a 10 \\
\hline Iná & 36,83 & 56,75 & & 201,87 & 1,54 & & & 5,48 & 5 a 10 & 3 a 10 \\
\hline Costeira & & 34,17 & & 213,40 & & & & 6,25 & 3 a 10 & 3 a 10 \\
\hline Quissisana & 27,46 & 42,65 & & 146,55 & 1,55 & & 3,44 & 5,34 & 3 a 5 & 3 a 5 \\
\hline Rio Pequeno & & 13,36 & & 115,75 & & & & 8,66 & 5 a 15 & 3 a 10 \\
\hline Academia & 10,68 & 30,69 & & 51,44 & 2,87 & & 1,68 & 4,82 & 5 a 10 & 3 a 5 \\
\hline Ipê & 20,45 & 45,02 & 50,00 & 127,31 & 2,20 & 1,11 & 2,55 & 6,23 & 5 a 10 & $<3$ a 5 \\
\hline Guatupê & 16,92 & 17,84 & 113,64 & 101,52 & 1,05 & 6,37 & 0,89 & 6,00 & 3 a 5 & $<3$ a 10 \\
\hline Cristal & & 21,87 & & 67,88 & & & & 3,10 & 3 a 5 & 3 a 5 \\
\hline Borda do Campo & & 16,34 & 12,10 & 67,26 & & 0,74 & 5,56 & 4,12 & $<3$ a 10 & $<3$ a 10 \\
\hline Dom Rodrigo & 11,41 & 18,23 & & 39,35 & 1,60 & & & 3,45 & $<3$ a 10 & $<3$ a 10 \\
\hline $\begin{array}{l}\text { Roseira de São } \\
\text { Sebastião }\end{array}$ & 14,63 & 24,59 & 31,65 & 46,09 & 1,68 & 1,29 & 1,46 & 3,15 & 5 a 10 & 5 a 10 \\
\hline Jurema & 13,69 & 22,91 & & 90,53 & 1,67 & & & 6,61 & 3 a 5 & $<3$ a 5 \\
\hline Ouro Fino & 55,60 & & & 115,46 & & & & 2,08 & 3 a 5 & 3 a 10 \\
\hline Itália & 13,01 & 80,34 & & 113,89 & 6,18 & & 1,42 & 8,75 & 3 a 10 & 3 a 10 \\
\hline Arujá & 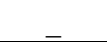 & - & & - & & & & & 3 a 5 & 3 a 5 \\
\hline Barro Preto & & & & 56,08 & & & & & 3 a 10 & 3 a 10 \\
\hline Del Rey & 5,00 & 37,24 & & 69,40 & 7,45 & & 1,86 & 13,88 & & \\
\hline São Marcos & 8,33 & 23,65 & 60,63 & 147,00 & 2,84 & 2,56 & 2,42 & 17,65 & 3 a 5 & $<3$ a 10 \\
\hline $\begin{array}{l}\text { Campina do } \\
\text { Taquaral }\end{array}$ & & 3,10 & & & & & & & & \\
\hline $\begin{array}{l}\text { Campo Largo da } \\
\text { Roseira }\end{array}$ & & 8,08 & & 41,56 & & & & 5,14 & & \\
\hline & LORIZ & ÃO MÉ & POR & ERVALO & 2,62 & 1,83 & 2,98 & 9,62 & & \\
\hline
\end{tabular}


Da correlação entre a renda e o preço da terra - com base em uma visão geral do comportamento das variáveis no cone leste que no período estudado - pode-se afirmar que os processos de movimentação tanto do preço como da renda partiram da área central de Curitiba em direção aos municípios conurbados, comprovando que a dinâmica de apropriação do território da periferia se dá com a expulsão de população da área central pela elevação do preço da terra, acarretando o extravasamento da classe média em sua direção, ou seja, um movimento que caracteriza a expansão urbana a reboque da segregação sócio-espacial. De outro lado, foi surpreendente identificar que nos demais municípios conurbados - Colombo, Pinhais e São José dos Pinhais, na maioria de seus bairros, os intervalos de rendimento ocorridos em 1991 se mantiveram em 2000, principalmente os referentes às classes de 3 a 5 SM e 5 a 10 SM.

Sobre os movimentos das classes mais desfavorecidas - dos sem rendimento até 3 SM - faz-se necessária uma inserção sobre a dinâmica do mercado informal de terras no cone leste da Curitiba Metrópole. Parte-se então da análise realizada pela COMEC no PDI-2006, relativa à região metropolitana como um todo, quando constata que:

"[...] em 2002, na RMC é preciso uma renda mínima familiar de 4 salários mínimos por mês para ter acesso à moradia disponível no mercado, em áreas onde o preço da terra é equivalente a $R \$ 30,00$ por m2. Essa área contorna praticamente todo $o$ território de Curitiba, assim como uma boa parte dos territórios municipais de Pinhais e São José dos Pinhais. Esse nível de renda mínima é incompatível com a realidade orçamentária de uma parcela expressiva das famílias residentes na RMC. Segundo a Pesquisa Nacional por Amostra de Domicílios (IBGE), em 2001, cerca de $28 \%$ das famílias da RMC auferiam rendimentos médios mensais inferiores a 3 salários mínimos e 21\% estava na faixa de 3 a 5 salários mínimos, o que totaliza um percentual de $49 \%$ das famílias da RMC com rendimentos mensais inferiores a 5 salários mínimos. Além disso, a elevada taxa de informalidade do mercado de trabalho regional dificulta o acesso a financiamentos de médio e longo prazo para aquisição de terrenos e (ou) de casa própria. Esses dados indicam a gravidade da questão habitacional na RMC e coloca o seu equacionamento como um fator crucial para a melhoria das condições de vida de uma parcela expressiva de seus habitantes". 369

${ }^{369}$ COMEC (2006), p. 140. 
PEREIRA e SILVA ${ }^{370}$ destacam que, na década de 90 emerge o mercado imobiliário informal em Curitiba e região, dado o binômio "redução significativa da produção de lotes formais e crescimento das ocupações irregulares". Apresentam as dimensões da produção informal atrelada à evolução das ocupações irregulares no aglomerado metropolitano:

"[...] entre 1987 e 1996 duplicou o número de ocupações irregulares e triplicou o número de domicílios em ocupações irregulares na cidade de Curitiba. Uma década depois, entre 1996 e 2005, dobrou o número de ocupações e de domicílios irregulares. [...] verifica-se que a preferência locacional dos domicílios irregulares no aglomerado metropolitano ainda hoje é o pólo Curitiba, mas, de 1992 para 1998, esse município contribuiu com apenas 32,19\% do acréscimo da população residente nesses assentamentos. Nesse período, a maior parte do crescimento de população residente em áreas irregulares foi absorvida pelos demais municípios do aglomerado metropolitano, destacando-se os localizados à leste da região".

Em 1998, 65,89\% da população residente em ocupações irregulares concentrava-se no pólo Curitiba, ao passo que dos $34,11 \%$ residentes nos demais municípios da região metropolitana 7,75\% localizavam-se em Colombo, 4,75\% em São José dos Pinhais e 2,84\% em Pinhais.

\begin{tabular}{|c|c|c|c|c|}
\hline \multicolumn{5}{|c|}{ Tabela 3.10 - EVOLUÇÃO DAS OCUPAÇÕES IRREGULARES NO CONE LESTE } \\
DA CURITIBA METRÓPOLE (1992-1998) \\
\hline \multirow{2}{*}{ Município } & \multicolumn{2}{|c|}{ Número de Domicílios } & \multicolumn{2}{c|}{ População Residente } \\
\cline { 2 - 5 } & 1992 & 1998 & 1992 & 1998 \\
\hline Curitiba & 44.713 & 53.162 & 165.438 & 196.699 \\
\hline Colombo & 3.303 & 6.253 & 13.740 & 23.136 \\
\hline Pinhais & 1.556 & 2.293 & 6.302 & 8.484 \\
\hline $\begin{array}{c}\text { São José dos } \\
\text { Pinhais }\end{array}$ & 581 & 3.838 & 2.353 & 14.201 \\
\hline RMC & 53.446 & 80.676 & 201.405 & 298.501 \\
\hline Fonte: UFPR (2004), p. 63. Em PEREIRA e SILVA (2007), p. 85. Adaptado pela autora. & \\
\hline
\end{tabular}

\footnotetext{
${ }^{370}$ PEREIRA e SILVA (2007), p. 84-85.
} 
Quanto à composição do preço da terra no mercado informal, ${ }^{371}$ as autoras ressaltam que há uma diferenciação grande em relação à posição do imóvel dentro da ocupação e também em relação à qualidade construtiva da edificação, bem como às condições do terreno (firme, fora do risco de inundações). Critérios relativos à proteção ambiental e edificabilidade presentes em legislação urbanística não interessam ao mercado informal, dada a sua irregularidade intrínseca. Outros critérios relevantes são: a proximidade com fontes de emprego, o sentimento de pertencimento à comunidade, a concentração de população e as atividades de comércio e serviços na área. Sobre a situação dos preços nas áreas irregulares em relação aos bairros populares, colocam as autoras:

"A comparação entre os preços praticados nas áreas irregulares com os bairros populares vizinhos indica que nem sempre ocorre uma disparidade exagerada entre eles, o que pode ser justificado pelo fato de os preços nas ocupações irregulares referirem-se ao terreno mais a casa existente." 372

Porém, nas áreas enquadradas em programas de regularização fundiária, afirmam que a diferença nos preços entre as áreas irregulares e bairros vizinhos passa a ser significativa. Apontam também, com base em pesquisa realizada em 2002 pelo Banco Mundial, que o peso da infra-estrutura na composição do preço é bastante superior em relação ao título de propriedade: ${ }^{373}$

"[...] em Curitiba, o preço mediano dos terrenos com título de propriedade é $R \$ 68,00$, pouco maior do que o preço correspondente para terrenos sem titulação: $R \$ 66,00$. Essa situação é bem diferente quando se trata de provisão de infraestrutura: o preço mediano 2000/2001 dos terrenos com infra-estrutura (medido pela presença de ruas asfaltadas) é $R \$ 108,00$, bem maior que o preço correspondente de terrenos sem infra-estrutura, $R \$ 38,00$. Por outro lado, a existência simultânea de infra-estrutura e título afeta positivamente os preços dos terrenos. O preço para lotes com infra-estrutura e título é $R \$ 73,00$ contra $R \$ 29,00$. Verifica-se, portanto, que o título, por si só, não gera efeitos estatisticamente significativos - o efeito aparece apenas quando combinado com a infra-estrutura."

\footnotetext{
${ }^{371}$ Idem, p. 88-89.

${ }^{372}$ PEREIRA e SILVA (2007), p. 88.

${ }^{373}$ Idem, p. 89.
} 
O caminho percorrido até aqui em busca da revelação da lógica da exclusão incutida na dinâmica do mercado de terras, bem como a sua correlação com a apropriação do território pelas classes sociais, trouxe a inquietação: apesar da elevação exacerbada do preço da terra e da permanência da renda, as classes média e baixa não foram em busca de terra mais longínqua de preço mais acessível? Quais as razões que garantiram a permanência no local de moradia, razões estas que barraram o movimento de expansão para terras mais baratas e ainda mais afastadas do centro da metrópole? A contradição presente no movimento de apropriação do território pelas classes sociais conduz a uma investigação mais detalhada, que explore a correlação entre a evolução da mancha urbana e a evolução do transporte, no contexto da expansão da Curitiba Metrópole. 


\section{EXPANSÃO URBANA DA CURITIBA METRÓPOLE E A LÓGICA INCLUDENTE DA POLÍTICA DE MOBILIDADE}

O objetivo maior de se realizar a leitura da expansão urbana na Curitiba Metrópole por meio das correlações entre o acesso à rede integrada de transporte (RIT), a renda e a expansão da mancha urbana, é o de elucidar se no processo de expansão recente teria ocorrido a apropriação do território, contraditoriamente, também a partir de uma lógica de inclusão.

Para VILLAÇA a conurbação, em uma primeira definição, nada mais é do que a fusão de áreas urbanas. Segundo ele, o processo de conurbação se dá quando uma cidade "passa a absorver núcleos urbanos à sua volta", sejam estes núcleos pertencentes a outros municípios ou não. Explica Villaça que "uma cidade absorve outra quando passa a desenvolver com ela "intensa vinculação sócio-econômica" e que "esse processo envolve uma série de transformações tanto no núcleo urbano absorvido como no que absorve". ${ }^{374}$ Destaca ainda entre esses vínculos os deslocamentos espaciais de pessoas, pois caracterizam o espaço intra-urbano em oposição ao deslocamento de cargas. Os deslocamentos de pessoas, especialmente os de caráter cotidiano - diários ou quase diários - é que são representativos das citadas vinculações sócio-econômicas - como o deslocamento por motivo de trabalho ou de estudo.

ULTRAMARI e MOURA utilizam o termo aglomeração urbana para explicar o mesmo processo:

"espaço de comutação diária entre cidades, isto é, o desenvolvimento de relações interdependentes entre duas ou mais áreas urbanas, compondo um fenômeno único. Tal fenômeno é entendido quase sempre, como sendo físico, isto é, expresso pela continuidade de manchas urbanas. Todavia, relações sócioeconômicas complementares entre municípios também podem indicar aglomerados urbanos, independentemente de uma unicidade físico-territorial. Quando a aglomeração urbana compreende uma metrópole, é qualificada como uma área metropolitana, exercendo polarização direta sobre um espaço regional que transcende aquele nível de comutação diária."375

\footnotetext{
${ }^{374}$ VILLAÇA (1998), p. 51.

${ }^{375}$ ULTRAMARI e MOURA (1994), p. 125.
} 
Para os autores, o conceito de conurbação indica o crescimento de dois ou mais municípios contíguos - em termos espaciais - evidenciando mais uma complementaridade de funções e menos uma dependência.

Sobre o processo espacial de conurbação, VILLAÇA ${ }^{376}$ coloca que o mesmo tem se manifestado de quatro formas nas metrópoles brasileiras, que frequentemente ocorrem com um mesmo núcleo em distintos momentos históricos. A primeira das formas seria "constituída por núcleos que nunca chegaram a atingir plenamente a condição de cidade, pois já nasceram como subúrbio". A segunda dar-se-ia a partir de uma imensa periferia, em geral de baixa renda, com um núcleo local fraco, apenas com comércio de pequeno porte. Nesse caso, a periferia da cidade central ou de algumas das suas cidades-subúrbios, "transborda" sobre municípios vizinhos em pontos afastados de suas sedes, muitas vezes formando novos municípios. A terceira das formas seria constituída por aglomerações que chegaram a atingir significativo desenvolvimento enquanto cidades: "nelas aparece, ou aparecia até recentemente, uma burguesia local" e uma variedade de classes sociais. E a quarta forma é aquela constituída de cidades muito pequenas, correspondentes a antigos núcleos coloniais que permaneceram à margem da expansão.

Ainda segundo o autor, a expansão urbana é altamente influenciada pelas vias regionais, sejam rodovias ou ferrovias: "embora as vias regionais não tenham sido construídas para oferecer transporte intra-urbano, acabam oferecendo esse tipo de transporte, e aquelas regionalmente mais importantes, passam a ser mais importantes do ponto de vista intra-urbano e acabam atraindo maior expansão urbana ao longo delas". ${ }^{377}$

Para VILLAÇA, "sem o transporte urbano de passageiros, não pode haver expansão urbana":

"O sistema interurbano de transporte, quando apresenta a possibilidade de oferecer transporte urbano de passageiros, atrai a ocupação urbana nos pontos acessíveis ou potencialmente acessíveis, visto que altera o valor de uso da terra, garantindo uma oferta de novas localizações que são ocupadas por uma parte do excedente de população e atividades geradas a partir da cidade central em expansão. [...] À medida que a cidade cresce, ela se apropria e absorve os trechos urbanos das vias regionais, como nos casos das rodovias antigas que, com o tempo, se transformam em vias urbanas" ${ }^{378}$

\footnotetext{
${ }^{376}$ VILLAÇA (1998), p. 53-65.

${ }^{377}$ Idem, p. 69-70.

${ }^{378}$ Ibidem, p. 81-82.
} 


\section{Política de mobilidade na Curitiba Metrópole: a evolução da rede integrada de transporte - RIT (1996-2009)}

"Da acessibilidade depende a possibilidade de viver na cidade, e para viver é necessário produzir e reproduzir a vida material é necessário trabalhar; para isso, para fazer história, o homem urbano precisa se deslocar espacialmente e nisso despende energia e perde tempo. Aqui novamente, há uma distinção importante entre os dois. A primeira pode ser recuperada, o segundo, porém, é irrecuperável. Este último então domina o primeiro e determina a estruturação do espaço intraurbano." 379

O objetivo maior de se realizar a leitura da expansão urbana na Curitiba Metrópole sob a ótica da política de mobilidade, é o de demonstrar o fenômeno urbano a partir de uma lógica de inclusão, qual seja a da possibilidade do incremento da renda da população da periferia, possibilitada pela rede integrada de transporte - a RIT. Fazse necessário reafirmar aqui que a integração via RIT, ao se dar tanto física como tarifariamente, desempenha papel determinante na dialética entre expansão e estruturação do território, e portanto, no processo de produção das localizações intraurbanas.

Em 1996, a metropolização da RIT foi iniciada. De lá para cá, a RIT metropolitana foi sendo estendida a quase totalidade da mancha urbanizada. A principal questão a enfatizar, é que se passou de uma situação anterior onde a periferia $^{380}$ se conectava à cidade central a partir de um único ponto, qual seja, o Terminal Metropolitano do Guadalupe localizado no Centro de Curitiba, para um novo cenário - o da possibilidade de múltiplas conexões entre os diversos pontos da periferia e os diversos pontos da cidade central, onde cada ponto da periferia passou a se constituir em uma nova localização residencial, como resultado da gama de possibilidades de deslocamentos intra-urbanos.

É a partir da expansão física da RIT sobre a periferia e de todos os desdobramentos daí decorrentes, que se vai demonstrar a real dimensão do fenômeno de integração metropolitana em Curitiba.

\footnotetext{
${ }^{379}$ VILLAÇA (1998), p. 355.

${ }^{380}$ No caso do cone leste, as cidades de Colombo, Pinhais e São José dos Pinhais; na totalidade da Curitiba Metrópole, com 12 municípios, conforme exposto no capítulo 2.
} 


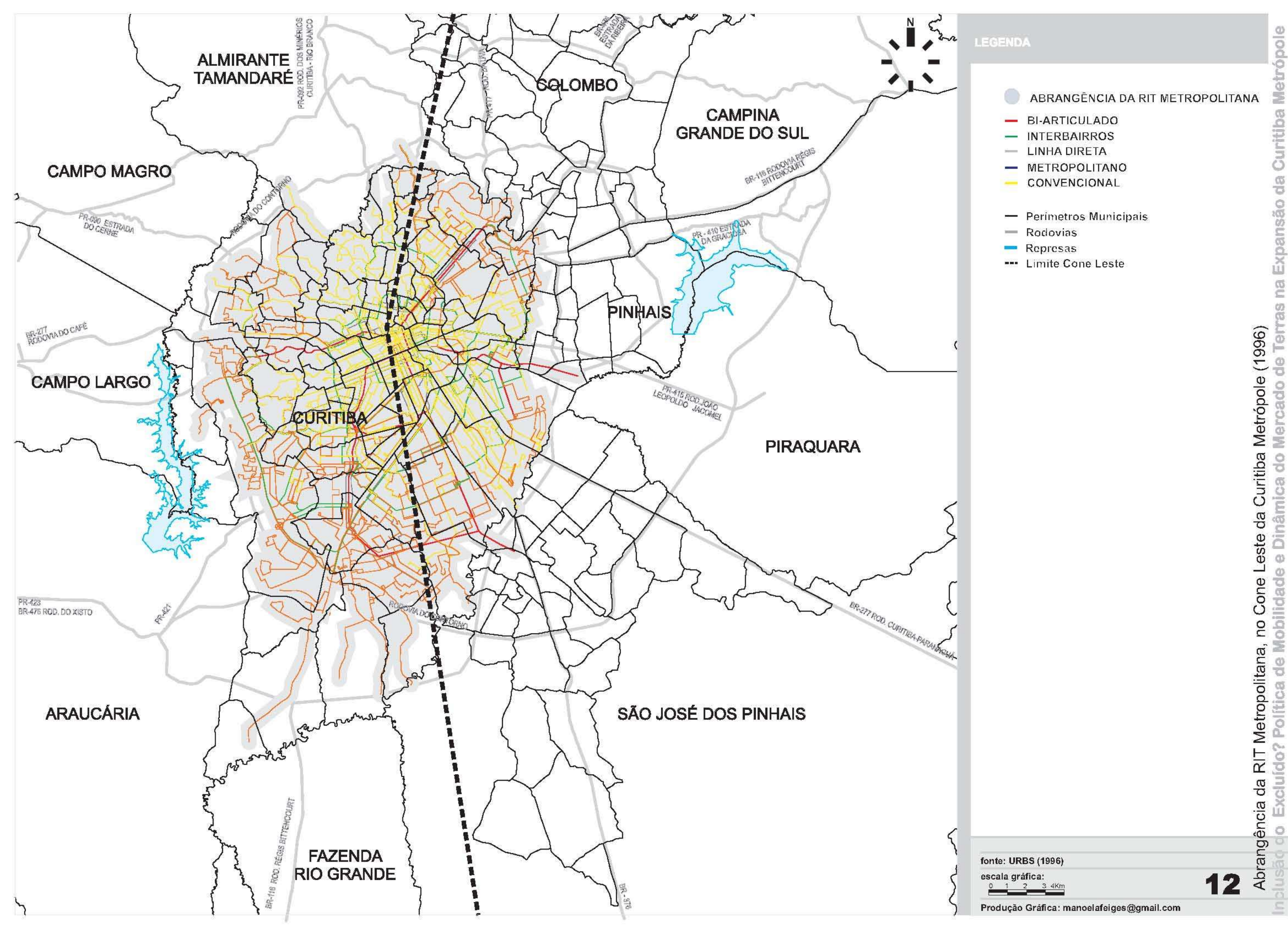




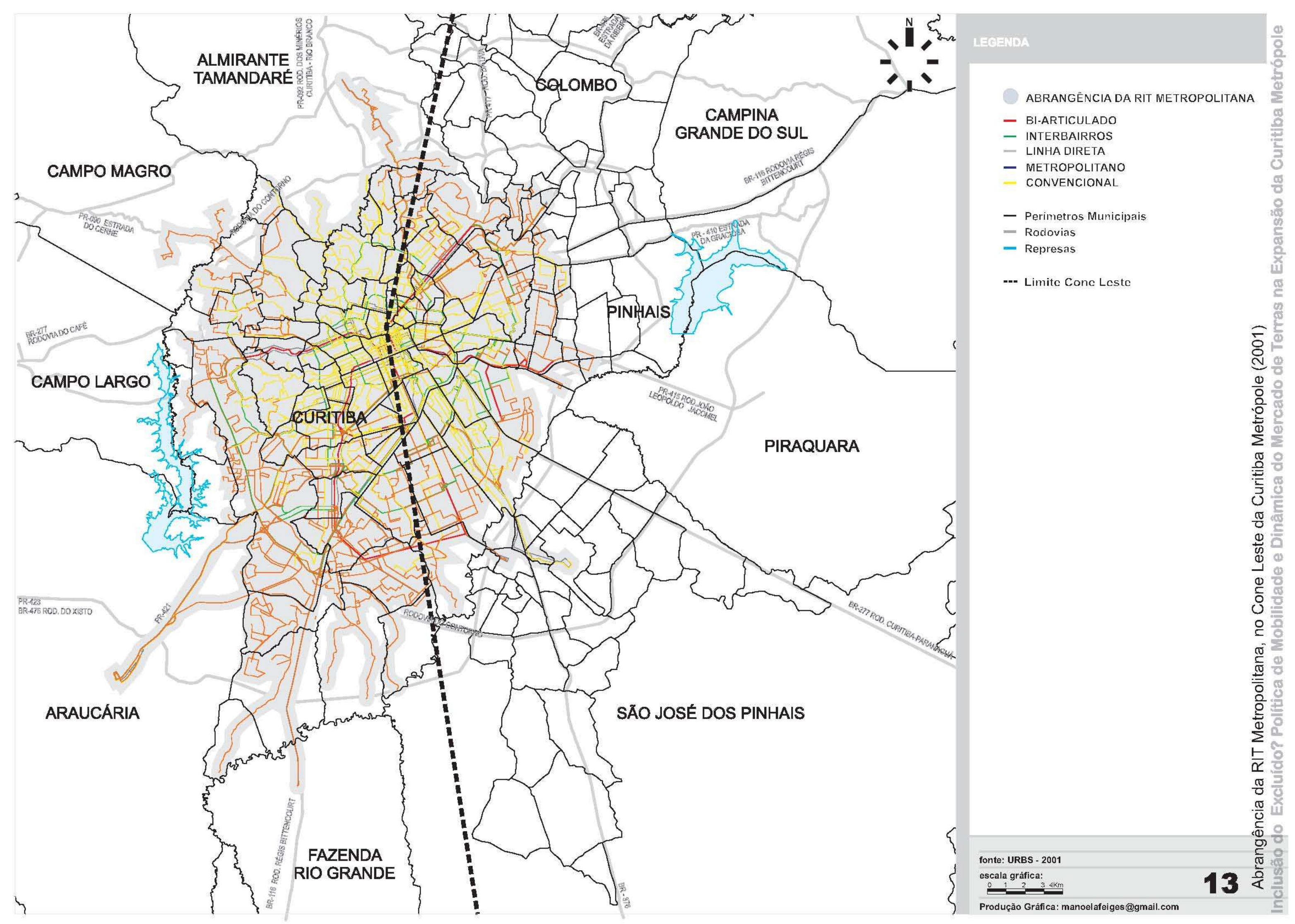




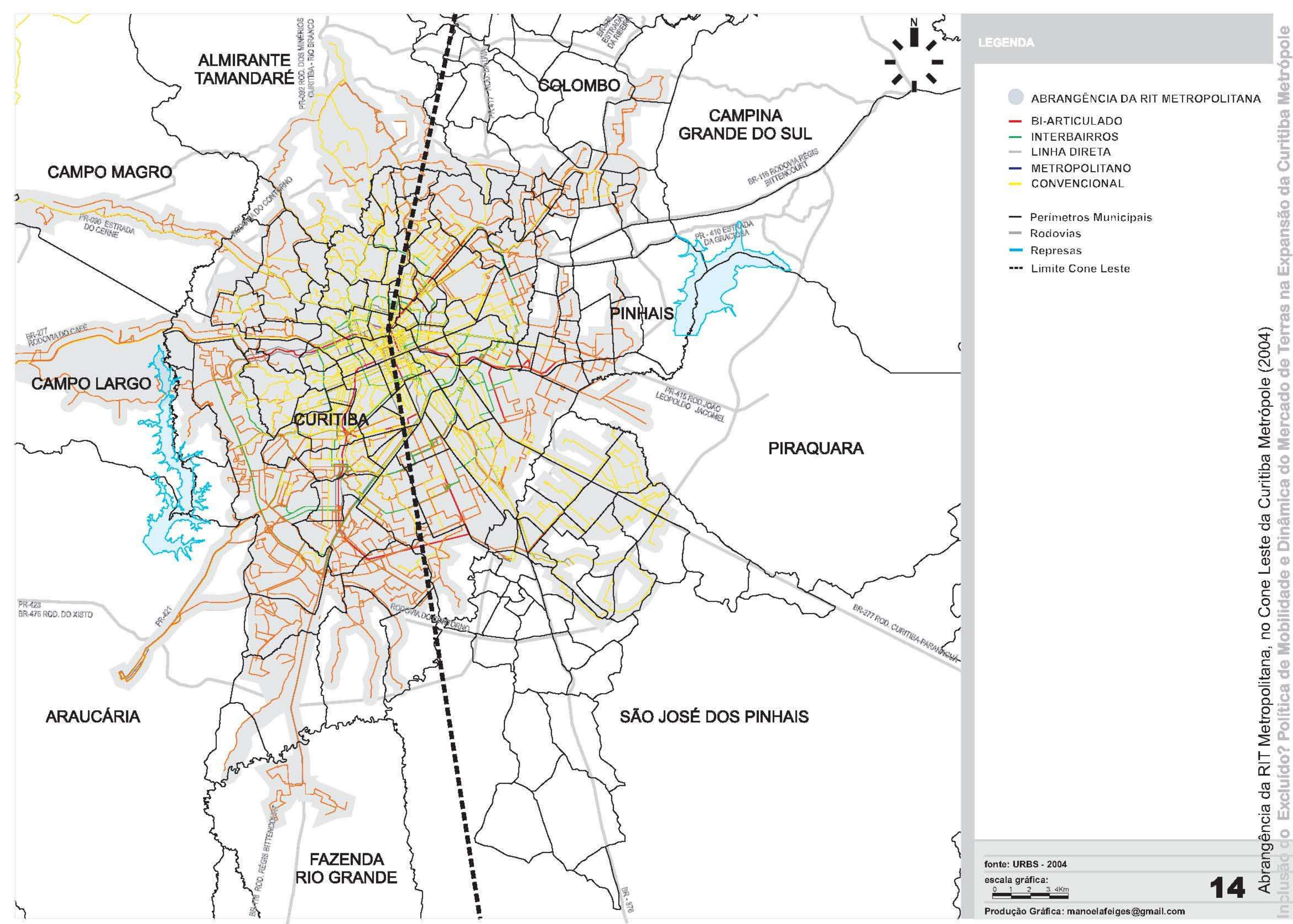




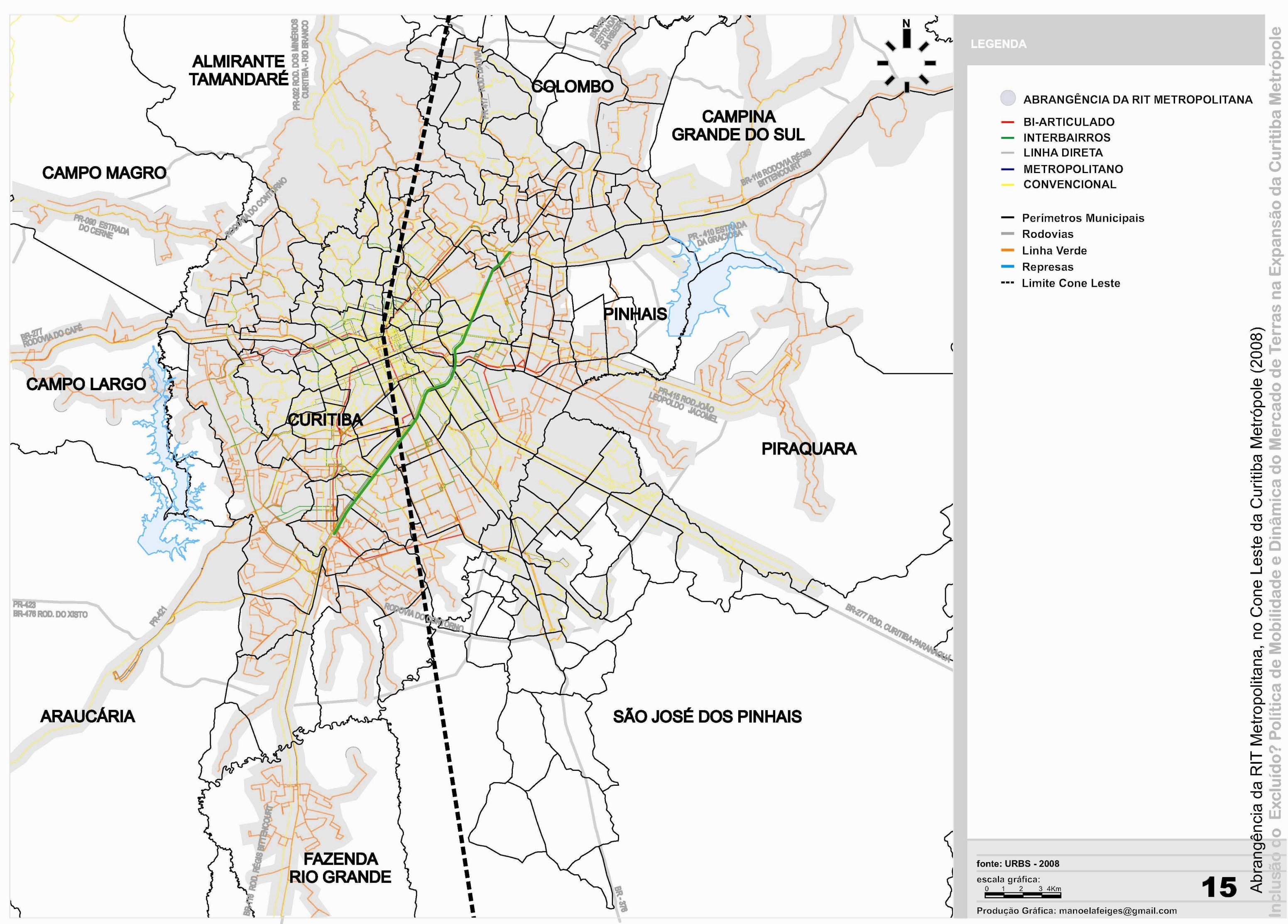


A série de mapas apresentada revela o processo de expansão da RIT, em quatro momentos - ano de 1996, de 2000, de 2004 e de 2009 - onde se demonstra em paralelo a expansão da mancha urbanizada, anteriormente apresentada. Percebe-se a nítida a inter-relação entre a estruturação do espaço em escala metropolitana via transporte integrado e a tendência de compactação da mancha urbana. Da sobreposição desses movimentos, tornou-se evidente o papel estruturador do transporte, bem como a consolidação do caráter intra-urbano dos eixos regionais enquanto corredores de transporte integrado.

O grau de inclusão da população da periferia à metrópole em função da acessibilidade e mobilidade urbanas pode ser evidenciado pela tabela que segue. Dos praticamente 500 mil passageiros que realizavam movimento pendular por transporte coletivo na região metropolitana de Curitiba, 240 mil passaram a usufruir da rede integrada de transporte, a RIT - cerca de 48\%dos passageiros transportados. Em 2000, esse percentual de atendimento passa para 69\%; em 2004 para 73\%; e atinge em 2008, 75\% dos movimentos pendulares em direção à cidade central, o que equivale a um total de 425 mil passageiros transportados pela RIT metropolitana.

Quanto à evolução do número de pessoas que realizam movimentos pendulares em direção à Curitiba a partir dos municípios integrantes do cone leste, segue a tabela abaixo, que ilustra à crescente inclusão da população da periferia à metrópole.

\begin{tabular}{|c|c|c|c|c|c|c|c|c|c|c|c|c|}
\hline \multirow{2}{*}{ MUNICÍPIO } & \multicolumn{3}{|c|}{1996} & \multicolumn{3}{|c|}{2000} & \multicolumn{3}{|c|}{2004} & \multicolumn{3}{|c|}{2008} \\
\hline & RIT & $\begin{array}{c}\text { Fora } \\
\text { da RIT }\end{array}$ & Total & RIT & $\begin{array}{c}\text { Fora } \\
\text { da RIT }\end{array}$ & Total & RIT & $\begin{array}{c}\text { Fora } \\
\text { da RIT }\end{array}$ & Total & RIT & $\begin{array}{l}\text { Fora } \\
\text { da RIT }\end{array}$ & Total \\
\hline COLOMBO & 77485 & 31923 & 109408 & 72155 & 27832 & 99987 & 81879 & 24182 & 106061 & 85039 & 25254 & 110293 \\
\hline PINHAIS & 23360 & 36102 & 59461 & 58396 & 2228 & 60624 & 60140 & 1949 & 62090 & 69690 & 2159 & 71849 \\
\hline $\begin{array}{c}\text { SÃO JOSÉ } \\
\text { DOS PINHAIS }\end{array}$ & 25698 & 54885 & 80583 & 29754 & 48871 & 78625 & 26106 & 40458 & 66564 & 30040 & 41723 & 71763 \\
\hline RMC & 239899 & 258471 & 498370 & 364086 & 161143 & 525229 & 375994 & 136828 & 512822 & 425468 & 143301 & 568769 \\
\hline
\end{tabular}

A partir dos gráficos abaixo se pretende demonstrar a situação inicial da pendularidade no cone leste em 1996 - a situação inicial de integração - e em 2008 - um cenário mais próximo da situação atual. 

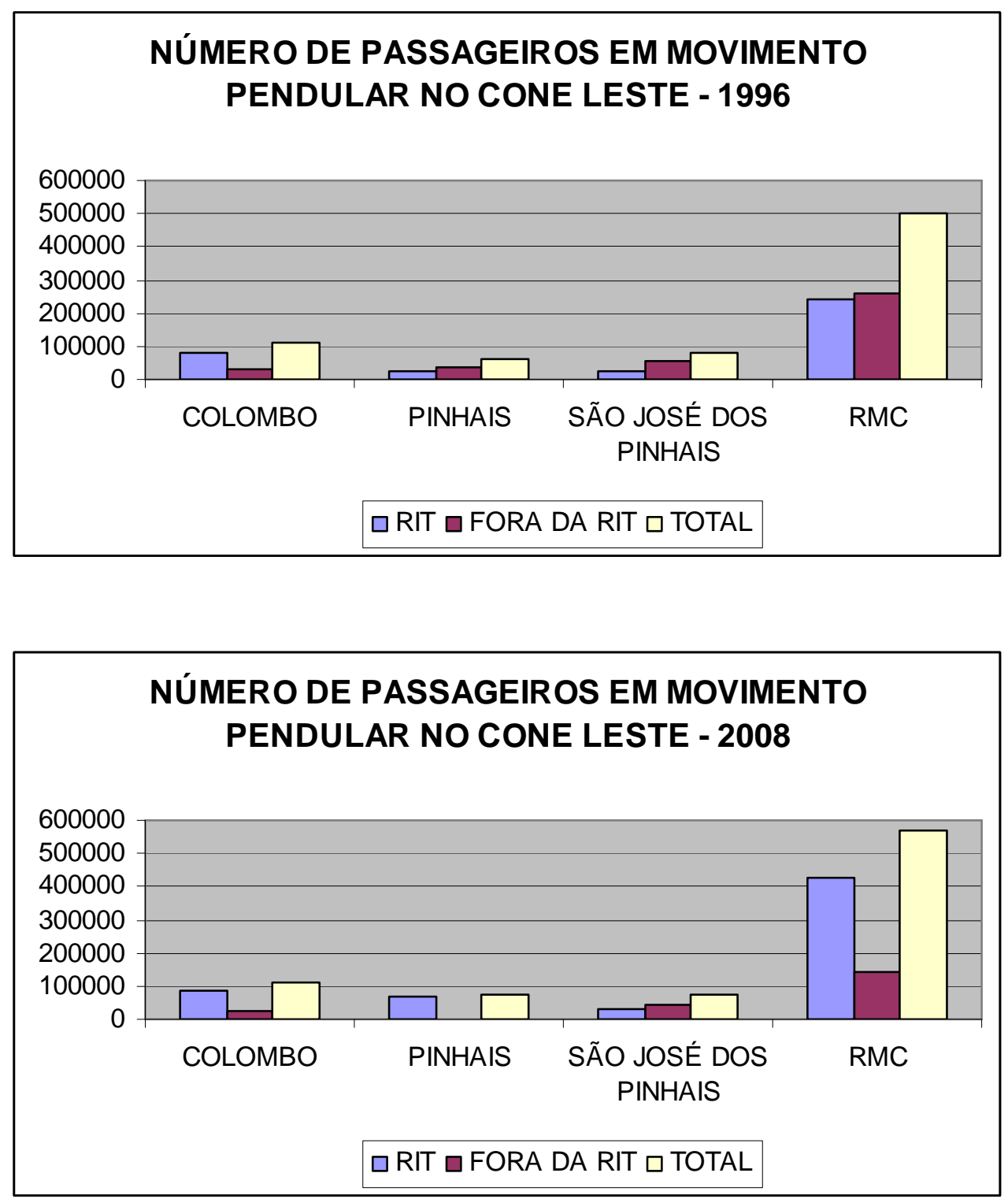

Nota-se que no período entre 1996 e 2008, as duas alterações mais visíveis são que a expansão da RIT em Pinhais é praticamente total, e que, no total da região metropolitana como um todo, a RIT é responsável por quase $75 \%$ dos deslocamentos pendulares; isto quer dizer também que $3 / 4$ da população usufrui da integração tarifária, o que representa um impacto de redução dos custos com deslocamentos da ordem de $50 \%$.

Ao se caracterizar a pendularidade a partir dos municípios integrantes do cone leste da Curitiba Metrópole, percebe-se que o impacto de expansão da RIT foi mais intenso em Pinhais, seguido logo após por Colombo. Isto se verifica respectivamente pela maior proximidade com a área central de Curitiba e pelo impacto positivo da integração na elevação da renda e na diminuição dos custos com deslocamentos. 

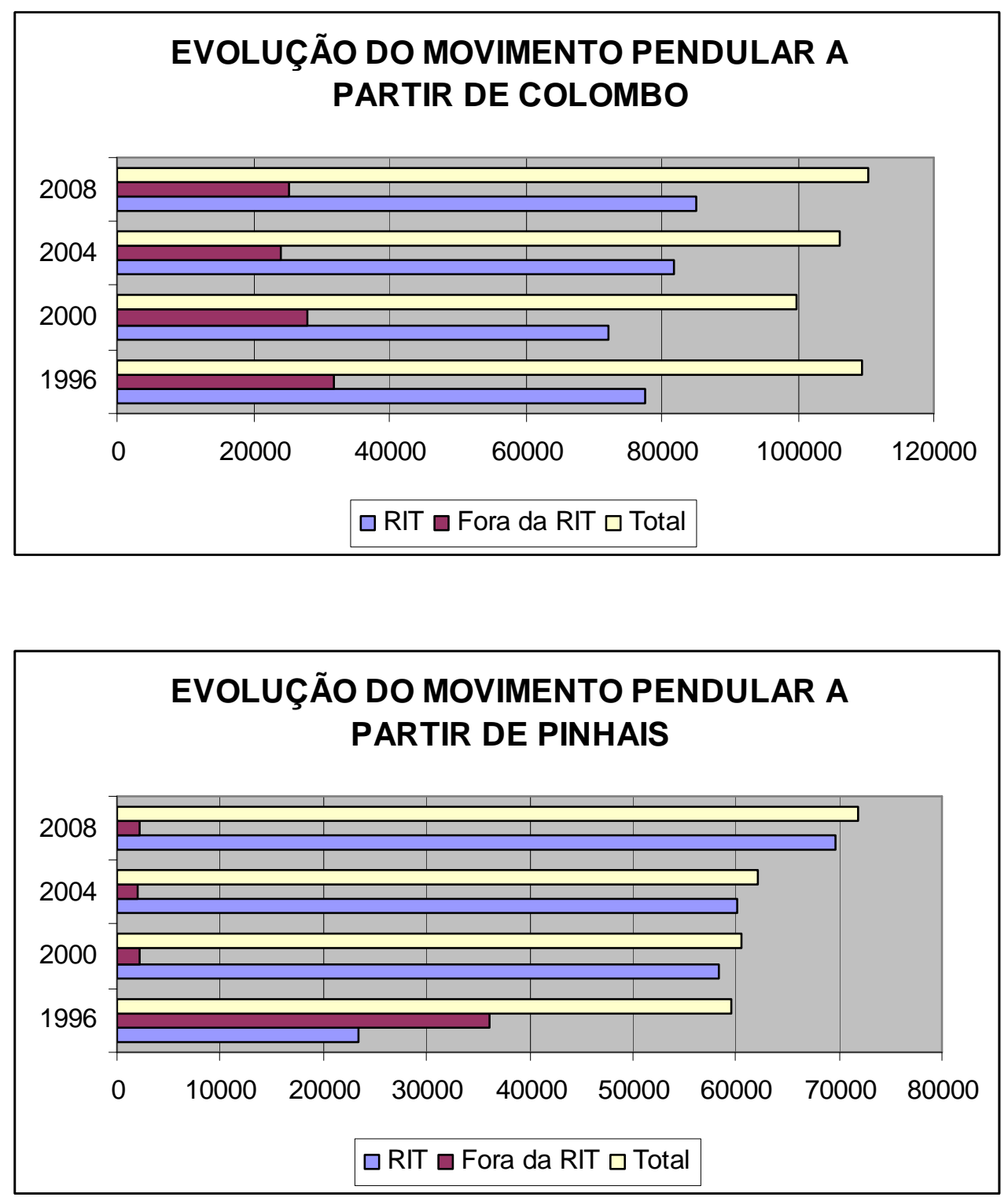

Já em São José dos Pinhais, os dados revelam a situação de tentativa de retenção de população no próprio município - política municipal adotada com relação à gestão da RIT Metropolitana - visto que a oferta da integração físico-tarifária é mais restrita à região central da cidade. De qualquer modo, apesar de revelar alguma retenção, percebe-se um contínuo movimento da população em direção à Curitiba, mesmo que não sustentado pela integração tarifária. 


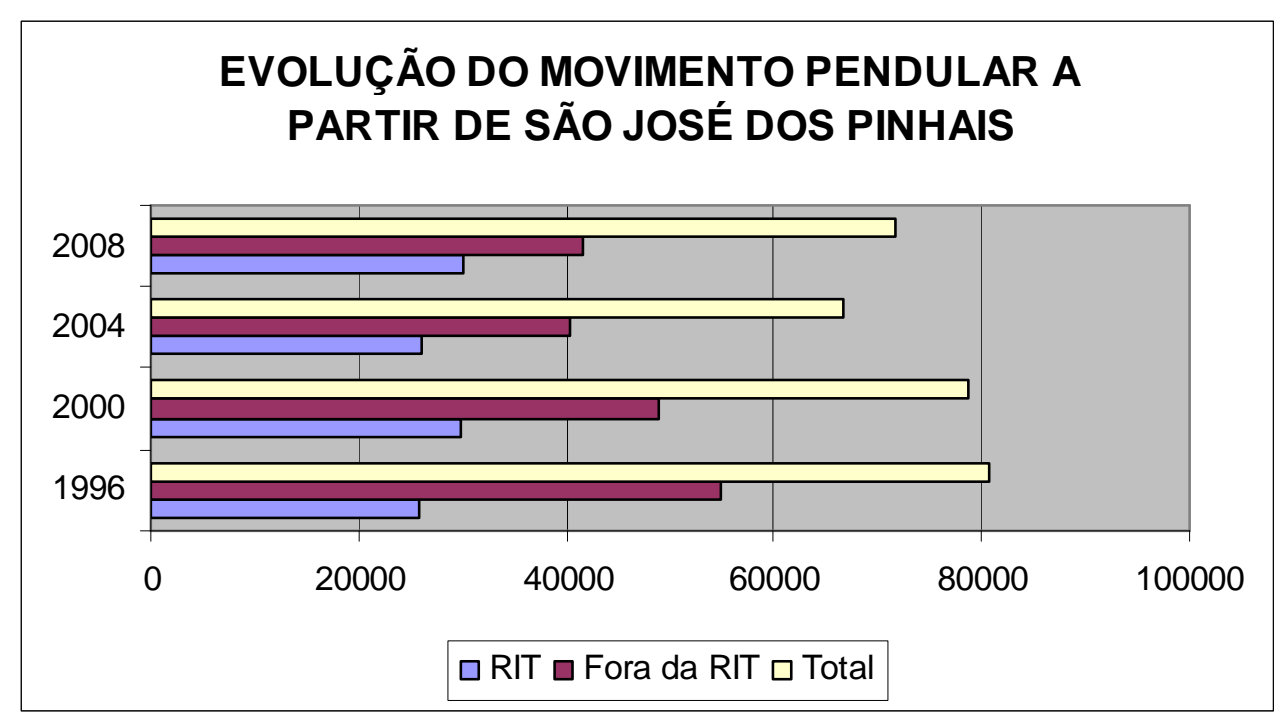

Com relação ao tempo de viagem, outra abordagem necessária para qualificar a integração metropolitana via RIT, cabe ressaltar que a URBS não monitora os tempos de deslocamento por séries históricas. Em decorrência desse fato, os dados disponibilizados são relativos aos tempos atualmente realizados. Segundo informações da área de operação do transporte coletivo da URBS, está-se buscando hoje reduzir em até $5 \%$ o tempo de viagem, pois um dos maiores desafios é a velocidade, mesmo ao longo das canaletas exclusivas; para tanto, estão sendo desenvolvidos os estudos de alternativas, com previsão para breve implantação. Em razão disso, a URBS considera ser o grande benefício da RIT metropolitana a integração tarifária, e não a redução do tempo de deslocamento, pois muitas dessas linhas apresentam maiores carregamentos em trechos intermediários, e não necessariamente nos pontos finais - os terminais metropolitanos. ${ }^{381}$

\footnotetext{
${ }^{381}$ De acordo com a entrevista realizada com o Eng. Luiz Filla, Diretor da Área de Operação do Transporte Coletivo da URBS, em 07/01/2010.
} 
Porém, ao se analisar a questão relativa ao controle do tempo, as múltiplas conexões geradas pela RIT associadas à sua regularidade e eficiência, pode-se afirmar que houve sim uma redução de tempo em relação à situação anterior da não integração - quando da existência apenas de linhas metropolitanas - à mesma medida que se potencializou um maior controle sobre o tempo de deslocamento, controle esse tão enfatizado por Villaça.

\begin{tabular}{|c|c|c|c|}
\hline \multirow[t]{2}{*}{ MUNICÍPIO } & \multirow[t]{2}{*}{$\begin{array}{c}\text { NÍVEL DE } \\
\text { INTEGRAÇÃO }\end{array}$} & \multicolumn{2}{|c|}{$\begin{array}{l}\text { TEMPO DE DESLOCAMENTO MÉDIO AO } \\
\text { CENTRO DE CURITIBA }\end{array}$} \\
\hline & & Bairros mais próximos & Bairros mais afastados \\
\hline \multirow[t]{2}{*}{ COLOMBO } & RIT & 45 minutos & 73 minutos \\
\hline & $\begin{array}{c}\text { Linha } \\
\text { Metropolitana }\end{array}$ & 76 minutos & 94 minutos \\
\hline \multirow[t]{2}{*}{ PINHAIS } & RIT & 37 minutos & 61 minutos \\
\hline & $\begin{array}{c}\text { Linha } \\
\text { Metropolitana }\end{array}$ & 53 minutos & 72 minutos \\
\hline \multirow{2}{*}{$\begin{array}{c}\text { SÃO JOSÉ } \\
\text { DOS PINHAIS }\end{array}$} & RIT $\left({ }^{*}\right)$ & (1) & (2) \\
\hline & $\begin{array}{c}\text { Linha } \\
\text { Metropolitana }\left(^{*}\right)\end{array}$ & 90 minutos & 180 minutos \\
\hline \multicolumn{4}{|c|}{ Fonte: URBS - Unidade de Programação Operacional da RIT - 2010} \\
\hline \multicolumn{4}{|c|}{$\begin{array}{l}\text { Notas: } \\
\text { Em Colombo e Pinhais, na maioria das vezes há a condição de se optar pela RIT ou pelas linhas } \\
\text { metropolitanas. } \\
\text { ( }{ }^{*} \text { Em São José dos Pinhais, dada a integração ser parcial, só se tem opção de acesso direto à RIT } \\
\text { nas proximidades dos terminais; no caso dos bairros mais afastados, soma-se o tempo da linha } \\
\text { municipal e mais o custo da tarifa municipal. } \\
\text { (1) tempo entre o Terminal Central e o Centro de Curitiba - } 30 \text { minutos; } \\
\text { (2) tempo entre o Terminal Afonso Pena e o Centro de Curitiba - } 43 \text { minutos. }\end{array}$} \\
\hline
\end{tabular}

Da leitura da correlação entre as isócronas relativas a 2009 e a distância ao centro principal, pode-se visualizar facilmente que, no cone leste da Curitiba Metrópole, nas áreas atendidas pela RIT metropolitana localizadas num raio entre 5 a $10 \mathrm{~km}$ da área central, que praticamente abrange toda a área urbana de Pinhais, os tempos de viagem dos deslocamentos por transporte coletivo variam de 37 a 61 minutos. Quando localizadas entre 10 a $15 \mathrm{~km}$, faixa que compreende a maior porção urbana de Colombo, os tempos passam para 45 e 73 minutos, respectivamente aos bairros mais próximos e aos mais afastados de Curitiba. Em São José dos Pinhais, em função da abrangência da RIT ser parcial, as áreas por ela atendida restringem-se às proximidades dos terminais - Central e Afonso Pena - de onde o tempo de viagem ao 
centro de Curitiba é da ordem de 30 a 43 minutos. Quando a distância da área de atendimento supera os $15 \mathrm{~km}$ - bairros mais afastados em Colombo - o tempos de viagem via RIT equivale ao patamar de 73 minutos, contra 94 minutos nas linhas não integradas. A este mesmo intervalo de distância ao centro da metrópole, correspondem os bairros mais afastados de São José dos Pinhais, que têm acesso somente às linhas metropolitanas, chegando a tempos de deslocamento entre 110 a 180 minutos.

Apenas a titulo de ilustração, de acordo com DÉAK, no caso de São Paulo, "a produção de viagens coletivas per capita teve queda considerável (a diferença sendo absorvida pelas viagens a pé) mantendo-se praticamente o volume total de viagens inalterado de 1977 a 1987. No entanto, a implantação da maior parte da rede de Metrô hoje existente na segunda das duas décadas, ainda que de comprimento reduzido, teve o importante efeito de neutralizar inteiramente o efeito potencial da extensão física da aglomeração urbana sobre duração das viagens por transporte coletivo, através da absorção de quase 1,5 milhão de viagens diárias ou, em conjunto com o trem, 12\% das viagens coletivas (contra 6,6\% em 1977). Assim, o tempo médio de percurso das viagens coletivas manteve-se em torno de uma hora (59 minutos em 1987 contra 57 minutos em 1977)". ${ }^{382}$

Cabe neste momento fazer uma reflexão sobre a contribuição da "Curitiba Planejada" e do desenho urbano, especificamente no tocante às canaletas exclusivas para circulação do transporte coletivo ao longo dos eixos estruturais, que permitem ao transporte coletivo integrado a manutenção da velocidade média em seus percursos dentro de Curitiba. Em relação à redução dos tempos de deslocamento numa fase de expansão urbana de escala metropolitana: um dos maiores desafios para o cidadão metropolitano já excluído pela dinâmica do mercado de terras é a possibilidade do controle do tempo.

\footnotetext{
${ }^{382}$ DÉAK (1990), p.43.
} 


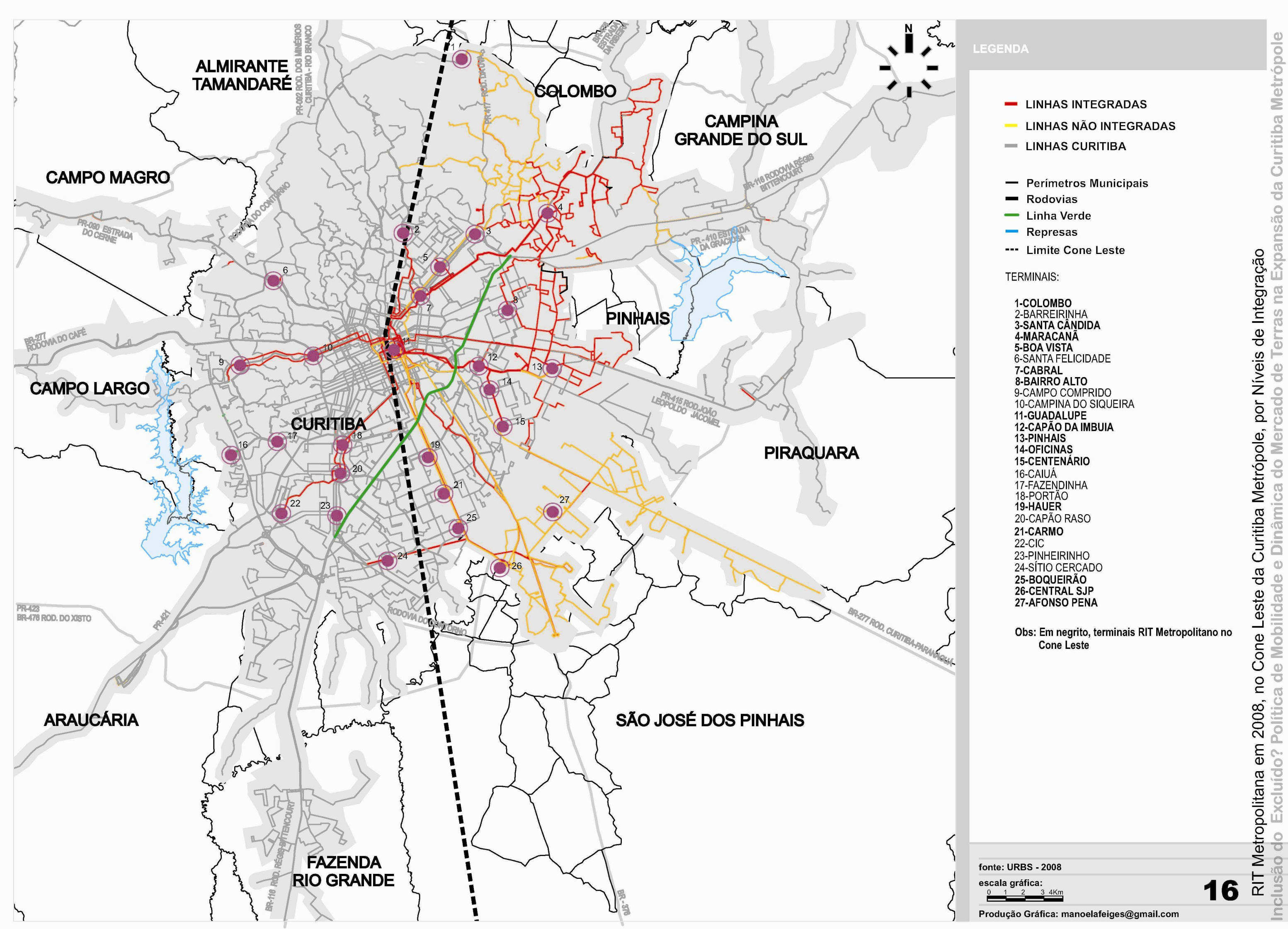




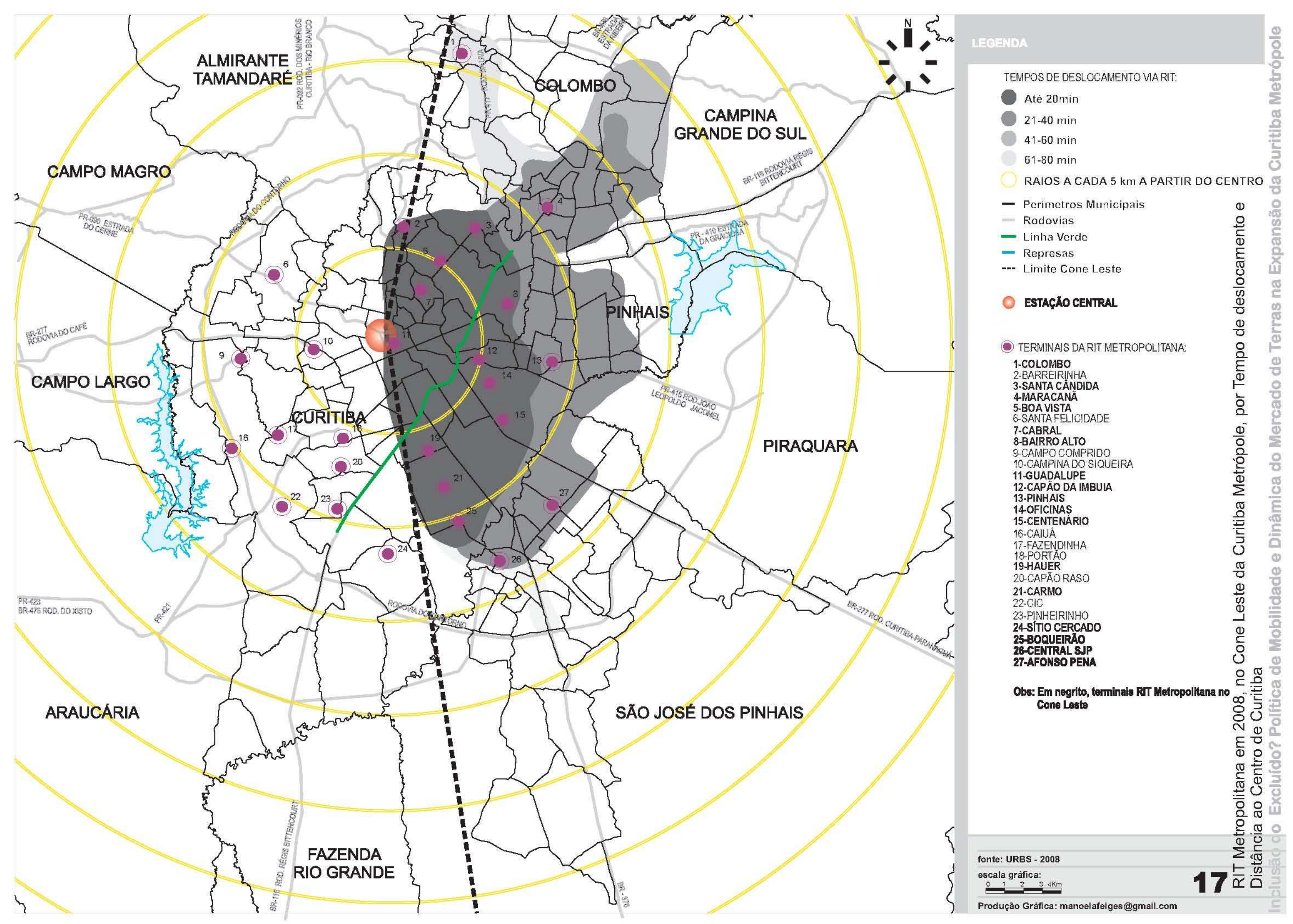




\section{Impactos da RIT metropolitana sobre a relação entre a acessibilidade e renda}

$\mathrm{Na}$ ausência de pesquisas do tipo origem-destino, foi com apoio em DESCHAMPS, ${ }^{383}$ que se pode caracterizar o perfil da população residente na Curitiba Metrópole que realiza movimentos pendulares, exclusivamente em busca de trabalho em outro município que não o de sua residência. Um dos objetivos da autora em sua pesquisa era o de verificar se há diferenças socioeconômicas significativas entre as pessoas que se deslocam para trabalhar e as que trabalham no próprio município, e é o que interessa aqui explorar. Das 196 mil pessoas que fazem movimentos pendulares na RMC por motivo de trabalho ou estudo, 85,35\% se dirigem à Curitiba, ou seja, 144 mil pessoas, de acordo com o censo 2000. Entre os municípios com maior participação nos deslocamentos pendulares - $80 \%$ dos fluxos - estão Colombo, Pinhais e São José dos Pinhais, além de outros como Almirante Tamandaré, Piraquara e Fazenda Rio Grande, todos contíguos à cidade central. Cabe dar destaque a que, com exceção de São José dos Pinhais, o percentual da população que se desloca diariamente para trabalho é supera a casa dos $40 \%$, o que torna evidente a falta de oferta de emprego no local de residência. Na tabela que segue, é possível visualizar a escala do fenômeno aqui exposto.

Tabela 3.13 - POPULAÇÃO RESIDENTE DE 15 ANOS E MAIS DE IDADE QUE TRABALHA OU ESTUDA E PESSOAS QUE REALIZARAM MOVIMENTO PENDULAR - RMC - 2000

\begin{tabular}{|c|c|c|c|c|c|}
\hline \multirow[b]{3}{*}{ MUNICÍPIO } & \multicolumn{5}{|c|}{ PESSOAS DE 15 ANOS E MAIS DE IDADE } \\
\hline & \multirow{2}{*}{$\begin{array}{c}\text { Que } \\
\text { trabalham } \\
\text { ou } \\
\text { estudam }\end{array}$} & \multirow[b]{2}{*}{$\begin{array}{c}\text { Que } \\
\text { trabalham } \\
\text { ou estudam } \\
\text { fora do } \\
\text { município } \\
\text { de } \\
\text { residência }\end{array}$} & \multirow{2}{*}{$\begin{array}{c}\text { Que } \\
\text { trabalham } \\
\text { ou } \\
\text { estudam, } \\
\text { dirigindo-se } \\
\text { ao pólo }\end{array}$} & \multicolumn{2}{|c|}{ PERCENTUAL DE PESSOAS } \\
\hline & & & & $\begin{array}{c}\text { Que } \\
\text { trabalham ou } \\
\text { estudam em } \\
\text { outro } \\
\text { município }\end{array}$ & $\begin{array}{c}\text { Que se } \\
\text { dirigem ao } \\
\text { pólo }\end{array}$ \\
\hline Curitiba & 822.270 & 27.171 & - & 3,30 & - \\
\hline Colombo & 81.445 & 37.935 & 34.215 & 46,58 & 90,19 \\
\hline Pinhais & 48.537 & 21.536 & 19.131 & 44,37 & 88,83 \\
\hline São José dos Pinhais & 95.511 & 22.861 & 20.540 & 23,94 & 89,85 \\
\hline Almirante Tamandaré & 37.941 & 20.934 & 19.452 & 55,17 & 92,92 \\
\hline Piraquara & 30.768 & 15.806 & 11.263 & 51,37 & 71,26 \\
\hline Fazenda Rio Grande & 25.994 & 12.207 & 10.986 & 46,96 & 89,99 \\
\hline TOTAL RMC & 1.327 .194 & 195.909 & 144.003 & 14,76 & 85,34 \\
\hline
\end{tabular}

Fontes: IBGE - Censo Demográfico, 2000 (micro dados); IPARDES - Tabulações Especiais, In DESCHAMPS (2004),

p. 42. Adaptação pela autora.

${ }^{383}$ DESCHAMPS (2004), p. 41-42. 
Sobre as principais características de quem sai de seu município em relação à Curitiba, Deschamps coloca que "em termos relativos, as mulheres saem mais de seus municípios para buscar trabalho na capital":

"Relativamente quem sai do seu município de residência para trabalhar na capital ganha mais do que aqueles que ficam. No primeiro caso, 40,3\% das pessoas ganham mais que três salários mínimos (SM), enquanto no segundo caso são 36,1\%. Também dos que ficam 15,4\% ganham até um SM contra apenas 5,9\% dos que saem para a capital.

As diferenças tornam-se mais significativas ao se fazer uma análise por gênero. Dos homens que trabalham no próprio município 43,2\% ganham mais que três SM contra apenas $22,8 \%$ das mulheres. A situação toma contornos mais críticos quanto há o deslocamento para trabalho em Curitiba: enquanto a proporção de homens que ganham mais de três SM aumenta para 51,4\%, a proporção de mulheres permanece praticamente a mesmo, 23,6\%.

Quando o local de residência é Curitiba, o total de pessoas de 10 anos e mais ocupadas, e que só trabalham é de 598.675 e, somente 15.121 (2,5\%) se deslocam para trabalho nos 15 municípios analisados da RMC." 384

As pessoas que se deslocam para Curitiba a trabalho, a partir de outros municípios metropolitanos, tem um deslocamento também em relação às faixas salariais considerado positivo: "há proporções maiores de pessoas, nos diversos setores de atividades, nas faixas salariais maiores". Com relação às atividades desenvolvidas, há uma proporção maior trabalhando em Curitiba no setor serviços domésticos do que em seus próprios municípios, em função de uma maior demanda. Já no setor serviços, onde há a maior proporção de trabalhadores, duas atividades se destacam para quem se desloca: vigilância e segurança e, condomínios prediais. $O$ perfil de quem se desloca de Curitiba para trabalhar em outros municípios da RMC, corresponde a pessoas com faixa salarial acima de $5 \mathrm{SM}$, em todos os setores. Destacam-se as atividades relacionadas à indústria, onde os que se deslocam teriam uma atividade mais especializada, envolvendo especificamente as montadoras de automóveis em São José dos Pinhais. ${ }^{385}$

As principais atividades de quem segue para Curitiba em movimento pendular são as ligadas ao setor de serviços: outros serviços de alimentação - exceto ambulantes $(12,12 \%)$, transporte rodoviário de passageiros $(7,35 \%)$, condomínios prediais $(6,56 \%)$, investigação, vigilância e segurança $(5,20 \%)$ e transporte rodoviário

\footnotetext{
${ }^{384}$ DESCHAMPS (2008), p. 11.

${ }^{385}$ DESCHAMPS (2008), p. 18.
} 
de cargas - exceto de mudanças (4,95\%). Em segundo lugar, está o comércio; e em terceiro, o setor de serviços domésticos (15,51\%). Para evidenciar o comportamento da renda por tipo de atividade para quem se desloca em relação a quem trabalha no próprio município, cabe colocar que: no setor agrossilvopastoril, os ocupados no seu próprio município recebem até um salário mínimo, já para quem se desloca o salário fica entre um a três SM; na indústria esse deslocamento se dá nas faixas superiores, ou seja, 35,62\% para quem fica recebe mais que três SM; aumenta para 49,09\% entre os que se deslocam para trabalhar na indústria em Curitiba. Em se tratando dos serviços domésticos, entre os que ficam, $49,82 \%$ recebem entre um e três salários mínimos; o patamar aumenta para $71,72 \%$ para quem se desloca; para os setores comércio e serviços observa-se um leve decréscimo na proporção das pessoas que se encontram na última faixa salarial (acima de cinco SM) em relação a quem fica e quem sai. ${ }^{386}$

Interessante observar que, ao mesmo tempo que DESCHAMPS demonstra que a mobilidade urbana possibilita maior acesso ao emprego e portanto ao incremento da renda, DEAK afirma que a renda é o fator que mais determina a mobilidade. ${ }^{387} \mathrm{O}$ fato é que, de 1991 - situação anterior à RIT - para 2000, ao se considerar o percentual de chefes de domicílios por faixa de renda, houve, sem dúvida, uma mobilidade social geral, porém especificamente considerável na faixa de rendimento mais baixa, de 0 a $2 \mathrm{SM}$, como verificado na tabela abaixo.

\begin{tabular}{|c|c|c|c|c|c|c|}
\hline \multicolumn{7}{|c|}{$\begin{array}{c}\text { Tabela } 3.14 \text { - EVOLUCCÃO DA RENDA DO CHEFE DO DOMICÍLIO } \\
\text { POR FAIXA, POR MUNICÍPIO E RMC (1991-2000) }\end{array}$} \\
\hline \multirow{3}{*}{$\begin{array}{c}\text { CENSO / } \\
\text { PNAD }\end{array}$} & \multirow{3}{*}{ MUNICÍPIO } & \multicolumn{4}{|c|}{ FAIXA DE RENDA EM SALÁRIOS MÍNIMOS } & \multirow{3}{*}{$\begin{array}{l}\text { NÚMERO } \\
\text { TOTAL DE } \\
\text { CHEFES DE } \\
\text { DOMICÍLIO }\end{array}$} \\
\hline & & $0-2$ & $>2-5$ & $>5-10$ & $>10$ & \\
\hline & & $\%$ & $\%$ & $\%$ & $\%$ & \\
\hline \multirow[t]{5}{*}{1991} & Curitiba & 31,98 & 33,26 & 18,86 & 15,9 & 350.604 \\
\hline & Colombo & 53,16 & 37,10 & 7,80 & 1,94 & 28.118 \\
\hline & Pinhais & 44,16 & 40,87 & 11,28 & 3,69 & 17.912 \\
\hline & São José dos Pinhais & 46,99 & 37,55 & 11,00 & 4,46 & 31.043 \\
\hline & $\mathrm{RMC}$ & 40,12 & 33,11 & 15,27 & 11,5 & 528.227 \\
\hline 2001 & $\mathrm{RMC}$ & 20,45 & 32,46 & 25,76 & 21,34 & 809.229 \\
\hline
\end{tabular}

\footnotetext{
${ }^{386}$ DESCHAMPS (2008), p. 16.

${ }^{387}$ DESCHAMPS (2008), p. 16 e DÉAK (1990), p. 43.
} 


\section{A RIT e o movimento das classes sociais na Curitiba Metrópole: as direções da expansão e a emergência dos corredores intra-urbanos}

Na seqüência apresentam-se os mapas relativos à RIT 1996 correlacionada à renda 1991 e a RIT 2004 à renda 2000. Segue também a espacialização do carregamento das linhas da RIT metropolitana em 2008, a título de ilustrar os maiores fluxos de deslocamentos pendulares dos municípios do cone leste em direção à Curitiba, correlacionada à espacialização da renda 2000. 


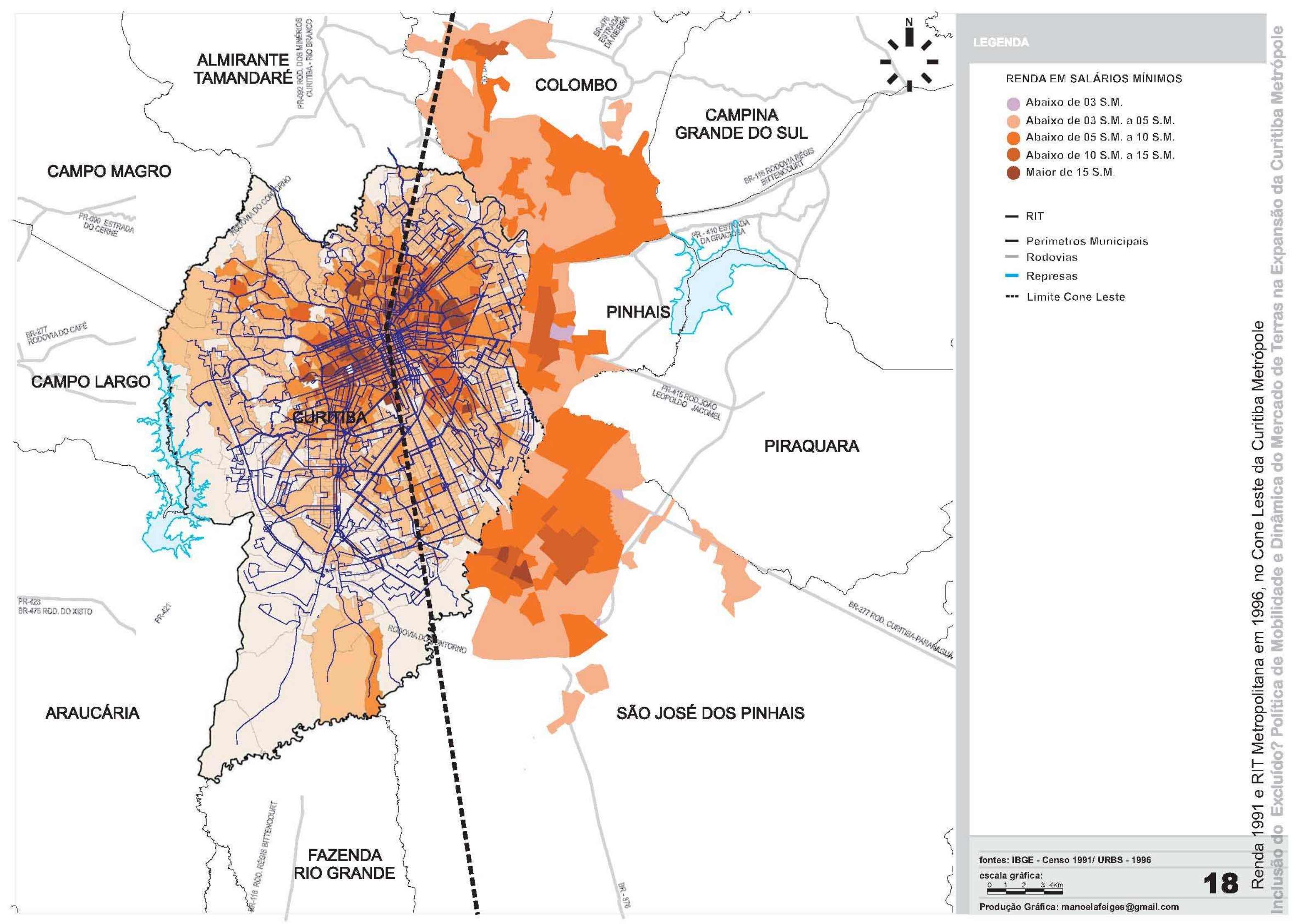




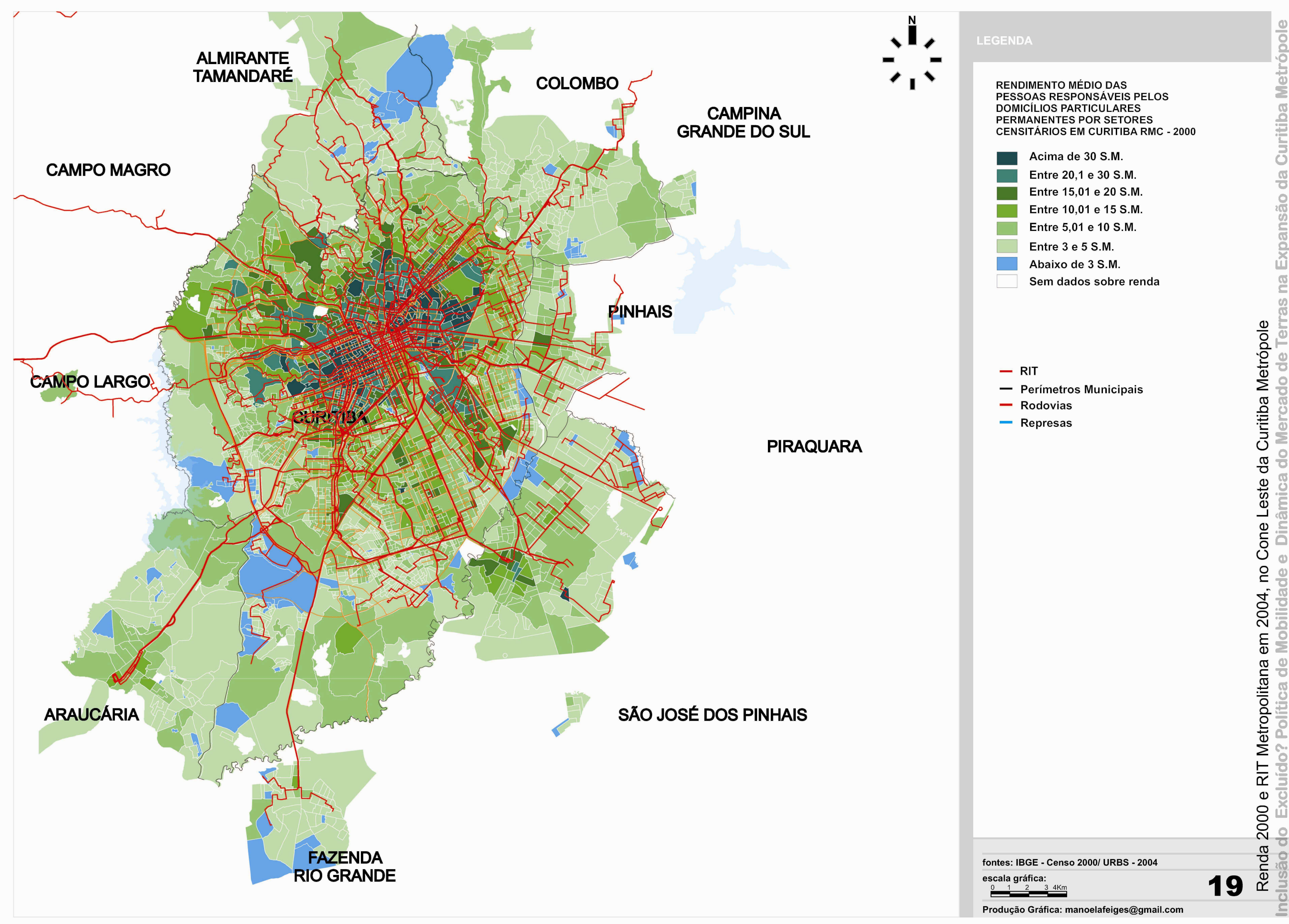




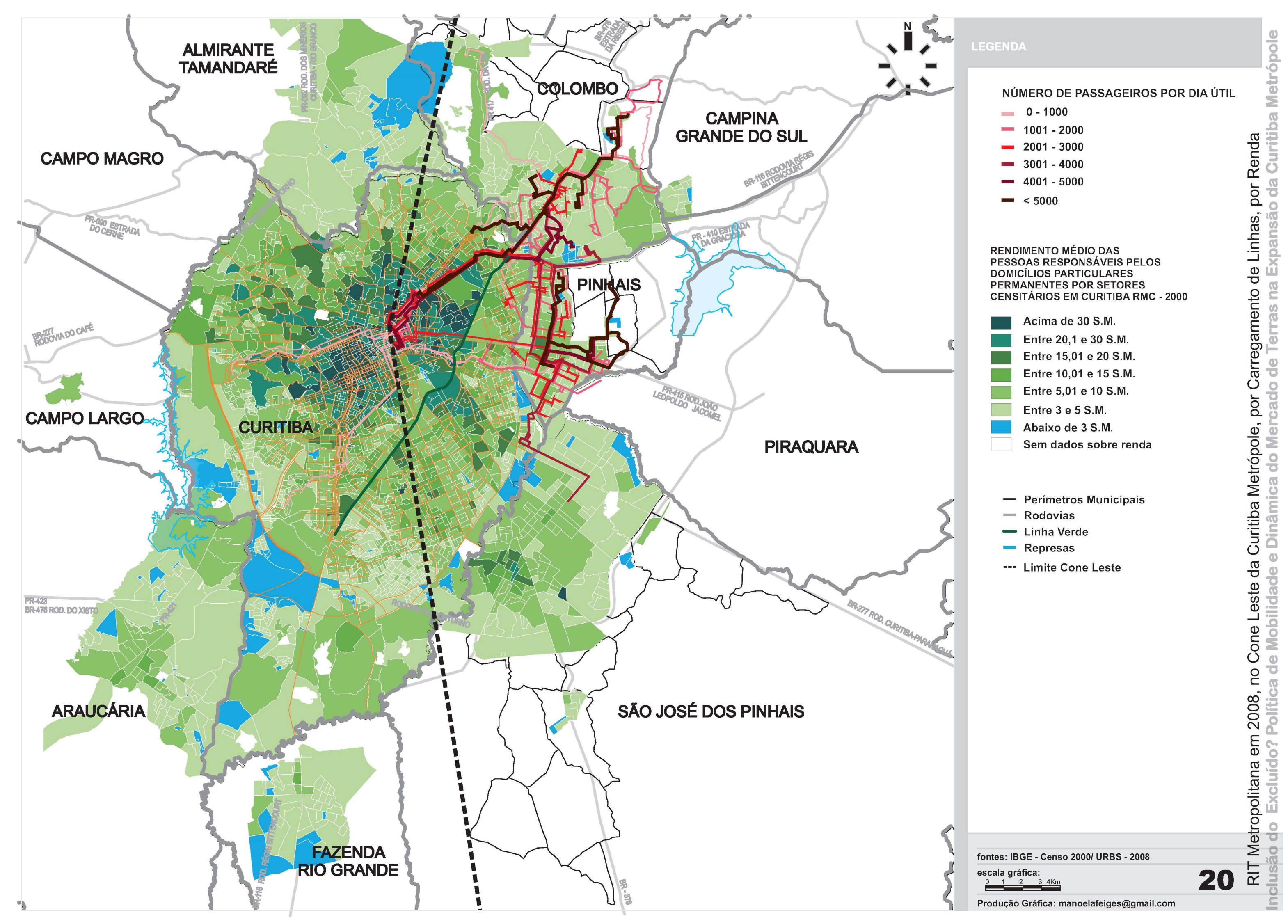


A fim de se apreender a movimentação das classes sociais no território da Curitiba Metrópole, em se tratando de correlacionar a evolução da renda com a evolução da RIT, a leitura do movimento partiu do centro para a periferia, os seja, de Curitiba em direção aos demais municípios, ao longo dos principais eixos viários que estruturam a metrópole, na tentativa de se identificar as direções da expansão urbana.

Em Curitiba, na quase totalidade dos bairros do setor leste - recorte dessa pesquisa - observou-se a elevação dos intervalos superiores das faixas de ocorrência. $\mathrm{Na}$ área central expandida - Centro e bairros do entorno - o intervalo superior passou de 15 ou > 15 SM, para 30 ou > 30 SM, ou seja, demonstra que, a apropriação da área central entre 1991 e 2000 se deu por uma população de média para alta renda.

Nos bairros de Curitiba limítrofes à área conurbada, o intervalo superior dobrou, triplicou ou mesmo quadruplicou. Na divisa com Colombo, demonstrados pelos bairros Atuba (de 3 a 5 SM em 1991 para 3 a 20 SM em 2000) e Santa Cândida (de 3 a 5 SM para 3 a $15 \mathrm{SM}$ ). Porém, ao se deparar com o movimento da renda nos bairros de Colombo após a divisa com Curitiba, constatou-se no período, a permanência das mesmas faixas de rendimento dos chefes de família. Assim, em Colombo, de forma geral as faixas de renda praticamente não sofreram alterações do censo de 1991 para o de 2000. Talvez por isso fosse mais efetivo indicar a variação da renda familiar para os bairros de Colombo, uma vez que o transporte metropolitano integrado favoreceu maior inserção da presença feminina no mercado de trabalho, dada a possibilidade da pendularidade. ${ }^{388}$

Ao se analisar o comportamento da renda a partir da divisa Curitiba-Pinhais, percebe-se claramente a ocorrência de população com renda mais elevada se dirigindo para a borda leste de Curitiba. Isto se evidencia pelas ocorrências nos bairros Cajuru (de < 3 a 10 SM para < 3 a 20 SM), Bairro Alto (de < 3 a 10 SM para 5 a 15 SM), Tarumã (de 5 a 15 SM para 5 a 30 SM) e Capão da Imbuia (de 3 a 10 SM para 5 a 20 SM). Em um panorama geral de Pinhais - diferente de Colombo - na maioria dos bairros a alteração da ocorrência das faixas de renda se deu no intervalo superior: de 3 a 5 SM em 1991, para 3 a 10 SM em 2000. Já nos bairros imediatamente adjacentes à Curitiba pelo prolongamento dos eixos de transporte, a alteração ocorreu tanto no intervalo inferior, como no superior: de 3 a 10 SM para 5 a 10 SM no bairro Estância Pinhais, e de 3 a 15 SM para 3 a 10 SM no bairro Emiliano Perneta. Foi também possível por meio da dinâmica da renda, identificar o processo de consolidação de uma área central no município, atrelada à emergência de um terciário mais forte expandido a partir da continuidade dos eixos viários originados em Curitiba: as faixas

\footnotetext{
${ }^{388}$ DESCHAMPS (2008), p. 11.
} 
de renda de 10 a 15 SM presentes em 1991, se ampliam em 2000, para cima e para baixo, passando a variar entre 5 a 20 SM.

No caso da análise partir em direção a São José dos Pinhais, vale mencionar que, nos bairros conurbados de Curitiba a ocorrência das faixas de renda entre 1991 e 2000, revelou o mesmo padrão observado na área central, de elevação dos intervalos superiores. Assim, a variação no bairro Uberaba foi de 3 a 10 SM para < 3 a 30 SM; já no bairro Boqueirão, de 3 a 10 SM para 3 a 20 SM. O caso mais representativo de ocorrência de camadas de rendimento mais alto fora da área central de Curitiba correspondeu à área central de São José dos Pinhais e seu entorno: apresentava faixas entre 5 a > 15 SM em 1991, alterando-se em 2000 para a faixa compreendida entre 10 e 30 SM.

Pelo indicativo de que as classes de renda mais baixas pouco se movimentaram no cone leste após a sua reestruturação via RIT, cabe agora comprovar a presença de uma lógica inclusiva no fenômeno da expansão da Curitiba Metrópole pela observação da evolução da mancha de urbanização.

\section{A evolução da mancha urbana na Curitiba Metrópole (1996-2009)}

É importante nesse momento resgatar a tendência de crescimento da mancha urbana apresentada na Curitiba Metrópole nos anos oitenta, a fim de se identificar em que medida o movimento de expansão da mancha se relaciona ao da permanência das classes sociais no território, desde a década de noventa. Em conformidade com o PDI-2006, ${ }^{389}$ no período entre 1980 e 1991 as áreas periféricas internas de Curitiba e as áreas conurbadas cresceram apresentando taxas geométricas anuais mais elevadas que à média da região metropolitana, ampliando assim a extensão da mancha contínua de ocupação.

DESCHAMPS, ${ }^{390}$ ao interpretar o papel dos movimentos migratórios no crescimento da RMC, aponta que em relação aos fluxos de migrantes vindos de fora para a região,

"Os municípios que efetivamente atraem população são o pólo metropolitano (Curitiba) e os demais municípios do primeiro anel metropolitano, responsáveis por $96 \%$ do total de imigrantes. Curitiba recebe mais de $43 \%$ dos imigrantes, ou seja, 148,7 mil, enquanto os demais municípios do primeiro anel recebem 53\% (181,3

\footnotetext{
${ }^{389}$ COMEC (2006), p. 55.

${ }^{390}$ DESCHAMPS (2004), p. 66-74.
} 
mil) concentrados em cinco municípios: São José dos Pinhais, Colombo, Piraquara, Pinhais e Fazenda Rio Grande.

O que diferencia esses municípios é o tipo de fluxo que para eles se dirige. Os imigrantes procedentes de outras unidades da Federação têm como destino preferencial Curitiba (65,1\%), e, outros $32,6 \%$ se dividem entre os municípios do primeiro anel. Os imigrantes vindos do Interior do Estado, também se concentram em Curitiba, porém numa proporção menor do que aquela observada para os procedentes de outros estados (56,6\%). Para este tipo de fluxo, já são observadas proporções mais elevadas nos municípios do primeiro anel metropolitano, especialmente nos limítrofes ao pólo." 391

Já em se tratando da migração intra-metropolitana, Deschamps aponta que $82,8 \%$ dos fluxos intra-metropolitanos se dirigem para os municípios contíguos à Curitiba, e que em sentido contrário, menos de $10 \%$ se dirige para lá. A razão disto estaria no fato de que Curitiba é o principal ponto de partida dos imigrantes intrametropolitanos: de um total de 115.095 imigrantes, 73.066 (63,5\%) saem de Curitiba para os municípios de seu entorno imediato.

"Isto implica uma movimentação intensa entre os moradores da própria região, que [...] pode também estar indicando que essa população faz parte de um processo de expulsão de áreas que sofrem pressão imobiliária. No primeiro caso, pode-se observar que estão se intensificando os fluxos de pessoas que se dirigem a Curitiba, vindos principalmente de São José dos Pinhais, Araucária, Campo Largo, Pinhais e Colombo, municípios que, dentro de uma hierarquia metropolitana, posicionam-se num patamar imediatamente inferior ao do pólo.

No segundo caso, observa-se um aumento expressivo não só dos fluxos, mas do volume de pessoas envolvidas, que partem de Curitiba para os municípios do entorno imediato. São José dos Pinhais, Colombo e Fazenda Rio Grande são os municípios mais procurados por aqueles que deixam o pólo, com fluxos que envolvem mais de 10 mil pessoas, ou seja, são quase 34 mil pessoas que afirmaram residir em Curitiba em 1995 e que, em 2000, estavam residindo nesses três municípios. Também os municípios de Pinhais, Piraquara, Almirante Tamandaré e Araucária receberam fluxos significativos de pessoas vindas de Curitiba, sendo que cada um recebeu entre 5 mil e 8 mil pessoas.

Neste sentido, dois aspectos merecem ser mencionados: o primeiro se refere à existência de uma rede de transporte bem estruturada, integrando esses municípios entre si e à capital; o segundo se refere à maior facilidade de acesso à terra, seja ela de modo formal ou informal. Levando em conta esses dois aspectos,

${ }^{391}$ DESCHAMPS (2004), p. 66. 
pode-se sugerir que esse espraiamento da malha urbana a partir do pólo se dá de forma seletiva." 392

Ainda em Deschamps, sobre o perfil do migrante, tem-se que, $75 \%$ daqueles que se dirigem à Curitiba possuem renda média mensal familiar per capita acima de 1 $\mathrm{SM}$ e somente $9 \%$ possuem renda abaixo de 0,5 SM. Assim verifica-se que para o pólo metropolitano se dirigem, em sua maioria, pessoas que se encontram em uma situação familiar mais favorável. Para os que se dirigem aos municípios limítrofes à Curitiba, enquanto $53 \%$ possuem renda acima de 1 SM, $47 \%$ possuem renda abaixo de $1 \mathrm{SM}$ - entre os quais 19\% se encontram em situação de pobreza. Ao serem verificados os valores absolutos, 34,2 mil imigrantes pobres se dirigem para os municípios limítrofes ao pólo, ao passo que 13,5 mil se dirigem para Curitiba e 4,7 mil para os demais municípios da região. "Com isso, torna-se claro que, de forma geral, a ocupação do espaço metropolitano obedece a uma lógica seletiva em que o municípiopólo é privilegiado com proporções infinitamente maiores de imigrantes em situação econômica favorável; [..] quanto mais distantes os municípios do pólo, maiores são as proporções de pobres em cada fluxo que para eles se dirigem, num processo em que sobressai claramente a associação entre a distância física e a distância social: "

"É importante observar, para esta análise, que nos Municípios periféricos a Curitiba, onde são observadas as maiores taxas de crescimento populacional, grande parte de sua população reside fora das sedes municipais, em áreas contíguas a Curitiba, ressaltando o extravasamento da metrópole e a criação de periferias em uma faixa extensa e contígua ao pólo. Como conseqüência desse fenômeno de periferização, principal traço da metropolização de Curitiba, observam-se agravos ao setor público no que tange à oferta de serviços e infraestrutura, impondo uma qualidade de vida de baixo padrão a uma população crescente." 393

Para se avaliar as características espaciais da expansão recente da Curitiba Metrópole, tem-se em MOURA e ULTRAMARI que na década de oitenta, "o sistema viário tradicional continua a ter um papel relevante na conformação de novas ocupações". Os autores indicam também uma tendência de compactação da mancha de urbanização:

"Todavia, o que se observou no período 1980-1991 foi a intensificação da ocupação de forma transversal aos eixos de penetração nos municípios,

\footnotetext{
${ }^{392}$ DESCHAMPS (2004), p. 73-74.

${ }^{393}$ DESCHAMPS (2004), p. 73-74, em referência a ULTRAMARI e MOURA (1994).
} 
configurando radianos, o que constitui um dado positivo, uma vez que preenche grandes vazios metropolitanos, otimizando serviços e infra-estrutura. [...] Tal ocupação, embora contribua para eliminar grandes vazios, contém evidentemente baixas densidades, o que pode ser observado pelo significativo percentual de lotes vagos, características do modelo vigente de apropriação do espaço" ${ }^{394}$

Essa tendência das maiores taxas ocorrerem nessas áreas conurbadas permanece no período entre 1991 e 2000, porém com incrementos maiores nos municípios periféricos em relação à Curitiba. Dessa forma, a consolidação e o adensamento da aglomeração metropolitana vêm em decorrência desse processo de crescimento revelado nessas duas décadas, acompanhado das taxas mais elevadas verificadas entre as regiões metropolitanas no país.

Quanto ao adensamento, destaca-se a situação de Curitiba: "[...] praticamente, na mesma área onde vivia um milhão de habitantes em 1980, morava 1,5 milhão em 2000, tendo havido portanto um acréscimo de população da ordem de 50\% em 20 anos". Já nos demais municípios, a dinâmica do processo de urbanização - mais expressiva nas décadas de 60 e 70 - diminui acentuadamente nos anos oitenta e, praticamente, estabiliza-se a partir dos anos noventa. Somado a isso, a taxa de urbanização da região metropolitana que era de 74,05\% em 1970, passando para $87,83 \%$ em 1980, estabiliza-se a partir dos anos noventa: de 91\% em 1991 para $90,71 \%$ em 2000. Do incremento de população na RMC entre 1970 e 2000 perfazendo um total de 1,86 milhões de habitantes, 52,57\% morava em Curitiba, 9,15\% em São José dos Pinhais, 8,82\% em Colombo e 8,30\% em Pinhais/Piraquara.

Em relação à dinâmica de parcelamento do solo e a produção de lotes nos anos noventa - segundo o PDI-2006 - apresentou sensível queda, já constatada na década anterior. Entre 2000 e 2004, a produção de lotes é mais significativa na porção sul de Curitiba, em Araucária, Fazenda Rio Grande e São José dos Pinhais, caracterizando um vetor de crescimento ao sul, "o que é condizente com as características destes municípios que possuem poucas restrições ambientais e relativa acessibilidade". Ainda se deve ressaltar o descompasso do processo de produção de lotes em relação ao crescimento da população:

"Em 1980, para uma população de 375.236 habitantes urbanos no NUC (sem Curitiba), havia 169.139 lotes aprovados, estabelecendo uma média de 2,2 habitantes por lote. Em 1991, essa média sobe a 2,9 habitantes por lote e em 2000, chega a 4,11 habitantes por lote, indicando que o número de lotes produzidos, principalmente até 1980, nos municípios do NUC (sem Curitiba) foi

\footnotetext{
${ }^{394}$ ULTRAMARI e MOURA (1994), p. 28-30.
} 
bem superior à demanda gerada pelo crescimento populacional no mesmo período". 395

Estas características de expansão por adensamento também foram confirmadas pelos resultados da pesquisa realizada por DOWALL, sobre as características do mercado de terras e de habitação no Brasil. A partir de estudos comparativos entre as metrópoles de Recife, Brasília e Curitiba, o autor aponta a compactação da mancha em Curitiba como um padrão de crescimento, identificado a partir da distribuição da população em relação à distância do centro principal. ${ }^{396}$

Na seqüência, apresenta-se o mapa correspondente à evolução da mancha de urbanização relativa aos anos de 1996, 2000 e 2004.

Da leitura da evolução da mancha de urbanização na Curitiba Metrópole, percebe-se que em um período de quase quinze anos, a expansão apresentou-se discreta em relação ao descrito para as décadas anteriores - anos setenta e oitenta. A espacialização das manchas só vem confirmar os diversos estudos apresentados anteriormente. Com relação às direções da expansão, demonstra além da influência dos eixos rodoviários, também a consolidação à leste, pela tendência recente de compactação da forma urbana. Ao absorver as ocupações originadas a partir dos eixos viários regionais, pelo extravasamento da periferia de Curitiba, os eixos assumem caráter intra-metropolitano, dada a sua função de corredores de transporte integrado, como será detalhado mais a frente.

\footnotetext{
${ }^{395}$ COMEC (2006), p. 60-61.

396 DOWALL (2006), p. 33-35: “Change in population between 1991 and 2000 reveals several interesting results. The first and most dramatic finding is that Brasilia's population is distributed quite differently than Curitiba's or Recife's - most of its population is concentrated far from the city center. In 1991, over half (53.6\%) of Brasilia's metropolitan population was located more than 25 kilometers from the city. By 2000, the percentage had declined somewhat to 50\%, but still remained distinctly different from the spatial patterns in the other two cities. The percentage of population located within 10 kilometers of Brasilia's center averaged about 8\% for both 1991 and 2000.

In sharp contrast, in 1991 nearly $70 \%$ of Curitiba's population resided within 10 kilometers of the city center. By 2000, Curitiba's population had begun to decentralize and 58.5\% of the total metropolitan population was located within 10 kilometers of the center. Peripheral population in Curitiba was low in comparison to Brasilia-less than 6\% in 1991 and less than $9 \%$ in 2000 of the total population resided more than 25 kilometers from the central city.

In Recife, the patterns are similar to Curitiba. In 1991, over $48 \%$ of the population resided within 10 kilometers of the city center. In 2000, the portion was 44\%. Recife's peripheral population was about the same as Curitiba's, and well below that of Brasilia. In 1991, 8.5\% lived more than 25 kilometers from the city center. In 2000, the figure increased to $9.2 \%$.

[...] In Curitiba, population growth moved out beyond 10 kilometers from the city center. Between 1991 and 2000, nearly half of the increase took place in areas between 10 and 20 kilometers from the city. This suggests that Curitiba has been relatively successful in achieving compact development-channeling growth into areas that are contiguous to existing urban areas. Compact development is not necessarily high density. In the case of Curitiba, the city used 37 hectares of land for each additional 1,000 persons -this is much more land than in Brasilia, which used 26 hectares."
} 


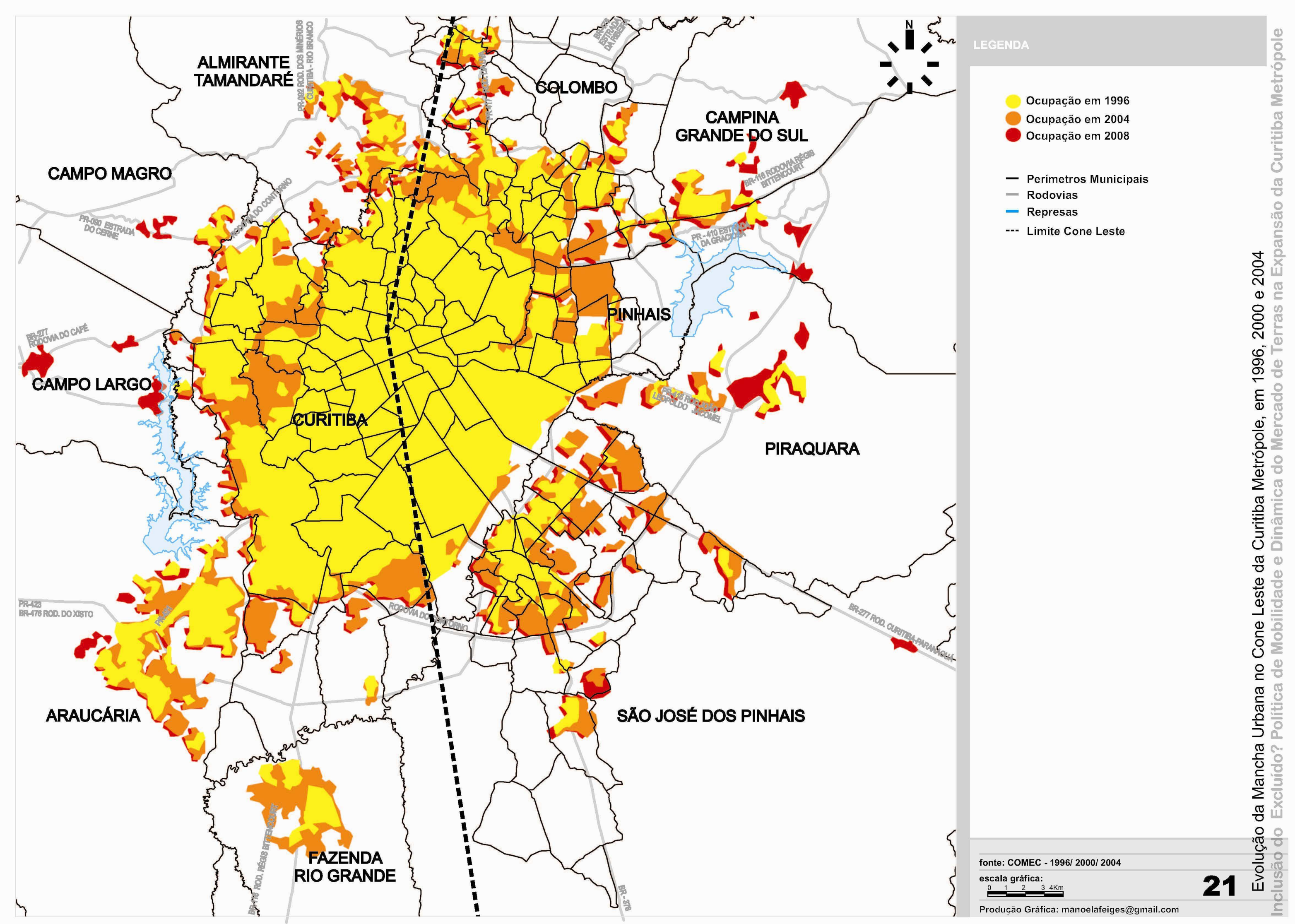




\section{INCLUSÃO DO EXCLUÍDO NA CURITIBA METRÓPOLE: EXPANSÃO URBANA E TIPOLOGIAS DAS NOVAS LOCALIZAÇÕES}

A multiplicidade de novas localizações produzidas na periferia da Curitiba Metrópole pela integração metropolitana via RIT, está vinculada ao incremento da renda, a condição necessária ao seu consumo e à sua apropriação. Assim, o processo de expansão urbana retratado foi vislumbrado a partir de uma lógica aqui denominada de "a inclusão do excluído". A fim de desvelar tal lógica mais detalhadamente, encontra-se apoio em HARVEY, quando trata dos efeitos redistributivos da mudança de localização de empregos e de habitação.

"As cidades cresceram muito rapidamente nos últimos vinte anos ou mais, e esse crescimento resultou em algumas mudanças significativas na sua forma espacial. Houve assim (e presumivelmente sempre haverá) uma reorganização na localização, e distribuição de algumas atividades no sistema urbano.

$[\ldots]$

A mudança de localização da atividade econômica na cidade significa uma mudança de localização de oportunidades de emprego. A mudança de localização da atividade residencial significa mudança de localização de oportunidade de moradia. Ambas devem, presumivelmente, estar associadas a gastos de mudanças em transporte. Mudanças em transporte afetam certamente, em grande escala, o custo de acesso a oportunidades de emprego a partir da localização das moradias. Essas mudanças podem ser claramente entendidas, certo; elas são invariavelmente criadas em qualquer modelo de crescimento urbano, mas suas implicações para a redistribuição da renda não são sempre claramente percebidas". ${ }^{397}$

Diz VILLAÇA ${ }^{398}$ que Harvey, ao relacionar a localização com a oportunidade de emprego, destaca a importância do tempo de deslocamento para a sua existência, porém não se reporta em nenhum momento à infra-estrutura para que seja produzida uma nova localização, a menos que essa infra-estrutura seja aquela relativa ao transporte. Também sobre uma possível correlação das localizações intra-urbanas

\footnotetext{
${ }^{397}$ HARVEY (1980), p. 48 - 49.

${ }^{398}$ VILLAÇA (1998), p. 73 e p. 151.
} 
com a renda, Villaça encontra em HARVEY $(1976,53)$, o seguinte argumento: "o processo social de determinação do salário é parcialmente modificado por mudanças na localização das oportunidades de emprego (por categorias) comparadas com as mudanças em oportunidades residenciais (por tipo)".

Ao se fazer um paralelo entre a reflexão de Harvey sobre a estruturação física da metrópole americana e dos impactos das localizações centrais lá apropriadas pela camada de mais baixa renda sobre as oportunidades de emprego e renda, pode-se afirmar que em Curitiba o processo social de determinação do salário foi modificado a partir da reconfiguração da estrutura intra-urbana resultante da metropolização da RIT, da qual resultou a possibilidade de permanência na localização de moradia. Dessa afirmação decorre a próxima: a de que, portanto, a reestruturação intra-urbana da Curitiba Metrópole se deu a partir de uma lógica de inclusão do excluído.

HARVEY, com apoio em Meyer, constrói sua argumentação sobre aspectos de redistribuição regressiva da renda advinda dos movimentos de localização do emprego e da moradia nas metrópoles americanas:

"O processo de relocação dentro do sistema urbano tem, assim, servido para as opções dos moradores suburbanos em ascensão, eliminado as possibilidades da família de renda baixa no centro da cidade. Essa situação pode ser parcialmente modificada pela política de transportes, mas ordinariamente, essa política tem favorecido a situação existente mais do que alterado.

[...] o único sistema que tem sido pouco desenvolvido (e na maioria dos casos totalmente negligenciado) é o sistema de fluxos para conduzir as pessoas das áreas centrais da cidade a oportunidades de emprego nos subúrbios: "a empregada doméstica negra trabalhando numa casa de subúrbio e morando num gueto centralmente localizado é o arquétipo: hoje, contudo, ela está sendo cada vez mais imitada por rapazes negros, porque as oportunidades de emprego em fábricas, em transporte intra-urbano, assim como em atacadistas e varejistas, estão progressivamente sendo encontradas nos subúrbios, enquanto que as oportunidades de moradia permanecem restritas ao gueto central."

[...] Em geral, os ajustamentos ao sistema de transporte têm favorecido áreas suburbanas e negligenciado as necessidades das áreas centrais no que diz respeito ao acesso ao emprego. Mas mesmo se a política de transporte invertesse essa tendência, há alguma coisa paradoxal em relação às expectativas dos moradores de renda baixa, cuja racionalidade de localização no centro da cidade, em primeiro lugar (já dissemos), dependeu da minimização de desembolsos de custos de transporte, com o objetivo de empenhar o gasto necessário em buscar empregos nos subcentros suburbanos, simplesmente porque o mercado de moradias não pode ajustar-se (em termos de quantidade de locação) à mudança de localização do emprego. Este parece ser um caso clássico da inflexibilidade da 
forma espacial de uma cidade, gerando desequilíbrio quase permanente no sistema social urbano". 399

Aclarar o processo de inclusão do excluído na Curitiba Metrópole é o que se pretende fazer deste ponto em diante. Depois de elucidar os movimentos de produção e de apropriação do território na Curitiba Metrópole pela dinâmica do mercado de terras e pela expansão da rede integrada de transporte, cabe agora seguir com os pormenores das tipologias de novas localizações geradas a partir da dialética desses movimentos, características do processo de expansão urbana a partir da lógica de inclusão do excluído. Esta-se referindo aqui aos bairros populares atendidos pela RIT metropolitana e aos eixos viários intra-metropolitanos que passaram a desempenhar a função de corredores de transporte integrado.

\section{A dinâmica do mercado de terras e a inclusão do excluído: bairros populares e corredores de transporte intra-urbanos}

Como um último passo para demonstrar que o processo de expansão recente na Curitiba Metrópole se deu pela inclusão do excluído, resta finalmente estabelecer a correlação entre os corredores metropolitanos de transporte integrado e os bairros populares estruturados pela RIT metropolitana - que nada mais são do que os novos valores de uso há pouco revelados pela dialética entre a produção do espaço e a sua apropriação.

"O dispêndio de tempo de deslocamento do ser humano é indissociável do espaço social, do espaço produzido. Todo e qualquer "ponto" do espaço social está associado a um certo gasto de tempo nas diversas viagens que o ser humano pode fazer de e para ele. Há aí, então, um entrelaçamento dialético entre tempo e espaço." 400

Apresenta-se a seguir o processo de constituição das novas localizações geradas pelo aumento da acessibilidade dos bairros periféricos com a presença da RIT metropolitana. Por meio da espacialização da evolução das variáveis preço da terra e abrangência da RIT, pretende-se demonstrar que é da dialética dos seus movimentos que emergem as novas localizações intra-urbanas detentoras da materialização do processo de inclusão do excluído que caracterizou a reconfiguração recente do território da Curitiba Metrópole.

\footnotetext{
${ }^{399}$ HARVEY (1980), p. 48 - 51.

${ }^{400}$ VILLAÇA (1998), p. 356-357.
} 


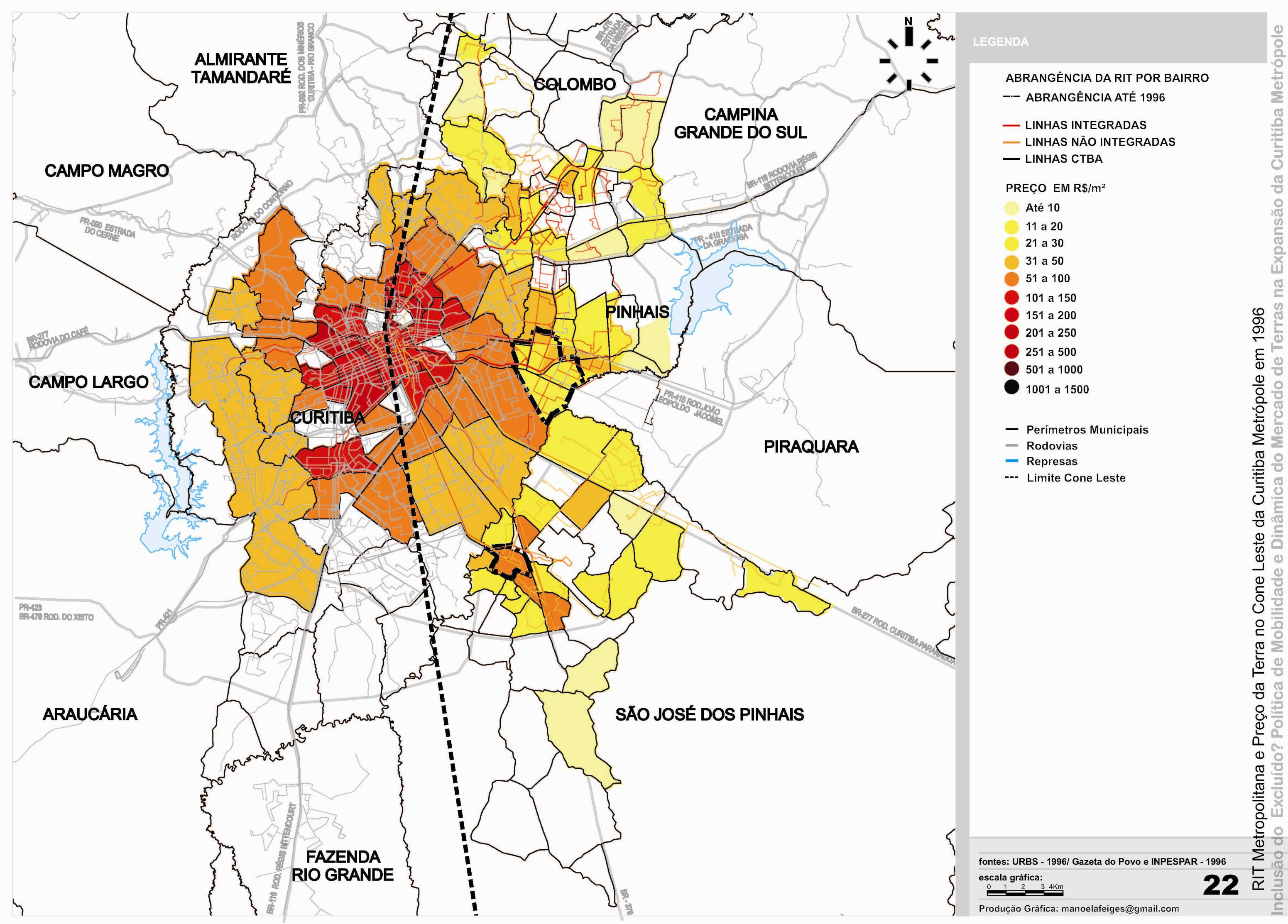




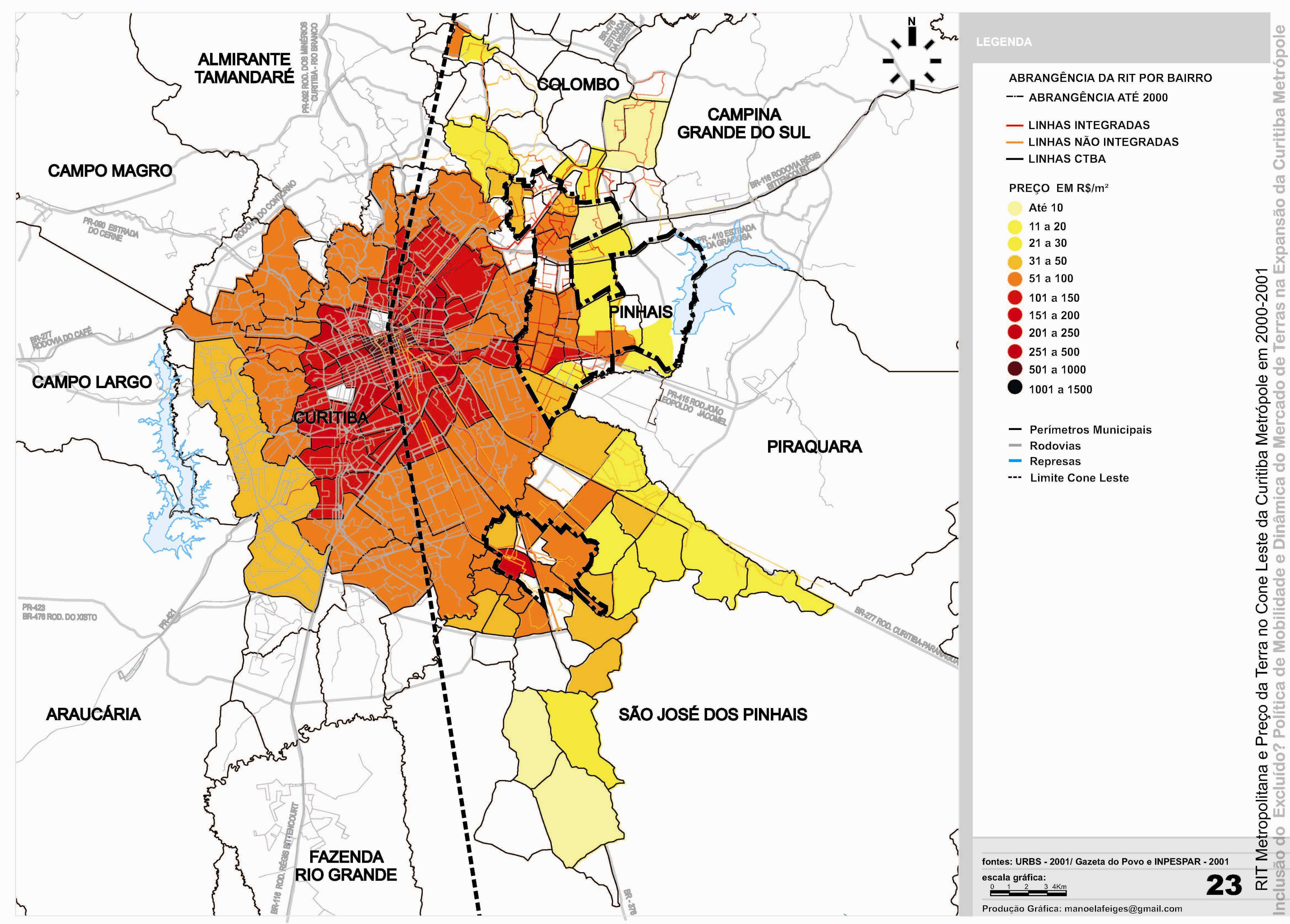




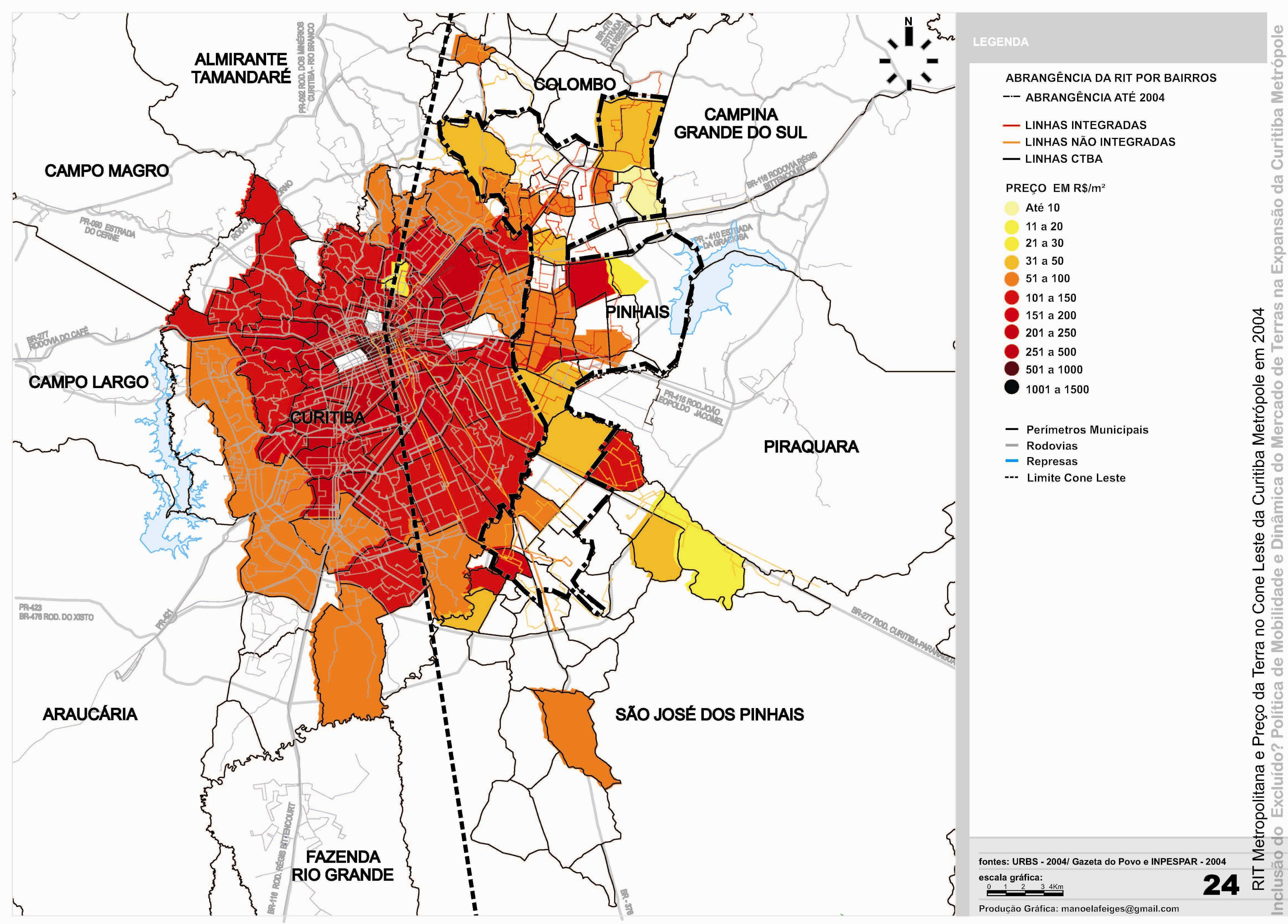




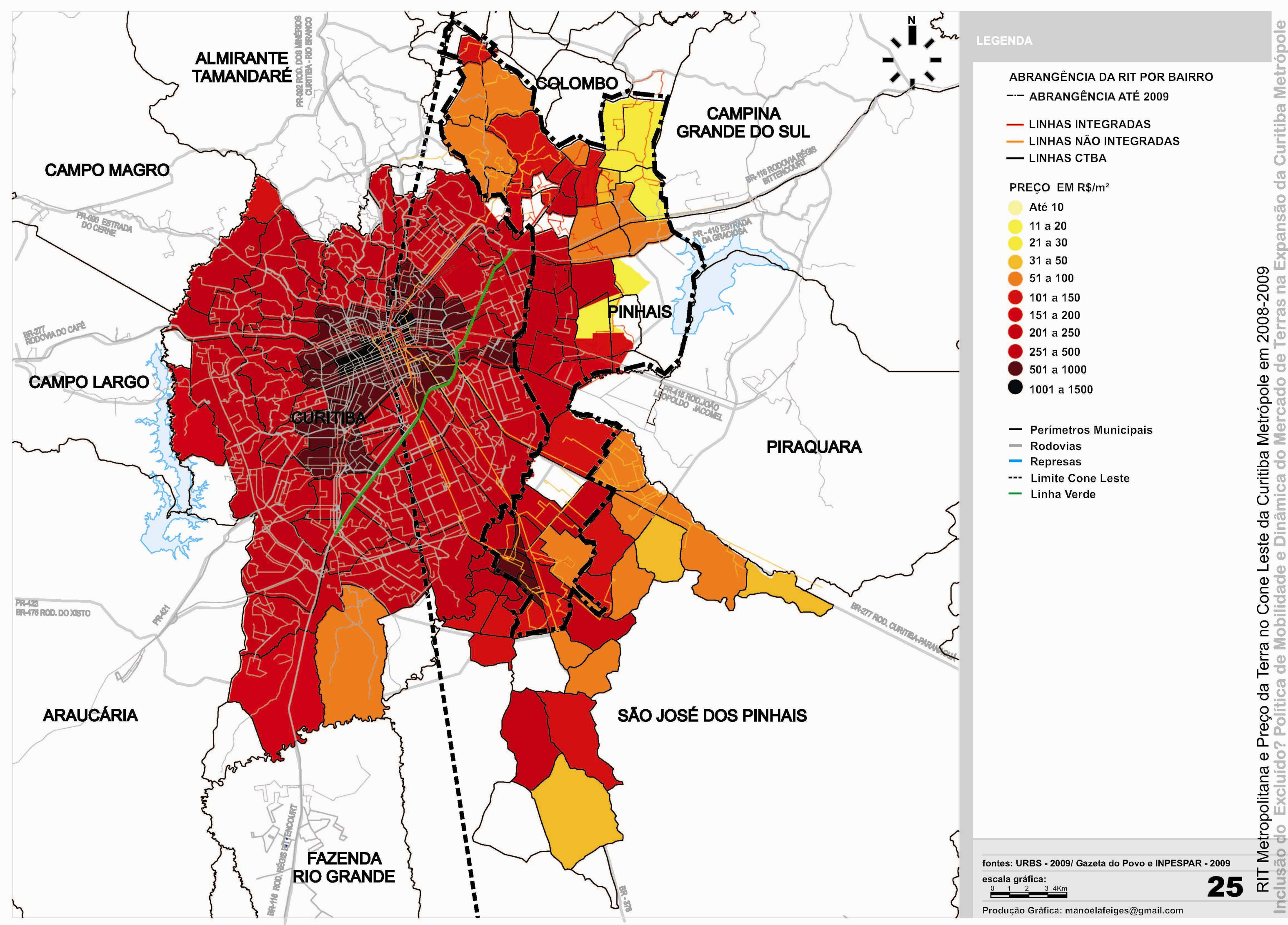


No ano de 1996 foi então iniciada a implantação da RIT metropolitana, cabendo apenas relembrar que tanto em Pinhais como em Colombo a crescente expansão da rede se deu no sentido de atender a todas as partes urbanizadas. Entretanto, em São José dos Pinhais a opção de integração apenas parcial à RIT advém de uma política de retenção da população no município, condicionada na época, às possibilidades de ampliação da oferta de empregos diante da expectativa de um novo ciclo econômico de base industrial.

O início da integração via RIT no cone leste foi marcado pela extensão de linhas diretas operantes em Curitiba - popularmente conhecidas pelos "ligeirinhos": uma em direção a Pinhais e outra a São José dos Pinhais, de onde emergiram os primeiros corredores metropolitanos de transporte integrado, ou seja, uma nova tipologia de localização na estrutura intra-urbana da metrópole. Assim, a linha direta que operava no corredor estrutural leste de Curitiba, a Av. Afonso Camargo, ao se prolongar pela Av. Irai transformou-a em um corredor metropolitano de transporte integrado. Da mesma forma, a linha direta vinda do corredor da Av. Mal. Floriano Peixoto via Boqueirão, logo após a transposição da divisa de Curitiba já chegava na área central de São José dos Pinhais. Logo, em função dessa situação inicial de incipiente abrangência em Pinhais e em São José dos Pinhais, bem como da sua ausência em Colombo, pode-se dizer que o comportamento dos preços da terra equivalente a 1996 referia-se à condição de uma periferia parcamente conectada ao centro da metrópole. Da observação das isolinhas de preços, lê-se claramente a segmentação que existia entre as localizações pertencentes à dinâmica de pólo e as da periferia, fortemente evidenciada pela queda das faixas de preço após o limite com os municípios conurbados. Desse modo, é no cenário de preços pós-1996 que serão percebidas as transformações nos valores de uso no território da metrópole, revelados por meio das localizações mais valorizadas, entre as quais as tipologias referentes à lógica de inclusão do excluído - os bairros populares estruturados pela RIT e os corredores metropolitanos de transporte integrado.

No mapa referente ao ano de 2000 destaca-se que se em Curitiba as isolinhas de preços se apresentam a partir de círculos concêntricos - organizados a partir de um centro mais valorizado - a lógica se altera nos municípios conurbados para a valorização dos principais eixos radiais da metrópole, evidenciando a emergência dos corredores metropolitanos da RIT, enquanto novos valores de uso ou novas localizações na estrutura urbana em processo de reconfiguração.

Já é perceptível também em 2000 um outro impacto decorrente da expansão da rede - a valorização da terra. Constatou-se que o fato de se passar da falta de integração para a integração via RIT representou valorizações nos preços da terra 
entre $122 \%$ e $244 \%$ em Colombo - nos bairros Campo Pequeno e Atuba - e entre $160 \%$ e $213 \%$ em Pinhais, nos bairros Emiliano Perneta e Vila Amélia respectivamente. Já em São José dos Pinhais, a ampliação do atendimento da RIT no período 1996-2000 se deu pela implantação de apenas mais uma linha direta, que ao acessar o Aeroporto Afonso Pena pelo corredor da Av. das Torres, provocou alterações na dinâmica de preços nos bairros ao longo do percurso, agora integrados $185 \%$ no Cidade Jardim, $148 \%$ no Boneca do Iguaçu e $202 \%$ no Cruzeiro.

Verificou-se pela conformação das isolinhas de preços da terra apresentada em 2004 o indicativo da produção de mais uma tipologia de localização - a dos bairros periféricos da cidade central, caracterizados agora pelo deslocamento dos anéis correspondentes às faixas medianas de preço para as bordas de Curitiba, provocado pela expansão da área central detentora dos preços mais altos, lógica essa de caráter excludente, intrínseca ao mercado de terras. Contraditoriamente, essa lógica de valorização excludente é rompida nesse momento no território dos municípios conurbados, pela expansão extensiva da RIT e a decorrente homogeneização dos preços na periferia.

Assim, entre 2000 e 2004, a abrangência da rede avançou sobre a totalidade da área urbana na cidade de Pinhais; em Colombo, a integração via RIT só deixava de contemplar os bairros contíguos à Rodovia da Uva, que até então se caracterizavam por uma ocupação decrescente e descontínua em direção à sede do município; e também os bairros voltados à BR-116, uma área de expansão contígua ao eixo regional com potencial para atividades logísticas e industriais, caracterizada também pela presença de grande invasão - a Vila Zumbi dos Palmares. Do paralelo com o mercado de terras, percebe-se nesse momento uma tendência de homogeneização de preços, nitidamente visível na espacialização das isolinhas. Esse fenômeno, anteriormente citado, é explicado por Déak pela disseminação da acessibilidade aos vários pontos do território. Assim, argumenta DÉAK sobre a homogeneização dos preços a partir da homogeneização da acessibilidade metropolitana:

“[...] a redução dos diferenciais de preço do solo da aglomeração urbana, isto é, redução dos preços relativos das localizações mais privilegiadas ("preço do solo urbano") devido ao efeito de homogeneização da acessibilidade na região metropolitana como um todo. Trata-se aqui, na verdade, do instrumento mais efetivo - senão o único - de combate à especulação imobiliária descontrolada, frequentemente enunciado e visto como um dos grandes objetos do planejamento urbano." 401

${ }^{401}$ DÉAK (1990), p. 52. 
Interessante também destacar que em função da acessibilidade ampliada, do ritmo das valorizações em relação ao período anterior se manteve, indicando assim um processo de valorização da terra de caráter não especulativo. Isto pode ser comprovado pelo comportamento dos preços em diversos bairros - Roça Grande (185\%) e Maracanã (143\%) em Colombo; e em Pinhais, nos bairros Weissópolis (128\%), Palmital (118\%) e Centro (109\%).

A rede integrada em São José dos Pinhais também se amplia entre 2000 e 2004, porém em proporções bem menores em relação a Colombo e a Pinhais. Algumas linhas são implantadas no sentido de propiciar o acesso à RIT a partir dos terminais urbanos Central e Afonso Pena, este último localizado na Av. Rui Barbosa eixo estruturante norte-sul que interliga a BR-277 ao Centro. Dessa forma, a área de abrangência passa a incorporar uma alça - composta pela BR-277, pela Av. Rui Barbosa e pela Rua XV de Novembro, interligando os terminais existentes. Quanto à valorização da terra nos bairros agora atendidos pela RIT, pode-se dizer que as faixas de preço lá verificadas em 2000 permanecem em 2004, fato similar ao observado em Colombo e Pinhais no mesmo período. A valorização de maior expressividade ocorreu no bairro Afonso Pena (127\%), decorrente da presença do terminal que passou a operar linhas da RIT metropolitana.

No período de análise mais recente, compreendido entre 2004 e 2009, cabe evidenciar a ocorrência da homogeneização generalizada da faixa de preços medianos na Curitiba Metrópole, fenômeno este que aponta uma situação de maior equilíbrio da estrutura sócio-espacial da metrópole. Como já citado anteriormente, a faixa de preço entre 251 a 500 reais por metro quadrado equiparou-se em múltiplas localizações - independente da sua natureza - seja no corredor estrutural de Curitiba, seja no bairro periférico limítrofe à área conurbada, seja no Alphaville Graciosa em Pinhais ou no bairro Maracanã em Colombo, no corredor metropolitano da Estrada da Ribeira. O que essas localizações todas têm em comum? Certamente as condições de acessibilidade. Estão situadas em um anel compreendido entre 5 a $10 \mathrm{~km}$ do centro da metrópole, que circunda a área central de preços mais elevados (expandida em um raio de até $5 \mathrm{~km}$ ). Fora desse anel, porém contígua a ele, a faixa de preços mediana só se verifica nos bairros do entorno do Centro de São José dos Pinhais.

"O adquirente de espaço continua a adquirir um valor de uso. Qual? Ele não compra apenas um volume habitável, permutável como outros... O adquirente é detentor de uma distância, aquela que interliga sua habitação aos lugares, os centros de comércio, de trabalho, de lazer, de cultura, de decisão. Aqui o tempo entra novamente em cena." 402

${ }^{402}$ LEFÈBVRE (1974, 391), apud VILLAÇA (1998), p. 73. 
Por fim, recorre-se novamente à VILLAÇA, quando afirma que "a distância é tempo, não apenas tempo de um deslocamento, mas de todos os deslocamentos, bem como seus custos e freqüências para todos os membros da família." A seguir, apresenta-se a correlação entre a abrangência da RIT e a dinâmica de preços no mercado de terras da Curitiba Metrópole, em maiores detalhes a partir das escalas de bairro e de municípios. O detalhamento da constituição dessas localizações segue sob a forma de tabelas que explicitam a correlação entre as variáveis - ora organizadas a partir da evolução do preço da terra por bairros, ora pelos corredores metropolitanos da RIT. A lacuna de dados relativos aos preços presente nas tabelas relativas a Colombo, Pinhais e São José dos Pinhais, justificada pela baixa oferta de lotes à venda no período, não compromete a leitura da valorização da terra oriunda da expansão da RIT metropolitana. Para facilitar a análise das tabelas, dentre os bairros listados, foram assinalados aqueles que corresponderam às valorizações mais expressivas no período pesquisado.

A produção de localizações em Colombo identificada pela correlação entre as variáveis será verificada a partir dos bairros que apresentaram as maiores valorizações. Em Osasco, um bairro mais próximo à divisa de Curitiba - até 2004 atendido apenas pelas linhas metropolitanas não integradas - verificou-se que, ao passar a integrar a área atendida pela RIT, em termos de impacto imediato os preços da terra lá se elevaram em 232\%. Em São Dimas, bairro periférico na área de expansão limítrofe à Campina Grande do Sul, quando da integração com a RIT, valorizou em 420\%. Já o bairro Maracanã, onde se localiza o terminal metropolitano, apresentou uma intensa valorização - 1100\% entre 2000 e 2009, a maior registrada no município no período pesquisado. Como impacto da operação de transporte integrado, deu-se a formação de um subcentro pela concentração de atividades comerciais e de serviços até então inexistente na periferia da cidade dormitório, desenvolvido ao longo da Estrada da Ribeira, com efeito polarizador sobre toda a área urbana. 
Tabela 3.15 - COLOMBO

EVOLUÇÃO DO PREÇO MÉDIO (R\$/ $\mathbf{m}^{2}$ ) DE TERRENOS OFERTADOS PARA VENDA, POR BAIRRO, COM A EVOLUÇÃO DE ABRANGÊNCIA DA RIT METROPOLITANA

\begin{tabular}{|c|c|c|c|c|}
\hline BAIRROS & 1996 & 2000 & 2004 & 2009 \\
\hline Centro & 13,44 & 26,44 & 71,32 & 108,40 \\
\hline Gabirobal & 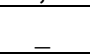 & 60,61 & & - \\
\hline Arruda & 6,25 & & & 72,12 \\
\hline Embu & & & & 55,59 \\
\hline Roça Grande & 14,77 & 32,40 & 37,76 & 83,97 \\
\hline São Gabriel & & & & 139,91 \\
\hline Osasco & 6,29 & 41,21 & 95,82 & 90,45 \\
\hline Campo Pequeno & 34,70 & 42,51 & 78,72 & 186,33 \\
\hline Rio Verde & 28,80 & _ & 74,07 & _- \\
\hline Guarani & & 52,38 & _ & 105,60 \\
\hline Atuba & 25,95 & 63,35 & 42,00 & 206.95 \\
\hline \multicolumn{5}{|l|}{ Monza } \\
\hline Fátima & 2 & 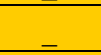 & & 120,41 \\
\hline Maracanã & _ & 43,61 & 62,50 & 479,95 \\
\hline Santa Terezinha & 40,00 & -1 & , & 216,84 \\
\hline Guaraituba & 16,49 & 23,43 & - & 107,57 \\
\hline Das Graças & $=$ & 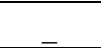 & - & 88,89 \\
\hline Paloma & 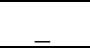 & & 76,92 & 48,53 \\
\hline Palmital & - & 9,22 & & 83,85 \\
\hline Mauá & 10,71 & 25,73 & 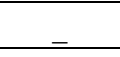 & 64,29 \\
\hline Canguiri & 20,33 & & & 90,46 \\
\hline Rincão & 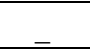 & & & 53,91 \\
\hline Colônia Farias & 14,74 & & 9,50 & 18,50 \\
\hline São Dimas & 7,00 & 8,98 & 37,75 & 27,27 \\
\hline \multirow{4}{*}{$\begin{array}{c}\text { Fontes: GALE I A DU PUVO, } \\
\text { EVOLUCCAOO DA } \\
\text { ABRANGÊNCIA DE } \\
\text { ATENDIMENTO DA RIT } \\
\text { METROPOLITANA } \\
\end{array}$} & & aut & & \\
\hline & & \multicolumn{3}{|c|}{ RIT 1996} \\
\hline & & \multicolumn{3}{|c|}{ RIT 2004} \\
\hline & & \multicolumn{3}{|c|}{ RIT 2009} \\
\hline
\end{tabular}


Tabela 3.16 - PINHAIS

EVOLUÇÃO DO PREÇO MÉDIO (R\$/m2) DE TERRENOS OFERTADOS PARA VENDA, POR BAIRRO, COM A EVOLUÇÃO DE ABRANGÊNCIA DA RIT METROPOLITANA

\begin{tabular}{|c|c|c|c|c|}
\hline BAIRROS & 1996 & 2000 & 2004 & 2009* \\
\hline Alto Atuba & & - & _ & 406,68 \\
\hline Emiliano Perneta & 34,29 & 54,98 & 90,46 & 321,45 \\
\hline Estância Pinhais & 27,08 & 52,16 & 59,40 & 285,34 \\
\hline Weissópolis & 18,72 & 34,86 & 44,94 & 242,90 \\
\hline Vargem Grande & 26,74 & 28,10 & 48,17 & 181,96 \\
\hline Centro & 31,73 & 125,26 & 136,83 & 340,27 \\
\hline Palmital & 30,53 & 73,73 & 87,23 & 290,99 \\
\hline Sete Vilas & & 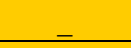 & - & 239,53 \\
\hline Vila Amélia & 22,46 & 47,90 & 86,68 & 147,26 \\
\hline Maria Antonieta & 34,97 & & & 160,78 \\
\hline Vale das Águas & 2,61 & 16,99 & $=$ & \\
\hline Graciosa & & 26,66 & 162,62 & 269,93 \\
\hline Entre Rios & 15,00 & 11,68 & & 18,68 \\
\hline Vale das Nascentes $\left(^{*}\right)$ & & & 24,54 & 11,62 \\
\hline \multicolumn{5}{|l|}{ Esperança $\left(^{*}\right)$} \\
\hline \multicolumn{5}{|l|}{ Vale do Capão (*) } \\
\hline \multicolumn{5}{|c|}{$\begin{array}{l}\text { Fontes: GAZETA DO POVO, INPESPAR e URBS. Elaborado pela autora. } \\
\text { Nota: }\left(^{*}\right) \text { Bairros integrantes da APA do Rio Irai, região de mananciais. }\end{array}$} \\
\hline \multirow{3}{*}{$\begin{array}{c}\text { EVOLUĈ́AO DA } \\
\text { ABRANGÊNCIA DE } \\
\text { ATENDIMENTO DA RIT } \\
\text { METROPOLITANA }\end{array}$} & & \multicolumn{3}{|c|}{ RIT 1996} \\
\hline & & \multicolumn{3}{|c|}{ RIT 2001} \\
\hline & & \multicolumn{3}{|c|}{ RIT 2004} \\
\hline
\end{tabular}

Quanto à Pinhais, da correlação entre a RIT metropolitana e o preço da terra, similar ao processo identificado em Colombo, constatou-se o imenso poder estruturador da acessibilidade, que deflagrou a emergência de uma centralidade urbana até então inexistente, expressa por uma valorização da terra da ordem de $1100 \%$. Tal valorização superou inclusive o patamar de $1000 \%$ alcançado pelo Alphaville Graciosa desde sua implantação em 2000, uma localização resultante do deslocamento de camadas de maior rendimento para a periferia de Pinhais, anteriormente citada. Entre as localizações assinaladas na tabela, é a do bairro Weissópolis a de maior valorização. O bairro, apesar da contigüidade à Curitiba, apresentou histórico de preço da terra $30 \%$ mais baixo em relação a outros bairros também contíguos à divisa, em razão de ter sido apropriado por classes de menores rendimentos, tendo inclusive a ocorrência de ocupações irregulares no fundo de vale. Desde a sua integração à RIT, o preço da terra lá valorizou em $1300 \%$. 
Tabela 3.17 - SÃO JOSÉ DOS PINHAIS

EVOLUÇÃO DO PREÇO MÉDIO (R\$/ $\left.\mathrm{m}^{2}\right)$ DE TERRENOS OFERTADOS PARA VENDA, POR BAIRRO, COM A EVOLUÇÃO DE ABRANGÊNCIA DA RIT METROPOLITANA

\begin{tabular}{|c|c|c|c|c|}
\hline BAIRROS & 1996 & 2000 & 2004 & $2009^{*}$ \\
\hline Centro & 69,81 & 158,36 & 196,74 & 797,23 \\
\hline Aristocrata & 27,79 & 65,44 & 125,33 & 384,30 \\
\hline São Domingos & 35,03 & 93,41 & - & 361,92 \\
\hline São Pedro & 67,05 & & & 539,12 \\
\hline Pedro Moro & 22,26 & 67,13 & 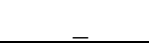 & 307,45 \\
\hline Bom Jesus & 17,87 & 85,65 & - & 257,44 \\
\hline Colônia Rio Grande & & 46,97 & 50,00 & 178,82 \\
\hline Santo Antônio & $\ldots$ & 45,70 & _ & 149,73 \\
\hline Cidade Jardim & 26,85 & 49,70 & 78,13 & 344,10 \\
\hline São Cristóvão & _ & $=$ & - & 504,85 \\
\hline Boneca do Iguaçu & 61,43 & 91,24 & _ & 244,15 \\
\hline Águas Belas & & & - & 142,42 \\
\hline Cruzeiro & 27,96 & 56,73 & - & 413,63 \\
\hline Aeroporto & & 66,93 & - & 96,56 \\
\hline Afonso Pena & 25,30 & 56,04 & 72,53 & 228,28 \\
\hline Aviação & & 78,67 & _ & 286,23 \\
\hline Independência & 21,48 & 37,24 & 36,11 & 185,54 \\
\hline Iná & 36,83 & 56,75 & - & 201,87 \\
\hline Costeira & _ & 34,17 & _ & 213,40 \\
\hline Quissisana & 27,46 & 42,65 & _ & 146,55 \\
\hline Rio Pequeno & $=$ & 13,36 & _ & 115,75 \\
\hline Academia & 10,68 & 30,69 & _ & 51,44 \\
\hline Ipê & 20,45 & 45,02 & 50,00 & 127,31 \\
\hline Guatupê & 16,92 & 17,84 & 113,64 & 101,52 \\
\hline Cristal & $=$ & 21,87 & & 67,88 \\
\hline Borda do Campo & - & 16,34 & 12,10 & 67,26 \\
\hline Dom Rodrigo & 11,41 & 18,23 & $\ldots$ & 39,35 \\
\hline Roseira de São Sebastião & 14,63 & 24,59 & 31,65 & 46,09 \\
\hline Jurema & 13,69 & 22,91 & - & 90,53 \\
\hline Ouro Fino & 55,60 & & - & 115,46 \\
\hline Itália & 13,01 & 80,34 & & 113,89 \\
\hline \multicolumn{5}{|l|}{ Arujá } \\
\hline Barro Preto & & & _ & 56,08 \\
\hline Del Rey & 5,00 & 37,24 & - & 69,40 \\
\hline São Marcos & 8,33 & 23,65 & 60,63 & 147,00 \\
\hline Campina do Taquaral & & 3,10 & & 227,43 \\
\hline Campo Largo da Roseira & & 8,08 & & 41,56 \\
\hline \multicolumn{5}{|c|}{ Fontes: GAZETA DO POVO, INPESPAR e URBS. Elaborado pela autora. } \\
\hline \multirow{4}{*}{$\begin{array}{c}\text { EVOLUČ̃̃O DA } \\
\text { ABRANGÉNCIA DE } \\
\text { ATENDIMENTO DA RIT } \\
\text { METROPOLITANA }\end{array}$} & & \multicolumn{3}{|c|}{ RIT 1996} \\
\hline & & \multicolumn{3}{|c|}{ RIT 2001} \\
\hline & & \multicolumn{3}{|c|}{ RIT 2004} \\
\hline & & \multicolumn{3}{|c|}{ RIT 2009} \\
\hline
\end{tabular}


Em se tratando de São José dos Pinhais, vale relembrar que pela opção de se forçar um desenvolvimento municipal de caráter endógeno, a política adotada em relação à integração metropolitana via RIT foi a de retenção da população no município. Desse modo, em função da abrangência parcial, dos 70 mil passageiros transportados por dia útil em movimento pendular para Curitiba em 2008, 30 mil utilizavam a RIT. Por esse motivo, quando se interpreta a evolução do preço da terra associada à evolução da RIT, verifica-se que a integração física e tarifária abrange inicialmente a região central de São José dos Pinhais, em detrimento dos seus bairros mais populares nas bordas periféricas, atendidos pelas linhas metropolitanas que os conectam ao centro de Curitiba em um ponto determinado - o Terminal Metropolitano do Guadalupe.

Disso decorre que, entre as localizações assinaladas na tabela acima pela expressividade de valorização do preço da terra no período, apenas a do bairro Afonso Pena pertence à tipologia em análise, pela presença do terminal metropolitano. A valorização do preço da terra no período logo após a integração correspondeu a 220\%; ao se considerar o período integral de análise, pode-se dizer que a valorização ocorrida foi de $900 \%$ em treze anos. As demais localizações podem ser categorizadas em duas tipologias: a dos movimentos das classes de maior rendimento promovendo a expansão da área central (bairros Bom Jesus e Cruzeiro); e a dos bairros periféricos em áreas de expansão recente, atreladas aos eixos regionais correspondentes às novas localizações industriais. $\mathrm{Na}$ BR-277, os bairros Guatupê e Borda do Campo, próximos ao distrito industrial RENAULT; e na Av. das Torres (bairro Itália nas imediações do Contorno Leste) e no seu prolongamento, já como BR-376 (bairros Del Rey e São Marcos, este último nas proximidades do distrito industrial Audi-Volkswagen).

Quando se realiza a análise da correlação entre a RIT e o preço da terra entre 1996 e 2009 a partir dos corredores metropolitanos de transporte, outras interpretações se fazem possíveis.

\footnotetext{
"Sendo os transportes intra-urbanos os maiores determinantes das transformações dos pontos, as vias de transportes tem enorme influência não só no arranjo interno das cidades, mas também sobre os diferenciais de expansão urbana." 403
}

A série de tabelas que segue foi organizada para demonstrar o processo de produção dos corredores metropolitanos de transporte integrado enquanto novas

${ }^{403}$ VILLAÇA (1998), p. 79. 
localizações na estrutura intra-urbana, em função do comportamento dos preços entre 1996 e 2009. O paralelismo entre os movimentos de crescente valorização da terra e da expansão de abrangência da RIT verificado nos bairros, vem confirmar a emergência dos corredores enquanto novas localizações intra-urbanas geradas pela expansão da metrópole.

No sentido Curitiba-Colombo, percebe-se que a valorização nos bairros ao longo dos corredores acompanhou o ritmo da expansão da RIT: à gradativa expansão da RIT na Estrada da Ribeira correspondeu uma crescente valorização da terra; na Rodovia da Uva, até pouco tempo fora da área atendida pela RIT, nota-se um movimento de elevação nos preços somente a partir da sua integração à rede.

\begin{tabular}{|c|c|c|c|c|c|c|c|}
\hline \multirow[t]{2}{*}{ Município } & \multirow{2}{*}{$\begin{array}{l}\text { Trecho do } \\
\text { Corredor }\end{array}$} & \multirow{2}{*}{$\begin{array}{c}\text { Bairros } \\
\text { contíguos aos } \\
\text { Corredores da } \\
\text { RIT (do pólo } \\
\text { para a periferia) }\end{array}$} & \multirow{2}{*}{$\begin{array}{l}\text { Terminais } \\
\text { RIT por } \\
\text { Corredor e } \\
\text { por Bairro }\end{array}$} & \multicolumn{4}{|c|}{ Preço da Terra por Bairro $(\mathrm{R} \$$ / m2) } \\
\hline & & & & 2009 & 2004 & 2000 & 1996 \\
\hline \multirow[t]{10}{*}{ Curitiba } & \multirow[t]{4}{*}{$\begin{array}{l}\text { Av. João } \\
\text { Gualberto }\end{array}$} & Centro (Curitiba) & $\begin{array}{l}\text { "Tubos } \\
\text { Centrais" }\end{array}$ & $1.412,98$ & 963,41 & 545,35 & 474,03 \\
\hline & & Centro Cívico & & 875,52 & 379,79 & 199,76 & 258,38 \\
\hline & & Alto da Glória & & $1.096,38$ & 354,50 & 321,85 & 224,72 \\
\hline & & Juvevê & & 851,10 & 309,76 & 286,13 & 217,30 \\
\hline & \multirow[t]{4}{*}{ Av. Paraná } & Cabral & $\begin{array}{c}\text { Terminal } \\
\text { Cabral }\end{array}$ & 870,47 & 316,00 & 262,63 & 150,24 \\
\hline & & Bacacheri & & 484,47 & 224,47 & 129,63 & 85,76 \\
\hline & & Boa Vista & & 454,33 & 173,50 & 106,70 & 72,05 \\
\hline & & Tingui & & 331,66 & 126,24 & 81,22 & 93,62 \\
\hline & \multirow{2}{*}{$\begin{array}{l}\text { Av. Mal. } \\
\text { Mascare- } \\
\text { nhas de } \\
\text { Moraes }\end{array}$} & Santa Cândida & $\begin{array}{l}\text { Terminal } \\
\text { Santa } \\
\text { Cândida } \\
\end{array}$ & 260,91 & 88,42 & 56,51 & 34,18 \\
\hline & & Atuba & & 259,58 & 103,78 & - & 26,58 \\
\hline \multirow[t]{8}{*}{ Colombo } & \multirow{8}{*}{$\begin{array}{l}\text { Estrada da } \\
\text { Ribeira }\end{array}$} & Rio Verde & & - & 74,07 & & 28,80 \\
\hline & & Guarani & & 105,60 & & 52,38 & \\
\hline & & Fátima & & 120,41 & & & \\
\hline & & Maracanã & $\begin{array}{l}\text { Terminal } \\
\text { Maracanã }\end{array}$ & 479,95 & 62,50 & 43,61 & 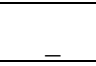 \\
\hline & & Monza & & & - & - & - \\
\hline & & Santa Terezinha & & 216,84 & - & . & 40,00 \\
\hline & & Guaraituba & $\begin{array}{c}\text { Novo } \\
\text { Terminal } \\
\text { (1) }\end{array}$ & 107,57 & & 23,43 & 16,49 \\
\hline & & São Dimas & & 27,27 & 37,75 & 8,98 & 7,00 \\
\hline \multirow{5}{*}{\multicolumn{4}{|c|}{$\begin{array}{l}\text { Fontes: GAZETA DO POVO, INPESPAR e URBS. } \\
\text { Elaborado pela autora. }\end{array}$}} & LEGENDA & & \multicolumn{2}{|c|}{$\begin{array}{c}\text { ALIMENTADORES } \\
\text { METROPOLITANOS }\end{array}$} \\
\hline & & & & & & \multicolumn{2}{|c|}{ RIT 1996} \\
\hline & & & & & & \multicolumn{2}{|c|}{ RIT 2001} \\
\hline & & & & & & \multicolumn{2}{|c|}{ RIT 2004} \\
\hline & & & & & & \multicolumn{2}{|c|}{ RIT 2009} \\
\hline
\end{tabular}




\begin{tabular}{|c|c|c|c|c|c|c|c|}
\hline \multirow[t]{2}{*}{ Município } & \multirow{2}{*}{$\begin{array}{l}\text { Trecho do } \\
\text { Corredor }\end{array}$} & \multirow{2}{*}{$\begin{array}{c}\text { Bairros } \\
\text { contíguos aos } \\
\text { Corredores da } \\
\text { RIT (do pólo } \\
\text { para a periferia) }\end{array}$} & \multirow{2}{*}{$\begin{array}{l}\text { Terminais } \\
\text { RIT por } \\
\text { Corredor e } \\
\text { por Bairro }\end{array}$} & \multicolumn{4}{|c|}{ Preço da Terra por Bairro $(\mathrm{R} \$ / \mathrm{m} 2)$} \\
\hline & & & & 2009 & 2004 & 2000 & 1996 \\
\hline \multirow[t]{9}{*}{ Curitiba } & \multirow[t]{4}{*}{$\begin{array}{l}\text { Av. João } \\
\text { Gualberto }\end{array}$} & Centro (Curitiba) & $\begin{array}{l}\text { "Tubos } \\
\text { Centrais" }\end{array}$ & $1.412,98$ & 963,41 & 545,35 & 474,03 \\
\hline & & Centro Cívico & & 875,52 & 379,79 & 199,76 & 258,38 \\
\hline & & Alto da Glória & & $1.096,38$ & 354,50 & 321,85 & 224,72 \\
\hline & & Juvevê & & 851,10 & 309,76 & 286,13 & 217,30 \\
\hline & \multirow[t]{5}{*}{ Av. Paraná } & Cabral & $\begin{array}{c}\text { Terminal } \\
\text { Cabral }\end{array}$ & 870,47 & 316,00 & 262,63 & 150,24 \\
\hline & & Bacacheri & & 484,47 & 224,47 & 129,63 & 85,76 \\
\hline & & Boa Vista & & 454,33 & 173,50 & 106,70 & 72,05 \\
\hline & & Tingui & & 331,66 & 126,24 & 81,22 & 93,62 \\
\hline & & Santa Cândida & $\begin{array}{l}\text { Terminal } \\
\text { Santa } \\
\text { Cândida }\end{array}$ & 260,91 & 88,42 & 56,51 & 34,18 \\
\hline \multirow[t]{5}{*}{ Colombo } & \multirow[t]{5}{*}{$\begin{array}{l}\text { Rodovia da } \\
\text { Uva }\end{array}$} & Osasco & & 90,45 & 95,82 & 41,21 & 6,29 \\
\hline & & Roça Grande & $\begin{array}{c}\text { Novo } \\
\text { Terminal } \\
(1)\end{array}$ & 83,97 & 37,76 & 32,40 & 14,77 \\
\hline & & Arruda & & 72,12 & & & 6,25 \\
\hline & & Embu & & 55,59 & & & \\
\hline & & $\begin{array}{c}\text { Centro } \\
\text { (Colombo) }\end{array}$ & & 158,00 & 71,32 & 26,44 & 13,44 \\
\hline \multirow{5}{*}{\multicolumn{4}{|c|}{$\begin{array}{l}\text { Fontes: GAZETA DO POVO, INPESPAR e URBS. } \\
\text { Elaborado pela autora. }\end{array}$}} & LEGENDA & & \multicolumn{2}{|c|}{$\begin{array}{l}\text { ALIMENTADORES } \\
\text { METROPOLITANOS }\end{array}$} \\
\hline & & & & & & \multicolumn{2}{|c|}{ RIT 1996} \\
\hline & & & & & & \multicolumn{2}{|c|}{ RIT 2001} \\
\hline & & & & & & \multicolumn{2}{|c|}{ RIT 2004} \\
\hline & & & & & & \multicolumn{2}{|c|}{ RIT 2009} \\
\hline
\end{tabular}

Quanto aos corredores de transporte integrado no sentido Curitiba-Pinhais, deve ser ressaltar que o fato de se transpor o limite entre municípios não se manifesta em queda de preços; ao contrário, percebe-se a continuidade de valorização - seja no corredor da Avenida Irai ou no da Rodovia João Leopoldo Jacomel. Tal fato pode ser associado à distância ao centro principal da metrópole - da ordem de $7 \mathrm{~km}$ - uma vez que os bairros de Pinhais ao longo desses corredores estão mais próximos ao centro valorizado de Curitiba do que muitos dos bairros periféricos situados em Curitiba. Remete-se à isso uma das razões do deslocamento de parcela da população das camadas de alta renda aos condomínios horizontais localizados nas bordas periféricas de Pinhais. 


\begin{tabular}{|c|c|c|c|c|c|c|c|c|}
\hline \multirow{3}{*}{$\begin{array}{l}\text { Corredores } \\
\text { Metropolitanos } \\
\text { da RIT }\end{array}$} & \multicolumn{7}{|c|}{$\begin{array}{l}\text { AV. PRES. AFFONSO CAMARGO / AV. IRAI } \\
\text { AV. VICTOR FERREIRA DO AMARAL / RODOVIA JOÃO LEOPOLDO JACOMEL }\end{array}$} & \\
\hline & \multirow[t]{2}{*}{ Município } & \multirow{2}{*}{$\begin{array}{l}\text { Trecho do } \\
\text { Corredor }\end{array}$} & \multirow{2}{*}{$\begin{array}{l}\text { Bairros } \\
\text { contíguos aos } \\
\text { Corredores da } \\
\text { RIT (do pólo } \\
\text { para a periferia) }\end{array}$} & \multirow{2}{*}{$\begin{array}{l}\text { Terminais } \\
\text { da RIT por } \\
\text { Corredor }\end{array}$} & \multicolumn{4}{|c|}{ Preço da Terra por Bairro } \\
\hline & & & & & 2009 & 2004 & 2000 & 1996 \\
\hline \multirow{10}{*}{$\begin{array}{l}\text { AV. PRES. } \\
\text { AFFONSO } \\
\text { CAMARGO / } \\
\text { AV. IRAI }\end{array}$} & \multirow[t]{5}{*}{ Curitiba } & \multirow{5}{*}{$\begin{array}{l}\text { Av. Pres. } \\
\text { Affonso } \\
\text { Camargo }\end{array}$} & Centro (Curitiba) & $\begin{array}{l}\text { "Tubos } \\
\text { Centrais" }\end{array}$ & $1.412,98$ & 963,41 & 545,35 & 474,03 \\
\hline & & & Cristo Rei & & 717,96 & 308,26 & 344,44 & 123,09 \\
\hline & & & Jardim Botânico & & 679,61 & 248,45 & 152,95 & 134,89 \\
\hline & & & Cajuru & & 371,83 & 106,14 & 81,97 & 64,84 \\
\hline & & & $\begin{array}{l}\text { Capão da } \\
\text { Imbuia }\end{array}$ & $\begin{array}{c}\text { Terminal } \\
\text { Capão da } \\
\text { Imbuia }\end{array}$ & 508,39 & 172,71 & 129,82 & 74,42 \\
\hline & \multirow[t]{5}{*}{ Pinhais } & \multirow[t]{5}{*}{ Av. Iraí } & Estância Pinhais & & 285,34 & 59,40 & 52,16 & 27,08 \\
\hline & & & Weissópolis & & 242,90 & 44,94 & 34,86 & 18,72 \\
\hline & & & Centro (Pinhais) & $\begin{array}{l}\text { Terminal } \\
\text { Pinhais }\end{array}$ & 340,27 & 136,83 & 125,26 & 31,73 \\
\hline & & & Vargem Grande & & 181,96 & 48,17 & 28,10 & 26,74 \\
\hline & & & Maria Antonieta & & 160,78 & & & 34,97 \\
\hline \multirow{10}{*}{$\begin{array}{l}\text { AV. VICTOR } \\
\text { FERREIRA DO } \\
\text { AMARAL / } \\
\text { RODOVIA } \\
\text { JOÃO } \\
\text { LEOPOLDO } \\
\text { JACOMEL }\end{array}$} & \multirow[t]{4}{*}{ Curitiba } & \multirow{2}{*}{$\begin{array}{l}\text { Mal. } \\
\text { Deodoro/ } \\
\text { Rua XV de } \\
\text { Novembro }\end{array}$} & Centro (Curitiba) & $\begin{array}{l}\text { "Tubos } \\
\text { Centrais" }\end{array}$ & $1.412,98$ & 963,41 & 545,35 & 474,03 \\
\hline & & & Alto da XV & & 834,59 & 322,05 & 284,11 & 163,00 \\
\hline & & \multirow{2}{*}{$\begin{array}{l}\text { Av. Victor } \\
\text { Ferreira do } \\
\text { Amaral }\end{array}$} & Tarumã & & 413,80 & 194,77 & 87,67 & 55,52 \\
\hline & & & $\begin{array}{l}\text { Capão da } \\
\text { Imbuia }\end{array}$ & $\begin{array}{l}\text { Terminal } \\
\text { Capão da } \\
\text { Imbuia }\end{array}$ & 508,39 & 172,71 & 129,82 & 74,42 \\
\hline & \multirow[t]{6}{*}{ Pinhais } & \multirow{6}{*}{$\begin{array}{l}\text { Rodovia } \\
\text { João } \\
\text { Leopoldo } \\
\text { Jacomel }\end{array}$} & Estância Pinhais & & 285,34 & 59,40 & 52,16 & 27,08 \\
\hline & & & $\begin{array}{l}\text { Emiliano } \\
\text { Perneta }\end{array}$ & & 321,45 & 90,46 & 54,98 & 34,29 \\
\hline & & & Centro (Pinhais) & $\begin{array}{l}\text { Terminal } \\
\text { Pinhais }\end{array}$ & 340,27 & 136,83 & 125,26 & 31,73 \\
\hline & & & Vila Amélia & & 147,26 & 86,68 & 47,90 & 22,46 \\
\hline & & & Maria Antonieta & & 160,78 & 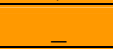 & & 34,97 \\
\hline & & & Vale das Águas & & - & - & 16,99 & 2,61 \\
\hline \multirow{5}{*}{\multicolumn{4}{|c|}{$\begin{array}{l}\text { Fontes: GAZETA DO POVO, INPESPAR e URBS. } \\
\text { Elaborado pela autora. } \\
\text { Nota: }\left(^{*}\right) \text { Bairro integrante da APA do Rio Irai, região de } \\
\text { mananciais. }\end{array}$}} & \multirow{5}{*}{ LEGENDA } & & \multicolumn{3}{|c|}{$\begin{array}{l}\text { ALIMENTADORES } \\
\text { METROPOLITANOS }\end{array}$} \\
\hline & & & & & & & RIT 1996 & \\
\hline & & & & & & & RIT 2001 & \\
\hline & & & & & & & RIT 2004 & \\
\hline & & & & & & & RIT 2009 & \\
\hline
\end{tabular}

Os corredores da RIT no sentido Curitiba - São José dos Pinhais apresentam especificidades em relação aos dos demais municípios estudados, primeiramente devido à condição de integração se dar por uma abrangência parcial. O corredor Av. Mal. Floriano Peixoto - Av. das Américas foi o primeiro a se configurar, pela integração Boqueirão - Centro (SJP) via linha direta, pela necessidade de conectar o subcentro metropolitano ao centro principal da metrópole. Dessa forma, a ampliação da acessibilidade ao pólo suplantava a integração tarifária, uma vez que propiciava a interligação entre localizações intra-urbanas previamente delineadas pela concentração de população de mais alta renda em São José dos Pinhais e em 
Curitiba. Nesse caso, não faz sentido atribuir a valorização do preço da terra às novas condições de acessibilidade via RIT até 2000, pois ela era inerente à expansão da área central de São José dos Pinhais, pela movimentação das classes de maior renda em direção aos bairros contíguos ao Centro. Em 2009 é possível depreender que a valorização segue em direção à Av. Rui Barbosa até o Terminal Afonso Pena.

\begin{tabular}{|c|c|c|c|c|c|c|c|c|}
\hline \multirow{3}{*}{$\begin{array}{l}\text { Corredores } \\
\text { Metropolitanos } \\
\text { da RIT }\end{array}$} & \multicolumn{8}{|c|}{ AV. MAL. FLORIANO PEIXOTO/ AV. DAS AMÉRICAS/ RUA XV DE NOVEMBRO/ AV. RUI BARBOSA } \\
\hline & \multirow[t]{2}{*}{ Município } & \multirow{2}{*}{$\begin{array}{l}\text { Trecho do } \\
\text { Corredor }\end{array}$} & \multirow{2}{*}{$\begin{array}{c}\text { Bairros } \\
\text { contíguos aos } \\
\text { Corredores da } \\
\text { RIT (do pólo } \\
\text { para a periferia) }\end{array}$} & \multirow{2}{*}{$\begin{array}{l}\text { Terminais } \\
\text { da RIT por } \\
\text { Corredor }\end{array}$} & \multicolumn{4}{|c|}{ Preço da Terra por Bairro } \\
\hline & & & & & 2009 & 2004 & 2000 & 1996 \\
\hline \multirow{14}{*}{$\begin{array}{l}\text { AV. MAL. } \\
\text { FLORIANO } \\
\text { PEIXOTO//AV. } \\
\text { DAS AMÉRICAS/ } \\
\text { RUA XV DE } \\
\text { NOVEMBRO/ } \\
\text { AV. RUI } \\
\text { BARBOSA }\end{array}$} & \multirow[t]{7}{*}{ Curitiba } & \multirow{7}{*}{$\begin{array}{l}\text { Av. Mal. } \\
\text { Floriano } \\
\text { Peixoto }\end{array}$} & Centro (Curitiba) & $\begin{array}{l}\text { "Tubos } \\
\text { Centrais" }\end{array}$ & $1.412,98$ & 963,41 & 545,35 & 474,03 \\
\hline & & & Rebouças & & 829,57 & 280,54 & 192,12 & 160,64 \\
\hline & & & Parolin & & 459,04 & 219,64 & 127,63 & 49,05 \\
\hline & & & Prado Velho & & 643,34 & 169,11 & 128,54 & 105,75 \\
\hline & & & Hauer & $\begin{array}{c}\text { Terminal } \\
\text { Hauer }\end{array}$ & 385,75 & 169,07 & 124,17 & 65,14 \\
\hline & & & Boqueirão & $\begin{array}{r}\text { Terminal } \\
\text { do Carmo }\end{array}$ & 348,45 & 115,36 & 81,23 & 50,02 \\
\hline & & & & $\begin{array}{l}\text { Terminal } \\
\text { Boqueirão }\end{array}$ & & & & \\
\hline & \multirow[t]{7}{*}{$\begin{array}{l}\text { São José } \\
\text { dos } \\
\text { Pinhais }\end{array}$} & $\begin{array}{c}\text { Av. das } \\
\text { Américas/ } \\
\text { Rua XV de } \\
\text { Novembro } \\
\end{array}$ & Centro (SJP) & $\begin{array}{l}\text { Terminal } \\
\text { Central }\end{array}$ & 797,23 & 196,74 & 158,36 & 69,81 \\
\hline & & \multirow{6}{*}{$\begin{array}{l}\text { Av. Rui } \\
\text { Barbosa }\end{array}$} & São Cristóvão & & 504,85 & & & 67,05 \\
\hline & & & $\begin{array}{c}\text { Boneca do } \\
\text { Iguaçu }\end{array}$ & & 244,15 & & 91,24 & 61,43 \\
\hline & & & Águas Belas & & 142,42 & & & \\
\hline & & & Aeroporto & & 96,56 & . & 66,93 & 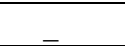 \\
\hline & & & Aviação & & 286,23 & & 78,67 & \\
\hline & & & Afonso Pena & $\begin{array}{l}\text { Terminal } \\
\text { A. Pena }\end{array}$ & 228,28 & 72,53 & 56,04 & 25,30 \\
\hline \multirow{5}{*}{\multicolumn{4}{|c|}{$\begin{array}{l}\text { Fontes: GAZETA DO POVO, INPESPAR e URBS. } \\
\text { Elaborado pela autora. }\end{array}$}} & LEGENDA & & \multicolumn{3}{|c|}{ ALIMENTADORES METROPOLITANOS } \\
\hline & & & & & & \multicolumn{3}{|c|}{$\begin{array}{l}\text { RIT } 1996 \\
\end{array}$} \\
\hline & & & & & & \multirow{2}{*}{\multicolumn{3}{|c|}{$\begin{array}{l}\text { RIT } 2001 \\
\text { RIT } 2004\end{array}$}} \\
\hline & & & & & & & & \\
\hline & & & & & & \multicolumn{3}{|c|}{ RIT 2009} \\
\hline
\end{tabular}

O mais recente corredor da RIT em São José dos Pinhais é o da BR-277 - Av. Rui Barbosa, que veio a complementar a alça de eixos viários que estruturam a cidade, conforme já descrito na leitura dos mapas. Por esse motivo, não chega a atender os bairros que se estendem pela BR-277 além da Av. Rui Barbosa - Guatupê, Cristal, Academia, Roseira, Borda do Campo efetivamente o trecho que concentra a parcela de população mais pobre no município, para a qual a integração física e tarifária da RIT seria indutora da 
transformação desse corredor ainda segregado em uma nova localização, pela inclusão do excluído.

Tabela 3.22 - CORREDORES METROPOLITANOS DA RIT - CURITIBA / SÃO JOSÉ DOS PINHAIS BR-277 / AVENIDA RUI BARBOSA e AVENIDA DAS TORRES / BR-376

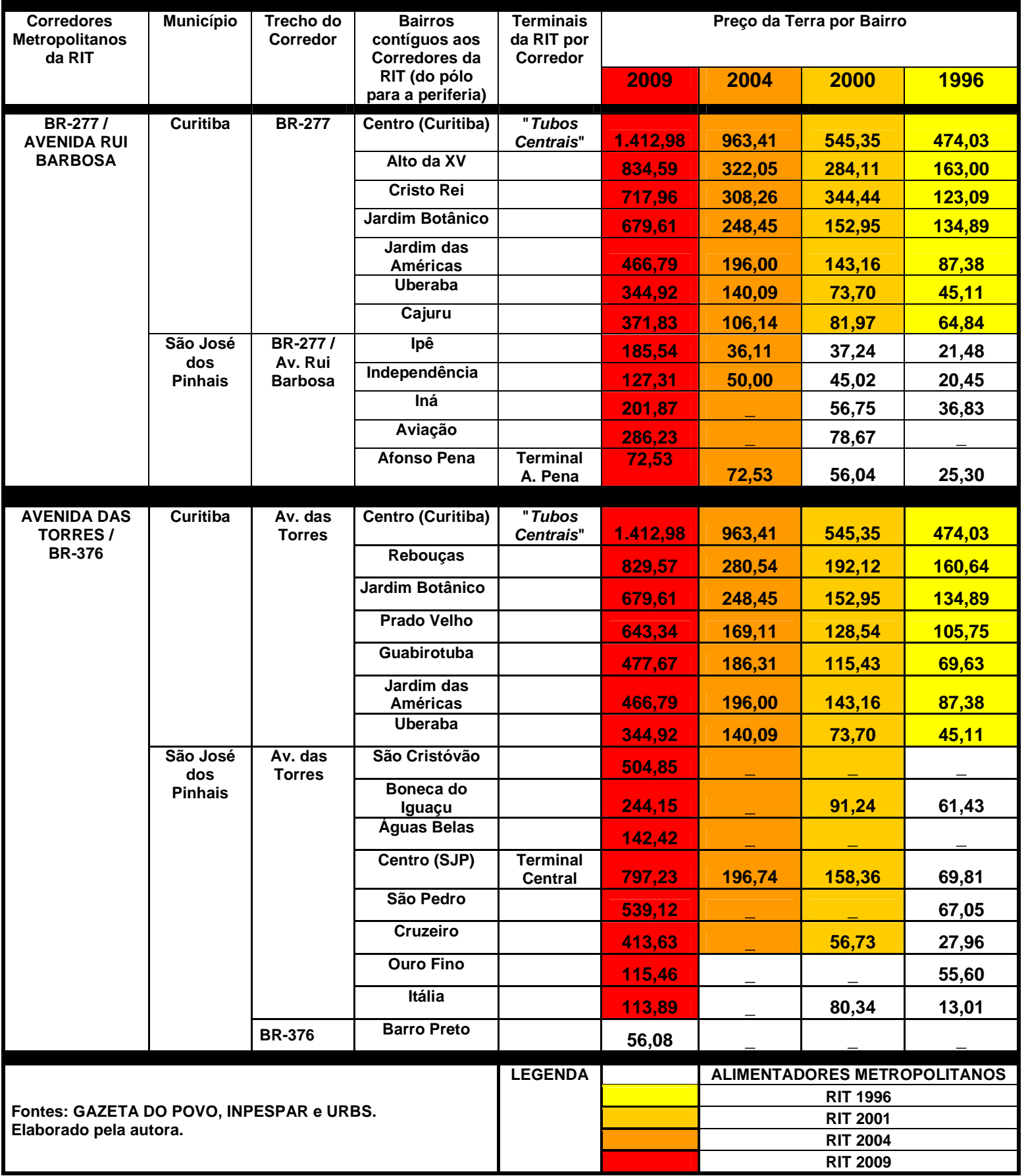

A integração Curitiba - São José dos Pinhais pela Avenida das Torres - BR-376 ao atender aos deslocamentos da população de Curitiba em direção ao Aeroporto Afonso Pena e ao Campus II da Pontifícia Universidade Católica do Paraná. Tal qual o 
corredor que se prolonga da Av. Mal. Floriano Peixoto ao Centro de São José dos Pinhais, apresenta o diferencial de constituir-se como um corredor intra-urbano que se estruturou a partir da polarização da cidade central em relação ao subcentro metropolitano, à medida que tangencia os bairros integrantes da área central valorizada. Portanto, conclui-se daí que a valorização caracterizada pela relação de dependência vinculada à lógica de inclusão do excluído se verifica em parte somente em 2009, como impacto decorrente da última expansão da RIT demandada pela PUCPR, ao incluir na área de atendimento bairros em área de expansão, apropriados por população de baixa e média rendas - Ouro Fino e Itália. A valorização correspondente ao bairro Itália no período $1996-2009$ foi de $875 \%$, para a qual se atribui além da contigüidade ao Contorno Leste e da presença da universidade, o fato de ser atendido agora pela rede integrada de transporte metropolitano.

\section{As novas localizações na Curitiba Metrópole: valores de uso e preço da terra urbana}

Para identificar o momento em que as citadas tipologias de localização emergem enquanto novos valores de uso, vai-se partir das alterações mais significativas ocorridas nos preços da terra no período entre 1996 e 2009, inseridas no contexto geral de alteração da configuração intra-urbana da Curitiba Metrópole. Isto se justifica na medida em que os valores de uso, por sua vez modificados, são traduzidos pelo mercado sob a forma de preços da terra mais elevados. 
Tabela 3.23 - OCORRÊNCIA DE MAIOR PREÇO, MENOR PREÇO E RELAÇÃO ENTRE MAIOR E MENOR PREÇO, POR MUNICÍPIO (1996, 2000, 2004, 2009)

\begin{tabular}{|c|c|c|c|c|c|c|}
\hline MUNICÍPIO & ANO & BAIRRO & $\begin{array}{c}\text { MAIOR } \\
\text { PREÇO } \\
\text { (R/m2) }\end{array}$ & BAIRRO & $\begin{array}{l}\text { MENOR } \\
\text { PREÇO } \\
\text { (R/m2) }\end{array}$ & $\begin{array}{l}\text { MAIOR PREÇO/ } \\
\text { MENOR PREÇO }\end{array}$ \\
\hline \multirow[t]{4}{*}{ Curitiba } & 1996 & Centro & 474,03 & Atuba & 26,58 & 17,8 \\
\hline & 2000 & Centro & 545,35 & Santa Cândida & 56,51 & 9,7 \\
\hline & 2004 & Centro & 963,41 & Santa Cândida & 88,42 & 10,9 \\
\hline & 2009 & Centro & $1.412,98$ & Atuba & 259,58 & 5,4 \\
\hline \multirow[t]{4}{*}{ Colombo } & 1996 & Santa Terezinha & 40,00 & Arruda & 6,25 & 6,4 \\
\hline & 2000 & Atuba & 63,35 & São Dimas & 8,98 & 7,1 \\
\hline & 2004 & Osasco & 95,82 & Colônia Farias & 9,5 & 10,1 \\
\hline & 2009 & Maracanã & 479,95 & Colônia Farias & 18,5 & 25,9 \\
\hline \multirow[t]{4}{*}{ Pinhais } & 1996 & Emiliano Perneta & 34,29 & Vale das Águas & 2,61 & 13,1 \\
\hline & 2000 & Centro & 125,26 & Entre Rios & 11,68 & 10,7 \\
\hline & 2004 & Graciosa & 162,62 & Vale das Nascentes & 24,54 & 6,6 \\
\hline & 2009 & Alto Atuba & 406,68 & Vale das Nascentes & 11,82 & 34,4 \\
\hline \multirow{4}{*}{$\begin{array}{c}\text { São José } \\
\text { dos } \\
\text { Pinhais }\end{array}$} & 1996 & Centro & 69,81 & Del Rey & 5,00 & 14,0 \\
\hline & 2000 & Centro & 158,36 & Campo Largo da Roseira & 8,08 & 19,6 \\
\hline & 2004 & Centro & 196,74 & Borda do Campo & 12,10 & 16,3 \\
\hline & 2009 & Centro & 797,23 & Dom Rodrigo & 39,35 & 20,3 \\
\hline
\end{tabular}

A leitura das ocorrências de maior preço verificadas entre 1996 e 2009 no cone leste indica a rearticulação da estrutura intra-urbana da Curitiba Metrópole, cronologicamente, a partir de valores de uso relacionados (i) às centralidades metropolitanas - em Curitiba o centro principal; em São José dos Pinhais, o subcentro; (ii) à emergência dos corredores metropolitanos de transporte integrado em Colombo e em Pinhais; e (iii) à emergência de bairros nobres na periferia, em Pinhais. Já a leitura dos menores preços vem revelar, em contraponto, as localizações às quais se atribuiu no período os menores valores de uso: em Curitiba, áreas limítrofes ao município dormitório, Colombo; em Colombo e Pinhais, as áreas de expansão recente; e em São José dos Pinhais, as novas áreas industriais e suas adjacências.

Um segundo ponto a destacar vem da observação da relação entre o maior e o menor preço por período de análise. Em Curitiba, se em 1996 o preço mais alto era 17,8 vezes maior que o preço mais baixo, em 2009 essa relação passou para 5,4. Daí decorre a tendência já aventada da homogeneização do preço da terra enfatizada na cidade central. De outro lado, se em Pinhais e São José dos Pinhais a relação entre o preço mais elevado e o mais baixo indicava uma menor diferenciação entre as localizações, hoje revela a presença de processo especulativo, em função da relação ter passado de 13 e 14 vezes, para 34,4 e 20,3 respectivamente. Em Colombo ressalta-se que o índice apresentado em 1996 de 6,4 indicava certa tendência de 
homogeneização - dada pela característica de periferia descolada da área central passa para 25,9 em 2009, demonstrando também aqui a valorização excessiva desencadeada pela especulação imobiliária.

O conceito de especulação imobiliária de acordo com SANTOS - conceito esse também referenciado por Villaça - é o de que

"A especulação imobiliária deriva, em ultima analise, da conjugação de dois movimentos convergentes: a superposição de um sítio social ao sítio natural e a disputa entre atividades ou pessoas por dada localização. $A$ especulação se alimenta dessa dinâmica, que inclui expectativas. Criam-se sítios sociais uma vez que o funcionamento da sociedade urbana transforma seletivamente os lugares, afeiçoando-os às suas exigências funcionais. É assim que certos pontos se tornam mais acessíveis, certas artérias mais atrativas e, também, uns e outras mais valorizados. Por isso, são as atividades mais dinâmicas que se instalam nessas áreas privilegiadas; quanto aos lugares de residência, a lógica é a mesma, com as pessoas de maiores recursos buscando alojar-se onde thes pareça mais conveniente, segundo os cânones de cada época, o que também inclui a moda. É desse modo que as diferentes parcelas da cidade ganham ou perdem valor ao longo do tempo. O planejamento urbano acrescenta um elemento de organização ao mecanismo de mercado. O marketing urbano (das construções e dos terrenos) gera expectativas que influem nos preços". ${ }^{404}$

CAMPOS FILHO alerta sobre os efeitos decorrentes da especulação imobiliária:

"A distorção do espaço urbano provocada pela especulação imobiliária, desequilibrando-o através de áreas centrais congestionadas e periferias rarefeitas, encarece não apenas os serviços urbanos, mas tudo o que é produzido nas cidades: produtos industriais, comércio e serviços. Encarece a mão-de-obra pelo custo de atendimento às necessidades básicas de vida do trabalhador, que exigirá, por exemplo, salário maior para poder pagar mais pelo transporte urbano. $O$ aumento das tarifas não ampliará os lucros do empresário privado, dono da empresa de ônibus urbanos, pois este tem um gasto maior com o congestionamento central e as distâncias maiores percorridas nas periferias das cidades, mas beneficiará, em última instância, o especulador imobiliário que, parasitariamente, provoca uma supervalorização com sua atitude anti-social." " 405

\footnotetext{
${ }^{404}$ SANTOS (1994), p. 96.

${ }^{405}$ CAMPOS FILHO (1989), p. 107.
} 
A análise da relação entre a renda familiar e o preço da terra em Curitiba - para o ano de 2002 - realizada pela COMEC, aponta que em uma estrutura concêntrica, no epicentro estariam os preços altos e as famílias de maior renda; na periferia e porção meridional da RMC estariam as rendas familiares e os preços da terra mais baixos. Intercalada entre eles, uma zona intermediária, caracterizada pela heterogeneidade social, em termos da relação preço da terra e renda, evidenciada nos bairros Boqueirão, Bom Retiro, Xaxim, Novo Mundo, Guaíra e Hauer. Acrescenta ainda a análise que "os preços altos da terra coincidem com as áreas que apresentam maior mobilidade, garantida pela infra-estrutura viária e acessibilidade, ou seja, onde o sistema de transporte coletivo garante, ao longo dos principais eixos de comunicação, tempos menores de deslocamento até o centro." 406

PEREIRA e SILVA, ${ }^{407}$ em estudo sobre a dinâmica do mercado imobiliário formal, colocam que "no período 1970/1994 foram aprovados 89.089 novos lotes na RMC, a grande maioria deles localizados entre sudeste e norte do aglomerado Metropolitano, sendo as décadas de 1970 e 1980 responsáveis por 96,69\% desse total". Em uma pesquisa realizada pelas autoras em 2007, com vistas a caracterizar as especificidades do mercado de lotes formais, identificaram um total de 2.228 terrenos à venda em onze municípios integrantes do aglomerado metropolitano. Aqui foram compilados apenas os dados referentes ao recorte de pesquisa - o cone leste da Curitiba Metrópole, a fim de explicitar a relação entre a oferta de tipologia de parcelamento e o preço médio por município.

Importante salientar que apesar dos lotes ofertados nos municípios conurbados corresponderem aos loteamentos apropriados por classes de menor renda, a oferta de lotes concentra-se nas faixas de tamanho entre 360 a 1500 m2, mais características das décadas de 70 e 80. Quanto à oferta de lotes voltados à habitação de interesse social, cabe dizer que a mesma é praticamente inexistente, o que condiz com a baixíssima produção de lotes no período mais recente na área de estudo, sendo ainda justificada pelas autoras PEREIRA e SILVA, quando colocam a existência de grandes porcentagens de lotes não edificados ainda em 2007. 408

Da observação da valorização mais expressiva do preço da terra e a interrelação com o comportamento da renda nos respectivos bairros, constatou-se que foram distintos os padrões de especulação imobiliária ocorridos nos municípios, dadas

\footnotetext{
${ }^{406}$ COMEC (2006), p. 138-140.

${ }^{407}$ PEREIRA e SILVA (2009), p. 300-304.

${ }^{408}$ PEREIRA e SILVA (2009), p. 301.
} 
as também distintas relações de consumo do direito de propriedade pelas classes sociais.

\begin{tabular}{|c|c|c|c|c|c|c|c|c|c|c|c|}
\hline \multicolumn{12}{|c|}{$\begin{array}{l}\text { Tabela } 3.24 \text { - OFERTA DE TERRENOS À VENDA POR FAIXA DE TAMANHO E } \\
\text { MÉDIA DE PREÇO NO CONE LESTE DA CURITIBA METRÓPOLE (2007) }\end{array}$} \\
\hline \multirow[t]{2}{*}{ MUNICÍPIO } & \multicolumn{2}{|c|}{ TERRENOS À VENDA } & \multicolumn{7}{|c|}{ OFERTAS POR FAIXA DE TAMANHO (m2) } & \multirow{2}{*}{$\begin{array}{c}\text { MÉDIA } \\
\text { DE } \\
\text { PREÇO } \\
\text { (US\$/m2) }\end{array}$} & \multirow{2}{*}{$\begin{array}{c}\text { FAIXA DE } \\
\text { TAMANHO } \\
\text { COM } \\
\text { MAIOR } \\
\text { OFERTA } \\
\text { (m2) }\end{array}$} \\
\hline & $\begin{array}{l}\text { ABSOLUTO } \\
\text { (NÚMERO) }\end{array}$ & $\begin{array}{l}\text { RELATIVO } \\
(\%)\end{array}$ & $\begin{array}{l}\text { Até } \\
125\end{array}$ & $\begin{array}{c}> \\
125 \\
a \\
250\end{array}$ & $\begin{array}{c}> \\
250 \\
a \\
360 \\
\end{array}$ & $\begin{array}{c}> \\
360 \\
a \\
600\end{array}$ & $\begin{array}{c}> \\
600 \\
a \\
1500\end{array}$ & $\begin{array}{c}> \\
1500 \\
a \\
3000\end{array}$ & 3000 & & \\
\hline CURITIBA & 1505 & 67,55 & 15 & 125 & 138 & 456 & 464 & 133 & 174 & 139 & $\begin{array}{l}>360 a \\
600\end{array}$ \\
\hline COLOMBO & 82 & 3,68 & 0 & 7 & 15 & 25 & 21 & 7 & 7 & 31 & $\begin{array}{l}>360 a \\
600\end{array}$ \\
\hline PINHAIS & 65 & 2,92 & 0 & 9 & 0 & 12 & 30 & 5 & 8 & 106 & $\begin{array}{l}>600 a \\
1500\end{array}$ \\
\hline $\begin{array}{l}\text { SÃO JOSÉ DOS } \\
\text { PINHAIS }\end{array}$ & 199 & 8,93 & 5 & 18 & 20 & 88 & 20 & 8 & 40 & 150 & $\begin{array}{c}>600 a \\
1500\end{array}$ \\
\hline $\begin{array}{l}\text { AGLOMERADO } \\
\text { METROPOLITANO }\end{array}$ & 2228 & 100 & 23 & 175 & 273 & 717 & 579 & 169 & 289 & - & - \\
\hline
\end{tabular}

Em Curitiba, em 1996 a maior valorização vinculava-se aos movimentos das classes mais altas no sentido de expandir a área central, associada a um novo vetor de verticalização. Porém, a partir de 2000, as valorizações mais expressivas se deram em duas tipologias de localizações. A primeira delas, ocorrida em função da expectativa do aumento da conexão entre o centro e a periferia, a ser propiciado pelo novo corredor de transporte metropolitano - a Linha Verde, ainda em processo de implantação; a segunda, envolvendo os bairros do anel periférico da cidade, que fazem divisa com os municípios de Colombo, Pinhais e São José dos Pinhais. Na maioria deles, pode-se identificar um padrão de heterogeneidade de renda, indicado pela ocorrência de classes sociais de baixos rendimentos em concomitância com classes médias e altas. Ressalta-se a valorização do bairro Atuba - divisa com Colombo e Pinhais: o preço da terra aumentou da ordem de 10 vezes entre 1996 e 2009. 
Tabela 3.25 - RELAÇÃO ENTRE VALORIZAÇÃO MAIS EXPRESSIVAS DO PREÇO DA TERRA E $O$ MOVIMENTO DAS CLASSES SOCIAIS, EM BAIRROS DE CURITIBA (1996-2009)

\begin{tabular}{|c|c|c|c|c|c|}
\hline \multirow[t]{2}{*}{ Período } & \multirow[t]{2}{*}{ Bairro } & \multirow{2}{*}{$\begin{array}{c}\text { Índice de } \\
\text { Valorização } \\
\text { Preço da } \\
\text { Terra }\end{array}$} & \multicolumn{2}{|c|}{$\begin{array}{l}\text { Comportamento da Renda } \\
\text { (faixas em SM) }\end{array}$} & \multirow[t]{2}{*}{$\begin{array}{l}\text { Relação com novas } \\
\text { localizações }\end{array}$} \\
\hline & & & 1991 & 2000 & \\
\hline $1996-2000$ & Cristo Rei & 2,80 & 5 a 15 & $20 a>30$ & $\begin{array}{l}\text { Nova localização camadas de } \\
\text { alta renda - verticalização }\end{array}$ \\
\hline 2000-2004 & Atuba & 3,90 & $<3$ a 5 & $<3$ a 20 & Divisa Colombo \\
\hline 2004-2009 & Prado Velho & 3,80 & $<3$ a 10 & $<3$ a 20 & Linha Verde \\
\hline \multirow[t]{8}{*}{ 1996-2009 } & Tarumã & 7,45 & 5 a 15 & 5 a 30 & Divisa Pinhais e Linha Verde \\
\hline & Capão da Imbuia & 6,83 & 3 a 10 & 5 a 20 & Divisa Pinhais e Linha Verde \\
\hline & Uberaba & 7,64 & 3 a 10 & $<3$ a 30 & Divisa São José dos Pinhais \\
\hline & Boqueirão & 6,96 & 3 a 10 & 3 a 20 & Divisa São José dos Pinhais \\
\hline & Atuba & 9,76 & $<3$ a 5 & $<3$ a 20 & Divisa Colombo e Linha Verde \\
\hline & Santa Cândida & 7,63 & 3 a 5 & 3 a 15 & Divisa Colombo e Linha Verde \\
\hline & Guabirotuba & 6,86 & 3 a 15 & 5 a 30 & Linha Verde \\
\hline & Parolin & 9,35 & $<3 a>15$ & $<3$ a 30 & Linha Verde \\
\hline
\end{tabular}

Fontes: GAZETA DO POVO, INPESPAR, IBGE Censos 1991 e 2000. Elaborado pela autora.

Permanece a convenção anteriormente estabelecida para facilitação de leitura das tabelas, onde em verde estão assinaladas as camadas sociais de maior renda para o período, e em amarelo, as de menor renda.

No caso de Colombo, as localizações mais valorizadas no período 1996-2000 correspondiam aos bairros limítrofes à Curitiba, revelando a distância ao centro principal como um atributo maior. No período mais recente, de 2004 a 2009, e também no intervalo dos últimos treze anos, fica claro que o aumento da acessibilidade tanto ao centro principal como aos demais pontos da metrópole constituem as localizações mais valorizadas - relativas ao bairro Maracanã, contíguo à Estrada da Ribeira, onde está o Terminal Maracanã. Ao se estabelecer uma correlação com as faixas de renda lá presentes no período, pode-se afirmar que a população de mais baixa renda que lá permaneceu, apropriou-se efetivamente da valorização da terra, valorização esta da ordem de 7,5 vezes em relação a 1996. Os efeitos especulativos advindos da expectativa da conclusão da Linha Verde devem-se manter nos bairros contíguos à Estrada da Ribeira, uma vez que a mesma configura-se como o seu prolongamento. 


\begin{tabular}{|c|c|c|c|c|c|}
\hline \multirow[t]{2}{*}{ Período } & \multirow[t]{2}{*}{ Bairro } & \multirow{2}{*}{$\begin{array}{l}\text { Índice de } \\
\text { Valorização } \\
\text { Preço da } \\
\text { Terra }\end{array}$} & \multicolumn{2}{|c|}{$\begin{array}{l}\text { Comportamento da Renda } \\
\text { (faixas em SM) }\end{array}$} & \multirow[t]{2}{*}{$\begin{array}{l}\text { Relação com novas } \\
\text { localizações }\end{array}$} \\
\hline & & & 1991 & 2000 & \\
\hline $1996-2000$ & Osasco & 2,80 & 3 a 5 & 3 a 5 & Divisa Curitiba \\
\hline 2000-2004 & São Dimas & 3,90 & 3 a 10 & $<3$ a 10 & $\begin{array}{l}\text { Área de Expansão no Eixo } \\
\text { Regional (BR-116), conurbada } \\
\text { ao município de Campina } \\
\text { Grande do Sul } \\
\end{array}$ \\
\hline 2004-2009 & Maracanã & 3,80 & 3 a 5 & 3 a 10 & $\begin{array}{l}\text { Terminal Metropolitano e Linha } \\
\text { Verde }\end{array}$ \\
\hline \multirow[t]{3}{*}{ 1996-2009 } & Osasco & 7,45 & 3 a 5 & 3 a 5 & Divisa Curitiba e Linha Verde \\
\hline & Gabirobal & 6,83 & 3 a 5 & 3 a 5 & Contorno Norte \\
\hline & Maracanã & 7,64 & 3 a 5 & 3 a 10 & $\begin{array}{l}\text { Terminal Metropolitano e Linha } \\
\text { Verde }\end{array}$ \\
\hline
\end{tabular}

Da leitura da valorização ocorrida em Pinhais, cabe dar ênfase à especificidade do seu processo. As novas localizações lá surgidas pós-1996, correspondentes às valorizações mais expressivas em termos de preço da terra, manifestam-se no sentido da sua estruturação urbana, e não mais de um "conjunto de bairros da metrópole". Isto se concretiza pela emergência de um Centro em Pinhais, pela consolidação dos corredores metropolitanos da RIT - que pela proximidade à Curitiba apresentam forte caráter urbano - e pela constituição de bairros nobres, em função da chegada do Alphaville Graciosa e de outros condomínios horizontais, para onde se deslocou parte das camadas de alta renda de Curitiba. A maior valorização no período decorre da estruturação de um bairro popular pelo corredor metropolitano da Av. Irai prolongamento do eixo estrutural leste de Curitiba - onde o preço da terra subiu da ordem de 13 vezes em 13 anos. Em ordem decrescente de valorização figuram os bairros Centro $(10,72)$ e Estância Pinhais $(10,54)$, ambos correlatos à estruturação via corredores metropolitanos da RIT, e em seguida, o bairro Graciosa, correspondente ao Alphaville Graciosa $(10,54)$. 
Tabela 3.27 - RELAÇÃO ENTRE VALORIZAÇÃO MAIS EXPRESSIVAS DO PREÇO DA TERRA E O MOVIMENTO DAS CLASSES SOCIAIS, EM BAIRROS DE PINHAIS (1996-2009)

\begin{tabular}{|c|c|c|c|c|c|}
\hline \multirow[t]{2}{*}{ Período } & \multirow[t]{2}{*}{ Bairro } & \multirow{2}{*}{$\begin{array}{c}\text { Índice de } \\
\text { Valorização } \\
\text { Preço da } \\
\text { Terra }\end{array}$} & \multicolumn{2}{|c|}{$\begin{array}{l}\text { Comportamento da Renda } \\
\text { (faixas em SM) }\end{array}$} & \multirow[t]{2}{*}{$\begin{array}{l}\text { Relação com novas } \\
\text { localizações }\end{array}$} \\
\hline & & & 1991 & 2000 & \\
\hline \multirow[t]{2}{*}{$1996-2000$} & Centro & 3,95 & 10 a 15 & 5 a 20 & Terminal Metropolitano \\
\hline & Vale das Águas & 6,51 & 3 a 5 & 3 a 5 & $\begin{array}{l}\text { Área de Expansão no Eixo } \\
\text { Regional (Rod. João Leopoldo } \\
\text { Jacomel) }\end{array}$ \\
\hline 2000-2004 & Graciosa (*) & 6,10 & $(*)$ & $\left({ }^{*}\right)_{-}$ & $\begin{array}{l}\text { Nova localização camadas de } \\
\text { alta renda - condomínios }\end{array}$ \\
\hline \multirow[t]{2}{*}{ 2004-2009 } & Estância Pinhais & 4,80 & 3 a 10 & 5 a 10 & Divisa Curitiba \\
\hline & Weissópolis & 5,40 & 3 a 10 & 3 a 10 & Divisa Curitiba \\
\hline \multirow[t]{4}{*}{ 1996-2009 } & Weissópolis & 12,98 & 3 a 10 & 3 a 10 & Divisa Curitiba \\
\hline & Centro & 10,72 & 10 a 15 & 5 a 20 & $\begin{array}{l}\text { Terminal Metropolitano e } \\
\text { consolidação da centralidade }\end{array}$ \\
\hline & Estância Pinhais & 10,54 & 3 a 10 & 5 a 10 & Divisa Curitiba \\
\hline & Graciosa & 10,12 & $\left({ }^{*}\right)_{-}$ & $\left(^{*}\right)_{-}$ & $\begin{array}{l}\text { Nova localização camadas de } \\
\text { alta renda - condomínios }\end{array}$ \\
\hline
\end{tabular}

Fontes: GAZETA DO POVO, INPESPAR, IBGE Censos 1991 e 2000. Elaborado pela autora.

Nota: $\left({ }^{* *}\right)$ Alphaville Graciosa implantado em 2000.

Quanto a São José dos Pinhais, deve-se dizer que as maiores valorizações referem-se a bairros populares em dinâmica de expansão mais recente, similar ao ocorrido em Curitiba. Por outro lado, semelhante a Colombo e a Pinhais, os bairros onde a valorização foi maior correspondem aos corredores metropolitanos da RIT mais recentes. Convém relembrar que alguns bairros mais periféricos de São José dos Pinhais estão fora da área de atendimento da RIT. Importante também esclarecer que a maior valorização nesse período dos últimos treze anos em São José dos Pinhais ocorreu no bairro São Marcos - onde o incremento correspondeu a 18 vezes o preço de 1996 - um bairro residencial, em área de expansão próxima à BR-376 e ao setor industrial sul - onde está localizada a montadora AUDI-Volkswagen. A área é caracterizada pela ocorrência de loteamentos populares e também por parcelamento de interesse social, que apesar da descontinuidade da mancha urbanizada, está conectada pelo corredor metropolitano da Av. das Torres, o mesmo pelo qual se acessa o aeroporto Afonso Pena. Uma outra tipologia de localização que despontou no período foi a do bairro Cruzeiro - na qual a valorização atingiu em 2009 o patamar de 15 vezes o preço auferido em 1996 - decorrente da expansão do centro de São José dos Pinhais, apropriada portanto por classes de maior rendimento. 


\begin{tabular}{|c|c|c|c|c|c|}
\hline \multicolumn{6}{|c|}{$\begin{array}{l}\text { Tabela } 3.28 \text { - RELAÇÃO ENTRE VALORIZAÇÃO MAIS EXPRESSIVAŚ DO PREÇO DA TERRA E O } \\
\text { MOVIMENTO DAS CLASSES SOCIAIS, EM BAIRROS DE SÃO JOSÉ DOS PINHAIS (1996-2009) }\end{array}$} \\
\hline \multirow[t]{2}{*}{ Período } & \multirow[t]{2}{*}{ Bairro } & \multirow{2}{*}{$\begin{array}{l}\text { Índice de } \\
\text { Valorização } \\
\text { Preço da } \\
\text { Terra }\end{array}$} & \multicolumn{2}{|c|}{$\begin{array}{l}\text { Comportamento da Renda } \\
\text { (faixas em SM) }\end{array}$} & \multirow[t]{2}{*}{$\begin{array}{l}\text { Relação com novas } \\
\text { localizações }\end{array}$} \\
\hline & & & 1991 & 2000 & \\
\hline \multirow[t]{2}{*}{$1996-2000$} & Itália & 6,18 & 3 a 10 & 3 a 10 & $\begin{array}{l}\text { Área de Expansão e Contorno } \\
\text { Leste }\end{array}$ \\
\hline & Del Rey & 7,45 & $\left({ }^{*}\right)_{-}$ & $\left({ }^{*}\right)_{-}$ & $\begin{array}{l}\text { Área de Expansão e Contorno } \\
\text { Leste }\end{array}$ \\
\hline $2000-2004$ & Guatupê & 6,37 & 3 a 5 & $<3$ a 10 & $\begin{array}{l}\text { BR-277 / Proximidade Distrito } \\
\text { Industrial Renault }\end{array}$ \\
\hline 2004-2009 & Borda do Campo & 5,56 & $<3$ a 10 & $<3$ a 10 & $\begin{array}{l}\text { BR-277 / Proximidade Distrito } \\
\text { Industrial Renault }\end{array}$ \\
\hline \multirow[t]{5}{*}{ 1996-2009 } & São Marcos & 17,65 & 3 a 5 & $<3$ a 10 & $\begin{array}{l}\text { BR-376 / Proximidade Distrito } \\
\text { Industrial AUDI-Volkswagen }\end{array}$ \\
\hline & Cruzeiro & 14,79 & 3 a 10 & 3 a 30 & $\begin{array}{l}\text { Nova localização camadas de } \\
\text { alta renda_Av. Torres / } \\
\text { Aeroporto-Expansão do Centro } \\
\text { de SJP }\end{array}$ \\
\hline & Bom Jesus & 14,41 & 5 a 10 & 5 a 10 & Expansão do Centro de SJP \\
\hline & Del Rey & 13,88 & $\left({ }^{*}\right)_{-}$ & $\left({ }^{*}\right)_{-}$ & $\begin{array}{l}\text { Área de Expansão e Contorno } \\
\text { Leste }\end{array}$ \\
\hline & Afonso Pena & 9,02 & 5 a 15 & 5 a 15 & $\begin{array}{l}\text { Av. Rui Barbosa e Proximidade } \\
\text { Terminal Urbano/ Metropolitano }\end{array}$ \\
\hline \multicolumn{6}{|c|}{ Fontes: GAZETA DO POVO, INPESPAR, IBGE Censos 1991 e 2000. Elaborado pela autora. } \\
\hline \multicolumn{6}{|c|}{ Nota: $\left(^{*}\right)$ Censos 1991 e 2000 não apresentam dados de renda para o Bairro Del Rey } \\
\hline
\end{tabular}

\section{Uma síntese das novas localizações produzidas na Curitiba Metrópole}

A categorização das localizações referentes ao recente processo de produção e apropriação do espaço na Curitiba Metrópole por tipologias contribuiu sobremaneira para a síntese desta pesquisa. Desse modo, o mapa que segue contém a espacialização das tipologias de localizações produzidas no cone leste entre 19962009, relacionadas à expansão da metrópole a partir da lógica de inclusão do excluído.

Os gráficos que o acompanham abarcam o conjunto de tipologias das novas localizações produzidas. O primeiro deles objetiva ilustrar por meio da evolução do preço da terra, quais as localizações que mais valorizaram no cone leste entre $1996 \mathrm{e}$ 2009, a partir dos bairros. O segundo gráfico, além de indicar a valorização que as novas tipologias de localizações apresentaram no período, pretende demonstrar quais as classes sociais que se apropriaram dessas novas tipologias de localizações, pela verificação da permanência das faixas de renda entre 1991 e 2000, ou pela sua substituição. 


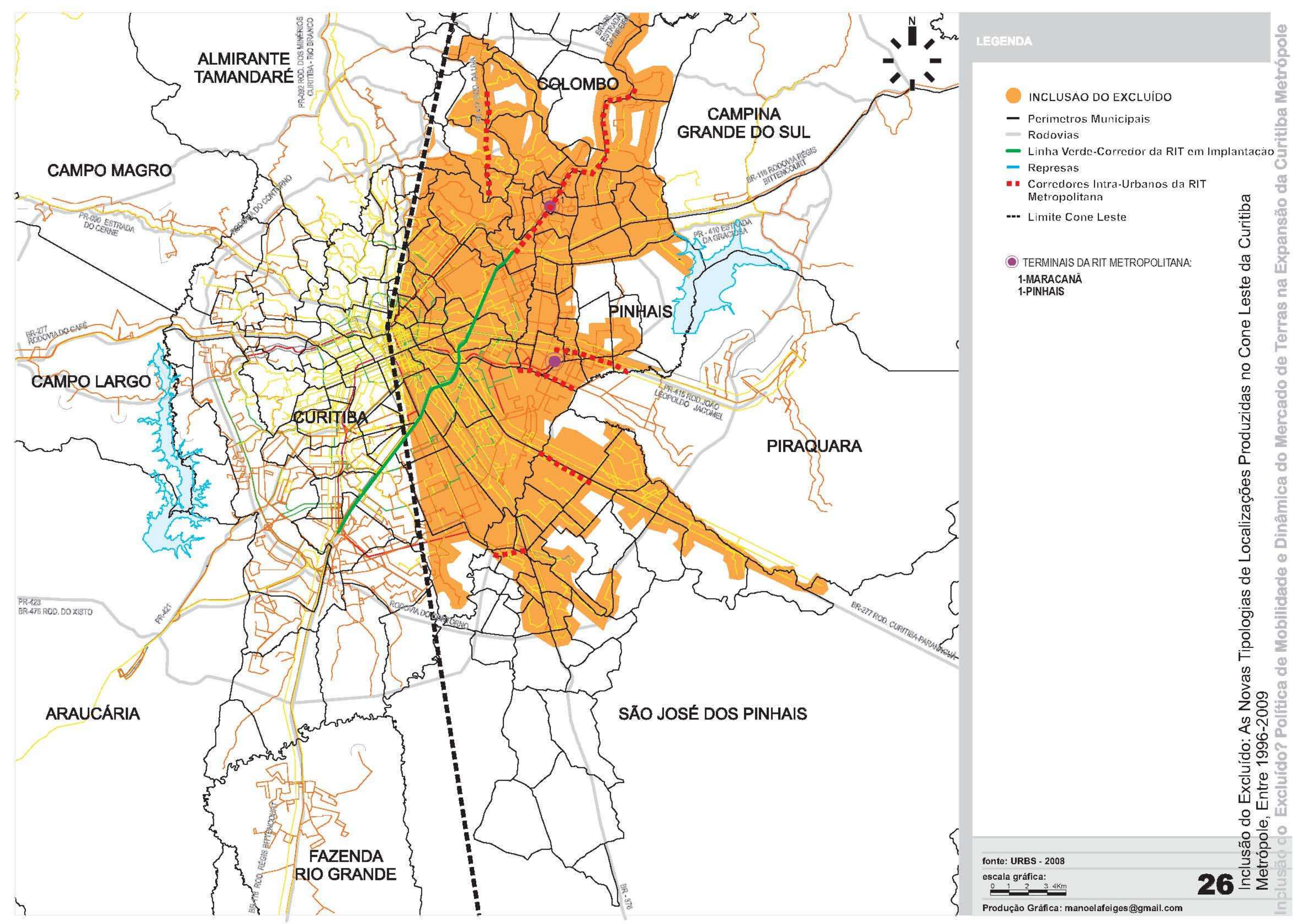



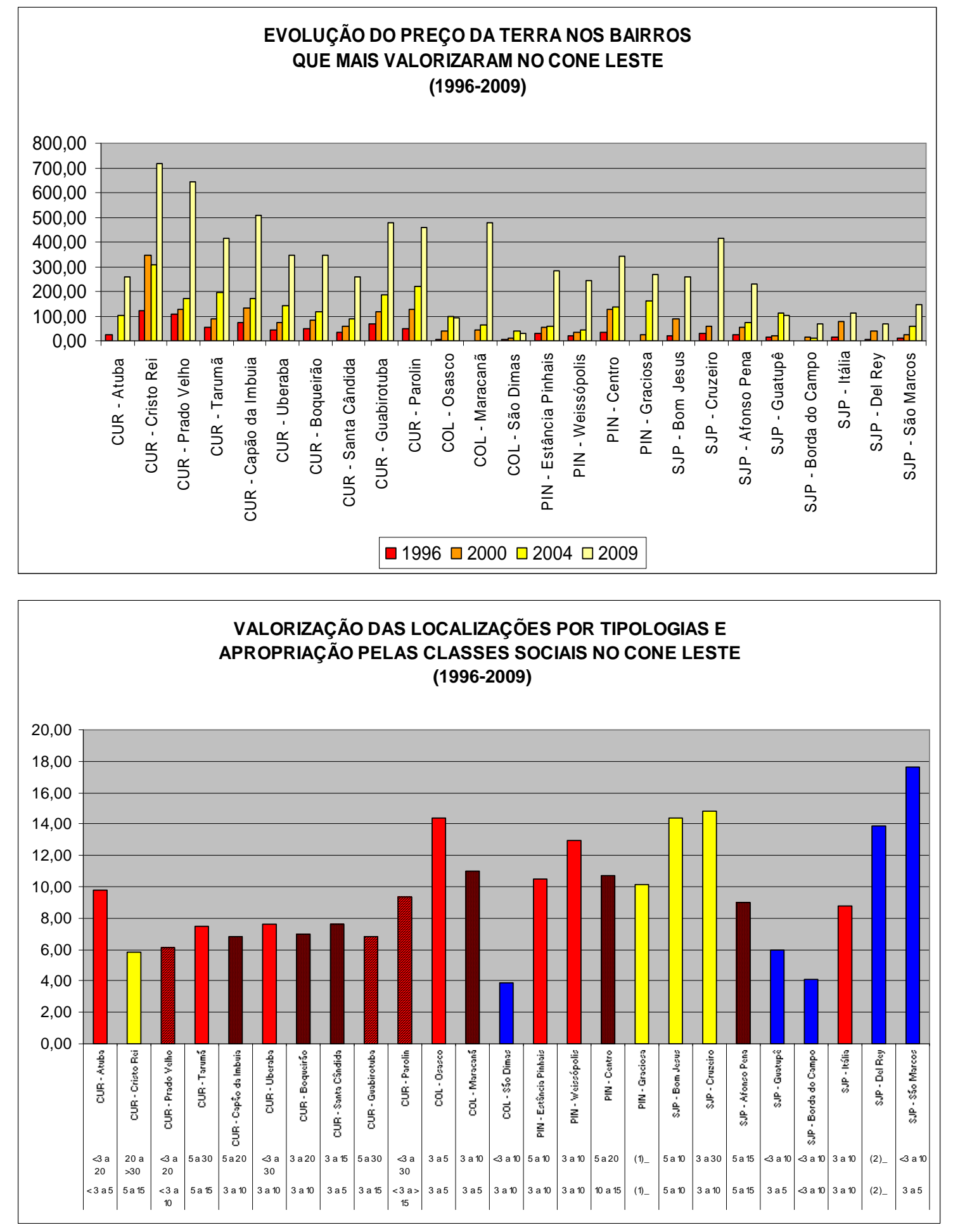

\begin{tabular}{|c|c|}
\hline \multirow{5}{*}{$\begin{array}{l}\text { TIPOLOGIAS DE LOCALIZAÇÕES MAIS } \\
\text { VALORIZADAS NO CONE LESTE }\end{array}$} & MOVIMENTAÇÃO CAMADAS DE ALTA RENDA \\
\hline & BAIRROS POPULARES EM ÁREAS DE EXPANSÃO \\
\hline & CORREDORES DA RIT METROPOLITANA \\
\hline & CORREDOR RIT EM IMPLANTAÇÃO - LINHA VERDE \\
\hline & TERMINAIS DA RIT METROPOLITANA \\
\hline
\end{tabular}


A visualização do conjunto das novas tipologias de localizações produzidas conduziu aos seguintes resultados:

(i) apesar da clareza dos movimentos de expansão das camadas de mais alta renda, tanto nas áreas centrais de Curitiba (Cristo Rei) e de São José dos Pinhais (Bom Jesus e Cruzeiro), como dos seus deslocamentos em direção à periferia em Pinhais (Graciosa), a grande maioria das novas localizações produzidas refere-se ao conjunto de tipologias relativas aos corredores metropolitanos de transporte da RIT e dos bairros onde se localizam os terminais de integração metropolitana, tipologias que caracterizaram o processo de expansão pela lógica de inclusão do excluído;

(ii) fica mais do que evidente a presença de especulação imobiliária ao longo da Linha Verde - a nova localização produzida a partir da reificação da metrópole - cuja tipologia associa funções de corredor metropolitano de transporte e de adensamento - face ao elevado potencial construtivo e à possibilidade de verticalização; em seus bairros contíguos já se verifica a tendência de apropriação por camadas de maiores rendimentos;

(iii) no conjunto das tipologias, as localizações que apresentaram as valorizações mais expressivas - onde o incremento no preço da terra em 2009 atingiu patamares entre 14 a 18 vezes o preço de 1996 caracterizam-se pela dinâmica recente de produção de lotes voltados a interesse social, produto mais do que escasso na região. Remete-se portanto à situação da escassez o caráter especulativo dos preços, constatado a partir do distanciamento dos reais valores de uso, do que vem decorrendo a sua distorcida apropriação por camadas de rendimento mediano;

(iv) as tipologias referentes aos corredores metropolitanos de transporte e aos bairros contemplados pelos terminais metropolitanos efetivamente se confirmam como o conjunto de localizações que exprime a nova lógica da expansão na Curitiba Metrópole, a da inclusão do excluído: a constatação de que as classes de baixa renda presentes nos bairros populares de Colombo, Pinhais e São José dos Pinhais no período que antecedeu à RIT, lá permaneceram ou pouco se alteraram quando do aumento da acessibilidade pós-RIT, aponta com toda a clareza a inversão no movimento de exclusão - intrínseco à valorização da terra urbana anteriormente verificado pela substituição das classes sociais em direção à crescente periferia. 


\section{CAPÍTULO 4}

\section{A INCLUSÃO DO EXCLUÍDO: UMA NOVA LEITURA DA EXPANSÃO URBANA NA CURITIBA METRÓPOLE}

Após a realização da pesquisa, cabe a pergunta: em que medida a tese aqui proposta se confirma? Essas últimas páginas serão dedicadas a respondê-la, a partir da retomada das hipóteses formuladas inicialmente, aqui reapresentadas:

A integração física da metrópole via rede integrada de transporte constitui-se como a base de sustentação da Curitiba Metrópole, pois ao satisfazer a relação clássica entre habitação e trabalho mediante o movimento pendular, favorece a diminuição do custo da reprodução da força de trabalho e da reprodução do capital;

Contraditoriamente, os constantes investimentos em transporte coletivo na cidade central da metrópole, de um lado, conduziram à segmentação do território e à exclusão decorrente do movimento de valorização da terra, e de outro, propiciaram a sustentação das sucessivas ideologias de planejamento a Curitiba Planejada e a Capital Ecológica - promovendo assim a manutenção do poder do Estado e dos interesses da sociedade de elite;

A integração metropolitana alcançada com a RIT - rede integrada de transporte - ao conferir o acesso à terra ao cidadão excluído, dele obteve a legitimação da nova ideologia atrelada à qualidade de vida e a disseminação do discurso de pertencimento à Capital Ecológica, apesar da visibilidade do conjunto de demandas ainda reprimidas.

A ideologia da Capital Ecológica vem apregoando, desde o início dos anos noventa, a qualidade de vida advinda do planejamento urbano - associada ao verde e ao transporte coletivo, ícone maior do planejamento urbano em Curitiba - e também o imperativo do cidadão pertencer ao seu lugar. Todavia, o território da Capital Ecológica se constitui apenas do centro de uma metrópole segmentada, na qual a periferia se encontra bastante descolada da apregoada qualidade de vida, assim portanto excluída. 
A Capital Ecológica vem a ser, na verdade, a reificação da ideologia de planejamento anterior - a da Curitiba Planejada dos anos setenta e oitenta, que privilegiava o transporte coletivo sobre o individual - e que, ao ser exaltada pelo marketing urbano, alcançou a visibilidade necessária à atração de investimentos voltados à produção. Desse modo, o empresariamento urbano logrou êxito e, com ele, mais uma vez o planejamento - dessa vez dito estratégico, porém em nenhum momento participativo - passa a ser glorificado.

A contradição maior que se instala nesse momento é a de que, a população da periferia metropolitana segmentada, tal qual a da cidade central, passa a legitimar a ideologia da Capital Ecológica. Porém, as razões que conduziram essas "duas curitibas" a legitimar a nova ideologia, são realmente, o que as diferem.

$\mathrm{Na}$ cidade central, a Capital Ecológica é marcada pela renovação da imagem associada a uma nova geração de ícones urbanos. Destacam-se entre eles uma coleção de novos parques urbanos e de espaços culturais, que na verdade acabam por acarretar a produção de uma série de novas localizações urbanas. A qualidade de vida materializada por meio de tais ícones, além de inserir o território na rede de cidades efetivamente industrializadas - destaque-se aí a vinda maciça das indústrias automobilísticas - alcança também a visibilidade necessária para a atração de capital de um terciário superior, que ao reforçar a imagem de uma metrópole progressista, teve como impacto a produção de uma série de novas localizações na cidade central, das quais resultaram a movimentação e os deslocamentos das elites em razão de novos valores de uso gerados, a partir da dinamização de atuação do mercado imobiliário. Assim, a terra mais valorizada na cidade central agrava a exclusão na periferia segmentada, sob um movimento que reproduz a lógica classista centroperiferia, movimento esse que caracteriza a própria metrópole.

No contraponto à cidade central, os investimentos do Estado na periferia metropolitana vinham sendo maciçamente dirigidos à oferta de condições gerais de produção - no tocante à acessibilidade e mobilidade regionais, materializadas primeiramente pelo Contorno Leste; seguidos da infra-estrutura para os novos distritos industriais automobilísticos. Como conseqüência, na medida em que emergem novas localizações - sejam as áreas industriais, sejam os eixos logísticos - altera-se também a estrutura intra-urbana, que agora atinge efetivamente à escala de metrópole. 
Mesmo a atuação do Estado voltada aos meios de consumo coletivo na periferia segmentada estando restrita a normativas de proteção aos mananciais, a Capital Ecológica se concretiza para o cidadão metropolitano a reboque da expansão da rede integrada de transporte - a RIT metropolitana. Desse modo, a acessibilidade à metrópole deriva da ampliação efetiva da acessibilidade urbana, do que vem a emergir o pertencimento. A política de mobilidade urbana inclusiva, além da gama de possibilidades de deslocamentos no território da Curitiba Metrópole - a integração física - traz também a integração tarifária. Os custos das distâncias mais longas são subsidiados pelos custos das distâncias mais curtas e, com uma única passagem, pode-se circular dentro do sistema durante o dia todo.

Decorre que da industrialização recente e da dinamização do setor de comércio e serviços, a expansão do trabalho assalariado com carteira assinada é constatado pelo crescimento de $25,9 \%$ para os empregados e de $65 \%$ para trabalhadores domésticos. Isso se deve em grande parte à pendularidade propiciada pela rede integrada de transporte, na qual a dimensão da inclusão pode ser traduzida por meio da proporção de usuários da RIT metropolitana que realiza movimento pendular por motivo de trabalho: hoje equivalente a um terço do total dos usuários. Em termos de gestão da metrópole a integração tarifária, apesar de sua lógica de compensação interna, demanda subsídios por parte da Prefeitura Municipal de Curitiba. Esse subsídio, recentemente ampliado com a tarifa domingueira de $\mathrm{R} \$ 1,00$ (um real), na medida em que possibilita também os deslocamentos voltados ao lazer, potencializa o sentimento de pertencimento do cidadão metropolitano, que agora passa a usufruir, ou melhor, consumir as emblemáticas localizações da capital ecológica - os parques urbanos, o verde, símbolo mais divulgado da "qualidade de vida", até então apropriadas apenas pelas classes de média e alta rendas.

Diante do exposto, advém o conceito que aqui se propõe - o da expansão urbana pela lógica de inclusão do excluído, especificidade da Curitiba Metrópole - um conceito ao mesmo tempo sociológico e econômico, mas que só pôde ser apreendido pela relação espaço-tempo contida na mobilidade intra-urbana.

A nova lógica de expansão urbana oportunizou ao cidadão metropolitano a mobilidade social, atrelada à política de mobilidade urbana inclusiva. A mobilidade urbana associada primeiramente à expansão da empregabilidade na cidade central, é seguida do incremento de renda em relação aos empregos ofertados no município de moradia. Mais do que isso, o caráter redistributivo da criação das múltiplas localizações na periferia oportunizou, por sua vez, o consumo da própria localização produzida. O cidadão até então excluído - fosse ele refém do movimento de expulsão intrínseco valorização fundiária ou migrante em busca de emprego - passa portanto à 
condição de consumidor dos novos valores de uso da terra urbana produzidos socialmente. Em função da regularidade e da eficiência do sistema de transporte, tem agora um maior domínio sobre o tempo dos seus deslocamentos, o que em última instância, incrementa substancialmente os níveis de qualidade de vida. Diante de tudo isso, pertencer à metrópole significa agora pertencer também ao seu bairro: a acessibilidade via RIT transformou os bairros populares segmentados em múltiplas localizações intra-urbanas. Como impacto associado, formam-se novas centralidades metropolitanas pela concentração de comércio e serviços, geralmente motivadas pela presença de terminais de transporte ou em maior escala ao longo dos eixos viários intra-urbanos, o que vem reafirmar o poder estruturador atribuído ao transporte coletivo. Assim, a legitimação da Capital Ecológica pelas classes de menor renda da periferia adveio da ação do Estado em promover as condições de reprodução da força de trabalho pela oferta de um dos meios de consumo coletivo, qual seja, o do transporte integrado. Cabe neste momento uma inserção complementar sobre a dialética entre Estado e mercado: quando de um lado, o Estado é chamado a cobrir os custos das condições gerais de reprodução da força de trabalho, de outro, o mercado força para pagar salários menores; porém, por essa relação não se constituir como objeto desta pesquisa, sugere-se aqui a sua investigação.

Inclusão do excluído é também um conceito econômico, primeiramente porque o acesso à metrópole ao se dar pelo transporte integrado não só fisicamente, mas também por uma tarifa única, viabiliza a redução de gastos com deslocamentos da ordem de 50\%, considerada a situação de não integração, onde havia o custo de pelo menos duas passagens por deslocamento. Em um segundo momento, a inclusão assume a sua maior proporção, quando o acesso à metrópole se traduz por um incremento na renda, condicionada de um lado pela expansão da empregabilidade na cidade central - representando a extensão das relações capitalistas - e de outro pelo efetivo incremento salarial relativo ao emprego em Curitiba, da ordem de 2 a 4 SM em relação à situação de emprego no mesmo município de moradia, viabilizando assim a sempre almejada mobilidade social. Um terceiro ponto, pelo qual a mobilidade social não só barra o movimento de exclusão pela constante valorização da terra, mas também o reverte, agora pela possibilidade do cidadão da periferia da metrópole capturar a valorização imobiliária da nova localização produzida, a do bairro periférico estruturado pela RIT. Em quarto lugar, a inclusão do excluído é também um conceito econômico quando a inclusão se verifica sob um fenômeno constatado no período mais recente, o da homogeneização dos preços da terra, gerada pelo efeito de homogeneização da acessibilidade na Curitiba Metrópole, que consiste na redução dos intervalos de preço entre as novas localizações produzidas na periferia e as 
localizações mais privilegiadas. Faz-se importante ressaltar que a homogeneização dos preços ocorre exatamente em um momento de dinamização do mercado imobiliário - estagnado desde a saída de investimentos recém alocados do setor automobilístico (Chrysler) - agora então reaquecido pela drenagem de capital imobiliário de circuitos externos - mais fortemente o de São Paulo - do que decorreu a elevação generalizada do conjunto de preços homogeneizados. Isto vem indicar a emergência de um movimento de caráter especulativo, impulsionado pelo mercado imobiliário no sentido de tentar incorporar a lucratividade advinda da terra, em detrimento do seu proprietário. Em última instância, a homogeneização de preços da terra oportuniza ao cidadão metropolitano, pela apropriação do valor de troca da sua localização, a possibilidade de transferência do seu local de moradia para mais perto da área central, passando a assumir desta forma, um maior controle sobre o tempo dos seus deslocamentos. 


\section{REFERÊNCIAS}

AGLIETTA, Michel. Fases da expansão capitalista nos Estados Unidos da América.

Espaço e Debates, n. 28, São Paulo,1989.

BLANCO, Mirian. Curitiba: da cautela ao crescimento. Empresas locais foram mais conservadoras no boom imobiliário e agora sentem pouco o desaquecimento. [online] Disponível na internet via WWW. PINI WEB, URL:http://revista.construcaomercado.com.br/negocios-incorporacaoconstrucao/93/curitiba-da-cautela-ao-crescimento-empresas-locais-foram-mais-1302851.asp. Acesso em março de 2010.

BONDUKI, Nabil; SANTORO, Paula Freire. O desafio do parcelamento do solo a partir do periurbano: a composição do preço da terra na mudança de uso do solo rural para urbano. In XIII Encontro da Associação Nacional de Pós-Graduação e Pesquisa em Planejamento Urbano e Regional. Florianópolis: Anais, 2009.

CALDEIRA, T. P. do R. Cidade dos Muros. Crime, segregação e cidadania em São Paulo. São Paulo: Ed. Edusp, 2000.

CAMPOS FILHO, C. M. Cidades brasileiras: seu controle ou o caos. São Paulo: Nobel, 1989. (Coleção Cidade Aberta).

CASTELLS, Manuel. O poder da identidade. São Paulo: Paz e Terra, 1999. (A era da informação: economia, sociedade e cultura; v. 2).

CASTELLS, Manuel. A questão urbana. São Paulo: Paz e Terra, 2000.

COMEC. Plano de Desenvolvimento Integrado da Região Metropolitana de Curitiba. Curitiba, 2006.

COMEC. GEOPROCESSAMENTO. Mapas temáticos da Região Metropolitana de Curitiba: Plano de Desenvolvimento Integrado. Curitiba: COMEC, 2000.

COMEC. Plano de Desenvolvimento Integrado da Região Metropolitana de Curitiba Documento para discussão. Curitiba, 2002.

COMEC. Metrópolis em Revista. Ano 01, №. 01, dez. - 1999.

CURITIBA. PREFEITURA MUNICIPAL DE CURITIBA. Curitiba, na prática. Curitiba: IPPUC, 2002. 
DÉAK, Csaba. Acumulação entravada no Brasil e a crise dos anos 80. In: DÉAK, C.;

SCHIFFER, S. (orgs). O processo de urbanização no Brasil. São Paulo: EDUSP, 1999.

Elementos de uma política de transportes para São Paulo. In: DÉAK, C.;

SCHIFFER, S. (orgs). O processo de urbanização no Brasil. São Paulo: EDUSP, 1999.

O mercado e o Estado na organização espacial da produção capitalista. Espaço e

Debates, n. 28, São Paulo,1989.

DESCHAMPS, Marley Vanice; CINTRA, Anael. Movimento pendular para trabalho na região metropolitana de Curitiba: uma análise das características de quem sai e quem fica. In XVI Encontro Brasileiro de Estudos Populacionais. Caxambu, MG: Anais, 2008.

Vulnerabilidade socioambiental na Região Metropolitana de Curitiba. Curitiba, 2004. Tese (Doutorado em Meio Ambiente e Desenvolvimento). UFPR.

Divisão Socioespacial e Fluxos Migratórios na Região Metropolitana

de Curitiba na Década de 80. Trabalho apresentado no XIII Encontro da Associação Brasileira de Estudos Populacionais, realizado em Ouro Preto, Minas Gerais, Brasil, novembro de 2002.

DOWALL, David. BRASIL's urban land and housing markets: how well are they working? Institute of Urban and Regional Development. University of California, Berkeley. Working Paper 2006-08.

FIRKOWSKI, O.L.C. A Nova Territorialidade da Indústria e o Aglomerado Metropolitano de Curitiba. São Paulo, 2001. 260 f. Tese (Doutorado em Geografia) Programa de PósGraduação em Geografia Humana, Faculdade de Filosofia, Letras e Ciências Humanas, Universidade de São Paulo.

GARCIA, Fernanda Ester Sánchez. Cidade espetáculo: política, planejamento e city marketing. Curitiba: Palavra, 1997.

GOTTDIENNER, Mark. A produção social do espaço urbano. São Paulo: EDUSP, 1997.

GROSTEIN, M. D. Metrópole e expansão urbana: a persistência de processos "insustentáveis". São Paulo em Perspectiva. vol.15 no.1 São Paulo Jan./Mar. 2001. 
GUNN, P. A mídia na guerra dos lugares. A experiência tucana no Ceará. In: DÉAK, C.;

SCHIFFER, S. (orgs). O processo de urbanização no Brasil. São Paulo: EDUSP, 1999.

HABERT, Nadine. A década de 70: Apogeu e crise da ditadura militar. $3^{a}$. ed. São Paulo: Ática, 1996.

HARVEY, David. Wall Street e o direito à cidade. Entrevista publicada em Le Monde Diplomatique Brasil, março 2009.

A produção capitalista do espaço. São Paulo: Annablume, 2005.

Condição pós-moderna. São Paulo: Edições Loyola, 1992.

A justiça social e a cidade. São Paulo: Hucitec, 1980.

IPPUC. [online] http//: www.ippuc.org.br, acessado em dezembro de 2009.

IPPUC. Revista Espaço Urbano. №3. Curitiba, jan. 2003.

IPPUC. GEOPROCESSAMENTO. Mapas Temáticos de Curitiba. Curitiba: IPPUC, 2002.

IPPUC. PREFEITURA MUNICIPAL DE CURITIBA. Curitiba, na prática. Curitiba: IPPUC, 2002.

Memória da Curitiba Urbana: v.8. Curitiba, ene. 1992. Edición Especial. Escuela de Urbanismo Ecológico.

Memória da Curitiba Urbana: Depoimentos 6. Curitiba, abr. 1991. (E. Sganzerla, E. Gomes, K. Rischbieter, C. Taniguchi, H. Trevisan e outros).

Memória da Curitiba Urbana: Depoimentos 2. Curitiba, fev. 1990. (C. Lunardi, R. Dely, C. Ceneviva)

Memória da Curitiba Urbana: Depoimentos 1. Curitiba, nov. 1989. (Ivo Arzua Pereira)

JORGE, Wilson Edson. O conceito de Estado - síntese das teorias formuladas por Machiavel, Lenin, Gramsci, Weber. Sinopses, n. 8, São Paulo, 1985. 
JORGE, Wilson Edson; SALGADO, Elizabeth Carvalho de Oliveira. Alterações na estrutura urbana da região metropolitana de São Paulo.Pós - Revista do Programa de PósGraduação em Arquitetura e Urbanismo FAUUSP, n. 6, São Paulo, 1996.

KLEINKE, Maria de Lourdes Urban, DESCHAMPS, Marley Vanice; MOURA, Rosa; Movimento migratório do Paraná (1986-91 e 1991-96) origens distintas e destinos convergentes. Paraná Desenvolvimento, n.95, p.27-50. Curitiba, 1999.

KOWARICK, Lúcio. Espoliação urbana, lutas sociais e cidadania: fatias de nossa história recente. Espaço e Debates, n. 40, São Paulo,1997.

LAGO, L. C. do. O que há de novo na clássica núcleo-periferia: a metrópole do Rio de Janeiro. In: RIBEIRO, Luiz César de Queiroz (org.) O futuro da metrópoles: desigualdades e governabilidade.. Rio de Janeiro: Editora Revan, FASE: 2000. p. 207- 228.

LAMPARELLI, Celso. As entidades espaciais: território e poder. Versão preliminar. São Paulo: IEA USP, 1988.

LEFEBVRE, Henri. A revolução urbana. Belo Horizonte: Ed. UFMG, 1999.

LEITÃO, Sylvia Ramos. O discurso do planejamento urbano em Curitiba: um enigma entre a prática e a cidade real. São Paulo, 2002. Dissertação (Mestrado em Estruturas Ambientais Urbanas). FAUUSP.

LOJKINE, Jean. O Estado capitalista e a questão urbana. São Paulo: Martins Fontes, 1981.

LOURENÇO, Gilmar Mendes. Retaguarda institucional das transformações econômicas no Paraná. Análise Conjuntural, v. 22, n. 11-12, p. 2-9, nov-dez, 2000.

MACEDO, Mariano de Matos; VIEIRA, Viviane Fiedler ; MEINERS, Wilheim E. M. A. Fases de desenvolvimento regional no Brasil e no Paraná: da emergência de um novo modelo de desenvolvimento na economia paranaense. In REVISTA PARANAENSE DE DESENVOLVIMENTO, Curitiba, n. 103, p. 5-22, jul./dez. 2002.

MARICATO, Ermínia. Metrópole na periferia do capitalismo. São Paulo: HUCITEC, 1996.

MAUTNER, Yvonne. A periferia como fronteira de expansão do capital. In: DÉAK, C.; SCHIFFER, S. (orgs). O processo de urbanização no Brasil. São Paulo: EDUSP, 1999. 
MENDONÇA, F., LOPES, E., CANEPARO, S. Análise das modificações e identificação de conflitos no uso da terra no município de Pinhais - Paraná -Brasil, numa perspectiva espaço-temporal (1980-2000), com a utilização do sistema de informação geográfico. Curitiba: Ed. UFPR, 2002.

MEYER, R.M.P., GROSTEIN, M.D., BIDERMAN, C. São Paulo Metrópole. São Paulo: Edusp/ Imprensa Oficial, 2004.

MOURA, Rosa; DELGADO, Paulo Roberto; DESCHAMPS, Marley V.; CARDOSO, Nelson Ari. Brasil Metropolitano: uma configuração heterogênea. In REVISTA PARANAENSE DE DESENVOLVIMENTO, Curitiba, n. 105, p. 33-56, jul./dez. 2003.

MOURA, R. Regulación de uso del suelo urbano: discusión sobre el caso de Curitiba. In:

Desenvolvimento e Meio Ambiente, n. 3, p. 115-124, jan./jun. 2001. Editora da UFPR.

Planejamento e segregação sócio-espacial na Região Metropolitana de Curitiba. Experimental, n.4/5, p.57-69, Curitiba, 1998a.

Concentração e exclusão na RMC. Revista Paranaense de Geografia, n.3, p.49-57. Curitiba, 1998b.

NAMUR, Marly. Estado e empresariado em Curitiba: a formação da cidade industrial (19731980). São Paulo, 1992. Tese (Doutorado em Estruturas Ambientais Urbanas). FAUUSP.

OBA, Leonardo Tossiaki. Os marcos urbanos e a construção da cidade: a identidade de Curitiba. São Paulo, 1998. Tese (Doutorado em Estruturas Ambientais Urbanas). FAUUSP.

OLIVEIRA, D. de. Curitiba e o mito da cidade modelo. Curitiba: Ed. da UFPR, 2000.

PEREIRA, G. Novas perspectivas para gestão das cidades: Estatuto da Cidade e mercado imobiliário. Desenvolvimento e Meio Ambiente, n. 9, p. 77-92, jan./jun. 2004. Editora UFPR

PEREIRA, Gislene. Produção da cidade e degradação do ambiente: a realidade da urbanização desigual. Curitiba, 2002. Tese (Doutorado em Meio Ambiente e Desenvolvimento). UFPR. 
PEREIRA, Gislene; SILVA, Madianita. Dinâmica imobiliária na Região Metropolitana de Curitiba: o mercado formal e informal e a estruturação da metrópole. In MOURA, R., FIRKOWSKI, O.L. (orgs.). Dinâmicas Intrametropolitanas e produção do espaço na Região Metropolitana de Curitiba. Rio de Janeiro: Letra Capital Editora, 2009.

PEREIRA, Gislene; SILVA, Madianita. Mercado imobiliário e estruturação do espaço na Região Metropolitana de Curitiba. Cadernos Metrópole, n. 18. PUC/SP; IPPUR-UFRJ, 2007.

POLLI, S. A. Curitiba, Metrópole Corporativa. Fronteiras da Desigualdade. Rio de Janeiro, 2006. Dissertação (Programa de Pós-Graduação em Planejamento Urbano e Regional), UFRJ.

REIS, Nestor Goulart dos. Notas sobre a organização das Regiões Metropolitanas. Cadernos de Pesquisa do LAP, FAUUSP. São Paulo (12), mar-abr. 1996.

REVISTA VEJA (1993). CURITIBA: a cidade modelo de um país viável. Revista Veja, ed. 1281, ano 26, n. 13, 31 mar. 1993.

RIBEIRO, Luiz Cesar Queiroz; CARDOSO, Adauto Lúcio. Planejamento urbano no Brasil: paradigmas e experiências. Espaço e Debates n.ํ 37, São Paulo, 1994.

ROLNIK, R. A cidade e a lei: legislação, política urbana e territórios na cidade de São Paulo. São Paulo: Studio Nobel, 1997.

ROSARIO, N. Planejamento Urbano em Curitiba: saber técnico, classificação dos citadinos e partilha da cidade. Revista de Sociologia e Política, N. 16, jun-2001. Editora UFPR.

SALLEM, Angela Leitão. Morfologia e desenho urbano na configuração da cidade planejada: o caso de Curitiba. Curitiba, 2006. Dissertação (Mestrado em Gestão Técnica do Meio Urbano). PPGTU - PUCPR.

SAMPAIO, Maria Ruth Amaral de. O papel da iniciativa privada na formação da periferia paulistana. Espaço e Debates, n. 37, São Paulo,1994.

SANTOS, Boaventura de Sousa. Reinventar a democracia. Lisboa: Gradiva, 1998.

SANTOS, Milton. A urbanização brasileira. São Paulo: HUCITEC,1994.(Estudos Urbanos; 5)

Espaço e método. São Paulo: Nobel,1992. 
SCHUSSEL, Zulma das Graças Lucena. A aglomeração metropolitana de Curitiba e as tendências contemporâneas do planejamento urbano. Curitiba, 2002. Tese (Doutorado em Meio Ambiente e Desenvolvimento). UFPR.

Em entrevista à autora, em 29/01/2010, no Anexo 1 desta tese.

SMITH, Neil. A gentrificação generalizada: de uma anomalia local à "regeneração" urbana como estratégia urbana global. In: Bidou-Zachariensen, C. (coord.) De volta à cidade: dos processos de gentrificação às políticas de revitalização dos centros urbanos. São Paulo: Annablume, 2006

SOJA, E. Geografias pós-modernas. Rio de Janeiro: Jorge Zahar, 1993.

SOMEHK, N. A cidade vertical e o urbanismo modernizador. São Paulo: Studio Nobel: EDUSP: FAPESP, 1997. (Coleção Cidade Aberta).

SOUZA, M. A. A. A identidade da metrópole: a verticalização em São Paulo. São Paulo: Hucitec:EDUSP, 1994 (Estudos Urbanos; 8).

TRINDADE, Etelvina Maria de Castro. (coord.) Cidade, homem e natureza: uma história das políticas ambientais de Curitiba. Curitiba: UNILIVRE, 1997.

ULTRAMARI, C., MOURA, R. (orgs.). Metrópole - Grande Curitiba: teoria e prática. Curitiba: IPARDES, 1994.

URBS. [online] http//: www.urbs.curitiba.pr.gov.br, acessado em dezembro de 2009.

VILLAÇA, Flávio. Espaço intra-urbano no Brasil. São Paulo: Studio Nobel: FAPESP: Lincoln Institute, 1998.

WILDERODE, Daniel Julien Van. Cidade à venda: interpretações do processo imobiliário. São Paulo, 2000. Tese (Doutorado em Estruturas Ambientais Urbanas). FAUUSP.

ZAMBERLAN, R. Planos e valores no espaço urbano de Curitiba: setor estrutural nortesul. Curitiba, 2006. Dissertação (Mestrado em Gestão Técnica do Meio Urbano). PPGTU PUCPR. 


\section{ANEXO 1}

Entrevista com a arquiteta Zulma das Graças Lucena Schussel 


\section{ENTREVISTA COM A PROF.: DR. ' ZULMA DAS GRAÇAS LUCENA SCHUSSEL ${ }^{242}$, EM 29/01/2010.}

S - Quais as principais características do processo de parcelamento do solo nos municípios lindeiros à Curitiba, especialmente à leste, durante o período que antecede a criação da COMEC e portanto as legislações municipais?

Z - Até a década de 1980, o processo de parcelamento do solo nos municípios lindeiros à Curitiba ocorreu sem controle, gerando vazios urbanos entre os loteamentos aprovados, falta de continuidade no sistema viário e um excesso de lotes que eram vendidos com infraestrutura mínima. Esses lotes eram vendidos nos terminais de ônibus de Curitiba, com facilidades de pagamento e parcelados a longo prazo, e eram adquiridos pela população de baixa renda, que em muitos casos não conseguia a documentação do imóvel. Com a instituição da Lei Lehman em 1979, e a exigência da anuência prévia pela COMEC, esse cenário se alterou e houve uma diminuição no número de lotes aprovados nesses municípios.

Nos municípios à leste, principalmente em Piraquara, o processo de parcelamento intensivo ocorreu na década de 1950, com a aprovação de loteamentos em áreas frágeis do ponto de vista ambiental e que posteriormente se transformaram em áreas de proteção dos mananciais de abastecimento de Curitiba, com a execução das represas do rio Piraquara e do rio Iraí. Esses loteamentos não foram implantados e suas áreas se tornaram focos de invasões na década de 1990, surgindo a maior ocupação da RMC, o Guarituba, onde atualmente residem em torno de 40.000 pessoas. No município de São José dos Pinhais foram implantados muitos loteamentos ao longo da BR 277, criando um grande conflito entre o tráfego rodoviário e as áreas residenciais, com um número expressivo de atropelamentos na região.

\section{S - Qual o perfil do loteador nesse período? E o do comprador?}

Z - Os loteadores eram empresas imobiliárias que implantavam os loteamentos com uma infraestrutura mínima e vendiam em prestações de 10 a 15 anos. Os compradores por sua vez, eram de baixa renda e muitas vezes se tornavam inadimplentes, possibilitando que os loteadores retomassem os lotes e os vendessem novamente.

\footnotetext{
${ }^{242}$ A Prof. ${ }^{\text {a }}$ Dr. ${ }^{\text {a }}$ Zulma das Graças Lucena Schussel é arquiteta, Doutora em Meio Ambiente e Desenvolvimento pela UFPR, tendo defendido sua tese em 2002, intitulada A aglomeração metropolitana de Curitiba e as tendências contemporâneas do planejamento urbano. Ex-Diretora da Coordenação da Região Metropolitana de Curitiba (COMEC), onde trabalhou de 1976 à 2003, desempenhando diversas funções, entre as quais de Diretora Técnica e Coordenadora Geral. Atualmente leciona no Curso de Arquitetura e Urbanismo da PUCPR, nas disciplinas de Planejamento Urbano e Regional, além de dirigir a empresa RZS Consultoria e Planejamento Ltda. onde presta consultorias na área de planejamento urbano e regional.
} 
S - A produção de lotes populares nas décadas de 60 e 70 foi maior que a demanda. Em vista disso, teria havido alguma prática de retenção de lotes à espera da infra-estrutura como estratégia de especulação imobiliária na região? Ou mesmo, teria chegado a conformar vazios urbanos significativos?

Z - O que ocorreu na realidade, foi a aprovação de loteamentos em número muito maior do que a demanda, fazendo com que esses loteamentos tivessem uma ocupação muito dispersa. Em 1985, foi feito um levantamento pela COMEC do número de lotes aprovados nesses municípios e do número de lotes vagos, e o resultado mostrou essa situação: Mandirituba $87,14 \%$ dos lotes existentes no município se encontravam vagos (Fazenda Rio Grande nessa época ainda era distrito de Mandirituba); Quatro Barras - 82,64\%; Campina Grande do Sul 78,58\%; São José dos Pinhais - 70,34\%; Piraquara - 62,29\%. Com isso formaram-se vazios urbanos significativos que se somaram aos vazios intersticiais entre os loteamentos, já existentes.

S - Como se deu o processo de formação das grandes ocupações irregulares na área leste? Teria relação com a falta de oferta de lotes populares e talvez, uma relação com a proximidade ao centro da metrópole?

Z - As grandes ocupações irregulares nessa área ocorreram principalmente no início da década de 1990 (Zumbi dos Palmares em Colombo, Jardim Alegria em São José dos Pinhais, Guarituba em Piraquara, são alguns exemplos disso) foram planejadas e tiveram apoio de políticos na estratégia de ocupação. Essas ocupações ocorreram numa fase em que os loteamentos populares se tornaram mais escassos em função das exigências de infra-estrutura que a lei Lehman passou a impor para sua aprovação e que encareceram os custos de implantação, diminuindo a margem de lucros dos empreendedores. Em função da sua proximidade de Curitiba, essas áreas foram mais pressionadas pelas ocupações, também pelo fato de que em 1990 já estavam classificadas como áreas de proteção de mananciais, com restrições à sua ocupação, fazendo com que em muitos casos, os seus proprietários se desinteressassem por elas.

S - Quanto às dinâmicas emergentes que reestruturaram a Curitiba Metrópole nos últimos anos, é visível a tendência de implantação de grandes condomínios horizontais voltados às camadas de mais alta renda na área leste. A acessibilidade ao centro de Curitiba somada ao baixo custo da terra em função dos mananciais teriam sido os atrativos para os empreendimentos? E a nova estratégia da criação das UTP"s ao final dos anos 90 ?

Z - As UTPs criadas no final dos anos 90 tinham como objetivo, criar uma área de transição entre as áreas urbanizadas e as áreas das bacias hidrográficas dos mananciais de abastecimento público. Também objetivavam manter uma densidade média que permitisse 0 adensamento de algumas áreas no espigão das bacias hidrográficas em troca da preservação permanente das matas ciliares ao longo das margens dos rios. Os condomínios nessas áreas eram entendidos pela estratégia proposta pelas UTPs, como uma forma de conseguir a 
manutenção da densidade, uma vez que permitem a construção de uma única habitação em cada lote, enquanto que nos loteamentos abertos, a tendência da construção de mais de uma moradia por lote vem se consolidando cada vez mais em função do custo da terra. Em município como Piraquara e Quatro Barras a implementação de lotes populares era muito restrita em função da legislação ambiental em vigor. A imposição de uma baixa densidade obrigou à definição de lotes grandes pelo zoneamento, impossibilitando loteamentos de característica social. O município de Pinhais tem atraído os condomínios em função de sua proximidade a Curitiba e do valor da terra.

S - Em sua opinião, a estratégia do planejamento urbano em reificar Curitiba sob a ideologia da qualidade de vida teria sido o maior atrativo à expansão do capital imobiliário na periferia da metrópole?

Z - É importante observar que a consolidação de Curitiba como metrópole ocorreu na década de 70, quando houve uma expulsão muito forte da população rural do Paraná, com a mudança da cultura do café pela da soja, liberando um contingente muito grande de mão de obra. $O$ crescimento que ocorreu a partir de então manteve-se grande, mas similar ao das demais metrópoles brasileiras. Essa população que migrou na primeira fase para Curitiba, se localizou nesses municípios periféricos em função do preço dos imóveis. Atualmente o capital imobiliário vem se interessando por essas periferias para a implementação de condomínios de alta renda, mas ainda dando preferência para as áreas localizadas dentro do município de Curitiba.
S - Obrigada!
Z - De nada. 
ANEXO 2

Levantamento da oferta de terrenos à venda

em Curitiba, Colombo, Pinhais e São José dos Pinhais em 1996, 2000, 2004 e 2009 


\begin{tabular}{|c|c|c|c|c|c|c|c|c|c|c|c|c|c|c|}
\hline \multicolumn{15}{|c|}{ PREÇO MÉDIO $\left(R \$ / \mathrm{m}^{2}\right)$ DE TERRENO OFERTADOS PARA VENDA EM CURITIBA } \\
\hline & 1996 & 1997 & 1998 & 1999 & 2000 & 2001 & 2002 & 2003 & 2004 & 2005 & 2006 & 2007 & 2008 & 2009* \\
\hline Abranches & 44,65 & 54,28 & 46,67 & 74,33 & 61,25 & $79,90-4$ & 69,90 & $75,76-2$ & 95,87 & 102,03 & 141,89 & 166,33 & 183,96 & 230,42 \\
\hline Àgua Verde & 202,07 & 199,21 & 194,39 & 169,10 & 230,55 & 274,62 & 316,71 & 279,62 & 299,71 & 362,95 & 494,42 & 489,14 & 649,90 & 881,47 \\
\hline Ahú & 129,14 & 103,38 & 125,78 & 141,74 & 150,60 & 167,90 & 179,93 & 252,81 & 30,74 & 338,30 & 480,31 & 381,14 & 517,83 & 796,82 \\
\hline Alto Boqueirão & $41,67-1$ & $57,31-5$ & 52,54 & $70,91-4$ & 62,37 & $70,93-2$ & 62,15 & - & 90,81 & 103,10 & 149,86 & 165,68 & 278,43 & 279,15 \\
\hline Alto da Glória & $224,72-1$ & 207,65 & 239,23 & 228,26 & 321,85 & 340,76 & 307,68 & $289,05-4$ & 354,50 & $345,92-3$ & 450,64 & 454,39 & 797,11 & $1.096,38$ \\
\hline Alto da XV & 163,00 & $263,61-3$ & 219,52 & $222,19-5$ & 284,11 & 284,78 & 252,82 & 377,76 & 322,05 & 402,86 & 462,91 & 510,58 & 652,91 & 834,59 \\
\hline Atuba & 26,58 & 15,79 & 30,54 & - & - & $101,34-1$ & $84,59-5$ & - & 103,78 & 114,93 & 140,85 & 177,02 & 193,68 & 259,58 \\
\hline Augusta & - & - & - & - & - & - & - & - & - & - & $79,80-7$ & 80,68 & 109,73 & 180,67 \\
\hline Bacacheri & 85,76 & 95,51 & 101,95 & 120,26 & 129,63 & 137,96 & 157,59 & 191,99 & 224,47 & 233,85 & 328,40 & 377,67 & 498,46 & 484,47 \\
\hline Bairro Alto & 40,16 & 43,71 & 48,28 & 54,71 & 67,88 & 61,10 & 81,74 & 79,36 & 97,84 & 105,47 & 189,38 & 169,12 & 217,16 & 288,42 \\
\hline Barreirinha & 42,92 & 52,88 & 42,43 & 48,34 & 53,46 & 63,85 & 69,65 & 83,80 & 84,27 & 97,25 & 192,26 & 147,25 & 222,77 & 298,31 \\
\hline Batel & 159,33 & 349,58 & 328,03 & 251,39 & 341,40 & 283,52 & 494,74 & $291,45-3$ & $267,71-3$ & 742,91 & $1.012,02$ & $1.093,57$ & $1.135,30$ & $1.247,14$ \\
\hline Bigorrilho & 257,99 & 261,44 & 236,18 & 193,14 & 231,58 & 270,25 & 282,16 & 219,48 & 331,86 & 350,93 & 466,18 & 471,23 & 596,18 & 796,63 \\
\hline Boa Vista & 72,05 & 78,73 & 89,43 & 88,27 & 106,70 & 135,73 & 126,90 & 159,79 & 173,50 & 199,83 & 335,33 & 251,50 & 372,57 & 454,33 \\
\hline Bom Retiro & 96,49 & 97,01 & 103,50 & 135,92 & 130,38 & $161,02-4$ & 160,85 & 203,42 & 207,44 & 248,25 & 353,27 & 289,14 & 414,78 & 467,18 \\
\hline Boqueirão & 50,02 & 63,65 & 71,56 & 69,48 & 81,23 & 72,76 & 109,81 & 95,24 & 115,36 & 137,56 & 209,21 & 217,23 & 266,92 & 348,45 \\
\hline Butiatuvinha & - & - & - & - & $39,61-4$ & - & $64,18-3$ & - & $82,20-7$ & $88,48-2$ & 148,61 & 124,00 & 149,07 & 246,36 \\
\hline Cabral & 150,24 & 272,51 & 237,29 & 183,22 & 262,63 & 254,95 & 305,93 & 305,39 & 316,00 & 386,53 & 502,41 & 513,77 & 716,56 & 870,47 \\
\hline Cachoeira & - & $23,02-4$ & - & - & $26,33-5$ & - & - & - & $46,32-6$ & - & 70,25 & 153,54 & 132,02 & $197,92-8$ \\
\hline Cajuru & 64,84 & 62,88 & 60,27 & 70,97 & 81,97 & 112,07 & 100,74 & 111,69 & 106,14 & 124,73 & 194,37 & 197,24 & 283,93 & 371,83 \\
\hline Campina do Siqueira & $129,15-5$ & $94,59-3$ & 118,10 & $78,13-4$ & 139,71 & $118,86-4$ & 155,25 & $280,70-2$ & 229,49 & 287,82 & 340,01 & 496,12 & 729,07 & 807,12 \\
\hline Campo Comprido & 45,07 & 58,39 & 58,43 & 65,36 & 70,12 & 76,00 & 94,51 & 87,14 & 135,01 & 165,00 & 216,06 & 269,20 & 323,22 & 373,73 \\
\hline Campo de Santana & - & - & - & - & - & - & $7,27-1$ & - & - & - & $108,18-5$ & 123,25 & 146,56 & 181,23 \\
\hline Capão da Imbuia & 74,42 & 87,28 & 78,52 & $76,41-4$ & 129,82 & $132,75-4$ & 139,76 & $125,23-2$ & 172,71 & 201,97 & 218,43 & 318,06 & 415,26 & 508,39 \\
\hline Capão Raso & 70,71 & 87,05 & 91,00 & 105,18 & 117,68 & 132,77 & 124,77 & 129,01 & 205,48 & 216,63 & 270,44 & 322,62 & 417,19 & 468,73 \\
\hline Cascatinha & $57,58-1$ & $51,38-2$ & $73,69-5$ & $57,29-1$ & 81,81 & $93,87-3$ & 92,44 & $85,79-3$ & 107,13 & 133,06 & 154,64 & 219,61 & 287,16 & 343,36 \\
\hline Caximba & - & - & - & - & - & - & $11,53-2$ & - & - & - & $75,52-2$ & $75,52-2$ & $100,69-1$ & - \\
\hline Centro Cívico & 258,38 & 203,03 & 157,16 & 178,38 & 199,76 & 212,38 & 285,98 & $338,65-5$ & 379,79 & 339,85 & 424,80 & 524,16 & 720,64 & 875,52 \\
\hline
\end{tabular}




\begin{tabular}{|c|c|c|c|c|c|c|c|c|c|c|c|c|c|c|}
\hline \multicolumn{15}{|c|}{ PREÇO MÉDIO (R\$/m²) DE TERRENO OFERTADOS PARA VENDA EM CURITIBA } \\
\hline & 1996 & 1997 & 1998 & 1999 & 2000 & 2001 & 2002 & 2003 & 2004 & 2005 & 2006 & 2007 & 2008 & 2009* \\
\hline Centro & 474,03 & 319,00 & 404,83 & 387,94 & 545,35 & 636,05 & 598,08 & 687,92 & 963,41 & 840,72 & 760,95 & 890,38 & $1.241,22$ & $1.412,98$ \\
\hline $\mathrm{CIC}$ & 35,17 & $39,29-5$ & 33,16 & $26,65-2$ & 41,52 & $51,19-2$ & 45,02 & $94,07-2$ & 73,08 & 119,68 & 119,20 & 164,59 & 212,93 & 329,69 \\
\hline Cristo Rei & $123,09-4$ & 183,82 & 190,04 & $221,87-5$ & 344,44 & 219,27 & 298,55 & 320,25 & 308,26 & 317,89 & 488,98 & 469,64 & 561,65 & 717,96 \\
\hline Fanny & 84,23 & 85,43 & 84,04 & $83,63-5$ & 117,09 & 95,62 & 121,49 & $125,93-5$ & 142,90 & 155,54 & 247,47 & 266,87 & 334,07 & 381,52 \\
\hline Fazendinha & 45,68 & 54,55 & 64,24 & 68,60 & 68,17 & 98,96 & 83,64 & $112,95-3$ & 156,67 & 152,12 & 219,76 & 278,12 & 298,20 & 365,01 \\
\hline Ganchinho & - & - & - & - & - & - & - & - & - & - & $18,05-4$ & $91,80-5$ & $75,79-5$ & $189,59-9$ \\
\hline Guabirotuba & 69,63 & 71,38 & 77,58 & 73,29 & 115,43 & 119,84 & 136,32 & $103,61-6$ & 186,31 & 212,66 & 291,74 & 252,18 & 298,95 & 477,67 \\
\hline Guaíra & 77,25 & 82,16 & 93,71 & 129,43 & 123,94 & 125,18 & 123,33 & $109,35-3$ & 159,76 & 179,36 & 264,65 & 267,86 & 303,71 & 417,42 \\
\hline Hauer & 65,14 & 83,20 & 86,38 & 77,00 & 124,17 & 97,22 & 125,98 & 153,46 & 169,07 & 190,64 & 259,13 & 267,38 & 364,20 & 385,75 \\
\hline Hugo Lange & 117,27 & $135,16-4$ & 153,10 & 163,08 & 184,25 & 199,39 & 247,49 & $291,67-1$ & 308,79 & 372,93 & 436,69 & 538,90 & 579,84 & 641,33 \\
\hline Jardim Botânico & 134,89 & 206,24 & 158,05 & $148,35-5$ & 152,95 & 216,36 & 209,70 & $267,32-4$ & 248,45 & 184,88 & 261,58 & 351,86 & 550,33 & 679,61 \\
\hline Jardim das Américas & 87,38 & 94,22 & 102,17 & $125,45-5$ & 143,16 & 139,33 & 164,22 & $147,36-4$ & 196,00 & 271,29 & 278,30 & 310,72 & 365,87 & 466,79 \\
\hline Jardim Social & 110,87 & 105,14 & 111,77 & 117,17 & 148,01 & 155,87 & 190,31 & $220,22-5$ & 222,28 & 276,52 & 342,20 & 323,07 & 441,83 & 532,32 \\
\hline Juvevê & 217,30 & 304,20 & 232,20 & $236,05-5$ & 286,13 & 236,35 & $318,57-7$ & 320,85 & 309,76 & 410,56 & 603,86 & 582,62 & 753,05 & 851,10 \\
\hline Lamenha Pequena & - & - & $15,38-1$ & - & $49,12-3$ & - & $47,03-6$ & - & 107,59 & 103,63 & 127,64 & $120,02-4$ & $152,39-7$ & 136,54 \\
\hline Lindóia & $63,10-5$ & $58,41-2$ & 82,02 & $75,52-4$ & 126,35 & $56,42-1$ & $126,75-5$ & $157,91-5$ & 168,50 & 127,35 & 202,78 & 242,21 & 270,14 & 416,52 \\
\hline Mercês & 116,20 & 112,33 & 117,03 & 138,55 & 152,56 & 196,11 & 188,85 & 209,43 & 283,10 & 363,09 & 357,73 & 410,15 & 497,15 & 543,32 \\
\hline Mossunguê & 63,45 & $42,30-5$ & 65,59 & 66,65 & 91,64 & 118,74 & 165,18 & $112,95-3$ & 180,47 & 186,50 & 218,09 & 234,39 & 385,77 & 374,76 \\
\hline Novo Mundo & 104,98 & 77,50 & 94,20 & 111,58 & 120,66 & 110,45 & 152,96 & 163,04 & 210,24 & 227,76 & 297,87 & 283,77 & 444,40 & 535,82 \\
\hline Orleans & 49,96-3 & $62,50-2$ & 58,65 & - & 78,01 & $93,42-2$ & $117,31-9$ & $85,71-1$ & 123,95 & 172,12 & 164,31 & 212,23 & 287,62 & 333,04 \\
\hline Parolin & $49,05-5$ & 86,16 & 77,84 & 80,77 & 127,63 & $157,90-5$ & 173,04 & $143,41-5$ & 219,64 & 265,80 & 230,27 & 273,47 & 389,17 & 459,04 \\
\hline Pilarzinho & 50,66 & 51,63 & 60,91 & 70,33 & 74,58 & 89,62 & 84,50 & 104,54 & 111,36 & 140,40 & 148,48 & 162,84 & 258,77 & 299,62 \\
\hline Pinheirinho & 56,58 & 54,35 & 64,08 & 92,87 & 79,19 & 94,67 & 94,38 & 132,90 & 100,27 & 121,07 & 154,03 & 159,57 & 240,46 & 308,02 \\
\hline Portão & 110,10 & 109,57 & 130,29 & 120,20 & 164,16 & 185,31 & 215,06 & 246,04 & 245,52 & 278,47 & 414,38 & 435,34 & 557,13 & 642,11 \\
\hline Prado Velho & 105,75 & 150,08 & 143,15 & 136,30 & 128,54 & 136,60 & 155,04 & 189,32 & 169,11 & 195,22 & 262,42 & 457,69 & 446,18 & 643,34 \\
\hline Rebouças & 160,64 & 147,93 & 178,56 & 237,67 & 192,12 & 208,24 & 212,25 & 303,63 & 280,54 & 372,39 & 547,13 & 650,72 & 675,48 & 829,57 \\
\hline Riviera & - & - & - & - & - & - & - & - & - & - & - & - & - & - \\
\hline Santa Cândida & 34,18 & 41,16 & 50,81 & 62,39 & 56,51 & 80,57 & 79,23 & 84,53 & 88,42 & 98,58 & 177,98 & 198,61 & 234,72 & 260,91 \\
\hline
\end{tabular}




\begin{tabular}{|c|c|c|c|c|c|c|c|c|c|c|c|c|c|c|}
\hline \multicolumn{15}{|c|}{ PREÇO MÉDIO (R\$/m²) DE TERRENO OFERTADOS PARA VENDA EM CURITIBA } \\
\hline & 1996 & 1997 & 1998 & 1999 & 2000 & 2001 & 2002 & 2003 & 2004 & 2005 & 2006 & 2007 & 2008 & 2009* \\
\hline Santa Felicidade & 51,40 & 51,38 & 61,29 & 45,35 & 70,00 & 73,09 & 84,18 & 113,85 & 131,16 & 134,53 & 177,73 & 203,45 & 270,73 & 345,09 \\
\hline Santa Quitéria & 77,55 & 72,83 & 97,94 & 80,66 & 104,75 & 138,47 & 143,79 & 138,33 & 165,26 & 292,42 & 283,97 & 294,24 & 437,08 & 421,03 \\
\hline Santo Inácio & 71,20 & 82,13 & 95,64 & 88,92 & 97,18 & 94,54 & 118,25 & 119,13 & 159,49 & 178,00 & 247,75 & 249,25 & 306,32 & 400,77 \\
\hline São Braz & 44,55 & 47,30 & 61,47 & 76,17 & 71,61 & 88,99 & 92,73 & 122,49 & 101,30 & 115,30 & 173,78 & 226,59 & 265,33 & 330,62 \\
\hline São Francisco & $195,41-5$ & $100,44-2$ & 135,06 & 195,81 & $214,14-5$ & 270,91 & 277,30 & $308,98-3$ & $363-27-5$ & 379,20 & 468,75 & 651,79 & 642,14 & 907,32 \\
\hline São João & $48,73-1$ & - & - & - & $68,31-2$ & - & $80,16-3$ & - & - & - & $170,44-4$ & 208,33 & 212,34 & 310,46 \\
\hline São Lourenço & 75,80 & 75,80 & 89,64 & 95,57 & 104,65 & 118,72 & 128,41 & $159,80-4$ & 174,98 & 192,64 & 261,06 & 243,28 & 352,25 & 481,30 \\
\hline São Miguel & - & - & - & - & - & - & - & - & - & - & - & - & - & - \\
\hline Seminário & 121,18 & 64,80 & 98,44 & 116,22 & 154,15 & 162,75 & 161,32 & 193,90 & 191,75 & 338,66 & 332,00 & 391,19 & 810,89 & 845,95 \\
\hline Sítio Cercado & $97,22-2$ & $90,98-1$ & 71,51 & - & 68,84 & $56,25-1$ & 95,81 & - & 110,20 & $140,58-4$ & 239,93 & 222,77 & 257,70 & 324,07 \\
\hline Taboão & - & $50,53-2$ & - & - & $28,61-3$ & $56,15-2$ & 54,73-1 & - & $78,01-7$ & - & $88,37-7$ & 156,48 & 137,70 & $166,13-3$ \\
\hline Tarumã & 55,52 & $84,01-4$ & 89,17 & $84,11-3$ & 87,67 & $108,92-3$ & 127,06 & $89,51-1$ & $194,77-5$ & 202,65 & $199,41-3$ & 210,44 & 378,84 & 413,80 \\
\hline Tatuquara & $12,63-1$ & - & $16,68-2$ & $63,60-1$ & $38,13-4$ & - & $32,02-4$ & - & $48,40-4$ & - & 107,70 & 113,90 & 179,67 & 201,46 \\
\hline Tingüi & $93,62-2$ & 55,64 & 74,51 & 84,24 & 81,22 & 90,30 & 109,60 & 119,98 & 126,24 & 161,00 & 211,74 & 205,39 & 252,76 & 331,66 \\
\hline Uberaba & 45,11 & 54,52 & 64,48 & 75,00 & 73,70 & 83,51 & 101,29 & 128,06 & 140,09 & 152,00 & 196,54 & 215,29 & 263,66 & 344,92 \\
\hline Umbará & - & - & - & - & $59,07-7$ & 64,10 & $66,79-6$ & - & 95,68 & 181,80 & 154,62 & 169,83 & 178,74 & 223,40 \\
\hline Vila Izabel & 153,54 & 155,26 & 146,73 & 191,34 & 213,19 & 222,39 & $308,89-9$ & 297,70 & 304,25 & 330,49 & 415,54 & 513,21 & 684,35 & 943,54 \\
\hline Vista Alegre & 56,69 & 62,34 & 77,90 & 78,23 & 92,27 & 90,38 & 123,49 & 128,10 & 134,39 & 160,71 & 217,36 & 291,15 & 310,05 & 390,23 \\
\hline Xaxim & 52,99 & 52,60 & 67,32 & 70,16 & 82,12 & 85,75 & 106,41 & 113,90 & 134,21 & 145,46 & 212,12 & 231,28 & 332,81 & 369,05 \\
\hline
\end{tabular}

Elaborado por: INPESPAR - Instituto Paranaense de Pesquisa e Desenvolvimento do Mercado Imobiliário e Condominial

Nota: Quando o número de imóveis ofertados não possibilita média com nível de confiança, os valores foram apresentados

em vermelho, indicando o número de imóveis utilizado para o cálculo.

* média de janeiro a setembro de 2009 


\begin{tabular}{|c|c|c|c|c|c|c|c|}
\hline \multicolumn{8}{|c|}{ GAZETA DO POVO - CADERNO IMOBILIÁRIO - TERRENOS OFERTADOS PARA VENDA, DOM. 02 jun 1996} \\
\hline MUNICÍPIO & $\mathbf{R} \$ \mathbf{M} 2$ & BAIRRO & LOTEAMENTO & ENDEREÇO & ÁREA (m2) & PREÇO & ANUNCIANTE \\
\hline Colombo & 31,08 & ATUBA & & próximo ao SANTA CÂNDIDA & 547,00 & $\mathrm{R} \$ 17.000,00$ & Nova Real \\
\hline Colombo & 5,00 & ARRUDA & Jardim Santa Tereza & & $7.000,00$ & $R \$ 35.000,00$ & Proprietário \\
\hline Colombo & 17,26 & ATUBA & & passando o TREVO DO ATUBA & $17.385,00$ & $\mathrm{R} \$ 300.000,00$ & Futurama \\
\hline Colombo & 17,65 & ROÇA GRANDE & & ESTRADA VELHA DE COLOMBO & 5097,88 & $\mathrm{R} \$ 90.000,00$ & Futurama \\
\hline Colombo & 7,50 & ARRUDA & & próximo à RODOVIA DA UVA & $2.400,00$ & $R \$ 18.000,00$ & JBA Imóveis \\
\hline Colombo & 27,97 & ATUBA & Planta Thomaz Lissa & $250 \mathrm{~m}$ do TREVO DO ATUBA & 858,00 & $R \$ 24.000,00$ & Dama Imóveis \\
\hline Colombo & 27,78 & ATUBA & & TREVO DO ATUBA, próximo a ITAPEMIRIM & $1.800,00$ & $R \$ 50.000,00$ & Ebenezer Imóveis \\
\hline Colombo & 40,00 & SANTA TEREZINHA & Santa terezinha & Av. marginal à ESTRADA DA RIBEIRA & 450,00 & $R \$ 18.000,00$ & Proprietário \\
\hline Colombo & 9,94 & SÃO DIMAS & & a 800m da ESTRADA DA RIBEIRA & $2.514,00$ & $R \$ 25.000,00$ & Proprietário \\
\hline Colombo & 21,43 & GUARAITUBA & Guaraituba & & 420,00 & $R \$ 9.000,00$ & Proprietário \\
\hline Colombo & 28,80 & RIO VERDE & Rio verde & & 625,00 & $R \$ 18.000,00$ & Lancer Imoveis \\
\hline Colombo & 11,89 & ROÇA GRANDE & Roça Grande & $\begin{array}{l}\text { Jardim do Contorno; próximo à RODOVIA DA UVA e ao } \\
\text { CONTORNO NORTE }\end{array}$ & $2.691,00$ & $R \$ 32.000,00$ & Imobiliária 2000 \\
\hline Colombo & 20,33 & CANGUIRI & Jardim Palmares & Atuba / Santa Mônica & $2.607,00$ & $\mathrm{R} \$ 53.000,00$ & Grupo Panamericana \\
\hline Colombo & 13,44 & CENTRO & & RODOVIA DAS GRUTAS, próximo ao centro & $2.083,23$ & $\mathrm{R} \$ 28.000,00$ & Imob. Alto da XV \\
\hline Colombo & 15,63 & GUARAITUBA & Guaraítuba & Rua Pedro Rosário & 480,00 & $\mathrm{R} \$ 7.500,00$ & Grupo Daga \\
\hline Colombo & 16,13 & GUARAITUBA & & Rua Toledo esquina Rua Rebouças & 527,00 & $\mathrm{R} \$ 8.500,00$ & 3J Imobiliária Ltda \\
\hline Colombo & 3,30 & SÃO DIMAS & Guaraítuba & ESTRADA DA RIBEIRA, junto ao futuro CONT. NORTE & $3.600,00$ & $\mathrm{R} \$ 11.880,00$ & Imobiliária Água Verde \\
\hline Colombo & 7,80 & SÃO DIMAS & Guaraítuba & ESTRADA DA RIBEIRA, junto ao futuro CONT. NORTE & $7.000,00$ & $\mathrm{R} \$ 54.600,00$ & Imobiliária Água Verde \\
\hline Colombo & 15,63 & ATUBA & Atuba & próximo ao Santa Mônica; BR 116 & 960,00 & $\mathrm{R} \$ 15.000,00$ & Imóveis Presidente \\
\hline Colombo & 12,41 & GUARAITUBA & Guaraituba & & 564,00 & $\mathrm{R} \$ 7.000,00$ & Imobiliária Nicocelli \\
\hline Colombo & 5,00 & & & após o SANTA CÂNDIDA & $1.000,00$ & $156,00 /$ mês & Proprietário (?) \\
\hline Pinhais & 26,67 & VILA AMÉLIA & & próximo ao CARREFOUR & 450,00 & $R \$ 12.000,00$ & Sartor Imóveis \\
\hline Pinhais & 8,00 & VARGEM GRANDE & & Rua Graça Aranha & $2.000,00$ & $R \$ 16.000,00$ & AW Empreend. Imob. \\
\hline Pinhais & 32,00 & VARGEM GRANDE & Vargem Grande & & 625,00 & $R \$ 20.000,00$ & Imóveis Acrópole \\
\hline
\end{tabular}




\begin{tabular}{|c|c|c|c|c|c|c|c|}
\hline \multicolumn{8}{|c|}{ GAZETA DO POVO - CADERNO IMOBILIÁRIO - TERRENOS OFERTADOS PARA VENDA, DOM. 02 jun 1996} \\
\hline MUNICÍPIO & $\mathrm{R} \$ \mathbf{M} 2$ & BAIRRO & LOTEAMENTO & ENDEREÇO & ÁREA (m2) & PREÇO & ANUNCIANTE \\
\hline Pinhais & 13,00 & WEISSÓPOLIS & & próximo à AV. IRAí & $6.000,00$ & $\mathrm{R} \$ 78.000,00$ & Futurama \\
\hline Pinhais & 14,58 & WEISSÓPOLIS & & Rua Rio Paranapanema, a uma quadra da AV. IRAÍ & $1.200,00$ & $\mathrm{R} \$ 17.500,00$ & Dama Imóveis \\
\hline Pinhais & 30,53 & PALMITAL & & a $100 \mathrm{~m}$ da AV. JACOB MACANHAN & 655,00 & $R \$ 20.000,00$ & Proprietário \\
\hline Pinhais & 10,00 & VILA AMÉLIA & Bois de Boulogne & & $3.000,00$ & $\mathrm{R} \$ 30.000,00$ & Proprietário \\
\hline Pinhais & 22,50 & VARGEM GRANDE & Vargem Grande & & $2.000,00$ & $\mathrm{R} \$ 45.000,00$ & Prorietário \\
\hline Pinhais & 3,00 & VALE DAS ÁGUAS & & após o CARREFOUR PINHAIS & $5.000,00$ & $\mathrm{R} \$ 15.000,00$ & Imobiliária Puppi \\
\hline Pinhais & 2,07 & VALE DAS ÁGUAS & & ao lado do MAKRO & $338.800,00$ & $\mathrm{R} \$ 700.000,00$ & Mandala Empreend. Imob. \\
\hline Pinhais & 33,33 & EMILIANO PERNETA & Vila Perneta & Rua Uniflor, oróximo ao depósito Parati & 600,00 & $\mathrm{R} \$ 20.000,00$ & Imobiliária Absoluta \\
\hline SJP & 50,86 & CENTRO & & ao lado do Supermercado CONDOR & $6.881,00$ & $\mathrm{R} \$ 350.000,00$ & Imobiliária THÁ \\
\hline SJP & 9,03 & $\begin{array}{l}\text { ROSEIRA DE SÃO } \\
\text { SEBASTIÃO }\end{array}$ & & próximo à Futura RENAULT e Chácara Dom Rodrigo & $4.650,00$ & $R \$ 42.000,00$ & Spazzio \\
\hline SJP & 18,82 & INDEPENDÊNCIA & $\begin{array}{l}\text { Jardim } \\
\text { Independência }\end{array}$ & & 637,50 & $R \$ 12.000,00$ & Proprietário \\
\hline SJP & 34,72 & INDEPENDÊNCIA & $\begin{array}{l}\text { Jardim } \\
\text { Independência }\end{array}$ & Vila São Pedro & 360,00 & $\mathrm{R} \$ 12.500,00$ & AW Empreend. Imob. \\
\hline SJP & 20,24 & $\begin{array}{l}\text { ROSEIRA DE SÃO } \\
\text { SEBASTIÃO }\end{array}$ & & próximo à RENAULT & 420,00 & $R \$ 8.500,00$ & Albini Imóveis \\
\hline SJP & 5,78 & GUATUPÊ & Guatupê & a $3 \mathrm{~km}$ da RENAULT e Trevo de SJP & $1.383,00$ & $\mathrm{R} \$ 8.000,00$ & Albini Imóveis \\
\hline SJP & 14,17 & ARISTOCRATA & Jardim Aristocrata & & 600,00 & $\mathrm{R} \$ 8.500,00$ & Proprietário \\
\hline SJP & 19,35 & AFONSO PENA & Afonso Pena & próximo ao TERMINAL & 672,00 & $R \$ 13.000,00$ & Proprietário \\
\hline SJP & 19,44 & INDEPENDÊNCIA & & próximo ao motel LE NOUAGE & 360,00 & $\mathrm{R} \$ 7.000,00$ & Proprietário \\
\hline SJP & 5,05 & GUATUPÊ & & próximo à BR 277, a 14 km do CENTRO DE CURITIBA & $4.360,00$ & $\mathrm{R} \$ 22.000,00$ & Proprietário \\
\hline SJP & 44,00 & ARISTOCRATA & Jardim Aristocrata & & 375,00 & $\mathrm{R} \$ 16.500,00$ & Mota Empreend. Imob. \\
\hline SJP & 26,67 & ARISTOCRATA & Jardim Aristocrata & Rua Mahatma Gandhi & 600,00 & $\mathrm{R} \$ 16.000,00$ & Imobiliária 2000 \\
\hline SJP & 31,25 & ARISTOCRATA & Jardim Aristocrata & Rua Tomás de Aquino, a $1 \mathrm{~km}$ da rua principal & 480,00 & $R \$ 15.000,00$ & Imobiliária 2001 \\
\hline SJP & 29,80 & INÁ & & ao lado do TERMINAL Afonso Pena & 436,24 & $R \$ 13.000,00$ & Imobiliária Asa \\
\hline SJP & 47,92 & SÃO DOMINGOS & Jardim Dona Letícia & & 480,00 & $R \$ 23.000,00$ & Rocco \\
\hline SJP & 27,03 & PEDRO MORO & Vila Bordin & Rua Quintino Zagonel & $1.036,00$ & $\mathrm{R} \$ 28.000,00$ & Rocco \\
\hline SJP & 56,25 & SÃO PEDRO & Parque São Caetano & & 480,00 & $\mathrm{R} \$ 27.000,00$ & Rocco \\
\hline SJP & 37,70 & BONECA DO IGUAÇU & Vila Palmira & & 504,00 & $\mathrm{R} \$ 19.000,00$ & Rocco \\
\hline
\end{tabular}




\begin{tabular}{|c|c|c|c|c|c|c|c|}
\hline \multicolumn{8}{|c|}{ GAZETA DO POVO - CADERNO IMOBILIÁRIO - TERRENOS OFERTADOS PARA VENDA, DOM. 02 jun 1996} \\
\hline MUNICÍPIO & $\mathrm{R} \$ / \mathrm{M} 2$ & BAIRRO & LOTEAMENTO & ENDEREÇO & ÁREA (m2) & PREÇO & ANUNCIANTE \\
\hline SJP & 28,37 & SÃO DOMINGOS & Jardim Dona Letícia & & 564,00 & $\mathrm{R} \$ 16.000,00$ & Rocco \\
\hline SJP & 14,47 & CRUZEIRO & Jardim Cruzeiro & Rua Apucarana & 864,00 & $R \$ 12.500,00$ & Rocco \\
\hline SJP & 32,00 & ARISTOCRATA & Jardim Aristocrata & & 375,00 & $R \$ 12.000,00$ & Rocco \\
\hline SJP & 24,33 & CRUZEIRO & Jardim Cruzeiro & próximo ao AEROPORTO & 411,00 & $R \$ 10.000,00$ & Rocco \\
\hline SJP & 29,76 & CIDADE JARDIM & $\begin{array}{l}\text { Vila Inácio dos } \\
\text { Santos }\end{array}$ & Rua Nações Unidas & 672,00 & $R \$ 20.000,00$ & Rocco \\
\hline SJP & 22,08 & BOM JESUS & Bom Jesus & Rua João Angelo Cordeiro & 453,00 & $R \$ 10.000,00$ & Rocco \\
\hline SJP & 13,01 & ITÁLIA & Portal do Sol & Alameda 17 & 692,00 & $R \$ 9.000,00$ & Rocco \\
\hline SJP & 21,43 & ARISTOCRATA & Jardim Aristocrata & & 420,00 & $R \$ 9.000,00$ & Rocco \\
\hline SJP & 13,68 & BOM JESUS & Bom Jesus & Frente para a Av. Rui Barbosa & $4.387,20$ & $\mathrm{R} \$ 60.000,00$ & Washingtn Ortega \\
\hline SJP & 99,43 & BONECA DO IGUAÇU & Vila Palmira & Rua Paulo Scherner & 352,00 & $\mathrm{R} \$ 35.000,00$ & Washingtn Ortega \\
\hline SJP & 27,78 & ARISTOCRATA & Jardim Aristocrata & a 2 quadras da avenida principal & 360,00 & $R \$ 10.000,00$ & Washingtn Ortega \\
\hline SJP & 26,39 & ARISTOCRATA & Jardim Aristocrata & Rua Emanuel Candi & 360,00 & $R \$ 9.500,00$ & Washingtn Ortega \\
\hline SJP & 12,96 & INDEPENDÊNCIA & $\begin{array}{l}\text { Jardim } \\
\text { Independência }\end{array}$ & Rua Anibal Silva & 540,00 & $\mathrm{R} \$ 7.000,00$ & Washingtn Ortega \\
\hline SJP & 89,14 & BONECA DO IGUAÇU & & $\begin{array}{l}\text { próximo ao AEROPORTO, a } 300 \mathrm{~m} \text { da AV. DAS } \\
\text { TORRES }\end{array}$ & 291,00 & $R \$ 25.940,00$ & $\begin{array}{l}\text { Inccorpore Inc. e Particip. } \\
\text { Imobiliários }\end{array}$ \\
\hline
\end{tabular}




\begin{tabular}{|c|c|c|c|c|c|c|c|}
\hline \multicolumn{8}{|c|}{ GAZETA DO POVO - CADERNO IMOBILIÁRIO - TERRENOS OFERTADOS PARA VENDA, DOM. 01 dez 1996} \\
\hline MUNICÍPIO & $\mathrm{R} \$ \mathbf{M} 2$ & BAIRRO & LOTEAMENTO & ENDEREÇO & ÁREA (m2) & PREÇO & ANUNCIANTE \\
\hline Colombo & 10,71 & MAUÁ & Centro Industrial Mauá & & 400,00 & $R \$ 15.000,00$ & Futurama \\
\hline Colombo & 27,97 & ATUBA & Jd Rosaelena & Rua Thomaz Liss, n. 239; a 250 m do ATUBA & 58,00 & $\mathrm{R} \$ 24.000,00$ & Dama Imóveis \\
\hline Colombo & 6,29 & OSASCO & & $\begin{array}{l}\text { a } 1500 \mathrm{~m} \text { da ESTRADA NOVA DE COLOMBO; na altura } \\
\text { do Clube Banestado }\end{array}$ & 544,00 & $R \$ 60.000,00$ & Cilar \\
\hline Colombo & 34,72 & CAMPO PEQUENO & Campo Pequeno & Rua Angelo Frasão esquina com Quintino Bocaiúva & 32,00 & $\mathrm{R} \$ 15.000,00$ & Imobiliária Liberdade \\
\hline Colombo & 14,74 & COLÔNIA FARIAS & Chácara Colônia Farias & próximo ao Santa Mônica; BR 116 & 429,00 & $\mathrm{R} \$ 80.000,00$ & VIP Assessoria Imob. \\
\hline Colombo & - & CANGUIRI & Jardim Santa Mônica & & .1. & $\mathrm{R} \$ 8.064,00$ & J.N. Imóveis \\
\hline Pinhais & 15,00 & ENTRE RIOS & & JACOB MACANHAN & $8.000,00$ & $\begin{array}{l}\mathrm{R} \$ \\
570.000,00 \\
\end{array}$ & Proprietário \\
\hline Pinhais & 37,50 & VILA AMÉLIA & Vila Amélia & a $100 \mathrm{~m}$ do CARREFOUR PINHAIS & 80,00 & $\mathrm{R} \$ 18.000,00$ & Proprietário \\
\hline Pinhais & 31,37 & VARGEM GRANDE & & Rua Manoel Bandeira, esquina com Aloísio de Azevedo & 020,00 & $\mathrm{R} \$ 32.000,00$ & Imobiliária Mota \\
\hline Pinhais & 50,98 & EMILIANO PERNETA & & JACOB MACANHAN, em frente ao PINEVILLE & 10,00 & $R \$ 26.000,00$ & Spazzio \\
\hline Pinhais & 18,75 & WEISSÓPOLIS & & a 3 quadras da AV. IRAì & 400,00 & $R \$ 45.000,00$ & Albini Imóveis \\
\hline Pinhais & 21,98 & VILA AMÉLIA & Bois de Boulogne & & 64,00 & $\mathrm{R} \$ 8.000,00$ & Ambrosio Alves Ass. Imob. \\
\hline Pinhais & 27,08 & ESTÂNCIA PINHAIS & & próximo ao CARTÓRIO & 80,00 & $\mathrm{R} \$ 13.000,00$ & Champagnat Imóveis \\
\hline Pinhais & 31,73 & CENTRO & & a $200 \mathrm{~m}$ do BANCO DO BRASIL & 576,00 & $R \$ 50.000,00$ & Champagnat Imóveis \\
\hline Pinhais & 28,57 & WEISSÓPOLIS & & Rua Rio Javari & 20,00 & $R \$ 12.000,00$ & Wilke Imóveis \\
\hline Pinhais & 2,70 & VALE DAS ÁGUAS & & próximo ao CARREFOUR PINHAIS & $1.111,00$ & $\mathrm{R} \$ 30.000,00$ & Dimensional \\
\hline Pinhais & 44,54 & EMILIANO PERNETA & & $\begin{array}{l}\text { a uma quadra da Av. JACOB MACANHAN, próximo ao } \\
\text { Condomínio PINEVILLE }\end{array}$ & 49,00 & $R \$ 20.000,00$ & VIP Assessoria Imob. \\
\hline Pinhais & 30,89 & VARGEM GRANDE & & Rua Euclides da Cunha & 18,00 & $R \$ 16.000,00$ & ARRIMO Empreend. Imob. \\
\hline Pinhais & 20,33 & VILA AMÉLIA & & Rua Delfim Moreira & 18,00 & $\mathrm{R} \$ 8.500,00$ & Lorusso Imóveis \\
\hline Pinhais & 34,97 & MARIA ANTONIETA & Vila Maria Antonieta & & 29,00 & $R \$ 15.000,00$ & Navarro Atend. Personalizado \\
\hline Pinhais & 35,71 & VARGEM GRANDE & Vargem Grande & & $\mathrm{b} 0,00$ & $R \$ 25.000,00$ & Navarro Atend. Personalizado \\
\hline
\end{tabular}




\begin{tabular}{|c|c|c|c|c|c|c|c|}
\hline \multicolumn{8}{|c|}{ GAZETA DO POVO - CADERNO IMOBILIÁRIO - TERRENOS OFERTADOS PARA VENDA, DOM. 01 dez 1996} \\
\hline MUNICÍPIO & $\mathrm{R} \$ \mathbf{M} 2$ & BAIRRO & LOTEAMENTO & ENDEREÇO & ÁREA (m2) & PREÇO & ANUNCIANTE \\
\hline SJP & 20,79 & GUATUPÊ & Guatupê & próximo à Academia Militar & 05,00 & $R \$ 10.500,00$ & Proprietário \\
\hline SJP & 5,00 & DEL REY & Conjunto Del Rey & & bo,00 & $\mathrm{R} \$ 3.000,00$ & Proprietário \\
\hline SJP & 20,56 & ARISTOCRATA & Jardim Aristocrata & & $\mathrm{b} 0,00$ & $R \$ 18.500,00$ & Proprietário \\
\hline SJP & 34,72 & ARISTOCRATA & Jardim Aristocrata & a $1000 \mathrm{~m}$ do terminal & 32,00 & $R \$ 15.000,00$ & Proprietário \\
\hline SJP & 22,29 & IPÊ & Jardim da Luz & próximo à RENAULT & 48,70 & $\mathrm{R} \$ 10.000,00$ & Proprietário \\
\hline SJP & 68,18 & INÁ & & a 3 quadras da AV. RUI BARBOSA, próximo ao terminal & 40,00 & $R \$ 30.000,00$ & Regional Imóveis \\
\hline SJP & 36,84 & ARISTOCRATA & Jardim Aristocrata & & 80,00 & $\mathrm{R} \$ 14.000,00$ & Futurama \\
\hline SJP & 25,00 & ARISTOCRATA & Jardim Aristocrata & & 60,00 & $R \$ 9.000,00$ & Cilar \\
\hline SJP & 49,45 & ARISTOCRATA & Jardim Aristocrata & & 64,00 & $R \$ 18.000,00$ & Imobiliária Mota \\
\hline SJP & 55,60 & OURO FINO & & frente para a BR-376, ao lado do BRADESCO & 29,46 & $R \$ 35.000,00$ & Cibraco-Axelrud \\
\hline SJP & 19,68 & ACADEMIA & & a 2 quadras da BR-277, próximo a RENAULT & 32,00 & $\mathrm{R} \$ 8.500,00$ & Buso Imóveis \\
\hline SJP & 71,43 & BONECA DO IGUAÇU & & a poucos metros da CHURRASCARIA NAPOLITANA & 50,00 & $\mathrm{R} \$ 25.000,00$ & AW Empreend. Imob. \\
\hline SJP & 77,85 & SÃO PEDRO & & próximos ao Hospital São José & 734,00 & \begin{tabular}{|l|}
$R \$$ \\
$135.000,00$ \\
\end{tabular} & Ferreira Corr. Imóveis \\
\hline SJP & 27,03 & CRUZEIRO & Jardim Cruzeiro & & 55,00 & $R \$ 15.000,00$ & Ferreira Corr. Imóveis \\
\hline SJP & 14,58 & GUATUPÊ & Guatupê & & 80,00 & $\mathrm{R} \$ 7.000,00$ & SEMPREBOM Corr. Autôn. \\
\hline SJP & 163,52 & CENTRO & Centro & & 95,00 & \begin{tabular}{|l}
$R \$$ \\
$130.000,00$ \\
\end{tabular} & Rocco Imóveis \\
\hline SJP & 138,36 & CENTRO & Centro & Rua Visconde do Rio Branco & 95,00 & \begin{tabular}{|l}
$\mathrm{R} \$$ \\
$110.000,00$ \\
\end{tabular} & Rocco Imóveis \\
\hline SJP & 130,02 & CENTRO & Centro & Rua Visconde do Rio Branco & 46,00 & \begin{tabular}{|l}
$R \$$ \\
$110.000,00$ \\
\end{tabular} & Rocco Imóveis \\
\hline SJP & 55,56 & CENTRO & Centro & & 50,00 & $R \$ 25.000,00$ & Rocco Imóveis \\
\hline SJP & 64,29 & CENTRO & Centro & & 20,00 & $R \$ 27.000,00$ & Rocco Imóveis \\
\hline SJP & 48,08 & ARISTOCRATA & Jardim Aristocrata & & 20,00 & $R \$ 25.000,00$ & Rocco Imóveis \\
\hline SJP & 35,50 & SÃO DOMINGOS & Jardim Dona Letícia & & 07,00 & $\mathrm{R} \$ 18.000,00$ & Rocco Imóveis \\
\hline SJP & 40,00 & INÁ & Vila Edite & & $\mathrm{b} 0,00$ & $R \$ 16.000,00$ & Rocco Imóveis \\
\hline
\end{tabular}


GAZETA DO POVO - CADERNO IMOBILIÁRIO - TERRENOS OFERTADOS PARA VENDA, DOM. 01 dez 1996

\begin{tabular}{|c|c|c|c|c|c|c|c|}
\hline MUNICÍPIO & $\mathrm{R} \$ \mathbf{M} 2$ & BAIRRO & LOTEAMENTO & ENDEREÇO & ÁREA (m2) & PREÇO & ANUNCIANTE \\
\hline SJP & 21,62 & ARISTOCRATA & Jardim Aristocrata & & 40,00 & $\mathrm{R} \$ 16.000,00$ & Rocco Imóveis \\
\hline SJP & 38,87 & CRUZEIRO & Jardim Cruzeiro & & 11,60 & $\mathrm{R} \$ 16.000,00$ & Rocco Imóveis \\
\hline SJP & 28,37 & SÃO DOMINGOS & Jardim Dona Letícia & & 64,00 & $R \$ 16.000,00$ & Rocco Imóveis \\
\hline SJP & 25,00 & ARISTOCRATA & Jardim Aristocrata & & 00,00 & $R \$ 15.000,00$ & Rocco Imóveis \\
\hline SJP & 29,17 & CIDADE JARDIM & Jardim Elvira I & & 80,00 & $R \$ 14.000,00$ & Rocco Imóveis \\
\hline SJP & 34,01 & CRUZEIRO & Jardim Cruzeiro & & 11,60 & $\mathrm{R} \$ 14.000,00$ & Rocco Imóveis \\
\hline SJP & 30,86 & CRUZEIRO & Jardim Cruzeiro & & 11,60 & $\mathrm{R} \$ 12.700,00$ & Rocco Imóveis \\
\hline SJP & 30,82 & PEDRO MORO & Jardim Christina & & 89,40 & $\mathrm{R} \$ 12.000,00$ & Rocco Imóveis \\
\hline SJP & 29,33 & ARISTOCRATA & Jardim Aristocrata & & 75,00 & $\mathrm{R} \$ 11.000,00$ & Rocco Imóveis \\
\hline SJP & 24,33 & CRUZEIRO & Jardim Cruzeiro & & 11,00 & $R \$ 10.000,00$ & Rocco Imóveis \\
\hline SJP & 4,18 & PEDRO MORO & Jardim Cristina & & 390,00 & $R \$ 10.000,00$ & Rocco Imóveis \\
\hline SJP & 14,88 & CIDADE JARDIM & Jardim Eunice & & 72,00 & $R \$ 10.000,00$ & Rocco Imóveis \\
\hline SJP & 23,81 & IPÊ & Jardim da Luz & & 20,00 & $\mathrm{R} \$ 10.000,00$ & Rocco Imóveis \\
\hline SJP & 24,00 & ARISTOCRATA & Jardim Aristocrata & & 75,00 & $\mathrm{R} \$ 9.000,00$ & Rocco Imóveis \\
\hline SJP & 25,00 & ARISTOCRATA & Jardim Aristocrata & & 60,00 & $\mathrm{R} \$ 9.000,00$ & Rocco Imóveis \\
\hline SJP & 23,44 & INÁ & Jardim Arthêmia & & 84,00 & $\mathrm{R} \$ 9.000,00$ & Rocco Imóveis \\
\hline SJP & 24,00 & ARISTOCRATA & Jardim Aristocrata & & 75,00 & $R \$ 9.000,00$ & Rocco Imóveis \\
\hline SJP & 20,83 & ARISTOCRATA & Jardim Aristocrata & & 60,00 & $\mathrm{R} \$ 7.500,00$ & Rocco Imóveis \\
\hline SJP & 31,25 & AFONSO PENA & Afonso Pena & & 24,00 & $\mathrm{R} \$ 7.000,00$ & Rocco Imóveis \\
\hline SJP & 8,33 & SÃO MARCOS & Jardim Carmen & & 60,00 & $\mathrm{R} \$ 3.000,00$ & Rocco Imóveis \\
\hline SJP & 11,90 & JUREMA & Jardim Jurema & & 20,00 & $R \$ 5.000,00$ & Wan Dall Imóveis \\
\hline SJP & 15,83 & ARISTOCRATA & Jardim Aristocrata & & 00,00 & $R \$ 9.500,00$ & Wan Dall Imóveis \\
\hline SJP & 27,78 & CIDADE JARDIM & Cidade Jardim & & 60,00 & $R \$ 10.000,00$ & Wan Dall Imóveis \\
\hline SJP & 27,46 & QUISSISANA & Vila Quissisana & & 86,00 & $R \$ 10.600,00$ & Wan Dall Imóveis \\
\hline SJP & 35,21 & BONECA DO IGUAÇU & Vila Icaraí & & 26,00 & $\mathrm{R} \$ 15.000,00$ & Wan Dall Imóveis \\
\hline SJP & 35,71 & BONECA DO IGUAÇU & Jardim Santos Dumont & & 20,00 & $R \$ 15.000,00$ & Wan Dall Imóveis \\
\hline
\end{tabular}




\begin{tabular}{|c|c|c|c|c|c|c|c|}
\hline \multicolumn{8}{|c|}{ GAZETA DO POVO - CADERNO IMOBILIÁRIO - TERRENOS OFERTADOS PARA VENDA, DOM. 01 dez 1996} \\
\hline MUNICÍPIO & $\mathbf{R} \$ \mathbf{M} 2$ & BAIRRO & LOTEAMENTO & ENDEREÇO & ÁREA (m2) & PREÇO & ANUNCIANTE \\
\hline SJP & 37,71 & GUATUPÊ & Guatupê & & 80,00 & $R \$ 18.100,00$ & Wan Dall Imóveis \\
\hline SJP & 50,28 & GUATUPÊ & Guatupê & & 60,00 & $R \$ 18.100,00$ & Wan Dall Imóveis \\
\hline SJP & 41,35 & CENTRO & Centro & Rua Clevelândia & 32,00 & $\mathrm{R} \$ 22.000,00$ & Wan Dall Imóveis \\
\hline SJP & 51,47 & CRUZEIRO & Vila Rocco II & & 08,00 & $\mathrm{R} \$ 21.000,00$ & Wan Dall Imóveis \\
\hline SJP & 49,15 & CRUZEIRO & Vila Rocco II & & 68,00 & $\mathrm{R} \$ 23.000,00$ & Wan Dall Imóveis \\
\hline SJP & 73,89 & CENTRO & Centro & & 06,00 & $R \$ 30.000,00$ & Wan Dall Imóveis \\
\hline SJP & 36,08 & CENTRO & Centro & & 940,00 & $\mathrm{R} \$ 70.000,00$ & Wan Dall Imóveis \\
\hline SJP & 95,92 & CENTRO & & próximo ao centro & 34,00 & $\mathrm{R} \$ 80.000,00$ & Irajá Vargas Empreend. Imob. \\
\hline SJP & 15,28 & IPÊ & Jardim Izaura & & 60,00 & $R \$ 5.500,00$ & Mesquita Imóveis \\
\hline SJP & 26,39 & ARISTOCRATA & Jardim Aristocrata & Rua Gonzalez Pecotche, a $40 \mathrm{~m}$ da avenida principal & 60,00 & $\mathrm{R} \$ 9.500,00$ & Comissária Bourguignon \\
\hline SJP & 15,48 & JUREMA & Jardim Jurema & Rua Rosa Moro Machado, próximo à RENAULT & 20,00 & $\mathrm{R} \$ 6.500,00$ & Comissária Bourguignon \\
\hline SJP & 11,41 & DOM RODRIGO & $\begin{array}{l}\text { Condomínio Chácara } \\
\text { Dom Rodrigo }\end{array}$ & com acesso pela BR-277 & 068,00 & $R \$ 35.000,00$ & David Pelissari Imóveis \\
\hline SJP & 18,80 & GUATUPÊ & Guatupê & & 330,00 & $\mathrm{R} \$ 25.000,00$ & $\begin{array}{l}\text { Aguinaldo Vaz Nascimento } \\
\text { Empreend. Imob. }\end{array}$ \\
\hline SJP & 15,54 & ARISTOCRATA & Jardim Aristocrata & a 5 minutos do centro SJP & 40,00 & $\mathrm{R} \$ 11.500,00$ & Carvalho Imóveis \\
\hline
\end{tabular}




\begin{tabular}{|c|c|c|c|c|c|c|c|}
\hline \multicolumn{8}{|c|}{ GAZETA DO POVO - CADERNO IMOBILIÁRIO - TERRENOS OFERTADOS PARA VENDA, DOM. 04 jun 2000} \\
\hline MUNICÍPIO & $\mathrm{R} \$ \mathbf{M} 2$ & BAIRRO & LOTEAMENTO & ENDEREÇO & ÁREA (m2) & PREÇO & ANUNCIANTE \\
\hline Colombo & 12,00 & ATUBA & Atuba & & $20.000,00$ & $R \$ 240.000,00$ & \\
\hline Colombo & 41,21 & OSASCO & Jardim Guanabara & & 364,00 & $R \$ 15.000,00$ & LS Castro \\
\hline Colombo & 41,67 & ROÇA GRANDE & Jardim Curitibano & & 360,00 & $R \$ 15.000,00$ & LS Castro \\
\hline Colombo & 9,30 & GUARAÍTUBA & Guaraituba & & $2.688,00$ & $R \$ 25.000,00$ & Apolar \\
\hline Colombo & 60,61 & GABIROBAL & Olaria & & 330,00 & $R \$ 20.000,00$ & Apolar \\
\hline Colombo & 40,32 & & & Rua José Brito Juca, n. 44; próximo ao CONTORNO NORTE & 372,00 & $R \$ 15.000,00$ & Dama Imóveis \\
\hline Colombo & 6,03 & PALMITAL & & BR-116, em frente ao Santa Mônica Clube de Campo & $126.000,00$ & $R \$ 760.000,00$ & Cesário Pereira \\
\hline Colombo & 25,64 & ROÇA GRANDE & Roça Grande & & 390,00 & $R \$ 10.000,00$ & CASAMIL Imóveis \\
\hline Colombo & 52,38 & GUARANI & Vila Guarani & Rua José Maria da Silva Paranhos & 420,00 & $\mathrm{R} \$ 22.000,00$ & Imobiliária JB \\
\hline Colombo & 20,03 & GUARAÍTUBA & Guaraituba & Rua Andirá & 624,00 & $R \$ 12.500,00$ & Mesquita Imóveis \\
\hline Colombo & 26,44 & GUARAÍTUBA & Guaraituba & a uma quadra da ESTRADA DA RIBEIRA & 624,00 & $R \$ 16.500,00$ & Karima Imóveis \\
\hline Colombo & 23,33 & MARACANÃ & Alto Maracanâ & & $12.000,00$ & $\mathrm{R} \$ 280.000,00$ & EMEGEGE Imóveis \\
\hline Colombo & 54,09 & MARACANÃ & Alto Maracanâ & & 220,00 & $R \$ 11.900,00$ & S Rodrigues Imóveis \\
\hline Colombo & 116,50 & CENTRO & Jardim Guadalajara & & 515,00 & $\mathrm{R} \$ 60.000,00$ & Apolar \\
\hline Pinhais & 13,33 & GRACIOSA & & próximo ao ALPHAVILLE GRACIOSA & $3.000,00$ & $\mathrm{R} \$ 40.000,00$ & CIBRACO-AXELRUD \\
\hline Pinhais & 22,22 & WEISSÓPOLIS & & AV. IRAÍ & $1.800,00$ & $R \$ 40.000,00$ & Imobiliária BERGER \\
\hline Pinhais & 46,15 & PALMITAL & Atuba & Av. JACOB MACANHAN, próximo ao ALPHAVILLE & $1.300,00$ & $\mathrm{R} \$ 60.000,00$ & Apolar \\
\hline Pinhais & 169,27 & CENTRO & Centro & & 384,00 & $R \$ 65.000,00$ & Apolar \\
\hline Pinhais & 41,67 & PALMITAL & Jardim Pedro Demeterco & & 360,00 & $R \$ 15.000,00$ & Apolar \\
\hline Pinhais & 12,37 & VILA AMÉLIA & Bois de Boulogne & & $3.234,00$ & $\mathrm{R} \$ 40.000,00$ & Imobiliária TANTUS \\
\hline Pinhais & 37,65 & ESTÂNCIA PINHAIS & Tarumã & rua paralela à JOÃO LEOPOLDO JACOMEL & $1.992,00$ & $R \$ 75.000,00$ & Imobiliária TANTUS \\
\hline Pinhais & 20,00 & VILA AMÉLIA & Bois de Boulogne & nas imediações do CARREFOUR PINHAIS & $3.000,00$ & $\mathrm{R} \$ 60.000,00$ & NOSSO LAR Imóveis \\
\hline
\end{tabular}




\begin{tabular}{|c|c|c|c|c|c|c|c|}
\hline \multicolumn{8}{|c|}{ GAZETA DO POVO - CADERNO IMOBILIÁRIO - TERRENOS OFERTADOS PARA VENDA, DOM. 04 jun 2000} \\
\hline MUNICÍPIO & $\mathrm{R} \$ \mathbf{M} 2$ & BAIRRO & LOTEAMENTO & ENDEREÇO & ÁREA (m2) & PREÇO & ANUNCIANTE \\
\hline Pinhais & 27,50 & VARGEM GRANDE & & $\begin{array}{l}\text { Rua Euclides da Cunha, próximo a ENSOLO; a } 4 \text { quadras } \\
\text { da AV. IRAİ }\end{array}$ & $4.000,00$ & $R \$ 110.000,00$ & Dama Imóveis \\
\hline Pinhais & 95,08 & CENTRO & & Rua Camilo de Lelis & $5.259,00$ & $R \$ 500.000,00$ & Regional Imóveis \\
\hline Pinhais & 64,95 & EMILIANO PERNETA & & Rua Mandaguari & 816,00 & $R \$ 53.000,00$ & Mesquita Imóveis \\
\hline Pinhais & 68,06 & VILA AMÉLIA & Vale da Boa Esperança & & 360,00 & $\mathrm{R} \$ 24.500,00$ & $\begin{array}{l}\text { Bizineli Empreend. } \\
\text { Imob. }\end{array}$ \\
\hline Pinhais & 102,78 & PALMITAL & Pineville & & 360,00 & $\mathrm{R} \$ 37.000,00$ & $\begin{array}{l}\text { Bizineli Empreend. } \\
\text { Imob. }\end{array}$ \\
\hline Pinhais & 227,27 & CENTRO & & Rua Camilo de Lelis, próximo ao Banco do Brasil & $1.100,00$ & $\mathrm{R} \$ 250.000,00$ & Lessa Imóveis \\
\hline Pinhais & 28,47 & VILA AMÉLIA & Bois de Boulogne & próximo ao CARREFOUR PINHAIS & 421,50 & $R \$ 12.000,00$ & $\begin{array}{l}\text { Ambrosio Alves Ass. } \\
\text { Imob. }\end{array}$ \\
\hline Pinhais & 38,16 & CENTRO & Varginha & & $1.991,85$ & $R \$ 76.000,00$ & EMEGEGE Imóveis \\
\hline Pinhais & 55,00 & EMILIANO PERNETA & Vila Perneta & próximo ao Shopping GRALHA AZUL & 600,00 & $R \$ 33.000,00$ & Escritório Imobiliário \\
\hline Pinhais & 66,67 & PALMITAL & & em frente ao ALPHAVILLE GRACIOSA & 600,00 & $\mathrm{R} \$ 40.000,00$ & Escritório Imobiliário \\
\hline Pinhais & 41,67 & WEISSÓPOLIS & Jardim Weissópolis & & $2.400,00$ & $R \$ 100.000,00$ & Escritório Imobiliário \\
\hline Pinhais & 66,67 & ESTÂNCIA PINHAIS & Estância & & 750,00 & $R \$ 50.000,00$ & Escritório Imobiliário \\
\hline Pinhais & 32,00 & VARGEM GRANDE & Vargem Grande & & 625,00 & $R \$ 20.000,00$ & Segmento Imóveis \\
\hline Pinhais & 150,00 & VILA AMÉLIA & & $\begin{array}{l}\text { na AV.JOÂO LEOPOLDO JACOMEL, ao lado da } \\
\text { CHURRASCARIA VALEJO }\end{array}$ & $2.000,00$ & $\mathrm{R} \$ 300.000,00$ & M de MARI \\
\hline SJP & 3,30 & $\begin{array}{l}\text { CAMPO LARGO DA } \\
\text { ROSEIRA }\end{array}$ & & a 2,5km da AUDI; a $1 \mathrm{~km}$ da BR-376 & $242.000,00$ & $\mathrm{R} \$ 798.600,00$ & \\
\hline SJP & 7,00 & $\begin{array}{l}\text { CAMPO LARGO DA } \\
\text { ROSEIRA }\end{array}$ & & ao lado da PUCPR - SJP & $4.000,00$ & $\mathrm{R} \$ 28.000,00$ & \\
\hline SJP & 16,40 & SANTO ANTONIO & Jardim Patrícia & & 975,60 & $\mathrm{R} \$ 16.000,00$ & \\
\hline
\end{tabular}




\begin{tabular}{|c|c|c|c|c|c|c|c|}
\hline \multicolumn{8}{|c|}{ GAZETA DO POVO - CADERNO IMOBILIÁRIO - TERRENOS OFERTADOS PARA VENDA, DOM. 04 jun 2000} \\
\hline MUNICÍPIO & $\mathrm{R} \$ \mathbf{M} 2$ & BAIRRO & LOTEAMENTO & ENDEREÇO & ÁREA (m2) & PREÇO & ANUNCIANTE \\
\hline SJP & 9,60 & GUATUPÊ & Guatupê & & $1.875,00$ & $R \$ 18.000,00$ & Panamericana \\
\hline SJP & 16,67 & GUATUPÊ & Guatupê & & $1.200,00$ & $R \$ 20.000,00$ & Panamericana \\
\hline SJP & 10,00 & $\begin{array}{l}\text { CAMPO LARGO DA } \\
\text { ROSEIRA }\end{array}$ & Roseira & excelente área em frente à AUDI & $40.000,00$ & $R \$ 400.000,00$ & Apolar \\
\hline SJP & 105,56 & AFONSO PENA & Afonso Pena & AV. RUI BARBOSA, próximo ao terminal Afonso Pena & 720,00 & $\mathrm{R} \$ 76.000,00$ & Apolar \\
\hline SJP & 47,62 & AFONSO PENA & Afonso Pena & & 420,00 & $R \$ 20.000,00$ & Apolar \\
\hline SJP & 22,22 & GUATUPÊ & Guatupê & próximo à ACADEMIA DE POLìCIA & 585,00 & $R \$ 13.000,00$ & Apolar \\
\hline SJP & 25,64 & $\begin{array}{l}\text { ROSEIRA DE SÃO } \\
\text { SEBASTIÃO }\end{array}$ & Vila Roseli & próximo a RENAULT & 507,00 & $R \$ 13.000,00$ & Apolar \\
\hline SJP & 18,52 & $\begin{array}{l}\text { ROSEIRA DE SÃO } \\
\text { SEBASTIÃO }\end{array}$ & Jardim Guarani & & 432,00 & $R \$ 8.000,00$ & Apolar \\
\hline SJP & 34,95 & & & $\begin{array}{l}\text { Rua David Campista, próximo do AEROPORTO, a } 300 \mathrm{~m} \\
\text { da AV. RUI BARBOSA }\end{array}$ & $12.646,00$ & $\mathrm{R} \$ 442.000,00$ & Imobiliária 2000 \\
\hline SJP & 78,13 & & & próximo à Rua Alexandrino & 256,00 & $\mathrm{R} \$ 20.000,00$ & Imobiliária 2001 \\
\hline SJP & 74,47 & INÁ & Jardim das Acácias & & 376,00 & $\mathrm{R} \$ 28.000,00$ & \\
\hline SJP & 20,00 & & Moradas do Sol & próximo à RENAULT & $2.000,00$ & $R \$ 40.000,00$ & \begin{tabular}{|l} 
Nova Orleans \\
Empreend. Imob.
\end{tabular} \\
\hline SJP & 131,58 & CENTRO & Centro & & 418,00 & $\mathrm{R} \$ 55.000,00$ & CILAR - SJP \\
\hline SJP & 85,65 & BOM JESUS & Bom Jesus & & 467,00 & $\mathrm{R} \$ 40.000,00$ & CILAR - SJP \\
\hline SJP & 69,44 & ARISTOCRATA & Jardim Aristocrata & & 360,00 & $R \$ 25.000,00$ & CILAR - SJP \\
\hline SJP & 34,52 & $\begin{array}{l}\text { ROSEIRA DE SÃO } \\
\text { SEBASTIÃO }\end{array}$ & Vila Roseli & & 507,00 & $R \$ 17.500,00$ & CILAR - SJP \\
\hline SJP & 60,13 & AVIAÇÃO & Jardim Aviação & & 449,00 & $R \$ 27.000,00$ & CILAR - SJP \\
\hline SJP & 20,83 & BORDA DO CAMPO & Planta Nemari II & & 864,00 & $R \$ 18.000,00$ & Imobiliária SALLVI \\
\hline SJP & 28,13 & INÁ & & $\begin{array}{l}\text { próximo ao terminal de ônibus Afonso Pena, a } 2 \text { quadras } \\
\text { da AV. RUI BARBOSA }\end{array}$ & 480,00 & $R \$ 13.500,00$ & Regional Imóveis \\
\hline SJP & 3,99 & & & Rua Waldemiro Waloski, 998 & $36.300,00$ & $\mathrm{R} \$ 145.000,00$ & RAZÂO Imóveis \\
\hline
\end{tabular}




\begin{tabular}{|c|c|c|c|c|c|c|c|}
\hline \multicolumn{8}{|c|}{ GAZETA DO POVO - CADERNO IMOBILIÁRIO - TERRENOS OFERTADOS PARA VENDA, DOM. 04 jun 2000} \\
\hline MUNICÍPIO & $\mathrm{R} \$ \mathbf{M} 2$ & BAIRRO & LOTEAMENTO & ENDEREÇO & ÁREA (m2) & PREÇO & ANUNCIANTE \\
\hline SJP & 24,23 & IPÊ & Jardim Ipê & & 392,00 & $\mathrm{R} \$ 9.500,00$ & Lorusso Imóveis \\
\hline SJP & 11,85 & BORDA DO CAMPO & Borda do Campo & Vila Santa Tereza & 675,00 & $\mathrm{R} \$ 8.000,00$ & $\begin{array}{l}\text { Ambrósio Alves Ass. } \\
\text { Imob. }\end{array}$ \\
\hline SJP & 18,18 & PEDRO MORO & Vila Braga & & $11.000,00$ & $\mathrm{R} \$ 200.000,00$ & Pollatti \& Cordeiro \\
\hline SJP & 20,83 & GUATUPE & Guatupê & antes da Associação dos Professores & 480,00 & $\mathrm{R} \$ 10.000,00$ & Albini Imóveis \\
\hline SJP & 15,00 & $\begin{array}{l}\text { ROSEIRA DE SÃO } \\
\text { SEBASTIÃO }\end{array}$ & & frente ao CONTORNO LESTE, próximo à RENAULT & $30.000,00$ & $\mathrm{R} \$ 450.000,00$ & Assessoria Imobiliária \\
\hline SJP & 11,05 & GUATUPÊ & Guatupê & próximo à AV. RUI BARBOSA & $12.000,00$ & $\mathrm{R} \$ 132.600,00$ & Assessoria Imobiliária \\
\hline SJP & & & Jardim Eldorado & & 250,00 & $\begin{array}{l}\text { entrada de } 3500,00 \\
\text { mais } 131 \text { parcelas } \\
\text { de } 160 \% \text { do salário } \\
\text { mínimo }\end{array}$ & Antena Imóveis Ltda. \\
\hline SJP & & & Jardim Eldorado & & 304,00 & $\begin{array}{l}\text { entrada de } 8000,00 \\
\text { mais } 135 \text { parcelas } \\
\text { de } 220 \% \text { do salário } \\
\text { mínimo }\end{array}$ & Antena Imóveis Ltda. \\
\hline SJP & 7,41 & INDEPENDÊNCIA & Jardim Independência & & 675,00 & $\mathrm{R} \$ 5.000,00$ & Antena Imóveis Ltda. \\
\hline SJP & 51,44 & & Jardim Iguassu & & 204,12 & $\mathrm{R} \$ 10.500,00$ & Antena Imóveis Ltda. \\
\hline SJP & 12,05 & $\begin{array}{l}\text { CAMPO LARGO DA } \\
\text { ROSEIRA }\end{array}$ & Campo Largo da Roseira & ao lado da AUDI, a 800m da BR-376 & $165.930,00$ & $\mathrm{R} \$ 2.000 .000,00$ & Washington Ortega \\
\hline SJP & 19,00 & & & $\begin{array}{l}\text { próximo ao AEROPORTO AFONSO PENA, a } 150 \mathrm{~m} \text { da } \\
\text { BR-376 }\end{array}$ & $100.000,00$ & $\mathrm{R} \$ 1.900 .000,00$ & Washington Ortega \\
\hline SJP & 40,00 & AFONSO PENA & Afonso Pena & & $17.609,00$ & $\mathrm{R} \$ 704.360,00$ & Washington Ortega \\
\hline SJP & 40,00 & AFONSO PENA & Afonso Pena & & $8.657,00$ & $\mathrm{R} \$ 346.292,00$ & Washington Ortega \\
\hline SJP & 66,93 & AEROPORTO & & Rua Barão do Cerro Azul; AEROPORTO & $1.016,00$ & $\mathrm{R} \$ 68.000,00$ & Washington Ortega \\
\hline SJP & 55,90 & PEDRO MORO & Vila Braga & Rua Quintino Zagonel & 769,22 & $\mathrm{R} \$ 43.000,00$ & Washington Ortega \\
\hline SJP & 51,92 & CRUZEIRO & Jardim Cruzeiro & Rua Rolândia & 385,20 & $\mathrm{R} \$ 20.000,00$ & Washington Ortega \\
\hline
\end{tabular}




\begin{tabular}{|c|c|c|c|c|c|c|c|}
\hline \multicolumn{8}{|c|}{ GAZETA DO POVO - CADERNO IMOBILIÁRIO - TERRENOS OFERTADOS PARA VENDA, DOM. 04 jun 2000} \\
\hline MUNICÍPIO & $\mathrm{R} \$ \mathbf{M} 2$ & BAIRRO & LOTEAMENTO & ENDEREÇO & ÁREA (m2) & PREÇO & ANUNCIANTE \\
\hline SJP & 23,67 & $\begin{array}{l}\text { ROSEIRA DE SÃO } \\
\text { SEBASTIÃOO }\end{array}$ & Jardim Paraíso & & 507,00 & $\mathrm{R} \$ 12.000,00$ & Washington Ortega \\
\hline SJP & 35,56 & COSTEIRA & Costeira & & 675,00 & $\mathrm{R} \$ 24.000,00$ & Washington Ortega \\
\hline SJP & 72,03 & $\begin{array}{l}\text { BONECA DO } \\
\text { IGUAÇU }\end{array}$ & Vila Icaraí & & $1.180,00$ & $\mathrm{R} \$ 85.000,00$ & $A B$ Imóveis \\
\hline SJP & 46,95 & $\begin{array}{l}\text { BONECA DO } \\
\text { IGUAÇU }\end{array}$ & Vila Icaraí & & 426,00 & $\mathrm{R} \$ 20.000,00$ & AB Imóveis \\
\hline SJP & 96,36 & $\begin{array}{l}\text { BONECA DO } \\
\text { IGUAÇU }\end{array}$ & Vila Palmira & & 467,00 & $\mathrm{R} \$ 45.000,00$ & $A B$ Imóveis \\
\hline SJP & 97,22 & $\begin{array}{l}\text { BONECA DO } \\
\text { IGUAÇU }\end{array}$ & Vila Palmira & & 360,00 & $R \$ 35.000,00$ & $A B$ Imóveis \\
\hline SJP & 85,33 & ARISTOCRATA & Jardim Aristocrata & av. principal & 375,00 & $\mathrm{R} \$ 32.000,00$ & AB Imóveis \\
\hline SJP & 66,67 & ARISTOCRATA & Jardim Aristocrata & & 360,00 & $\mathrm{R} \$ 24.000,00$ & AB Imóveis \\
\hline SJP & 71,43 & CRUZEIRO & Jardim Santos Dumont I & & 420,00 & $R \$ 30.000,00$ & AB Imóveis \\
\hline SJP & 44,44 & IPÊ & J. Rio Branco / Afonso Pena & & 450,00 & $R \$ 20.000,00$ & AB Imóveis \\
\hline SJP & 49,38 & QUISSISANA & Quissisana & & 405,00 & $\mathrm{R} \$ 20.000,00$ & AB Imóveis \\
\hline SJP & 41,67 & CIDADE JARDIM & Cidade Jardim & & 480,00 & $\mathrm{R} \$ 20.000,00$ & AB Imóveis \\
\hline SJP & 33,71 & ACADEMIA & Vila Bond & próximo à RENAULT & 356,00 & $R \$ 12.000,00$ & AB Imóveis \\
\hline SJP & 27,78 & GUATUPÊ & Guatupê / Jardim Brasil & & 396,00 & $\mathrm{R} \$ 11.000,00$ & AB Imóveis \\
\hline SJP & 200,00 & $\begin{array}{l}\text { BONECA DO } \\
\text { IGUAÇU }\end{array}$ & Vila Palmira & & 500,00 & $R \$ 100.000,00$ & $\begin{array}{l}\text { CW Corretores de } \\
\text { Imóveis }\end{array}$ \\
\hline SJP & 65,10 & AFONSO PENA & Jardim Curitibano & & 384.00 & $R \$ 25.000 .00$ & CW Corretores de \\
\hline SJP & 54,55 & INDEPENDÊNCIA & Subúrbio Curitibano & & 330.00 & $\mathrm{R} \$ 18.000 .00$ & CW Corretores de \\
\hline SJP & 50.37 & IPE & Jardim Rio Branco & & 337.50 & $R \$ 17.000 .00$ & CW Corretores de \\
\hline SJP & 17.36 & DOM RODRIGO & Jardim Libanópolis & & 432.00 & $\mathrm{R} \$ 7.500 .00$ & CW Corretores de \\
\hline SJP & 90,88 & ITÁLIA & Jardim Guadalaiara & & 228.00 & $R \$ 20.720 .00$ & CW C. de Imóveis \\
\hline SJP & 51,85 & $\begin{array}{l}\text { COLÔNIA RIO } \\
\text { GRANDE }\end{array}$ & Colônia Rio Grande & & 432,00 & $\mathrm{R} \$ 22.400,00$ & CW C. de Imóveis \\
\hline
\end{tabular}




\begin{tabular}{|c|c|c|c|c|c|c|c|}
\hline \multicolumn{8}{|c|}{ GAZETA DO POVO - CADERNO IMOBILIÁRIO - TERRENOS OFERTADOS PARA VENDA, DOM. 03 dez 2000} \\
\hline MUNICÍPIO & $\mathrm{R} \$ \mathbf{M} 2$ & BAIRRO & LOTEAMENTO & ENDEREÇO & ÁREA (m2) & PREÇO & ANUNCIANTE \\
\hline Colombo & 25,73 & MAUÁ & & BR-116, próximo ao Santa Mônica Clube de Campo & $13.603,00$ & $\mathrm{R} \$ 350.000,00$ & FUTURAMA \\
\hline Colombo & 45,56 & MARACANÃ & Jardim dos Eucaliptos & loteamento contíguo ao Parque Linear do Palmital & 360,00 & $R \$ 16.400,00$ & $\begin{array}{l}\text { HELLER Empreend. } \\
\text { Imob. }\end{array}$ \\
\hline Colombo & 45,64 & MARACANÃ & Jardim dos Eucaliptos & loteamento contíguo ao Parque Linear do Palmital & 354,77 & $R \$ 16.190,00$ & $\begin{array}{l}\text { HELLER Empreend. } \\
\text { Imob. }\end{array}$ \\
\hline Colombo & 50,00 & MARACANÃ & Jardim dos Eucaliptos & loteamento contíguo ao Parque Linear do Palmital & 300,00 & $R \$ 15.000,00$ & $\begin{array}{l}\text { HELLER Empreend. } \\
\text { Imob. }\end{array}$ \\
\hline Colombo & 35,05 & MARACANÃ & Jardim dos Eucaliptos & loteamento contíguo ao Parque Linear do Palmital & 367,32 & $R \$ 12.873,00$ & $\begin{array}{l}\text { HELLER Empreend. } \\
\text { Imob. }\end{array}$ \\
\hline Colombo & 41,51 & MARACANÃ & Jardim dos Eucaliptos & loteamento contíguo ao Parque Linear do Palmital & 307,26 & $R \$ 12.754,00$ & $\begin{array}{l}\text { HELLER Empreend. } \\
\text { Imob. }\end{array}$ \\
\hline Colombo & 41,67 & MARACANÃ & Jardim dos Eucaliptos & loteamento contíguo ao Parque Linear do Palmital & 300,00 & $R \$ 12.500,00$ & $\begin{array}{l}\text { HELLER Empreend. } \\
\text { Imob. }\end{array}$ \\
\hline Colombo & 55,00 & MARACANÃ & Jardim dos Eucaliptos & loteamento contíguo ao Parque Linear do Palmital & 200,00 & $\mathrm{R} \$ 11.000,00$ & $\begin{array}{l}\text { HELLER Empreend. } \\
\text { Imob. }\end{array}$ \\
\hline Colombo & 50,00 & MARACANÃ & Jardim dos Eucaliptos & loteamento contíguo ao Parque Linear do Palmital & 200,00 & $R \$ 10.000,00$ & $\begin{array}{l}\text { HELLER Empreend. } \\
\text { Imob. }\end{array}$ \\
\hline Colombo & 12,44 & PALMITAL & Vila Maria do Rosário & & $2.250,00$ & $\mathrm{R} \$ 28.000,00$ & J. Godoi Imóveis \\
\hline Colombo & 14,00 & CENTRO & & CONTORNO NORTE, frente para a RODOVIA DA UVA & $20.077,05$ & $\mathrm{R} \$ 281.078,70$ & $\begin{array}{l}\text { Washington Ortega } \\
\text { (SJP) }\end{array}$ \\
\hline Colombo & 14,00 & ROÇA GRANDE & & a 2 km da IGREJA de SANTA CÂNDIDA & $11.528,00$ & $\mathrm{R} \$ 161.392,00$ & $\begin{array}{l}\text { Bella Torre Imóveis } \\
\text { Especiais }\end{array}$ \\
\hline Colombo & 40,32 & CENTRO & & Rua José Brito Juca & 372,00 & $R \$ 15.000,00$ & Dama Imóveis \\
\hline Colombo & 84,21 & ATUBA & Atuba & TREVO DO ATUBA, divisa, BR-116 & $1.900,00$ & $\mathrm{R} \$ 160.000,00$ & $\begin{array}{l}\text { ODA Imóveis } \\
\text { (Colombo) }\end{array}$ \\
\hline Colombo & 25,00 & CENTRO & Centro (Colombo) & & $7.200,00$ & $\mathrm{R} \$ 180.000,00$ & $\begin{array}{l}\text { ODA Imóveis } \\
\text { (Colombo) }\end{array}$ \\
\hline Colombo & 45,96 & CAMPO PEQUENO & Jardim Bela Vista & a $800 \mathrm{~m}$ da divisa com Curitiba & 544,00 & $R \$ 25.000,00$ & $\begin{array}{l}\text { ODA Imóveis } \\
\text { (Colombo) }\end{array}$ \\
\hline
\end{tabular}




\begin{tabular}{|c|c|c|c|c|c|c|c|}
\hline \multicolumn{8}{|c|}{ GAZETA DO POVO - CADERNO IMOBILIÁRIO - TERRENOS OFERTADOS PARA VENDA, DOM. 03 dez 2000} \\
\hline MUNICÍPIO & $\mathbf{R} \$ \mathbf{M} 2$ & BAIRRO & LOTEAMENTO & ENDEREÇO & ÁREA (m2) & PREÇO & ANUNCIANTE \\
\hline Colombo & 39,06 & CAMPO PEQUENO & Jardim Bela Vista & & 384,00 & $R \$ 15.000,00$ & $\begin{array}{l}\text { ODA Imóveis } \\
\text { (Colombo) }\end{array}$ \\
\hline Colombo & 22,22 & GUARAITUBA & Jardim Itália & & 720,00 & $R \$ 16.000,00$ & $\begin{array}{l}\text { ODA Imóveis } \\
\text { (Colombo) }\end{array}$ \\
\hline Colombo & 24,12 & GUARAITUBA & Guaraituba & a duas quadras da ESTRADA DA RIBEIRA & 456,00 & $\mathrm{R} \$ 11.000,00$ & $\begin{array}{l}\text { ODA Imóveis } \\
\text { (Colombo) }\end{array}$ \\
\hline Colombo & 66,67 & MARACANÃ & Alto Maracanã & & 450,00 & $\mathrm{R} \$ 30.000,00$ & $\begin{array}{l}\text { ODA Imóveis } \\
\text { (Colombo) }\end{array}$ \\
\hline Colombo & 62,50 & ROÇA GRANDE & Roça Grande & & 480,00 & $\mathrm{R} \$ 30.000,00$ & $\begin{array}{l}\text { ODA Imóveis } \\
\text { (Colombo) }\end{array}$ \\
\hline Colombo & 24,58 & GUARAITUBA & Guaraituba & & 480,00 & $\mathrm{R} \$ 11.800,00$ & Assessoria Imobiliária \\
\hline Colombo & 42,50 & ATUBA & Atuba & & $4.000,00$ & $\mathrm{R} \$ 170.000,00$ & SEMPREBOM Imóveis \\
\hline Colombo & 17,01 & ROÇA GRANDE & Jardim Contorno & a $100 \mathrm{~m}$ da RODOVIA DA UVA & $1.881,00$ & $\mathrm{R} \$ 32.000,00$ & Cilar (SJP) \\
\hline Colombo & 8,66 & GUARAITUBA & Guaraituba & & $2.888,00$ & $\mathrm{R} \$ 25.000,00$ & APOLAR Imóveis \\
\hline Colombo & 54,12 & MARACANÃ & Alto Maracanã & & 220,00 & $\mathrm{R} \$ 11.906,00$ & $\begin{array}{l}\text { S. Rodrigues Compra } \\
\text { e Venda de Imóveis }\end{array}$ \\
\hline Pinhais & 107,14 & & Chácara Suiça & & 700,00 & $R \$ 75.000,00$ & \\
\hline Pinhais & 26,71 & MARIA ANTONIETA & & Rua Joaquim Nabuco & 936,00 & $\mathrm{R} \$ 25.000,00$ & Regional Imóveis \\
\hline Pinhais & 28,47 & VILA AMÉLIA & Bois de Boulogne & próximo ao CARREFOUR PINHAIS & 421,50 & $\mathrm{R} \$ 12.000,00$ & $\begin{array}{l}\text { Ambrosio Alves Ass. } \\
\text { Imob. }\end{array}$ \\
\hline Pinhais & 62,07 & VILA AMÉLIA & Vale da Boa Esperança & & 594,52 & $\mathrm{R} \$ 36.900,00$ & $\begin{array}{l}\text { Bizineli Empreend. } \\
\text { Imob. }\end{array}$ \\
\hline Pinhais & 62,82 & VILA AMÉLIA & Vale da Boa Esperança & & 390,00 & $R \$ 24.500,00$ & $\begin{array}{l}\text { Bizineli Empreend. } \\
\text { Imob. }\end{array}$ \\
\hline
\end{tabular}




\begin{tabular}{|c|c|c|c|c|c|c|c|}
\hline \multicolumn{8}{|c|}{ GAZETA DO POVO - CADERNO IMOBILIÁRIO - TERRENOS OFERTADOS PARA VENDA, DOM. 03 dez 2000} \\
\hline MUNICÍPIO & $\mathrm{R} \$ \mathbf{M} 2$ & BAIRRO & LOTEAMENTO & ENDEREÇO & ÁREA (m2) & PREÇO & ANUNCIANTE \\
\hline Pinhais & 94,87 & PALMITAL & Pineville & & 390,00 & $\mathrm{R} \$ 37.000,00$ & $\begin{array}{l}\text { Bizineli Empreend. } \\
\text { Imob. }\end{array}$ \\
\hline Pinhais & 32,89 & VILA AMÉLIA & Vila Amélia & & 456,00 & $R \$ 15.000,00$ & $\begin{array}{l}\text { Bizineli Empreend. } \\
\text { Imob. }\end{array}$ \\
\hline Pinhais & 58,33 & EMILIANO PERNETA & Vila Perneta & & 600,00 & $\mathrm{R} \$ 35.000,00$ & AJV Ass. Imob. \\
\hline Pinhais & 58,90 & WEISSÓPOLIS & $\begin{array}{l}\text { Planta Guilhermina } \\
\text { Weiss }\end{array}$ & ao lado do CARTÓDROMO & 543,30 & $\mathrm{R} \$ 32.000,00$ & Wilson A. Johnson \\
\hline Pinhais & 13,94 & VILA AMÉLIA & Bois de Boulogne & $\begin{array}{l}\text { Rua vereador Antonio Romeu Simoni, próximo ao } \\
\text { CARREFOUR PINHAIS }\end{array}$ & $3.228,22$ & $\mathrm{R} \$ 45.000,00$ & HANSEL Imóveis \\
\hline Pinhais & 11,68 & ENTRE RIOS & & $\begin{array}{l}\text { AV. JACOB MACANHAN, próximo ao ALPHAVILLE } \\
\text { GRACIOSA }\end{array}$ & $55.650,00$ & $R \$ 650.000,00$ & $\begin{array}{l}\text { Bella Torre Imóveis } \\
\text { Especiais }\end{array}$ \\
\hline Pinhais & 16,99 & VALE DAS ÁGUAS & & $\begin{array}{l}\text { RODOVIA JOÃO LEOPOLDO JACOMEL, ao lado do } \\
\text { Condomínio Recanto (Pinhais-Piraquara) }\end{array}$ & $25.900,00$ & $\mathrm{R} \$ 440.000,00$ & Imobiliária 2000 \\
\hline Pinhais & 63,78 & ESTÂNCIA PINHAIS & Vila Tarumâ & $\begin{array}{l}\text { Rua Sete de Setembro, próximo à Gráfica do Colégio } \\
\text { Expoente }\end{array}$ & 784,00 & $\mathrm{R} \$ 50.000,00$ & Mesquita Imóveis \\
\hline Pinhais & 30,40 & VARGEM GRANDE & & Rua Casimiro de Abreu, próximo ao terminal & $3.125,00$ & $\mathrm{R} \$ 95.000,00$ & Mesquita Imóveis \\
\hline Pinhais & 41,67 & EMILIANO PERNETA & Vila Emiliano Perneta & Rua Alto Paraná & 600,00 & $\mathrm{R} \$ 25.000,00$ & Imobiliária M\&D Ltda. \\
\hline Pinhais & 22,50 & VARGEM GRANDE & Vargem Grande & a 4 quadras da AV. IRAÍ & $2.000,00$ & $\mathrm{R} \$ 45.000,00$ & Assessoria Imobiliária \\
\hline Pinhais & 16,67 & WEISSÓPOLIS & Weissópolis & a 8 quadras da AV. IRAÍ & $1.200,00$ & $\mathrm{R} \$ 20.000,00$ & Assessoria Imobiliária \\
\hline Pinhais & 40,00 & GRACIOSA & Jardim Cláudia & próximo à AV. JACOB MACANHAN & 300,00 & $\mathrm{R} \$ 12.000,00$ & Noruega Ass. Imob. \\
\hline Pinhais & 140,63 & CENTRO & Centro (Pinhais) & & 384,00 & $\mathrm{R} \$ 54.000,00$ & APOLAR Imóveis \\
\hline Pinhais & 71,43 & PALMITAL & Pineville & & 420,00 & $\mathrm{R} \$ 30.000,00$ & $\begin{array}{l}\text { Mendes Construtora e } \\
\text { Imobiliária }\end{array}$ \\
\hline Pinhais & 95,56 & CENTRO & Centro (Pinhais) & & 900,00 & $\mathrm{R} \$ 86.000,00$ & Cibraco-Axelrud \\
\hline
\end{tabular}




\begin{tabular}{|c|c|c|c|c|c|c|c|}
\hline \multicolumn{8}{|c|}{ GAZETA DO POVO - CADERNO IMOBILIÁRIO - TERRENOS OFERTADOS PARA VENDA, DOM. 03 dez 2000} \\
\hline MUNICÍPIO & R\$/M2 & BAIRRO & LOTEAMENTO & ENDEREÇO & ÁREA (m2) & PREÇO & ANUNCIANTE \\
\hline SJP & 1,80 & GUATUPÊ & Guatupê & próxima à RENAULT & $10.000,00$ & $\mathrm{R} \$ 18.000,00$ & \\
\hline SJP & 11,85 & BORDA DO CAMPO & Borda do Campo & Planta Vila Santa Tereza & 675,00 & $\mathrm{R} \$ 8.000,00$ & $\begin{array}{l}\text { Ambrosio Alves Ass. } \\
\text { Imob. }\end{array}$ \\
\hline SJP & 15,41 & & & próximo ao CONTORNO SUL & $1.622,00$ & $\mathrm{R} \$ 25.000,00$ & Osiowy Ass. Imob. \\
\hline SJP & 13,50 & RIO PEQUENO & Rio Pequeno & frente para o CONTORNO LESTE & $98.840,00$ & $\begin{array}{l}\mathrm{R} \$ \\
1.334 .340,00\end{array}$ & $\begin{array}{l}\text { Washington Ortega } \\
\text { (SJP) }\end{array}$ \\
\hline SJP & 7,08 & GUATUPÊ & Guatupê & & $120.000,00$ & $\mathrm{R} \$ 850.000,00$ & $\begin{array}{l}\text { Washington Ortega } \\
\text { (SJP) }\end{array}$ \\
\hline SJP & 12,00 & COSTEIRA & Costeira & frente para o CONTORNO LESTE & $59.682,21$ & $\mathrm{R} \$ 716.194,00$ & $\begin{array}{l}\text { Washington Ortega } \\
\text { (SJP) }\end{array}$ \\
\hline SJP & 40,00 & AFONSO PENA & Afonso Pena & & $17.609,00$ & $\mathrm{R} \$ 704.360,00$ & $\begin{array}{l}\text { Washington Ortega } \\
\text { (SJP) }\end{array}$ \\
\hline SJP & 3,10 & CAMPINA DO TAQUARAL & Fazenda Miringuava & & $193.600,00$ & $\mathrm{R} \$ 600.000,00$ & $\begin{array}{l}\text { Washington Ortega } \\
\text { (SJP) }\end{array}$ \\
\hline SJP & 16,00 & RIO PEQUENO & Rio Pequeno & frente para o CONTORNO LESTE & $30.984,98$ & $\mathrm{R} \$ 495.759,00$ & $\begin{array}{l}\text { Washington Ortega } \\
\text { (SJP) }\end{array}$ \\
\hline SJP & 11,02 & & & CONTORNO LESTE & $43.000,00$ & $\mathrm{R} \$ 474.000,00$ & $\begin{array}{l}\text { Washington Ortega } \\
\text { (SJP) }\end{array}$ \\
\hline SJP & 34,96 & COLÔNIA RIO GRANDE & Colônia Rio Grande & frente para AV. RUI BARBOSA & $12.470,69$ & $\mathrm{R} \$ 436.000,00$ & $\begin{array}{l}\text { Washington Ortega } \\
\text { (SJP) }\end{array}$ \\
\hline SJP & 10,60 & RIO PEQUENO & Rio Pequeno & próximo ao CONTORNO LESTE & $39.643,70$ & $\mathrm{R} \$ 420.223,22$ & $\begin{array}{l}\text { Washington Ortega } \\
\text { (SJP) }\end{array}$ \\
\hline SJP & 14,46 & COLÔNIA RIO GRANDE & Colônia Rio Grande & frente para o CONTORNO SUL, próximo à indústria THERA & $26.275,50$ & $\mathrm{R} \$ 380.000,00$ & $\begin{array}{l}\text { Washington Ortega } \\
\text { (SJP) }\end{array}$ \\
\hline SJP & 40,00 & AFONSO PENA & Afonso Pena & & $8.657,00$ & $\mathrm{R} \$ 346.292,00$ & $\begin{array}{l}\text { Washington Ortega } \\
\text { (SJP) }\end{array}$ \\
\hline SJP & 250,00 & CENTRO & Centro (SJP) & Rua Voluntários da Pátria & $1.000,00$ & $\mathrm{R} \$ 250.000,00$ & $\begin{array}{l}\text { Washington Ortega } \\
\text { (SJP) }\end{array}$ \\
\hline
\end{tabular}




\begin{tabular}{|c|c|c|c|c|c|c|c|}
\hline \multicolumn{8}{|c|}{ GAZETA DO POVO - CADERNO IMOBILIÁRIO - TERRENOS OFERTADOS PARA VENDA, DOM. 03 dez 2000} \\
\hline MUNICÍPIO & R\$/M2 & BAIRRO & LOTEAMENTO & ENDEREÇO & ÁREA (m2) & PREÇO & ANUNCIANTE \\
\hline SJP & 148,15 & & & AV. TORRES esquina com Barão do Cerro Azul & 810,00 & $R \$ 120.000,00$ & $\begin{array}{l}\text { Washington Ortega } \\
\text { (SJP) }\end{array}$ \\
\hline SJP & 100,84 & CENTRO & Centro (SJP) & & $1.190,00$ & $R \$ 120.000,00$ & $\begin{array}{l}\text { Washington Ortega } \\
\text { (SJP) }\end{array}$ \\
\hline SJP & 168,65 & CENTRO & Centro (SJP) & & 504,00 & $\mathrm{R} \$ 85.000,00$ & $\begin{array}{l}\text { Washington Ortega } \\
\text { (SJP) }\end{array}$ \\
\hline SJP & 13,59 & COSTEIRA & Costeira & & $5.740,69$ & $R \$ 78.000,00$ & $\begin{array}{l}\text { Washington Ortega } \\
\text { (SJP) }\end{array}$ \\
\hline SJP & 34,21 & COLÔNIA RIO GRANDE & Colônia Rio Grande & frente para AV. RUI BARBOSA & $1.987,50$ & $\mathrm{R} \$ \mathbf{6 8 . 0 0 0 , 0 0}$ & $\begin{array}{l}\text { Washington Ortega } \\
\text { (SJP) }\end{array}$ \\
\hline SJP & 66,93 & AEROPORTO & Aeroporto & Rua Barão do Cerro Azul, ao lado da COPEL & $1.016,00$ & $\mathrm{R} \$ 68.000,00$ & $\begin{array}{l}\text { Washington Ortega } \\
\text { (SJP) }\end{array}$ \\
\hline SJP & 12,00 & GUATUPÊ & Guatupê & & $5.000,00$ & $\mathrm{R} \$ \mathbf{6 0 . 0 0 0 , 0 0}$ & $\begin{array}{l}\text { Washington Ortega } \\
\text { (SJP) }\end{array}$ \\
\hline SJP & 59,38 & AFONSO PENA & Afonso Pena & à meia quadra da AV. RUI BARBOSA & 960,00 & $\mathbf{R} \$ \mathbf{5 7 . 0 0 0 , 0 0}$ & $\begin{array}{l}\text { Washington Ortega } \\
\text { (SJP) }\end{array}$ \\
\hline SJP & 135,38 & SÃO DOMINGOS & Jardim Letícia & Rua Pedro Alberti & 406,25 & $\mathrm{R} \$ \mathbf{5 5 . 0 0 0 , 0 0}$ & $\begin{array}{l}\text { Washington Ortega } \\
\text { (SJP) }\end{array}$ \\
\hline SJP & 16,67 & AFONSO PENA & Afonso Pena & $\begin{array}{l}\text { Rua Tavares de Lira esquina com Rua Tereza Caetano } \\
\text { de Lima }\end{array}$ & $3.000,00$ & $\mathbf{R} \$ \mathbf{5 0 . 0 0 0 , 0 0}$ & $\begin{array}{l}\text { Washington Ortega } \\
\text { (SJP) }\end{array}$ \\
\hline SJP & 71,43 & BARRO PRETO & Barro Preto & próximo à PUC-SJP & 630,00 & $R \$ 45.000,00$ & $\begin{array}{l}\text { Washington Ortega } \\
\text { (SJP) }\end{array}$ \\
\hline SJP & 70,92 & SÃO DOMINGOS & Jardim Letícia & próximo ao Centro SJP & 564,00 & $R \$ 40.000,00$ & $\begin{array}{l}\text { Washington Ortega } \\
\text { (SJP) }\end{array}$ \\
\hline SJP & 65,32 & CRUZEIRO & Jardim Cruzeiro & Rua Castro & 444,00 & $\mathbf{R} \$ \mathbf{2 9 . 0 0 0 , 0 0}$ & $\begin{array}{l}\text { Washington Ortega } \\
\text { (SJP) }\end{array}$ \\
\hline SJP & 15,35 & SÃO MARCOS & São Marcos & & $1.824,00$ & $\mathbf{R} \$ \mathbf{2 8 . 0 0 0 , 0 0}$ & $\begin{array}{l}\text { Washington Ortega } \\
\text { (SJP) }\end{array}$ \\
\hline SJP & 63,64 & CRUZEIRO & Jardim Cruzeiro & Rua Adrianópolis & 440,00 & $R \$ 28.000,00$ & $\begin{array}{l}\text { Washington Ortega } \\
\text { (SJP) }\end{array}$ \\
\hline SJP & 56,25 & SÃO DOMINGOS & São Domingos & & 480,00 & $\mathrm{R} \$ 27.000,00$ & $\begin{array}{l}\text { Washington Ortega } \\
\text { (SJP) }\end{array}$ \\
\hline
\end{tabular}




\begin{tabular}{|c|c|c|c|c|c|c|c|}
\hline \multicolumn{8}{|c|}{ GAZETA DO POVO - CADERNO IMOBILIÁRIO - TERRENOS OFERTADOS PARA VENDA, DOM. 03 dez 2000} \\
\hline MUNICÍPIO & $\mathrm{R} \$ \mathbf{M} 2$ & BAIRRO & LOTEAMENTO & ENDEREÇO & ÁREA (m2) & PREÇO & ANUNCIANTE \\
\hline SJP & 55,63 & CRUZEIRO & Jardim Cruzeiro & Rua Adrianópolis & 449,40 & $R \$ 25.000,00$ & $\begin{array}{l}\text { Washington Ortega } \\
\text { (SJP) }\end{array}$ \\
\hline SJP & 22,64 & CRUZEIRO & Jardim Cruzeiro & & $1.104,00$ & $R \$ 25.000,00$ & $\begin{array}{l}\text { Washington Ortega } \\
\text { (SJP) }\end{array}$ \\
\hline SJP & 34,72 & SÃO MARCOS & São Marcos & & 432,00 & $R \$ 15.000,00$ & $\begin{array}{l}\text { Washington Ortega } \\
\text { (SJP) }\end{array}$ \\
\hline SJP & 35,35 & QUISSISANA & Quissisana & & 396,00 & $R \$ 14.000,00$ & $\begin{array}{l}\text { Washington Ortega } \\
\text { (SJP) }\end{array}$ \\
\hline SJP & 27,78 & $\begin{array}{l}\text { ROSEIRA DE SÃO } \\
\text { SEBASTIÃO }\end{array}$ & Jardim Guarani & próximo à RENAULT & 432,00 & $R \$ 12.000,00$ & $\begin{array}{l}\text { Washington Ortega } \\
\text { (SJP) }\end{array}$ \\
\hline SJP & 101,83 & BONECA DO IGUAÇU & Vila Palmira & & 982,00 & $R \$ 100.000,00$ & $\begin{array}{l}\text { CW Corretor de } \\
\text { Imóveis (SJP) }\end{array}$ \\
\hline SJP & 54,55 & INDEPENDÊNCIA & Subúrbio Curitibano & & 330,00 & $R \$ 18.000,00$ & $\begin{array}{l}\text { CW Corretor de } \\
\text { Imóveis (SJP) }\end{array}$ \\
\hline SJP & 50,37 & IPÊ & Jardim Rio Branco & & 337,50 & $R \$ 17.000,00$ & $\begin{array}{l}\text { CW Corretor de } \\
\text { Imóveis (SJP) }\end{array}$ \\
\hline SJP & 54,55 & INDEPENDÊNCIA & Subúrbio Curitibano & & 330,00 & $R \$ 18.000,00$ & $\begin{array}{l}\text { CW Corretor de } \\
\text { Imóveis (SJP) }\end{array}$ \\
\hline SJP & 23,67 & $\begin{array}{l}\text { ROSEIRA DE SÃO } \\
\text { SEBASTIÃO }\end{array}$ & Planta Roseli & & 507,00 & $R \$ 12.000,00$ & $\begin{array}{l}\text { CW Corretor de } \\
\text { Imóveis (SJP) }\end{array}$ \\
\hline SJP & 27,78 & JUREMA & Vila Jurema & & 360,00 & $R \$ 10.000,00$ & $\begin{array}{l}\text { CW Corretor de } \\
\text { Imóveis (SJP) }\end{array}$ \\
\hline SJP & 17,36 & DOM RODRIGO & Jardim Libanópolis & & 432,00 & $R \$ 7.500,00$ & $\begin{array}{l}\text { CW Corretor de } \\
\text { Imóveis (SJP) }\end{array}$ \\
\hline SJP & 37,24 & DEL REY & Jardim Del Rey & & 456,00 & $R \$ 16.980,00$ & $\begin{array}{l}\text { CW Corretor de } \\
\text { Imóveis (SJP) }\end{array}$ \\
\hline SJP & 90,88 & ITÁLIA & Jardim Guadalajara & & 228,00 & $R \$ 20.720,00$ & $\begin{array}{l}\text { CW Corretor de } \\
\text { Imóveis (SJP) }\end{array}$ \\
\hline SJP & 84,72 & COLÔNIA RIO GRANDE & Colônia Rio Grande & & 432,00 & $R \$ 36.600,00$ & $\begin{array}{l}\text { CW Corretor de } \\
\text { Imóveis (SJP) }\end{array}$ \\
\hline SJP & 12,00 & GUATUPE & Guatupê & frente para AV. GUATUPE & $10.000,00$ & $R \$ 120.000,00$ & AB Imóveis (SJP) \\
\hline SJP & 225,12 & CENTRO & Centro (SJP) & Av. Souza Naves & 422,00 & $R \$ 95.000,00$ & AB Imóveis (SJP) \\
\hline SJP & 111,11 & SÃO DOMINGOS & Jardim Dona Letícia & Travessa Pedro Alberti & 450,00 & $\mathbf{R} \$ \mathbf{5 0 . 0 0 0 , 0 0}$ & AB Imóveis (SJP) \\
\hline
\end{tabular}




\section{GAZETA DO POVO - CADERNO IMOBILIÁRIO - TERRENOS OFERTADOS PARA VENDA, DOM. 03 dez 2000}

\begin{tabular}{|c|c|c|c|c|c|c|c|}
\hline MUNICÍPIO & $\mathrm{R} \$ / \mathrm{M} 2$ & BAIRRO & LOTEAMENTO & ENDEREÇO & ÁREA (m2) & PREÇO & ANUNCIANTE \\
\hline SJP & 35,71 & AFONSO PENA & Afonso Pena & Rua Alfredo Pinto & $1.260,00$ & $R \$ 45.000,00$ & AB Imóveis (SJP) \\
\hline SJP & 61,67 & ARISTOCRATA & Jardim Aristocrata & & 600,00 & $\mathbf{R} \$ 37.000,00$ & AB Imóveis (SJP) \\
\hline SJP & 67,13 & AFONSO PENA & Afonso Pena & Planta Umuarama & 432,00 & $\mathrm{R} \$ 29.000,00$ & AB Imóveis (SJP) \\
\hline SJP & 58,11 & BONECA DO IGUAÇU & Vila Icaraí & Rua Pará & 456,00 & $\mathrm{R} \$ 26.500,00$ & AB Imóveis (SJP) \\
\hline SJP & 32,59 & INDEPENDÊNCIA & Jardim Independência & & 675,00 & $\mathrm{R} \$ 22.000,00$ & AB Imóveis (SJP) \\
\hline SJP & 122,22 & PEDRO MORO & Vila Braga & & 180,00 & $\mathrm{R} \$ 22.000,00$ & AB Imóveis (SJP) \\
\hline SJP & 50,00 & COSTEIRA & São Francisco & & 360,00 & $R \$ 18.000,00$ & AB Imóveis (SJP) \\
\hline SJP & 55,56 & COSTEIRA & São Francisco & & 360,00 & $\mathrm{R} \$ 20.000,00$ & AB Imóveis (SJP) \\
\hline SJP & 40,48 & ARISTOCRATA & Jardim Aristocrata & Rua Goiás & 420,00 & $\mathrm{R} \$ 17.000,00$ & AB Imóveis (SJP) \\
\hline SJP & 75,00 & SANTO ANTONIO & Parque dos Beija-Flores & & 200,00 & $R \$ 15.000,00$ & AB Imóveis (SJP) \\
\hline SJP & 34,72 & SÃO MARCOS & São Marcos I & Rua Ulisses Cordeiro & 432,00 & $R \$ 15.000,00$ & AB Imóveis (SJP) \\
\hline SJP & 27,62 & ACADEMIA & Vila Bond & próximo à RENAULT e BR-277 & 543,00 & $\mathrm{R} \$ 15.000,00$ & AB Imóveis (SJP) \\
\hline SJP & 33,71 & ACADEMIA & Vila Bond & próximo à RENAULT & 356,00 & $R \$ 12.000,00$ & AB Imóveis (SJP) \\
\hline SJP & 23,15 & DOM RODRIGO & Jardim Libanópolis & & 432,00 & $R \$ 10.000,00$ & AB Imóveis (SJP) \\
\hline SJP & 20,83 & BORDA DO CAMPO & Planta Nemari & próximo à RENAULT e BR-277 & 432,00 & $R \$ 9.000,00$ & AB Imóveis (SJP) \\
\hline SJP & 62,22 & INÁ & Jardim das Acácias & & 450,00 & $\mathrm{R} \$ \mathbf{2 8 . 0 0 0 , 0 0}$ & Imobiliária 2000 \\
\hline SJP & 63,57 & AFONSO PENA & Afonso Pena & & 409,00 & $\mathrm{R} \$ 26.000,00$ & Imobiliária 2001 \\
\hline SJP & 216,05 & CENTRO & Centro (SJP) & AV. RUI BARBOSA, próximo à NUTRIMENTAL & $1.296,00$ & $\mathrm{R} \$ \mathbf{2 8 0 . 0 0 0 , 0 0}$ & Rocco Imóveis \\
\hline SJP & 34,52 & PEDRO MORO & Vila Braga & Rua Quintino Zagonel & $1.014,00$ & $\mathrm{R} \$ 35.000,00$ & Rocco Imóveis \\
\hline SJP & 76,92 & ARISTOCRATA & Jardim Aristocrata & Rua Mark Twain & 390,00 & $\mathbf{R} \$ \mathbf{3 0 . 0 0 0 , 0 0}$ & Rocco Imóveis \\
\hline SJP & 20,00 & & & CONTORNO LESTE, próximo à THERA & $8.000,00$ & $R \$ 160.000,00$ & Rocco Imóveis \\
\hline SJP & 150,27 & CENTRO & Centro (SJP) & Rua Sete de Setembro, 661 & 366,00 & $\mathrm{R} \$ 55.000,00$ & Rocco Imóveis \\
\hline SJP & 40,48 & ARISTOCRATA & Jardim Aristocrata & & 420,00 & $\mathrm{R} \$ 17.000,00$ & EMAB Ass. Imob. \\
\hline SJP & 97,22 & AVIAÇÃO & Jardim Maria Cecília & & 360,00 & $\mathrm{R} \$ 35.000,00$ & SAHDAI Ass. Imob. \\
\hline SJP & 18,01 & GUATUPÊ & Guatupê & Planta Jardim São Paulo & 555,30 & $\mathrm{R} \$ 10.000,00$ & AKG Imóveis \\
\hline
\end{tabular}




\begin{tabular}{|c|c|c|c|c|c|c|c|}
\hline \multicolumn{8}{|c|}{ GAZETA DO POVO - CADERNO IMOBILIÁRIO - TERRENOS OFERTADOS PARA VENDA, DOM. 03 dez 2000} \\
\hline MUNICÍPIO & $\mathbf{R} \$ \mathbf{M} 2$ & BAIRRO & LOTEAMENTO & ENDEREÇO & ÁREA (m2) & PREÇO & ANUNCIANTE \\
\hline SJP & 27,78 & GUATUPÊ & Guatupê & Planta Jardim São Paulo & 360,00 & $R \$ 10.000,00$ & AKG Imóveis \\
\hline SJP & 48,73 & ITÁLIA & Jardim Itália & próximo à IGREJA Santa Margarida & 718,27 & $R \$ 35.000,00$ & Ponto Mil Imóveis \\
\hline SJP & 92,91 & & Jardim Vinhedos & & 592,00 & $\mathrm{R} \$ \mathbf{5 5 . 0 0 0 , 0 0}$ & Ponto Mil Imóveis \\
\hline SJP & 97,07 & AFONSO PENA & Afonso Pena & próximo à rua Almirante Alexandrino & $2.369,46$ & $\mathrm{R} \$ \mathbf{2 3 0 . 0 0 0 , 0 0}$ & Cilar (SJP) \\
\hline SJP & 18,75 & CRISTAL & Jardim Cristal & & 480,00 & $R \$ 9.000,00$ & Cilar (SJP) \\
\hline SJP & 25,00 & CRISTAL & Jardim Cristal & & 480,00 & $R \$ 12.000,00$ & Cilar (SJP) \\
\hline SJP & 57,64 & CIDADE JARDIM & Cidade Jardim & & 399,00 & $R \$ 23.000,00$ & APOLAR Imóveis \\
\hline SJP & 18,06 & JUREMA & Vila Jurema & & 360,00 & $\mathrm{R} \$ 6.500,00$ & APOLAR Imóveis \\
\hline SJP & 36,00 & & Condomínio Villas & HARAS BOM PASTOR, ao lado do Hotel PARANÁ GOLF & $1.250,00$ & $R \$ 45.000,00$ & APOLAR Imóveis \\
\hline SJP & 21,93 & SÃO MARCOS & São Marcos & & 456,00 & $R \$ 10.000,00$ & APOLAR Imóveis \\
\hline SJP & 11,57 & SÃO MARCOS & São Marcos & & 432,00 & $\mathrm{R} \$ 5.000,00$ & APOLAR Imóveis \\
\hline SJP & 29,17 & GUATUPÊ & Vila Itatiaia & a $7 \mathrm{~km}$ do Centro SJP & 480,00 & $\mathrm{R} \$ 14.000,00$ & APOLAR Imóveis \\
\hline SJP & 16,80 & DOM RODRIGO & $\begin{array}{l}\text { Cond. Chác. Dom } \\
\text { Rodrigo }\end{array}$ & BORDA DO CAMPO & $3.334,00$ & $\mathrm{R} \$ \mathbf{5 6 . 0 0 0 , 0 0}$ & APOLAR Imóveis \\
\hline SJP & 21,71 & ACADEMIA & Vila Bond / Guatupê & & 645,00 & $R \$ 14.000,00$ & Galo Imóveis \\
\hline
\end{tabular}




\begin{tabular}{|c|c|c|c|c|c|c|c|}
\hline \multicolumn{8}{|c|}{ GAZETA DO POVO - CADERNO IMOBILIÁRIO - TERRENOS OFERTADOS PARA VENDA, DOM. 06 jun 2004} \\
\hline MUNICÍPIO & $\mathrm{R} \$ \mathbf{M} 2$ & BAIRRO & LOTEAMENTO & ENDEREÇO & ÁREA (m2) & PREÇO & ANUNCIANTE \\
\hline Colombo & 71,32 & CENTRO & Centro & Rua Venâncio Trevisan & 631,00 & $\mathrm{R} \$ 45.000,00$ & Imobiliária X \\
\hline Pinhais & 115,19 & GRACIOSA & Alphaville & Condomínio Andorinhas & $1.215,40$ & $\mathrm{R} \$ 140.000,00$ & \\
\hline Pinhais & 148,98 & GRACIOSA & Alphaville Graciosa & Andorinhas & 704,80 & $\mathrm{R} \$ 105.000,00$ & \\
\hline Pinhais & 190,45 & GRACIOSA & Alphaville Graciosa & Andorinhas & 745,61 & $\mathrm{R} \$ 142.000,00$ & \\
\hline Pinhais & 33,33 & WEISSÓPOLIS & & Rua Rio Piraquara & $1.200,00$ & $R \$ 40.000,00$ & $\begin{array}{l}\text { Mesquita } \\
\text { Imóveis }\end{array}$ \\
\hline Pinhais & 28,00 & VARGEM GRANDE & Vargem Grande & Rua Joaquim Nabuco & $1.000,00$ & $\mathrm{R} \$ 28.000,00$ & $\begin{array}{l}\text { Maccagnan } \\
\text { Imóveis }\end{array}$ \\
\hline Pinhais & 72,46 & VARGEM GRANDE & Vargem Grande & Condomínio Terra Nova & 138,00 & $R \$ 10.000,00$ & \\
\hline Pinhais & 104,17 & PALMITAL & Jardim Demeterco & & 432,00 & $\mathrm{R} \$ 45.000,00$ & \\
\hline Pinhais & 45,02 & PALMITAL & Vila Bourdignon & Rua Rolândia & $2.821,00$ & $\mathrm{R} \$ 127.000,00$ & M\&D Imóveis \\
\hline Pinhais & 84,09 & PALMITAL & Vila Bourdignon & Rua Rolândia & 440,00 & $R \$ 37.000,00$ & \begin{tabular}{|l} 
com o \\
proprietário \\
\end{tabular} \\
\hline Pinhais & 66,91 & EMILIANO PERNETA & Vila Perneta & & 343,75 & $\mathrm{R} \$ 23.000,00$ & SEMPREBOM \\
\hline Pinhais & 97,22 & VILA AMÉLIA & Vila Boa Esperança & & 360,00 & $\mathrm{R} \$ 35.000,00$ & \\
\hline Pinhais & 76,19 & VILA AMÉLIA & Vila Boa Esperança & & 420,00 & $\mathrm{R} \$ 32.000,00$ & Galvão \\
\hline Pinhais & 107,69 & PALMITAL & Pineville & Rua Adolfo Sora & 390,00 & $\mathrm{R} \$ 42.000,00$ & \\
\hline Pinhais & 89,74 & PALMITAL & Pineville & & 390,00 & $R \$ 35.000,00$ & \begin{tabular}{|l} 
Josué Souza \\
Imóveis
\end{tabular} \\
\hline Pinhais & 105,13 & PALMITAL & Pineville & & 390,00 & $\mathrm{R} \$ 41.000,00$ & $\begin{array}{l}\begin{array}{l}\text { Josué Souza } \\
\text { Imóveis }\end{array} \\
\end{array}$ \\
\hline Pinhais & 115,35 & EMILIANO PERNETA & & $\begin{array}{l}\text { Rua Benvenuto Rattmann, a } 3 \text { quadras da } \\
\text { AV. MARINGÁ }\end{array}$ & $4.768,00$ & $R \$ 550.000,00$ & Mercasa \\
\hline Pinhais & 52,12 & PALMITAL & Conjunto Maringá & & 518,00 & $\mathrm{R} \$ 27.000,00$ & \\
\hline Pinhais & 136,83 & CENTRO & & frente para AYRTON SENNA & 877,00 & $\mathrm{R} \$ 120.000,00$ & JBA Imóveis \\
\hline
\end{tabular}




\begin{tabular}{|c|c|c|c|c|c|c|c|}
\hline \multicolumn{8}{|c|}{ GAZETA DO POVO - CADERNO IMOBILIÁRIO - TERRENOS OFERTADOS PARA VENDA, DOM. 06 jun 2004} \\
\hline MUNICÍPIO & $\mathbf{R} \$ \mathbf{M} 2$ & BAIRRO & LOTEAMENTO & ENDEREÇO & ÁREA (m2) & PREÇO & ANUNCIANTE \\
\hline Pinhais & 2,07 & VILA AMÉLIA & Bois de Boulogne & & $9.642,00$ & $\mathrm{R} \$ 20.000,00$ & Apolar \\
\hline Pinhais & 76,75 & PALMITAL & & Rua Santa Fé, próximo à AV. MARINGÁ & 912,00 & $R \$ 70.000,00$ & $\begin{array}{l}\text { Mesquita } \\
\text { Imóveis }\end{array}$ \\
\hline SJP & 12,10 & BORDA DO CAMPO & Borda do Campo & & $1.488,00$ & $R \$ 18.000,00$ & $\begin{array}{l}\text { Imóveis } \\
\text { Presidente }\end{array}$ \\
\hline SJP & 125,33 & ARISTOCRATA & Jardim Aristocrata & & 375,00 & $\mathrm{R} \$ 47.000,00$ & $\begin{array}{l}\text { Ecoville } \\
\text { Imóveis }\end{array}$ \\
\hline SJP & 196,74 & CENTRO & Centro & $\begin{array}{l}\text { Rua Colombo, quase esquina com a AV. RUI } \\
\text { BARBOSA, a } 400 \text { m do FÓRUM }\end{array}$ & $2.516,00$ & $R \$ 495.000,00$ & \\
\hline SJP & 96,42 & & & Rua José P. do Vale Filho & 363,00 & $\mathrm{R} \$ 35.000,00$ & Imobiliária THÁ \\
\hline SJP & 93,48 & SÃO MARCOS & Jardim Carmem II & AUDI & 240,00 & $R \$ 22.434,00$ & \\
\hline SJP & 17,86 & & & na BR-277, próximo à C.R. ALMEIDA & $28.000,00$ & $R \$ 500.000,00$ & Mercasa \\
\hline SJP & 0,93 & & Colônia Marcelino & & \#\#\#\#\#\#\# & $\mathrm{R} \$ 320.000,00$ & Galvão \\
\hline SJP & 33,78 & & & Rua Tubarão & 444,00 & $R \$ 15.000,00$ & Sallvi \\
\hline SJP & 36,11 & INDEPENDÊNCIA & Jardim Independência & Rua Prof.a. Marieta Souza e Silva & 540,00 & $R \$ 19.500,00$ & \\
\hline SJP & 50,00 & IPE & Jardim Americano & em frente ao BOTICÁRIO & $7.280,00$ & $\mathrm{R} \$ 364.000,00$ & Cibraco \\
\hline SJP & 126,00 & & & Tv. Rocha Pombo, na saída do AEROPORTO & $8.730,00$ & \begin{tabular}{|l}
$\mathrm{R} \$$ \\
$1.100 .000,00$ \\
\end{tabular} & Imobiliária X \\
\hline SJP & 72,53 & AFONSO PENA & Afonso Pena & Rua Anselmo Vacari, próximo à Av. RUI BARBOSA & $4.825,36$ & $R \$ 350.000,00$ & $\begin{array}{l}\text { Santa Sé } \\
\text { Imóveis }\end{array}$ \\
\hline SJP & & GUATUPÊ & Guatupê & & & & $\begin{array}{l}\text { Andrade } \\
\text { Imóveis } \\
\end{array}$ \\
\hline SJP & & RIO PEQUENO & Rio Pequeno & próximo à Igreja do Moranguinho & & $\begin{array}{l}\text { prestações } \\
\text { desde } R \$ \\
240,00 \text { ao mês } \\
\end{array}$ & A.Z. Imóveis \\
\hline SJP & & & Jardim Suzuki & & 200,00 & $\begin{array}{l}\text { prestações a } \\
\text { partir de } R \$ \\
205,00 \text { mensais }\end{array}$ & A.Z. Imóveis \\
\hline
\end{tabular}


GAZETA DO POVO - CADERNO IMOBILIÁRIO - TERRENOS OFERTADOS PARA VENDA, DOM. 05 deZ 2004

\begin{tabular}{|c|c|c|c|c|c|c|c|}
\hline MUNICÍPIO & $\mathrm{R} \$ / \mathrm{M} 2$ & BAIRRO & LOTEAMENTO & ENDEREÇO & ÁREA (m2) & PREÇO & ANUNCIANTE \\
\hline Colombo & 39,87 & ATUBA & & próximo ao Atuba e BR-116 & $1.254,00$ & $\mathrm{R} \$ 50.000,00$ & CIBRACO \\
\hline Colombo & 9,50 & COLÔNIA FARIAS & Colônia Farias & $\begin{array}{l}\text { Rua Antonio Ferrarini, próximo à fabrica da } \\
\text { ETERNIT }\end{array}$ & $10.000,00$ & $R \$ 95.000,00$ & \\
\hline Colombo & 95,82 & $\begin{array}{l}\text { OSASCO OU ROÇA } \\
\text { GRANDE }\end{array}$ & & ESTRADA NOVA DE COLOMBO & $10.436,00$ & \#\#\#\#\#\#\#\#\#\#\# & \\
\hline Colombo & 21,75 & & & ESTRADA DA RIBEIRA & $3.127,00$ & $\mathrm{R} \$ 68.000,00$ & M\&D Imóveis \\
\hline Colombo & 37,76 & ROÇA GRANDE & Jardim das Flores & NOKI & 331,00 & $R \$ 12.500,00$ & M\&D Imóveis \\
\hline Colombo & 78,72 & CAMPO PEQUENO & & $\begin{array}{l}\text { Rua Rondônia, esquina com Mato Grosso, } \\
\text { próximo ao Conglomerado BANESTADO }\end{array}$ & $4.700,00$ & $\mathrm{R} \$ 370.000,00$ & CASAMIL \\
\hline Colombo & 74,07 & RIO VERDE & & Avenida Londres & 432,00 & $\mathrm{R} \$ 32.000,00$ & DIVISÃO \\
\hline Colombo & 37,95 & SÃO DIMAS & $\begin{array}{l}\text { Vila Vale das } \\
\text { Flores }\end{array}$ & Rua das Orquídeas & 448,00 & $\mathrm{R} \$ 17.000,00$ & Mesquita Imóveis \\
\hline Colombo & 76,92 & PALOMA & Vila São José & & 455,00 & $\mathrm{R} \$ 35.000,00$ & DIVISÃO \\
\hline Colombo & 62,50 & MARACANÃ & Alto Maracanâ & ESTRADA DA RIBEIRA & 480,00 & $R \$ 30.000,00$ & C3 Imóveis \\
\hline Colombo & 45,11 & ATUBA & Atuba & próximo à Igreja, a $100 \mathrm{~m}$ da Av. Bel Scussiato & 532,00 & $\mathrm{R} \$ 24.000,00$ & HOFFMANN \\
\hline Pinhais & 199,03 & GRACIOSA & $\begin{array}{l}\text { Residencial } \\
\text { Iguaçu }\end{array}$ & ao lado do campo de Golf do Alphaville & 829,00 & $\mathrm{R} \$ 165.000,00$ & Imobiliária THÁ \\
\hline Pinhais & 45,99 & VARGEM GRANDE & Vargem Grande & Rua José de Alencar & $1.196,00$ & $\mathrm{R} \$ 55.000,00$ & \\
\hline Pinhais & 86,67 & VILA AMÉLIA & Vila Amélia & $\begin{array}{l}\text { ao lado do CARREFOUR, acesso ao MAKRO e } \\
\text { ALPHAVILLE }\end{array}$ & $1.500,00$ & $R \$ 130.000,00$ & \\
\hline Pinhais & 41,67 & WEISSÓPOLIS & & Rua Rio Solimões, próximo ao posto do SUS & $1.200,00$ & $\mathrm{R} \$ 50.000,00$ & Olimpo Imóveis \\
\hline Pinhais & 17,66 & VALE DAS NASCENTES & Chácara Marumby & próximo ao ALPHAVILLE & $3.115,00$ & $R \$ 55.000,00$ & Osvaldo Nakamura \\
\hline Pinhais & 31,43 & VALE DAS NASCENTES & & ESTRADA DA GRACIOSA & $35.000,00$ & \#\#\#\#\#\#\#\#\#\#\# & \\
\hline Pinhais & 91,67 & PALMITAL & Parque Bordignon & Próximo ao Shopping Gralha Azul & 360,00 & $\mathrm{R} \$ 33.000,00$ & DIVISÃO \\
\hline Pinhais & 107,69 & PALMITAL & Pineville & Rua Adolfo Sora & 390,00 & $\mathrm{R} \$ 42.000,00$ & Imobiliária THÁ \\
\hline
\end{tabular}


GAZETA DO POVO - CADERNO IMOBILIÁRIO - TERRENOS OFERTADOS PARA VENDA, DOM. 05 deZ 2004

\begin{tabular}{|c|c|c|c|c|c|c|c|}
\hline MUNICÍPIO & $\mathrm{R} \$ / \mathrm{M} 2$ & BAIRRO & LOTEAMENTO & ENDEREÇO & ÁREA (m2) & PREÇO & ANUNCIANTE \\
\hline Pinhais & 46,25 & VARGEM GRANDE & & AV. IRAÍ, com fundos para Rua Graça Aranha & $4.000,00$ & $\mathrm{R} \$ 185.000,00$ & \\
\hline Pinhais & 71,43 & WEISSÓPOLIS & $\begin{array}{l}\text { Jardim } \\
\text { Weissópolis }\end{array}$ & Rua Rio Paraná & 420,00 & $\mathrm{R} \$ 30.000,00$ & Mesquita Imóveis \\
\hline Pinhais & 60,47 & ESTÂNCIA PINHAIS & Vila Tarumâ & a $7 \mathrm{~km}$ do centro de Curitiba & 430,00 & $\mathrm{R} \$ 26.000,00$ & Apolar \\
\hline Pinhais & 73,88 & PALMITAL & Moradias Palmital & próximo ao Pineville & 582,00 & $\mathrm{R} \$ 43.000,00$ & Josué Souza Imóveis \\
\hline Pinhais & 162,20 & GRACIOSA & $\begin{array}{l}\text { Alphaville } \\
\text { Graciosa }\end{array}$ & & 585,68 & $\mathrm{R} \$ 95.000,00$ & Casagrande Imóveis \\
\hline Pinhais & 58,33 & ESTÂNCIA PINHAIS & Vila Tarumâ & Rua 22 de abril & 600,00 & $\mathrm{R} \$ 35.000,00$ & FENIX \\
\hline Pinhais & 160,00 & GRACIOSA & $\begin{array}{l}\text { Alphaville } \\
\text { Graciosa }\end{array}$ & Setor Andorinhas & 700,00 & $\mathrm{R} \$ 112.000,00$ & \\
\hline Pinhais & 164,29 & GRACIOSA & $\begin{array}{l}\text { Alphaville } \\
\text { Graciosa }\end{array}$ & Residencial Andorinhas & 700,00 & $\mathrm{R} \$ 115.000,00$ & Galvão \\
\hline Pinhais & 171,43 & GRACIOSA & $\begin{array}{l}\text { Alphaville } \\
\text { Graciosa }\end{array}$ & Setor Andorinhas & 700,00 & $\mathrm{R} \$ 120.000,00$ & Galvão \\
\hline Pinhais & 185,29 & GRACIOSA & $\begin{array}{l}\text { Alphaville } \\
\text { Graciosa }\end{array}$ & Residencial Parati, Rua Tucunaré & 782,54 & $\mathrm{R} \$ 145.000,00$ & Mediato Imóveis \\
\hline Pinhais & 92,31 & PALMITAL & Pineville & & 390,00 & $\mathrm{R} \$ 36.000,00$ & Apolar \\
\hline Pinhais & 89,79 & EMILIANO PERNETA & & próximo ao DETRAN & $8.353,00$ & $\mathrm{R} \$ 750.000,00$ & Daga Imóveis \\
\hline Pinhais & \#REF! & & & próximo ao terminal & 125,00 & $\begin{array}{l}\text { entrada mais } \\
\text { saldo de } \\
\mathrm{R} \$ 289,00 \\
\text { mensais }\end{array}$ & Bueno Imóveis \\
\hline SJP & 50,00 & COLÔNIA RIO GRANDE & $\begin{array}{l}\text { Colônia Rio } \\
\text { Grande }\end{array}$ & & $2.291,70$ & $\mathrm{R} \$ 114.585,00$ & SEMPREBOM \\
\hline SJP & 113,64 & GUATUPE & Guatupê & BR-277, entrada da RENAULT & $2.200,00$ & $\mathrm{R} \$ 250.000,00$ & Galvão \\
\hline SJP & 78,13 & CIDADE JARDIM & Cidade Jardim & próximo à escola Santa Rosa & 384,00 & $\mathrm{R} \$ 30.000,00$ & \\
\hline SJP & 95,24 & & & Rua Alfredo Pinto, 1894 & 420,00 & $\mathrm{R} \$ 40.000,00$ & CIBRACO \\
\hline SJP & 27,78 & SÃO MARCOS & São Marcos I & Rua José Trevisan; Miringuava; BR-376 & 432,00 & $R \$ 12.000,00$ & \\
\hline SJP & 30,87 & & & BR-277, próximo ao BOTICÁRIO & $51.838,00$ & \#\#\#\#\#\#\#\#\#\# & Imobiliária X \\
\hline SJP & 31,65 & $\begin{array}{l}\text { ROSEIRA DE SÃO } \\
\text { SEBASTIÃO }\end{array}$ & Vila Paraíso & $\begin{array}{l}\text { ESTRADA DA ROSEIRA, 1410; próximo à } \\
\text { RENAULT }\end{array}$ & 790,00 & $\mathrm{R} \$ 25.000,00$ & CIBRACO \\
\hline
\end{tabular}




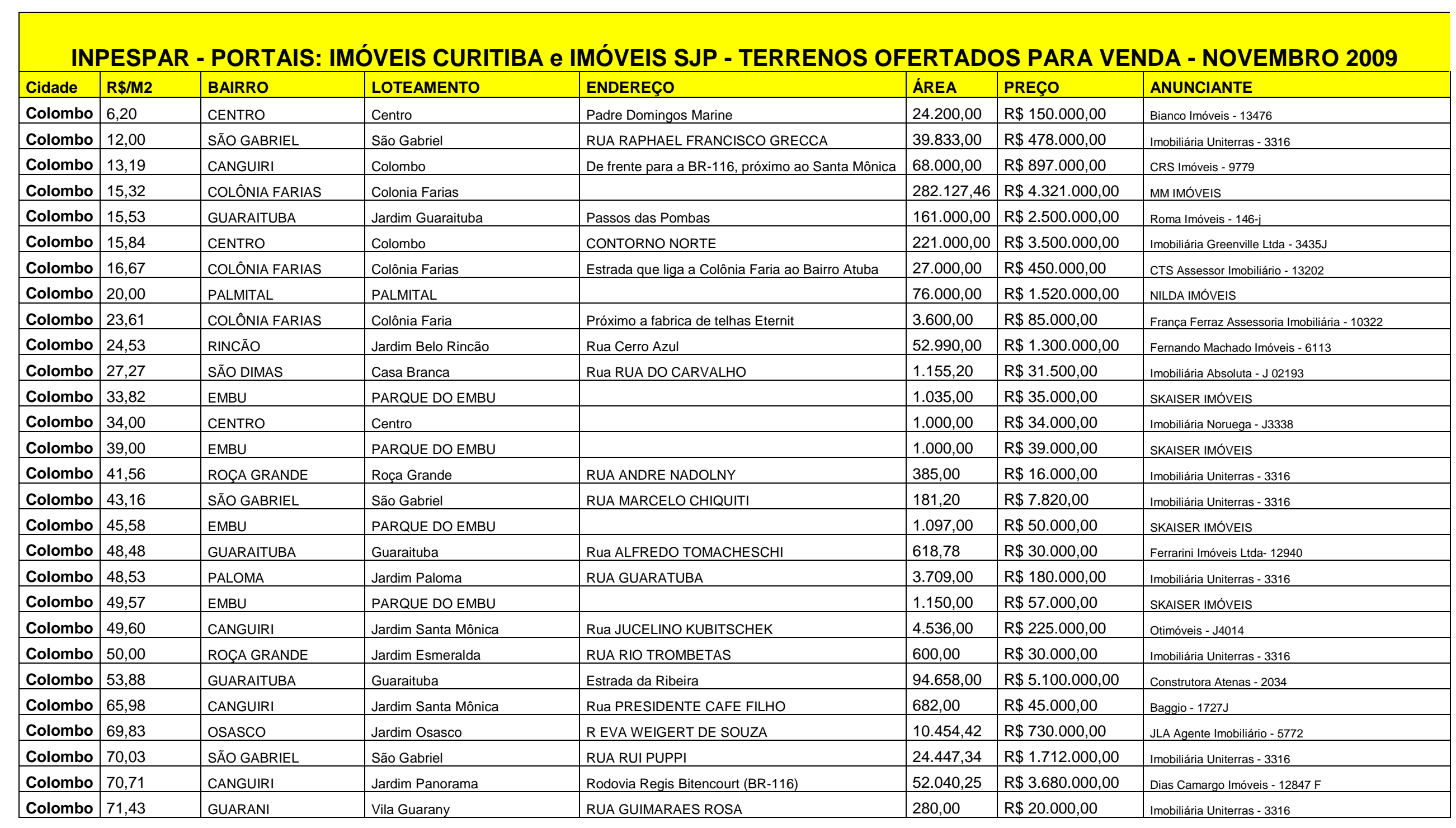




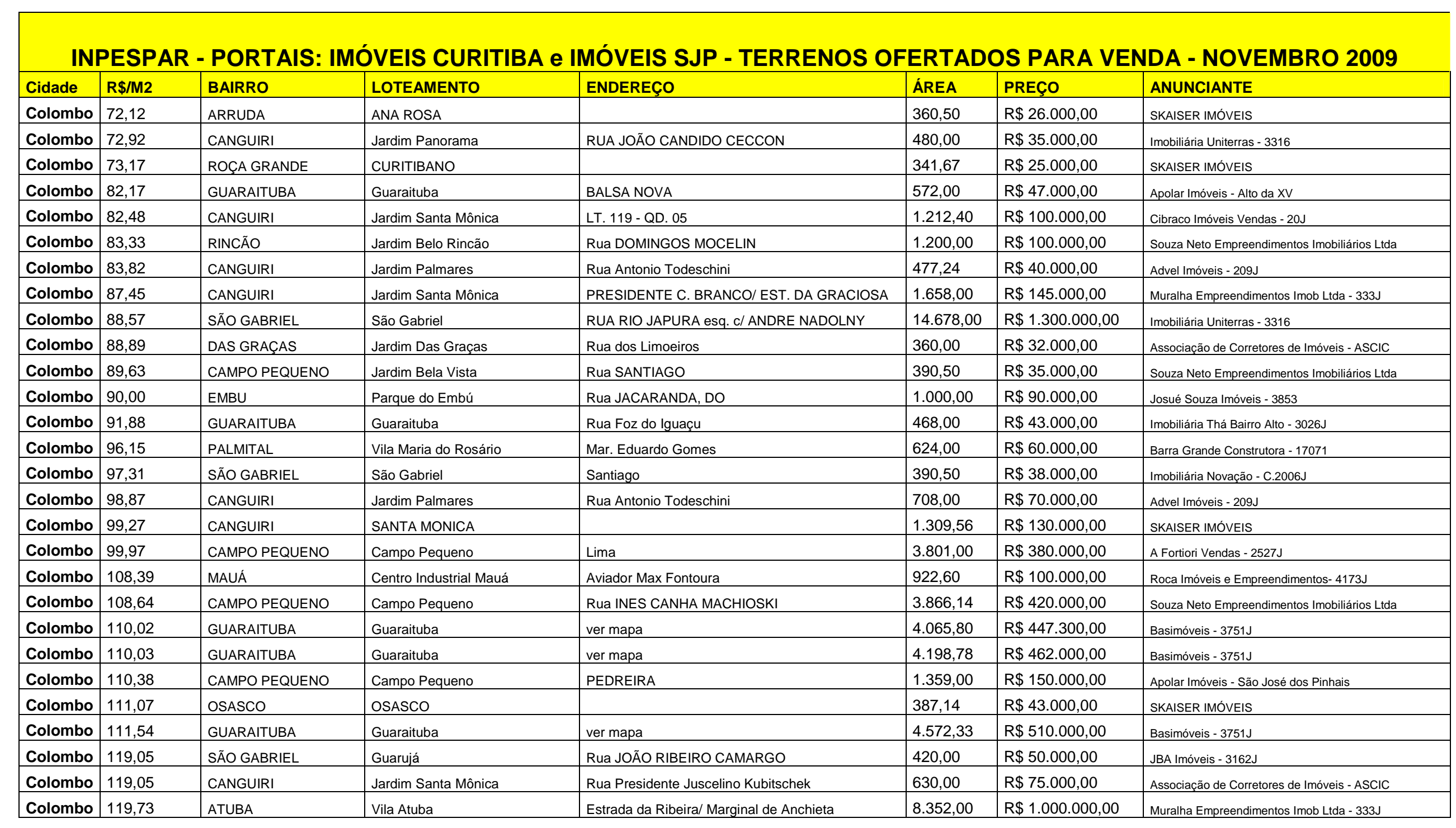


INPESPAR - PORTAIS: IMÓVEIS CURITIBA e IMÓVEIS SJP - TERRENOS OFERTADOS PARA VENDA - NOVEMBRO 2009

\begin{tabular}{|c|c|c|c|c|c|c|c|}
\hline Cidade & $\mathrm{R} \$ / \mathrm{M} 2$ & BAIRRO & LOTEAMENTO & ENDEREÇO & ÁREA & PREÇO & ANUNCIANTE \\
\hline Colombo & 119,73 & GUARANI & Vila Guarany & Estrada da Ribeira/ Marginal José de Anchieta & $8.352,00$ & $\mathrm{R} \$ 1.000 .000,00$ & Muralha Empreendimentos Imob Ltda - 333J \\
\hline Colombo & 120,35 & MAUÁ & MAUA & & $3.988,43$ & $\mathrm{R} \$ 480.000,00$ & REGINALDO IMÓVEIS \\
\hline Colombo & 120,41 & FÁTIMA & $\begin{array}{l}\text { Jardim Nossa Senhora de } \\
\text { Fátima }\end{array}$ & Dorval Ceccon & 490,00 & $\mathrm{R} \$ 59.000,00$ & Imobiliária Novação - C.2006J \\
\hline Colombo & 123,08 & MAUÁ & MAUA & & $2.600,00$ & $\mathrm{R} \$ 320.000,00$ & REGINALDO IMÓVEIS \\
\hline Colombo & 123,17 & SÃO GABRIEL & São Gabriel & Rua RAPHAEL FRANCISCO GRECA & $1.217,78$ & $\mathrm{R} \$ 150.000,00$ & Imobiliária Sergio Luiz - $3564 \mathrm{~J}$ \\
\hline Colombo & 125,64 & GUARANI & Vila Guarany & FELIPE CAMARÃO ESQ. JOAQUIM NABUCO & 390,00 & $\mathrm{R} \$ 49.000,00$ & G-Luma J4174 \\
\hline Colombo & 133,06 & ATUBA & ATUBA & & $2.404,97$ & $\mathrm{R} \$ 320.000,00$ & CARVALHO IMÓVEIS \\
\hline Colombo & 135,42 & MAUÁ & Centro Industrial Mauá & Av-Manoel Prestes & 960,00 & $\mathrm{R} \$ 130.000,00$ & Associação de Corretores de Imóveis - ASCIC \\
\hline Colombo & 135,42 & PALMITAL & Vila Maria do Rosário & Rua- João Caldera & 960,00 & $\mathrm{R} \$ 130.000,00$ & Associação de Corretores de Imóveis - ASCIC \\
\hline Colombo & 149,66 & MARACANÃ & MARACANA & & $2.205,00$ & $\mathrm{R} \$ 330.000,00$ & IMOBILIARIA NORUEGA \\
\hline Colombo & 150,00 & SÃO GABRIEL & São Gabriel & Endereço: AV SANTOS DUMONT & 600,00 & $\mathrm{R} \$ 90.000,00$ & Apolar Imóveis - Pilarzinho \\
\hline Colombo & 152,00 & GUARAITUBA & Guaraituba & RUA 18 & 250,00 & $\mathrm{R} \$ 38.000,00$ & Apolar Imóveis - Pinhais J 3791 \\
\hline Colombo & 152,84 & MARACANÃ & Jardim Eucaliptos & R.afonso arinos & 229,00 & $\mathrm{R} \$ 35.000,00$ & Imobiliária Juvevê Vendas - 2221J \\
\hline Colombo & 156,25 & SÃO GABRIEL & São Gabriel & AV. SANTOS DUMONT esq. c/ São Fco & 768,00 & $\mathrm{R} \$ 120.000,00$ & Imobiliária Uniterras - 3316 \\
\hline Colombo & 160,26 & GUARAITUBA & Guaraituba & Rua ARAUCARIA & 624,00 & $R \$ 100.000,00$ & Souza Neto Empreendimentos Imobiliários Ltda \\
\hline Colombo & 166,67 & MARACANÃ & Jardim Eucaliptos & OLAVO BILAC & 420,00 & $\mathrm{R} \$ 70.000,00$ & Apolar Imóveis - Colombo J 3817 \\
\hline Colombo & 168,14 & CAMPO PEQUENO & Jardim Jalisco & FORTALEZA & 202,21 & $\mathrm{R} \$ 34.000,00$ & Apolar Imóveis - Juvevê \\
\hline Colombo & 168,49 & CAMPO PEQUENO & Jardim Jalisco & FORTALEZA & 290,81 & $\mathrm{R} \$ 49.000,00$ & Apolar Imóveis - Juvevê \\
\hline Colombo & 171,15 & ROÇA GRANDE & Jardim Guadalajara & RUA JERONIMO ALBERTI & 520,00 & $\mathrm{R} \$ 89.000,00$ & Alicerce Imóveis Ltda - 4298J \\
\hline Colombo & 175,44 & GUARAITUBA & Jardim Guaraituba & & 684,00 & $\mathrm{R} \$ 120.000,00$ & Varnier Imóveis - 15442 \\
\hline Colombo & 183,66 & GUARAITUBA & Jardim Guaraituba & PEDRO DO ROSARIO ESQ RUA RENASCENEA & 517,25 & $\mathrm{R} \$ 95.000,00$ & Apolar Imóveis - Colombo J 3817 \\
\hline Colombo & 189,80 & MARACANÃ & Maracanã & ROD.BR 476 - ESTRADA DA RIBEIRA & $2.950,43$ & $\mathrm{R} \$ 560.000,00$ & Apolar Imóveis - Kennedy \\
\hline Colombo & 200,00 & SÃO GABRIEL & São Gabriel & Raphael Franscisco Greca & $1.163,17$ & $\mathrm{R} \$ 232.634,00$ & Bianco Imóveis - 13476 \\
\hline Colombo & 214,29 & SÃO GABRIEL & São Gabriel & NICARAGUA & 840,00 & $\mathrm{R} \$ 180.000,00$ & Apolar Imóveis - Juvevê \\
\hline Colombo & 215,69 & SÃO GABRIEL & Guarujá & NULL & 510,00 & $\mathrm{R} \$ 110.000,00$ & Imobiliária Juvevê Vendas - 2221J \\
\hline Colombo & 216,67 & MARACANÃ & Maracanã & Rua João Licério de Brito & 360,00 & $\mathrm{R} \$ 78.000,00$ & Capital Imóveis - 12281 \\
\hline Colombo & 216,84 & SANTA TEREZINHA & Santa Terezinha & AUGUSTA & 392,00 & $\mathrm{R} \$ 85.000,00$ & Apolar Imóveis - Colombo J 3817 \\
\hline Colombo & 229,32 & SÃO GABRIEL & São Gabriel & RUA INACIO GREGORIO SCHULKA & 252,92 & $R \$ 58.000,00$ & Imobiliária Uniterras - 3316 \\
\hline
\end{tabular}




\begin{tabular}{|c|c|c|c|c|c|c|c|}
\hline Cidade & $\mathrm{R} \$ / \mathrm{M} 2$ & BAIRRO & LOTEAMENTO & ENDEREÇO & ÁREA & PREÇO & ANUNCIANTE \\
\hline Colombo & 239,95 & SÃO GABRIEL & São Gabriel & RUA INACIO GREGORIO SCHULKA & 177,12 & $\mathrm{R} \$ 42.500,00$ & Imobiliária Uniterras - 3316 \\
\hline Colombo & 261,90 & CAMPO PEQUENO & Jardim Santa Cândida & Rua Segismundo Busato & 420,00 & $\mathrm{R} \$ 110.000,00$ & Oda Imóveis - 10568 \\
\hline Colombo & 264,29 & CAMPO PEQUENO & Jardim Santa Cândida & Rua Segismundo Busato & 420,00 & $\mathrm{R} \$ 111.000,00$ & Oda Imóveis - 10568 \\
\hline Colombo & 270,83 & CANGUIRI & Jardim Paraná & PIETRO CANESTRARO FILHO & 240,00 & $\mathrm{R} \$ 65.000,00$ & Tantus Corretora de Imóveis - 1523J \\
\hline Colombo & 295,63 & CAMPO PEQUENO & JARDIM SANTA CANDIDA & & 504,00 & $\mathrm{R} \$ 149.000,00$ & SKAISER IMÓVEIS \\
\hline Colombo & 296,30 & CAMPO PEQUENO & Campo Pequeno & AV. SAO GABRIEL esq/Guilherme Rodbard & 270,00 & $\mathrm{R} \$ 80.000,00$ & Imobiliária Uniterras - 3316 \\
\hline Colombo & 368,06 & ATUBA & Vila lara & Rua Abel Scuissiato & 720,00 & $\mathrm{R} \$ 265.000,00$ & Oda Imóveis - 10568 \\
\hline Colombo & 376,71 & MARACANÃ & Maracanã & KELWIN & 292,00 & $\mathrm{R} \$ 110.000,00$ & Apolar Imóveis - Colombo J 3817 \\
\hline Colombo & 566,67 & MARACANÃ & Maracanã & $\mathrm{R}$ dos Eucaliptos & 300,00 & $\mathrm{R} \$ 170.000,00$ & Capital Imóveis - 12281 \\
\hline Colombo & 608,97 & MARACANÃ & Maracanã & Estrada da Ribeira & $1.560,00$ & $\mathrm{R} \$ 950.000,00$ & Imobiliária Novação - C.2006J \\
\hline Colombo & 775,26 & MARACANÃ & Maracanã & Rua Abel Scuiciato & $1.148,00$ & $\mathrm{R} \$ 890.000,00$ & LLJ Corretora de Imóveis - CRECI 16.555 \\
\hline Colombo & 892,86 & MARACANÃ & Alto Maracanã & R. Vitorino Poli & 448,00 & $\mathrm{R} \$ 400.000,00$ & Loft Imóveis / Juvevê - 16735 \\
\hline Colombo & 1183,43 & MARACANÃ & Maracanã & Rua Abel Scuissiato & 507,00 & $\mathrm{R} \$ 600.000,00$ & Imobiliária Novação - C.2006J \\
\hline Pinhais & 10,02 & VILA AMÉLIA & Planta Karla & Planta Karla & $26.557,88$ & $\mathrm{R} \$ 266.000,00$ & Advel Imóveis - 209J \\
\hline Pinhais & 11,62 & $\begin{array}{l}\text { VALE DAS } \\
\text { NASCENTES }\end{array}$ & Pinhais & Estrada Ecológica de pinhais & $18.066,00$ & $R \$ 210.000,00$ & Muralha Empreendimentos Imob Ltda - 333J \\
\hline Pinhais & 18,68 & ENTRE RIOS & Jardim Boa Vista & Rua ESTRADA ECOLOGICA & $29.445,43$ & $\mathrm{R} \$ 550.000,00$ & Cibraco Imóveis Vendas - 20J \\
\hline Pinhais & 19,08 & VARGEM GRANDE & NUCLEO COLONIAL PINHAIS & & 325,00 & $\mathrm{R} \$ 6.200,00$ & REGINALDO IMÓVEIS \\
\hline Pinhais & 21,00 & WEISSOPOLIS & WEISSOPOLIS & & $1.200,00$ & $\mathrm{R} \$ 25.200,00$ & CICERO IMÓVEIS \\
\hline Pinhais & 41,17 & CENTRO & Centro & Jardim Primavera & $5.101,00$ & $\mathrm{R} \$ 210.000,00$ & Canto Consultoria Imobiliária - J4069 \\
\hline Pinhais & 47,73 & GRACIOSA & Alphaville & Rua Estrada Ecológica de Pinhais & $6.285,48$ & $\mathrm{R} \$ 300.000,00$ & Imobiliária Thá Santa Felicidade - 3026J \\
\hline Pinhais & 58,00 & VILA AMÉLIA & Planta Karla & Rua IRIS & 750,00 & $\mathrm{R} \$ 43.500,00$ & Souza Neto Empreendimentos Imobiliários Ltda \\
\hline Pinhais & 58,55 & GRACIOSA & Alphaville & Rua ESTRADA ECOLÓGICA & $6.285,48$ & $\mathrm{R} \$ 368.000,00$ & Otimóveis - J4014 \\
\hline Pinhais & 59,69 & GRACIOSA & GRACIOSA & & $10.890,00$ & $\mathrm{R} \$ 650.000,00$ & MIRANDA IMOVEIS \\
\hline Pinhais & 66,43 & VILA AMÉLIA & JARDIM AMÉLIA & & $2.860,00$ & $\mathrm{R} \$ 190.000,00$ & MM IMÓVEIS \\
\hline Pinhais & 68,18 & CENTRO & Centro & Av. FRANCISCO VIEIRA DE ARAÚJO & $4.400,00$ & $\mathrm{R} \$ 300.000,00$ & Moro Imóveis Ltda Vendas - $1603 \mathrm{~J}$ \\
\hline Pinhais & 69,97 & VARGEM GRANDE & VARGEM GRANDE & & $2.787,00$ & $\mathrm{R} \$ 195.000,00$ & MM IMÓVEIS \\
\hline Pinhais & 75,00 & WEISSOPOLIS & Weissópolis & Rua.Rio Tocantins & 720,00 & $\mathrm{R} \$ 54.000,00$ & JV Corretor de Imóveis - 14395 \\
\hline Pinhais & 75,00 & WEISSOPOLIS & WEISSOPOLIS & & $2.400,00$ & $\mathrm{R} \$ 180.000,00$ & MM IMÓVEIS \\
\hline
\end{tabular}


INPESPAR - PORTAIS: IMÓVEIS CURITIBA e IMÓVEIS SJP - TERRENOS OFERTADOS PARA VENDA - NOVEMBRO 2009

\begin{tabular}{|c|c|c|c|c|c|c|c|}
\hline Cidade & $\mathrm{R} \$ / \mathrm{M} 2$ & BAIRRO & LOTEAMENTO & ENDEREÇO & ÁREA & PREÇO & ANUNCIANTE \\
\hline Pinhais & 85,00 & VARGEM GRANDE & VARGEM GRANDE & & $2.000,00$ & $\mathrm{R} \$ 170.000,00$ & MM IMÓVEIS \\
\hline Pinhais & 90,00 & VARGEM GRANDE & VARGEM GRANDE & & $1.000,00$ & $\mathrm{R} \$ 90.000,00$ & PINHAIS IMÓVEIS \\
\hline Pinhais & 90,28 & WEISSOPOLIS & Weissópolis & RIO TOCANTINS & 720,00 & $\mathrm{R} \$ 65.000,00$ & Apolar Imóveis - Pinhais J 3791 \\
\hline Pinhais & 98,04 & VILA AMÉLIA & Vila Amélia & RUA MARGARIDA & 408,00 & $\mathrm{R} \$ 40.000,00$ & Apolar Imóveis - Pinhais J 3791 \\
\hline Pinhais & 98,97 & VARGEM GRANDE & VARGEM GRANDE & & 454,70 & $\mathrm{R} \$ 45.000,00$ & IMOBILESTE \\
\hline Pinhais & 120,00 & VARGEM GRANDE & Vargem Grande & NULL & $2.000,00$ & $\mathrm{R} \$ 240.000,00$ & Casarão Imóveis - 435J \\
\hline Pinhais & 123,34 & VILA AMÉLIA & Jardim Triângulo & Rua Alfredina Maciel Pinto - Esquina & 527,00 & $\mathrm{R} \$ 65.000,00$ & Dorival Leite - Corretor de Imóveis- 15563 \\
\hline Pinhais & 125,00 & VARGEM GRANDE & Vargem Grande & Graça Aranha & $2.000,00$ & $\mathrm{R} \$ 250.000,00$ & Ferrarini Imóveis Ltda- 12940 \\
\hline Pinhais & 127,31 & CENTRO & Centro & Estrada da Graciosa & $3.141,85$ & $\mathrm{R} \$ 400.000,00$ & Imobiliária Thá Bacacheri - 3026J \\
\hline Pinhais & 130,00 & GRACIOSA & Alphaville & Rua ESTRADA DA GRACIOSA & $1.065,85$ & $\mathrm{R} \$ 138.560,00$ & Cibraco Imóveis Vendas - 20J \\
\hline Pinhais & 131,50 & ESTÂNCIA PINHAIS & ESTANCIA & & $3.193,93$ & $\mathrm{R} \$ 420.000,00$ & MM IMÓVEIS \\
\hline Pinhais & 136,22 & PALMITAL & Vila Esplanada & Rua Liberia & 624,00 & $\mathrm{R} \$ 85.000,00$ & Casagrande Imóveis - 1813 - J \\
\hline Pinhais & 136,36 & MARIA ANTONIETA & MARIA ANTONIETA & & 330,00 & $\mathrm{R} \$ 45.000,00$ & CARVALHO IMÓVEIS \\
\hline Pinhais & 138,17 & PALMITAL & Vila Palmital & Rua Liberia & 579,00 & $\mathrm{R} \$ 80.000,00$ & Casagrande Imóveis - 1813 - J \\
\hline Pinhais & 140,00 & VARGEM GRANDE & VARGEM GRANDE & & $2.000,00$ & $\mathrm{R} \$ 280.000,00$ & MIRANDA IMOVEIS \\
\hline Pinhais & 141,33 & WEISSOPOLIS & Weissópolis & Rua-Rio Solimões & $1.200,00$ & $R \$ 169.600,00$ & Associação de Corretores de Imóveis - ASCIC \\
\hline Pinhais & 145,83 & MARIA ANTONIETA & MARIA ANTONIETA & & 480,00 & $\mathrm{R} \$ 70.000,00$ & NILDA IMÓVEIS \\
\hline Pinhais & 146,80 & PALMITAL & Pineville & Rua Senegal & 579,00 & $\mathrm{R} \$ 85.000,00$ & Casagrande Imóveis - 1813 - J \\
\hline Pinhais & 162,50 & VARGEM GRANDE & VARGEM GRANDE & & $4.000,00$ & $\mathrm{R} \$ 650.000,00$ & MIRANDA IMOVEIS \\
\hline Pinhais & 162,79 & ESTÂNCIA PINHAIS & Vila Tarumã & MARIA LUIZA BORBA & 430,00 & $\mathrm{R} \$ 70.000,00$ & Apolar Imóveis - Visconde \\
\hline Pinhais & 170,45 & MARIA ANTONIETA & JARDIM PINHAIS & & 264,00 & $\mathrm{R} \$ 45.000,00$ & IMOBILESTE \\
\hline Pinhais & 170,83 & SETE VILAS & Jardim Cláudia & Adolfo G Mulhmann & 480,00 & $\mathrm{R} \$ 82.000,00$ & Sol de Verão \\
\hline Pinhais & 175,00 & VARGEM GRANDE & Vargem Grande & Av. Iraí & $2.000,00$ & $\mathrm{R} \$ 350.000,00$ & BK Imóveis J02794 \\
\hline Pinhais & 175,00 & WEISSOPOLIS & WEISSOPOLIS & & 600,00 & $\mathrm{R} \$ 105.000,00$ & CARVALHO IMÓVEIS \\
\hline Pinhais & 175,00 & SETE VILAS & VILA CAROLINA & & 200,00 & $\mathrm{R} \$ 35.000,00$ & IMOBILESTE \\
\hline Pinhais & 183,33 & WEISSOPOLIS & WEISSOPOLIS & & 600,00 & $R \$ 110.000,00$ & CARVALHO IMÓVEIS \\
\hline Pinhais & 183,73 & PALMITAL & Vila Esplanada & Rua Liberia & 408,20 & $\mathrm{R} \$ 75.000,00$ & Casagrande Imóveis - 1813 - J \\
\hline Pinhais & 184,21 & VARGEM GRANDE & Vargem Grande & Rua Rui Barbosa & 228,00 & $R \$ 42.000,00$ & Mesquita Imóveis 3381-J \\
\hline
\end{tabular}


INPESPAR - PORTAIS: IMÓVEIS CURITIBA e IMÓVEIS SJP - TERRENOS OFERTADOS PARA VENDA - NOVEMBRO 2009

\begin{tabular}{|c|c|c|c|c|c|c|c|}
\hline Cidade & $\mathrm{R} \$ / \mathrm{M} 2$ & BAIRRO & LOTEAMENTO & ENDEREÇO & ÁREA & PREÇO & ANUNCIANTE \\
\hline Pinhais & 184,60 & CENTRO & Centro & ERua Pedro Elias Graciano & 568,80 & $\mathrm{R} \$ 105.000,00$ & Imobiliária Razão Vendas - 1699J \\
\hline Pinhais & 186,67 & EMILIANO PERNETA & PERNETA & & $1.500,00$ & $\mathrm{R} \$ 280.000,00$ & CICERO IMÓVEIS \\
\hline Pinhais & 190,48 & MARIA ANTONIETA & ANTONIETA & & 420,00 & $\mathrm{R} \$ 80.000,00$ & MM IMÓVEIS \\
\hline Pinhais & 190,77 & VARGEM GRANDE & VARGEM GRANDE & & 325,00 & $\mathrm{R} \$ 62.000,00$ & REGINALDO IMÓVEIS \\
\hline Pinhais & 200,00 & PALMITAL & Pineville & Av. Pineville & 590,00 & $\mathrm{R} \$ 118.000,00$ & Complexo Pineville 14894 \\
\hline Pinhais & 200,00 & PALMITAL & Pineville & Rua Floral & 725,00 & $\mathrm{R} \$ 145.000,00$ & Complexo Pineville 14894 \\
\hline Pinhais & 200,00 & EMILIANO PERNETA & PERNETA & & $4.500,00$ & $\mathrm{R} \$ 900.000,00$ & CICERO IMÓVEIS \\
\hline Pinhais & 204,08 & PALMITAL & BORDIGNON & & 441,00 & $\mathrm{R} \$ 90.000,00$ & MIRANDA IMOVEIS \\
\hline Pinhais & 206,56 & GRACIOSA & Alphaville & NULL & $1.646,00$ & $\mathrm{R} \$ 340.000,00$ & Imobiliária Juvevê Vendas - 2221J \\
\hline Pinhais & 207,97 & SETE VILAS & JARDIM FENIX & & 312,55 & $\mathrm{R} \$ 65.000,00$ & MIRANDA IMOVEIS \\
\hline Pinhais & 209,95 & EMILIANO PERNETA & PERNETA & & $13.431,75$ & $\mathrm{R} \$ 2.820 .000,00$ & MM IMÓVEIS \\
\hline Pinhais & 210,53 & SETE VILAS & CAROLINA & & 427,50 & $\mathrm{R} \$ 90.000,00$ & MIRANDA IMOVEIS \\
\hline Pinhais & 212,50 & WEISSOPOLIS & WEISSOPOLIS & & 400,00 & $\mathrm{R} \$ 85.000,00$ & MIRANDA IMOVEIS \\
\hline Pinhais & 212,59 & EMILIANO PERNETA & PERNETA & & 588,00 & $\mathrm{R} \$ 125.000,00$ & CICERO IMÓVEIS \\
\hline Pinhais & 213,18 & CENTRO & VILA VARGINHA & & 516,00 & $\mathrm{R} \$ 110.000,00$ & MM IMÓVEIS \\
\hline Pinhais & 213,33 & VILA AMÉLIA & Jardim Triângulo & Av Leopoldo Jacomel & 375,00 & $\mathrm{R} \$ 80.000,00$ & Epoca Imóveis - 3341J \\
\hline Pinhais & 214,44 & VARGEM GRANDE & NUCLEO COLONIAL PINHAIS & & $1.445,60$ & $\mathrm{R} \$ 310.000,00$ & IMOBILESTE \\
\hline Pinhais & 216,67 & WEISSOPOLIS & WEISSOPOLIS & & 600,00 & $\mathrm{R} \$ 130.000,00$ & IMOBILESTE \\
\hline Pinhais & 216,98 & PALMITAL & Pineville & RUA FLORAL ESQUINA WENCESLAU FORLEPA & 530,00 & $\mathrm{R} \$ 115.000,00$ & Complexo Pineville 14894 \\
\hline Pinhais & 218,49 & PALMITAL & Pineville & Av. Pineville & 595,00 & $\mathrm{R} \$ 130.000,00$ & Premiére Imóveis - $4075 \mathrm{~J}$ \\
\hline Pinhais & 220,29 & PALMITAL & PALMITAL & & 172,50 & $\mathrm{R} \$ 38.000,00$ & MM IMÓVEIS \\
\hline Pinhais & 222,41 & PALMITAL & Pineville & COND. RES. PINEVILLAGGE/PINEVILLE & 607,00 & $\mathrm{R} \$ 135.000,00$ & SNP Corretora de Imóveis- $15738 \mathrm{~F}$ \\
\hline Pinhais & 225,00 & WEISSOPOLIS & WEISSOPOLIS & & 400,00 & $\mathrm{R} \$ 90.000,00$ & CARVALHO IMÓVEIS \\
\hline Pinhais & 229,01 & GRACIOSA & Alphaville & Rua Estrada da Graciosa & $2.096,00$ & $\mathrm{R} \$ 480.000,00$ & Polatti \& Cordeiro Imóveis - J-3587 \\
\hline Pinhais & 230,88 & PALMITAL & Vale da Boa Esperança & Rua PINEVILLE & 606,38 & $\mathrm{R} \$ 140.000,00$ & Souza Neto Empreendimentos Imobiliários Ltda \\
\hline Pinhais & 233,07 & VILA AMÉLIA & Jardim Triângulo & Av Leopoldo Jacomel & $1.875,00$ & $\mathrm{R} \$ 437.000,00$ & Epoca Imóveis - 3341J \\
\hline Pinhais & 240,00 & WEISSOPOLIS & WEISSOPOLIS & & 200,00 & $\mathrm{R} \$ 48.000,00$ & MM IMÓVEIS \\
\hline Pinhais & 241,38 & EMILIANO PERNETA & Emiliano Perneta & Av. Maringá & $6.090,00$ & $R \$ 1.470 .000,00$ & Futulare - 2800J \\
\hline
\end{tabular}


INPESPAR - PORTAIS: IMÓVEIS CURITIBA e IMÓVEIS SJP - TERRENOS OFERTADOS PARA VENDA - NOVEMBRO 2009

\begin{tabular}{|c|c|c|c|c|c|c|c|}
\hline Cidade & $\mathrm{R} \$ / \mathrm{M} 2$ & BAIRRO & LOTEAMENTO & ENDEREÇO & ÁREA & PREÇO & ANUNCIANTE \\
\hline Pinhais & 248,89 & PALMITAL & Pineville & Endereço: Rua das Castanheiras & 803,57 & $\mathrm{R} \$ 200.000,00$ & DME Imobiliária - 3123J \\
\hline Pinhais & 249,53 & PALMITAL & ALTO TARUMA & & 400,75 & $\mathrm{R} \$ 100.000,00$ & MM IMÓVEIS \\
\hline Pinhais & 250,00 & PALMITAL & Pineville & RUA JACAREZINHO & 560,00 & $\mathrm{R} \$ 140.000,00$ & Apolar Imóveis - Capão Raso \\
\hline Pinhais & 250,00 & WEISSOPOLIS & Weissópolis & & 600,00 & $\mathrm{R} \$ 150.000,00$ & JNS Corretora de Imóveis - 15187 \\
\hline Pinhais & 251,75 & VILA AMÉLIA & PRIVE & & 286,00 & $\mathrm{R} \$ 72.000,00$ & LIRA CORRETORA DE IMOVEIS \\
\hline Pinhais & 253,09 & GRACIOSA & Alphaville & Alphaville Graciosa & 711,22 & $\mathrm{R} \$ 180.000,00$ & Capital Imóveis - 12281 \\
\hline Pinhais & 261,16 & PALMITAL & Pineville & & $4.212,00$ & $\mathrm{R} \$ 1.100 .000,00$ & Complexo Pineville 14894 \\
\hline Pinhais & 261,55 & CENTRO & VILA DONA GUIOMAR & & 952,00 & $\mathrm{R} \$ 249.000,00$ & CARVALHO IMÓVEIS \\
\hline Pinhais & 262,40 & GRACIOSA & Alphaville & Alphaville Graciosa & $2.096,00$ & $\mathrm{R} \$ 550.000,00$ & Invebras Imóveis Champagnat \\
\hline Pinhais & 263,16 & ALTO ATUBA & DEMETERCO & & 456,00 & $\mathrm{R} \$ 120.000,00$ & CICERO IMÓVEIS \\
\hline Pinhais & 263,84 & PALMITAL & Pineville & Av. Pineville & $3.108,00$ & $\mathrm{R} \$ 820.000,00$ & Complexo Pineville 14894 \\
\hline Pinhais & 264,29 & GRACIOSA & Alphaville & Rua das Paineiras & 700,00 & $\mathrm{R} \$ 185.000,00$ & Carlos Busch corretor de Imóveis \\
\hline Pinhais & 265,15 & PALMITAL & Progresso & & $1.320,00$ & $\mathrm{R} \$ 350.000,00$ & Paulo Nobre Corretor de Imóveis \\
\hline Pinhais & 266,20 & ESTÂNCIA PINHAIS & ESTÃNCIA PINHAIS & & 864,00 & $\mathrm{R} \$ 230.000,00$ & REGINALDO IMÓVEIS \\
\hline Pinhais & 266,67 & EMILIANO PERNETA & Emiliano Perneta & Rua JANDAIA DO SUL & 600,00 & $\mathrm{R} \$ 160.000,00$ & MM Imóveis Pinhais - 4049J \\
\hline Pinhais & 266,67 & EMILIANO PERNETA & PERNETA & & 600,00 & $\mathrm{R} \$ 160.000,00$ & MM IMÓVEIS \\
\hline Pinhais & 267,86 & PALMITAL & PINEVILLE & & 560,00 & $R \$ 150.000,00$ & MM IMÓVEIS \\
\hline Pinhais & 268,09 & CENTRO & CENTRO & & $2.350,00$ & $\mathrm{R} \$ 630.000,00$ & MM IMÓVEIS \\
\hline Pinhais & 271,43 & VILA AMÉLIA & & NILO PEÇANHA & 560,00 & $\mathrm{R} \$ 152.000,00$ & ELV IMOVEIS \\
\hline Pinhais & 272,00 & VARGEM GRANDE & VARGEM GRANDE & & 312,50 & $\mathrm{R} \$ 85.000,00$ & MM IMÓVEIS \\
\hline Pinhais & 272,73 & EMILIANO PERNETA & PERNETA & & 440,00 & $\mathrm{R} \$ 120.000,00$ & CICERO IMÓVEIS \\
\hline Pinhais & 281,31 & GRACIOSA & Alphaville & Endereço: ESTRADA DA GRACIOSA & 551,00 & $\mathrm{R} \$ 155.000,00$ & Pronto Imóveis - J 4107 \\
\hline Pinhais & 285,71 & PALMITAL & PINEVILLE & & 647,50 & $\mathrm{R} \$ 185.000,00$ & MM IMÓVEIS \\
\hline Pinhais & 287,88 & PALMITAL & Vale da Boa Esperança & Rua JACAREZINHO & 99,00 & $\mathrm{R} \$ 28.500,00$ & Souza Neto Empreendimentos Imobiliários Ltda \\
\hline Pinhais & 294,12 & GRACIOSA & Alphaville & ESTRADA DA GRACIOSA & 561,00 & $\mathrm{R} \$ 165.000,00$ & Marilise Hetzer Imóveis - 12988 \\
\hline Pinhais & 295,75 & GRACIOSA & Alphaville & Rua AROEIRAS / RUA DOS INGÁS & 939,99 & $\mathrm{R} \$ 278.000,00$ & JBA Imóveis - 3162J \\
\hline Pinhais & 295,86 & CENTRO & Centro & RUA HONDURAS & 507,00 & $R \$ 150.000,00$ & Apolar Imóveis - Pinhais J 3791 \\
\hline Pinhais & 300,00 & PALMITAL & PINEVILLE & & 100,00 & $\mathrm{R} \$ 30.000,00$ & CICERO IMÓVEIS \\
\hline
\end{tabular}


INPESPAR - PORTAIS: IMÓVEIS CURITIBA e IMÓVEIS SJP - TERRENOS OFERTADOS PARA VENDA - NOVEMBRO 2009

\begin{tabular}{|c|c|c|c|c|c|c|c|}
\hline Cidade & $\mathrm{R} \$ / \mathrm{M} 2$ & BAIRRO & LOTEAMENTO & ENDEREÇO & ÁREA & PREÇO & ANUNCIANTE \\
\hline Pinhais & 301,58 & CENTRO & Centro & & $4.178,00$ & $\mathrm{R} \$ 1.260 .000,00$ & Imóveis Exclusivos - $3547 \mathrm{~J}$ \\
\hline Pinhais & 303,77 & GRACIOSA & Alphaville & NULL & 823,00 & $\mathrm{R} \$ 250.000,00$ & Premiére Imóveis - $4075 \mathrm{~J}$ \\
\hline Pinhais & 312,50 & PALMITAL & Progresso & Rua PANAMA & $1.312,00$ & $\mathrm{R} \$ 410.000,00$ & Souza Neto Empreendimentos Imobiliários Ltda \\
\hline Pinhais & 312,93 & ESTÂNCIA PINHAIS & Estância Pinhais & Rua Sete de Setembro & 735,00 & $\mathrm{R} \$ 230.000,00$ & Imobiliária Triunfo - $16288 \mathrm{~F}$ \\
\hline Pinhais & 314,96 & WEISSOPOLIS & WEISSOPOLIS & & 127,00 & $\mathrm{R} \$ 40.000,00$ & MIRANDA IMOVEIS \\
\hline Pinhais & 319,44 & EMILIANO PERNETA & EMILIANO PERNETA & & 360,00 & $\mathrm{R} \$ 115.000,00$ & CARVALHO IMÓVEIS \\
\hline Pinhais & 319,79 & EMILIANO PERNETA & DONA JOAQUINA & & $4.377,90$ & $\mathrm{R} \$ 1.400 .000,00$ & REGINALDO IMÓVEIS \\
\hline Pinhais & 319,85 & EMILIANO PERNETA & DONA JOAQUINA & & $4.377,00$ & $\mathrm{R} \$ 1.400 .000,00$ & REGINALDO IMÓVEIS \\
\hline Pinhais & 320,00 & PALMITAL & & AV. JACOB MACANHAN & $1.500,00$ & $\mathrm{R} \$ 480.000,00$ & REGINALDO IMÓVEIS \\
\hline Pinhais & 320,00 & PALMITAL & & JACOB MACANHAN & $1.500,00$ & $\mathrm{R} \$ 480.000,00$ & REGINALDO IMÓVEIS \\
\hline Pinhais & 320,75 & EMILIANO PERNETA & PERNETA & & $2.120,00$ & $\mathrm{R} \$ 680.000,00$ & MM IMÓVEIS \\
\hline Pinhais & 321,43 & GRACIOSA & Alphaville & Rua RESIDENCIAL ARAUCÁRIAS & 700,00 & $\mathrm{R} \$ 225.000,00$ & Cibraco Imóveis Vendas - 20J \\
\hline Pinhais & 321,96 & CENTRO & CENTRO & & $1.553,00$ & $\mathrm{R} \$ 500.000,00$ & MM IMÓVEIS \\
\hline Pinhais & 324,86 & GRACIOSA & Alphaville & Rua APORE - RESIDENCIAL IGUACU & 708,00 & $\mathrm{R} \$ 230.000,00$ & Cibraco Imóveis Vendas - 20J \\
\hline Pinhais & 325,00 & VARGEM GRANDE & Vargem Grande & CASSIMIRO DE ABREU & 200,00 & $\mathrm{R} \$ 65.000,00$ & Apolar Imóveis - Pinhais J 3791 \\
\hline Pinhais & 327,16 & PALMITAL & & PAULO ROBERTO CORDEIRO & 162,00 & $\mathrm{R} \$ 53.000,00$ & ELV IMOVEIS \\
\hline Pinhais & 333,33 & PALMITAL & Pineville & Rua Genoveva Forlepa Kopca & 180,00 & $\mathrm{R} \$ 60.000,00$ & LLJ Corretora de Imóveis - CRECI 16.555 \\
\hline Pinhais & 333,33 & PALMITAL & Pineville & Rua Genoveva Forlepa Kopca & 360,00 & $\mathrm{R} \$ 120.000,00$ & LLJ Corretora de Imóveis - CRECI 16.555 \\
\hline Pinhais & 333,33 & PALMITAL & BORDIGNON & & 180,00 & $\mathrm{R} \$ 60.000,00$ & MM IMÓVEIS \\
\hline Pinhais & 335,77 & GRACIOSA & Alphaville & ESTRADA DA GRACIOSA & 833,91 & $\mathrm{R} \$ 280.000,00$ & Pronto Imóveis - J 4107 \\
\hline Pinhais & 337,50 & ESTÂNCIA PINHAIS & Vila Tarumã & RUA LEOPOLDO JACOMEL & $4.000,00$ & $\mathrm{R} \$ 1.350 .000,00$ & Casaredo Imóveis - J01142 \\
\hline Pinhais & 344,50 & GRACIOSA & Alphaville & Rua H DA QUADRA M 1 LOTE 07 & 552,27 & $\mathrm{R} \$ 190.257,02$ & Washington Ortega Imóveis Vendas - 3301J \\
\hline Pinhais & 344,77 & GRACIOSA & Alphaville & ESTRADA DA GRACIOSA & 551,09 & $\mathrm{R} \$ 190.000,00$ & Pronto Imóveis - J 4107 \\
\hline Pinhais & 345,68 & PALMITAL & Pineville & Mario Marques Guimarães & 202,50 & $\mathrm{R} \$ 70.000,00$ & LLJ Corretora de Imóveis - CRECI 16.555 \\
\hline Pinhais & 347,22 & GRACIOSA & Alphaville & & 720,00 & $\mathrm{R} \$ 250.000,00$ & Prates Imóveis - J4177 \\
\hline Pinhais & 348,80 & GRACIOSA & Alphaville & Alphaville graciosa araucarias & 711,00 & $\mathrm{R} \$ 248.000,00$ & \begin{tabular}{|l|} 
Complexo Pineville 14894 \\
\end{tabular} \\
\hline Pinhais & 349,60 & GRACIOSA & Alphaville & Rua dos Cedros & 881,00 & $\mathrm{R} \$ 308.000,00$ & Complexo Pineville 14894 \\
\hline Pinhais & 350,00 & CENTRO & Centro & NULL & $4.000,00$ & $R \$ 1.400 .000,00$ & TC Imóveis - 03360J \\
\hline
\end{tabular}


INPESPAR - PORTAIS: IMÓVEIS CURITIBA e IMÓVEIS SJP - TERRENOS OFERTADOS PARA VENDA - NOVEMBRO 2009

\begin{tabular}{|c|c|c|c|c|c|c|c|}
\hline Cidade & $\mathrm{R} \$ / \mathrm{M} 2$ & BAIRRO & LOTEAMENTO & ENDEREÇO & ÁREA & PREÇO & ANUNCIANTE \\
\hline Pinhais & 357,14 & GRACIOSA & Alphaville & Alphaville Graciosa / Residencial das Araucárias & 700,00 & $\mathrm{R} \$ 250.000,00$ & Gomes Consultor Imobiliário Ltda - J 3.943 \\
\hline Pinhais & 363,64 & CENTRO & Varginha & Rua Trinidad Tobago & 154,00 & $\mathrm{R} \$ 56.000,00$ & D Miranda Imóveis - 15024 \\
\hline Pinhais & 365,85 & PALMITAL & BOA ESPERANÇA & & 410,00 & $\mathrm{R} \$ 150.000,00$ & CICERO IMÓVEIS \\
\hline Pinhais & 367,65 & EMILIANO PERNETA & DONA JOAQUINA & & 408,00 & $\mathrm{R} \$ 150.000,00$ & REGINALDO IMÓVEIS \\
\hline Pinhais & 367,65 & EMILIANO PERNETA & DONA JOAQUINA & & 408,00 & $R \$ 150.000,00$ & REGINALDO IMÓVEIS \\
\hline Pinhais & 375,00 & VARGEM GRANDE & VARGEM GRANDE & & $8.000,00$ & $\mathrm{R} \$ 3.000 .000,00$ & IMOBILESTE \\
\hline Pinhais & 378,79 & ESTÃNCIA PINHAIS & ESTANCIA PINHAIS & & 660,00 & $\mathrm{R} \$ 250.000,00$ & CARVALHO IMÓVEIS \\
\hline Pinhais & 380,12 & PALMITAL & Pineville & CONDOMÍNIO RESIDENCIAL PINEWOODS & 684,00 & $\mathrm{R} \$ 260.000,00$ & SNP Corretora de Imóveis- 15738 F \\
\hline Pinhais & 382,65 & ALTO ATUBA & DEMETERCO & & 392,00 & $\mathrm{R} \$ 150.000,00$ & MM IMÓVEIS \\
\hline Pinhais & 384,62 & CENTRO & DONA GUIOMAR & & 260,00 & $\mathrm{R} \$ 100.000,00$ & ELV IMOVEIS \\
\hline Pinhais & 388,89 & PALMITAL & Pineville & & 450,00 & $\mathrm{R} \$ 175.000,00$ & Complexo Pineville 14894 \\
\hline Pinhais & 400,00 & ALTO ATUBA & Jardim Pedro Demeterco & Rua MARIALVA & 450,00 & $R \$ 180.000,00$ & MM Imóveis Pinhais - 4049J \\
\hline Pinhais & 400,00 & EMILIANO PERNETA & PERNETA & & 450,00 & $\mathrm{R} \$ 180.000,00$ & MM IMÓVEIS \\
\hline Pinhais & 400,00 & ALTO ATUBA & ATUBA & & 500,00 & $\mathrm{R} \$ 200.000,00$ & MM IMÓVEIS \\
\hline Pinhais & 407,41 & EMILIANO PERNETA & PERNETA & & $5.400,00$ & $\mathrm{R} \$ 2.200 .000,00$ & MM IMÓVEIS \\
\hline Pinhais & 412,50 & CENTRO & Centro & R. RIO NEGRO & $1.200,00$ & $\mathrm{R} \$ 495.000,00$ & Imobiliária Cilar - Vendas - 150J \\
\hline Pinhais & 412,50 & PALMITAL & PALMITAL & & 160,00 & $\mathrm{R} \$ 66.000,00$ & MM IMÓVEIS \\
\hline Pinhais & 423,53 & WEISSOPOLIS & Weissópolis & Rua RIO PARANA & 425,00 & $\mathrm{R} \$ 180.000,00$ & Cibraco Imóveis Vendas - 20J \\
\hline Pinhais & 427,35 & ALTO ATUBA & PEDRO DEMETERCO & & $1.872,00$ & $\mathrm{R} \$ 800.000,00$ & CARVALHO IMÓVEIS \\
\hline Pinhais & 433,33 & SETE VILAS & JARDIM FENIX & & 150,00 & $\mathrm{R} \$ 65.000,00$ & REGINALDO IMÓVEIS \\
\hline Pinhais & 446,43 & VARGEM GRANDE & Vargem Grande & Rua Clóvis Bevilaqua, & 448,00 & $\mathrm{R} \$ 200.000,00$ & LLJ Corretora de Imóveis - CRECI 16.555 \\
\hline Pinhais & 446,43 & ALTO ATUBA & DEMETERCO & & 392,00 & $\mathrm{R} \$ 175.000,00$ & MM IMÓVEIS \\
\hline Pinhais & 448,10 & GRACIOSA & Alphaville & Endereço: & 781,07 & $\mathrm{R} \$ 350.000,00$ & Prates Imóveis - J4177 \\
\hline Pinhais & 449,37 & PALMITAL & ALTO TARUMÃ & & $3.338,00$ & $\mathrm{R} \$ 1.500 .000,00$ & MM IMÓVEIS \\
\hline Pinhais & 490,32 & EMILIANO PERNETA & PERNETA & & 775,00 & $\mathrm{R} \$ 380.000,00$ & MIRANDA IMOVEIS \\
\hline Pinhais & 527,22 & ALTO ATUBA & Jardim Atuba & Av. MARINGA & 360,38 & $R \$ 190.000,00$ & Pesquisa Vendas - 843j \\
\hline Pinhais & 548,59 & PALMITAL & ALTO TARUMÃ & & 638,00 & $\mathrm{R} \$ 350.000,00$ & MM IMÓVEIS \\
\hline Pinhais & 597,94 & PALMITAL & Pineville & JAIR MARTINS DE SOUZA & 125,43 & $\mathrm{R} \$ 75.000,00$ & Apolar Imóveis - Jd das Américas J 4143 \\
\hline
\end{tabular}




\begin{tabular}{|c|c|c|c|c|c|c|c|}
\hline Cidade & $\mathrm{R} \$ \mathbf{M} 2$ & BAIRRO & LOTEAMENTO & ENDERECO & ÁREA & PRECO & ANUNCIANTE \\
\hline Pinhais & 616,67 & EMILIANO PERNETA & PERNETA & & 600,00 & $\mathrm{R} \$ 370.000,00$ & CICERO IMÓVEIS \\
\hline Pinhais & 655,22 & CENTRO & Centro & NULL & $2.213,00$ & $\mathrm{R} \$ 1.450 .000,00$ & Premiére Imóveis - $4075 \mathrm{~J}$ \\
\hline Pinhais & 655,22 & CENTRO & Centro & NULL & $2.213,00$ & $\mathrm{R} \$ 1.450 .000,00$ & Premiére Imóveis - $4075 \mathrm{~J}$ \\
\hline Pinhais & 880,00 & CENTRO & CENTRO & & 500,00 & $\mathrm{R} \$ 440.000,00$ & IMOBILESTE \\
\hline Pinhais & 1000,00 & WEISSOPOLIS & WEISSOPOLIS & & $1.200,00$ & $R \$ 1.200 .000,00$ & MM IMÓVEIS \\
\hline SJP & $\begin{array}{c}\mathrm{R} \$ \\
65,96 \\
\end{array}$ & CENTRO & Centro & RUA ANTONIO ZARAMELLA & 15160,00 & \begin{tabular}{|l|}
$R \$$ \\
$1.000 .000,00$ \\
\end{tabular} & Anastácio Corretor de Imóveis - F-17093 \\
\hline SJP & \begin{tabular}{|c|}
$\mathrm{R} \$$ \\
205,91
\end{tabular} & CENTRO & Centro & & 12141,00 & $\begin{array}{l}\mathrm{R} \$ \\
2.500 .000,00\end{array}$ & 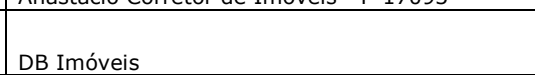 \\
\hline SJP & \begin{tabular}{|l|}
$R \$$ \\
233,88 \\
\end{tabular} & CENTRO & Centro & & 1496,50 & \begin{tabular}{|l|}
$\mathrm{R} \$$ \\
$350.000,00$
\end{tabular} & Revelação Imóveis \\
\hline SJP & $\begin{array}{l}\mathrm{R} \$ \\
338,54\end{array}$ & CENTRO & Centro & & 384,00 & $\begin{array}{l}\mathrm{R} \$ \\
130.000,00\end{array}$ & WASHINGTON ORTEGA CORRETORA DE IMOVEIS \\
\hline SJP & $\begin{array}{c}\mathrm{R} \$ \\
357,14 \\
\end{array}$ & CENTRO & Centro & R JOAQUIM NABUCO & 2800,00 & $\begin{array}{l}\mathrm{R} \$ \\
1.000 .000,00\end{array}$ & Jo Imóveis - 3915] \\
\hline SJP & $\begin{array}{l}\mathrm{R} \$ \\
414,51 \\
\end{array}$ & CENTRO & Centro & & 965,00 & $\begin{array}{l}\mathrm{R} \$ \\
400.000,00\end{array}$ & Solaris Imóveis \\
\hline SJP & \begin{tabular}{|l|}
$\mathrm{R} \$$ \\
439,92
\end{tabular} & CENTRO & Centro & & 795,60 & $\begin{array}{l}\mathrm{R} \$ \\
350.000,00\end{array}$ & Revelação Imóveis \\
\hline SJP & $\begin{array}{l}\mathrm{R} \$ \\
440,63\end{array}$ & CENTRO & Centro & & 839,70 & $\begin{array}{l}\mathrm{R} \$ \\
370.000,00\end{array}$ & Solaris Imóveis \\
\hline SJP & $\begin{array}{c}\mathrm{R} \$ \\
460,53\end{array}$ & CENTRO & Centro & & 456,00 & $\begin{array}{l}\mathrm{R} \$ \\
210.000,00\end{array}$ & Idélcio Corretor de Imóveis \\
\hline SJP & \begin{tabular}{|l|}
$R \$$ \\
470,09 \\
\end{tabular} & CENTRO & Centro & & 468,00 & $\begin{array}{l}\mathrm{R} \$ \\
220.000,00\end{array}$ & Prosper Imóveis \\
\hline SJP & \begin{tabular}{|l}
$\mathrm{R} \$$ \\
562,50
\end{tabular} & CENTRO & Centro & & 480,00 & \begin{tabular}{|l}
$\mathrm{R} \$$ \\
$270.000,00$
\end{tabular} & Revelação Imóveis \\
\hline SJP & $\begin{array}{c}\mathrm{R} \$ \\
577,25\end{array}$ & CENTRO & Centro & & 2598,54 & $\begin{array}{l}\mathrm{R} \$ \\
1.500 .000,00\end{array}$ & AB Imóveis \\
\hline SJP & $\begin{array}{l}\mathrm{R} \$ \\
617,52\end{array}$ & CENTRO & Centro & & 468,00 & $\begin{array}{l}\mathrm{R} \$ \\
289.000,00\end{array}$ & Revelação Imóveis \\
\hline SJP & \begin{tabular}{|l|}
$\mathrm{R} \$$ \\
636,36
\end{tabular} & CENTRO & Centro & & 440,00 & $\begin{array}{l}\mathrm{R} \$ \\
280.000,00\end{array}$ & MARQUES IMOVEIS \\
\hline SJP & $\begin{array}{l}\mathrm{R} \$ \\
644,17\end{array}$ & CENTRO & Centro & & 946,95 & $\begin{array}{l}\mathrm{R} \$ \\
610.000,00\end{array}$ & Eliana Corretora de Imóveis - 15371 \\
\hline SJP & $\begin{array}{l}\mathrm{R} \$ \\
659,80 \\
\end{array}$ & CENTRO & Centro & & 378,90 & $\begin{array}{l}\mathrm{R} \$ \\
250.000,00\end{array}$ & Revelação Imóveis \\
\hline
\end{tabular}


INPESPAR - PORTAIS: IMÓVEIS CURITIBA e IMÓVEIS SJP - TERRENOS OFERTADOS PARA VENDA - NOVEMBRO 2009

\begin{tabular}{|c|c|c|c|c|c|c|c|}
\hline Cidade & $\mathrm{R} \$ \mathbf{M} 2$ & BAIRRO & LOTEAMENTO & ENDEREÇO & ÁREA & PREÇO & ANUNCIANTE \\
\hline SJP & $\begin{array}{c}\mathrm{R} \$ \\
665,63\end{array}$ & CENTRO & Centro & & 640,00 & $\begin{array}{l}\mathrm{R} \$ \\
426.000,00\end{array}$ & Revelação Imóveis \\
\hline SJP & $\begin{array}{c}\mathrm{R} \$ \\
672,73\end{array}$ & CENTRO & Centro & & 550,00 & $\begin{array}{l}\mathrm{R} \$ \\
370.000,00\end{array}$ & DB Imóveis \\
\hline SJP & $\begin{array}{l}\mathrm{R} \$ \\
695,00 \\
\end{array}$ & CENTRO & Centro & & 546,76 & $\begin{array}{l}\mathrm{R} \$ \\
380.000,00\end{array}$ & DB Imóveis \\
\hline SJP & $\begin{array}{c}\mathrm{R} \$ \\
700,98\end{array}$ & CENTRO & Centro & & 408,00 & $\begin{array}{l}\mathrm{R} \$ \\
286.000,00\end{array}$ & Revelação Imóveis \\
\hline SJP & $\begin{array}{c}\mathrm{R} \$ \\
744,99\end{array}$ & CENTRO & Centro & & 1745,00 & $\begin{array}{l}\mathrm{R} \$ \\
1.300 .000,00\end{array}$ & Revelação Imóveis \\
\hline SJP & $\begin{array}{l}\mathrm{R} \$ \\
747,13 \\
\end{array}$ & CENTRO & Centro & Próximo à Rua XV de Novembro & 1740,00 & $\begin{array}{l}\mathrm{R} \$ \\
1.300 .000,00\end{array}$ & Jo Imóveis - 3915] \\
\hline SJP & $\begin{array}{l}\mathrm{R} \$ \\
800,00\end{array}$ & CENTRO & Centro & & 600,00 & $\begin{array}{l}\mathrm{R} \$ \\
480.000,00\end{array}$ & Revelação Imóveis \\
\hline SJP & $\begin{array}{c}\mathrm{R} \$ \\
821,02\end{array}$ & CENTRO & Centro & & 3045,00 & $\begin{array}{l}\mathrm{R} \$ \\
2.500 .000,00\end{array}$ & Captare Negócios Imobiliários - J-4198 \\
\hline SJP & $\begin{array}{c}\mathrm{R} \$ \\
821,92\end{array}$ & CENTRO & Centro & & 1460,00 & $\begin{array}{l}\mathrm{R} \$ \\
1.200 .000,00\end{array}$ & Revelação Imóveis \\
\hline SJP & $\begin{array}{l}\mathrm{R} \$ \\
894,74 \\
\end{array}$ & CENTRO & Centro & & 950,00 & $\begin{array}{l}\mathrm{R} \$ \\
850.000,00\end{array}$ & DB Imóveis \\
\hline SJP & $\begin{array}{l}\mathrm{R} \$ \\
950,12\end{array}$ & CENTRO & Centro & & 842,00 & $\begin{array}{l}\mathrm{R} \$ \\
800.000,00\end{array}$ & WASHINGTON ORTEGA CORRETORA DE IMOVEIS \\
\hline SJP & $\begin{array}{c}\mathrm{R} \$ \\
967,03\end{array}$ & CENTRO & Centro & & 341,25 & $\begin{array}{l}\mathrm{R} \$ \\
330.000,00\end{array}$ & Revelação Imóveis \\
\hline SJP & $\begin{array}{l}\mathrm{R} \$ \\
986,09\end{array}$ & CENTRO & Centro & VERISSIMO MARQUES & 1582,00 & $\begin{array}{l}\mathrm{R} \$ \\
1.560 .000,00\end{array}$ & Kim Imóveis - 13010 \\
\hline SJP & $\begin{array}{l}\mathrm{R} \$ \\
996,00\end{array}$ & CENTRO & Centro & & 1000,00 & $\begin{array}{l}\mathrm{R} \$ \\
996.000,00\end{array}$ & Rocco Imóveis \\
\hline SJP & $\begin{array}{l}\mathrm{R} \$ \\
1.025,64\end{array}$ & CENTRO & Centro & Rua Veríssimo Marques & 1560,00 & $\begin{array}{l}\mathrm{R} \$ \\
1.600 .000,00\end{array}$ & Moro Imóveis Ltda Vendas - $1603 \mathrm{~J}$ \\
\hline SJP & $\begin{array}{l}\mathrm{R} \$ \\
1.286,55\end{array}$ & CENTRO & Centro & Izabel Redentora & 855,00 & $\begin{array}{l}\mathrm{R} \$ \\
1.100 .000,00\end{array}$ & Kim Imóveis - 13010 \\
\hline SJP & $\begin{array}{l}\mathrm{R} \$ \\
1.295,73\end{array}$ & CENTRO & Centro & & 656,00 & $\begin{array}{l}\mathrm{R} \$ \\
850.000,00\end{array}$ & Corretor Santiago \\
\hline SJP & $\begin{array}{l}\mathrm{R} \$ \\
2.081,08\end{array}$ & CENTRO & Centro & $\begin{array}{l}\text { R. XV de Novembro/ Frente da praça Getulio } \\
\text { Vargas }\end{array}$ & 370,00 & $\begin{array}{l}\mathrm{R} \$ \\
770.000,00\end{array}$ & Manoel Abreu Corretor de Imóveis- F16.633 \\
\hline SJP & $\begin{array}{l}\mathrm{R} \$ \\
2.211,54\end{array}$ & CENTRO & Centro & & 624,00 & $\begin{array}{l}\mathrm{R} \$ \\
1.380 .000,00\end{array}$ & WASHINGTON ORTEGA CORRETORA DE IMOVEIS \\
\hline SJP & $\begin{array}{l}\mathrm{R} \$ \\
2.211,54\end{array}$ & CENTRO & Centro & Rua IZABEL A REDENTORA & 624,00 & $\begin{array}{l}\mathrm{R} \$ \\
1.380 .000,00\end{array}$ & Washington Ortega Imóveis Vendas - 3301J \\
\hline
\end{tabular}




\begin{tabular}{|c|c|c|c|c|c|c|c|c|}
\hline$\frac{\text { IN }}{\text { Cidade }}$ & \multicolumn{2}{|c|}{$\mathrm{R} \$ \mathbf{M} 2$} & \multirow{2}{*}{\begin{tabular}{|l} 
BAIRRO \\
ARISTOCRATA \\
\end{tabular}} & \multirow{2}{*}{$\begin{array}{l}\text { LOTEAMENTO } \\
\text { ARISTOCRATA } \\
\end{array}$} & \multirow{2}{*}{ ENDEREÇO } & \multirow{2}{*}{\begin{tabular}{|l|} 
ÁREA \\
1168,50 \\
\end{tabular}} & \multirow{2}{*}{\begin{tabular}{|l|}
\multicolumn{1}{|l}{ PREÇO } \\
$\mathrm{R} \$$ \\
$220.000,00$ \\
\end{tabular}} & \multirow{2}{*}{$\begin{array}{l}\text { ANUNCIANTE } \\
\text { Solaris Imóveis }\end{array}$} \\
\hline SJP & $\mathrm{R} \$$ & 188,28 & & & & & & \\
\hline SJP & $\mathrm{R} \$$ & 291,67 & ARISTOCRATA & ARISTOCRATA & & 600,00 & \begin{tabular}{|l|}
$\mathrm{R} \$$ \\
$175.000,00$
\end{tabular} & Corteze Imóveis \\
\hline SJP & $\mathrm{R} \$$ & 316,67 & ARISTOCRATA & Aristocrata & & 600,00 & \begin{tabular}{|l|}
$\mathrm{R} \$$ \\
$190.000,00$
\end{tabular} & DB Imóveis \\
\hline SJP & $\mathrm{R} \$$ & 316,67 & ARISTOCRATA & ARISTOCRATA & & 600,00 & \begin{tabular}{|l|}
$R \$$ \\
$190.000,00$
\end{tabular} & Revelação Imóveis \\
\hline SJP & $\mathrm{R} \$$ & 319,44 & ARISTOCRATA & ARISTOCRATA & & 360,00 & $\begin{array}{l}\mathrm{R} \$ \\
115.000,00\end{array}$ & Idélcio Corretor de Imóveis \\
\hline SJP & $\mathrm{R} \$$ & 346,67 & ARISTOCRATA & ARISTOCRATA & & 375,00 & \begin{tabular}{|l|}
$R \$$ \\
$130.000,00$
\end{tabular} & Revelação Imóveis \\
\hline SJP & $\mathrm{R} \$$ & 346,67 & ARISTOCRATA & ARISTOCRATA & & 375,00 & \begin{tabular}{|l|}
$R \$$ \\
$130.000,00$
\end{tabular} & Venturi Consultoria Imobiliária \\
\hline SJP & $\mathrm{R} \$$ & 346,67 & ARISTOCRATA & ARISTOCRATA & & 375,00 & $\begin{array}{l}\mathrm{R} \$ \\
130.000,00\end{array}$ & Revelação Imóveis \\
\hline SJP & $\mathrm{R} \$$ & 358,97 & ARISTOCRATA & ARISTOCRATA & & 390,00 & \begin{tabular}{|l|}
$\mathrm{R} \$$ \\
$140.000,00$
\end{tabular} & DB Imóveis \\
\hline SJP & $\mathrm{R} \$$ & 360,00 & ARISTOCRATA & Aristocrata & & 375,00 & \begin{tabular}{|l|}
$\mathrm{R} \$$ \\
$135.000,00$
\end{tabular} & Ribeiro Imóveis \\
\hline SJP & $\mathrm{R} \$$ & 362,67 & ARISTOCRATA & ARISTOCRATA & & 375,00 & $\begin{array}{l}\mathrm{R} \$ \\
136.000,00\end{array}$ & Viver Bem Imóveis \\
\hline SJP & $\mathrm{R} \$$ & 373,33 & ARISTOCRATA & ARISTOCRATA & & 375,00 & $\begin{array}{l}\mathrm{R} \$ \\
140.000,00\end{array}$ & MARQUES IMOVEIS \\
\hline SJP & $\mathrm{R} \$$ & 426,67 & ARISTOCRATA & ARISTOCRATA & & 375,00 & \begin{tabular}{|l|}
$R \$$ \\
$160.000,00$
\end{tabular} & $\begin{array}{l}\text { WASHINGTON ORTEGA CORRETORA DE } \\
\text { IMOVEIS }\end{array}$ \\
\hline SJP & $\mathrm{R} \$$ & 555,56 & ARISTOCRATA & ARISTOCRATA & & 405,00 & \begin{tabular}{|l|}
$\mathrm{R} \$$ \\
$225.000,00$
\end{tabular} & Solaris Imóveis \\
\hline SJP & $\mathrm{R} \$$ & 574,79 & ARISTOCRATA & ARISTOCRATA & & 468,00 & \begin{tabular}{|l}
$\mathrm{R} \$$ \\
$269.000,00$
\end{tabular} & Revelação Imóveis \\
\hline SJP & $\mathrm{R} \$$ & 664,10 & ARISTOCRATA & ARISTOCRATA & & 390,00 & $\begin{array}{l}\mathrm{R} \$ \\
259.000,00\end{array}$ & Revelação Imóveis \\
\hline SJP & $\mathrm{R} \$$ & 20,00 & ITÁLIA & Jardim Itália & & 9960,00 & \begin{tabular}{|l|}
$\mathrm{R} \$$ \\
$199.200,00$
\end{tabular} & Rocco Imóveis \\
\hline SJP & $\mathrm{R} \$$ & 20,00 & ITÁLIA & Jardim Itália & & 21709,00 & $\begin{array}{l}\mathrm{R} \$ \\
434.183,00\end{array}$ & Rocco Imóveis \\
\hline SJP & $\mathrm{R} \$$ & 20,00 & ITÁLIA & Jardim Itália & & 6622,00 & $\begin{array}{l}\mathrm{R} \$ \\
132.448,00\end{array}$ & Rocco Imóveis \\
\hline
\end{tabular}




\begin{tabular}{|c|c|c|c|c|c|c|c|c|}
\hline$\frac{\text { IN }}{\text { Cidade }}$ & \multicolumn{2}{|c|}{$\mathrm{R} \$ \mathbf{M} 2$} & \multirow{2}{*}{$\begin{array}{l}\text { BAIRRO } \\
\text { ZANIOLO }\end{array}$} & \multirow{2}{*}{$\begin{array}{l}\text { LOTEAMENTO } \\
\text { Zaniolo } \\
\end{array}$} & \multirow{2}{*}{ ENDEREÇO } & \multirow{2}{*}{$\begin{array}{l}\text { ÁREA } \\
2000,00 \\
\end{array}$} & \multirow{2}{*}{\begin{tabular}{|l|} 
PREÇO \\
$R \$$ \\
$115.000,00$ \\
\end{tabular}} & \multirow{2}{*}{$\begin{array}{l}\text { ANUNCIANTE } \\
\text { Revelacão Imóveis }\end{array}$} \\
\hline SJP & $\mathrm{R} \$$ & 57,50 & & & & & & \\
\hline SJP & $\mathrm{R} \$$ & 107,87 & ITÁLIA & Portal do Sol & & 927,00 & \begin{tabular}{|l|}
$\mathrm{R} \$$ \\
$100.000,00$
\end{tabular} & Venturi Consultoria Imobiliária \\
\hline SJP & $\mathrm{R} \$$ & 163,15 & PEDRO MORO & Braga & & 582,28 & \begin{tabular}{|l|}
$\mathrm{R} \$$ \\
$95.000,00$
\end{tabular} & Ribeiro Imóveis \\
\hline SJP & $\mathrm{R} \$$ & 164,44 & PEDRO MORO & Braga & & 483,46 & \begin{tabular}{|l|}
$\mathrm{R} \$$ \\
$79.500,00$
\end{tabular} & Ribeiro Imóveis \\
\hline SJP & $\mathrm{R} \$$ & 167,54 & PEDRO MORO & Braga & & 483,46 & \begin{tabular}{|l|}
$\mathrm{R} \$$ \\
$81.000,00$
\end{tabular} & Ribeiro Imóveis \\
\hline SJP & $\mathrm{R} \$$ & 189,39 & ITÁLIA & Portal do Sol & & 396,00 & \begin{tabular}{|l|}
$\mathrm{R} \$$ \\
$75.000,00$ \\
\end{tabular} & DB Imóveis \\
\hline SJP & $\mathrm{R} \$$ & 203,96 & BOM JESUS & Bom Jesus & & 3432,00 & \begin{tabular}{|l|}
$\mathrm{R} \$$ \\
$700.000,00$
\end{tabular} & DB Imóveis \\
\hline SJP & $\mathrm{R} \$$ & 219,83 & BOM JESUS & Bom Jesus & & 696,00 & \begin{tabular}{|l|}
$R \$$ \\
$153.000,00$ \\
\end{tabular} & $\begin{array}{l}\text { WASHINGTON ORTEGA CORRETORA DE } \\
\text { IMOVEIS }\end{array}$ \\
\hline SJP & $\mathrm{R} \$$ & 252,83 & PEDRO MORO & Braga & & 6328,33 & \begin{tabular}{|l|}
$\mathrm{R} \$$ \\
$1.600 .000,00$
\end{tabular} & Revelação Imóveis \\
\hline SJP & $\mathrm{R} \$$ & 266,20 & SÃO DOMINGOS & São Domingos & & 432,00 & \begin{tabular}{|l|}
$\mathrm{R} \$$ \\
$115.000,00$
\end{tabular} & Revelação Imóveis \\
\hline SJP & $\mathrm{R} \$$ & 268,70 & PEDRO MORO & Braga & & 361,00 & \begin{tabular}{|l|}
$\mathrm{R} \$$ \\
$97.000,00$
\end{tabular} & $\begin{array}{l}\text { WASHINGTON ORTEGA CORRETORA DE } \\
\text { IMOVEIS }\end{array}$ \\
\hline SJP & $\mathrm{R} \$$ & 326,09 & ITÁLIA & Portal do Sol & & 1472,00 & $\begin{array}{l}\mathrm{R} \$ \\
480.000,00\end{array}$ & MARQUES IMOVEIS \\
\hline SJP & $\mathrm{R} \$$ & 348,53 & BOM JESUS & Bom Jesus & & 373,00 & \begin{tabular}{|l|}
$R \$$ \\
$130.000,00$
\end{tabular} & $\begin{array}{l}\text { WASHINGTON ORTEGA CORRETORA DE } \\
\text { IMOVEIS }\end{array}$ \\
\hline SJP & $\mathrm{R} \$$ & 442,65 & SÃO PEDRO & São Pedro & & 519,60 & $\begin{array}{l}\mathrm{R} \$ \\
230.000,00\end{array}$ & Revelação Imóveis \\
\hline SJP & $\mathrm{R} \$$ & 457,64 & SÃO DOMINGOS & Silveira da Motta & & 1048,86 & \begin{tabular}{|l|}
$\mathrm{R} \$$ \\
$480.000,00$
\end{tabular} & Ribeiro Imóveis \\
\hline SJP & $\mathrm{R} \$$ & 476,19 & PEDRO MORO & Braga & & 546,00 & \begin{tabular}{|l|}
$\mathrm{R} \$$ \\
$260.000,00$
\end{tabular} & Venturi Consultoria Imobiliária \\
\hline SJP & $\mathrm{R} \$$ & 497,47 & SÃO PEDRO & Vila Heitor & & 396,00 & \begin{tabular}{|l|}
$\mathrm{R} \$$ \\
$197.000,00$
\end{tabular} & Corteze Imóveis \\
\hline SJP & $\mathrm{R} \$$ & 530,00 & SÃO PEDRO & São Pedro & & 500,00 & \begin{tabular}{|l|}
$\mathrm{R} \$$ \\
$265.000,00$
\end{tabular} & Toniolo Corretora de Imóveis \\
\hline SJP & $\mathrm{R} \$$ & 612,75 & SÃO PEDRO & Vila Heitor & & 408,00 & \begin{tabular}{|l|}
$\mathrm{R} \$$ \\
$250.000,00$
\end{tabular} & Ribeiro Imóveis \\
\hline
\end{tabular}




\begin{tabular}{|c|c|c|c|c|c|c|c|c|}
\hline \multicolumn{9}{|c|}{ INPESPAR - PORTAIS: IMÓVEIS CURITIBA e IMÓVEIS SJP - TERRENOS OFERTADOS PARA VENDA - NOVEMBRO 2009} \\
\hline Cidade & $\mathbf{R} \$ / \mathbf{M}$ & & BAIRRO & LOTEAMENTO & ENDEREÇO & ÁREA & PREÇO & ANUNCIANTE \\
\hline SJP & $\mathrm{R} \$$ & 612,75 & SÃO PEDRO & Vila Heitor & & 408,00 & $\begin{array}{l}\mathrm{R} \$ \\
250.000,00\end{array}$ & Ribeiro Imóveis \\
\hline SJP & $\mathrm{R} \$$ & 659,32 & PEDRO MORO & Vila Braga & & 379,18 & $\begin{array}{l}\mathrm{R} \$ \\
250.000,00\end{array}$ & Sueli Fernandes Imóveis \\
\hline SJP & & 58,00 & $\begin{array}{l}\text { BONECA DO } \\
\text { IGUAÇU }\end{array}$ & Boneca do Iguaçu & Rua Acre & 25000,00 & $\begin{array}{l}\mathrm{R} \$ \\
1.450 .000,00\end{array}$ & Reikdal Corretora de Imóveis - creci 14.300 \\
\hline SJP & $\mathrm{R} \$$ & 92,07 & ÁGUAS BELAS & Jardim Aeroporto & & 5322,18 & $\begin{array}{l}\mathrm{R} \$ \\
490.000,00\end{array}$ & Revelação Imóveis \\
\hline SJP & $\mathrm{R} \$$ & 94,95 & $\begin{array}{l}\text { BONECA DO } \\
\text { IGUAÇU }\end{array}$ & Boneca do Iguaçu & & 8952,29 & $\begin{array}{l}\mathrm{R} \$ \\
850.000,00\end{array}$ & Venturi Consultoria Imobiliária \\
\hline SJP & $\mathrm{R} \$$ & 96,53 & AEROPORTO & Aeroporto & A 500 MTS DO BOTICÁRIO & 62160,00 & $\begin{array}{l}\mathrm{R} \$ \\
6.000 .000,00\end{array}$ & G-Luma J4174 \\
\hline SJP & $\mathrm{R} \$$ & 101,85 & CIDADE JARDIM & CIDADE JARDIM & & 540,00 & $\begin{array}{l}\mathrm{R} \$ \\
55.000,00\end{array}$ & Imo House \\
\hline SJP & $\mathrm{R} \$$ & 120,07 & $\begin{array}{l}\text { BONECA DO } \\
\text { IGUAÇU }\end{array}$ & Santos Dumont I & & 583,00 & $\begin{array}{l}\mathrm{R} \$ \\
70.000,00\end{array}$ & Venturi Consultoria Imobiliária \\
\hline SJP & $\mathrm{R} \$$ & 122,38 & $\begin{array}{l}\text { BONECA DO } \\
\text { IGUAÇU }\end{array}$ & Santos Dumont I & & 572,00 & $\begin{array}{l}\mathrm{R} \$ \\
70.000,00\end{array}$ & Venturi Consultoria Imobiliária \\
\hline SJP & $\mathrm{R} \$$ & 150,00 & ÁGUAS BELAS & Vila Margarida & & 5000,00 & $\begin{array}{l}\mathrm{R} \$ \\
750.000,00\end{array}$ & ene \\
\hline SJP & $\mathrm{R} \$$ & 157,41 & CIDADE JARDIM & CIDADE JARDIM & & 540,00 & $\begin{array}{l}\mathrm{R} \$ \\
85.000,00\end{array}$ & Viver Bem Imóveis \\
\hline SJP & $\mathrm{R} \$$ & 162,04 & CIDADE JARDIM & CIDADE JARDIM & & 432,00 & $\begin{array}{l}\mathrm{R} \$ \\
70.000,00\end{array}$ & Rocco Imóveis \\
\hline SJP & $\mathrm{R} \$$ & 185,19 & ÁGUAS BELAS & Aguas Belas & & 432,00 & $\begin{array}{l}\mathrm{R} \$ \\
80.000,00\end{array}$ & Santos Corretor de Imóveis \\
\hline SJP & $\mathrm{R} \$$ & 194,00 & CRUZEIRO & Vila Brunning & & 250,00 & $\begin{array}{l}\mathrm{R} \$ \\
48.500,00\end{array}$ & MARQUES IMOVEIS \\
\hline SJP & $\mathrm{R} \$$ & 204,68 & CRUZEIRO & Cruzeiro & & 684,00 & $\begin{array}{l}\mathrm{R} \$ \\
140.000,00\end{array}$ & Santos Corretor de Imóveis \\
\hline SJP & $\mathrm{R} \$$ & 208,33 & CIDADE JARDIM & CIDADE JARDIM & & 360,00 & $\begin{array}{l}\mathrm{R} \$ \\
75.000,00\end{array}$ & Toniolo Corretora de Imóveis \\
\hline SJP & $\mathrm{R} \$$ & 221,35 & CIDADE JARDIM & CIDADE JARDIM & & 384,00 & $\begin{array}{c}\mathrm{R} \$ \\
85.000,00\end{array}$ & MARQUES IMOVEIS \\
\hline SJP & $\mathrm{R} \$$ & 224,54 & CIDADE JARDIM & CIDADE JARDIM & & 432,00 & $\begin{array}{l}\mathrm{R} \$ \\
97.000,00\end{array}$ & Toniolo Corretora de Imóveis \\
\hline SJP & $R \$$ & 232,62 & CRUZEIRO & JARDIM CRUZEIRO & & 365,40 & $\begin{array}{l}\mathrm{R} \$ \\
85.000,00\end{array}$ & Santos Corretor de Imóveis \\
\hline SJP & $\mathrm{R} \$$ & 236,11 & CIDADE JARDIM & CIDADE JARDIM & & 360,00 & $\begin{array}{l}\mathrm{R} \$ \\
85.000,00\end{array}$ & Toniolo Corretora de Imóveis \\
\hline
\end{tabular}




\begin{tabular}{|c|c|c|c|c|c|c|c|c|}
\hline \multicolumn{9}{|c|}{ INPESPAR - PORTAIS: IMÓVEIS CURITIBA e IMÓVEIS SJP - TERRENOS OFERTADOS PARA VENDA - NOVEMBRO 2009} \\
\hline Cidade & & & BAIRRO & LOTEAMENTO & ENDEREÇO & ÁREA & PREÇO & ANUNCIANTE \\
\hline SJP & $\mathrm{R} \$$ & 239,13 & AVIAÇÃO & JARDIM DONA ROSA & & 230,00 & $\begin{array}{c}\mathrm{R} \$ \\
55.000,00\end{array}$ & CW Corretor de Imóveis \\
\hline SJP & & 240,00 & CRUZEIRO & Vila Brunning & & 250,00 & $\begin{array}{l}\mathrm{R} \$ \\
60.000,00 \\
\end{array}$ & Ribeiro Imóveis \\
\hline SJP & $\mathrm{R} \$$ & 260,00 & AFONSO PENA & Monte Libano & & 250,00 & $\begin{array}{l}\mathrm{R} \$ \\
65.000,00\end{array}$ & Santos Corretor de Imóveis \\
\hline SJP & $\mathrm{R} \$$ & 260,42 & $\begin{array}{l}\text { BONECA DO } \\
\text { IGUAÇU }\end{array}$ & Boneca do Iguaçu & & 384,00 & $\begin{array}{l}R \$ \\
100.000,00\end{array}$ & MARQUES IMOVEIS \\
\hline SJP & $\mathrm{R} \$$ & 267,20 & CRUZEIRO & Cruzeiro & & 374,25 & $\begin{array}{l}\mathrm{R} \$ \\
100.000,00\end{array}$ & Revelação Imóveis \\
\hline SJP & $\mathrm{R} \$$ & 271,41 & AFONSO PENA & Monte Libano & & 276,33 & $\begin{array}{l}\mathrm{R} \$ \\
75.000,00\end{array}$ & CW Corretor de Imóveis \\
\hline SJP & $\mathrm{R} \$$ & 276,55 & AVIAÇÃO & JARDIM DONA ROSA & & 249,50 & $\begin{array}{l}\mathrm{R} \$ \\
69.000,00\end{array}$ & Corteze Imóveis \\
\hline SJP & $\mathrm{R} \$$ & 277,78 & AFONSO PENA & Monte Libano & & 252,00 & $\begin{array}{l}\mathrm{R} \$ \\
70.000,00\end{array}$ & Haas Assessoria Imobiliária \\
\hline SJP & $\mathrm{R} \$$ & 279,11 & AFONSO PENA & Monte Libano & & 250,80 & $\begin{array}{l}\mathrm{R} \$ \\
70.000,00\end{array}$ & Haas Assessoria Imobiliária \\
\hline SJP & $\mathrm{R} \$$ & 280,00 & CRUZEIRO & Cruzeiro & & 250,00 & $\begin{array}{l}\mathrm{R} \$ \\
70.000,00\end{array}$ & Corteze Imóveis \\
\hline SJP & $\mathrm{R} \$$ & 281,07 & AVIAÇÃO & JARDIM DONA ROSA & & 249,05 & $\begin{array}{l}\mathrm{R} \$ \\
70.000,00\end{array}$ & Corteze Imóveis \\
\hline SJP & $\mathrm{R} \$$ & 282,61 & AVIAÇÃO & JARDIM DONA ROSA & & 230,00 & $\begin{array}{l}\mathrm{R} \$ \\
65.000,00\end{array}$ & Corteze Imóveis \\
\hline SJP & $\mathrm{R} \$$ & 282,61 & AVIAÇÃO & JARDIM DONA ROSA & & 230,00 & $\begin{array}{l}\mathrm{R} \$ \\
65.000,00\end{array}$ & Corteze Imóveis \\
\hline SJP & $\mathrm{R} \$$ & 285,17 & AFONSO PENA & Monte Libano & & 263,00 & $\begin{array}{l}\mathrm{R} \$ \\
75.000,00\end{array}$ & Venturi Consultoria Imobiliária \\
\hline SJP & $\mathrm{R} \$$ & 288,20 & AVIAÇÃO & JARDIM DONA ROSA & & 201,25 & $\begin{array}{c}\mathrm{R} \$ \\
58.000,00\end{array}$ & Corteze Imóveis \\
\hline SJP & $\mathrm{R} \$$ & 288,20 & AVIAÇÃO & JARDIM DONA ROSA & & 201,25 & $\begin{array}{l}\mathrm{R} \$ \\
58.000,00\end{array}$ & Corteze Imóveis \\
\hline SJP & $\mathrm{R} \$$ & 298,70 & CRUZEIRO & Cruzeiro & & 385,00 & $\begin{array}{l}\mathrm{R} \$ \\
115.000,00\end{array}$ & CW Corretor de Imóveis \\
\hline SJP & $\mathrm{R} \$$ & 328,89 & CRUZEIRO & Santos Dumont II & & 450,00 & $\begin{array}{l}R \$ \\
148.000,00\end{array}$ & Corretor Santiago \\
\hline SJP & $\mathrm{R} \$$ & 328,91 & CRUZEIRO & Vila Rocco III & & 1885,00 & $\begin{array}{l}\mathrm{R} \$ \\
620.000,00\end{array}$ & Alaimoveis \\
\hline SJP & $\mathrm{R} \$$ & 333,33 & CRUZEIRO & Cruzeiro & & 360,00 & $\begin{array}{l}\mathrm{R} \$ \\
120.000,00\end{array}$ & Haas Assessoria Imobiliária \\
\hline
\end{tabular}




\begin{tabular}{|c|c|c|c|c|c|c|c|c|}
\hline \multicolumn{9}{|c|}{ INPESPAR - PORTAIS: IMÓVEIS CURITIBA e IMÓVEIS SJP - TERRENOS OFERTADOS PARA VENDA - NOVEMBRO 2009} \\
\hline Cidade & $\mathrm{R} \$ / \mathbf{M}$ & & BAIRRO & LOTEAMENTO & ENDEREÇO & ÁREA & PREÇO & ANUNCIANTE \\
\hline SJP & & 338,92 & CRUZEIRO & Cruzeiro & & 280,30 & \begin{tabular}{|l|}
$\mathrm{R} \$$ \\
$95.000,00$ \\
\end{tabular} & Haas Assessoria Imobiliária \\
\hline SJP & & 339,37 & CRUZEIRO & Cruzeiro & & 221,00 & $\begin{array}{l}\mathrm{R} \$ \\
75.000,00 \\
\end{array}$ & Imobiliária Kalli \\
\hline SJP & $\mathrm{R} \$$ & 341,67 & CIDADE JARDIM & CIDADE JARDIM & & 360,00 & \begin{tabular}{|l|}
$R \$$ \\
$123.000,00$ \\
\end{tabular} & Toniolo Corretora de Imóveis \\
\hline SJP & $\mathrm{R} \$$ & 347,22 & AFONSO PENA & Monte Libano & & 216,00 & $\begin{array}{l}\mathrm{R} \$ \\
75.000,00 \\
\end{array}$ & Idélcio Corretor de Imóveis \\
\hline SJP & $\mathrm{R} \$$ & 389,61 & $\begin{array}{l}\text { BONECA DO } \\
\text { IGUAÇU }\end{array}$ & Santos Dumont I & & 385,00 & $\begin{array}{l}\mathrm{R} \$ \\
150.000,00\end{array}$ & $\begin{array}{l}\text { WASHINGTON ORTEGA CORRETORA DE } \\
\text { IMOVEIS }\end{array}$ \\
\hline SJP & $\mathrm{R} \$$ & 440,26 & $\begin{array}{l}\text { BONECA DO } \\
\text { IGUAÇU }\end{array}$ & Santos Dumont & & 385,00 & \begin{tabular}{|l|}
$\mathrm{R} \$$ \\
$169.500,00$ \\
\end{tabular} & Ribeiro Imóveis \\
\hline SJP & $\mathrm{R} \$$ & 460,53 & CRUZEIRO & Cruzeiro & & 456,00 & \begin{tabular}{|l|}
$\mathrm{R} \$$ \\
$210.000,00$
\end{tabular} & Revelação Imóveis \\
\hline SJP & $\mathrm{R} \$$ & 462,50 & CIDADE JARDIM & Cidade Jardim & Rua José Nabuco & 1600,00 & $\begin{array}{l}\mathrm{R} \$ \\
740.000,00 \\
\end{array}$ & Gomes Consultor Imobiliário Ltda - J 3.943 \\
\hline SJP & $\mathrm{R} \$$ & 464,00 & CRUZEIRO & Cruzeiro & & 250,00 & \begin{tabular}{|l|}
$\mathrm{R} \$$ \\
$116.000,00$ \\
\end{tabular} & Rocco Imóveis \\
\hline SJP & $\mathrm{R} \$$ & 467,53 & $\begin{array}{l}\text { BONECA DO } \\
\text { IGUACSU }\end{array}$ & Boneca do Iguaçu & & 385,00 & \begin{tabular}{|l|}
$R \$$ \\
$180.000,00$ \\
\end{tabular} & $\begin{array}{l}\text { WASHINGTON ORTEGA CORRETORA DE } \\
\text { IMOVEIS }\end{array}$ \\
\hline SJP & $\mathrm{R} \$$ & 504,85 & SÃO CRISTÓVÃO & São Cristóvão & AV DA TORRES & 515,00 & \begin{tabular}{|l|}
$\mathrm{R} \$$ \\
$260.000,00$ \\
\end{tabular} & Eliana Corretora de Imóveis - 15371 \\
\hline SJP & $\mathrm{R} \$$ & 544,96 & CRUZEIRO & Jardim Cruzeiro & & 275,25 & \begin{tabular}{|l|}
$R \$$ \\
$150.000,00$
\end{tabular} & Ribeiro Imóveis \\
\hline SJP & $\mathrm{R} \$$ & 675,68 & CRUZEIRO & Cruzeiro & & 888,00 & $\begin{array}{l}\mathrm{R} \$ \\
600.000,00 \\
\end{array}$ & Revelação Imóveis \\
\hline SJP & $\mathrm{R} \$$ & 769,23 & CIDADE JARDIM & Cidade Jardim & & 52,00 & $\begin{array}{l}\mathrm{R} \$ \\
40.000,00 \\
\end{array}$ & Ribeiro Imóveis \\
\hline SJP & & 900,09 & CIDADE JARDIM & CIDADE JARDIM & & 4176,00 & \begin{tabular}{|l|}
$\mathrm{R} \$$ \\
$3.758 .760,00$ \\
\end{tabular} & Venturi Consultoria Imobiliária \\
\hline SJP & $\mathrm{R} \$ 1$ & $1.500,00$ & CRUZEIRO & Cruzeiro & & 100,00 & $\begin{array}{l}\mathrm{R} \$ \\
150.000,00\end{array}$ & Ribeiro Imóveis \\
\hline SJP & $\mathrm{R} \$$ & 16,67 & AFONSO PENA & Afonso Pena & Rua Altevir de Lara & 24000,00 & \begin{tabular}{|l|}
$\mathrm{R} \$$ \\
$400.000,00$
\end{tabular} & Toniolo Corretora de Imóveis \\
\hline SJP & $\mathrm{R} \$$ & 45,00 & AFONSO PENA & Afonso Pena & & 20557,16 & \begin{tabular}{|l}
$\mathrm{R} \$$ \\
$925.072,00$ \\
\end{tabular} & Ribeiro Imóveis \\
\hline SJP & $\mathrm{R} \$$ & 60,00 & $\begin{array}{l}\text { CAMPO LARGO DA } \\
\text { ROSEIRA }\end{array}$ & Haras Bom Pastor & & 2500,00 & \begin{tabular}{|l|}
$R \$$ \\
$150.000,00$ \\
\end{tabular} & $\begin{array}{l}\text { WASHINGTON ORTEGA CORRETORA DE } \\
\text { IMOVEIS }\end{array}$ \\
\hline SJP & $\mathrm{R} \$$ & 72,00 & $\begin{array}{l}\text { CAMPO LARGO DA } \\
\text { ROSEIRA }\end{array}$ & Haras Bom Pastor & & 2500,00 & \begin{tabular}{|l|}
$R \$$ \\
$180.000,00$
\end{tabular} & $\begin{array}{l}\text { WASHINGTON ORTEGA CORRETORA DE } \\
\text { IMOVEIS }\end{array}$ \\
\hline
\end{tabular}




\begin{tabular}{|c|c|c|c|c|c|c|c|c|}
\hline \multicolumn{9}{|c|}{ INPESPAR - PORTAIS: IMÓVEIS CURITIBA e IMÓVEIS SJP - TERRENOS OFERTADOS PARA VENDA - NOVEMBRO 2009} \\
\hline Cidade & $\mathbf{R} \$ / \mathbf{M}$ & & BAIRRO & LOTEAMENTO & ENDEREÇO & ÁREA & PREÇO & ANUNCIANTE \\
\hline SJP & $\mathrm{R} \$$ & 72,59 & AFONSO PENA & Afonso Pena & & 675,00 & $\begin{array}{l}\mathrm{R} \$ \\
49.000,00\end{array}$ & Alaimoveis \\
\hline SJP & $\mathrm{R} \$$ & 73,60 & $\begin{array}{l}\text { CAMPO LARGO DA } \\
\text { ROSEIRA }\end{array}$ & Haras Bom Pastor & & 1250,00 & $\begin{array}{l}\mathrm{R} \$ \\
92.000,00\end{array}$ & $\begin{array}{l}\text { WASHINGTON ORTEGA CORRETORA DE } \\
\text { IMOVEIS }\end{array}$ \\
\hline SJP & $\mathrm{R} \$$ & 74,07 & AFONSO PENA & Afonso Pena & & 540,00 & $\begin{array}{l}\mathrm{R} \$ \\
40.000,00\end{array}$ & 然 \\
\hline SJP & $\mathrm{R} \$$ & 80,56 & AFONSO PENA & Afonso Pena & & 360,00 & $\begin{array}{l}\mathrm{R} \$ \\
29.000,00\end{array}$ & Alaimoveis \\
\hline SJP & $\mathrm{R} \$$ & 80,56 & AFONSO PENA & Afonso Pena & & 360,00 & $\begin{array}{l}\mathrm{R} \$ \\
29.000,00\end{array}$ & Alaimoveis \\
\hline SJP & $\mathrm{R} \$$ & 86,27 & INDEPENDÊNCIA & JARDIM INDEPENDENCIA & & 637,50 & $\begin{array}{l}\mathrm{R} \$ \\
55.000,00\end{array}$ & Santos Corretor de Imóveis \\
\hline SJP & $\mathrm{R} \$$ & 101,96 & INDEPENDÊNCIA & JARDIM INDEPENDENCIA & & 637,50 & $\begin{array}{l}\mathrm{R} \$ \\
65.000,00\end{array}$ & Santos Corretor de Imóveis \\
\hline SJP & $\mathrm{R} \$$ & 104,66 & AFONSO PENA & Afonso Pena & Expedicionario Antonio Machado & 4299,74 & $\begin{array}{l}\mathrm{R} \$ \\
450.000,00\end{array}$ & Sueli Fernandes Imóveis \\
\hline SJP & $\mathrm{R} \$$ & 113,33 & INDEPENDÊNCIA & JARDIM INDEPENDENCIA & & 750,00 & $\begin{array}{l}\mathrm{R} \$ \\
85.000,00\end{array}$ & MARQUES IMOVEIS \\
\hline SJP & $\mathrm{R} \$$ & 123,38 & AFONSO PENA & Afonso Pena & Rua Alfredo Pinto & 77000,00 & $\begin{array}{l}\mathrm{R} \$ \\
9.500 .000,00\end{array}$ & Revelação Imóveis \\
\hline SJP & $\mathrm{R} \$$ & 137,14 & INÁ & Vila Iná & & 175,00 & $\begin{array}{l}\mathrm{R} \$ \\
24.000,00 \\
\end{array}$ & MARQUES IMOVEIS \\
\hline SJP & $\mathrm{R} \$$ & 138,33 & AFONSO PENA & Afonso Pena & & 600,00 & $\begin{array}{l}\mathrm{R} \$ \\
83.000,00\end{array}$ & Venturi Consultoria Imobiliária \\
\hline SJP & $\mathrm{R} \$$ & 138,33 & AFONSO PENA & Afonso Pena & & 600,00 & $\begin{array}{l}\mathrm{R} \$ \\
83.000,00\end{array}$ & Venturi Consultoria Imobiliária \\
\hline SJP & $\mathrm{R} \$$ & 140,00 & INDEPENDÊNCIA & Jardim Monte Claro & & 250,00 & $\begin{array}{l}\mathrm{R} \$ \\
35.000,00\end{array}$ & Revelação Imóveis \\
\hline SJP & $\mathrm{R} \$$ & 140,69 & AFONSO PENA & Afonso Pena & & 462,00 & $\begin{array}{l}\mathrm{R} \$ \\
65.000,00\end{array}$ & Venturi Consultoria Imobiliária \\
\hline SJP & $\mathrm{R} \$$ & 185,36 & AFONSO PENA & Afonso Pena & & 377,65 & $\begin{array}{l}\mathrm{R} \$ \\
70.000,00\end{array}$ & Sueli Fernandes Imóveis \\
\hline SJP & $\mathrm{R} \$$ & 191,41 & AFONSO PENA & Afonso Pena & & 256,00 & $\begin{array}{l}\mathrm{R} \$ \\
49.000,00\end{array}$ & $\begin{array}{l}\text { WASHINGTON ORTEGA CORRETORA DE } \\
\text { IMOVEIS }\end{array}$ \\
\hline SJP & $\mathrm{R} \$$ & 194,44 & AFONSO PENA & Afonso Pena & & 360,00 & $\begin{array}{l}\mathrm{R} \$ \\
70.000,00\end{array}$ & Solaris Imóveis \\
\hline SJP & $R \$$ & 195,00 & 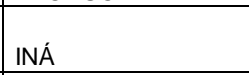 & Fenix & & 200,00 & $\begin{array}{l}\mathrm{R} \$ \\
39.000,00\end{array}$ & Fonseca Imóveis \\
\hline SJP & $\mathrm{R} \$$ & 214,73 & AFONSO PENA & Afonso Pena & R. Almirante Alexandrino & 16765,00 & $\begin{array}{l}\mathrm{R} \$ \\
3.600 .000,00\end{array}$ & Moro Imóveis Ltda Vendas - 1603J \\
\hline
\end{tabular}




\begin{tabular}{|c|c|c|c|c|c|c|c|c|}
\hline \multicolumn{9}{|c|}{ INPESPAR - PORTAIS: IMÓVEIS CURITIBA e IMÓVEIS SJP - TERRENOS OFERTADOS PARA VENDA - NOVEMBRO 2009} \\
\hline Cidade & $\mathbf{R} \$ /$ & & BAIRRO & LOTEAMENTO & ENDEREÇO & ÁREA & PREÇO & ANUNCIANTE \\
\hline SJP & $\mathrm{R} \$$ & 221,77 & INÁ & Fenix & & 248,00 & $\begin{array}{l}\mathrm{R} \$ \\
55.000,00\end{array}$ & Rocco Imóveis \\
\hline SJP & $\mathrm{R} \$$ & 225,44 & AFONSO PENA & Afonso Pena & & 4347,00 & $\begin{array}{l}\mathrm{R} \$ \\
980.000,00\end{array}$ & $\begin{array}{l}\text { WASHINGTON ORTEGA CORRETORA DE } \\
\text { IMOVEIS }\end{array}$ \\
\hline SJP & $\mathrm{R} \$$ & 253,57 & INÁ & Fenix & & 280,00 & $\begin{array}{l}\mathrm{R} \$ \\
71.000,00\end{array}$ & Rocco Imóveis \\
\hline SJP & $\mathrm{R} \$$ & 257,94 & AFONSO PENA & Afonso Pena & & 252,00 & $\begin{array}{l}\mathrm{R} \$ \\
65.000,00\end{array}$ & $\begin{array}{l}\text { WASHINGTON ORTEGA CORRETORA DE } \\
\text { IMOVEIS }\end{array}$ \\
\hline SJP & $\mathrm{R} \$$ & 265,87 & AFONSO PENA & Afonso Pena & & 252,00 & $\begin{array}{l}\mathrm{R} \$ \\
67.000,00\end{array}$ & $\begin{array}{l}\text { WASHINGTON ORTEGA CORRETORA DE } \\
\text { IMOVEIS }\end{array}$ \\
\hline SJP & $\mathrm{R} \$$ & 266,45 & AFONSO PENA & Afonso Pena & & 1200,96 & $\begin{array}{l}\mathrm{R} \$ \\
320.000,00\end{array}$ & Revelação Imóveis \\
\hline SJP & $\mathrm{R} \$$ & 272,73 & AFONSO PENA & Afonso Pena & & 399,66 & $\begin{array}{l}\mathrm{R} \$ \\
109.000,00\end{array}$ & Ribeiro Imóveis \\
\hline SJP & $\mathrm{R} \$$ & 277,78 & AFONSO PENA & Afonso Pena & & 252,00 & $\begin{array}{l}\mathrm{R} \$ \\
70.000,00\end{array}$ & Corretor Santiago \\
\hline SJP & $\mathrm{R} \$$ & 288,98 & AFONSO PENA & Afonso Pena & & 481,00 & $\begin{array}{l}\mathrm{R} \$ \\
139.000,00\end{array}$ & Fernanda Oliveira Imóveis \\
\hline SJP & $\mathrm{R} \$$ & 304,35 & AVIAÇÃO & Conj. Resid. Apolo & & 230,00 & $\begin{array}{l}\mathrm{R} \$ \\
70.000,00\end{array}$ & MARQUES IMOVEIS \\
\hline SJP & $\mathrm{R} \$$ & 312,50 & AFONSO PENA & Afonso Pena & & 240,00 & $\begin{array}{l}\mathrm{R} \$ \\
75.000,00\end{array}$ & DB Imóveis \\
\hline SJP & $\mathrm{R} \$$ & 334,82 & AFONSO PENA & Afonso Pena & & 224,00 & $\begin{array}{l}\mathrm{R} \$ \\
75.000,00\end{array}$ & Imobiliária Kalli \\
\hline SJP & $\mathrm{R} \$$ & 334,82 & AFONSO PENA & Afonso Pena & & 224,00 & $\begin{array}{l}\mathrm{R} \$ \\
75.000,00\end{array}$ & Imobiliária Kalli \\
\hline SJP & $\mathrm{R} \$$ & 334,82 & AFONSO PENA & Afonso Pena & & 224,00 & $\begin{array}{l}\mathrm{R} \$ \\
75.000,00\end{array}$ & Viver Bem Imóveis \\
\hline SJP & $\mathrm{R} \$$ & 337,30 & AFONSO PENA & Afonso Pena & & 252,00 & $\begin{array}{l}\mathrm{R} \$ \\
85.000,00\end{array}$ & Rocco Imóveis \\
\hline SJP & $\mathrm{R} \$$ & 357,14 & AFONSO PENA & Afonso Pena & & 420,00 & $\begin{array}{l}\mathrm{R} \$ \\
150.000,00\end{array}$ & Valle corretor de IMÓVEIS \\
\hline SJP & $R \$$ & 391,30 & AFONSO PENA & Afonso Pena & & 230,00 & $\begin{array}{l}\mathrm{R} \$ \\
90.000,00\end{array}$ & Ribeiro Imóveis \\
\hline SJP & $\mathrm{R} \$$ & 438,88 & AFONSO PENA & Afonso Pena & & 250,64 & $\begin{array}{l}\mathrm{R} \$ \\
110.000,00 \\
\end{array}$ & Ribeiro Imóveis \\
\hline SJP & $\mathrm{R} \$$ & 486,11 & INDEPENDÊNCIA & JARDIM INDEPENDENCIA & & 288,00 & $\begin{array}{l}\mathrm{R} \$ \\
140.000,00\end{array}$ & Apolar São José \\
\hline SJP & $\mathrm{R} \$$ & 2,57 & BORDA DO CAMPO & Borda do Campo & & 27200,00 & $\begin{array}{l}\mathrm{R} \$ \\
70.000,00\end{array}$ & Ribeiro Imóveis \\
\hline
\end{tabular}




\begin{tabular}{|c|c|c|c|c|c|c|c|c|}
\hline \multicolumn{9}{|c|}{ INPESPAR - PORTAIS: IMÓVEIS CURITIBA e IMÓVEIS SJP - TERRENOS OFERTADOS PARA VENDA - NOVEMBRO 2009} \\
\hline Cidade & $\mathbf{R} \$ \mathbf{M}$ & & BAIRRO & LOTEAMENTO & ENDEREÇO & ÁREA & PREÇO & ANUNCIANTE \\
\hline SJP & $\mathrm{R} \$$ & 7,00 & BORDA DO CAMPO & Guatupê & Avenida Guatupê & 180000,00 & $\begin{array}{l}\mathrm{R} \$ \\
1.260 .000,00\end{array}$ & Reikdal Corretora de Imóveis - creci 14.300 \\
\hline SJP & $\mathrm{R} \$$ & 15,00 & $\begin{array}{l}\text { ROSEIRA SÃO } \\
\text { SEBASTIÃO }\end{array}$ & Roseira & & 160000,00 & $\begin{array}{l}\mathrm{R} \$ \\
2.400 .000,00\end{array}$ & Lr7 Imóveis - 10010 \\
\hline SJP & $\mathrm{R} \$$ & 15,00 & GUATUPÊ & Guatupê & & 128849,00 & $\begin{array}{l}\mathrm{R} \$ \\
1.932 .745,50\end{array}$ & $\begin{array}{l}\text { WASHINGTON ORTEGA CORRETORA DE } \\
\text { IMOVEIS }\end{array}$ \\
\hline SJP & $\mathrm{R} \$$ & 16,00 & BORDA DO CAMPO & Borda do Campo & Estrada da Roseira & 136910,00 & $\begin{array}{l}\mathrm{R} \$ \\
2.190 .000,00\end{array}$ & GCX Consultoria 16.688 \\
\hline SJP & $\mathrm{R} \$$ & 20,00 & GUATUPÊ & Guatupê & & 72600,00 & $\begin{array}{l}\mathrm{R} \$ \\
1.452 .000,00\end{array}$ & $\begin{array}{l}\text { WASHINGTON ORTEGA CORRETORA DE } \\
\text { IMOVEIS }\end{array}$ \\
\hline SJP & $\mathrm{R} \$$ & 20,38 & GUATUPÊ & Guatupê & & 5398,00 & $\begin{array}{l}\mathrm{R} \$ \\
110.000,00\end{array}$ & $\begin{array}{l}\text { WASHINGTON ORTEGA CORRETORA DE } \\
\text { IMOVEIS }\end{array}$ \\
\hline SJP & $\mathrm{R} \$$ & 20,61 & RIO PEQUENO & Rio Pequeno & & 4125,00 & $\begin{array}{l}\mathrm{R} \$ \\
85.000,00\end{array}$ & MARQUES IMOVEIS \\
\hline SJP & $\mathrm{R} \$$ & 30,00 & COSTEIRA & Costeira & & 119359,70 & $\begin{array}{l}\mathrm{R} \$ \\
3.581 .000,00\end{array}$ & Alaimoveis \\
\hline SJP & $\mathrm{R} \$$ & 35,00 & GUATUPÊ & Guatupê & & 75461,52 & $\begin{array}{l}\mathrm{R} \$ \\
2.641 .153,20\end{array}$ & Solaris Imóveis \\
\hline SJP & $\mathrm{R} \$$ & 37,50 & $\begin{array}{l}\text { ROSEIRA SÃO } \\
\text { SEBASTIÃO }\end{array}$ & Roseira & & 480,00 & $\begin{array}{l}\mathrm{R} \$ \\
18.000,00\end{array}$ & Corretor Santiago \\
\hline SJP & $\mathrm{R} \$$ & 37,50 & BORDA DO CAMPO & Borda do campo & & 4000,00 & $\begin{array}{l}\mathrm{R} \$ \\
150.000,00 \\
\end{array}$ & Solaris Imóveis \\
\hline SJP & $\mathrm{R} \$$ & 38,96 & GUATUPE & Guatupê & & 77000,00 & $\begin{array}{l}\mathrm{R} \$ \\
3.000 .000,00\end{array}$ & Toniolo Corretora de Imóveis \\
\hline SJP & $\mathrm{R} \$$ & 39,35 & DOM RODRIGO & Libanópolis & & 432,00 & $\begin{array}{l}\mathrm{R} \$ \\
17.000,00\end{array}$ & Pereira Assessoria Imobiliaria \\
\hline SJP & $\mathrm{R} \$$ & 47,88 & $\begin{array}{l}\text { ROSEIRA SÃO } \\
\text { SEBASTIÃO }\end{array}$ & Roseira & & 10443,00 & $\begin{array}{l}\mathrm{R} \$ \\
500.000,00\end{array}$ & Venturi Consultoria Imobiliária \\
\hline SJP & $\mathrm{R} \$$ & 51,44 & ACADEMIA & Planta Zenith & & 1458,00 & $\begin{array}{l}\mathrm{R} \$ \\
75.000,00\end{array}$ & MARQUES IMOVEIS \\
\hline SJP & $\mathrm{R} \$$ & 51,85 & BORDA DO CAMPO & Borda do Campo & & 675,00 & $\begin{array}{l}\mathrm{R} \$ \\
35.000,00\end{array}$ & Solaris Imóveis \\
\hline SJP & $\mathrm{R} \$$ & 54,02 & QUISSISANA & Quississana & & 12885,00 & $\begin{array}{l}\mathrm{R} \$ \\
696.000,00\end{array}$ & Venturi Consultoria Imobiliária \\
\hline SJP & $\mathrm{R} \$$ & 56,00 & RIO PEQUENO & Rio Pequeno & & 2500,00 & $\begin{array}{l}\mathrm{R} \$ \\
140.000,00\end{array}$ & Sueli Fernandes Imóveis \\
\hline SJP & $\mathrm{R} \$$ & 60,00 & $\begin{array}{l}\text { ROSEIRA SÃO } \\
\text { SEBASTIÃO }\end{array}$ & Roseira & & 5050,00 & $\begin{array}{l}\mathrm{R} \$ \\
303.000,00\end{array}$ & Venturi Consultoria Imobiliária \\
\hline SJP & $\mathrm{R} \$$ & 60,00 & COSTEIRA & Costeira & & 15522,27 & $\begin{array}{l}\mathrm{R} \$ \\
931.336,20\end{array}$ & Revelação Imóveis \\
\hline
\end{tabular}




\begin{tabular}{|c|c|c|c|c|c|c|c|c|}
\hline \multicolumn{9}{|c|}{ INPESPAR - PORTAIS: IMÓVEIS CURITIBA e IMÓVEIS SJP - TERRENOS OFERTADOS PARA VENDA - NOVEMBRO 2009} \\
\hline Cidade & $\mathrm{R} \$ / \mathrm{I}$ & & BAIRRO & LOTEAMENTO & ENDEREÇO & ÁREA & PREÇO & ANUNCIANTE \\
\hline SJP & $R \$$ & 62,84 & CRISTAL & Jardim Marambaia & & 461,50 & $\begin{array}{l}\mathrm{R} \$ \\
29.000,00\end{array}$ & Alaimoveis \\
\hline SJP & $\mathrm{R} \$$ & 66,67 & JUREMA & Jardim Jurema & & 420,00 & $\begin{array}{l}\mathrm{R} \$ \\
28.000,00\end{array}$ & MARQUES IMOVEIS \\
\hline SJP & $\mathrm{R} \$$ & 70,25 & GUATUPÊ & Guatupê & & 48400,00 & $\begin{array}{l}\mathrm{R} \$ \\
3.400 .000,00\end{array}$ & Revelação Imóveis \\
\hline SJP & $\mathrm{R} \$$ & 72,92 & CRISTAL & JARDIM CRISTAL & & 480,00 & $\begin{array}{l}\mathrm{R} \$ \\
35.000,00\end{array}$ & MARQUES IMOVEIS \\
\hline SJP & $\mathrm{R} \$$ & 76,00 & RIO PEQUENO & Rio Pequeno & & 1250,00 & $\begin{array}{l}\mathrm{R} \$ \\
95.000,00\end{array}$ & Haas Assessoria Imobiliária \\
\hline SJP & $\mathrm{R} \$$ & 78,13 & IPE & Araguari & * & 1280,00 & $\begin{array}{l}\mathrm{R} \$ \\
100.000,00\end{array}$ & DB Imóveis \\
\hline SJP & $\mathrm{R} \$$ & 81,98 & RIO PEQUENO & Rio Pequeno & & 2439,56 & $\begin{array}{l}\mathrm{R} \$ \\
200.000,00\end{array}$ & Rocco Imóveis \\
\hline SJP & $\mathrm{R} \$$ & 83,33 & JUREMA & Jardim Jurema & & 420,00 & $\begin{array}{l}\mathrm{R} \$ \\
35.000,00\end{array}$ & Santos Corretor de Imóveis \\
\hline SJP & $\mathrm{R} \$$ & 83,33 & JUREMA & Jardim Jurema & & 420,00 & $\begin{array}{c}\mathrm{R} \$ \\
35.000,00\end{array}$ & Santos Corretor de Imóveis \\
\hline SJP & $\mathrm{R} \$$ & 91,67 & BORDA DO CAMPO & Borda do Campo & & 600,00 & $\begin{array}{l}\mathrm{R} \$ \\
55.000,00\end{array}$ & Haas Assessoria Imobiliária \\
\hline SJP & $\mathrm{R} \$$ & 96,42 & GUATUPÊ & Guatupê & & 363,00 & $\begin{array}{l}\mathrm{R} \$ \\
35.000,00\end{array}$ & Santos Corretor de Imóveis \\
\hline SJP & $\mathrm{R} \$$ & 97,22 & RIO PEQUENO & Rio Pequeno & & 360,00 & $\begin{array}{l}\mathrm{R} \$ \\
35.000,00\end{array}$ & Santos Corretor de Imóveis \\
\hline SJP & $\mathrm{R} \$$ & 97,22 & RIO PEQUENO & Rio Pequeno & & 360,00 & $\begin{array}{l}\mathrm{R} \$ \\
35.000,00\end{array}$ & Santos Corretor de Imóveis \\
\hline SJP & $\mathrm{R} \$$ & 97,22 & RIO PEQUENO & Rio Pequeno & & 360,00 & $\begin{array}{l}\mathrm{R} \$ \\
35.000,00\end{array}$ & Santos Corretor de Imóveis \\
\hline SJP & $\mathrm{R} \$$ & 97,22 & RIO PEQUENO & Rio Pequeno & & 360,00 & $\begin{array}{l}\mathrm{R} \$ \\
35.000,00\end{array}$ & Santos Corretor de Imóveis \\
\hline SJP & $\mathrm{R} \$$ & 107,59 & GUATUPÊ & Guatupê & & 883,00 & $\begin{array}{l}\mathrm{R} \$ \\
95.000,00\end{array}$ & Santos Corretor de Imóveis \\
\hline SJP & $R \$$ & 109,24 & BORDA DO CAMPO & Borda do Campo & & 2014,00 & $\begin{array}{l}\mathrm{R} \$ \\
220.000,00\end{array}$ & Ribeiro Imóveis \\
\hline SJP & $\mathrm{R} \$$ & 109,52 & JUREMA & Jardim Jurema & & 420,00 & $\begin{array}{l}\mathrm{R} \$ \\
46.000,00\end{array}$ & DB Imóveis \\
\hline SJP & $R \$$ & 109,80 & JUREMA & Jardim Jurema & & 255,00 & $\begin{array}{l}\mathrm{R} \$ \\
28.000,00\end{array}$ & MARQUES IMOVEIS \\
\hline SJP & $\mathrm{R} \$$ & 125,00 & IPE & Ipê & & 392,00 & $\begin{array}{l}\mathrm{R} \$ \\
49.000,00\end{array}$ & Santos Corretor de Imóveis \\
\hline
\end{tabular}




\begin{tabular}{|c|c|c|c|c|c|c|c|c|}
\hline \multicolumn{9}{|c|}{ INPESPAR - PORTAIS: IMÓVEIS CURITIBA e IMÓVEIS SJP - TERRENOS OFERTADOS PARA VENDA - NOVEMBRO 2009} \\
\hline Cidade & $\mathrm{R} \$ \mathbf{M}$ & & BAIRRO & LOTEAMENTO & ENDEREÇO & ÁREA & PREÇO & ANUNCIANTE \\
\hline SJP & $\mathrm{R} \$$ & 128,21 & GUATUPE & Guatupê & & 507,00 & $\begin{array}{l}\mathrm{R} \$ \\
65.000,00\end{array}$ & Venturi Consultoria Imobiliária \\
\hline SJP & $\mathrm{R} \$$ & 149,73 & SANTO ANTONIO & Planta Santa terezinha & & 2805,00 & $\begin{array}{l}R \$ \\
420.000,00\end{array}$ & Metronorte Imóveis \\
\hline SJP & $\mathrm{R} \$$ & 153,06 & $\mathrm{IPE}$ & 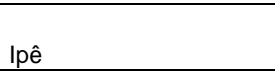 & & 392,00 & $\begin{array}{l}\mathrm{R} \$ \\
60.000,00\end{array}$ & Santos Corretor de Imóveis \\
\hline SJP & $\mathrm{R} \$$ & 153,06 & IPÊ & Ipê & & 392,00 & $\begin{array}{l}\mathrm{R} \$ \\
60.000,00\end{array}$ & Solaris Imóveis \\
\hline SJP & $\mathrm{R} \$$ & 164,84 & QUISSISANA & Planta Suiça & & 364,00 & $\begin{array}{l}\mathrm{R} \$ \\
60.000,00\end{array}$ & Haas Assessoria Imobiliária \\
\hline SJP & $\mathrm{R} \$$ & 166,67 & QUISSISANA & Planta Suiça & & 360,00 & $\begin{array}{l}\mathrm{R} \$ \\
60.000,00\end{array}$ & Viver Bem Imóveis \\
\hline SJP & $\mathrm{R} \$$ & 166,67 & QUISSISANA & Quississana & & 360,00 & $\begin{array}{l}\mathrm{R} \$ \\
60.000,00\end{array}$ & Metronorte Imóveis \\
\hline SJP & $\mathrm{R} \$$ & 171,43 & RIO PEQUENO & Rio Pequeno & & 262,50 & $\begin{array}{l}\mathrm{R} \$ \\
45.000,00\end{array}$ & Toniolo Corretora de Imóveis \\
\hline SJP & $\mathrm{R} \$$ & 180,56 & QUISSISANA & Quississana & & 360,00 & $\begin{array}{l}\mathrm{R} \$ \\
65.000,00\end{array}$ & Revelação Imóveis \\
\hline SJP & $\mathrm{R} \$$ & 188,00 & RIO PEQUENO & Jardim Santa Clara & & 250,00 & $\begin{array}{l}\mathrm{R} \$ \\
47.000,00\end{array}$ & DB Imóveis \\
\hline SJP & $\mathrm{R} \$$ & 191,11 & RIO PEQUENO & Jardim Santa Clara & & 225,00 & $\begin{array}{l}\mathrm{R} \$ \\
43.000,00\end{array}$ & DB Imóveis \\
\hline SJP & $\mathrm{R} \$$ & 208,33 & COSTEIRA & São Franscisco & & 360,00 & $\begin{array}{l}\mathrm{R} \$ \\
75.000,00\end{array}$ & Venturi Consultoria Imobiliária \\
\hline SJP & $\mathrm{R} \$$ & 208,33 & COSTEIRA & São Franscisco & & 360,00 & $\begin{array}{l}\mathrm{R} \$ \\
75.000,00\end{array}$ & Solaris Imóveis \\
\hline SJP & $\mathrm{R} \$$ & 215,00 & RIO PEQUENO & Jardim Santa Clara & & 200,00 & $\begin{array}{l}\mathrm{R} \$ \\
43.000,00\end{array}$ & DB Imóveis \\
\hline SJP & $\mathrm{R} \$$ & 222,22 & BORDA DO CAMPO & Borda do Campo & & 360,00 & $\begin{array}{l}\mathrm{R} \$ \\
80.000,00\end{array}$ & Haas Assessoria Imobiliária \\
\hline SJP & $\mathrm{R} \$$ & 244,44 & COSTEIRA & Costeira & & 225,00 & $\begin{array}{l}\mathrm{R} \$ \\
55.000,00\end{array}$ & Revelação Imóveis \\
\hline SJP & $\mathrm{R} \$$ & 259,80 & COSTEIRA & Parque São José & & 408,00 & $\begin{array}{c}\mathrm{R} \$ \\
106.000,00\end{array}$ & Haas Assessoria Imobiliária \\
\hline SJP & $\mathrm{R} \$$ & 269,66 & COSTEIRA & Parque São José & & 500,63 & $\begin{array}{l}R \$ \\
135.000,00\end{array}$ & Corteze Imóveis \\
\hline SJP & $R \$$ & 315,00 & COSTEIRA & Costeira & & 200,00 & $\begin{array}{l}\mathrm{R} \$ \\
63.000,00\end{array}$ & DB Imóveis \\
\hline SJP & $\mathrm{R} \$$ & 325,00 & COSTEIRA & Costeira & & 200,00 & $\begin{array}{l}\mathrm{R} \$ \\
65.000,00\end{array}$ & DB Imóveis \\
\hline
\end{tabular}




\begin{tabular}{|c|c|c|c|c|c|c|c|c|}
\hline \multicolumn{9}{|c|}{ INPESPAR - PORTAIS: IMÓVEIS CURITIBA e IMÓVEIS SJP - TERRENOS OFERTADOS PARA VENDA - NOVEMBRO 2009} \\
\hline Cidade & $\mathbf{R} \$ /$ & & BAIRRO & LOTEAMENTO & ENDEREÇO & ÁREA & PREÇO & ANUNCIANTE \\
\hline SJP & $\mathrm{R} \$$ & 341,78 & GUATUPE & Guatupê & BR 277 & 1901,80 & $\begin{array}{l}\mathrm{R} \$ \\
650.000,00\end{array}$ & Ivete Sens Corretora de Imóveis - 15052 \\
\hline SJP & $\mathrm{R} \$$ & 5,06 & $\begin{array}{l}\text { CAMPO LARGO DA } \\
\text { ROSEIRA }\end{array}$ & Artex & * & 96800,00 & $\begin{array}{l}\mathrm{R} \$ \\
490.000,00\end{array}$ & Revelação Imóveis \\
\hline SJP & $\mathrm{R} \$$ & 9,00 & $\begin{array}{l}\text { CAMPO LARGO DA } \\
\text { ROSEIRA }\end{array}$ & Campo Largo da Roseira & & 75500,00 & $\begin{array}{l}\mathrm{R} \$ \\
679.500,00 \\
\end{array}$ & Marcelo Rendake imoveis \\
\hline SJP & $\mathrm{R} \$$ & 13,50 & SÃO MARCOS & São Marcos & & 127570,00 & $\begin{array}{l}\mathrm{R} \$ \\
1.722 .199,00\end{array}$ & AB Imóveis \\
\hline SJP & $\mathrm{R} \$$ & 18,76 & DEL REY & Del Rey & & 4264,00 & $\begin{array}{l}\mathrm{R} \$ \\
80.000,00\end{array}$ & Rocco Imóveis \\
\hline SJP & $\mathrm{R} \$$ & 19,84 & $\begin{array}{l}\text { CAMPO LARGO DA } \\
\text { ROSEIRA }\end{array}$ & Campo Largo da Roseira & & 5041,00 & $\begin{array}{l}\mathrm{R} \$ \\
100.000,00\end{array}$ & Rocco Imóveis \\
\hline SJP & $\mathrm{R} \$$ & 22,00 & BARRO PRETO & Barro Preto & & 10262,00 & $\begin{array}{l}\mathrm{R} \$ \\
225.764,00\end{array}$ & AB Imóveis \\
\hline SJP & $\mathrm{R} \$$ & 22,26 & $\begin{array}{l}\text { CAMPINA DO } \\
\text { TAQUARAL }\end{array}$ & Miringuava & & 65138,00 & $\begin{array}{l}\mathrm{R} \$ \\
1.450 .000,00\end{array}$ & $\begin{array}{l}\text { WASHINGTON ORTEGA CORRETORA DE } \\
\text { IMOVEIS }\end{array}$ \\
\hline SJP & $\mathrm{R} \$$ & 24,00 & BARRO PRETO & Barro Preto & & 39375,00 & $\begin{array}{l}\mathrm{R} \$ \\
945.000,00 \\
\end{array}$ & Revelação Imóveis \\
\hline SJP & $\mathrm{R} \$$ & 29,62 & $\begin{array}{l}\text { ROSEIRA SÃO } \\
\text { SEBASTIÃO }\end{array}$ & Dist.Ind. Renault & Avenida das Indústrias - Eixo Renault & 22960,03 & $\begin{array}{l}\mathrm{R} \$ \\
680.000,00\end{array}$ & De Matos Imóveis - 13469 \\
\hline SJP & $\mathrm{R} \$$ & 30,00 & SÃO MARCOS & São Marcos & & 31114,00 & $\begin{array}{l}\mathrm{R} \$ \\
933.420,00\end{array}$ & $\begin{array}{l}\text { WASHINGTON ORTEGA CORRETORA DE } \\
\text { IMOVEIS }\end{array}$ \\
\hline SJP & $\mathrm{R} \$$ & 48,98 & DEL REY & Del Rey & & 612,50 & $\begin{array}{l}\mathrm{R} \$ \\
30.000,00\end{array}$ & Marcelo Rendake imoveis \\
\hline SJP & $\mathrm{R} \$$ & 51,44 & $\begin{array}{l}\text { CAMPO LARGO DA } \\
\text { ROSEIRA }\end{array}$ & Campo Largo da Roseira & & 25759,00 & $\begin{array}{l}\mathrm{R} \$ \\
1.325 .000,00\end{array}$ & $\begin{array}{l}\text { WASHINGTON ORTEGA CORRETORA DE } \\
\text { IMOVEIS }\end{array}$ \\
\hline SJP & $\mathrm{R} \$$ & 53,57 & $\begin{array}{l}\text { COLÔNIA RIO } \\
\text { GRANDE }\end{array}$ & Colonia Rio Grande & & 10453,70 & $\begin{array}{l}\mathrm{R} \$ \\
560.000,00 \\
\end{array}$ & AB Imóveis \\
\hline SJP & $\mathrm{R} \$$ & 55,56 & BARRO PRETO & Barro Preto & & 360,00 & $\begin{array}{l}\mathrm{R} \$ \\
20.000,00\end{array}$ & Viver Bem Imóveis \\
\hline SJP & $\mathrm{R} \$$ & 57,07 & BARRO PRETO & Barro Preto & & 52567,00 & $\begin{array}{l}\mathrm{R} \$ \\
3.000 .000,00\end{array}$ & $\begin{array}{l}\text { WASHINGTON ORTEGA CORRETORA DE } \\
\text { IMOVEIS }\end{array}$ \\
\hline SJP & $\mathrm{R} \$$ & 57,87 & SÃO MARCOS & Jardim São Marcos & & 3456,00 & $\begin{array}{l}\mathrm{R} \$ \\
200.000,00\end{array}$ & Marcelo Rendake imoveis \\
\hline SJP & $\mathrm{R} \$$ & 58,91 & DEL REY & Del Rey & & 1290,00 & $\begin{array}{l}\mathrm{R} \$ \\
76.000,00\end{array}$ & Revelação Imóveis \\
\hline SJP & $\mathrm{R} \$$ & 66,31 & $\begin{array}{l}\text { ROSEIRA SÃO } \\
\text { SEBASTIÃO }\end{array}$ & renault & & 558,00 & $\begin{array}{l}\mathrm{R} \$ \\
37.000,00\end{array}$ & Venturi Consultoria Imobiliária \\
\hline SJP & $\mathrm{R} \$$ & 66,31 & $\begin{array}{l}\text { ROSEIRA SÃO } \\
\text { SEBASTIÃO }\end{array}$ & renault & & 558,00 & $\begin{array}{l}\mathrm{R} \$ \\
37.000,00\end{array}$ & Venturi Consultoria Imobiliária \\
\hline
\end{tabular}




\begin{tabular}{|c|c|c|c|c|c|c|c|c|}
\hline \multicolumn{9}{|c|}{ INPESPAR - PORTAIS: IMÓVEIS CURITIBA e IMÓVEIS SJP - TERRENOS OFERTADOS PARA VENDA - NOVEMBRO 2009} \\
\hline Cidade & $\mathrm{R} \$ / \mathbf{M}$ & & BAIRRO & LOTEAMENTO & ENDEREÇO & ÁREA & PREÇO & ANUNCIANTE \\
\hline SJP & $\mathrm{R} \$$ & 72,31 & BARRO PRETO & Barro Preto & & 484,00 & \begin{tabular}{|l|}
$\mathrm{R} \$$ \\
$35.000,00$ \\
\end{tabular} & Idélcio Corretor de Imóveis \\
\hline SJP & $\mathrm{R} \$$ & 105,56 & BARRO PRETO & Barro Preto & & 360,00 & \begin{tabular}{|l|}
$R \$$ \\
$38.000,00$ \\
\end{tabular} & DB Imóveis \\
\hline SJP & $\mathrm{R} \$$ & 115,46 & OURO FINO & Ouro Fino & & 2425,00 & \begin{tabular}{|l|}
$\mathrm{R} \$$ \\
$280.000,00$ \\
\end{tabular} & DB Imóveis \\
\hline SJP & $\mathrm{R} \$$ & 125,00 & SÃO MARCOS & JARDIM FABIOLA & & 200,00 & \begin{tabular}{|l|}
$\mathrm{R} \$$ \\
$25.000,00$ \\
\end{tabular} & MARQUES IMOVEIS \\
\hline SJP & $\mathrm{R} \$$ & 150,93 & DEL REY & Del Rey & Av. Rui Barbosa & 1186,00 & $\begin{array}{l}\mathrm{R} \$ \\
179.000,00 \\
\end{array}$ & $\begin{array}{l}\text { WASHINGTON ORTEGA CORRETORA DE } \\
\text { IMOVEIS }\end{array}$ \\
\hline SJP & $\mathrm{R} \$$ & 162,34 & $\begin{array}{l}\text { CAMPINA DO } \\
\text { TAQUARAL } \\
\end{array}$ & Campina & & 462,00 & \begin{tabular}{|l|}
$\mathrm{R} \$$ \\
$75.000,00$ \\
\end{tabular} & Solaris Imóveis \\
\hline SJP & $\mathrm{R} \$$ & 173,61 & SÃO MARCOS & São Marcos & & 432,00 & \begin{tabular}{|l|}
$\mathrm{R} \$$ \\
$75.000,00$ \\
\end{tabular} & Revelação Imóveis \\
\hline SJP & $\mathrm{R} \$$ & 214,29 & $\begin{array}{l}\text { COLÔNIA RIO } \\
\text { GRANDE } \\
\end{array}$ & Colonia Rio Grande & & 280,00 & $\begin{array}{l}\mathrm{R} \$ \\
60.000,00 \\
\end{array}$ & Valle corretor de IMÓVEIS \\
\hline SJP & $\mathrm{R} \$$ & 268,60 & $\begin{array}{l}\text { COLÔNIA RIO } \\
\text { GRANDE } \\
\end{array}$ & Colonia Rio Grande & & 242,00 & \begin{tabular}{|l|}
$\mathrm{R} \$$ \\
$65.000,00$ \\
\end{tabular} & Clerio Souza Imóveis \\
\hline SJP & $\mathrm{R} \$$ & 472,22 & SÃO MARCOS & São Marcos & & 180,00 & \begin{tabular}{|l|}
$\mathrm{R} \$$ \\
$85.000,00$ \\
\end{tabular} & Venturi Consultoria Imobiliária \\
\hline SJP & $\mathrm{R} \$$ & 497,68 & \begin{tabular}{|l|} 
CAMPINA DO \\
TAQUARAL \\
\end{tabular} & Miringuava & BR - 376 & 180,84 & \begin{tabular}{|l|}
$\mathrm{R} \$$ \\
$90.000,00$ \\
\end{tabular} & Prosper Imóveis - J 4061 \\
\hline SJP & $\mathrm{R} \$$ & 156,79 & SÃO MARCOS & São Marcos & & 510,25 & \begin{tabular}{|l|}
$\mathrm{R} \$$ \\
$80.000,00$
\end{tabular} & AB Imóveis \\
\hline
\end{tabular}




\section{ANEXO 3}

Quadro Operacional da RIT Metropolitana relativo a Colombo, Pinhais e São José dos Pinhais 


\begin{tabular}{|c|c|c|c|c|c|c|c|c|c|c|}
\hline \multicolumn{11}{|c|}{$\begin{array}{c}\text { UNIDADE DE PROGRAMAÇÃO OPERACIONAL - UPO } \\
\text { QUADRO OPERACIONAL - LINHAS POR CIDADE }\end{array}$} \\
\hline \multicolumn{11}{|c|}{ GUADRO OPERACIONAL."RECIAOMIETROPOLITANA } \\
\hline CIDADE & cób. & LINHA & EXT. KM & F.OPER. & T.V. MIN. & $\begin{array}{l}\mathrm{VELOC} . \\
\mathrm{KM} / \mathrm{H}\end{array}$ & $\begin{array}{l}\text { INTERV } \\
\text { H.M.M. }\end{array}$ & $\begin{array}{l}\text { VIAGEM } \\
\text { H.M.M. } \\
\end{array}$ & $\begin{array}{l}\text { VIAGEM } \\
\text { D.U. }\end{array}$ & $\begin{array}{l}K M \\
\text { D.U. } \\
\end{array}$ \\
\hline \multirow{29}{*}{ COLOMBO } & 221 & RIO VERDE & 19,107 & 4 & 50 & 22,93 & 12.50 & 4,80 & 62,00 & 1.184 .63 \\
\hline & 222 & ESPERANÇA & 15,024 & 4 & 50 & 18.03 & 12,50 & 4,80 & 66,00 & 991,58 \\
\hline & 231 & BANESTADO / CALIFÓRNIA & 12,086 & 2 & 40 & 18.13 & 20,00 & 3.00 & 29,61 & 357.87 \\
\hline & B11 & MARACANĀ / STA. CÂNDIDA & 10,962 & 6 & 33 & 19,93 & 5,50 & 10,91 & 113,81 & 1.247 .59 \\
\hline & $\mathrm{B} 13$ & JD. DAS GRAÇAS & 9.096 & 2 & 30 & 18.19 & 15,00 & 4,00 & 48,00 & 436,61 \\
\hline & B14 & PLANALTO & 7.337 & 3 & 23 & 19,14 & 7,67 & 7,83 & 65,00 & 476,91 \\
\hline & B15 & ANA TERRA / ADRIANE & 12.074 & 2 & 40 & 18,11 & 20,00 & 3,00 & 40,08 & 483,93 \\
\hline & B17 & STA. HELENA & 7.904 & 4 & 26 & 18.24 & 6,50 & 9,23 & 95.00 & 750,88 \\
\hline & B18 & ROSEIRA & 20,516 & 1 & 60 & 20.52 & 60,00 & 1,00 & 20,00 & 410,32 \\
\hline & $\mathrm{B} 19$ & MONTE CASTELO & 11,496 & 6 & 32 & 21.56 & 5.33 & 11,25 & 115,16 & 1.323 .88 \\
\hline & $\mathrm{B} 20$ & GUARAITUBA / CABRAL & 25,005 & 9 & 65 & 23.08 & 7.22 & 8,31 & 97,98 & 2.449 .99 \\
\hline & $\mathrm{B} 22$ & PALOMA & 15,943 & 3 & 23 & 41,59 & 7,67 & 7,83 & 33,54 & 534,73 \\
\hline & $\mathrm{B} 23$ & GUARAITUBA & 4.963 & 2 & 20 & 14,89 & 10,00 & 6,00 & 71,00 & 352,37 \\
\hline & B24 & COLÔNIA FARIA & 13,795 & 1 & 40 & 20,69 & 40,00 & 1,50 & 24,00 & 331,08 \\
\hline & B25 & MARACANÃ / BAIRRO ALTO & 17,155 & 2 & 61 & 16,87 & 30,50 & 1.97 & 25,00 & 428,88 \\
\hline & $\mathrm{B} 26$ & JD. EUCALIPTOS & 6,609 & 3 & 24 & 16,52 & 8,00 & 7,50 & 60,00 & 396,54 \\
\hline & $B 27$ & RIBEIRA / FCO. CORADIN & 20,999 & 1 & 45 & 28.00 & 45,00 & 1,33 & 8,00 & 167.99 \\
\hline & B28 & V. MARIA DO ROSÁRIO & 9.634 & 1 & 30 & 19,27 & 30,00 & 2,00 & 38,00 & 366,09 \\
\hline & $B 29$ & SEDE / APEDEC & 37,276 & 1 & 30 & 74,55 & 30,00 & 2,00 & 7,00 & 260,93 \\
\hline & $\mathrm{B} 32$ & MARACANÃ / STA. CÂNDIDA & 11,458 & 2 & 18 & 38,19 & 9,00 & 6.67 & 5.96 & 68,29 \\
\hline & $\mathrm{B} 33$ & BOCAIÚVA DO SUL & 45,978 & 4 & 80 & 34,48 & 20,00 & 3,00 & 34,00 & 1.563 .25 \\
\hline & $\mathrm{B} 35$ & PORTEIRA/PALOMA & 12,007 & 1 & 40 & 18.01 & 40,00 & 1.50 & 10,50 & 126,07 \\
\hline & $\mathrm{B} 41$ & MARACANÃ / C. IMBUIA & 24,231 & 9 & 65 & 22.37 & 7,22 & 8,31 & 64,50 & $1.562,90$ \\
\hline & $\mathrm{B} 42$ & MARACANÃ / LINHA VERDE & 30,608 & 4 & 66 & 27.83 & 16,50 & 3,64 & 45,00 & $1.377,36$ \\
\hline & $\mathrm{C} 28$ & JACOB MACANHAN & 19,404 & 2 & 50 & 23,28 & 25,00 & 2,40 & 32,00 & 620.93 \\
\hline & \multicolumn{2}{|c|}{\begin{tabular}{|l|} 
SUBTOTAL - ALIMENTADOR \\
\end{tabular}} & $*$ & 79 & $\sim$ & 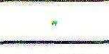 & $*$ & 123.76 & $1.211,14$ & $18.271 .5 \%$ \\
\hline & $\mathrm{B} 61$ & CTBA / CAP. ATUBA & 29,027 & 4 & 72 & 24,19 & 18,00 & 3,33 & 47,00 & $1.364,27$ \\
\hline & C.66 & CTBA / V. ZUMBI & 34,236 & 3 & 93 & 22,09 & 31,00 & 1.94 & 29,00 & 992,84 \\
\hline & \multicolumn{2}{|c|}{ SUBTOIAL - CONVENCIONAL } & - & 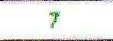 & $\because$ & - & . & 5.27 & 76,00 & 2.357 .11 \\
\hline
\end{tabular}

20/01/2010 - Região Metropolitana.xIs Elaborado Eng. Pedro Darci 
UNIDADE DE PROGRAMAÇÃO OPERACIONAL - UPO

QUADRO OPERACIONAL - LINHAS POR CIDADE

\section{QUADRO OPERACIONAL - REGIÃO METROPOLITANA}

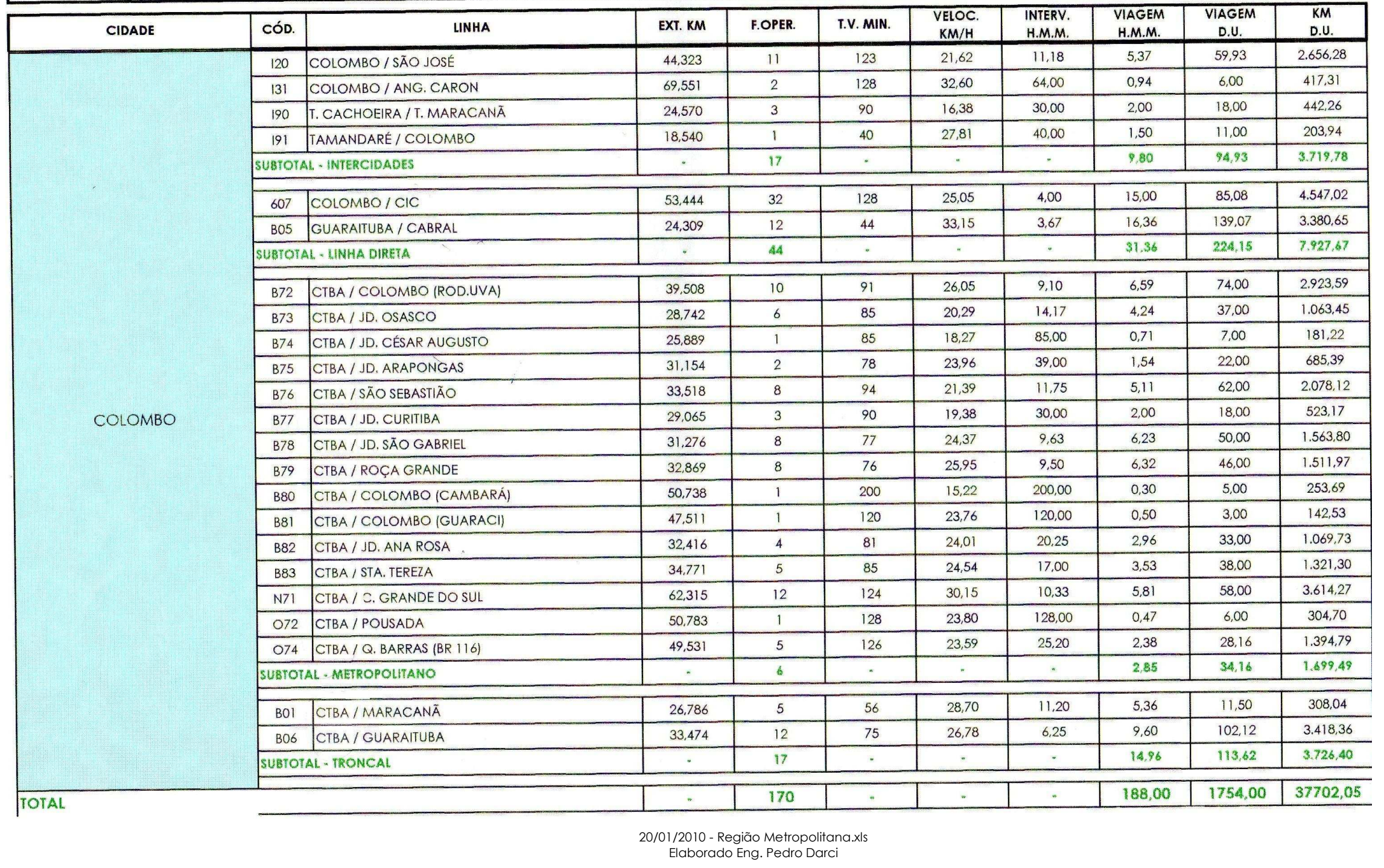




\section{产}

UNIDADE DE PROGRAMAÇÃO OPERACIONAL - UPO

QUADRO OPERACIONAL - LINHAS POR CIDADE

\begin{tabular}{|c|c|c|c|c|c|c|c|c|c|c|}
\hline \multicolumn{11}{|c|}{ GUADRO OPERACIONAL-REGIAOMETROMOLITAMA } \\
\hline CIDADE & Cód. & UNHA & EXT. KM & F.OPER. & T.V. MIN. & $\begin{array}{l}\mathrm{VELOC} . \\
\mathrm{KM} / \mathrm{H}\end{array}$ & $\begin{array}{l}\text { INTERV. } \\
\text { H.M.M. }\end{array}$ & $\begin{array}{l}\text { VIAGEM } \\
\text { H.M.M. }\end{array}$ & $\begin{array}{l}\text { VIAGEM } \\
\text { D.U. }\end{array}$ & $\begin{array}{l}\text { KM } \\
\text { D.U. }\end{array}$ \\
\hline \multirow{29}{*}{ PINHAIS } & 313 & AVENIDA IRAÍ/ CAPÃO DA IMBUIA & 10,891 & 2 & 32 & 20,42 & 16,00 & 3,75 & 49,00 & 533,66 \\
\hline & B4I & MARACANÃ / C. IMBUIA & 24,231 & 9 & 65 & 22,37 & 7,22 & 8,31 & 64,50 & $1.562,90$ \\
\hline & $\mathrm{c} 11$ & JD. HOLANDES & 12,992 & 5 & 40 & 19.49 & 8,00 & 7,50 & 67,00 & 870,46 \\
\hline & $\mathrm{Cl} 2$ & V. NOVA & 14,374 & 5 & 44 & 19,60 & 8,80 & 6,82 & 39,00 & 560.59 \\
\hline & $\mathrm{C} 13$ & ÁGUA CLARA & 22,987 & 5 & 67. & 20,59 & 13,40 & 4,48 & 47,91 & 1.101 .31 \\
\hline & $\mathrm{C} 15$ & WEISSÓPOLIS & 9,388 & 2 & 28 & 20,12 & 14,00 & 4,29 & 48,00 & 450,62 \\
\hline & $\mathrm{Cl} 6$ & ID. IRAI & 9,095 & 2 & 28 & 19,49 & 14,00 & 4,29 & 45,00 & 409.28 \\
\hline & $\mathrm{C} 17$ & V. MARIA ANTONIETA & 6,245 & 2 & 20 & 18.74 & 10,00 & 6,00 & 60,00 & 374,70 \\
\hline & $\mathrm{C} 18$ & JD. TROPICAL & 9,560 & 2 & 34 & 16,87 & 17,00 & 3.53 & 43,00 & 411,08 \\
\hline & $\mathrm{C} 20$ & JD. CLÁUDIA & 12,887 & 5 & 42 & 18,41 & 8,40 & 7.14 & 70,03 & 902,48 \\
\hline & $\mathrm{C} 22$ & PLANTA KARLA & 16,339 & 5 & 54 & 18.15 & 10,80 & 5.56 & 64,31 & 1.050 .76 \\
\hline & $\mathrm{C} 23$ & EMILIANO PERNETA & 9,105 & 1 & 30 & 18,21 & 30,00 & 2,00 & 38,00 & 345,99 \\
\hline & $\mathrm{C} 25$ & V. AMÉLIA & 11,329 & 3 & 32 & 21,24 & 10,67 & 5.63 & 63,00 & 713,73 \\
\hline & $\mathrm{C} 26$ & PRIVÊ & 11.717 & 2 & 38 & 18.50 & 19,00 & 3.16 & 37,00 & 433,53 \\
\hline & $\mathrm{C} 27$ & JOAQUINA & 5,456 & 2 & 34 & 9,63 & 17,00 & 3.53 & 42,00 & 229,15 \\
\hline & $\mathrm{C} 30$ & V. GRANDE / TARUMÃ & 11,378 & 2 & 40 & 17,07 & 20,00 & 3,00 & 38,27 & 435,44 \\
\hline & $\mathrm{C} 41$ & B. ALTO / E. PERNETA A & 11,014 & 1 & 32 & 20.65 & 32,00 & 1,88 & 32,00 & 352,45 \\
\hline & $\mathrm{C}_{42}$ & PINHAIS / B. ALTO & 18,314 & 3 & 60 & 18.31 & 20,00 & 3,00 & 41,51 & 760,21 \\
\hline & D14 & PINHAIS /PIRAQUARA & 40,714 & 3 & 101 & 24,19 & 33,67 & 1.78 & 26,00 & $1.058,56$ \\
\hline & D21 & STA. MOONICA & 21,818 & 5 & 50 & 26.18 & 10,00 & 6,00 & 50,50 & 1.101 .81 \\
\hline & D22 & GUARTIUBA & 19,809 & 5 & 48 & 24.76 & 9,60 & 6,25 & 57,00 & 1.129 .11 \\
\hline & $\mathrm{D} 23$ & V. MACEDO & 26,532 & 4 & 64 & 24,87 & 16,00 & 3.75 & 49,58 & $1,315,46$ \\
\hline & D31 & JD. BELA VISTA & 27,947 & 6 & 60 & 27.95 & 10,00 & 6,00 & 57,50 & $1,606,95$ \\
\hline & \multicolumn{2}{|c|}{ SUBTOTAL-ALIMENTADOR } & - & Bi & - & - & 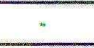 & 107,62 & 1.130 .11 & 17.710 .22 \\
\hline & $\mathrm{C} 63$ & CTBA / CONJ. ATUBA & 27.874 & 4 & 74 & 22.60 & 18,50 & 3.24 & 46,00 & $1.282,20$ \\
\hline & $\mathrm{C} 72$ & CTBA $/ V$ V. PALMITAL & 31,318 & 3 & 84 & 22,37 & 28,00 & 2.14 & 25,00 & 782,95 \\
\hline & \multicolumn{2}{|c|}{ SUBTOTAL-CONVENCIONAL } & " & 7 & 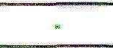 & " & * & $5.3 \%$ & 71,00 & $2.065,15$ \\
\hline & 301 & PINHAIS / RUI BARBOSA & 21,621 & 16 & 66 & 19,66 & 4,13 & 14,55 & 140,00 & $3.026,94$ \\
\hline & $\mathrm{CO4}$ & T. C. IMBUIA / T. PINHAIS (SOMENTE P3) & 9,434 & 2 & 22 & 25,73 & 11,00 & 5,45 & 7.96 & 75,09 \\
\hline
\end{tabular}

20/01/2010 - Região Metropolitana.xls Elaborado Eng. Pedro Darci 


\section{UNIDADE DE PROGRAMAÇÃO OPERACIONAL - UPO
QUADRO OPERACIONAL - LINHAS POR CIDADE}

\begin{tabular}{|c|c|c|c|c|c|c|c|c|c|c|}
\hline \multicolumn{11}{|c|}{ QUADRO OPERACIONAL - RECIAO WETROPOLITANA } \\
\hline CIDADE & cód. & LINHA & EXT. KM & F.OPER. & T.V. MiN. & $\begin{array}{l}\text { VELOC. } \\
\text { KM/H }\end{array}$ & $\begin{array}{l}\text { INTERV. } \\
\text { H.M.M. }\end{array}$ & $\begin{array}{l}\text { VIAGEM } \\
\text { H.M.M. } \\
\end{array}$ & $\begin{array}{l}\text { VIAGEM } \\
\text { D.U. }\end{array}$ & $\begin{array}{l}\mathrm{K} M \\
0 . U \text {. } \\
\end{array}$ \\
\hline \multirow{10}{*}{ PINHAIS } & \multicolumn{2}{|c|}{ SUBTOTAL - EXPRESSO } & - & 18 & - & 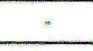 & . & 20,00 & 147.96 & 3.102 .03 \\
\hline & 120 & COLOMBO / SÃO JOSÉ & 44,323 & 11 & 123 & 21,62 & 11,18 & 5,37 & 59,93 & $2.656,28$ \\
\hline & \multicolumn{2}{|c|}{ SUBTOTAL-INTERCIDADES } & $\cdots$ & 11 & $\cdots$ & . & $\cdot$ & 5.37 & 59.93 & $2.656 .28 \mathrm{~B}$ \\
\hline & 304 & PINHAIS / CAMPO COMPRIDO & 42,681 & 16 & 102 & 25.11 & 6.38 & 9,41 & 105,06 & $4.484,07$ \\
\hline & \multicolumn{2}{|c|}{ SUBTOTAL - UNHA DIRETA } & - & 16 & 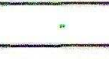 & - & 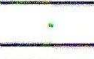 & 9,41 & 105,06 & $4,484,07$ \\
\hline & D61 & CTBA/PIRAQUARA & 45,257 & 16 & 98 & 27,71 & 6.13 & 9,80 & 95,00 & $4.299,42$ \\
\hline & \begin{tabular}{|l|l|l|l|l|l}
$D 66$ \\
\end{tabular} & CTBA / PIRAQUARA (DIRETO) & 45,479 & 10 & 91 & 29,99 & 9.10 & 6.59 & 57.05 & 2.594 .58 \\
\hline & \multicolumn{2}{|c|}{ SUBTOTAL-METROPOLITANO } & 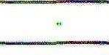 & 26 & . & - & $\therefore$ & 16.39 & 152.05 & 6.893 .99 \\
\hline & $\mathrm{CO3}$ & PINHAIS / GUADAPULE & 19,903 & 13 & 59 & 20,24 & 4,54 & 13,22 & 102,27 & 2.035 .48 \\
\hline & \multicolumn{2}{|c|}{\begin{tabular}{|l} 
SUBTOTAL - TRONCAL \\
\end{tabular}} & - & 13 & 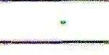 & 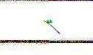 & $\cdot$ & 13.22 & 102.27 & $20.095,48$ \\
\hline YOTAL & & & 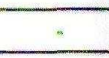 & 172 & - & - & - & 177,40 & $1.768,38$ & $38,947,23$ \\
\hline
\end{tabular}

20/01/2010 - Região Metropolitana.xls Elaborado Eng. Pedro Darci 


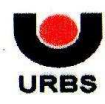

UNIDADE DE PROGRAMAÇÃO OPERACIONAL - UPO

QUADRO OPERACIONAL - LINHAS POR CIDADE

\begin{tabular}{|c|c|c|c|c|c|c|c|c|c|c|}
\hline \multicolumn{11}{|c|}{ OUADRO OPERAGIONAL - RECIAO METROPOLWTANA } \\
\hline CIDADE & Cód. & LINHA & EXT. KM & F.OPER. & T.V. MIN. & $\begin{array}{l}\text { VELOC. } \\
\text { KM/H }\end{array}$ & $\begin{array}{l}\text { INTERV. } \\
\text { H.M.M. }\end{array}$ & $\begin{array}{l}\text { VIAGEM } \\
\text { H.M.M. }\end{array}$ & $\begin{array}{l}\text { VIAGEM } \\
\text { D.U. }\end{array}$ & $\begin{array}{l}\text { KM } \\
\text { D.U. }\end{array}$ \\
\hline \multirow{27}{*}{ SÃO JOSÉ DOS PINHAIS } & E31 & PUC / SÃO JOSÉ & 19,405 & 5 & 46 & 25,31 & 9,20 & 6,52 & 40,70 & 789,78 \\
\hline & \multicolumn{2}{|c|}{ SUEYOTAL-AUMENTADOR } & - & 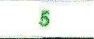 & . & . & $\cdot$ & 6.52 & 40.70 & 789,78 \\
\hline & 120 & COLOMBO / SÃO JOSÉ & 44,323 & 11 & 123 & 21,62 & 11.18 & 5,37 & 59,93 , & 2.656 .28 \\
\hline & \multicolumn{2}{|c|}{ SUETOTAL - INTERCIDADES } & . & 11 & $\cdot$ & - & - & 5.37 & 59,93 & $2.456,28$ \\
\hline & 206 & BARREIRINHA / SÃO JOSÉ & 42,440 & 12 & 121 & 21,04 & 10,08 & 5,95 & 59,50 & $2.525,18$ \\
\hline & 208 & AEROPORTO & 41,036 & 4 & 104 & 23,67 & 26,00 & 2,31 & 38,00 & $1.559,37$ \\
\hline & \multicolumn{2}{|c|}{ SUBTOTAL - LINHA DIRETA } & $=$ & 16 & . & . & - & 8.26 & 97,50 & $4.084,55$ \\
\hline & E01 & CTBA URANO & 33,523 & 11 & 83 & 24,23 & 7.55 & 7.95 & 87,50 & $2.933,26$ \\
\hline & E02 & CTBA / APOLO & 35.028 & 3 & 90 & 23,35 & 30,00 & 2,00 & 19,00 & 665,53 \\
\hline & E05 & CTBA / SÃO JOSÉ & 30,141 & 8 & 72 & 25,12 & 9,00 & 6.67 & 83,00 & 2.501 .70 \\
\hline & E11 & T. BOQ. / T. AFONSO PENA & 16,403 & 11 & 49 & 20,09 & 4,45 & 13.47 & 106,00 & $1.738,72$ \\
\hline & E21 & T. BOQ./T. CENTRAL & 7,546 & 1 & 24. & 18,87 & 24,00 & 2,50 & 28,00 & 211,29 \\
\hline & E62 & CTBA / PEDRO MORO & 36,525 & 8 & 494. & 4,44 & 61,75 & 0,97 & 48,56 & $1.773,65$ \\
\hline & E63 & PRADO VELHO / P. MORO & 35,147 & 3 & 90 & 23,43 & 30,00 & 2,00 & 19,06 & 669,90 \\
\hline & E64 & EXECUTI VO / AEROPORTO & 38,461 & 5 & 82 & 28,14 & 16,40 & 3,66 & 53,60 & 2.061 .51 \\
\hline & E65 & CTBA / XINGU & 39,990 & 5 & 94 & 25,53 & 18,80 & 3,19 & 24,00 & 959,76 \\
\hline & E66 & CTBA / INDEPENDENNCIA & 38,592 & 13 & 100 & 23,16 & 7,69 & 7,80 & 73,00 & $2.817,22$ \\
\hline & E67 & CTBA / BRAGA & 40,187 & 3 & 90 & 26,79 & 30,00 & 2,00 & 25,00 & $1.004,68$ \\
\hline & E68 & CTBA / QUISISANA & 46,800 & 8 & 100 & 28,08 & 12,50 & 4,80 & 43,57 & 2.039 .08 \\
\hline & E70 & CTBA / PUC & 37,113 & 1 & 100 & 22,27 & 100,00 & 0,60 & 1.00 & 37,11 \\
\hline & $E 71$ & CTBA / JD. IPÊ & 35,720 & 11 & 90 & 23,81 & 8,18 & 7.33 & 57.17 & 2.042 .11 \\
\hline & $\mathrm{E} 72$ & CTBA / JD. IZAURA & 46,346 & 10 & 104 & 26,74 & 10,40 & 5,77 & 50,61 & $2.345,57$ \\
\hline & E75 & CTBA / JD. CRISTAL & 48,667 & 3 & 70 & 41,71 & 23,33 & 2.57 & 1.26 & 61,32 \\
\hline & E76 & CTBA / POSTO PARIS & 51,953 & 15 & 103 & 30,26 & 6,87 & 8,74 & 60,68 & $3.152,51$ \\
\hline & E77 & CTBA / GUATUPÊ & 43,257 & 3 & 180 & 14,42 & 60,00 & 1,00 & 15,56 & 673,08 \\
\hline & E78 & CTBA / ROSEIRA & 58.996 & 2 & 110 & 32,18 & 55,00 & 1.09 & 11,51 & 679,04 \\
\hline & \multicolumn{2}{|c|}{ SUBTOIAL-METROPOLITANO } & $\therefore$ & 124 & " & “ & - & 84.11 & 808,08 & $28.367,04$ \\
\hline AL & & & - & 156 & . & . & . & 104,26 & $1.006,21$ & $35.897,65$ \\
\hline
\end{tabular}

20/01/2010 - Região Metropolitana.xls

Elaborado Eng. Pedro Darci 